BRUNO CORRÊA BURINI

\title{
PROCESSO ADMINISTRATIVO DE APURAÇÃO DE CONDUTA ANTICONCORRENCIAL: \\ PERSPECTIVA INSTRUMENTALISTA
}

Orientador: Professor FLÁVIO LUIZ YARSHELL

Universidade de São Paulo

Faculdade de Direito

São Paulo - 2010 
A pesquisa destinada à elaboração desta tese de doutorado contou com o apoio da Coordenação de Aperfeiçoamento de Pessoal de Nível Superior - CAPES. 
Mãe, Pai, exemplos de amor e dedicação incondicional.

Bi, nem percebi e você foi, de forma suave, virando meu exemplo, meu modelo.

Ao meu sobrinho(a?). Você nem bem chegou e já encheu a família de alegria. 


\section{Agradecimentos}

À minha família. A todos aqueles que torceram muito e às vezes quietos para não incomodar o neto-sobrinho-primo-tio rabugento.

À Fá, que sempre esteve ao meu lado.

Aos Professores Flávio Luiz Yarshell, Cândido Rangel Dinamarco, Ada Pellegrini Grinover e Achille Salletti, pela orientação e inspiração.

Aos amigos antigos, que souberam deixar sempre a porta aberta para o sumido. Tathi e Zi, especialmente para vocês. Também agradeço Guilherme Rafare, Daniela Santos, José Antonio, Rafael, Bruno, André B1, Surcan, Patrícia Maria, tão importantes, cada um a sua maneira.

Um primeiro agradecimento ao doutorado. Por causa dele, tive a oportunidade de conhecer algumas pessoas que em nove minutos ou em nove meses, ajudaram-me sem saber a catar os cacos. Questa parte del ringraziamento è per tutti voi: Remo Sacchi ed Elena Martinelle, che con singoli gesti hanno "cambiato la storia"; Luca "Il Coach" Madini, Paolo Sormani, Patrizia Pistoni, Marco Rovelini, Max Mondiani, avete accolto il brasiliano come uno di voi; Antonini, Marcelo, Gramegna, Gigi, Luca, Silvia, Raul, Lorena, Stefano, Roberto, Simo, Alberto-Stefano, Guido, Mian, Stoppani, Monica, Mauri, Paolo Tron, Enzo (aspetto di non aver lasciato nessuno di fuori...) non vi dimenticherò mai; Viviana, Graziela, grazie per la pacienza; Vitor, Vasco, vi ringrazio per l'amicizia, (perche anche a voi il ringraziamento dev'essere in italiano).

Wildfire, motorino, kibeloco, meu violão, Zeca Baleiro, Britti, Grignani: bons instrumentos de manutenção de sanidade. Por quê não agradecê-los?

Um agradecimento final aos bons incentivos. 4:15 am, cansado, véspera do depósito, maratona honesta de estudos. Fecho os olhos, vejo uma rua de terra batida, vegetação densa de ambos os lados, algumas casas de muro baixo, um frio suportável e uma garoa fina. Ao final, a mata fecha e sobra apenas um corredor estreito. No fim do corredor, o mar se abre e na praia só mais uma pessoa, sobre um tronco de madeira, olhando para o nada. Mergulho no mar e fico um tempo debaixo d'água e em seguida começo a nadar. O mundo pára de fazer barulho. 


\section{Resumo}

A presente tese propôs-se a examinar a possibilidade de se transportar a teoria instrumentalista ao processo administrativo de apuração de condutas perante o Sistema Brasileiro de Defesa da Concorrência. Foram cotejadas premissas estruturais e de técnicas processuais, de modo a examinar se o processo administrativo de apuração de condutas anticoncorrenciais é hábil para a consecução do escopo magno de pacificação com justiça, valendo-se ainda de técnicas processuais adequadas para o alcance daqueles escopos sociais, políticos e jurídicos estabelecidos como premissa de raciocínio. O trabalho faz uma análise da história do pensamento antitruste estrangeiro e no Brasil para a definição do escopo do direito antitruste no Brasil, expõe o conceito de função administrativa judicante (quase jurisidicional) exercida pelo CADE, concebida a partir da ausência de rigidez da concepção tripartite das funções-poderes-atividades do Estado. Debate-se a natureza do órgão, sua concepção no desenho institucional do Estado e a influência da política e da discricionariedade administrativa sobre a sua atividade. No âmbito dos axiomas processuais, são analisados ao longo do texto os preceitos democráticos, o conceito de processo e sua definição em um modelo processual constitucional. A Teoria Geral do Processo também fornece relevante disciplina metodológica aplicável a todo e qualquer processo, dentre eles, o administrativo-concorrencial, cuja natureza também é examinada. Propôs-se então a análise crítica do processo administrativo concorrencial por meio de seus escopos e respectivas técnicas de atuação, a partir da estrutura fornecida pelo pensamento instrumentalista do processo de Dinamarco. O escopo social é examinado à luz das técnicas relacionadas com a imunização, a idoneidade estrutural, a imparcialidade (sob a ótica do princípio da demanda, do princípio dispositivo, do exame da nomeação, mandato e quarentena dos julgadores) e a finalidade educativa. Os escopos políticos são cotejados com as concepções de poder e liberdade (constitucionalização e devido processo legal), participação democrática (como acesso à ordem jurídica justa de representantes, terceiros interessados), direito à informação e publicidade de atos. Por fim, o escopo jurídico do processo é examinado sob a ótica da atuação prática da vontade jurídica preexistente mediante técnicas incidentes sobre os temas do conflito entre correntes unitárias e dualistas do direito, da busca da verdade possível e sua relação com o ideal de pacificação trazido com a solução definitiva e célere de controvérsias por técnicas de imutabilidade e de aceleração de julgamentos, da segurança jurídica outorgada pelas formas, do direito à prova e os meios inerentes ao seu exercício, do duplo grau e da uniformização de decisões. Conclui-se pela identificação de pontos sensíveis em que o processo administrativo não atinge satisfatoriamente os escopos do processo, mas que o sistema caminha em direção da legitimação de sua atividade. 


\section{Riassunto}

Questa tesi propone l'esame dell'applicazione della teoria strumentale all'istruttoria nel Sistema Brasiliano di Difesa della Concorrenza. Sono stati paragonati aspetti strutturali e tecniche procedurali, al fine di esaminare se l'istruttoria è in grado di raggiungere lo scopo maggiore di pacificazione con giustizia, facendo anche l'uso di tecniche procedurale appropriate per raggiungere scopi sociali, politici e giuridici, stabiliti come premessa di ragionamento. Si è fatta l'analisi della storia del diritto antitrust all'estero per definire il campo di applicazione del diritto antitrust in Brasile, si è spiegato il concetto di funzione amministrativa giudicante (quasi giurisdizionale) esercitata dal CADE, progettata dalla mancanza di rigidità del modello tripartito di potere-funzione-attività dello Stato. È stata discussa la natura del CADE, la sua concezione nel disegno istituzionale, l'influenza politica e della discrezionalità amministrativa sull'attività. Con il discorso sugli assiomi procedurali, vengono discussi nel testo i precetti della democrazia, il concetto e la definizione di processo nel suo modello costituzionale. La Teoria Generale prevede anche rilevante metodologia della disciplina applicabile a qualsiasi processo, tra i quali, l'amministrativo-concorrenziale. È stato quindi proposto di rivedere l'istruttoria attraverso gli scopi e le tecniche della loro applicabilità, rispetto alla struttura prevista dalla strumentalità del processo esistente nell'opera di Dinamarco. Lo scopo sociale è esaminato alla luce degli aspetti tecnici dell'immutabilità, dell'integrità strutturale, dell'imparzialità (dal punto di vista del principio della domanda, del principio dispositivo, del'esame della nomina, del mandato e della quarantena dei giudici) e della finalità educativa. Scopi politici si confrontano con i concetti di potere e libertà (previsione costituzionale e idea di un giusto processo), di partecipazione democratica (raggiungimento dell'acusatore e di terzi al giusto processo), di diritto alla informazione e di pubblicità degli atti. Infine lo scopo giuridico viene esaminato dal punto di vista dell'attuazione concreta della volontà preesistente della legge, per mezzo dello scontro tra le scuole unitaria e dualista della giurisdizione, della ricerca della verità possibile e il suo rapporto con l'ideale di pacificazione che si raggiunge con la soluzione definitiva e veloce alle domande (valendosi di tecniche di immutabilità e di accelerazione della procedura), della sicurezza data dalla forma, del diritto alla prova e ai suoi mezzi, del doppio grado e dell'uniformità delle decisioni. Concludiamo con l'individuazione dei punti critici in cui l'istruttoria non raggiunge soddisfacentemente gli scopi del processo, ma il sistema si sposta verso la legittimazione della sua attività. 


\begin{abstract}
The present thesis proposes to examine the hypothesis of carrying the instrumentalist theory to the antitrust proceedings before the Brazilian Competition Policy System (SBDC). Structural and procedural technique assumptions were collated in order to examine whether the antitrust proceedings is able to achieve the grand purpose of pacification with justice, availing itself of appropriate procedural techniques to reach those social, political and legal scopes established as premise of reasoning thinking. Throughout the present thesis, the history of the foreign and Brazilian antitrust thought is analyzed to define the scope of the antitrust law in Brazil, and it exams the concept of administrative adjudicate function (almost jurisdictional) exerted by the Brazilian Council for Economic Defense (CADE), conceived from the absence of formality of the tripartite conception of the function-power-activities of the State. The agency nature, its conception in the institutional design of the State and the influence of the politics and the administrative discretionarity on its activity is discussed. In the scope of the procedural axioms, the democratic principles, the concept of process and its definition in a constitutional procedural model are analyzed throughout the text. The General Theory of the Process also supplies relevant methodological disciplines applicable to all and any procedure, amongst them, the administrative-antitrust procedure, whose nature is also examined. Moreover, a critical analysis of the process by means of its scope and by its respective techniques of performance is proposed, from the structure provided by the instrumentalist thought of the process by Professor Candido Rangel Dinamarco. The social scope is examined in the light of the techniques related with the immunization, the structural suitability, the impartiality (considering the principle of the action, the dispositive principle, the examination of the appointment, term and quarantine of the Commissioners) and the educational purpose. The political scopes are discussed taking into account the conceptions of power and freedom (constitutionality and due process of law), democratic participation (as access of interested parties and third parties to the legal system), right to information and publicity of acts. Finally, the legal scope of the process is examined from the perspective of the practical performance of the preexisting law by means of techniques incident on the subjects of the conflict between Unitarian and Dualist doctrines, the pursue of the possible truth and its relation with the ideal of pacification brought with the definitive and fast solution of controversies by techniques of immutability and acceleration of judgments, of legal certainty afforded by the forms, of the right of production of evidence and those inherent instruments, of the right of appeal to a hierarchically superior body and the predictability of decisions. In conclusion, sensitive points are identified where the administrative procedures do not satisfactorily achieve the scope of process, but where the system moves toward the legitimization of its activity.
\end{abstract}




\section{ÍNDICE}

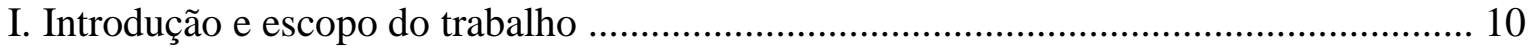

II. Breves considerações sobre a tutela da concorrência ................................................. 16

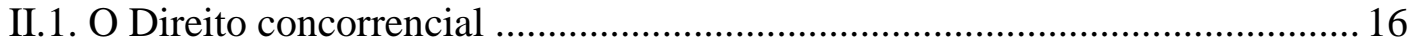

II.2. O Direito concorrencial no Brasil: histórico e legislação ............................... 24

II.3. Considerações sobre o escopo central de atuação do direito antitruste no Brasil

III. Tutela administrativa e função administrativa judicante ......................................... 32

III.1. Notas sobre poder, tutela e jurisdição ........................................................ 32

III.2. A tutela administrativa concorrencial .......................................................... 35

III.3. O conceito de autoridade ............................................................................. 40

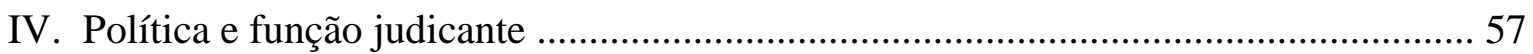

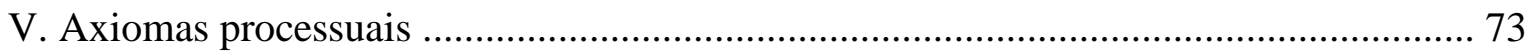

V.1 Modelo processual constitucional …........................................................ 74

V.2. Síntese de princípios e garantias constitucionais do processo ........................ 76

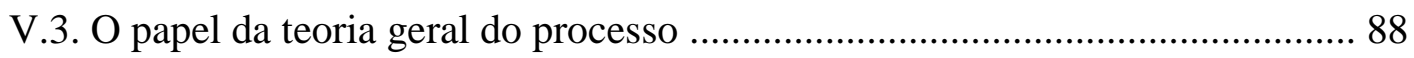

V.4. Natureza do processo de apuração de conduta ............................................. 91

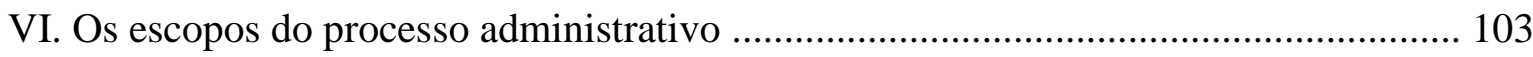

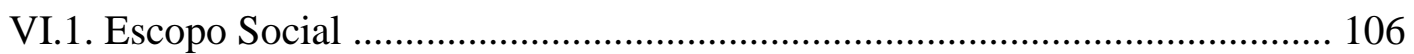

VI.1.1. Imunização, preclusão e coisa julgada ....................................... 106

VI.1.2. Idoneidade do meio pacificador: perspectiva estrutural .............. 116

VI.1.3. Imparcialidade ..................................................................... 118

VI.1.4. Imparcialidade e o princípio da demanda .................................. 121

VI.1.5. Imparcialidade e o princípio dispositivo ..................................... 127

VI.1.6. Imparcialidade: indicação, mandato e desligamento .................... 134

VI.1.7. Extensão da imparcialidade: o SBDC .......................................... 143

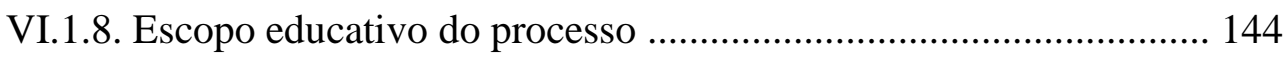

VI.1.9. A educação pela pena e as decisões condenatórias ..................... 147

VI.1.10. A educação construtivista e as formas de composição de interesses

VI.2. Escopo Político

VI.2.1. A relação entre o exercício do poder e a liberdade/dignidade do indivíduo 
VI.2.3. Acesso ao SBDC 166

VI.2.4. Participação e os papéis do representante e dos terceiros 178

VI.2.5. Acesso e abuso 185

VI.2.6. Acesso às informações: publicidade e sigilo 195

VI.3. Escopo Jurídico 202

VI.3.1. Atuação da vontade concreta do direito antitruste 204

VI.3.2. Verdade e paz 208

VI.3.3. Processo e procedimento antitruste 222

VI.3.4. A disciplina da prova (os meios de prova) 230

VI.3.5. Os recursos no processo antitruste 251

VI.3.6. A uniformização das decisões: verdade e segurança 266

VII. Conclusões 274

Bibliografia 283 


\section{INTRODUÇÃO E ESCOPO DO TRABALHO}

O presente trabalho é uma proposta de exame do processo administrativo $^{1}$ de apuração de conduta perante o Sistema Brasileiro de Defesa da Concorrência - SBDC, à luz dos preceitos da instrumentalidade do processo, numa aproximação entre o direito material e processual, tendência antiga, expressa nas linhas gerais do pensamento instrumentalista. Pergunta-se aqui se é possível transportar a teoria instrumentalista ao processo administrativo de apuração de condutas perante o SBDC, partindo de uma comparação metodológica, do cotejo de premissas estruturais e de técnicas processuais. Com isso, pretende-se verificar se o processo administrativo de apuração de condutas anticoncorrenciais seria hábil para a consecução do escopo magno de pacificação com justiça, e dos escopos social, político e jurídico estabelecidos como premissa de raciocínio instrumentalista.

O trabalho explora alguns temas introdutórios de direito econômico, constitucional e administrativo relacionados com o direito concorrencial/antitruste, ${ }^{2}$ em especial o escopo de proteção da concorrência ${ }^{3}$ por meio da educação para a difusão da cultura da concorrência e da repressão de ilícitos anticoncorrenciais por meio dos processos administrativos de apuração de conduta. ${ }^{4}$

\footnotetext{
1 Dentro do gênero do processo administrativo está a espécie destinada à apuração de condutas anticoncorrenciais. No texto é feita referência também à espécie como processo administrativo, sempre dentro de um contexto em que se possa discernir que se trata dela, e não do gênero.

${ }^{2}$ No texto são utilizados de forma indistinta os termo concorrencial e antitruste. Algum debate poderia existir sobre a conceituação de ambos, sobre uma maior ou menor amplitude de um ou de outro, ou ainda sobre a rejeição de anglicanismos. A história do termo antistruste remonta os trustees americanos e a disciplina do seu combate, que resultou em profunda reação do Congresso americano, na edição do Sherman Act (norma de referência, editada em 1890) e representa a tradição centenária americana sobre a matéria. $\mathrm{O}$ autor não se opõe a utilização indistinta de conceitos capazes de transmitir bem a idéia.

${ }^{3} \mathrm{Na}$ atuação antitruste, o Conselho Administrativo de Defesa Econômica - CADE assume a conhecida função administrativa de orientar, fiscalizar, prevenir e apurar abusos de poder econômico, estruturalmente auxiliado pela Secretária de Direito Econômico do Ministério da Justiça (SDE) e pela Secretaria de Acompanhamento Econômico do Ministério da Fazenda (SEAE), compondo assim o Sistema Brasileiro de Defesa da Concorrência. A Agência Nacional de Telecomunicações - ANATEL, por determinação do art. 19, inc. XIX, da lei n. 9.472/97 (a Lei Geral de Telecomunicações - LGT), exerce competências legais em matéria de controle, prevenção e repressão às infrações à ordem econômica. É, portanto, responsável pela instrução de processos administrativos. Não se pretende o exame específico da instrução realizada na ANATEL, porém, é importante destacar que se trata de agência reguladora que se imiscui em atividade concorrencial, por determinação que acrescenta agente instrutor estranho ao SBDC e, sob aspecto estritamente processual, não contribui para a simplificação do processo administrativo.

${ }^{4}$ Ficam excluídas as análises de atos de concentração e de consulta.
} 
Na vertente processual, à luz de escopos específicos, o Estado impõe seu poder por meio de uma autoridade - conceito importado do direito norte americano e ulteriormente do direito francês - que exerce função administrativa judicante e expressa sua capacidade de decidir e impor coercitivamente (ainda que de forma limitada) os seus comandos fora do âmbito jurisdicional.

Na construção de uma decisão voltada à imposição de poder estatal em matéria de infrações contra a ordem econômica perante um órgão não pertencente ao Poder Judiciário, verificam-se aqueles atos concatenados de forma lógica e racional destinados ao fim protetivo pretendido, realizados essencialmente após a formação de uma relação jurídico-processual entre as partes envolvidas e que culminam, ao final, com a declaração administrativa da existência ou não de uma infração e, no primeiro caso, com a imposição e controle da efetividade de medidas destinadas à preservação da concorrência. Trata-se de processo administrativo que inegavelmente se serve de axiomas processuais.

Por meio desse devido processo (CF, art. $5^{\circ}$, inc. LIV) em sede administrativa/repressiva que se faz valer as disposições do art. 170 da Constituição Federal (valorização do trabalho humano, livre iniciativa, existência digna, justiça social, observando sempre a propriedade privada, a livre concorrência e a defesa do consumidor). A atividade de proteção da ordem econômica, em seu flanco repressivo a condutas de caráter abusivo, somente se legitima se o processo de atuação da administração estiver permeado por normas processuais constitucionais e preceitos da teoria geral do processo.

A aproximação dos conceitos processuais - analisados usualmente no processo jurisdicional - do processo administrativo em questão tem então a finalidade clara de fortalecimento da atuação administrativa, exaltando sua importância no exercício do Poder Estatal no âmbito da defesa da livre concorrência. Para tanto, são estabelecidas premissas para a análise que se pretende fazer no presente trabalho: a criação de um órgão vinculado ao Poder Executivo de defesa da concorrência, que exerce função judicante (mantida sempre a garantia de inafastabilidade do controle jurisdicional); a coordenação conceitual de atividades administrativas e jurisdicionais de modo a criar sinergias entre ambas, alcançando-se na medida do possível uma tutela que seja célere, efetiva e que administrativamente pacifique com justiça (no sentido instrumentalista do dizer); a evolução significativa do processo jurisdicional brasileiro e a necessidade de se incorporar ao processo administrativo o que há de melhor (e rejeitar lições oriundas de um 
imanentismo exacerbado ou de um formalismo injustificado) e a necessidade de equilíbrio entre as garantias processuais e as dinâmicas necessidades do direito material do direito antitruste.

Com esse exercício procura-se também vencer alguma resistência mútua entre ramos do direito que dependem de uma intensa intercomunicação.

Não se pode negar que o processo historicamente sofre uma propensão ao formalismo e isolamento e dista da realidade da vida e da linguagem do homem comum "o homem comum o ignora, o próprio jurista o desdenha e os profissionais do foro lamentam as suas imperfeições, sem atinar com meios para melhorá-lo".5 O ranço formalista (na concepção pejorativa liebmaniana ${ }^{6}$ ) trazido da história do processo e da exacerbação de sua fase autonomista, tão comumente utilizado pelos operadores do direito em todas as esferas onde o processo se faz presente, pouco colabora para a quebra de preconceitos. Esse panorama traz uma falsa impressão de que a ciência processual seria uma mazela à solução de processos, destinada apenas à procrastinação e à proteção de interesses ilegítimos, porque materialmente (e supostamente) infundados - em miúdos, um obstáculo à administração da justiça. Trata-se evidentemente de um pensamento de pouco rigor científico: as regras processuais são inerentes aos processos decisórios; não podem ser desprezadas e devem ser cautelosamente examinadas e aperfeiçoadas.

Para combater esse repúdio ao processo, é preciso examinar o estágio atual de desenvolvimento da ciência processual, ratificando estudos anteriores que demonstram a sua intensa preocupação social, econômica, política e, por óbvio, jurídica. Esta é apenas mais uma oportunidade de se expor que processo não é um sinônimo de formalismo, procrastinação ou injustiça. Ao contrário, o processo bem entendido e bem aplicado não é "lento", mas sim um instrumento de imposição de poder, garantista e célere, no limite do democraticamente tolerável e estruturalmente factível, sendo suficiente que este se adapte às necessidades de um direito material dinâmico, complexo, exigente e que requer do processualista atenção em alguns pontos nodais. Alguns desses pontos serão analisados com mais atenção à luz da idéia instrumentalista do processo.

\footnotetext{
${ }^{5}$ Dinamarco, A instrumentalidade do processo, p. 11.

6 "As formas são necessárias, mas o formalismo é uma deformação" (Liebman, Manual de processo civil, p. 327-328).
} 
Por sua vez, a atenção ao direito processual em processos administrativos de apuração de conduta é instrumento de fortalecimento e consolidação das decisões administrativas sobre a matéria. A esfera administrativa é uma das instâncias onde a ilegalidade de uma conduta (no sentido concorrencial da palavra) poderá ser apreciada. Para oferecer real utilidade à decisão do CADE no âmbito da defesa efetiva da concorrência, é preciso legitimá-la institucional e tecnicamente; torná-la a referência para futuros julgamentos (pela aplicação da cláusula de inafastabilidade do controle pelo Poder Judiciário), um paradigma estabelecido por um órgão com profundo conhecimento sobre a matéria. Em poucas palavras, deve ser incessante a luta para sanar vícios formais e estruturais em processos de apuração de conduta, bem como também incessante a correta perseguição dos escopos processuais antitruste.

Não se propõe uma desatenta jurisdicionalização do processo administrativo. Evidente que a importação de conceitos e de experiências é inevitável mais do que isso, ela é desejada, quando se toma consciência de que "o processo bem estruturado na lei e conduzido racionalmente pelo juiz cônscio dos objetivos preestabelecidos é o melhor penhor da segurança dos litigantes (...)" sendo "apto a cumprir integralmente toda a sua função sócio-político-jurídica atingindo em toda a plenitude todos os seus escopos institucionais". ${ }^{7}$ Mas essa importação deve ser sempre atenta, ou ao menos profícua e seletiva: que se importe aquilo que funciona; que os defeitos sejam deixados de lado.

A OCDE afirma que "The BCPS (Brazilian Competition Policy System) agencies exhibit a strong institutional dedication to high standards of integrity, autonomy, sound policy, and fair procedure; have an excellent leadership cadre; and enjoy a supportive business community". 8 Somos capazes ainda assim de uma autocrítica processual? Aos olhos estrangeiros, merecemos ecômios. Será possível melhorar, fazendo da procedure ainda mais fair? Seria nosso processo fair enough?

Comparato já reconhecia em concepção mais ampla que "não basta reconhecer o mal-estar persistente do mundo jurídico, diante da evolução da sociedade moderna, e o incontestável divórcio entre o direito e a realidade social. Por outro lado,

\footnotetext{
${ }^{7}$ Dinamarco, A instrumentalidade do processo, p. 329-330.

8 OECD, "Competition law and policy in Brazil", in Policy Brief, 2005 (disponível em http://www.oecd.org/dataoecd/62/35/35415135.pdf).
} 
seria inútil, senão ridículo, continuar a denunciar a torto e a direito o demônio das ‘inovações perniciosas'. O exorcismo é totalmente ineficaz nesse terreno. A moléstia exige, ao contrário, um diagnóstico menos precipitado e uma terapêutica mais minuciosa".9

São claras as benesses de se transportar para a esfera administrativa alguma riqueza conceitual extraída do desenvolvimento da ciência processual perante a esfera judicial. Em especial aquela referente ao processo civil, cujo apuro é referência de desenvolvimento científico. ${ }^{10}$

Espera então a criação de círculo virtuoso: o reforço institucional do SBDC chega ao conhecimento da sociedade; reconhece-se o instrumental antitruste, com o enraizamento de uma cultura de defesa da concorrência; o enraizamento dessa cultura auxilia na quebra de uma possível litigiosidade contida a respeito da matéria; garantido o acesso aos órgãos do SBDC, deve ele, além de aplicar com rigor as normas de direito material, respeitar atentamente normas processuais; fazendo dessa forma, a possibilidade de anulação de uma decisão condenatória perante o Poder Judiciário é substancialmente reduzida; se o percentual de anulação é reduzido, a arrecadação aumenta; com a redução do percentual de anulação, a confiança dos cidadãos na instituição aumenta, o que pode também levar ao aumento de denúncias de condutas; o excesso de demandas conduz à crescente necessidade de ampliação da estrutura dos órgãos do SBDC (v.g., crescimento físico, de pessoal), possibilitando ao órgão atender adequadamente todas as representações feitas; finalmente o aumento do número de demandas cuja decisão final - ainda que proferida em sede Jurisdicional - coincida com a decisão do CADE consolida o fortalecimento institucional do SBDC, estabelecendo uma mensagem aos administrados destinada a educar e coibir a realização de ilícitos antitruste, fechando esse círculo virtuoso.

Aplica-se o direito processual em sede administrativa, sem perder de vista sua específica função nesta sede de oferecer meios para a preservação da ordem econômica, regulada por intermédio de intervenção estatal e sem descurar também do fato de que o direito concorrencial é instrumento de preservação da ordem econômica, implementado por meio da proteção do consumidor e do pleno emprego, da redução das

\footnotetext{
${ }^{9}$ Comparato, “O indispensável direito econômico", p. 453.

${ }^{10}$ Ainda que se discuta a própria natureza do processo administrativo de apuração de conduta, conforme será exposto no item V.4.
} 
desigualdades sociais, da proteção da livre iniciativa dentro dos limites da legalidade, da razoabilidade e da proporcionalidade. Somente dessa forma é possível promover mudanças político-institucionais e a discussão política de valores protegidos pelas normas: sempre ciente de que o direito material e o direito processual aliados trabalham como a mola propulsora da mudança político institucional e expressam aquilo que se conhece da própria sociedade. Sendo assim, "urge então reconhecer normas que incorporem valores, metas individuais e sociais, exatamente para que não sejam mera extensão dos direitos individuais" - não só as de direito material, como também as de direito processual, conforme será demonstrado. ${ }^{11}$

É o que se pretende ao examinar o instrumento do instrumento, de modo que essa potência seja capaz de instrumentalizar a correta imposição de poder.

\footnotetext{
${ }^{11}$ Salomão Filho, Direito concorrencial - as condutas, p. 43-45.
} 


\section{BREVES CONSIDERAÇÕES SOBRE A TUTELA DA CONCORRÊNCIA}

\section{II.1. O Direito Concorrencial}

O mercado surge de práticas reiteradas de comerciantes em seus usos e costumes, impondo-se a lex mercatoria com seus tipos contratuais e contratos socialmente típicos, organizando-se sobre patamares compostos por uma racionalidade jurídica e econômica que interagem. É indispensável a idéia de uma ordem jurídica do mercado que estabeleça comportamentos calculáveis destinados a oferecer segurança e previsibilidade e possibilitar o fluxo das relações econômicas por meio de uniformidade e de regularidade de condutas. Desde a Grécia Antiga são feitas remissões a monopólios e as práticas concertadas; no Império Romano, há referências à regulamentação de estatal de monopólios e sua ulterior proibição per se. A idade média contempla pontos interessantes para o antitruste nas corporações de ofício. Essas instituições têm como missão a proteção dos interesses privados comuns, a neutralização da concorrência entre seus partícipes por meio de estatutos e outras formas de fiscalização, o controle da oferta, a manutenção da atividade monopolística e a gênese dos cartéis; das Comunas vem a reação a essas corporações por meio de regulações no interesse do consumidor, da fixação de lucro máximo e das feiras como mecanismos viabilizadores de concorrência. No desenvolvimento do mercantilismo, fizeram-se notar medidas destinadas à redução dos efeitos nocivos dos monopólios ilegais, enquanto ainda presentes os monopólios legais estabelecidos pelos soberanos em prol do bem comum. ${ }^{12}$

O cenário passa a um novo patamar quando, em 1603, inicia-se na Inglaterra um movimento de reação aos monopólios legais, determinados pelo Estado (ainda que incipientes as idéias de livre iniciativa e livre mercado), com o caso dos monopólios das cartas de jogo. Os efeitos danosos do monopólio para a economia e para o bem comum eram questionados, o que culminou em 1624 com a aprovação do Statute of Monopolies inglês e a vedação à concessão real de monopólios. Sucederam-se então novos marcos. A revolução industrial traz o anseio pela liberdade na conquista de mercado e de consumidores; eliminam-se gradativamente as corporações de ofício; Adam Smith concebe

\footnotetext{
${ }^{12}$ Forgioni, Os fundamentos do antitruste, pp. 23-52.
} 
The Whealth of Nations e a libertação do agente econômico pelo não-intervencionismo estatal; pregam-se as benesses da concorrência como meio de preservar preços menores, garantir maior qualidade de produto, assegurar a liberdade de atuação do empresário, reagir aos monopólios e regular o mercado sem a atuação exógena, cabendo ao Estado a harmonização de conflitos e a viabilidade da fluência das relações de mercado. ${ }^{13}$

Mas o regime acaba por favorecer altas concentrações, preços de monopólio, prejuízos à classe operária, insatisfação popular, sendo necessárias regras de correção do sistema para preservação do livre mercado por meio do controle da excessiva acumulação de poder - é a superação do paradoxo da regulação como forma de preservação de estruturas, sem extirpar a liberdade, por meio da eliminação de distorções conjunturais decorrentes do próprio mercado ou do modo de produção. Em 1890, como fruto de decisões que internalizaram a concepção da regulação, é editado o Sherman Act (primeiro diploma antitruste de relevância) como instrumento de reação aos trustes, de tutela do mercado contra seus efeitos autodestrutíveis e de encorajamento da concorrência. A tal diploma abstrato foi integrado o exemplificativo e sistemático Clayton Act, que inspirou legislações com a descrição de condutas tipificadas e as qualifying clauses. Criase a Federal Trade Comission em 1914. ${ }^{14}$

Novos dados históricos são relevantes para a disciplina da concorrência, entre eles a primeira grande guerra, ${ }^{15}$ o crash da bolsa de Nova York, a estagnação e desemprego decorrentes que levam a um novo intervencionismo do Estado na indústria, na agricultura e no sistema financeiro, securitário e de comércio: é a idéia de que "o Estado passa a dirigir o sistema, com o escopo de evitar crises", influenciada por Keynes. Nesse contexto, "identificam os teóricos o nascimento do direito econômico como um ramo do direito: 'o conjunto as técnicas de que lança mão o Estado contemporâneo na realização de sua política econômica'". ${ }^{16}$ Em seguida, a segunda grande guerra, a concentração de poder em países industrializados, as políticas de desenvolvimento do terceiro mundo, a guerra fria, a corrida armamentista, as empresas supranacionais e os respectivos órgãos de

\footnotetext{
${ }^{13}$ Forgioni, Os fundamentos do antitruste, pp. 58-82.

${ }_{15}^{14}$ Forgioni, Os fundamentos do antitruste, pp. 52 e ss.

15 "A economia, mais do que qualquer outra atividade, tradicionalmente civil, transformou-se sob a ação do novo fenômeno bélico. Demonstrado que a guerra não se ganha somente nas frentes de combate, mas também e sobretudo nos campos, nas usinas, nas fábricas e nos laboratórios, ao estado não era mais indiferente a evolução das atividades econômicas ou as decisões dos agentes da economia privada. Cumpria, ao contrário, submete-los antes de tudo às exigências da guerra" (Comparato, "O indispensável direito econômico", p. 15).

${ }^{16}$ Forgioni, Os fundamentos do antitruste, p. 85, referindo-se à definição de Comparato.
} 
controle são fatos que desenham o contexto de uma ciência recentemente descoberta e que precisaria se adaptar a um novo cenário. As doutrinas alemã, francesa e italiana se debruçam sobre um tema pouco tradicional e reescrevem o intervencionismo global e sistemático do Estado sobre as estruturas econômicas. ${ }^{17}$

A intervenção do Estado passa a se dar por meio das técnicas que vão da preservação à condução, direção e organização do mercado, de forma direta ou indireta, por absorção, participação e regulação do processo de produção. ${ }^{18}$ Dentre essas técnicas, fica o destaque às normas de regulação da concorrência entre os agentes econômicos, a norma antitruste. Vem então a noção de concorrência como instrumento, pois "não é um valor absoluto, mas um meio normal, eventualmente privilegiado, de obter o equilíbrio econômico" extraído dos ideais dos tratados da Comunidade Européia. É uma disciplina inserida em contexto de dupla instrumentalidade, que organiza processos segundo regras de mercado e converte-se em instrumento de influência sobre esses mesmos processos, para o desenvolvimento de políticas públicas. ${ }^{19}$

De extrema importância foi o desenvolvimento de grupos que interpretaram normas antitruste à luz do desenvolvimento histórico, político, econômico e jurídico de seus respectivos contextos. São as chamadas escolas de pensamento, linhas gerais sobre a função da lei antitruste, analisadas aqui de forma sucinta. ${ }^{20}$

A chamada escola de Harvard, estruturalista, defende que o Estado deve evitar excessivas concentrações do poder de mercado (small is beautiful), encontrar um modelo de workable competition e aumentar o número de agentes econômicos. ${ }^{21}$ Os axiomas da escola de Chicago (iniciada nos anos 50 e com seu ápice nos anos 80), por sua vez, vertem para as seguintes idéias: a análise econômica como instrumento de eficiência alocativa de mercado e do bem estar da economia (dar aos beneficiários das medidas mais dinheiro do que o montante retirado dos prejudicados) $)^{22}$ com reflexos positivos para os

\footnotetext{
${ }^{17}$ Comparato, "O indispensável direito econômico", passim.

${ }^{18}$ Grau, A ordem econômica na constituição de 1988, nn. 49 e ss.

19 Especialmente no caso da Comunidade Européia, o valor concorrência foi utilizado com importante bandeira de integração Comunitária. Forgioni, Os fundamentos do antitruste, p. 85-93.

${ }^{20}$ Ainda que com o risco de aparente esterilidade e sem considerar as diferenças de perspectivas doutrinárias de cada um dos autores das escolas, para os fins propostos neste estudo. "Mais que objetivos, estamos falando da relação entre instrumentos e objetivos possíveis. E, acima de tudo, estamos tratando com princípios" (Forgioni, Os fundamentos do antitruste, p. 164).

${ }^{21}$ Forgioni, Os fundamentos do antitruste, n. 4.1.

22 "Orthodox Chicago School Antitrust policy is predicated on two assumptions about the goals of the federal antitrust laws: (1) the best policy tool currently available for maximizing economy efficiency in the real
} 
consumidores, contestação da ilicitude dos acordos verticais ${ }^{23}$ e o estudo do paradoxo decorrente da preservação e do combate à concorrência pela ingerência do Estado. ${ }^{24} \mathrm{~A}$ aplicação das normas da concorrência a casos concretos se daria em ambiente supostamente asséptico, livre de conflitos de princípio ou de interesses,${ }^{25}$ livre de escolhas políticas, técnico, racional, neutro, redutível em fórmulas econômicas. A previsibilidade econômica reduziria a complexidade do direito e da economia, na medida em que "the public purpose of theoretical economics is not to eliminate distributive justice as a public policy concern. Rather, it is to enable policymakers to make some judgments about the costs or effectiveness of a particular policy". ${ }^{26}{ }_{-}^{27}$

world is the neoclassical price theory model; and (2) the pursuit of economic efficiency should be the exclusive goal of antitrust enforcement policy" (Hovenkamp, "Antitrust policy after Chicago", p. 226).

${ }^{23}$ Sobre o tema, cfr. Hovenkamp, "The Harvard and Chicago Schools and the dominante firm", p. 5. Em relação à antiga disputa entre as correntes, o autor afirma que, "The Chicago School has produced many significant contributions to the antitrust literature of the last half century. Thanks in part to Chicago School efforts today we have an antitrust policy that is more rigorously economic, less concerned with protecting noneconomic values that are impossible to identify and weigh, and more confident that markets will correct themselves without government intervention. This Chicago School revolution came at the expense of the Harvard "structural" school, which flourished from the 1930s through the 1950s", mas conclui que "antitrust law as produced by the courts today comes much closer to representing the ideas of a somewhat chastised Harvard School than of any traditional version of the Chicago School" (idem, p. 1-8). Afirma ainda que a escola de Chicago é mortal, explicando a pertinência das críticas a ela feitas (Hovenkamp, "Antitrust policy after Chicago", pp. 216-217).

${ }^{24}$ Cfr. Sobre o tema Bork, The Antitrust Paradox , passim.

${ }^{25}$ Exemplo marcante do tema é dado por Richard Posner, ao analisar os benefícios da criação de um mercado de adoção de crianças. Examina o custo de "produção", os investimentos na manutenção e educação da uma criança, a negligência de pais que não desejam os filhos e seus efeitos para as crianças, o déficit do Estado no balanceamento da oferta e demanda por adoções e o mercado negro existente. Ao final, afirma que seria melhor atuar o direito por um contrato regulado por lei que em um mercado negro, estabelecendo claramente a diferença entre os "pais que criam", que nao receberiam direitos familiares, e os "pais adotivos", que receberiam esse direito ("The legal protection of children", pp. 149-154).

${ }^{26}$ Vale aqui a descrição breve do que Posner entende por economia para compreender em que ponto essa ciência encontra o direito. Economia seria " "the science of rational choice in a world - our world - in which resources are limited in relation to human wants'. Posner sees economics not as the science of choice per se, but of 'rational' choice. An understanding of his view of economics, therefore, requires that he develop a definition of rationality. In his most recent work, Posner gives an admittedly imprecise and non-rigorous definition of economic rationality as 'choosing the best means to the chooser's ends...'. He explains further in his textbook that ' $[t]$ he task of economics, so defined, is to explore the implications of assuming that man is a rational maximizer of his ends in life, his satisfactions -- what we shall call his 'self- interest"' (Jeanne L. Schroeder, "Economic rationality in law and economics scholarship").

${ }^{27}$ Hovenkamp, "Antitrust policy after Chicago", pp. 218-220; Forgioni, Os fundamentos do antitruste, n. 4.1. Hovenkamp afirma em outra obra que "orthodox Chicago School antitrust policy is predicated on two assumptions about de goals of the federal antitrust laws: (1) the best policy tool currently available for maximizing economic efficency in the real world is the neoclassical price theory model; and (2) the pursuit of economic efficency should be the exclusive goal of antitrust enforcement policy". O autor lista premissas básicas econômicas dessa escola, relacionadas com a eficiência alocativa e produtiva, a diferenciação de produtos, a auto-correção de um monopólio pelo mercado, as imaginárias barreiras naturais à entrada, as econômicas de escala, a relação entre a maximização dos lucros entre algumas empresas e as demais e o afastamento de conceitos políticos das decisões (“Antitrust policy after Chicago", p. 226). 
A escola de Chicago foi revisitada. Os críticos pós-Chicago afirmam que a despeito de alguns benefícios trazidos por determinadas condutas (especialmente no campo de acordos verticais), existe a possibilidade de prejuízo a justificar a atuação antitruste porque os ganhos de eficiência não compensariam as barreiras à entrada criadas e os prejuízos aos consumidores. Outro ponto também levantado está relacionado com os modelos econômicos, cuja simplicidade neoclássica cede espaço a uma política antitruste que admite complexidades e ambigüidades. Um modelo de eficiência é dificilmente aplicado na democracia do mundo real (não há notícia que uma política econômica tenha tido sucesso no alcance do ótimo paretiano) e não pode ser o único fator relevante em uma política antitruste, dada a impossibilidade, na maioria dos casos de comprovação ou afastamento das premissas ali estabelecidas (é preciso considerar o valor que as pessoas dão, v.g., ao poder político e ao pequeno negócio e não somente ao capital). ${ }^{28}$ Surgem teorias relevantes como as que questionam a natureza estática do price theory model e que analisam a repressão aos comportamentos estratégicos. ${ }^{29}$

Em artigo sobre a política antitruste de Obama, ratifica-se a idéia de que "if history is a reliable teacher, antitrust enforcement is cyclical - enforcement comes and goes. The Chicago School may simply have run its cycle and the time inevitably come for a more interventionist antitrust regime". ${ }^{30}$ Ao final, embora diversos objetivos sejam atribuídos à concorrência "o mais comum dos objetivos citados é a manutenção do processo competitivo ou da livre concorrência, ou a proteção ou promoção da concorrência eficaz. Os propósitos a eles associados são a liberdade de comércio, liberdade de escolha e acesso aos mercados". 31

Bem se vê que as escolas indicam uma maior ou menor intensidade da pretensão regulatória também sobre as chamadas falhas de mercado (imperfeições ou inoperacionalidades), ou "situação em que o mercado, por si só, não consegue produzir uma alocação eficiente de recursos (...) quando os mercados falham, a política pública

\footnotetext{
28 “(... First, the) notion of efficiency based on the neoclassical market efficiency model is naïve. That notion both overstates the ability of the policymaker to apply such a model to real world affairs and understate the complexity of the process by wich the policymaker must select among competing policy values. Second, the neoclassical market efficiency model is itself too simple to account for or to predict business firm behavior in the real world" (Hovenkamp, "Antitrust policy after Chicago", p. 284).

${ }^{29}$ Hovenkamp, “Antitrust policy after Chicago", esp. pp. 225 e ss; Forgioni, Os fundamentos do antitruste, n. 4.1.

${ }^{30}$ Crane, "Obama's antitrust ambitions", com referência ao aumento do enforcement of antitrust laws in Brazil.

${ }^{31}$ OECD, Diretrizes para elaboração e implementação de política de defesa da concorrência, p. 31.
} 
pode, em alguns casos, solucionar o problema e aumentar a eficiência da economia". ${ }^{32}$ Elas são ordinariamente designadas como: a falha de mobilidade (os fatores de produção não são dotados de mobilidade para reagir às indicações e evitar fatores indesejáveis como sub ou superprodução - o Estado tem o papel de indutor ou refreador da atividade econômica); de transparência (não há identificação perfeita de produtos, qualidades, atributos, diferenciações - reflexo está no Código de Defesa do Consumidor, numa Lei Societária mais atenta, de maior atenção no mercado de capitais, protegendo assim a economia popular); de estrutura (o mercado deve ser atomizado, com número elevado de compradores e vendedores em interação recíproca); de sinalização (o sistema de preços não transmite todas as informações relevantes para o mercado e nem todos os custos $\mathrm{e}$ benefícios da atividade são apropriados pelas unidades produtoras; são externalidades positivas ou negativas, com efeitos perante o direito tributário, ambiental, urbanístico); e de incentivo (o Estado supre da desídia do mercado em relação aos bens coletivos dotados de alto coeficiente de externalidades positivas). ${ }^{33}$ A eliminação dessas falhas de mercado pela intervenção do Estado, em política de regulamentação mais ostensiva, complementa a atuação abstrata de proteção institucional da concorrência e do bem estar social. ${ }^{34}$

A Europa vive um século XX inicialmente preocupado com políticas de nacionalização, destinadas à eficiência alocativa, a redistribuição democrática de recursos, pleno emprego, redução inflacionária, reequilíbrio econômico e crescimento. O direito europeu, a despeito da influência norte-americana, tem história própria e ampla influência da escola alemã de Frieburg, o chamado ordo-liberalismo. Ela nasce da produção de

\footnotetext{
${ }^{32}$ Mankiw, Introdução à economia, pp. 11 e 154.

${ }^{33}$ Fábio Nusdeo, Curso de economia, cap. 7. Sobre a correlação entre a atuação do Estado sobre as falhas de mercado, cfr. Crane, “Obama's antitrust ambitions”, passim). A questão das falhas de mercado é de longa data controversa e intensamente debatida, como verdadeiro duelo de escolas de pensamento. Há quem entenda as contramedidas devem ser sempre diretas, pressupondo cuidado e a incapacidade de se desenvolver mecanismos seguros para sua eliminação - uma secon best policy (cfr. Krugman-Obstfeld, International economics: theory and policy, pp. 226 e ss). O tema das falhas de mercado é amplamente debatido. Mattos afirma que em perspectiva econômica, a ação regulatória do Estado estaria destinada à correção de falhas de mercado, estabilização e desenvolvimento econômico e promoção de valores sociais e culturais. A atuação se daria por meio do controle de poder monopolista para solucionar problemas de eficiência alocativa; do controle sobre informações inadequadas em prol dos consumidores, da criação de incentivos econômicos entre agentes consumidores de bens coletivos, da correção de externalidades negativas, do controle de lucros inesperados, da eliminação de competição excessiva nos casos em que ela possa levar à prática de preços abaixo do custo e falência de empresas no longo prazo, da crise de escassez, do controle de problemas de representação, da solução de problemas distributivos e do planejamento econômico ( $O$ novo estado regulador no Brasil: direito e democracia, pp. 20-31).

${ }^{34}$ Posner, porém, critica a correlação o intervencionismo e as falhas: "aproximadamente quinze anos de pesquisas teóricas e empíricas, conduzidas principalmente por economistas, demonstraram que a regulação não está necessariamente relacionada à presença de externalidades, ou ineficiências, ou estruturas monopolistas de mercado" (Posner, "Teorias da regulação econômica", p. 51).
} 
Walter Euken, Franz Böhm e Hans Großmann-Doerth, na década de trinta, sobre os fundamentos constitucionais da livre economia e da sociedade. Da contraposição entre a institucionalização das colusões nazistas e o pensamento liberal alemão e da incapacidade de o sistema prevenir abusos do poder econômico, define-se um pensamento liberal ordenado. Segundo o pensamento ordo-liberal, o excesso de iniciativa pública e de poder econômico privado é nocivo à economia, razão pelo qual o direito influi sobre o sistema econômico para criar e manter condições para funcionamento da concorrência. Politicamente, encontrou apoio em correntes socialistas antimonopolistas e conservadores proprietários de pequenos negócios. O pensamento alemão influenciou na criação de um sistema econômico social de mercado $^{35}$ e promove crítica em relação aos neoliberais especialmente em relação à mera teorização de pressupostos econômicos liberais na definição de bem estar do consumidor e à impossibilidade de se almejar somente um conceito (a eficiência) como referência, promovendo-se ao contrário um quadro institucional capaz de promover a promoção de um ambiente concorrencial. ${ }^{36}$

O ordo-liberalismo e sua perspectiva constitucional têm influenciado o pensamento de modernização do direito antitruste. $\mathrm{O}$ direito europeu vem dedicando especial atenção aos critérios de exame de ilícitos (per se ou analisados caso a caso), aos potenciais efeitos pró-competitivos de determinados comportamentos e à eficiência como critério a ser considerado pelas autoridades. A perspectiva econômico-constitucional indicaria que esquemas econômicos hipotéticos devem ter como finalidade os interesses comuns dos cidadãos (o bem estar social): "welfare considerations can have their legitimate place only at the constitutional level where the rules of the economic game are

\footnotetext{
35 "For the Freiburg School the market order, as a non-discriminating, privilige-free order of competition, is in and by itself an ethical order. As fas as the need for "social insurance" is concerned, the Freiburg ordoliberals recognized that the competitive market order can be, and should be, combined with a system of minimal income guarantees for those who are, temporarily or permanently, unable to earn a living by providing saleable services in the market. They insisted, though, that such social insurance provisions must be of a nondiscriminating, privilege-free nature, and must not be provided in ways - e.g. in the form of subsidies or other privileges granted to particular industries - that corrupt the fundamental ethical principle of the market order, namely its privilege-free nature" (Vanberg, "The Frieburg school: Walter Eucken and ordoliberalism", Freiburg Discussionpapers on Constitutional Economics 04/11, disponível em http://www.walter-eucken-institut.de/fileadmin/bilder/Publikationen/Diskussionspapiere/04_11bw.pdf); cfr. ainda Leitão Marques, Um curso de direito da concorrência, pp. 29-34. A legislação alemã divide o Direito Concorrencial em duas áreas: concorrência no sentido lato, com a lei UWG - Gesetz gegen den unlauteren Wettbewerb, que trata de concorrência desleal, e concorrência em sentido estrito, GWB - Gesetz gegen Wettbewerbsbeschränkungen, que trata de direito antitruste (Direito de Cartel, como a doutrina alemã o denomina). O GWB foi alterado pela última vez em $1^{\circ}$ de julho de 2005 , quase totalmente harmonizado à legislação antitruste européia, em especial aos arts. 81 e 82 Tratado de Roma.

${ }^{36}$ Gaban-Domingues, Direito antitruste: o combate aos cartéis, p. 118-119.
} 
chosen. It is at this level, but not at the sub-constitutional level that an 'effects-based approach' can help to improve competition policy". ${ }^{37}$

$\mathrm{Na}$ Comunidade Européia, declara-se manifestamente que um dos principais escopos da atuação antitruste está previsto no art. $2^{\circ}$ de seu tratado, ${ }^{38}$ ou seja, a concorrência é instrumento para a criação e desenvolvimento harmonioso, sustentável e equilibrado de um mercado comum, passível porém de sacrifício em prol da prosperidade por não se tratar de um valor absoluto. É um instrumento que se origina da interação de idéias políticas e jurídicas de cada um dos países integrantes, o que denota uma luta constante (um paradoxo) entre a necessidade de preservação da concorrência e o protecionismo dos mercados nacionais. O direito concorrencial europeu firma-se então como instrumento de integração do mercado e de eliminação de práticas restritivas que interfiram nessa integração, aos cuidados da Comissão. ${ }^{39}$

Se o Brasil é um país que ainda absorve as lições do antitruste europeu e americano, vale a análise de país também marcado por regimes autoritários e mercado corporativo, desconfiado de virtudes concorrenciais e altamente intervencionista (por meio do condicionamento industrial e dos grêmios - associações - obrigatórios), que abre seus mercados tardiamente. Portugal liberta-se do autoritarismo e da institucionalização de restrições à concorrência em 1976 e em 1983 passa a ter um regime antitruste efetivamente

\footnotetext{
${ }^{37}$ Vanberg, "Consumer Welfare, Total Welfare and Economic Freedom - On the Normative Foundations of Competition Policy". Ao final, afasta-se a análise de ilícitos caso por caso, mas identifica a importância das predições econômicas na identificação de efeitos e eficiências.

38 "A Comunidade tem como missão, através da criação da um mercado comum e de uma união econômica e monetária e da aplicação das políticas ou ações comuns a que se referem os artigos $3^{\circ}$ e $4^{\circ}$, promover, em toda a Comunidade, o desenvolvimento harmonioso, equilibrado e sustentável das atividades econômicas, um elevado nível de emprego e de proteção social, a igualdade entre homens e mulheres, um crescimento sustentável e não inflacionista, um alto grau de competitividade e de convergência dos comportamentos das economias, um elevado nível de proteção e de melhoria da qualidade do ambiente, o aumento do nível e da qualidade de vida, a coesão econômica e social e a solidariedade entre os Estados-Membros".

${ }^{39} \mathrm{O}$ sistema concorrencial europeu tem origem no Tratado da Comunidade Européia do Carvão e do Aço (CECA), de 1951, que forneceu as bases para o Tratado de Roma. Da verve inicial, passando pela crise do petróleo, pelo retorno à internalização do mercado, pela liberalização inglesa da década de oitenta e pelo colapso da URSS, manteve-se sempre firme a estrutura que atribuía à Comissão o poder de zelar pela concorrência européia (Leitão Marques, Um curso de direito da concorrência, pp. 34-40). Na visão portuguesa, "a funcão das regras comuntárias da concorrência e dupla. Por um lado, uma função genérica de garantia de correcto funcionamento de um sistema de economia de mercado, procurando assegurar os fundamentos deste sistema, nomeadamente a liberdade de acesso ao mercado e as liberdades de determinação da oferta e da procura. Este objectivo deve ser articulado com a prossecução de finalidades econômicas mais concretas, como o crescimento, o equílibrio ou o pleno emprego, o que obriga a ter em consideração o quadro concreto de cada mercado e a compatibilizar a concorrência com outros instrumentos susceptiveis de atingir os funs enunciados no art. 2 do Tratado de Roma. (dos Santos-Goncalves-Marques, Direito economico, p. 295).

Cfr. ainda Oliveira-Rodas, Direito e economia da concorrência, pp. 9-13.
} 
aplicado, submetido à influência da constituição e das suas revisões. ${ }^{40}$ A Direcção-Geral da Concorrência e Preços foi recentemente substituída pela Autoridade da Concorrência (ADC), reformando-se a legislação com a promulgação da Lei n. 18/2003, assente na missão de assegurar a aplicação das regras de concorrência em Portugal, no respeito pelo princípio da economia de mercado e de livre concorrência, tendo em vista o funcionamento eficiente dos mercados, a elevação dos níveis de progresso técnico e a repartição eficaz dos recursos e os interesses dos consumidores.

A Itália também demonstra um histórico semelhante de pouca agilidade na edição de normas concorrenciais. A despeito de considerável doutrina econômica, foram necessários 100 anos para a edição, em setembro de 1990, da normativa antitruste, de poucos dispositivos axiológicos ou programáticos e de relevante inserção no contexto comunitário. ${ }^{41} \mathrm{O}$ país tentava editar norma concorrencial desde 1951, com amplos debates políticos sobre a natureza do órgão de controle da concorrência. Seguiram-se duas décadas de forte atuação direta do Estado na economia, firme na crença de que o setor produtivo e a industrialização italiana dependiam dessa intervenção - $60 \%$ das empresas do país chegaram a ser controladas pelo Estado - reduzindo, portanto, o risco de um monopólio criado fora do regime de intervenção. Foi somente a pressão decorrente do desenvolvimento da Comunidade Européia que catalizou a edição de uma normativa antitruste nacional a partir da década de 80. Das iniciativas do Senador Guido Rossi e do Ministro da Indústria Adolfo Battaglia surge, a lei n. $287 .{ }^{42}$

Todas essas escolas representam pensamentos que, de uma forma ou de outra, conformaram o direito antitruste brasileiro.

\section{II.2. O Direito concorrencial no Brasil - histórico e legislação}

No Brasil, a exploração da colônia era feita com vistas à ampliação das receitas fiscais da metrópole e não havia incentivos ao desenvolvimento industrial - trata-

\footnotetext{
${ }^{40}$ Leitão Marques, Um curso de direito da concorrência, pp. 40-49.

${ }^{41}$ Crf. seu art. $1^{\circ}$, pelo qual "le disposizioni della presente legge in attuazione dell'articolo 41 della Costituzione a tutela e garanzia del diritto di iniziativa economica, si applicano alle intese, agli abusi di posizione dominante e alle concentrazioni di imprese che non ricadono nell'ambito di applicazione degli articoli 65 e/o 66 del Trattato istitutivo della Comunità europea del carbone e dell'acciaio, degli articoli 85 e/o 86 del Trattato istitutivo della Comunità economica europea (CEE), dei regolamenti della CEE o di atti comunitari con efficacia normativa equiparata".

${ }^{42}$ Bernini, “In tema di norme a tutela della libertà di concorrenza: il caso Italia”, p. 259.
} 
se da chamada fase fiscalista, marcada de política intervencionista do Estado português em meio a monopólios reais ou concedidos. Esse sistema perdurou até a chegada da Corte portuguesa no início do século XIX, que incentivou o desenvolvimento econômico brasileiro pela abertura dos portos, a fundação do Banco do Brasil, a liberdade para criação de manufaturas e indústrias e a implementação do embrião do liberalismo (com o pensamento de Visconde de Cairu). ${ }^{43}$

A regência e o reinado, porém, foram períodos de consolidação de política agrícola, desenvolvimento do café, afirmação dos seus produtores no governo, crescimento da mão de obra, políticas cambiais questionáveis e pouca relevância do liberalismo (sem prejuízos do surgimento de figuras importantes e questionadoras como o Visconde de Mauá), dados que tiveram profundo reflexo na formação econômica do Brasil. $^{44}$

A partir da década de trinta, os fatos tornam-se cada vez mais relevantes e importantes para a construção de um ambiente concorrencial. A liberdade econômica ganha status constitucional (CF/34, art. 115), ainda que timidamente e restrita pelos interesses nacionais em razão do crack da Bolsa de Nova York. ${ }^{45}$ Essa ampla atuação do

\footnotetext{
${ }^{43}$ Sobre os reflexos de temas relevantes para a formação econômica brasileira, tais como a independência, a abertura dos portos e o desaparecimento do entreposto lusitano, cfr. Celso Furtado, Formação econômica do Brasil, n. 17. Sobre o tema, confira-se também as lições de Calixto Salomão Filho: o autor discorre, em perspectiva estrutural, sobre a relevância dos monopólios sobre o desenvolvimento das colonias como elemento que retirava estímulo econômico interno para a economia, a pequena transferência de renda acarretada, a dificuldade de formação de mercado de consumo e, em última análise, uma rigidez social de difícil permeabilidade, uma importância irrisória dada à pequena propriedade e a desorganização das forças de mercado ("Monopólio colonial e subdesenvolvimento", pp. 173 e ss.).

${ }^{44}$ Forgioni, Os fundamentos do antitruste, pp. 105-108. Furtado contextualiza a industrialização americana e o subdesenvolvimento latino americano (um dos fundamentos do menor desenvolvimento da cultura antitruste). Enquanto os Estados Unidos detinha classe de pequenos agricultores, grandes comerciantes urbanos e menor grau de medidas protecionistas, um intérprete que se transformaria no paladino da industrialização pela ação estatal de caráter positivo, uma forte alavancagem industrial promovida pelo algodão, uma correta gestão do crédito pelo Governo, o Brasil continha uma classe dominante de agricultores exportadores, presos aos ciclos altos e baixos e um pensador crente exclusivamente na mão invisível do mercado, a despeito de políticas protecionistas. Assim, "não conseguindo o Brasil integrar-se nas correntes em expansão do comércio mundial durante essa etapa de rápida transformação das estruturas econômicas dos países mais avançados, criaram-se profundas dessemelhanças entre seu sistema econômico e os daqueles países" (Formação econômica do Brasil, nn. 18, 25, 30). Cfr. ainda a obra de Aguillar, Direito econômico do direito nacional ao direito supranacional, pp. 71-176.

${ }^{45}$ Sentido no Brasil em razão de uma política de dependência da cultura do café, suas inversões, a pressão inflacionária exercida e a inicial ausência de alternativas industriais aos investidores. Após a quebra, há uma aceleração da produção industrial e o crescimento do mercado interno. Essa mudança de panorâma dita as regras de uma política cambiária que reconhece a substuição das importações por artigos de produção interna. Considere-se ainda o pós-guerra, a liberação das importações e o impacto sobre a balança, a ulterior limitação de importação de produtos manufaturados e o deslocamento do foco para as importações, com consequiências inflacionárias evidentes (Furtado, Formação econômica do Brasil, n. 32 e ss.). Para Salomão Filho "os monopólios de exportação transmudam-se de agrícolas em industriais. Mantém-se a economia, os outros
} 
Estado sobre o domínio econômico gerou reação de setores de uma indústria que emergia, clamando por um estado que atuasse somente para suprir as deficiências da iniciativa privada, coordenar fatores de produção, mas principalmente para a proteção da economia popular contra abusos, ideais refletidos nos arts. 135 e 141 da CF/37. Sobrevém então o Decreto lei n. 869/38, considerada a primeira lei antitruste brasileira, de pouca aplicação, voltada à tutela da economia popular e do consumidor contra açambarcamento, manipulação de oferta e demanda, preços predatórios e cláusulas de exclusividade. É editado ainda o Decreto 7.666/45 (lei Malaia), nascido do Projeto Agamemnon Magalhães no intuito de combater o poder econômico derivado do capital estrangeiro e aprovado em conturbado contexto político do Governo Getúlio Vargas. A lei Malaia teve vigência por menos de um ano, mas sistematizou o tratamento da concorrência ao estabelecer "a repressão administrativa aos trustes, aos cartéis e todas aquelas combinações que visam a dominar o mercado nacional”. Sob a égide da Constituição de 46 e do seu art. 148, que previu a repressão ao abuso do poder econômico, é promulgada a lei n. 1.512/51. ${ }^{46}$

Foi a promulgação da lei n. 4.137/62 que criou o CADE como Conselho Administrativo de Defesa Econômica, diploma que contém em si a dinâmica repressiva e preventiva do abuso do poder econômico. Porém, a norma teve escassa eficácia material, com apenas onze processos julgados até 1975, uma condenação, decisões suspensas pelo Poder Judiciário e, em um cômputo geral, a identificação de um órgão inoperante. Sobreveio então a constituição de 1988, dedicando todo um capítulo aos princípios gerais da atividade econômica, e especificamente a proteção à livre concorrência $(\mathrm{CF} / 88$, art. 170, inc. IV), em um ambiente político de abertura de mercado, liberalização econômica.

O direito concorrencial e a proteção da ordem econômica ganham importância no Brasil especialmente a partir da década de 90, em razão do fim do regime ditatorial, das "privatizações", da abertura da economia nacional, do fenômeno da globalização, da estabilização da moeda e do estímulo da economia de mercado. E tem sua pedra fundamental no art. 173, par. 4º da CF. Promulga-se a lei n. 8.158/91 (após conversão da MP 204/90), criando-se a Secretaria Nacional de Direito Econômico, do Ministério da Justiça. Retirou-se o CADE do ostracismo, mas mantinha-se a pecha de que

setores e o próprio Estado sob total domínio. Por depender dos preços dos produtos exportados, não se forma círculos virtuosos de criação de renda e investimento" ("Monopólio colonial e subdesenvolvimento", p. 185).

${ }^{46}$ Forgioni, Os fundamentos do antitruste, pp. 108-122. 
o órgão seria "instrumento de ameaça de retaliação por parte do governo federal contra determinados setores da economia". 47

Finalmente, o diploma de 1994 transforma o CADE em autarquia federal com dotação orçamentária própria, cria o Sistema Brasileiro de Defesa da Concorrência, composto por três órgãos - o CADE, a SDE e a SEAE. A nova lei concebida em ambiente de proteção constitucional da economia e da concorrência propõe em seu preâmbulo a "prevenção e a repressão às infrações contra a ordem econômica, orientada pelos ditames constitucionais de liberdade de iniciativa, livre concorrência, função social da propriedade, defesa dos consumidores e repressão ao abuso do poder econômico", de modo a proteger a coletividade, titular dos bens jurídicos por ela protegidos. Visa a assegurar existência digna, justiça social, aqueles valores sociais da livre iniciativa, a transformação social por meio da atuação do Estado. ${ }^{48}$

\section{II.3. Considerações sobre o escopo central de atuação do direito antitruste no Brasil}

Escopo é o ponto em que se mira, o alvo, a intenção, o objetivo. À luz das considerações feitas acima, é importante estabelecer então qual seria o escopo ou os escopos principais da atividade antitruste no Brasil.

As teorias que estabelecem os escopos para a atividade concorrencial (liberais, neoliberais, pós-chicago, ordo-liberais) procuram sempre estabelecer diretrizes que preservem, na medida do que se julga adequado ao bem estar social, a concorrência entre os agentes econômicos. Seja por meio de restrições às excessivas concentrações do poder de mercado, seja pela criação de instrumentos voltados à melhor eficiência alocativa, seja pela consideração de modelos sintéticos ou complexos que elevem valores outros ao patamar de dados relevantes para aquele que estuda e aplica o direito concorrencial, seja pela definição constitucional coordenada de preceitos economicos e sociais, o que se pretende é busca de um equilíbrio pró-competitivo que proteja a concorrência nas relações entre os agentes atuantes no mercado.

\footnotetext{
${ }^{47}$ Forgioni, Os fundamentos do antitruste, pp. 122-142.

${ }^{48}$ Sobre o histórico antitruste no Brasil, cfr. Oliveira-Rodas, Direito e economia da concorrência, pp. 17-24
} 
No Brasil, historicamente reconhece-se que a economia de mercado e a organização econômica demandam regras mínimas oferecidas pelo Estado para controle das relações econômicas. ${ }^{49}{ }_{-}^{50} \mathrm{O}$ direito econômico, em sua vertente antitruste preserva a legalidade no relacionamento entre concorrentes, a existência da concorrência e o repúdio às relações de poder típicas dos mercados livres. Assegura-se assim que "os agentes econômicos descubram as melhores opções e ordenem as relações econômicas da forma mais justa e equilibrada (...). Visto dessa forma - como garantidor da concorrência, e não do mercado -, o direito reassume aquele papel redistributivo ou garantidor da igualdade de condições nas relações econômicas, que sempre lhe incumbiu". ${ }^{51}$

Há quem aproxime o direito antitruste da proteção de indivíduos contra condutas efetivamente ou potencialmente lesivas, afirmando que a atuação antitruste é exercida por meio de atividade administrativa voltada a garantir e regular o correto desenvolvimento das relações econômicas privadas, admitindo-se, porém, uma "tutela dell'interesse pubblico generale al rispetto delle regole di concorrenza, affiancandosi su un piano distinto alla tutela dei diritti soggettivi pregiudicati da condotte vietate, ancorché l'azione amministrativa e la tutela giurisdizionale ben possano, talora, dispiegarsi contemporaneamente in relazione ad una stessa vicenda concreta". Independentemente da existência de um conflito entre privados, o direito antitruste age para repristinar as condições de concorrência em favor do interesse geral e para a manutenção das condições de concorrência, por meio de um sistema de garantia em benefício do interesse geral. Mesmo os mais renitentes reconhecem que a tutela do direito subjetivo do terceiro não é, de fato, condicional à valoração da administração: as duas atuações - tutela de direito subjetivo concorrencial e tutela de interesse geral à concorrência. ${ }^{52}{ }^{53}$

\footnotetext{
${ }^{49}$ Salomão Filho, Direito concorrencial-as estruturas, p. 15.

${ }^{50}$ A racionalidade econômica prevê o individualismo metodológico do agente econômico hobbesiano que exerce sua atividade voltado para a maximização dos lucros, do proveito com ou sem boa-fé. A racionalidade jurídica, de seu turno, atua como medida de equilíbrio, impondo que as condutas sejam tomadas em conformidade com um sistema normativo, calcado em escolhas políticas, históricas e sociais, fruto de um processo evolutivo. É a idéia de lucro e proveito sem predação e oportunismo, respeitando-se os princípios jurídicos orientadores do sistema. Os mercados são, portanto, uma produção jurídica que prevê a repetição de condutas necessária para a previsão de comportamentos e para o cálculo das ações, ordenada pelo direito posto pelo Estado. As relações do mercado não se realizariam se não houvesse o Estado produzindo direito, que instrumenta o governo objetivo das leis, instalando condições de segurança para o seu funcionamento, ainda que de forma peculiar, em um sistema aberto, incompleto e eventualmente incongruente, permeado pela estrutura ideológica (Grau, A ordem econômica na Constituição de 1988, caps. 1 e 2).

${ }^{51}$ Salomão Filho, Direito concorrencial - as condutas, p. 49.

52 Negri, Giurisdizione e amministrazione nella tutela della concorrenza, pp. 33-43. Parte da dúvida conceitual italiana pode ser atribuída ao processo de criação da norma antitruste. Em sua origem haviam dois
} 
Merece destaque, no campo dos escopos, a teoria que coloca em relevo a preocupação essencial do direito antitruste com as instituições, ao invés daquela atenção exacerbada aos mecanismos microeconômicos de orientação do mercado. $\mathrm{O}$ direito concorrencial tem assim como um dos escopos a garantia efetiva da concorrência, e não do mercado, devendo o Estado assumir posição intervencionista institucional, de modo a garantir o chamado processo de descoberta do consumidor, ampliando-se as possibilidades de escolha e oferecendo informações sobre preferências. ${ }^{54}$

A idéia de instituição é exposta no Brasil por Calixto Salomão Filho, que parte das normas de proteção do direito alemão (Schutzgesetze) e com uma crítica ao conceito processual, chega à idéia de que só se pode afirmar a existência de direitos difusos na presença de garantias institucionais, destinadas à proteção do interesse de cada indivíduo e da coletividade, seja ela numericamente determinável ou não, distinguindo-se um interesse juridicamente e economicamente destacável do interesse individual, com instrumentos protetores distintos dos interesses privados e com uma utilidade para a coletividade que não se confunda com a utilidade individual ou pública. Cria-se então um interesse sem titular onde pode ser identificada uma lesão patrimonial gerando condenação, cujo resultado é destinado a "recuperar e proteger o próprio interesse institucional", fortalecendo sobremaneira o papel político do órgão prolata um comando protetor de tal interesse. ${ }^{55}$ A idéia é reforçada pelo fato de que os direitos da ordem econômica são fundamentais de segunda geração direcionados às coletividades e que estabelecem comportamentos concretos para o Estado e, se necessário, para os indivíduos.

Em muitos casos a proteção direta do consumidor é inclusive contrária aos escopos a longo prazo do direito antitruste, como no caso dos efeitos imediatos dos preços predatórios. Vale, então, a conclusão de que “o Consumidor não é, normalmente, o destinatário direto das normas concorrenciais, mas é sempre sua justificação última (...) ele

projetos de acepções diversas: uma para proteger o consumidor, outorgando amplos poderes à autoridade e outro fortemente administrativo, criando-se instrumento para a atuação de uma política da concorrência.

53 Benedetto admite a proteção de interesses institucionais tendo em seu flanco os interesses dos consumidores, cabendo ao estado "le istanze di tutela della concorrenza insieme con quelle di tutela del consumatore: ci sembra l'unica strada percorribile per irrobustire la valenza costituzionale del principio di tutela della concorrenza". E vai além destacando a relevância da comunicação institucional e da expressão do poder no quadro de desenvolvimento dessa tutela promovida pelo Estado: “insomma, un'amministrazione che comunichi e che così, conquisti un convicente ruolo propulsivo (...) qualificandosi stabilmente come protagonista nel supportare gli ampi processi di governo dell'economia e nel disegnare nuove forme di espressione per l'intervento pubblico" (L'Autorità garante della concorrenza e del mercato, p. 370).

${ }^{54}$ Salomão Filho, Direito concorrencial - as condutas, pp. 24, 49.

${ }^{55}$ Salomão Filho, Direito concorrencial - as condutas, pp. 69-73. 
é protegido de maneira reflexa, através da proteção acordada aos interesses institucionais e aos concorrentes". 56

A definição não destoa daquilo que se define como meta do direito concorrencial no âmbito da Comunidade Européia: "scopo primario del diritto comunitario della concorrenza è sanzionare con l'illiceità gli atti che, in qualunque modo, siano anche solo potenzialmente idonei ad impedire la realizzazione di un regime inteso a garantire che la concorrenza non sia falsata nem mercato interno, nonché rimuovere gli effetti discorsivi che discendono da tali atti". 57

O corte feito nesta sede é relevante. Quando se definem escopos primordiais da atividade antitruste, é preciso deixar bastante clara a sua diferença em relação à técnica pela qual o legislador ou o operador atuante se vale para a implementação desses escopos. Não se pretende aqui estabelecer se as escolhas das Escolas americanas sobre a interpretação do Sherman Act (ou, para ser mais preciso, das obras dos incontáveis autores que o fazem, das quais são extraídos pontos de convergência ou divergência a respeito de técnicas de implementação de uma concorrência equilibrada e que tenha por escopo o bem estar social), se essas interpretações são precisas ou não. ${ }^{58}$ Neste trabalho é considerado escopo principal da atividade econômica, estabelecendo-o como premissa material para um pensamento processual que respeite e que lhe forneça o instrumental necessário para aquele conjunto as técnicas de que lança mão o Estado para realizar uma política econômica que respeite a concorrência e promova o bem estar social e atue a vontade concreta da lei (v. item VI.3.1).

A proteção da concorrência como instituição desde já delimita o objeto do estudo. Conforme a clássica assertiva de que a tutela antistruste não está voltada à proteção dos concorrentes, elimina-se desde já a pretensão ao exame de ulteriores aspectos processuais de demandas jurisdicionais individuas voltadas à reparação de danos causados por condutas anticoncorrenciais ou obrigações de fazer e não fazer destinadas à cessação

\footnotetext{
${ }^{56}$ Salomão Filho, Direito concorrencial - as condutas, p. 84.

${ }^{57}$ Laura Falcioni, "Ambito di applicazione", p. 49.

58 Oliveira-Rodas afirmam que "proteger 'a concorrência e não os concorrentes' tornou-se o dogma fundamental da política da concorrência através dos anos. A evolução dos objetivos-chave da concorrência nos Estados Unidos da América permaneceram consistentes com a eliminação dos efeitos anticompetitivos da colusão, monopolização, práticas exclusionárias e fusões. Devidos aos objetivos cambiantes de natureza econômica, política e social, a interpretação de como aplicar tais leis tem sofrido variações com o passar do tempo (Direito e economia da concorrência, p. 8).
} 
de uma conduta requerida por um concorrente contra o outro. ${ }^{59}$ Tais demandas tutelam imediatamente um direito subjetivo e apenas mediatamente a instituição da concorrência e tal não poderia ser diferente, por razões ordinárias derivadas da correlação entre interesses subjetivos e legitimidade ad causam. Nesta sede, apenas aquela atividade destinada à proteção institucional da concorrência e mediata dos concorrentes e consumidores que é considerada para fins de pesquisa processual.

Se o direito ora estudado tem por escopo a proteção da concorrência como instituição, se ela é um instrumento de promoção de bem estar social implementado pela prevenção e repressão às infrações contra a ordem econômica, orientada pelos ditames constitucionais de liberdade de iniciativa, livre concorrência, função social da propriedade, defesa dos consumidores e repressão ao abuso do poder econômico, e se tais instrumentos correspondem a técnicas para a realização de uma política econômica, é preciso então indentificar o que é essa política econômica, de quais técnicas ela se vale e como ela se corporifica no sistema antitruste repressivo brasileiro.

\footnotetext{
59 "No campo processual, através das formas tradicionais de tutela individual, há a já mencionada ação coletiva para a proteção de interesses individuais homogêneos. Assim, toda vez que for possível demonstrar que do ato anticoncorrencial decorreu prejuízo a um grupo identificável de consumidores será possível a qualquer associação de defesa dos consumidores promover a demanda (art. 82, inc. IV, c/c o art. 91, do CDC)" (Salomão Filho, Direito concorrencial - as condutas, p. 85).
} 


\section{TUTELA ADMINISTRATIVA E FUNÇÃO ADMINISTRATIVA JUDICANTE}

\section{III.1. Notas sobre poder, tutela e jurisdição}

O Estado brasileiro efetivamente oferece uma série de instrumentos destinados à proteção mediata ou imediata da concorrência. Fixa-se a premissa de que qualquer medida concebida no microcosmo ou no macrocosmo voltada para a consecução de políticas públicas destinadas ao bem estar social pela proteção da concorrência tem reflexos mais ou menos diretos perante a instituição tutelada.

Tutelar remete à idéia de proteger, amparar, defender, fazer valer, entregar. Dentro da estrutura do direito e em uma primeira análise, a tutela diz respeito "às regras de conduta que compõem um ordenamento ('direito objetivo'), visto que ele deve encontrar atuação nos fatos, proporcionando a passagem do abstrato para o concreto, do dever ser para o ser. Em sentido mais estrito, a mesma expressão pode referir-se a situações jurídicas de vantagem, que devem ser garantidas conforme critérios adotados pelo ordenamento". 60

O poder do Estado é uno, expresso em diversas funções que contêm objetivos específicos a serem perseguidos, afinal "trata-se de uma divisão meramente funcional do exercício do poder político, de acordo com os objetivos a serem perseguidos (funções)". ${ }^{61} \mathrm{O}$ primeiro sistema de imposição de poder como referência para este trabalho é o jurisdicional.

A jurisdição é o instrumento repressivo por excelência em razão de sua presença ordinária em situação de crises de direito material, da sua substitutividade, do poder de coerção do qual se vale e da referida imunização constitucionalmente garantida de seus comandos.

Carnelutti aduz que em situações de conflito, o direito atua como instrumento ético. Cabe então à jurisdição ministrar o direito e produzir preceitos para casos singulares, por meio de um ente autorizado pelo Estado, mediante a criação de

${ }^{60}$ Yarshell, Tutela jurisdicional, p. 29. Sobre a idéia, cfr. Mandrioli, Diritto processuale civile, vol. I, p. 1011 .

${ }^{61}$ Dinamarco, A instrumentalidade do processo, pp. 139 e 142. 
fórmulas e comandos (heterocomandos) após um juízo sobre as normas jurídicas. ${ }^{62}$ Já Calamandrei afirma que a jurisdição, além de uma garantia, é a "potestad o función (llamada jurisdicional o judicial) que el Estado, cuando administra justicia, ejerce en el proceso por medio de sus órganos judiciales", formulando o direito para o caso singular, além de "poner en práctica la coaccioón amenazada y a hacer efectiva la asistencia prometida por las leyes". ${ }^{63}$ Por sua vez, Chiovenda a define como "função do Estado que tem por escopo a atuação da vontade concreta da lei por meio da substituição, pela atividade de órgãos públicos, da atividade de particulares ou de outros órgãos públicos, já no afirmar a existência da vontade da lei, já no torná-la, praticamente, efetiva". ${ }^{64} \mathrm{O}$ autor desce às minúcias do conceito para explicar a função do Estado como exercício da soberania e da democracia por juízes que o representam, mediante a substituição de uma atividade privada por uma alheia e aplicação da vontade concreta da lei. Por fim, atribui-se eficácia ao comando, pois jurisdição e império não estabelecem relação de contraposição, mas sim de complementaridade.

A jurisdição conjuga, portanto, de três elementos: função, atividade e (exercício de um) poder. Atividade do Estado quando atua sobre a esfera da liberdade dos seus jurisdicionados mediante o exercício do poder de ditar e impor decisões, por meio da substituição da vontade das partes ${ }^{65}$ e da utilização de formas de coerção e pressão para o cumprimento de decisões; função destinada à imposição da vontade do direito ao caso concreto, (sujeição das partes à jurisdição) mediante o exercício de uma atividade pública regida por normas de direito público, permeada pela inevitabilidade e imunidade de seus comandos $^{66}$; e (exercício de um) poder quando analisada pelo enfoque político, permeada por um sistema aberto e flutuante conforme as pretensões históricas, filosóficas e sociais de um Estado.

Na definição de Dinamarco, tutela jurisdicional é "o amparo que, por obra dos juízes, o Estado ministra a quem tem razão num litígio deduzido em processo. Ela consiste na melhoria da situação de uma pessoa, pessoas ou grupo de pessoas, em relação ao bem pretendido ou à situação imaterial desejada ou indesejada. Receber tutela jurisdicional significa obter sensações felizes e favoráveis, propiciadas pelo Estado

\footnotetext{
${ }^{62}$ Carnelutti, Teoria geral do direito, $\S \S 34-59$.

${ }^{63}$ Calamandrei, Instituciones de derecho procesal civil - segun el nuevo código, vol. I, pp. 114-128.

${ }^{64}$ Chiovenda, Instituições de direito processual civil, vol. II, $3^{\mathrm{a}} \mathrm{ed}$, Campinas, Bookseller, 2002, p. 8.

${ }^{65}$ Cintra-Grinover-Dinamarco, Teoria Geral do Processo, p. 24.

${ }^{66}$ Dinamarco, Instituições de direito processual civil, pp. 305-313.
} 
mediante o exercício da jurisdição”. Do exercício do direito de ação e do preenchimento de requisitos processuais nasce o poder de exigir uma sentença, mas a tutela jurisdicional só é entregue se a pretensão tiver amparo no direito material e apenas a um dos litigantes em posições antagônicas. $\mathrm{O}$ autor fala ainda que a tutela não seria de direitos, mas sim de pessoas ou de grupos de pessoas. ${ }^{67}$

Bedaque entende que "todos podem requerer a tutela jurisdicional, ainda que dela não sejam merecedores. E o que está à disposição de todos, titulares de direitos ou de meras pretensões infundadas, é o mecanismo previsto pelo legislador constitucional, por ele minuciosamente modelado, para viabilizar a tutela jurisdicional a quem efetivamente fizer jus a ela". 68

Integrada à noção de tutela jurisdicional está a idéia de efetivação do comando. A entrega só existe quando efetivamente proporcionada a sensação de felicidade e favorecimento à pessoa, razão pela qual a tutela jurisdicional assume relação de complementaridade com o império porque "a eficiência da justiça civil, como valor a ser defendido e preservado, encontra amparo no princípio constitucional da efetividade da tutela jurisdicional e constitui elemento essencial do Estado de Direito". 69 A tutela jurisdicional não pode ser uma garantia meramente formal, mas deve valer-se de mecanismos que ofereçam aptidão a proporcionar efetividade e rapidez ao comando.

A tutela jurisdicional deve ser ainda dotada de eficácia. Nas palavras de Komatsu: "o ato não é, nem se diz eficaz, enquanto se conserva meramente idôneo para, ou capaz de modificar uma situação precedente, mas enquanto realiza concretamente essa modificação, enquanto, por outras palavras, traduz a aptidão que a norma lhe dá pra operála, na operação propriamente dita. Eficácia é força jurídica em ato, em ação e não só a aptidão ou potência". ${ }^{70} \mathrm{O}$ efeito jurídico consistiria na mutação da situação precedente

\footnotetext{
${ }^{67}$ Dinamarco, Instituições de direito processual civil, vol. I, n. 39.

${ }^{68}$ Bedaque, Tutela cautelar e tutela antecipada: tutelas sumárias e de urgência (tentativa de sistematização), p. 62.

${ }^{69}$ Bedaque, Tutela cautelar e tutela antecipada: tutelas sumárias e de urgência (tentativa de sistematização), p. 72.

${ }^{70}$ Komatsu, Da invalidade no processo civil, p. 36. Bernardes de Mello aborda a questão sob o seguinte enfoque, "o plano da eficácia é a parte do mundo jurídico onde os fatos jurídicos produzem os seus efeitos, criando as situações jurídicas, as relações jurídicas, com todo o seu conteúdo eficacial representado pelos direitos e deveres, pretensões e obrigações, ações e exceções ou os extinguindo"; isso leva a crer que entende eficácia como a efetiva produção de efeitos (Teoria do fato jurídico - plano da existência, p. 80).
} 
diante de uma situação sucessiva, constituindo, modificando ou extinguindo poderes, vínculos, qualificações, posições jurídicas, situações, qualidade ou o estado de sujeitos. ${ }^{71}$

Ainda é preciso deixar claro que a tutela jurisdicional não se confunde com o serviço jurisdicional: “ela não reside na sentença em si mesma como ato processual, mas nos efeitos que ela projeta para fora do processo e sobre as relações entre as pessoas". 72

\section{III.2. A tutela administrativa concorrencial}

O Estado atua como agente normativo e regulamentador/regulador da atividade econômica, por meio de atos de planejamento, incentivo e fiscalização, tanto no setor público quanto privado (CF, art. 174). Em linhas gerais, o Estado atua na economia de forma direta (por meio de sociedades de economia mista ou empresas públicas) ou indiretamente, valendo-se de seus poderes para planejar a economia por meio de normas (Poder Legislativo), executar o planejamento (Poder Executivo) $)^{73}$ e zelar pela sua correta aplicação, consentânea com ditames constitucionais e infraconstitucionais (Poder Judiciário).

É por meio dessa atuação indireta que o Estado efetiva políticas econômicas de curto prazo (valendo-se de medidas conjunturais/compensatórias) ou de longo prazo (por meio de medidas estruturais). ${ }^{74}$ Essa atuação se faz presente ordinariamente em diversas frentes: justiça distributiva, ${ }^{75}$ regulação da produção, da circulação e do consumo.

A questão ganha especificidade se entendermos que, no âmbito do antitruste, o Estado pretende implementar políticas públicas, mediante a repressão ao abuso

\footnotetext{
${ }^{71}$ Komatsu, Da invalidade no processo civil, p. 37.

${ }_{72}^{7}$ Dinamarco, Fundamentos do processo civil moderno, p. 812.

${ }^{73}$ São estabelecidos metas e meios primários para seu alcance, por meio de atos de atos de natureza política, econômica, administrativa e jurídica, podendo constituir-se de planos de longo, médio ou curto prazo; globais ou setoriais (Albino de Souza, Primeiras linhas de direito econômico, pp. 295, 302-303).

${ }_{74}^{74}$ Albino de Souza, Primeiras linhas de direito econômico, pp. 251, 256.

${ }^{75}$ Por meio da redução das desigualdades sociais e regionais (art. $3^{\circ}$, III e art. 170, VII), da valorização do trabalho (art. 170, caput), do respeito à função social da propriedade (art. $5^{\circ}$, XXII e XXIII; art. 170, II e III; art. 182, $\S 2^{\circ}$; art. 186), da defesa do consumidor (art. $5^{\circ}$, XXXII; art. 170, IV e V), da repressão ao abuso do poder econômico (art. 173, $\S 4^{\circ}$ ), da busca do pleno emprego (art. 170, VII) etc.
} 
do poder econômico e a tutela da livre concorrência. ${ }^{76}$ Para a tutela da livre concorrência, o Estado estabeleceu uma instância administrativa que se depara com uma crise de direito material (uma violação às normas antitruste) e um valor a proteger (a concorrência e o bem estar social), conhecendo, julgando uma situação de conflito à luz de normas de direito material pré-estabelecidas, impondo medidas necessárias à implementação do comando.

Esclarecido o poder-dever-função jurisdicional, a atenção se volta à Administração. É conhecida a idéia de não rigidez na concepção tripartite do Estado, que reconhece poderes-deveres-funções distintas para Jurisdição, Administração, e Legislação. Admitem-se pontos de contatos entre as atividades, relações entre essas manifestações do poder do Estado em razão da não rigidez dos esquemas traçados para cada um deles. É a legitimação, flexibilização e interação da distribuição de funções e atividades entre os diversos Poderes que compõem o Estado. ${ }^{77}$

Dessa concepção nasce a função judicante administrativa.

Administração é atividade estatal "que coadjuva as instituições políticas de cúpula no exercício da atividade de governo; organiza a realização das finalidades públicas postas pelas instituições políticas de cúpula; produz serviços, bens e utilidades para a população"; ${ }^{78}$ ou ainda "a função que o Estado, ou quem lhe faça as vezes, exerce na intimidade de uma estrutura e regime hierárquicos e que no sistema constitucional brasileiro se caracteriza pelo fato de ser desempenhada mediante comportamentos infralegais ou, excepcionalmente, infraconstitucionais submissos todos a controle de legalidade pelo Poder Judiciário", ${ }^{79}$

Em sua vertente judicante, o Poder Executivo julga situações atuais ou potencialmente conflitivas. ${ }^{80}$ Trata-se de função contraposta e complementar à função

\footnotetext{
${ }^{76}$ Forgioni, Os fundamentos do antitruste, p. 23. Gaban-Domingues promovem distinção: “apesar de o direito da concorrência e de a política de concorrência serem termos muitas vezes usados indistintamente, estes possuem diferenciação. A política de concorrência na verdade corresponde a um conjunto de medidas e instrumentos utilizados pelos governos com a finalidade de determinar as condições de concorrência existentes em seus mercados. Desse modo, as leis de concorrência estariam inseridas nas políticas de concorrência" (Direito antitruste: o combate aos cartéis, p. 89-90).

${ }^{77}$ Cunha Ferraz, Conflito de poderes, o poder congressual de sustar atos normativos do Poder Executivo; Zanetti Junior, Processo constitucional: o modelo constitucional do processo civil brasileiro, p. 117-123.

${ }^{78}$ Medauar, A processualidade no direito administrativo, p. 54.

${ }^{79}$ Bandeira de Mello, Curso de direito administrativo, p. 36.

${ }^{80}$ A Corte de Justiça da Comunidade Européia entende que um órgão tem característica judicante quando, cumulativamente, analisam-se os seguintes pontos: a origem legal do órgão, seu caráter permanente, a obrigatoriedade de sua decisão, a natureza contraditória do procedimento, a aplicação de normas jurídicas e o
} 
administrativa ativa. Marcos Paulo Veríssimo, referindo-se a Schuartz, afirma tratar-se de "um poder quase-judicial atribuído a esses órgãos administrativos, identificado tanto com a capacidade de julgar com vistas à aplicação de sanções administrativas, quanto com a capacidade de atuar como árbitros em disputas privadas entre agentes econômicos. No direito americano, a Lei de Processo Administrativo (como visto acima) de 1946 chegou inclusive a conceder considerável independência aos agentes públicos encarregados de presidir processos administrativos". 81

José Ignácio Gonzaga Franceschini afirma a natureza quase-jurisdicional do CADE, exercendo-se uma atividade-poder de decidir "qual a vontade da lei em relação a um caso concreto e de conferir à decisão autoridade pública e, por via judicial, exeqüibilidade compulsória", tutelando direitos coletivos. Dispõe o órgão, portanto, de funções e exerce atividade para-jurisdicional, embora conservando, ele próprio, estruturalmente, caráter administrativo. ${ }^{82}$

O Superior Tribunal de Justiça tratou sobre a matéria em julgamento relatado pelo Min. Luiz Fux, afirmando que "a decisão proferida pelo CADE tem, portanto (...), uma natureza administrativa, mas também jurisdicional, até porque a nova lei antitruste, no art. $3^{\circ}$, como já salientado, conceitua o CADE como um 'órgão judicante'. Não resta dúvida que as decisões do CADE, pela peculiaridade de versarem sobre matéria especificamente complexa, que requer um órgão especializado, apresentam natureza bastante similar a uma decisão judicial. E o legislador quis exatamente atribuir a essa decisão uma natureza especificamente judicial, posto que de origem administrativa". ${ }^{83} \mathrm{~A}$ despeito de alguma confusão conceitual em se admitir equivocadamente que a decisão do CADE tem natureza jurisdicional, porque faltam poderes e funções ao CADE que o elevem a tal categoria, ${ }^{84}{ }^{85}$ a idéia de aproximação entre as duas atividades fica bastante clara na decisão.

caráter de independência, ainda que se refute a referência jurisdicional aos provimentos de autoridades, especialmente em razão da possibilidade de revisão jurisdicional (Negri, Giurisdizione e amministrazione nella tutela della concorrenza, pp. 29-30).

${ }^{81}$ Veríssimo, Aproximação sistemática ao controle judicial das agências de regulação econômica no Brasil, p. 72.

${ }^{82}$ Franceschini, "Roteiro do processo penal-econômico na legislação de concorrência", p. 10.

${ }^{83}$ STJ, $1^{\text {a }}$. T, RESP 590960, Rel. Min. Luiz Fux, j. 26.10.04.

${ }^{84}$ Restaria examinar a capacidade de uma decisão prolatada pelo CADE ser capaz não só de atuar o direito como também efetivar preceitos e proporcionar alterações concretas em relações jurídicas ou sensações felizes em sujeitos. Aqui, deve-se ter em mente que a atuação antitruste revela uma proteção institucional direta e individual reflexa (cf. item II.3). Várias das sanções dos arts. 23-26 da lei n. 8.884/94 (publicações de 
A lei n. 8.884/94 é promulgada com a finalidade de adaptar o papel do Estado à nova realidade de mercado, de modo a desenvolver uma política de defesa da concorrência por meio de um sistema apto a tutelá-la (o Sistema Brasileiro de Defesa da Concorrência) que comporta três órgãos: a SDE, a SEAE e o CADE.

A SDE, Secretaria vinculada ao Ministério da Justiça, no âmbito dos processos de apuração de conduta, é responsável pelo momento postulatório e instrutório, especialmente por meio do Departamento de Proteção e Defesa Econômica - o DPDE. Ela recebe a denúncia de práticas anticompetitivas por representações de partes interessadas ou atua mesmo de ofício, determinando a instauração de investigações preliminares em procedimentos administrativos preparatórios, averiguações preliminares ou processos administrativos. A SEAE, vinculada ao Ministério da Fazenda, recebe informações da SDE quando instaurada uma investigação, auxiliando-a, caso julgue conveniente e oportuno, por meio da remessa de estudos e relatórios de aspectos econômicos acerca de condutas investigadas até o encerramento da instrução.

decisões, vedações de contratar com a Administração, inscrição no Cadastro Nacional de Defesa do Consumidor, recomendações a órgãos públicos de concessão de licenças compulsórias de patentes, não concessão de parcelamento de tributos, cancelamento de incentivos fiscais) não dependem da atuação exógena, amparada na colaboração entre os órgãos da Administração e na idéia de unicidade poder-funçãoatividade do Estado.

${ }^{85}$ Em relação às multas e obrigações de fazer e não fazer ("qualquer outro ato ou providência necessários para a eliminação dos efeitos nocivos à ordem econômica"), é sabido que a decisão do CADE é um título executivo como tantos outros é formado em outro processo (tais como a sentença penal condenatória e da sentença arbitral), conforme afirmei em outra sede (Efeitos civis da sentença penal, n. 16.1). Confira-se também a lição de Yarshell, para quem "quando a lei exige a citação do réu, só se pode e se deve entender que assim o faz porque não houve, com efeito, uma procedente atividade cognitiva em um mesmo processo, a ensejar, dessa forma, uma mera 'fase executiva'. Atividade cognitiva há, mas em outro processo. Dai porque é necessário 'citar' e instaurar um novo processo que, contudo, nem por isso precisa deixar de se submeter às regras de cumprimento da sentença. Não se pode, em outras palavras, extrair da exigência de citação que mais decorre da natureza das coisas do que de qualquer outra razão - a adoção de um regime que, a rigor, deixou de existir, somente vigorando - aí sim por disposição expressa - para a Fazenda Pública (...)" ("Cumprimento da sentença arbitral: análise à luz das disposições da lei 11.232/2005", pp. 193-194); com a valência de que é precedida de um processo administrativo que aplica a vontade concreta da lei. A decisão de cunho condenatório proferida pelo plenário do $\mathrm{CADE}$, no exercício de função administrativa judicante, de per se, não tem o condão de oferecer uma tutela plena na direta defesa institucional e reflexa defesa dos consumidores - da mesma forma que outros processos igualmente jurisdicionais. Porém, se agregada à atividade jurisdicional, produz sensações positivas que serão sentidas por indivíduos. Mas, de fato, no exercício da função administrativa judicante, o CADE exerce apenas o poder coercitivo, mas não o subrogatório para o cumprimento da decisões, precisando valer-se do Poder Judiciário para efetivar seus comandos. Dessa forma, é inegável que em determinadas situações, a tutela oferecida pelo CADE não é plena. Em relação ao passado, os danos aos consumidores decorrentes de tal conduta não serão objeto de tutela perante o CADE - ou seja, o CADE não indeniza sujeitos lesados por condutas anticoncorrenciais. Nessas situações, há a necessidade do indivíduo valer-se da atuação jurisdicional individual ou dos instrumentos disponíveis à tutela de interesses transindividuais, por meio de entes legitimados. 
O CADE, autarquia federal vinculada ao Ministério da Justiça, é responsável na estrutura do SBDC pelo julgamento dos referidos processos de apuração de conduta. Suas atribuições estão previstas na lei n. 8.884/94, estabelecendo como finalidade do órgão orientar, fiscalizar, prevenir e apurar abusos de poder econômico, exercendo papel tutor da prevenção e repressão do mesmo. É a última instância da esfera administrativa sobre matéria concorrencial e é formado por um Plenário composto por um presidente e seis conselheiros, indicados pelo Presidente da República, aprovados e sabatinados pelo Senado Federal para um mandato de dois anos com possibilidade de recondução por igual período. O órgão possui uma procuradoria (a ProCADE) contando com procuradores gerais e um procurador chefe, e tem por função em processos de apuração de conduta a emissão de pareceres e todas as medidas de cunho executivo tomadas no processo, em especial aquelas que demandam a interface com o Poder Judiciário. O CADE também comporta representante do Ministério Público Federal, por meio de membro designado pelo Procurador Geral da República, após parecer do Conselho Superior.

Um detalhe importante: o CADE é inserido no sistema com sua configuração atual em 1994, em um contexto de criação de agências reguladoras da década de 90 para formulação de políticas setoriais e desenvolvimento de um novo posto de circulação de poderes políticos dentro de um novo Estado regulador preocupado com mecanismos de participação democrática. ${ }^{86}$ Porém, a sua anterioridade (o órgão, a despeito de sua pouca ou nenhuma expressão, é criado em 1962), a sua atribuição essencialmente judicante, não normatizante e seus escopos específicos e determinantes lhe rendem posição diferenciada, especialmente em relação aos limites de formulação política que lhe são postos.

Em casos de apuração de conduta, em linhas gerais, os processos são instaurados perante a SDE quando existirem indícios de uma conduta anticoncorrencial, por representação do interessado, em decorrência de investigação própria feita pela SDE, representação do Congresso Nacional ou de suas Comissões e até mesmo por determinação de ofício de qualquer dos órgãos do SBDC. Após a instrução pública pela SDE (ressalvada a restrição de acesso às informações sigilosas), o processo é remetido para o CADE, designando-se um relator em sorteio realizado em sessão pública semanal de distribuição.

${ }^{86}$ Mattos, O novo estado regulador no Brasil: direito e democracia, p. 4. 
Os julgamentos são feitos com base nos arts. 20 e 21 da lei n. 8.884/94, que estabelecem exemplos de condutas anticoncorrenciais e seus efeitos. As decisões ali prolatadas podem ser submetidas ao controle do Poder Judiciário - e na prática efetivamente o são, especialmente em casos de decisões condenatórias e em casos de medidas tomadas no curso do processo e resolvidas interlocutoriamente pela SDE ou mesmo pelo próprio CADE.

Têm-se então órgãos do Poder Executivo que, por meio de atuação de administração indireta, agem sobre a atividade econômica para a aplicação de preceitos estabelecidos em lei, exercendo função administrativa judicante voltada à apuração de irregularidade de condutas e imposição de medidas destinadas a punir e impedir que a situação de ilegalidade se prolongue. Inobservadas regras de conduta impostas pelo direito objetivo, o CADE oferece a transposição do ser para o dever ser, eliminando crise de certeza e impondo situações jurídicas de desvantagem ao sujeito que contraria o ordenamento. As condenações adimplidas e as decisões de improcedência (arquivamento) esgotam a atividade do CADE; as condenações inadimplidas provocam a atividade da ProCADE e demandam a interface com o Poder Judiciário.

\section{III.3. O conceito de autoridade}

Com especial atenção à função do CADE, é preciso uma breve digressão sobre as chamadas agências (autoridades).

A idéia de agências nasce de tribunais semi-contenciosos ingleses criados para regulação de alguns setores e para decisões em matérias específicas, no século XVII, com poderes de adjudication, em setores que requerem expertise. Nos EUA, em 1887, é criada a ICC - Interstate Commerce Commission - para regulação da atividade ferroviária, com a ulterior criação da Federal Trade Comission - FTC - americana em 1914, período no qual o Estado assume a regulação da economia de forma consciente e incisiva. O FTC surge como primeira instituição a exercer papel de tutela da concorrência, criada para prevenir a concorrência desleal à luz do Sherman Act de 1890. A intervenção do governo da economia nos anos do New Deal acaba por consolidar a fórmula. Em 1935, com a sentença Humphrey's Executor vs United States, é consolidada a idéia de agência independente, impondo-se limites aos poderes do Presidente de remover um comissário da 
FTC de suas atribuições. Em 1946, são editados o Administrative Procedure Act (1946) com disciplina residual e garantística de regras em matéria de julgamento e produção de normas, no escopo de consolidar a noção de autoridade independente. ${ }^{87}$

No âmbito da tutela da concorrência americana, como já referido, há ainda a Antitrust Division do Department of Justice (DOJ). O DOJ atua as normas antitruste provendo processos civis e penais diante dos Tribunais, enquanto a FTC exerce função profilática na tutela preventiva dos consumidores e na manutenção de condições de competição econômica. Na FTC, a fiscalização das condutas é feita pelo Bureau of Competition, com função de prevenção dos comportamentos de concorrência desleal e de promoção da competição, é composto por advogados que exercem função investigativa e de efetivação da norma antitruste diante dos tribunais e dos Administratives Law Judges. Há ainda o Bureau of Consumer Protection cujo escopo de investigação e de litigation diante de cortes federais e administrativas. ${ }^{88}$

Na União Européia, quando de sua instituição havia a clara preocupação com a aplicação uniforme das normas em matéria concorrencial, tratada como "priorità assoluta ai fini della integrazione dei mercati”, especialmente com a instituição de um sistema centralizado a cargo da Comissão. Com a integração efetiva do mercado, "un sistema antitrust centralizzato appare ormai più di ostacolo, che di vantaggio, ai fini di una efficace tutela della concorrenza. Sta impedendo alla Comissione di concentrarsi sulle infrazioni più gravi, che raramente sono notificate, mentre risultano le più dannose per $\mathrm{i}$ consumatori e l'economia europea". Dessa forma, ao menos em tese (como se verá adiante com o esclarecimento das relações entre a Comissão e as Autoridades Nacionais), a partir de 2004, com o Regulamento 1/2003, é instituído um sistema descentralizado que amplia a competência das autoridades nacionais e que objetiva fundamentalmente "sollevare la Comissione da compiti che non contribuiscono ad una più efficente applicazione delle regole di concorrenza e avvicinare il processo decisionale ai cittadini". ${ }^{89}$

\footnotetext{
${ }^{87}$ Benedetto, L'Autorità garante della concorrenza e del mercato, n. II.2.1.

${ }^{88}$ Benedetto, L'Autorità garante della concorrenza e del mercato, pp. 116-121.

${ }^{89}$ Benedetto, L'Autorità garante della concorrenza e del mercato, pp. 116-121.
} 
Na Itália, a figura da AGCM é inspirada pelo direito francês (autorités administratives indépendantes ${ }^{90}$ ), ostensivo nas similitudes estruturais. O modelo começa a ganhar importância na década de 70 com a maior intervenção do Estado na economia e à necessidade de proteger o pleno respeito à lei em determinados setores sensíveis da economia. ${ }^{91} \mathrm{O}$ Estado deixa de ser um ator privilegiado e assume a função de árbitro, intermediário em relação aos interesses em jogo, de modo a melhorar a relação entre os cidadãos e a administração pela correção de desvios do mercado e controle da iniciativa econômica, por meio de órgãos de alta especialização técnica de "funzione 'naturalmente' ausiliare a servizio dagli organi rappresentativi"92. Cria-se então a AGCM com papel imparcial e similar ao do juiz, sinteticamente tratado "sul piano dei profili connotativi dell'indipendenza, particolarmente rispetto all'esecutivo, con la previsione di limite ai poteri di rimozione e scioglimento dei vertici, con il riconoscimento di un'ampia autonomia finanziaria e organizzatoria, e con l'attribuzione di poteri regolamentari e decisori ascrivibili alla categoria d'importazione dei poteri quasi-normativi e quasigiudiziali; - sul piano della struttura organizzativa collegiale, perché in grado di assicurar la migliore ponderazione di interesse, in modo da garantire l'imparzialità della funzione". ${ }^{93}$

E “il requisito dell'indipendenza non è di per sé inconciliabile con il concetto di amministrazione (...) non essendo ipotizzabile un'astratta ed aprioristica antitecità tra l'ideia stessa di amministrazione e la sua caratterizzazione come apparato indipendenti”, considerando a figura da administração como um instrumento separado do poder político, un pouvoir administratif, regulador pela lei. Dentro de uma hermenêutica evolutiva, contempla-se um policentrismo autônomo de um sistema de organização em rede que leva em conta a complexidade e multiplicidade de interesses de setores sociais. As autoridades independentes exercem uma função intermediária entre a Administração e o Poder Judiciário. Ainda assim se fala de atenuação da independência pelas peculiaridades da aprovação das nomeações de conselheiros e da determinação de respeito dos "indirizzi di politica generale formulati dal Governo". Porém isso não ocorreria na AGCM, na

\footnotetext{
${ }^{90} \mathrm{O}$ sistema francês ostenta a peculiaridade de que as autoridades fiscalizam as atividades de empresas privadas e públicas em casos de disfunções de poderes burocráticos (Benedetto, L'Autorità garante della concorrenza e del mercato, pp. 17-18).

91 V. também Negri, Giurisdizione e amministrazione nella tutela della concorrenza, p. 3, nota 6.

92 Méritos ainda da Escola Alemã de Frieburg, com a idéia de economia social do mercado pela via institucional alternativa ao liberalismo e ao dirigismo centralista. O Estado é forte e neutro, desenvove função de reequilíbrio e garantia institucional de mecanismos de mercado, por meio da administração pública da economia.

${ }^{93}$ Benedetto, L'Autorità garante della concorrenza e del mercato, pp. 49-57 e 61.
} 
medida em que não seria titular de poderes de administração ativa, não controla a inscrição de empresas, não regulamenta sua atividade e não persegue um fim público além daquele de fazer respeitar as regras sobre concorrência. A AGCM tem função contenciosa, conduzindo casos individuais concretos à hipótese prevista pelo legislador - atividade própria de autoridades judiciárias - razão pela qual sua atividade é considerada parajurisdicional. ${ }^{94}$

Na França, a separação dos poderes aliada à Revolução deu origem a sistema que vedava a interferência do Poder Judiciário na Administração. Com a evolução histórica, na Europa, narra-se a existência de tipos de modelos organizativos do contencioso administrativo: (a) administrativista ("administrador-juiz", "autotutela", “jurisdição reservada" ou "jurisdição conservada") - a decisão compete aos órgãos superiores da administração ativa (julgar a administração é administrar); (b) judicialista as decisões sobre questões administrativas cabe aos tribunais integrados a um sistema (julgar a administração é julgar); (c) judiciarista (quase judicialista) - "a resolução dos litígios relativos à administração, por não ser (substancialmente) estranha à função jurisdicional, cabe a autoridades 'judiciárias', que são órgãos administrativos independentes, alheios à orgânica dos tribunais (apesar de sua designação como 'tribunais administrativos')"; (d) administrativista mitigado - a decisão cabe a órgãos superiores da administração com procedimento jurisdicionalizado com intervenção consultiva obrigatória de órgão independente da administração e (e) judicialista mitigado - em que as sentenças têm força executiva nula ou limitada perante a Administração. ${ }^{95}$

O ponto traz à luz antiga polêmica sobre a legitimidade das agências/autoridades independentes, especialmente à luz do princípio da separação dos poderes. A autoridade independente estaria em uma uneasy constitucional position. Segundo modelo americano, ela decorre do poder do Presidente de assegurar a execução da lei, do Legislativo em delegar a normatização de questões específicas relacionadas com a atuação da lei. O problema da ilegitimidade constitucional reside na criação de corpos administrativos não inseridos em nenhum dos poderes, o que deixaria precário o equilíbrio garantístico previsto na tripartição dos poderes - o problema do fourth branch Government, autônomo em relação aos outros. A criação desse órgão poderia trazer uma

\footnotetext{
${ }^{94}$ Garofoli, "Procedimento, accesso e autorità indipendenti", p. 3335 e ss.

95 Andrade, A justiça administrativa, p. 37-38.
} 
ruptura com a função administrativa tradicional. A independência da autoridade em relação ao Executivo poderia levar a uma carência de legitimação democrática, com a quebra da tradicional idéia de tripartição dos poderes, eis que a Autoridade estaria situada entre a Administração e a Jurisdição (criando-se assim uma nova expressão de Poder do Estado), além de uma idéia de irresponsabilidade numa quebra de disposições constitucionais ou um tipo de criação não autorizada (escamotage) de juízos especiais - em violação da idéia de juiz natural. ${ }^{96}$

Mas "non ricorre in questo caso una patologia funzionale del fondamentale principio ordinatore del nostro sistema costituzionale (o princípio da tripartição de poderes): solo se 'chi possiede tutti i poteri di un determinato settore, assomi a sé tutti i poteri di un altro, vengono (...) sovvertiti i principi stessi su cui poggia una Costituzione democratica"”. De fato, a Suprema Corte americana apreciou a questão para afirmar que uma agência poderia ostentar poderes judicantes, funcionando como um lugar de contato entre os três poderes ("luogo di scontro tra i tre poteri"), ostentando uma natureza híbrida, um "strano amalgama", com combinação de poderes. ${ }^{97}$

As autoridades administrativas ostentam essa independência das atividades de direção do governo, mas estão submetidas a um sistema de controle que contribui para a solução do problema do "rapporto tra indipendenza e responsabilità: "ciò che è richiesto per riconciliare indipendenza e responsabilità sono più ricche e più flessibili forme di controllo che i tradizionali metodi di supervisione politica ed amministrativa. Chiari e limitati obiettivi legislativi, precise previsioni procedimentali come quelle imposte ai regolatori americani dall'Administrative Procedure act, sindacato giudiziale, analisi costi-benefici e il 'regulatory budget', professionalità e competenza, controllo da parte dei gruppi d'interesse, ed anche la rivalità tra agenzie, possono essere elementi di un pervasivo ma flessibile sistema di controllo. Quando il sistema lavora correttamente, nessuno controlla un'agenzia indipendente, eppure l'agenzia è 'sotto controllo"'. É necessário "rendere efficaci i controlli fattuali, superando i limiti della cultura istituzionale europea nello svolgimento di attività di regolazione che sembra essere 'altamente discrezionale,

\footnotetext{
${ }^{96}$ Negri, Giurisdizione e amministrazione nella tutela della concorrenza, pp. 5 e 6 , nota 15 .

${ }^{97}$ Benedetto, L'Autorità garante della concorrenza e del mercato, p. 391.
} 
soffrendo di scarsa responsabilità nei confronti del parlamento, debole sindacato giuziale, assenza di garanzie procedimentali e insufficiente partecipazione del pubblico". ${ }^{98}$

Marçal Justen Filho, comentando um aludido déficit democrático em agências reguladoras, aduz que a legitimação democrática se dá por diversas vias, e não somente pela eleição popular. E referindo-se a Chevalier, afirma que a democracia pressupõe respeito ao pluralismo, a garantia dos direitos e liberdades e o debate sobre escolhas coletivas, pautados sobre padrões éticos. ${ }^{99}$

Passando adiante, é ressabida a dificuldade de uniformização de conceitos sobre as agências, dadas as diferenças estruturais e funcionais identificadas entre agências de mesma função em diversos países ou mesmo diante de diversas agências dentro de um mesmo país. ${ }^{100}$ Negri afirma que tais agências divergem, v.g., na forma de indicação dos seus componentes - com reflexos sobre a imparcialidade -, na função exercida e nos poderes de que são investidas. ${ }^{101}$ Podem ser divididas em dois grandes grupos: aquelas com competência de regulação (intervenção direta sobre um setor com

\footnotetext{
${ }^{98}$ Nos EUA havia a intervenção do Legislativo sobre as agências por meio do direito de veto (uma reserva de poder de anulação de atos do executivo), declarado inconstitucional em 1983, deixando-as ao controle do Executivo. O controle sobre as despesas das agências é atribuído ao Congresso, mas desvinculado de qualquer condicionamento econômico. O poder do Senado de confirmar uma nomeação usualmente não rejeita a indicação do Presidente. Em relação ao presidente, destaca-se que a agência è unificada sobre direção presidencial, mas este tem um papel interventivo limitado; o presidente tem o poder de indicar e remover funcionários administrativos (poder de organização do executivo), mas o congresso limita esse exercício criando hipóteses legais e taxativas de remoção. A jurisprudência americana evolui nesse sentido, especialmene em 1935 com a referida sentença no caso Humphrey's Executor vs United States, sob a justificativa de que "i funzionari preposti alle independet agencies non sarebberero funzionari puramente esecutivi, ma esperti neutrali in posizione di indipendenza rispetto al Presidente, che avrebbe solo il potere di nominarli. Il carattere paricolare di questo ufficio richiederebbe di qualificarne i funzionari come esercenti potestà quase-giudiziali e quasi-legislative piuttosto che esecutive". Por fim, a decisão no caso Buckley vs. Valeo (1986) reconfirma o poder de remoção atribuído ao Presidente, inclusive dos membros de agências independentes (Benedetto, L'Autorità garante della concorrenza e del mercato, p. 41, 389-390 e nn. 3.1-3.3). 99 Justen Filho, “Agências reguladoras: existe um déficit democrático na regulação independente?” pp. 278279.

${ }^{100}$ Para Benedetto, "sarebbe così possibile delimitare, per approssiomazione concettuale, la figura della independent/administrative agency solo a partire da definizioni generiche, che si limitino ad indicare come costante l'exercicio di autorità delegata per funzioni di governo" (Benedetto, L'Autorità garante della concorrenza e del mercato, p. 24).

101 É exatamente nesse ponto que a Autoridade italiana se ampara para anunciar sua imparcialidade, afirmando: 'L'Autorità va ricompresa tra le 'Autorità Indipendenti', che svolgono la propria attività e prendono decisioni in piena autonomia rispetto al potere esecutivo. All'indipendenza dell'Autorità contribuiscono, tra l'altro, le modalità di nomina e i requisiti del Presidente e dei Componenti, $i$ quali sono nominati congiuntamente dai Presidenti di Camera e Senato e non possono essere confermati nella carica alla scadenza dei sette anni. In particolare, il Presidente viene scelto tra persone di notoria indipendenza che abbiano ricoperto alte cariche istituzionali; $i$ quattro Componenti sono scelti tra persone di notoria indipendenza da individuarsi tra magistrati del Consiglio di Stato, della Corte dei Conti o della Corte di Cassazione, professori universitari ordinari e personalità di alta e riconosciuta professionalità provenienti da settori economici" (www.agcm.it).
} 
poderes normativos) e de garantia (vigilância e garantia de valores predeterminados pela lei). ${ }^{102}$

Ainda assim, Benedetto promove uma tentativa de sistematização do conceito, afirmando como características dessas agências: i) a colegialidade, ii) o critério político para a nomeação dos 'comissários', iii) a ampla autoridade de regulamentação, iv) o poder de convocar audiências formais, v) o poder de investigação, vi) o mandato especial e vii) as restrições ao poder de remoção do Presidente (e este último se afirma como o verdadeiro traço caracterizador). Destaca ainda a recorrente falta de previsão constitucional justificada pela desnecessidade, à luz da possibilidade de regular vinculação ao executivo, destacando que o legislativo institui a agência e escolhe seu modo de funcionamento e o grau de independência. ${ }^{103}$ Mas ressalva: "se per terzietà si intende il carattere soggettivo che definisce la posizione del giudice all'interno del processo in cui si esercita la fuzione giurisdizionale, allora le autorità amministrative indipendenti - e fra loro l'Antitrust - non svolgono il loro ruolo da una posizione 'terza'. Esse, infatti, sono investite di una mission per la cura di un iteresse pubblico, rispetto al perseguimento del quale sono, come istituzioni, direttamente responsabili. Basti a questo proposito ricordare che la cura dell'interesse pubblico alla tutela della concorrenza e del mercato è affidata, direttamente, dalla legge all'Autorità, che la esercita discrezionalmente ed attivamente, sulla base di una expertise normalmente estranea all'esercizio della giurisdizione, valutando - nell'esercizio dei suoi poteri decisionali - la rilevanza anticoncorrenziale di condotte delle imprese, ed utilizzando a tal fine i propri duttili poteri procedimentali e sanzionatori". ${ }^{104}$

De fato, são vastos e diferenciados os modelos estruturais e funcionais de proteção da tutela da concorrência.

O mais importante deles provém da Common Law, contando com agências independentes com poderes investigativos e de fiscalização, tais como a Federal Trade Comission (FTC - EUA) e a Monopolies and Mergers Commission (MMC Inglaterra), e com órgãos vinculados ao poder executivo - órgãos ministeriais - com

\footnotetext{
${ }_{102}$ Negri, Giurisdizione e amministrazione nella tutela della concorrenza, p. 4 nota 10.

${ }^{103}$ Benedetto, L'Autorità garante della concorrenza e del mercato, pp. 43-44.

104 Benedetto, L'Autorità garante della concorrenza e del mercato, p. 375. Querzola também concorda ao afirmar, v.g., que a atividade no âmbito antitruste da Comissão Européia "non possa considerarsi attività giurisdizionale, in quanto proveniente da un organo che manca del requisito primo ed indispensabile della 'giurisdizionalità', ovverola posizione di terzietà rispetto agli interessi di cui è chiamata a conoscere" ("La tutela cautelare antitrust fra processo e amministrazione, riflessioni minime", p. 291); ainda Biavati, "Il diritto processuale e la tutela dei diritti in materia di concorrenza", p. 100.
} 
poderes de investigação e de "promoção de justiça", a saber o Department of Justice (Antitrust division - EUA) e o Office of Fair Trading (Inglaterra). ${ }^{105}$ Fala-se em uma divisão de trabalhos entre administração e as cortes contendo uma concepção restritiva da revisão judicial, na medida em que ao juiz cabe a aplicação das regras gerais de direito, com o exame decisões arbitrárias e without any evidence, enquanto à administração compete o exame de questões de direito - sendo que "attribuirle (decisões sobre fatos) alle corti significherebbe sostituire una discrezionalità (quella del giudice) ad un'altra (quella dell'amministrazione). La regola della supremacy of law non vuole questo: impone che la discretion amministrativa sia soggetta solo alla law". ${ }^{106}$

Na França, em relação ao Conseil de la Concurrence, responsável pela repressão de pratiques anticoncurrentielles, reconhece-se que seus provimentos têm sua natureza quase jurisdicional, sem as prerrogativas de uma decisão efetivamente jurisdicional. Eles estão sujeitos aos regimes dos atos administrativos, privados da eficácia da coisa julgada e não vinculam o juiz civil. Porém, a competência da corte de apelo de Paris para revisão das decisões do Conseil é considerada excepcional, tida por ingerência do Poder Judiciário em atos da administração. Mas fala-se de um órgão "em vias de jurisdicionalização", sendo que parte da doutrina francesa espera a transformação do Conselho em uma Jurisdição concorrencial. ${ }^{107}$

$\mathrm{Na}$ Alemanha, a autoridade administrativa é o Bundeskartellamt, coligado ao Ministério da Economia, cuja independência é largamente defendida. É fato que o Executivo, por meio do Ministro correspondente tem o poder de dar diretivas gerais sobre a aplicação da norma antitruste, mas nunca exercitou esse poder, além da competência para autorizar práticas tidas por anticoncorrenciais - aspecto marcadamente político. É uma autoridade afeita à responsabilidade ministerial - não se repetindo a discussão italiana sobre o distanciamento do controle do governo e a legitimidade constitucional da autonomia da Autoridade. ${ }^{108}$

Na Itália, a atuação administrativa de proteção da concorrência, exercida pela Autorità Garante della Concorrenza e del Mercato (AGCM), que exerce atividade por meio de processos e volta-se ao parlamento como o mais imediato referente institucional,

\footnotetext{
${ }^{105}$ Benedetto, L'Autorità garante della concorrenza e del mercato, p. 9-10.

${ }^{106}$ Benedetto, L'Autorità garante della concorrenza e del mercato, p. 219.

${ }^{107}$ Negri, Giurisdizione e amministrazione nella tutela della concorrenza, p. 22.

${ }^{108}$ Negri, Giurisdizione e amministrazione nella tutela della concorrenza, p. 23.
} 
embora seja estruturada para ser independente da política do governo. Assimila-se a teoria das Autoridades Administrativas Independentes (estrutura pública dotada de prerrogativas particulares de autonomia, livres da relação hierárquica, submetidas somente à lei), criando-se a AGCM, nos termos da lei n. 287 del 10 ottobre 1990, com competência para o exame de acordos restritivos da concorrência, do abuso de posição dominante e de atos de concentração que não incidam no âmbito de aplicação de Tratados da Comunidade Européia. Ostenta poderes ordinatórios, investigatórios, instrutórios, sancionatórios, e de “dispensa" ou autorização (em casos de atos de concentração), além de ser órgão judicante colegiado, composto por um presidente e outros quatro componentes nomeados pelo legislativo italiano, com um mandato de sete anos. Há ainda o chamado Secretário Geral da Autoridade, indicado pelo Ministro do Desenvolvimento Econômico. E trata-se de um órgão uno, que desenvolve em seu interior toda a atividade proposta. ${ }^{109}$

O sistema de defesa da concorrência está amparado pelo art. 41 da Constituição, que enuncia a liberdade da concorrência e a necessidade de coordenação do conceito com as idéias de utilidade social, dano à segurança, liberdade, e dignidade humana, cabendo à lei determinar os programas de controle "perché l'attività economica pubblica e privata possa essere indirizzata e coordinata a fini sociali". Fala-se ainda em "assicurare le condizioni generali per la libertà di impresa, che consentano agli operatori economici di poter accedere al mercato e di competere con pari opportunità; e tutelare $i$ consumatori, favorendo il contenimento dei prezzi e i miglioramenti della qualità dei prodotti che derivano dal libero gioco della concorrenza". A idéia de tutela da concorrência está atrelada à tutela da funcionalidade concorrencial do mercado nacional em um sistema de enforcement binário - que contempla a atuação administrativa (no âmbito nacional e comunitário) e jurisdicional. ${ }^{110}$

Por sua vez, a Comunidade Européia é uma Convenção por meio da qual os Estados conservam sua soberania, mas delegam poderes, em algumas áreas, para instituições comuns (Parlamento Europeu, Conselho da União Européia e a Comissão Européia, em um triângulo institucional, além de comitês, instituições financeiras, Serviços e Agências) para atingir objetivos específicos, em atuação que passa pela normatização, fiscalização e efetivação de comandos. Prevalecem ali os princípios de supremacia do

\footnotetext{
${ }^{109}$ Benedetto, L'Autorità garante della concorrenza e del mercato, pp. 2 e 10.

${ }^{110}$ Negri, Giurisdizione e amministrazione nella tutela della concorrenza, p. 1.
} 
direito comunitário, de leal colaboração entre os estados membros, de subsidiariedade na atuação Comunitária, incentivando-se o recurso aos entes nacionais (a Comissão pode deixar de intervir em relação a condutas que não representem um especial interesse comunitário, especialmente se o autor puder obter a tutela do órgão jurisdicional nacional). ${ }^{111}$

No que diz respeito ao tema da concorrência, ${ }^{112}$ destaca-se na Comunidade o papel da Comissão Européia, com sede em Bruxelas. A Comissão pode apresentar propostas legislativas (direito de iniciativa, se considerar que determinado problema não pode ser solucionado de forma eficaz no âmbito nacional, regional ou local princípio da subsidiariedade), gerir políticas concorrenciais (com poderes para autorizar, proibir concentrações, controlar subsídios estatais indevidos) e atuar em conjunto com o Tribunal de Justiça na aplicação dos tratados de direito concorrencial, na fiscalização e efetivação de eventuais comandos destinados a coibir, v.g. condutas anticoncorrenciais por meio de "procedimentos por infrações" e aplicação de sanções pecuniárias aplicadas, aí, pelo Tribunal de Justiça.

O Tribunal, por sua vez, criado em 1952 em sede em Luxemburgo, é composto por um juiz de cada Estado Membro com mandato de seis anos e possibilidade de renovação, reúne-se em sessões plenárias, grandes seções (compostas por treze juízes) ou seções de 3 ou 5 juízes (repartidas por competências), é assistido por advogados gerais incumbidos do oferecimento de pareceres, e tem como finalidade garantir a interpretação e aplicação uniformes da legislação da União Européia.

Há ainda o Tribunal de Primeira Instância, criado em 1988 para dar vazão ao grande número de processos propostos, composto também por um juiz de cada estado membro, com competência pré-definida usualmente destinada a solução de pendências entre particulares, empresas, organizações e, em especial, em matéria de concorrência. Fala-se em ações e recursos apresentados por indivíduos ou pessoas jurídicas contra atos das instituições comunitárias (v.g., ato pelo qual a Comissão aplica uma multa).

\footnotetext{
${ }^{111}$ Negri, Giurisdizione e amministrazione nella tutela della concorrenza, p. 71.

${ }^{112} \mathrm{O}$ direito antitruste aplicado pela Comissão se faz presente quando a violação puder prejudicar o mercado comum, e não um mercado exclusivamente interno. Porém, "la giurisdizione delle istituzioni comunitarie in materia di concorrenza può sussitere anche laddove le pratiche anticoncorrenziali siano realizzate esclusivamente sul territorio di un Stato membro o riguardino imprese aventi sede nelle stesso Stato membro, sempre che dall'analisi condotta emerga il pregiudizio, anche solo potenziale, al commercio intramunitario" (Laura Falcioni, "Ambito di applicazione", p. 64).
} 
Tem atuação especial em casos de acordos, decisões e práticas concertadas suscetíveis de afetar o comércio entre os Estados membros e que tenham por objetivo ou por efeito impedir, restringir ou falsear a concorrência no mercado comum, condutas essas sancionadas com multas. ${ }^{113}$

A Coordenação entre a atuação da Comissão Européia (de cunho Administrativo) e dos Tribunais dos Estados é de importância, pois permite uma comparação entre a atuação da Autoridade e do Poder Jurisdicional. Referência a uma tendência de atribuir uma eficácia "forte" às decisões da Comissão, Guardiã do Tratado (art. 211, CE) e responsável pela orientação da política comunitária da concorrência, além da intenção de buscar a aplicação uniforme do direito comunitário. O regulamento 44/2001 da CE fala inclusive da integração judiciária européia, do sistema full faith and credit, pelo qual se pode negar a eficácia de uma sentença estrangeira.

Vale a referência ao caso Masterfood que examinava processos paralelos (administrativo e judicial), no qual a Corte da Comunidade Européia afirmou explicitamente a eficácia vinculante para o juiz nacional de todas as decisões da Comissão sobre a aplicação dos arts. 81 e 82 do CE (condutas anticoncorrenciais ${ }^{114}$ ). Assim o fez no

\footnotetext{
${ }^{113} \mathrm{O}$ trâmite dos processos no Tribunal de Primeira Instância é semelhante, sem a existência de um advogado geral parecerista, função que pode ser atribuída excepcionalmente a um dos juízes. O início do processo se dá por petição escrita dirigida à secretaria, com a tradução dos pontos principais para todas as línguas oficiais e publicação no Jornal Oficial da União Européia; segue a notificação e prazo para contestação, réplica e tréplica. Qualquer pessoa que demonstre interesse na demanda, bem como estados Membro e instituições da comunidade, podem intervir no processo (modalidade de assistência). Há uma fase oral com perguntas aos representantes das partes (com tradução simultânea conforme necessário - língua oficial é o francês). O processo não sujeito a custas, os advogados são contratados pelas partes, mas existe previsão de um apoio judiciário. As decisões podem ser submetidas no prazo de dois meses ao Tribunal de Justiça. Há a possiblidade de dedução de pedido de medidas provisórias para suspender a execução de um provimento ou outras medidas, de cunho provisório e reversível, em despacho fundamentado, desde que presentes o fumus boni iuris, o perigo de dano grave e irreparável e desde que demonstrado o interesse das partes e o interesse geral. Contra a decisão, cabe recurso dirigido ao presidente do Tribunal de Justiça.

${ }^{114}$ Artigo $81^{\circ}$.

1. São incompatíveis com o mercado comum e proibidos todos os acordos entre empresas, todas as decisões de associações de empresas e todas as práticas concertadas que sejam susceptíveis de afectar o comércio entre os Estados-Membros e que tenham por objectivo ou efeito impedir, restringir ou falsear a concorrência no mercado comum, designadamente as que consistam em: a) Fixar, de forma directa ou indirecta, os preços de compra ou de venda, ou quaisquer outras condições de transacção; b) Limitar ou controlar a produção, a distribuição, o desenvolvimento técnico ou os investimentos; c) Repartir os mercados ou as fontes de abastecimento; d) Aplicar, relativamente a parceiros comerciais, condições desiguais no caso de prestações equivalentes colocando-os, por esse facto, em desvantagem na concorrência; e) Subordinar a celebração de contratos à aceitação, por parte dos outros contraentes, de prestações suplementares que, pela sua natureza ou de acordo com os usos comerciais, não têm ligação com o objecto desses contratos.

2. São nulos os acordos ou decisões proibidos pelo presente artigo.

3. As disposições no n.o 1 podem, todavia, ser declaradas inaplicáveis: - a qualquer acordo, ou categoria de acordos, entre empresas, - a qualquer decisão, ou categoria de decisões, de associações de empresas,
} 
ensejo de evitar decisões contrastantes, adequando-se o direito nacional às decisões já proferidas pela Comissão, com amparo no princípio de leal colaboração e aplicação uniforme do direito comunitário (sem maiores referências à certeza do direito) e na idéia de ausência de uma competência exclusiva e da possibilidade de decisões da Comissão com efeitos diretos aos indivíduos. Edita-se então ao regulamento 1/2003, referente à atuação dos arts. 81 e 82 do Tratado da CE, confirmando o caráter vinculante das suas decisões, ao afirmar no art. 16: "aplicação uniforme do direito comunitário da concorrência. Quando se pronunciarem sobre acordos, decisões ou práticas ao abrigo dos $\operatorname{artigos} 81^{\circ}$ ou $82^{\circ}$ do Tratado que já tenham sido objecto de decisão da Comissão, os tribunais nacionais não podem tomar decisões que sejam contrárias à decisão aprovada pela Comissão. Devem evitar tomar decisões que entrem em conflito com uma decisão prevista pela Comissão em processos que esta tenha iniciado. Para o efeito, o tribunal nacional pode avaliar se é ou não necessário suster a instância. Esta obrigação não prejudica os direitos e obrigações decorrentes do artigo $234^{\circ}$ do Tratado".

De fato o art. 1, 3 comma da Legge 287/90 italiana ratifica a intenção de uniformidade afirmando que, a fim de assegurar tanto a aplicação coerente das regras de concorrência como uma gestão otimizada da rede, é indispensável introduzir a regra segundo a qual, quando a Comissão der início a um processo, este sai automaticamente da alçada das autoridades dos Estados-Membros responsáveis em matéria de concorrência. Sempre que uma autoridade de um Estado-Membro responsável em matéria de concorrência já esteja a instruir um processo e a Comissão tencione dar início a um processo, esta instituição esforçar-se-á por concretizar a sua intenção o mais rapidamente

E - a qualquer prática concertada, ou categoria de práticas concertadas, que contribuam para melhorar a produção ou a distribuição dos produtos ou para promover o progresso técnico ou económico, contanto que aos utilizadores se reserve uma parte equitativa do lucro daí resultante, e que: a) Não imponham às empresas em causa quaisquer restrições que não sejam indispensáveis à consecução desses objectivos; b) Nem dêem a essas empresas a possibilidade de eliminar a concorrência relativamente a uma parte substancial dos produtos em causa.

Artigo $82^{\circ}$

É incompatível com o mercado comum e proibido, na medida em que tal seja susceptível de afectar o comércio entre os Estados-Membros, o facto de uma ou mais empresas explorarem de forma abusiva uma posição dominante no mercado comum ou numa parte substancial deste. Estas práticas abusivas podem, nomeadamente, consistir em: a) Impor, de forma directa ou indirecta, preços de compra ou de venda ou outras condições de transacção não equitativas; b) Limitar a produção, a distribuição ou o desenvolvimento técnico em prejuízo dos consumidores; c) Aplicar, relativamente a parceiros comerciais, condições desiguais no caso de prestações equivalentes colocando-os, por esse facto, em desvantagem na concorrência; d) Subordinar a celebração de contratos à aceitação, por parte dos outros contraentes, de prestações suplementares que, pela sua natureza ou de acordo com os usos comerciais, não têm ligação com o objecto desses contratos. (cf. Jornal Oficial das Comunidades Europeias 24.12.2002) 
possível. Antes de dar início ao processo, a Comissão deverá consultar a autoridade nacional competente. ${ }^{115}$

Para Biavati, as decisões jurisdicionais e administrativas da Comissão são conduzidas ao mesmo nível ("al medesimo genus di decisione"), ainda que, segundo o autor, o processo administrativo ostente um nível de imparcialidade da autoridade e contraditório muito lacunoso. ${ }^{116}$ A despeito do regulamento 1/2003 da Comissão ter sido elaborado com a proposta de descentralização (reforçando o papel das autoridades e juízes nacionais), seu resultado foi uma centralização da aplicação do direito comunitário, em razão dos poderes uniformizadores adquiridos pela Comissão. ${ }^{117}$

Porém, essa determinação é questionada na Itália, porque coloca em dúvida a independência do Juiz e do Poder Jurisdicional, muito embora exista quem afirme que a independência do juiz não seria valor absoluto, de modo a justificar a exatidão da medida uniformizadora. ${ }^{118}$

Todos esses sistemas demonstram existir, não apenas no Brasil, tribunais judicantes de natureza administrativa responsáveis por decisões em matéria antitruste.

\footnotetext{
${ }^{115}$ Algumas ressalvas são feitas. O provimento da Comissão não tem a eficácia constitutiva da nulidade do acordo ou da ilicitude da conduta, mas se impõe "proprio in quanto atto di giudizio (nella parte cioè in cui accerta la corrispondenza della fattispecie concreta a quella astrattamente vietata dall'art. 81 o 82 Trattato): il giudice civile non può interpretare autonomamente la norma giuridica, né apprezzare diversamente $\mathrm{i}$ fatti di causa, ma è tenuto a recepire gli apprezzamenti della Commissione sul punto della illiceità della condotta ai sensi del diritto antitrust"; a eficácia vinculante não se projeta quando se invoca um precedente da Autoridade nacional, ainda que fundado em intendimento da Comissão Européia; também não há um duplo sentido vetorial obrigando a Comissão a aguardar decisões jurisidicionais de estados-membro (Negri, Giurisdizione e amministrazione nella tutela della concorrenza, pp. 81-83).

${ }^{116}$ Biavati, "Il diritto processuale e la tutela dei diritti in materia di concorrenza", p. 107.

117 Enrico Adriano Raffaelli, "L'applicazione del diritto antitrust comunitario tra giudici nazionali e comissione", in Rivista di diritto processuale, anno LXIII, n. 3, 2008, pp. 649 e ss. O autor afirma que "al fine di evitare che tal auspicata 'decentralizzazione' si accompagnasse al proliferare di pronunce contrastanti sulla medesima fattispecie - conseguenza ontologicamente legata alla presenza di più organi simultaneamente competenti ad applicare le medesime norme -, il legislatore comunitario ha previsto tutta una serie di strumenti volti a favorire la cooperazione tra i vari soggetti coinvolti (Comissione, autorità garanti della concorrenza nazionali e giurisdizioni nazionali)", que resultou na supremacia da Comissão sobre Autoridades e juízes nacionais. O autor contesta a normativa ao afirmar que assimila a Comissão como autoridade nacional sem que ela haja imparcialidade suficiente para tal e sem que haja uma forte confiança em seus precedentes, correntemente reformados pelo Tribunal de Primeiro grau da União Européia (esse sentimento de desconfiança parece ser menor em relação à AGCM), que contraria os princípios constitucionais de autonomia da magistratura, do direito de obter justiça da autoridade jurisdicional, e o direito a um processo equo. Afirma que "se, come è vero, esiste la primautè del diritto comunitario, è anche altrettanto e sicuramente vero che, ove a livello europeo sussistano (...) forme di deficit democratico non adeguatamente colmate da interventi legislativi, l'unico resituale strumento a cui fare appello è dato dai principi costituzionali fondamentali comuni agli ordinamenti nazionali dei vari Stati Membri, con i quali difficilmente si coordina un sistema che imponga ai giudici civili di rispettare le decisioni adottate da un organo amministrativo quale è l'esecutivo comunitario" (idem, p. 666).

${ }^{118}$ Negri, Giurisdizione e amministrazione nella tutela della concorrenza, p. 82.
} 
Todos esses tribunais ostentam características mais ou menos autônomas dentro da própria estrutura da administração e sofrem mais ou menos com os influxos das decisões judiciárias em seu bojo. Os exemplos da Comissão Européia refletem, em última instância, casos em que a importância dada ao órgão administrativo é relevante, ainda que se conheça a sua função supranacional e o contexto político no qual é inserido - em especial a manutenção do mercado, da concorrência e da coesão entre os países participantes da Comunidade Européia.

Mas a indagação verdadeira é sugerida por Calixto Salomão Filho nos seguintes termos: "é preciso determinar em que medida a forma de proteção dos interesses institucionais (ou difusos) prevista na lei é compatível com as exigências específicas desse setor. (...) A pergunta a se fazer aqui é se os entes aos quais é atribuída legitimidade pela lei para a propositura das demandas de proteção aos interesses institucionais são tecnicamente qualificados para tal. A mesma indagação pode ser feita com relação ao órgão judicante". O autor faz referência a Cappelletti e à idéia de iniciativa administrativa e aquela proveniente de corpos intermédios para a propositura de demandas metaindividuais, demonstrando ceticismo em relação ao controle administrativo (em razão da pressão política). Mas afasta as críticas, voltadas mais para a inefetividade de comandos, e defende a presença de tribunais administrativos especializados. E agrega: "a reparação dos prejuízos causados não basta. O sistema sancionatório deve gozar de instrumentos capazes de preservar o sistema concorrencial, fazendo cessar as violações através de instrumentos punitivos que permitam desestimular novo descumprimento à norma". ${ }^{119}$

Tenha-se presente que para alguns, em razão da unidade do poder e sua subdivisão em funções, "ontologicamente a jurisdição não difere da administração e da legislação". A diferença estaria em tese nas "peculiaridades na forma, características e disciplina positiva do exercício do poder enquanto voltado a cada uma delas (funções) (...) e cada uma das funções do Estado é um conjunto de serviços a serem prestados mediante atividades preordenadas a certos objetivos e que costumam ser agrupados e distinguir-se das demais precisamente em razão dos objetivos perseguidos". A destinação do exercício jurisdicional aos casos concretos, associada aos objetivos descritos, é que o "identifica e distingue". ${ }^{120}$ Porém, a partir do momento em que Tribunais administrativos se propõem

\footnotetext{
${ }^{119}$ Salomão Filho, Direito concorrencial-as condutas, pp. 78-79.

${ }^{120}$ Dinamarco, A instrumentalidade do processo, pp. 139 e 142.
} 
exatamente à solução de conflitos concretos mediante a instauração de um processo em que são preservadas características típicas do processo jurisdicional (acesso, reação, contraditório, prova, consciência da fundamentação, sujeição a priori ao comando), estarse-ia por aproximar sobremaneira a atuação do Tribunal Jurisdicional à do Tribunal Administrativo.

O SBDC foi criado, prevendo-se uma instância administrativa especializada $^{121}$ para debate de questões relacionadas com infrações ao direito antitruste, sem que se coloque aqui em questão, a princípio, a cláusula da inafastabilidade do controle judiciário. ${ }^{122}$ Muito já se discutiu sobre a utilidade e racionalidade desse sistema, na medida em que a decisão do CADE pode ser - e na maioria dos casos condenatórios o é submetida ao controle judicial e, em caso de arquivamento, não impede investigações destinadas à punição de condutas anticoncorrenciais, ainda que em demandas visando às tutelas individuais ou transindividuais com objetivos outros que não a proteção da concorrência como instituição.

121 Conforme recomendado pela OCDE, "visto que os Judiciários em economias de transição ou em desenvolvimento são inexperentes no trato de problemas de mercado livre, pode ser recomendável a constituição de tribunais especializados para decidir os caos concorrenciais. Estes tribunais devem atender todas as disputas comerciais ou ser especializados em atender apenas os casos concorrenciais. Ao concentrar a análise desses casos em juízes especialmente treinados para tal, deve-se aumentar a velocidade da aquisição de experiência e a produção de decisões mais consistentes e previsíveis. Os tribunais especializados da concorrência poderiam adotar procedimentos e regras de rpova especificamente cabíveis para os casos concorrenciais. A composição do tribunal pode ser criada de maneira condizente com as necessidades dos casos concorrenciais. Por exemplo, ao menos um enconomista deve integrar cada tribunal" (OECD, Diretrizes para elaboração e implementação de política de defesa da concorrência, p. 308). Cfr. ainda Sundfeld, quando afirma:"é-nos difícil compreender - e aceitar - que o Judiciário não seja o único foro para a mediação e solução de conflitos. Daí causar-nos certo choque que esse papel seja também exercido por um ente administrativo, a agência reguladora. Afinal, nossa compreensão profunda ainda hesita em admitir que a produção jurídica no âmbito da Administração pública possa ser tão importante socialmente quanto a do Poder Judiciário. O Judiciário, com a estrutura que lhe foi dada no século passado, não é capaz de conhecer de todos os conflitos decorrentes da vida moderna e das normas editadas para transformar em valores jurídicos os novos valores que foram sendo incorporados pela sociedade" (Sundfeld, "Introdução às agências reguladoras", p. 31.

${ }^{122}$ Franceschini resume essa relação: "por força do preceito constitucional consagrador do princípio da inafastabilidade do Poder Judiciário (art. 5º inc. XXXV, da Constituição Federal) inestimável salvaguarda dos direitos individuais, poderá o condenado pelo CADE pleitear, sempre, o controle judicial do ato administrativo representado pela decisão final adversa que repute ilegal. Sabe-se ser essa resolução colegiada um ato administrativo vinculado ou regrado, sujeitando-se, portanto, à revisão. Caberá então, à Justiça Federal civil (e não à criminal, posto que, como visto, se trata de ação anulatória de ato administrativo), reexaminar o pronunciamento quase jurisdicional impugnado, reapreciando o mérito da causa (thema decidendum) com ampla liberdade (não há confundir esse conceito com o de mérito administrativo, ou seja, a oportunidade ou conveniência, da decisão), podendo anular ou confirmar (mas não modificar) o decisório proferido" ("Roteiro do processo penal-econômico na legislação de concorrência", p. 57). O STJ recentemente reafirmou que "o recorrente pode (e deve), sempre que entender cabível, acionar o Judiciário para combater estas espécies de condutas lesivas à ordem econômica, independentemente da atuação administrativa do Cade. Isto em razão do que dispõe o próprio art. $5^{\circ}$, inc. XXXV, da Constituição da República” (STJ, 2 ${ }^{\mathrm{a}}$ T., Resp 650892, Rel. Min. Mauro Campbell Marques, j. 13.11.09). Cfr. ainda STJ, $1^{\text {a }}$ T., REsp 677585, Rel. Min. Luiz Fux, j. 6.12.05. 
Nessas situações, a decisão do CADE poderia ser enxergada como subinstância jurisdicional em matéria antitruste, de cunho opinativo, que é reexaminada em totum pelos órgãos do Poder Judiciário. ${ }^{123}{ }^{124}$ Essa revisão decorre de vetores de controle de poder, de inspiração no sistema de checks and balances "por meio do qual os Poderes do Estado interagem, ainda que se valendo de funções que não lhes sejam típicas, de sorte

${ }^{123}$ Como exemplo, confira-se TRF-4, Ap n. 2003.71.02.009633-6/RS, rel. Juiz Márcio Antonio Rocha, j. 19.12.08. Nesse caso, foi proposta ação anulatória de procedimento administrativo contra o CADE para a discussão sobre a validade de cláusula de exclusividade prevista em contrato de estatuto social de médicos cooperados pela ótica concorrencial. O Poder Judiciário revisou in totum a matéria, refutando o posicionamento do CADE, amparado em precedentes inclusive do STJ (STJ, 4 ${ }^{\mathrm{a}}$ t., AGRESP 179711, Rel. Min. Fernando Gonçalves, DJ 19.12.05; STJ, 4a T., AGRESP 200000529591, Rel. Min. Aldir Passarinho Junior, DJ 25.10.04.

${ }^{124}$ As particularidades do direito italiano levam ainda ao debate sobre a vinculação do juiz acerca de decisões proferidas pela AGCM. Embora o art. 101 da Constituição Italiana determine que o juiz esteja submetido somente à lei e não à decisão de outras esferas de poder, em razão do princípio da separação dos poderes, na prática é freqüente que o processo civil siga a conclusão della "instruttoria amministrativa" (em razão de uma autoridade do fato e não do direito definido) por força de uma persuasività e serietà delle instrutorie dell'Autorità Garante. A jurisprudência nega, mas a doutrina admite que o juiz está, "in linea di principio", vinculado aos provimentos da AGCM, porém, sem admitir um vínculo absoluto que retire do juiz sua livre apreciação e o transforme em um mero escrivão, que não possa exercer livremente seu mister sobre temas como a competência, violação da lei ou excesso de poder da Autoridade. Ainda assim, existe a manifesta intenção de atribuir à autoridade a missão de velar pela tutela de mercado por meio de um papel de relevância na concretização dos preceitos antitruste, em razão da sua especial competência técnica e em prol da preservação da unidade do ordenamento: "ed è un fatto che il giudice amministrativo si sia finora mostrato incline a riconoscere un ambito - più o meno ampio - di valutazioni riservate all'Autorità garante non surrogabili dal giudice: e ciò particolarmente per quanto concerne la determinazione del 'mercato rilevante' ed in genere le valutazioni complesse che coinvolgono l'apprezzamento di fatti alla luce di criteri tratti dalle scienze economiche, in quanto asseritamente frutto di una valutazione tecnico-discrezionale altamente opinabile" (Negri, Giurisdizione e amministrazione nella tutela della concorrenza, pp. 50-59). Debate-se ainda a questão da inversão judicial do ônus da prova sobre o fato declarado em sede administrativa, muito embora a autora rejeite o raciocínio: "infatti, nulla autorizza a ritienere che le valutazioni in fatto compiutte dalla Autorità garante siano per ciò solo corrette ed esaustive, a meno di reintrodurre per questa via quel 'vincolo tendenziale' agli aprprezzamenti complessi, a carattere 'tecnico-discrezionale' e quindi in linea di principio 'esclusivamente riservati' all'organo publico specializzato', che abbiamo cobattuto nelle pagine precedenti” (idem, p. 148-149). Há ainda o debate sobre a possibilidade de suspensão do processo judicial em razão de procedimento administrativo diante da Autoridade nacional. Além da hipótese do art. 295 do CPC italiano ("Il giudice dispone che il processo sia sospeso in ogni caso in cui egli stesso o altro giudice deve risolvere una controversia, dalla cui definizione dipende la decisione della causa"), discute-se criação de uma suspensão facultativa do processo por motivo de oportunidade, sempre à luz do nexo prejudicialidadedependência - disvinculada do escopo de evitar o conflito de decisões, para para utilizar a sentença com ulterior valência probatória. Mas a autora sustenta que tal medida contraria o princípio da duração razoável do processo. A suspensão do processo é sempre uma negação de justiça, ainda que temporânea, contrária à essência do processo que é feito para progredir - o legislador deve se abster de interpretar e estender as causas de suspensão (idem, p. 130-135). A autora ainda adverte: "nulla esclude perciò che in un prossimo futuro il legislatore italiano, seguendo l'impulso derivante dal diritto comunitario, possa prescrivere espressamente (salva ogni considerazione circa la disputabile legittimità costituzionale di una disposizione di tale portata) il dovere del giudice di conformarsi al previo accertamento amministrativo; ma allo stato attuale, ed in via meramente interpretativa, un tale risultato non può certamente attingersi" (idem, p. 62). Biavati reconhece o fenômeno ao analisar um caso concreto italiano e extrair a conclusão de que "un organo che non ha natura giurisdizionale determina, ai propri fini, la verità di taluni fatti; un volta che la decisione sanzionatoria dell'Autorità garante risulti stabilizzata, dopo il vaglio del giudice amministrativo, anche il fatto che ne costituisce il presupposto gode, non certo di un'efficacia di giudicato, ma comunque di ua forza storica che rende superfluo ogni diverso accertamente da parte dei giudici civili" (Biavati, "Il diritto processuale e la tutela dei diritti in materia di concorrenza", p. 104). 
a permitir uma fiscalização mútua que concretize a conjugação harmônica das principais funções estatais". ${ }^{125}{ }_{-}{ }^{126}$

Fosse para questionar a estruturação e privilegiar a celeridade dos julgamentos, a economia processual, a uniformidade das decisões e uma eficiência alocativa, seria necessário criar sistemas de vinculação jurisdicional das decisões administrativas, revisibilidade limitada (horizontalmente ou com supressão de instâncias) ou então, em solução diametralmente oposta, a abolição da instância administrativa, relegando a apreciação de toda e qualquer questão ao Poder Judiciário, ainda que a questão seja examinada por varas ou turmas especializadas, com a legitimidade ativa entregue ao controle atomizado (consumidor) ou ao Ministério Público.

Como nenhuma dessas possibilidades é viável diante do quadro constitucional e infraconstitucional brasileiro, a questão que posta neste trabalho é exatamente aquela sugerida por Salomão Filho, mas transcende a simples dúvida e equilibra algum comodismo legislativo combinado ao ativismo acadêmico: não se trata de simplesmente apurar se a proteção prevista na lei é compatível com as exigências específicas desse setor. A questão é trabalhar para outorgar legitimidade e qualificação ao ambiente processual no qual opera o SBDC, por meio de uma perspectiva instrumentalista.

${ }^{125}$ STF, Pet n. 1302, Rel. Min. Maurício Correa, j. 3.2.03.

${ }^{126}$ Zanetti Junior, Processo constitucional: o modelo constitucional do processo civil brasileiro, p. 44-50. 


\section{POLÍTICA E FUNÇÃO JUDICANTE}

Falou-se muito sobre a pretensão do antitruste brasileiro, voltada para a implementação de políticas públicas ${ }^{127}$ que protejam a concorrência e o bem-estar social. A definição conduz a perspectivas bastante genéricas, que podem conduzir a uma interpretação equivocada do que realmente se pretende com a atividade desenvolvida pelos órgãos do SBDC, especialmente na faceta repressiva de sua atuação. Para evitar raciocínios enviesados, é preciso discorrer ainda que brevemente sobre o alcance dos escopos antitrustes mais detalhadamente.

Política, em sentido geral, diz respeito à organização social, exercício do poder, governo em um Estado e forças sociais. No exercício de poder, política é "a linha de princípio de ação, natureza e conteúdo da ação de uma autoridade, formas de implementação dessa ação, suscetíveis de serem aplicadas na esfera jurídica ('legal policy') ou no seio das quais o direito e suas instituições de implementação (a Justiça, a administração etc.) podem desempenhar um papel, notadamente na esfera das políticas públicas". ${ }^{128}$ Já a política pública é o "conjunto de atos e de não-atos que uma autoridade pública decide por em prática para intervir (ou não intervir) num domínio específico”. É um processo de escolhas de atos de governo à luz do que se escuta da sociedade, da qualidade de escolhas, da pretensão de alocação eficaz de recursos, caracterizada por um conteúdo, um programa, orientações, um grau de coerção e um centro subjetivo de afetação. $^{129}$

A ingerência do Estado sobre a economia se dá pela definição de prioridades, medidas e metas adequadas aos imperativos constitucionais e às perspectivas econômicas ali estabelecidas, coordenando aspectos públicos e privados, liberais e sociais, por meio de um tratamento sistêmico, que atribua segurança e previsibilidade às relações de mercado. O direito econômico, portanto, estuda a relação entre a política pública (econômica) e seus agentes. Analisa ali o conjunto de normas de conteúdo econômico

${ }^{127}$ Há intrínseca conexão entre o direito antitruste e o direito econômico. Este último, por seu turno, consolida-se como ramo atento à implementação de políticas públicas que observem estritamente as diretrizes constitucionais e que produzam direito e atribuam segurança às relações econômicas. O Estado, dessa forma, "enriquece suas funções de integração, de modernização e da legitimação capitalista" (Eros Roberto Grau, A ordem econômica na Constituição de 1988, n. 11).

${ }^{128}$ André-Jean Arnaud et al., Dicionário enciclopédico de teoria e de sociologia do direito, p. 599.

${ }^{129}$ André-Jean Arnaud et al., Dicionário enciclopédico de teoria e de sociologia do direito, pp. 600-601. 
relacionadas com a composição de interesses individuais e coletivos em determinado momento histórico-político-social. Trata-se de mecanismo apto à concretização de direitos sociais, veículo de efetivação de direitos individuais. ${ }^{130}$ Vale-se de preceitos particulares, tais como: o equilíbrio (de interesses individuais e sociais), a equivalência (entre o pagamento da obrigação e seu correspondente 'valor'), a recompensa (a contraprestação pela ação econômica, benéfica ao agente e à coletividade), a livre iniciativa (e suas restrições relacionadas com a justiça social, o bem comum, o interesse coletivo e a segurança nacional), a primazia da realidade social (regulamentação adequada ao contexto social econômico), a utilidade pública e a oportunidade (contextualização do ato econômico para avaliar sua legitimidade), a regra da razão (mesmo contrária à norma, um conduta poderá ser mais benéfica ao mercado em circunstâncias especiais, flexibilidade legal diante da modificação da realidade fática) e as regras da irreversibilidade e da precaução, que visam à manutenção ou alteração de plano econômico conforme a sua adequação ao sistema. ${ }^{131}$

Se considerarmos então que estruturalmente os órgãos do SBDC são vinculados ao Poder Executivo (o CADE é uma autarquia federal vinculada ao Poder Executivo, a SDE é Secretaria do Ministério da Justiça e a SEAE está vinculada ao Ministério da Fazenda), um primeiro olhar leva à afirmação de que julgamentos do CADE têm natureza política. Mas a afirmação seria precipitada.

A atividade judicante do CADE é sujeita às balizas legais, estabelecidas atualmente pela lei n. 8.884/94. As condutas anticompetitivas são exemplificadamente expostas nos arts. 20 e 21, as linhas gerais do processo administrativos foram ali postas e o aplicador não tem autonomia para deixar de aplicar este ou aquele dispositivo ao seu bel prazer.

Toda norma contém espaços para interpretações e o exercício hermenêutico é inato aos operadores do direito. ${ }^{132} \mathrm{Se}$ ao legislador não é dado nem

\footnotetext{
${ }^{130}$ Albino de Souza, Primeiras linhas de direito econômico, p. 25.

${ }^{131}$ Albino de Souza, Primeiras linhas de direito econômico, pp. 92-103.

132 Para Maximiliano, "as leis positivas são formuladas em termos gerais; fixam regras, consolidam princípios, estabelecem normas, em linguagem clara e precisa, porém ampla, sem descer a minúcias. É tarefa primordial do executor a pesquisa da relação entre o texto abstrato e o caso concreto, entre a norma jurídica e o fato social, isto é, aplicar o direito. Para o conseguir, se faz mister um trabalho preliminar. Descobrir e fixar o sentido verdadeiro da regra positiva; e, logo depois, o respectivo alcance, a sua extensão. Em resumo, o executor extrai da norma tudo o que na mesma se contém; é o que se chama
} 
desejado antever todas as situações potencialmente conflitantes ou que por qualquer razão demandem a criação de um dever, cabe ao operador do direito o exercício de interpretação e de subsunção do fato à norma, pelos diversos mecanismos existentes.

A norma, como conjunto de proibições, obrigações e permissões atua como elemento de subordinação, coordenação e organização de comportamento humano, além de delimitar o exercício do poder. O imperativo vinculante, após sua institucionalização, cria a tese normativa e indica a conseqüência jurídica, ${ }^{133}$ mas para tanto demanda o auxílio do operador que penetra no conhecimento, nas razões da criação e imposição normativa, à luz de atitudes esperadas pela sociedade, uma expectativa generalizada numa situação de normalidade. ${ }^{134}$ A norma antitruste transcende sua origem burocrática. Ela carrega em si mais de quinhentos anos de história, sofre influxos de mais de um século de direito concorrencial e mais de século e meio de direito processual; está inserida em um sistema extremamente vaso-comunicante, que correlaciona inúmeros ramos do direito (estado, concorrencial, econômico, processual, administrativo, civil, penal) e demanda interpretações sistemáticas. A hermenêutica atua, assim, incisivamente sobre e para o direito concorrencial. ${ }^{135}$

Forgioni reafirma esse conceito ao definir o direito concorrencial como ramo do direito destinado à implementação de políticas públicas, especificamente uma política econômica por meio da influência do Estado. Essa influência estaria destinada a

interpretar, isto é, determinar o sentido e o alcance das expressões do direito" (Maximiliano, Hermenêutica e aplicação do direito, pp. 33 e ss).

${ }_{133}^{133}$ Ferraz Jr. Introdução ao estudo do direito - técnica, decisão, dominação, p. 103.

${ }^{134}$ Cláudia Lima Marques, referindo-se a Erik Jayme, discorre justamente sobre a reação a esse pensamento: "Erik Jayme alerta-nos para os tempos pós-modernos, onde a pluralidade, a complexidade, a distinção impositiva dos direitos humanos e do 'droit à la differènce' (direito a ser diferente e a ser tratado diferentemente, sem a necessidade mais de ser 'igual' aos outros) não mais permitem este tipo de clareza ou mono-solução. A solução sistemática pós-moderna deve ser mais fluida, mais flexível, a permitir maior mobilidade e fineza de distinções. Nestes tempos, a superação de paradigmas é substituída pela convivência dos paradigmas" (Lima Marques-Benjamin-Miragem, Comentários ao Código de Defesa do Consumidor, pp. 24-28).

35 Sobre o direito Americano, Hovenkamp inicia recente trabalho afirmando que "if one hundred years of federal antitrsut policy have taught us anything, it is that antitrust is both political and cyclical". Examinou o pensamento de Chicago, auto entitulado não-político, para destacar o ceticismo de seus críticos, que afirmar ser isso uma "simple hogwash, or perhaps even a cover for a very strong, probusiness political bias that work to the benefit og the rich". A política antitruste é mutável, com alterações consideráveis ao longo do tempo. Negar a sua mutabilidade é negar ainda sua sujeição ao processo político e, portanto, democrático ("Antitrust policy after Chicago", pp. 213-214, 232-233). 
eliminar os efeitos autodestrutíveis do mercado e orientar grupos de empresas em relação ao desenvolvimento possível e desejado, sempre por meio da aplicação da lei antitruste. ${ }^{136}$

Todo esse processo recai sobre as escolhas do julgador, dos Conselheiros do CADE. Eles devem estar atentos à literalidade da norma, aos escopos da atividade administrativa judicante, à proteção da concorrência, ao bem estar social, aos diversos sistemas que tangenciam o antitruste, às conseqüências de sua decisão perante a liberdade de iniciativa, a função social da propriedade, a defesa dos consumidores e a repressão do abuso do poder econômico. Diante de variáveis dessa natureza, o julgador aplica o direito ao caso concreto, condenando ou não uma empresa pela prática de ato anticoncorrencial.

A questão que se põe é: o CADE é órgão político? Se há uma preocupação em analisar a legitimação de sua atividade, seria a função jurisdicional, judicante por excelência menos política que a função do CADE, ou então apolítica?

No exercício do poder julgar, Dinamarco refere-se a Jellinek para qualificar o intervencionismo estatal à luz do trinômio conservar, ordenar e ajudar. Há uma relação de direta proporção entre o acréscimo de interesses comuns, responsabilidade do Estado e intervencionismo. O repúdio à política de fins limitados do Estado leva-nos a cultuar o valor homem por meio da justiça, em um conteúdo substancial e efetivo, que reduza diferenças sociais e econômicas, gere oportunidades, assegure a fruição comum de bens materiais e imateriais e crie condições de mobilidade sócio-econômica. $\mathrm{O}$ "Estado, então, pretendendo ser a 'providência do seu povo', sente que o bem-estar coletivo depende intimamente da sua participação efetiva nos destinos da população. Ele é, por isso, declaradamente intervencionista, agindo sobre a ordem econômica e social e buscando sua modelagem segundo os objetivos da ideologia aceita". ${ }^{137}$

Poder se aproxima de política como "processo de escolhas axiológicas e fixação dos destinos do Estado". Se a ciência política é o estudo da formação, do exercício e da distribuição de poder, o processo serve como o elo entre o sistema processual e a política, porque serve como instrumento "capaz de produzir os efeitos pretendidos (ou simplesmente de alterar as probabilidades de obter esses efeitos) sobre a matéria ou sobre as pessoas", de forma decisória e imperativa. E mais, "no contexto de exposição do poder

\footnotetext{
${ }^{136}$ Forgioni, Os fundamentos do antitruste, pp. 196-199.

${ }^{137}$ Dinamarco, A instrumentalidade do processo, pp. 18, 34-35.
} 
desenvolvido sobre o eixo da decisão, falou-se também nele como 'processo de afetar políticas dos outros com a ajuda de privações severas', como o adendo de que 'ter poder é ser levado em conta nos atos (políticas) dos outros"”; além da relação do binômio vontade de dominar e disposição a obedecer, sendo que "sujeição é o exato contraposto negativo do poder e no binômio poder-sujeição bem se expressa a fundamental relação entre o Estado e o indivíduo". ${ }^{138}$

A aproximação entre o exercício do poder, política e o Poder Judiciário é evidente. ${ }^{139}$ Se politização da justiça é o "ativismo coordenado na realização de políticas públicas", após a Constituição de 1988 o papel do Judiciário se eleva substancialmente por força de seu relevante papel no controle de determinações de outros Poderes - referência ao sistema de checks and balances - quer na outorga de ferramentas de democratização do processo. A judicialização da política se faz presente com a interferência causada por instrumentos transindividuais e pelo volume de instrumentos individuais potencializados pela premissa renovatória do acesso à justiça, que atuam de forma consistente sobre as decisões políticas. ${ }^{140}$

A politização do Judiciário é concreta em um Estado democrático de direito e não passa de um falso problema, especialmente no seu apogeu: o momento judicante. De um lado, conforme ensina Taruffo, o processo de construção de decisão - o raciocínio racional-legal do juiz - "não é regido por normas nem determinado por critérios ou fatores de caráter jurídico" e que toda decisão envolve "linguagem técnica e linguagem comum, esquemas e modelos de argumentação, formas dedutivas, juízos de valor, instrumentos de persuasão retórica, conhecimentos de variada natureza, regras éticas e de comportamento, interpretações, escolhas de diversos gêneros etc. Trata-se, pois, de um raciocínio estruturalmente complexo e heterogêneo, no qual se encontram e se baralham diversas dimensões lógicas, lingüísticas, cognoscitivas e de argumentação". ${ }^{141}$ Larenz

\footnotetext{
${ }^{138}$ Dinamarco, A instrumentalidade do processo, pp. 100-102, 107-110, 119-124.

139 "Os objetivos da lei se assemelham, mais e mais, aos objetivos de políticas (...) essa evolução que consiste em fazer cada vez mais da questão jurídica uma questão política anuncia certamente uma espécie de mudança de perspectiva (ou um retorno às fontes) no seio das ciências sociais" (Arnaud, Dicionário enciclopédico de teoria e de sociologia do direito, p. 600).

${ }^{140}$ Tais mudanças "transformaram o papel do Judiciário que, de espectador passivo no paradigma legalista, passou a ser chamado a opinar em questões de dimensão política e social antes jamais imaginadas, quer em razão dos novos direitos materiais surgidos no quadro da nova Carta Magna, quer em razão da própria dimensão alargada dos instrumentos processuais postos à disposição da cidadania para garantir a efetividade desses direitos (Zanetti Junior, Processo constitucional: o modelo constitucional do processo civil brasileiro, pp. 150).

${ }^{141}$ Taruffo, "Senso comum, experiência e ciência no raciocínio do juiz".
} 
afirma que "cada homem está marcado em seu modo de entender as coisas, seja por sua origem, por seu envolvimento pessoal, pela educação cultural recebida, por suas experiências próprias e profissionais, e muitos outros fatores. A 'independência de pensamento' não é congênita para ninguém e tampouco se adquire com instrução e exige trabalho solitário do homem ao longo de sua vida". ${ }^{142}$

O juiz é um membro da sociedade em que vive, recebe os seus influxos culturais, está ciente de seus problemas e aplica esse conhecimento às escolhas decisórias. ${ }^{143}$ Ele está sujeito a influxos externos, mas têm severos limitadores de conduta: um sistema normativo, princípios constitucionais, regras éticas, morais e limitações jurídicas. De outro lado, existem mecanismos suficientes, garantidores de liberdades institucionais (v.g., garantias constitucionais da magistratura), que impedem a submissão das decisões judiciárias às orientações administrativas partidárias e não voltadas ao valor da justiça, mas não excluem o fato de o Poder Judiciário estar atento às políticas públicas por meio de seus agentes. ${ }^{144}$

A atividade jurisdicional acomoda a legislação à luz do sistema político: "magistratura e o sistema jurídico são cognitivamente abertos ao sistema político". Essa premissa decorre de conexões entre subsistemas e mudanças no seu próprio interior. Ainda assim, a despeito de elevadas taxas de independência e criatividade, o juiz não substitui orientações políticas ou econômicas constitucionais (sob pena de indevida corrupção de código do subsistema), muito embora seja inegável que o Judiciário tenha expandido seu peso no interior do sistema político. Trata-se de uma inerência do Estado social, um alargamento da esfera de ação pública no controle do Poder, razão pela qual o Judiciário se

\footnotetext{
${ }^{142}$ Karl Larenz, Derecho justo, p. 183.

${ }^{143}$ Dinamarco, A instrumentalidade do processo, p. 41. Anot-se ainda que "neppure i giudici si limitino ad applicare il diritto, ma che nel concreto (paicia o no) operino una selezione di interessi. A maggior ragione, non è accettabile una visione falsamente avalutativa delle scelte degli organi che tutelano il mercato. Questo, naturalmente, non significa che Comissione e autorità garanti non cerchino di svolgere al meglio il loro lavoro: significa soltanto dire che non sono soggetti neutrali, imparziali, terzi, ma che perseguono un interessi. Ne segue che non si può pensare che la tutela dei diritti soggettivi coinvolti dai loro provvedimenti possa essere soltanto una tutela interna, ma deve essere anche e soprattutto una tutela esterna, dinanzi ad altri organi, questa volta di piena forza giurisdizionale" (Biavati, "Il diritto processuale e la tutela dei diritti in materia di concorrenza”, p. 101). O conceito é apropriado, só não pode ser potenciado, tal como feito pelo autor, para justificar uma imparcialidade concreta e transponível às decisões.

${ }^{144}$ Zanetti Junior, Processo constitucional: o modelo constitucional do processo civil brasileiro, pp. 149-154.
} 
torna "importante arena de exposição, afirmação e condensação dos conflitos através de operações estratégicas". 145

Nesse aspecto, o ato judicante não é substancialmente distinto do ato decisório proferido perante o Poder Judiciário, o que, numa primeira observação, não retira a legitimidade dos julgamentos do CADE.

A idéia de julgamentos políticos pode então remeter ao conceito de discricionariedade ou vinculação dos atos da administração pública.

$\mathrm{O}$ ato administrativo dá concretude à norma pelo Estado, com finalidade de criar, modificar, extinguir, reconhecer relações jurídicas entre o prolator e o administrado. Podem ser classificados de diversas formas ${ }^{146}$ - e aqui nos importa a distinção entre atos discricionários e vinculados. Não é possível dizer que os atos do CADE são discricionários, passíveis de livre escolha pelo aplicador, desprezando letra da lei de forma livre e desvinculada à lógica hermenêutica.

Discricionariedade não significa aplicar ou não a vontade concreta da lei. Significa sim escolher, entre duas situações igualmente legítimas (amparada pelo sistema normativo) aquela que melhor se amolda ao caso concreto, o que usualmente exige a aplicação de técnicas de interpretação. O aplicador deve "escolher, segundo princípios constitucionais (em especial os da moralidade, eficiência, razoabilidade e proporcionalidade) que regem a Administração Pública, a medida ou solução legal que melhor atenda ao fim público que deflui da norma". ${ }^{147}$ É o "eleger, segundo critérios consistentes de razoabilidade, um, dentre pelo menos dois comportamentos cabíveis perante cada caso concreto, a fim de cumprir o dever de adotar a solução mais adequada à satisfação da finalidade legal, quando por força da fluidez das expressões da lei ou da liberdade conferida no mandamento, dela não se possa extrair objetivamente uma solução unívoca para a situação vertente". ${ }^{148}$

\footnotetext{
${ }^{145}$ Campilongo, Política, sistema jurídico e decisão judicial, pp. 61 e ss. Par Fiss, "nn my view, courts should not be viewed in isolation but as a coordinate source of governmental power. They should be viewed as an integral part of the larger political system. Democracy does in fact commit us to consent as the foundation of legitimacy, but that consent is not one that is granted separately to individual institutions" (Fiss, "The Social and Political Foundations of Adjudication" p. 125).

${ }^{146}$ V. Bandeira de Mello, Curso de direito administrativo, pp. 414 e ss.

${ }^{147}$ Pazzaglini Filho, Princípios constitucionais reguladores da administração pública, p. 83.

${ }^{148}$ Bandeira de Mello, Curso de direito administrativo, n. XI.
} 
Fonseca afirma "o caráter interativo ou complementar dos princípios que orientam o poder discricionário da autoridade. A observação óbvia é que não existe um poder discricionário ilimitado. O grau de discrição é função do enunciado das disposições legais". ${ }^{149}$ José Afonso da Silva analisa o tema para afirmar ser certo que a doutrina firmou "a orientação de que a discricionariedade é sempre relativa e parcial, porque, quanto à competência, à forma e à finalidade do ato, a autoridade está sempre subordinada ao que a lei dispõe; são eles, pois, aspectos vinculados do ato discricionário, pelo que este só se verifica quanto ao motivo e ao objeto do ato. E é aqui que se dá a distinção entre atos discricionários e vinculados. Se o motivo e o objeto forem expressos em lei, o ato é vinculado; se não o forem, resta um campo de liberdade ao administrador, e o ato é discricionário". ${ }^{150}$

No âmbito do CADE, supostamente admitida a "discricionariedade", ela parece ser nada além da interpretação do sistema normativo antitruste à luz da norma. É por isso que se afirma: "ao passar da abstração à concretude, os conceitos indeterminados da legislação concorrencial perdem a indeterminação, pois acabam explicitados, muitas vezes, pela própria ciência econômica, e, conseqüentemente, deixam de ser substrato para discricionariedade". ${ }^{151}{ }^{152}$

Todos os atos administrativos estão sujeitos à lei e o julgamento de decisões do CADE é ato vinculado, à luz da lei n. 8.884/94 e respectivos regulamentos, sendo que interpretações jurídicas derivadas de conclusões técnicas não atribuem à decisão a característica da discricionariedade. Se a lei atribui o poder ao Plenário do CADE de apreciar situações potencialmente ofensivas, uma vez acionado, deve ele proferir o comando perante o caso concreto sob a égide da lei. No caso do CADE, a idéia de que "a administração tem na lei o limite de sua atividade, não o objeto de seus cuidados (como os órgãos jurisdicionais)" precisa ser relida. ${ }^{153}$

\footnotetext{
${ }^{149}$ Fonseca, "Papel dos tribunais administrativos e sistema judicial", p. 22.

${ }^{150}$ Afonso da Silva, Curso de direito constitucional positivo, p. 427.

${ }^{151}$ Oliveira-Rodas, Direito e economia da concorrência, p. 326. V. ainda Ferraz Jr., "Discricionariedade nas decisões do CADE sobre atos de concentração econômica”, p. 88.

${ }^{152}$ Apesar de vinculação ser tratada como delimitação pela lei de atos de competência, contendo requisitos predeterminados relacionados com finalidade e forma e discricionariedade como liberdade de escolha de conteúdo de ato, por conveniência e oportunidade, autorizada explícita ou implicitamente por lei, até mesmo o direito administrativo vem reconhecendo a mitigação da discricionariedade em razão de limitadores como o princípio da legalidade, o dever de agir com base em escopo finalístico (Bandeira de Mello, Discricionariedade e Controle Jurisdicional, pp. 14/48).

${ }^{153}$ Dinamarco, A instrumentalidade do processo, p. 257.
} 
Negri, amparada em Marengo e Angiolini, refere-se à compatibilidade entre discrição e vinculação e à possibilidade de valoração discricionária em atos vinculados e sobre a relação entre discricionariedade administrativa e interpretação jurisdicional de conceitos indeterminados. Conclui que a autoridade procede à qualificação da licitude ou ilicitude da conduta dos particulares, por meio de regras de conduta inteiramente predeterminadas pelo legislador, sem espaço para ponderações ou análises discricionárias e sem, em particular, poder reconhecer ou negar os efeitos previstos pela lei por razões de oportunidade. ${ }^{154}$

Nessa linha o pensamento de Meirelles, para quem "bastaria a exigência de processo administrativo para afastar a natureza discricionária de suas decisões, pois para a prática de atos discricionários não haveria necessidade de processo de apuração dos fatos que os antecedem somente os atos vinculados exigem o processo a que se vinculam". ${ }^{155}$

A vagueza dos conceitos ${ }^{156}$ não é um simples mote para justificar a não aplicação da vontade concreta da norma: ela é um ressabido instrumento de dinâmica na aplicação direito. Na definição da fattispecie lesiva à concorrência, o legislador sempre mantém o nível de vagueza normativa tal a permitir uma aplicabilidade mais ampla, especialmente como válvula de escape destinada a permitir mutações e evoluções dos comportamentos econômicos, para assim evitar "i rischi di una rapida obsolescenza verosimilmente conessi ad una disciplina a tutela della concorrenza troppo rigida e minuziosa". 157

Se vinculados, amparados por noções técnicas, os atos comportariam inevitavelmente revisão pelo Judiciário. ${ }^{158}$ Há quem entenda o contrário, e por haver discricionariedade nas decisões do CADE, a sua revisibilidade pelo Poder Judiciário seria

\footnotetext{
${ }^{154}$ Negri, Giurisdizione e amministrazione nella tutela della concorrenza, pp.12-13, nota 36, 39 e 249.

155 Meirelles, "Repressão ao abuso do poder econômico", p. 135.

156 "È certo che le agencies esercitano discrezionalità nello svolgere le loro funzioni: si tratta di una discrezionalità esecutiva e tuttavia particolarmente ampia e significativa, che è giustificata dai livelli di competenza tencina richisti per il compimento della especifica mission, e dalla natura delle norme di regolazione, i cui stantard applicativi devono necessariamente esse piuttosto vaghi” (Benedetto, L'Autorità garante della concorrenza e del mercato, p. 27).

${ }^{157}$ Benedetto, L'Autorità garante della concorrenza e del mercato, p. 69. A autora afirma que "le norme che L'Autorità garante della concorrenza e del mercato si trova a dover applicare sarebbero, dunque, prevalentemente norme di principio la cui utilizzazione a fini di decisione comporta una costruzione più articolata della motivazione $\mathrm{e}$ - in qualche modo - una maggiore discrezionalità nello svolgersi del ragionamento giustificativo". É com essa extensão do conceito de discricionariedade na atividade antitruste que não se concorda.

${ }^{158}$ Afonso da Silva, Curso de direito constitucional positivo, p. 427.
} 
mitigada: "dentro dos limites que lhe permite a lei, ao judiciário caberá avaliar (...) se esses limites foram ou não ultrapassados, se os ditames constitucionais relativos à atividade administrativa foram ou não cumpridos, mas jamais modificar o juízo de valor a respeito de determinada situação". ${ }^{159}$

Ao contrário, a possibilidade de revisão de uma decisão que se faz presente no sistema ratifica que os julgamentos da CADE dizem o direito, aplicam a vontade concreta da norma e vinculam o comando. Se o administrador emite comando que diverge da norma (ou de boa técnica hermenêutica), a questão será fatalmente posta para a análise do Poder Judiciário. Se o juiz de primeiro grau faz o mesmo, o sistema processual oferece uma série de remédios voltados à impugnação da decisão, até a possível palavra final emitida pelo Supremo Tribunal Federal.

Benedetto encampa a idéia ao ratificar o controle sobre eventual "discricionariedade" do juiz em uma construção positivista vinculada às escolhas do legislador "di modo che si potesse assicurare l'idoneità strutturale della funzione giurisdizionale a far emergere e prevalere l'interesse pubblico tutelato dalla legge nel caso in specie, vale a dire si potesse assicurarne la sua terzietà". E, em raciocínio doutrinariamente amparado, sustenta uma discricionariedade criativa como "forma de atividade legislativa" uma relação entre discricionariedade e lacunas do direito por meio da reconstrução de um universo normativo que articula normas legais gerais (standards of conduct), regras e princípios: "le regole e i principi presentano diversi livelli di vaghezza ed astrazione concettuale: in particolare, si distinguono sotto il profilo della interpretazione-applicazione che nell'un caso si risolve in un silogismo, nell'altro in una argomentazione. Il Principle a sua volta è distinto dalla policy, 'standard che indica un obiettivo da raggiungere, in genere un miglioramento di qualche aspetto della vita della comunità". E a AGCM perseguiria objetivos de policy. ${ }^{160}$

A questão é controversa. Biavati, contrariamente, busca desmistificar a pressuposta falta de discricionalidade nas decisões da AGCM e da Comissão Européia. Aduz que nem mesmo os juízes se limitam a aplicar o direito, realizando no caso concreto

\footnotetext{
${ }^{159}$ Farina, "Do processo administrativo e da natureza do ato", Revista do IBRAC, v. 3, n. 6, pp. 104-108.

${ }^{160}$ Benedetto, L'Autorità garante della concorrenza e del mercato, pp. 377-378.
} 
uma "selezione di interessi". Objetivamente, defende que as Autoridades procuram desenvolver seu trabalho regularmente, mas afasta a neutralidade axiomática. ${ }^{161}{ }^{162}$

À Comissão Européia, por sua vez, atribui-se declarada e ostensiva discricionariedade. Ela decide sobre a necessidade de sua intervenção (na instauração do processo ou mesmo durante ele), ostentando discricionariedade no ato: "non esiste comunque un vero e proprio diritto dei denuncianti a che la Commissione dia seguito alla loro denuncia. La Comissione infatti non è tenuta ad adottare una decisione in merito all'esistenza di una infrazione, ne ha l'obbligo di procedere all'avvio di un'istruttoria ogniqualvolta riceva una denuncia. Infatti dal momento che alla Comissione è affidato un compito di vigilanza e controllo vasto e generale nel settore della concorrenza, il fatto che la Commissione assegni gradi di priorità differenti alle questioni sottoposte al suo esame è conforme agli obblighi che le impone il diritto comunitario". A questão pode ser remetida ao Tribunal da União, que deve examinar se a decisão foi proferida com base em fatos inexatos, erros de direito, de valoração ou desvio de poder e, principalmente, se foi fundamentada (motivação suficiente, precisa e detalhada, considerando-se, porém, que "la Comissione non è tuttavia tenuta a prendere posizione su tutti gli argomenti addotti dai denuncianti a sostegno della loro denuncia. Essa deve soltanto esporre gli elementi di diritto e di fatto che hanno importanza determinate per la decisione"). ${ }^{163}$

A questão precisa se afastar da semântica: o Judiciário e a autoridade têm o poder de dar a única solução hermeneuticamente viável a um caso concreto ou ambos são politicamente influenciados? A definição de discricionariedade acima atribuída conduz à resposta: em ambos os processos decisórios há interpretação de conceitos para se chegar a uma solução. Logo, também aqui se afasta a discricionariedade "política" na atuação dos órgãos do SBDC. Seus atos são vinculados e a margem atribuída na aplicação das normas se deve às mesmas técnicas hermenêuticas atribuídas a, por exemplo, órgãos do Poder Judiciário, judicantes por excelência. ${ }^{164}$

\footnotetext{
${ }^{161}$ Biavati, "Il diritto processuale e la tutela dei diritti in materia di concorrenza", p. 101.

${ }^{162}$ Garofoli entende que há discricionariedade na AGCM em sede de atos de concentração, sem exemplificar casos de apuração de conduta ("Procedimento, accesso e autorità indipendenti", pp. 3335 e ss).

${ }^{163}$ Bellodi, "Le denunce", pp. 88-89 e 117.

${ }^{164}$ Em sede jurisprudencial, fala-se em discricionariedade judicial na definição de ações conexas (STJ, 4 ${ }^{\mathrm{a}}$. T., RESP 5270, rel;. Min. Salvio de Figueiredo Teixera, j. 16.3.92), na concessão ou não de medidas liminares (STJ, 1 ${ }^{\mathrm{a}}$. T., RESP 153894, Rel. Min. Milton Luiz Pereira, j. 12.5.98), na realização ou não de provas ainda que já deferidas (STJ, 4ª T., RESP 83751, Rel. Min. Sálvio de Figueiredo Teixeira, j. 19.06.97). Com mais acerto as palavras de Amendoeira Jr., quando afirma que "o juiz não tem verdadeiramente ônus ou faculdades
} 
Há, porém, um ponto efetivamente político na atuação antitruste, mas fora da atividade judicante. Esse ponto não interfere substancialmente na atividade em si, mas sim nos meios oferecidos à consecução desses objetivos. Para entender os efeitos da disciplina política, temos inicialmente o renomado caso americano. Em interessante e recente artigo, Daniel Crane faz uma análise crítica sobre a influência do pensamento antitruste da Escola de Chicago, sobre a preocupação da atual administração americana a respeito do public antitrust enforcement. ${ }^{165}$

Forgioni faz menção ao caso norte-americano no qual o DOJ criou “"pautas de interpretação do Sherman Act, de forma a assegurar a realização do declarado objetivo de favorecer as exportações norte-americanas e sancionar os cartéis prejudiciais aos interesses do país" e ainda ao caso do cartel dos armadores ingleses, "aceitos, não obstante seu caráter restritivo da concorrência, por se entender que constituem um fato de estabilização e eficiência do mercado". Ao final, a autora afirma que a atuação estatal se concretiza mediante a interpretação/aplicação das normas de direito concorrencial. ${ }^{166}$

Tem-se também o caso Europeu, em que a aplicação de normas antitruste foi declaradamente utilizada como bandeira de unificação, dado que a proteção de um mercado unificadoera passo essencial para as demais propostas políticas, econômicas e sociais unificadoras da Comunidade.

No Brasil, a influência de certa forma política (com a sempre cautelosa leitura do termo) também se fez sentir, em especial no que diz respeito ao tema deste trabalho.

Como dito acima, a atuação do CADE e a própria atividade antitruste no Brasil foi tímida ou incipiente da sua criação até a promulgação da lei n. 8.884/94. A norma desde o início previu a atuação preventiva no controle das estruturas e a atuação repressiva no controle de condutas; contudo, num contexto social de abertura de mercado e

no processo, mas apenas e tão-somente poderes-deveres, de modo que, para nós, não é possível falar-se em discricionariedade judicial. Todos os atos do juiz, ainda que indiretamente, são vinculados à lei, mesmo naqueles casos em que a lei se valha de conceitos vagos ou indeterminados (como o fumus boni iuris, a verossimilhança, o periculum in mora, boa-fé, má-fé, bons costumes, ordem pública entre outros) ou use expressões como "prudente arbítrio do juiz" ou expressões assemelhadas" (Amendoeira Jr., Poderes do Juiz e tutela jurisdicional: a utilização racional dos poderes do Juiz como forma de obtenção de tutela jurisdicional efetiva, justa e tempestiva, n. 3.2).

${ }_{165}$ Crane, "Obama's antitrust ambitions", passim.

${ }^{166}$ Forgioni, Os fundamentos do antitruste, pp. 196-199. 
grandes operações de fusões e aquisições, o CADE concentrou sua atuação no exame de atos de concentração.

A Europa segue tradição germânica de análise de acordos de cooperação como estruturas a serem previamente controladas, o que se tem demonstrado impossível na prática, apontando-se para alguma tolerância das autoridades. Sendo assim, "as novas teorias econômicas, baseadas em recentes desenvolvimentos dos métodos econométricos e dos métodos analíticos, passam a se interessar pelo comportamento de empresas individuais ou de setores ou subsetores industriais isolados. Desnecessário dizer que a conseqüência, no plano jurídico, é o deslocamento do controle das estruturas para o controle dos comportamentos". ${ }^{167}$ Forgioni, exatamente sobre o tema, há algum tempo afirmava que "grande parte da energia e dos recursos públicos empregados pelo SBDC direciona-se à análise de atos de concentração e não de processos administrativos, que investigam condutas abusivas. Espera-se que, com o fortalecimento do CADE e dos demais órgãos integrantes do SBDC, perante o sistema político e a própria opinião pública, maior atenção seja dada, por parte das autoridades antitruste, às condutas anticoncorrenciais dos agentes". 168

De fato, passado o primeiro período embrionário, o processo de apuração de condutas passa a receber uma maior atenção do sistema. A lei n. 10.149/00, proveniente da MP 2.055, foi o primeiro e relevante passo ao ampliar os poderes investigatórios dos órgãos do SBDC, com a regulamentação do pedido de busca-e-apreensão, de astreintes, de inspeções e, em especial, do programa de leniência brasileiro; a OCDE alerta para a nocividade dos cartéis e o sobrepreço de 10 a $20 \%$ e um prejuízo de centena de bilhões a consumidores; o ano de 2003 é considerado um marco em razão do início de condutas mais incisivas no combate aos cartéis, com a realização da primeira operação de busca-eapreensão na história do SBDC no caso "Cartel das Britas", do primeiro acordo de leniência no caso do "Cartel dos Vigilantes" e todos os desdobramentos, inclusive em relação à objetividade de ulterior busca-e-apreensão; as atividades do SBDC passam a ser coordenadas com outros órgãos do Poder Público, viabilizando investigações mais

\footnotetext{
${ }^{167}$ Salomão Filho, Direito concorrencial - as condutas, p. 20-23.

${ }^{168}$ Forgioni, Os fundamentos do antitruste, pp. 144-145.
} 
complexas a partir sinergias criadas com Ministérios Públicos Estaduais e Federal, Polícia Federal e Secretarias de Segurança Pública. ${ }^{169}$

O número de buscas-e-apreensões realizadas no âmbito da SDE cresce no período de 2003 a 2005 para 98 em 2008, ano em que também o CADE passa a bater recordes (quantitativos) de multas aplicadas em razão de condutas anticoncorrenciais foram R $\$ 63$ bilhões, comparados aos pouco mais de R $\$ 2$ bilhões em $2003 .{ }^{170} \mathrm{O}$ canal do click denúncia presente nos sites da SDE, SEAE e CADE recebe 319 denúncias de práticas anticoncorrenciais; as duas prisões temporárias e preventivas realizadas de 2003 a 2006 converteram-se em 53 no ano de 2008; material explicativo sobre as condutas foram produzidos, dentre eles cartilhas ilustrativas do combate a cartéis e até mesmo um gibi desenhado por Maurício de Souza; cria-se o dia nacional de combate aos cartéis (8 de outubro) em 2008 e, nessa data, em 2009, firma-se o Convênio de Brasília, ${ }^{171}$ marco da Estratégia Nacional de Combate a Cartéis - ENCC. Esse mesmo documento indica que entre 1994 e 2002, "apenas dois casos de cartéis hard core haviam sido condenados pelo CADE: cartel do aço (1999) e cartel de postos de combustíveis de Florianópolis (2002). Em contrapartida, entre 2003 e 2009, vários cartéis foram desbaratados em setores

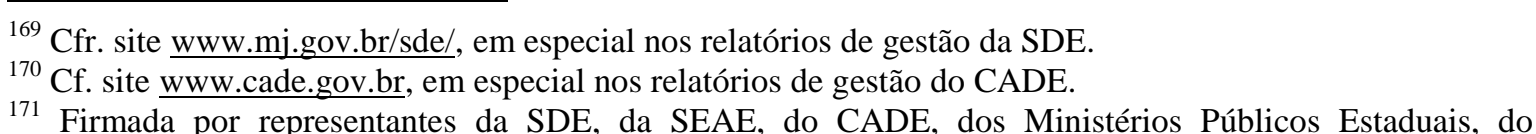
${ }^{171}$ Firmada por representantes da SDE, da SEAE, do CADE, dos Ministérios Públicos Estaduais, do
Ministério Público Federal, do Departamento de Polícia Federal, da Secretaria Nacional de Justiça, da Secretaria Nacional de Segurança Pública, das Secretarias de Segurança Pública Estaduais, do Conselho Nacional dos Procuradores-Gerais de Justiça, do Grupo Nacional de Combate às Organizações Criminosas, da Associação Nacional do Ministério Público Criminal e da Controladoria-Geral da União, por meio da Secretaria de Prevenção da Corrupção e Informações Estratégicas. Tem por objetivo "fomentar a definição de um plano coordenado e sistemático de atividades entre os diversos órgãos estatais responsáveis pela investigação e repressão às infrações contra a ordem econômica, em especial as Polícias Judiciárias e Ministério Público, conferindo sinergia, organicidade e capilaridade em todo território nacional à política de combate aos cartéis. Essa rede institucional visa à busca de sinergias entre as autoridades envolvidas, de modo a possibilitar o desenvolvimento de mecanismos e instrumentos mais sólidos e capazes de incrementar a investigação das autoridades, o que já foi iniciado pela Secretaria de Direito Econômico, entidade, no âmbito do Sistema Brasileiro de Defesa da Concorrência, primordialmente voltada à investigação de condutas anticompetitivas, com a celebração de Acordos de Cooperação Técnica com o Departamento da Polícia Federal, o Ministério Público Federal e com diversos Ministérios Públicos Estaduais, sendo incentivada a celebração de acordos de cooperação com todos os Ministérios Públicos Estaduais do país. A implementação dessa rede permitirá significativo incremento na comunicação entre as autoridades e persecução das investigações futuras" (Cf. site www.mj.gov.br/sde/). Nesse dia, em seu discurso, o presidente Lula afirma: "bem, com a quantidade de obra que nós estamos fazendo, Tarso, em uma livre concorrência, a gente pode, de cara, economizar entre $10 \%$ a $20 \%$ nos preços. Permitirá, igualmente, garantir a qualidade dos produtos e serviços contratados. Será fundamental a iniciativa do Ministério da Justiça nessa rede de inteligência com os mais diferentes órgãos, como a Controladoria-Geral e o Tribunal de Contas da União, para combater os cartéis em licitações públicas. Apesar dos avanços, falta concluir a reestruturação do Sistema Brasileiro de Defesa da Concorrência, como prevê o projeto de lei, pendente de aprovação pelo Senado Federal. Ele garantirá o aumento de investimento no País, dotará o Brasil de um marco regulatório adequado, incentivando a eficiência econômica e a produtividade e a inovação tecnológica" - discurso do presidente Lula no dia Nacional de Combate aos Cartéis (cfr. Site www.mj.gov.br/sde). 
estratégicos da economia nacional, sendo que 27 deles já foram condenados pelo CADE. Por outro lado, o Programa de Leniência brasileiro, iniciado em 2003, já é um dos mais ativos entre os países em desenvolvimento, havendo aproximadamente 15 acordos firmados. Na avaliação feita pela revista britânica Global Competition Review (GCR), o Brasil é o país que mais cresce no combate aos cartéis"; ${ }^{172}$ são 300 investigações em 2009. O próprio presidente Lula declara que "desde o início do governo, fizemos do combate aos cartéis uma prioridade absoluta. A Secretaria de Direito Econômico passou a utilizar ferramentas sofisticadas de investigação, como a realização de operações de busca-eapreensão e a celebração de acordo de leniência. A Secretaria tem cooperado crescentemente com autoridades estrangeiras. Paralelamente, o CADE passou a impor multas recordes a empresas, funcionários e sindicatos pela prática do cartel. Os avanços do Programa Brasileiro de Combate a Cartéis são reconhecidos hoje no mundo inteiro. A estratégia da Secretaria de focar seus recursos disponíveis no combate a cartéis tem permitido seu desmantelamento com impacto positivo na economia brasileira". ${ }^{173}$

Os dados expostos acima demonstram que a atividade de cunho declaradamente político não está no ato de julgamento, que continua cumprindo à risca a vontade da lei, em respeito ao princípio da legalidade. As profundas alterações qualitativas e quantitativas na atividade do SBDC resultam inicialmente de alterações legislativas significativas no campo de direito material (com a criação do instituto do acordo de leniência) e de direito processual (com a instituição de técnicas probatórias mais eficazes), que tiveram efeitos consideráveis ao longo do período de maturação de um processo administrativo de apuração de condutas ainda incipiente no Brasil.

A aludida "prioridade" estabelecida transformou-se sim em um esforço de cooperação entre diversas instâncias do Poder, por órgãos que atuam administrativa e judicialmente com fatos jurídicos que ostentam múltipla incidência, de modo a atuar a norma em sua faceta repressiva. ${ }^{174}$

\footnotetext{
${ }^{172}$ Cf. no site www.mj.gov.br/sde/, em especial nos relatórios de gestão da SDE.

${ }^{173}$ Discurso do Presidente no lançamento da Estratégia Nacional de Combate aos Cartéis, disponível no site www.mj.gov.br/sde.

${ }^{174}$ Bernardes de Mello define o fato jurídico, retratado em sua unidade, como um complexo de fatos sobre o qual incidiu a regra jurídica. A complexidade reside na diferenciação feita entre o fato real, o suporte fático e o fato jurídico, pois entre o primeiro e o segundo há o elemento valorativo que os qualifica diferentemente. Por sua vez, entre o suporte fático e o fato jurídico a diferença reside na verificação de que apenas parte do suporte fático (composto por omissões, silêncios e não acontecimentos) é relevante para o mundo jurídico e, por conseqüência, compõe o fato jurídico uno em sua concepção; além disso, o suporte fático é volátil e o
} 
Toda a primeira parte do trabalho foi dedicada à exposição sintética e basilar de conceitos antitruste pertinentes aos pontos de contato que serão estabelecidos com a teoria processual. Agora, parte-se ao exame de axiomas típicos processuais aplicáveis ao processo de apuração de condutas anticoncorrenciais.

fato jurídico permanece no mundo jurídico independentemente da constância dos elementos de seu suporte fático, resistindo até à lei (perda de sua vigência) (Teoria do fato jurídico - plano da existência, esp. §§13, 25 e 26). Araken de Assis separa dos fatos do mundo aqueles relevantes, aos quais é atribuído um papel no mundo jurídico nos termos de suportes normativos de condutas e eventos, após um juízo valorativo: "nada obsta ao mesmo fato ou complexo de fatos, como ensina a experiência comum, integrar elementos do suporte fático de duas ou mais regras. Conseguintemente, entram no mundo jurídico mediante várias aberturas, criadas pela diversidade de normas, que, de seu lado, denotam as incontáveis opções axiológicas do ordenamento. A isto se designa a incidência múltipla” (Assis, Eficácia civil da sentença penal, p. 21). Também minhas considerações sobre o tema em Os efeitos civis da sentença penal, n. 11. 


\section{AXIOMAS PROCESSUAIS}

Em termos conceituais, o processo é o reflexo de uma ideologia e, no Brasil, é um "microcosmo democrático do Estado-de-direito, com as conotações da liberdade, igualdade e participação (contraditório), em clima de legalidade e responsabilidade". ${ }^{175} \_176$ A ideologia como vínculo entre a crença política e seu reflexo no direito e sua vertente constitucional exerce um profundo e determinante reflexo sobre o processo.

Afinal, é ele, que concretiza e dá vida à atividade destinada à outorga de tutelas, ${ }^{177}$ é constituído pela relação jurídica processual estabelecida entre os sujeitos, atribuindo-lhes poderes, deveres, ônus, faculdades e sujeições. Essa relação é permeada por garantias constitucionais e infraconstitucionais, segue forma estabelecida por regras procedimentais e tem a finalidade de alcançar a prolação do comando, a decisão, a

${ }^{175}$ Dinamarco, A instrumentalidade do processo, p. 27. Comoglio segue a mesma linha em contexto mais amplo. Afirma que a ideologia dos países anglosaxões prevalece após a Segunda Grande Guerra e são transpostas para as convenções internacionais mais importantes versando sobre a Justiça, criando garantias "sem volta" como reação à justiça autoritária e inquisitória dos sistemas totalitários: "tali valori instaurano un saldo vincolo fra i principi di democrazia e le strutture del processo, indivinduandone la 'forza motrice' e la 'garanzia suprema' nel principio del contraditorio fra le parti in condizioni di parità, con il pieno rispetto dei diritti fondamentali della persona" ("Il 'giusto processo' civile in Italia e in Europa”, pp. 109-110).

${ }^{176}$ A conceituação minuciosa de democracia desborda o escopo do trabalho. Contudo, vale a nota de que questiona a democracia na complexa sociedade contemporânea e as idéias de pluralidade (ainda que criticada pela idéia de "ditadura da maioria" de Tocqueville) e participação. Fala-se em crise da democracia representativa para se chegar na idéia em que a democratização do estado cede à democratização da sociedade, com a permeabilidade das burocracias estatais. "A democracia dos modernos é o estado no qual a luta contra o abuso do poder é travada paralelamente em duas frentes - contra o poder que parte do alto em nome do poder que vem de baixo, e contrao o poder concentrado em nome do poder distribuído" (Bobbio, "Democracia representativa e democracia direta", p. 73).

${ }^{177} \mathrm{O}$ conceito de tutela jurisdicional pode ser abordado sob mais de um enfoque. De um lado, há a tradicional concepção da tutela jurisdicional como tutela de direitos. Trata-se da defesa de um direito diante de sua violação concreta ou ameaçada, relacionada com a própria efetividade do ordenamento jurídico (Yarshell, Tutela jurisdicional, p. 29). Dentro de linha que se aproxima (pela relação proposta entre o direito processual e substancial), defende-se também a noção de tutela de pessoas: "tutela jurídica, no sentido mais amplo, é a proteção que o Estado confere ao homem para a consecução de situações consideradas eticamente desejáveis segundo os valores vigentes na sociedade - seja em relação aos bens, seja em relação a outros membros do convívio. A tutela jurídica estatal realiza-se em dois planos: o da fixação de preceitos reguladores da convivência e o das atividades destinadas à efetividade desses preceitos" (Dinamarco, Fundamentos do processo civil moderno, p. 809). Há ainda que se designar a tutela jurisdicional pelos meios ordenados à obtenção desse mesmo resultado: "quando se cuida da atividade cognitiva, esses meios estão ligados essencialmente à idéia de procedimentos adequados à natureza da relação material controvertida que, manipulando diferentes níveis de cognição, propiciem resultados mais adequados às situações carentes de tutela; falando em termos de atividade executiva, busca-se o estabelecimento de meios executivos que possam dar efetividade aos comandos judiciais que deles necessitam para produzir efeitos substanciais" (Yarshell, Tutela jurisdicional, p. 35). Assim, a garantia de adequação do instrumento também é forma de tutela. 
emanação do preceito declarando o direito da parte, atuando-o ainda de forma concreta, em conformidade com os seus escopos sociais, políticos e jurídicos da atividade.

O processo é inserido em um sistema composto por órgãos, técnicas e institutos que operacionalizam a solução de conflitos - que por seu conteúdo, conformação e modo de ser se identificam, diferenciam-se e compõem um modelo processual consentâneo com o tempo e local de sua aplicação. Em perspectiva instrumental, ${ }^{178} \mathrm{o}$ processo recebe influências do direito material, ostenta caráter publicista e graus maiores de indisponibilidade, além de grandes preocupações com os institutos da ação e suas condições, de seus identificadores, das distinções entre processos, do acesso à justiça, da inafastabilidade do controle jurisdicional, da tutela coletiva, e, em especial, do direito processual constitucional. ${ }^{179}$

\section{V.1 Modelo processual constitucional}

Como instrumento a serviço do direito material em subsistemas civil, penal, administrativo etc., o processo encontra no direito constitucional a justificativa de métodos e a base de aplicação de suas disposições, projetando garantias, direitos e princípios. Ele é influenciado pelas camadas programáticas ou não Constituição e pela necessidade de interpretação de seus institutos consonância com o que ela estabelece, além de receber influxos na efetivação de princípios, direitos e garantias. ${ }^{180}$

Há aí um evidente reflexo no que foi denominado direito processual constitucional, como “condensação metodológica e sistemática dos princípios

\footnotetext{
${ }^{178}$ Sobre o tema, além da obra de referência, confira-se o pensamento de Comoglio, que o processo, pela ótica constitucional, tem o condão de estabelecer "il rapporto di strumentalità necessaria intercorrente fra il diritto sostanziale ed il processo, quale indispensabile presidio per la sua piena attuazione (o quale garanzie insostituibile della sua enforceability) (...)". A instrumentalidade é "caratterizzata da precise connotazioni deontologiche e tenda a preservare non soltanto gli scopi ed i profili tecnici, ma anche gli aspetti etici del procedimento giudiziario, pur necessariamente soggeto al principio di legalità ed alla sancita osservanza di determinate forme. Tale strumentalità esige che le guarentigie formali del processo non siano mai finì a se stesse, ma debbano sempre concorrere, sul piano istituzionale, al conseguimento di risultati decisori coerenti con i valori di equità sostanziale e di giutizia procedurale, consacrati dalle norme costituzionale o da quelle internazionali" (Comoglio, “Garanzie Costituzionali e 'giusto processo' (modeli a confronto)”, p. 102 e 106). ${ }^{179}$ Dinamarco, Instituições de direito processual civil, nn. 71-72.

${ }^{180}$ Dinamarco, Instituições de direito processual civil, p. 53.
} 
constitucionais do processo", ${ }^{181}$ que reflete uma onda de constitucionalização pela criação de modelos com garantias e direitos apriorísticos, frutos de tendência garantísticas. ${ }^{182}$

Em um modelo processual amplo, Luigi Paolo Comoglio parte do giusto processo para identificar pontos essenciais e constantes de premissas processuais pelas diversas nações, tais como a igualdade das partes perante o juiz, a independência, a imparcialidade e a vedação aos tribunais ad hoc, a publicidade de audiência e das decisões, a duração razoável do processo, o acesso à justiça, o contraditório e o direito à prova. ${ }^{183}$ Andolina e Vignera afirmam também que o processo deve ser concebido em seu ser ordinário e seu dever ser constitucional, identificando três características gerais para o processo constitucional: a sua idoneidade dos procedimentos, a sua capacidade de assumir formas diversas para adequação ao modelo constitucional e aos escopos da tutela e sua capacidade de ser aperfeiçoado pela legislação infraconstitucional. ${ }^{184}$

Mandrioli destaca no patamar constitucional o princípio do contraditório e de defesa, da igualdade não só formal entre as partes, ressalvados os limites no âmbito da razoabilidade, aplicando-se a idéia de um direito do destinatário do provimento de influir sobre o convencimento do juiz, o processo justo e regulado pela lei, o princípio da disponibilidade da tutela jurisdicional, da demanda e da disponibilidade do objeto do processo, a imparcialidade e independência do juiz, da motivação dos provimentos dos juízes, submetidos a um controle idôneo, o prazo razoável de duração do processo de ressarcimento de danos patrimoniais e não patrimoniais. ${ }^{185}$

\footnotetext{
${ }^{181}$ Grinover, As garantias constitucionais do direito de ação, p. 1. Dinamarco afirma o processo como microcosmo democrático. Cita a afirmação de Cappelletti no sentido de que "nel processo si riflettono, come in un specchio, $i$ grandi temi della libertà e della giustizia, $i$ fondamentali problemi della convivenza sociale e internazionale"; agrega a questão da jurisdição constitucional para concluir que "todo o direito processual constitucional constitui uma postura instrumentalista -, seja nessa instituição de remédios destinados ao zelo pela ordem constitucional, seja na oferta de garantias aos princípios do processo, para que ele possa cumprir adequadamente sua função de conduzir a resultados jurídico-substanciais desejados pela própria constituição e pela lei ordinária (tutela constitucional do processo). E finaliza: "o processo acompanha as opções políticas do constituinte, as grandes linhas ideológicas abrigadas sob o pálio constitucional" (A instrumentalidade do processo, pp. 27, 32-33).

${ }^{182} \mathrm{O}$ modelo comporta também a jurisdição constitucional das liberdades, o controle judicial de atos de poder e a organização judiciária e funções essenciais à administração da justiça. Porém, para o que diz respeito ao trabalho, serão examinadas somente as referidas garantias e direitos aprioristicos.

${ }^{183}$ Comoglio, "Il 'giusto processo' civile in Italia e in Europa”, pp. 97-158. Tantas referências sobre o tema também são encontrados em texto mais antigo do mesmo autor "Garanzie Costituzionali e 'giusto processo' (modeli a confronto)".

${ }^{184}$ Andolina-Vignera, I fondamenti costituzionali della giustizia civile - il modelo costituzionale del processo civile italiano, pp. 3-11.

${ }^{185}$ Mandrioli, Diritto processuale civile, vol. I, p. 488-491.
} 
Preserva-se assim um instrumento justo que resguarda o indivíduo ou indivíduos das suas liberdades, ${ }^{186}$ por meio da cláusula que traça princípios democráticos, baliza a atividade processual, preenche lacunas em situações concretas não previstas em lei e auxilia na função interpretativa, sempre à luz dos demais princípios constitucionais e infraconstitucionais relacionados com o processo.

É relevante para o presente a identificação dessa rede de princípios, $\operatorname{garantias}^{187}$ e direitos gerais, de inspiração democrática, indispensáveis no plano processual que, por sua relevância, foram inseridos em lei maior. ${ }^{188}$ Eles parametrizam as normas infraconstitucionais e sua interpretação, bem como as decisões dos juízes. Dentre eles, destacam-se alguns, com direto ou acentuado reflexo para o modelo processual brasileiro.

\section{V.2. Síntese de princípios e garantias constitucionais do processo}

Não é a finalidade do trabalho esmiuçar cada um deles, merecedores de monografias individualizadas, mas sim destacar introdutoriamente a sua pertinência para o modelo constitucional brasileiro ${ }^{189}$ de forma a serem utilizados como parâmetros nas

\footnotetext{
${ }^{186}$ Para Couture, a constituição pressupõe a existência de um processo como "garantía de la persona humana", a lei deve instruir o processo à luz do desenvolvimiento normativo jerárquico de preceptos", essa mesma lei não pode instituir "formas que haga ilusoria la concepción del proceso", inconstitucional se privar o indivíduo de "razonable oportunidad para haver valer su derecho" e deve oferecer meios de controle de constitucionalidade das normas (Couture, Fundamentos del derecho procesal civil, pp. 149-150).

${ }^{187}$ Princípios são dados exteriores à ciência, ligados a uma área de conhecimento que transcende os limites do processo e fixam pontos de partida e premissas científicas nas quais o ordenamento processual e a própria jurisdição se apóiam: o princípio é a "regra matriz de um sistema, da qual brotam as demais normas e que dá uniformidade ao conjunto. Admite-se que um determinado direito possa ter, além de um princípio geral do sistema, outros princípios que informam seus institutos fundamentais, ou seja, seus vários sistemas". Por sua vez, garantia é um sistema de proteção ou defesa organizado, sendo que uma norma de garantia pode ter a forma de princípio, na medida em que constitua uma norma matriz de sistema (Scarance Fernandes, "Princípios e garantias processuais penais em 10 anos de Constituição Federal", p. 185 e ss., esp. p. 186), ou ainda é dito que se entende por garantia "ogni strumento o presidio tecnico-giuridico, il quale sia in grado di far covnertire un diritto puramente 'riconosciuto', o 'attribuito' in astratto dalle norme, in un diritto effettivamente 'protetto' in concreto, e quindi suscettibile di piena 'attuazione' o 'reintegrazione' ogni qual volta risulti violato" (Comoglio, "Garanzie Costituzionali e 'giusto processo' (modeli a confronto)", p. 100).

${ }^{188}$ Especificamente em relação ao processo administrativo, Sundfeld afirma que a norma específica pretende "a uniformidade de comportamento no interior da máquina estatal, em nome da necessidade de sujeição do Estado a preceitos fundamentais da ordem jurídico-administrativa, sobretudo aos princípios e regras constitucionais" (Sundfeld, "Processo e procedimento administrativo no Brasil", p. 25).

${ }^{189}$ A Corte européia faz constante referência a garantias mínimas que do processo justo e equo, a saber o direito de acesso ao tribunal sem discriminações não razoáveis ou limintações excessivas, o direito de defesa, o contraditório, o direito à prova, a publicidade de audiência e decisões, a independência e imparcialidade dos juízes e a duração razoável do processo (Comoglio, "Il 'giusto processo' civile in Italia e in Europa", p. 117-119).
} 
análises de escopo e de técnicas do processo administrativo de apuração de condutas. É evidente que nessa perspectiva não se parte da perplexidade demonstrada por Zanetti Junior no exame do processo brasileiro como o ornitorrinco de Humberto Eco; uma vertente mais otimista identifica preceitos constitucionais que efetivamente norteiam o processo administrativo ou que devem orientar as interpretações realizadas pelos aplicadores e, em que medida, esse processo é capaz de fazer valer a pluralidade e a democracia desejadas pelo Estado de Direito brasileiro. ${ }^{190}$

O devido processo legal está previsto no art. $5^{\circ}$, inc. LIV, da CF. A cláusula do due process of law é oriunda do direito americano e foi criada para o combate à arbitrariedade, vedando ao legislador limitações de direitos fundamentais por meio de normas processuais. ${ }^{191}$ Ela ganha especial status no pós-guerra por institucionalizar o instrumento de proteção de direitos inalienáveis, pré-existentes e oponíveis às autoridades, poderes, independentemente de reconhecimento em norma. ${ }^{192}$

A cláusula é pertinente a qualquer tipo de processo de que possam resultar proteção e agressão a direitos constitucionalmente garantidos, refletindo filosofia institucional. ${ }^{193} \mathrm{Na}$ lição de Ada Pellegrini Grinover, na common law, a garantia é estendida a todas as situações judiciais em que é pertinente invocar a igualdade e a dialética, "pois só através do contraditório e da igualdade das partes, poderá o juiz proferir imparcialmente sua decisão" ${ }^{194}$ Rogério Lauria Tucci e José Rogério Cruz e

${ }^{190}$ Zanetti Junior, Processo constitucional: o modelo constitucional do processo civil brasileiro, pp. 61-65.
${ }^{191}$ Dinamarco, Fundamentos do processo civil moderno, vol. I, p. 178; Morado de Andrade, "O princípio do
devido processo legal e o processo administrativo", pp. 196-201. Zanetti Junior define o processo como
direito fundamental (Processo constitucional: o modelo constitucional do processo civil brasileiro, pp. 142-
14 ).
${ }^{192}$ Comoglio, "Garanzie Costituzionali e 'giusto processo' (modeli a confronto)", p. 99. A visão é
consentânea com o pensamento de Hermes Zanetti Junior, para quem, em uma sociedade democrática,
direitos fundamentais representam graus de auferição de democracia, são considerados tanto como subjetivos
e individuais como objetivos e comuns, ostentam a chamada eficácia irradiante. Fala de um "direito
fundamental à organização e ao procedimento como direito positivo ativo frente ao Estado e aos demais
órgãos de atuação do poder na sociedade democrática" (Processo constitucional: o modelo constitucional do
processo civil brasileiro, pp. 142-148).
193 Dinamarco, Fundamentos do processo civil moderno, vol. I, p. 175.
194 A interpretação da cláusula evolui para o que se convencionou chamar substantive due process: "ainda no
sistema da common law, por obra da interpretação da Suprema Corte norte americana, do conteúdo clássico
do due process of law como garantia do réu, passa-se à proteção mais ampla, sem distinção entre substance e
procedure. A cláusula transforma-se na garantia geral da ordem jurídica: judicial process traduz-se por
aplicação judiciária da lei e, por extensão, por interpretação judiciária da norma. Due process of law, em
sentido amplo, representa a garantia do 'processo' legislativo e a garantia de que a lei é razoável, justa e
contida nos limites da Constituição. Ao lado do procedural due process, sustenta-se a existência de um
substantive due process. A cláusula não se limita apenas à determinação processual de direitos substanciais, 
Tucci qualificam-na como função da aplicação regular da lei, amparada por razoabilidade, senso de justiça e constitucionalidade, além de garantir a aplicação das normas jurídicas e demais expressões do direito por instrumento processual hábil no qual se assegure a paridade de armas entre as partes. ${ }^{195}$

A razoabilidade é também pedra de toque para Juan Francisco Linares. O devido processo legal exige substancial e razoável relação entre lei, segurança, moralidade e bem estar do povo, numa "regla del equilibrio conveniente (ballance of convenience rule) o de racionalidad o de las relaciones sustanciales". A aplicação da regra se daria por raciocínios ponderados entre vantagens e desvantagens do ato estatal, adequação entre o meio e a finalidade perseguida, e a conformidade do ato com "uma serie de principios filosoficos, políticos, sociales, religiosos, a los cuales se considera ligada la existencia de la sociedad y de la civilización de los Estados Unidos". 196

A cláusula não desconsidera ainda o tempo e local em que é compreendida. Hegel já negava os pressupostos atemporais e as verdades eternas, afirmando que o conhecimento humano muda com o passar das gerações. A razão (e também a justiça) não existe desvinculada do tempo, sem estar certa ou errada, mas apenas consentânea com o momento. ${ }^{197}$ Por essa razão, Ada Pellegrini Grinover, referindo-se a Pound, ensina que "o due process of law não é um conceito abstrato do qual derivem conclusões absolutas, aplicáveis a qualquer tempo, em todo lugar, mas é um standard que guia o tribunal; e o standard há de aplicar-se com vistas a circunstâncias especiais de

mas se estende à garantia de que seu gozo não seja restringido de modo arbitrário ou desarrazoado" (Ada Pellegrini Grinover, Garantia constitucional do direito de ação, p. 36, 177-178).

195 Tucci-Tucci, Devido processo legal e tutela jurisdicional, pp. 18-19.

${ }^{196}$ Razonabilidad de las leyes - el 'debido proceso como garantía innominada em la Constitución Argentina, pp. 29-30.

197 "Na história política, o indivíduo, na singularidade da sua índole, do seu gênio, das suas paixões, da energia ou da fraqueza de caráter, em suma, em tudo o que caracteriza a sua individualidade, é o sujeito das ações e dos acontecimentos. Na história da filosofia, estas ações e acontecimentos, ao que parece, não têm o cunho da personalidade nem do caráter individual; deste modo, as obras são tanto mais insignes quanto menos a responsabilidade e o mérito recaem no indivíduo singular, quanto mais este pensamento liberto de peculiaridade individual é, ele próprio, o sujeito criador. Primeiramente, estes atos do pensamento, enquanto pertencentes à história, surgem como fatos do passado e para além da nossa existência real. Na realidade, porém, tudo o que somos, somo-lo por obra da história; ou, para falar com maior exatidão, do mesmo modo que na história do pensamento o passado é apenas uma parte, assim no presente, o que possuímos de modo permanente está inseparavelmente ligado com o fato da nossa existência histórica. $O$ patrimônio da razão autoconsciente que nos pertence não surgiu sem preparação, nem cresceu só do solo atual, mas é característica de tal patrimônio o ser herança e, mais propriamente, resultado do trabalho de todas as gerações precedentes do gênero humano" (Georg Wilhelm Friedrich Hegel, Introdução à história da filosofia, trad. Henrique Cláudio de Lima Vaz, [coleção Os pensadores] 1ª ed., São Paulo, Abril, 1974, p. 333). 
tempo, de lugar e de opinião pública". ${ }^{198}$ O juiz Frankfurter refere-se ao tema não como um instrumento mecânico ou padrão, mas sim um "processo de adaptação". ${ }^{199}$ Comoglio fala, por sua vez, da cláusula como uma referência de justiça procedimental, um princípio de "asseto variabile" ou "tessitura aperta", variável conforme a cultura de legalidade no Estado de Direito moderno, que na Itália ganha expressão nas cláusulas do contraditório, da imparcialidade e terzietà do juiz e da duração razoável do processo. ${ }^{200}$

O devido processo legal é ainda uma cláusula de fechamento, um preceito organizatório do sistema com vistas ao alcance de um processo justo e équo, um repositório sintético de todas as garantias do processo dentro de parâmetros políticoliberais, ${ }^{201}$ capaz de promover uma auto e hetero-integração com garantias individuais constitucionais e presentes em outros instrumentos integrados ao ordenamento jurídico ${ }^{202} \mathrm{e}$ receber influxos que transcendem a norma posta (agregando a moralidade da CF, art. 37, caput aos valores protegidos). Ela é encontrada da Declaração Universal dos Direitos do Homem (arts. $8^{\circ}$ e 10), na Convenção Européia de Salvaguarda de Direitos e das Liberdades Fundamentais de 1950 (arts. $6^{\circ}$ e 13), no Pacto Internacional de Direitos Civis e Políticos de 1966 (art. $14^{\circ}$ ) e do Pacto de São José da Costa Rica (art. $8^{\circ}$ e 25). ${ }^{203}$

Com o tempo, ele evolui da sua forma procedimental para aquela substantiva, que garante o gozo de direitos não seja restrito pelo Governo de modo arbitrário ou desarrazoado, transformando-se em instrumento protetor de liberdades públicas. ${ }^{204}$ No âmbito do direito antitruste, representa a limitação e o equilíbrio de atos do

\footnotetext{
${ }^{198}$ Grinover, Garantia constitucional do direito de ação, p. 34.

199 Referido por Franceschini, “A cláusula 'devido processo legal' e a lei antitruste nacional”, p. 220.

200 "Il due processo f law non è clausola dal contenuto prefissato e rigido in astratto, ma, al contrario, contiene aperture flessibili per una verifica concreta, caso per caso, della fairness di ciascun procedimento" e "rappresenta la garanzia positiva di un 'diritto naturale' del singolo ad un processo 'informato a principi superiori di giutizia” (Comoglio, "Il 'giusto processo' civile in Italia e in Europa”, p. 110).

${ }^{201}$ Dinamarco, Instituições de direito processual civil, n. 72.

${ }^{202}$ Comoglio, 'Il 'giusto processo' civile in Italia e in Europa", p. 155.

${ }^{203}$ É interessante a idéia de que na Europa a cláusula tem amparo na idéia de tradições constitucionais comuns, princípios democráticos, direitos fundamentais, a justificar princípios gerais de direito comunitário e uma cooperação judiciária que transcenda as fronteiras por meio da simplificação do procedimento, da revisitação de meios de prova, de sistemas de conhecimento de decisões jurisdicionais e da eleminação de obstáculos ao desenvolvimento do processo civil nos estados membros (Comoglio, "Il 'giusto processo' civile in Italia e in Europa", p. 116).

${ }^{204}$ Grinover, As garantias constitucionais do direito de ação, p. 178. Cfr. ainda Grotti, "Devido processo legal e o procedimento administrativo", p. 35.
} 
Poder Público no campo econômico, efetivando pela via legislativa o princípio da livre concorrência. $^{205}$

Pela ótica substantiva, "o procedimentalismo no campo econômico é bastante diverso daquele do campo político, pois enquanto a igualdade de participação este último pode permanecer apenas um dado formal, no primeiro, qualquer idéia procedimental depende, para manter um mínimo de efetividade, de um reequilíbrio real de forças, isto é, de efetivas medidas redistributivas". Sendo assim, "não basta garantir a correção de procedimentos. É fundamental garantir o equilíbrio dos agentes que interagem". 206

A idéia de acesso à justiça (os serviços de natureza jurisdicional "devem ser realizados com vistas postas no resultado final”, pela via do processo $^{207}$ ) também está vinculada ao modelo constitucional brasileiro, ainda que não esteja exatamente explícita na carta. Ela parte da idéia primordial de inafastabilidade do controle judiciário, princípio constitucional previsto no art. $5^{\circ}$, inc. XXXV (“a lei não excluirá da apreciação do Poder Judiciário lesão ou ameaça a direito"). ${ }^{208}$ Trata-se de direito ao exercício (ou poder de exigir o exercício) da atividade jurisdicional que pode trazer em si a idéia de acesso independentemente da parte ter razão ${ }^{209}$ ou, em perspectiva mais concretista, a lição no sentido de que "o princípio da inafastabilidade do controle jurisdicional manda que as pretensões sejam aceitas em juízo, sejam processadas e julgadas, que a tutela seja oferecida por ato do juiz àquele que tiver direito a ela - sobretudo que ela seja efetiva como resultado prático do processo". ${ }^{210}$

\footnotetext{
205 Franceschini, “A cláusula 'devido processo legal' e a lei antitruste nacional”, p. 218.

${ }^{206}$ Salomão Filho, Direito concorrencial - as condutas, p. 47.

${ }^{207}$ Dinamarco, Instituições de direito processual civil, n. 72. Para uma visão teleológica do tema, cfr. Capelletti-Garth, Acesso à justiça, passim, com referência ao movimento de acesso à justiça decorrente do Projeto de Florença e as conhecidas ondas renovatórias do processo.

${ }^{208} \mathrm{O}$ direito de ação é garantindo pela Primeira Emenda da Constituição americana ("Congress shall make no law (...) abridging (...) the right of the people (...) to petition the Government for a redress of grievances". U.S. Const., amend. I), muito embora o sistema da common law preveja limitações diferenciadas - ou analisando por enfoque diverso, um uso muito mais cauteloso ou responsável do direito de ação. Sobre a maior severidade no controle da atuação do advogado em sistemas de common law, confira-se Abdo, Abuso do processo, n. 28. Já a constituição portuguesa garante, em seu art. 20, que "a todos 1. A todos é assegurado o acesso ao direito e aos tribunais para defesa dos seus direitos e interesses legalmente protegidos, não podendo a justiça ser denegada por insuficiência de meios económicos".

${ }^{209} \mathrm{O}$ que muito se assemelharia do conceito de ação como direito autônomo e abstrato formulado por Degenkolb e Plósz no final do século XIX (cfr. em Cintra-Grinover-Dinamarco, Teoria geral do processo, p. 252).

${ }^{210}$ Dinamarco, Instituições de direito processual civil, n. 79.
} 
O direito de ação $\left(\mathrm{CF}\right.$, art. $5^{\circ}$, inc. XXXV) contempla o simples acesso ao Poder Judiciário, o direito-poder de exigir do Estado uma resposta à pretensão, desde que superados os óbices legítimos (pressupostos de admissibilidade de julgamento de mérito, consubstanciados nas condições da ação e pressupostos processuais) e, caso a parte haja razão, justifica-se não só o pronunciamento favorável como a consecução de medidas destinadas à efetivação do comando, caracterizando a subespécie do direito à tutela jurisdicional. ${ }^{211}$ É também considerado um dos componentes mínimos essenciais do processo giusto e equo. ${ }^{212}$

O acesso estabelece inclusive incindível relação entre democracia, participação social, definição de processo, procedimento e contraditório. As regras processuais e procedimentais devem guarir o acesso e a participação das partes, como determinação política lastreada na "criatividade dos atores sociais" e a substituição de uma “gramática social e estatal de exclusão por uma gramática de participação e inclusão. Para isso, é necessário o compromisso com o fortalecimento da demodiversidade". ${ }^{213}$

O contraditório e a ampla defesa (CF, art. $5^{\circ}$, inc. LV) também compõem pilares do devido processo legal. Carregam a idéia de isonomia, imparcialidade e paridade de armas, sendo "justamente o antagonismo entre as falas dos interessados no provimento final (contra dicere) que garante a imparcialidade do juiz, característica inseparável do exercício da jurisdição; daí a universal inclusão do contraditório entre as garantias fundamentais do processo justo (...)". A própria idéia de processo como procedimento em contraditório revela a elevada estatura da garantia em um Estado Democrático que preza intensamente pela participação plurima. Sem o diálogo e sem a ciência efetiva dos atos do processo, a decisão torna-se unilateral, injusta, ilegítima. Comoglio refere-se ao instituto como um direito natural derivado de pressupostos genéticos do processo democrático, que

\footnotetext{
${ }^{211}$ Liebman estabelece a distinção entre o direito à ação e o direito à tutela jurisdicional, conferido somente àqueles que ostentem o direito material afirmado: “a ação como direito ao processo e ao julgamento do mérito, não garante um resultado favorável no processo: esse resultado depende da convicção que o juiz. formar sobre a procedência da demanda proposta (levando em consideração o direito e a situação de fato) e, por isso, poderá ser favorável ao autor ou ao réu. Só com o exercício da ação se saberá se o autor tem ou não razão: só correndo o risco de perder, poderá ele procurar vitória" (Manual de direito processual civil, n. 73).

${ }^{212}$ Comoglio, "Il 'giusto processo' civile in Italia e in Europa”, p. 117.

213 Zanetti Junior, Processo constitucional: o modelo constitucional do processo civil brasileiro, pp. 141. V. ainda Capelletti-Garth, Acesso à justiça, passim.
} 
derivam do exercício do direito individual de ação e da inerente bilateralidade recíproca, como medida de igualdade formal e substancial. ${ }^{214}$

Uma das características fundamentais do processo como instrumento de imposição do poder é a celebração do procedimento em contraditório, garantindo a participação dos sujeitos e o exercício de faculdades e poderes inerentes à relação jurídica, criando ainda o amálgama entre democracia, participação, devido processo legal, processo e contraditório: "a observância do procedimento em si próprio e dos níveis constitucionalmente satisfatórios de participação efetiva e equilibrada, segunda a generosa cláusula due process of law, é que legitima o ato final do processo, vinculativo dos participantes". A efetividade da participação e o exercício do contraditório (informaçãoreação) correspondem, afinal, "a dois postulados de maior espectro do próprio Estado democrático, que são a liberdade de informação e a participação da sociedade". ${ }^{215}$ Pela perspectiva da defesa, ela se afigura como "diritto inviolabile in ogni stato e grado del procedimento (...). Il diritto di difesa costituisce una garanzia fondamentale, che ha una funzione analoga a quella che svolge la democrazia politica rispetto all'intero ordinamento. Il processo è un fenomeno caratterizzato dal contraddittorio: dove non c'è contraddittorio, dove non c'è la possibilità di replica ai mezzi di attacco e di difesa, agli argomenti, alle attività in genere posti in esse dagli altri soggetti, non c'è processo". 216

Esses pressupostos se coadunam com a idéia de que o princípio não se limita ao processo jurisdicional e, segundo a melhor doutrina, tampouco ao processo administrativo onde estão presentes litigantes, mas sim a todos os processos (judiciais, administrativos, punitivos ou não, em que existam acusados ou litigantes) tendo em vista que o caráter democrático influi sobre todos os atos públicos. ${ }^{217}$

\footnotetext{
${ }^{214}$ Comoglio, "Il 'giusto processo' civile in Italia e in Europa", p. 129 e "Garanzie Costituzionali e 'giusto processo' (modeli a confronto)”, p. 99.

${ }^{215}$ Dinamarco, A instrumentalidade do processo, pp. 79 e 164. É o "diritto di tutte le parti alla possibilità di svolgere un ruolo attivo nel processo di cui dovranno subire gli effeti". A regra decorre do princípio constitucional italiano de que "ogni processo se svolge nel contraddittorio delle parti, in condizioni di parità davanti a giudice terzo e imparziale" (art. 111, Const. It) (Mandrioli, Diritto processuale civile, vol. I, p. $120)$.

${ }^{216}$ Luiso, Diritto processuale civile, p. 29.

${ }^{217}$ Grotti, "Devido processo legal e o procedimento administrativo", p. 36-37. Note-se que no processo administrativo perante a Comissão européia, o regulamento 773/2004 (regulamento de execução de normas antitruste) é claro ao afirmar em suas premissas que "a fim de assegurar o respeito dos direitos de defesa das empresas, a Comissão deve dar aos interessados directos o direito de serem ouvidos antes de tomar uma decisão".
} 
De pouca serventia aqui as clássicas considerações sobre a autoexecutoriedade de decisões administrativas, a urgência no atendimento do interesse público e a discricionariedade administrativa, em razão das particularidades do processo administrativo de apuração de conduta vistas acima e que serão tratadas ao longo do texto e que tanto sorvem da fonte garantística comparativa do processo judiciário.

$\mathrm{Na}$ atividade de implementação de políticas públicas - dentro dos limites já estabelecidos acima, deve preocupar-se na mesma medida em que o Estado se preocupa com tópicos de maior abrangência. Por isso, também aqui devemos ter atenção ao fato de que acesso à justiça, acesso à tutela oferecida pelo CADE, ampla defesa e contraditório situam-se em patamares maiores. É preciso ter atenção à lição de que “o jogo de relações políticas internas ao Estado não é estático. Disputas políticas têm lugar nos canais de circulação política internos à burocracia estatal. Porém, por serem canais pouco públicos e pouco institucionalizados democraticamente, apenas determinados atores têm acesso ao jogo de barganha político que está na base da ação regulatória do Estado. Forma-se o que foi diagnosticado por alguns autores como os 'anéis burocráticos do Estado. Nesse contexto, tal modelo de Estado regulador se constitui no Brasil com déficits de legitimidade democrática. São poucos os grupos de interesse que têm acesso aos processos decisórios em matéria de políticas públicas. São poucos os grupos de interesse que têm acesso aos processos decisórios em matéria de políticas públicas e são poucos os mecanismos institucionalizados de controle democrático das decisões tomadas". ${ }^{218}$ Essas garantias atuam como instrumento ampliador da participação democrática, no auxílio processual da superestrutura estatal, uma retroalimentação positiva que contribuiu para a efetivação-recuperação da participação como instrumento democrático.

O princípio da legalidade ( $\mathrm{CF}$, art. $5^{\circ}$, inc. II e art. 37, caput), pilar democrático que sujeita todos ao império da lei (à expressão de uma vontade), realiza o princípio da igualdade e da justiça após um processo legislativo que respeite idéias de representatividade (em ambiente de divisão de poderes). É nessa concepção que se compreende a idéia de que o Poder Público não pode exigir ação, impor abstenção, ou proibir senão em virtude da lei. Mas só isso também não basta. Na aproximação entre a idéia de legalidade e legitimidade, "o princípio da legalidade de um Estado Democrático de Direito assenta numa ordem jurídica emanada de um poder legítimo, até porque, se o poder

\footnotetext{
${ }^{218}$ Mattos, O novo estado regulador no Brasil: direito e democracia, p. 2.
} 
não for legítimo, o Estado não será Democrático de Direito, como proclama a Constituição $\left(\operatorname{art.} 1^{\circ}\right)$. Fora disso, teremos possivelmente uma legalidade formal, mas não a realização do princípio da legalidade". ${ }^{219}$

No campo do processo, a legalidade é o respaldo que o jurisdicionadoadministrado tem de que poderá usufruir de todos os meios processuais pré-estabelecidos, das formas pré-constituídas, disponíveis pelo sistema na perspectiva de obtenção de um lawfull judgement. A imposição legal é medida de aceitação cívica, política e moral, uma garantia de que a justiça é administrada de forma transparente e sob controle de quem a enxerga de fora. ${ }^{220}$

O direito à prova é corolário do princípio do contraditório e da ampla defesa (CF, art. $5^{\circ}$, inc. LV). É o direito de dizer e contradizer provando ${ }^{221}$, vital para a efetividade da ação e da defesa. ${ }^{222}$ Mais que isso, não há eficácia probatória de elementos se a colheita não for realizada em ambiente em que se proporcione a possibilidade de participação de interessados: "é importante salientar que o princípio da ineficácia das provas que não sejam colhidas em contraditório não significa apenas que a parte possa defender-se em relação às provas contra ela apresentadas: exige-se, isso sim, que seja posta em condições de participar, assistindo à produção das mesmas enquanto ela se desenvolve". ${ }^{223}$ É a possibilidade de influir, "con l'esercizio dei poteri di argomentazione, di deduzione e di prova, sulla formazione del convincimento decisorio del giudice". ${ }^{224}$

O conteúdo da garantia indica a proibição de fundamentação com base em fatos não introduzidos e não debatidos, da colheita de provas na ausência das partes, da disposição sobre os meios de provas, da ampla participação dos interessados na sua produção. ${ }^{225}$ A prova há ainda que ser pública, como reflexo de lealdade, imparcialidade, responsabilidade e igualdade de oportunidades nos meios e resultados das provas

\footnotetext{
219 Afonso da Silva, Curso de direito constitucional positivo, p. 419. Lei aqui concebida como norma, respeitadas regras de competência. Aliás, o autor sustenta inclusive que o princípio justifica a inafastabilidade do controle judiciário. Discutir o tema seria debater conceitos que se complementam - democracia, legalidade, justiça - razão pela qual será dispensado debater "qual princípio origina qual”, preferindo-se o debate de um conjunto de garantias constitucionais aplicadas ao processo.

${ }^{220}$ Comoglio, "Il 'giusto processo' civile in Italia e in Europa", p. 108.

${ }^{221}$ Grinover, O processo em evolução, p. 54.

${ }^{222}$ Dinamarco, A instrumentalidade do processo, p. 407.

${ }^{223}$ Grinover, "O conteúdo da garantia do contraditório", p. 24.

${ }^{224}$ Comoglio, "Il 'giusto processo' civile in Italia e in Europa”, p. 132.

${ }^{225}$ Grinover, "O conteúdo da garantia do contraditório", pp. 21-22; Comoglio, "Il 'giusto processo' civile in Italia e in Europa", p. 137.
} 
produzidas. ${ }^{226} \mathrm{Na}$ administração pública, a instrução probatória de processos ganha igual relevância como direito de oferecer provas, produzi-las, fiscalizar sua produção, sendo a comunicação do resultado fruto da idéia de informação geral ${ }^{227}$ e de democracia.

A independência e a imparcialidade do juiz (expressão inicial na garantia da $\mathrm{CF}$, art. 95 e art. 37, caput na referência à impessoalidade) são retratadas na idéia objetiva de se assegurar um juiz natural pre-constituído pela lei, não designado pelo legislador ou outro ente em momento posterior à instauração da lide, em posição institucional de distanciamento em relação às partes - a terzietà que garante que o juiz seja diferente da parte. O magistrado atua de forma autônoma e independente, sem intromissão ou ingerência externa. Subjetivamente, o juiz deve sempre atuar com serenidade, ausentes os preconceitos pessoais, num exercício desinteressado da função, de forma eqüidistante em relação aos sujeitos envolvidos. ${ }^{228}$

A duração razoável do processo (CF, art. 5, inc. LXXVIII e art. 37, caput) é componente do devido processo legal e garante (caso a caso e de acordo com as peculiaridades estruturais, com a complexidade da causa e com o comportamento dos sujeitos processuais) o axioma da economia processual interna, de tempo, despesas, energia e recursos, e da economia processual externa, evitando novos juízos ou graus de juízos inúteis. Taxado de inútil, de pouca utilidade ou como uma novidade insignificante, sua inserção tem o escopo relevante sim de funcionar como norma programática e disciplinar para o legislador e critério de referência ou padrão de orientação para o juiz, em um reforço de seu papel de direção "idonee a ridurre tempi, durata e costi di ogni processo, sì da renderlo effettivamente giusto, con una correlata economia di risorse e di attività". ${ }^{22}$

É lugar comum referir-se à publicidade (CF, art. 37, caput) como reflexo democrático do processo, vinculada à idéia de garantia de informação geral sobre fatos que

\footnotetext{
${ }^{226}$ Araújo Cintra, Comentários ao código de processo civil, vol. IV, p. 244.

${ }^{227}$ Odete Medauar, A processualidade no direito administrativo, p. 104.

${ }^{228}$ Comoglio, "Il 'giusto processo' civile in Italia e in Europa", p. 141.

${ }^{229}$ Comoglio, 'Il 'giusto processo' civile in Italia e in Europa”, p. 148-151. A Constituição portuguesa define em seu art. 20, que "4. Todos têm direito a que uma causa em que intervenham seja objecto de decisão em prazo razoável e mediante processo equitativo. 5. Para defesa dos direitos, liberdades e garantias pessoais, a lei assegura aos cidadãos procedimentos judiciais caracterizados pela celeridade e prioridade, de modo a obter tutela efectiva e em tempo útil contra ameaças ou violações desses direitos". A idéia de devido processo levou os italianos a apresentarem indenizações perante o Estado italiano pela duração excessiva dos litígios no país, o que levou a edição de legislação específica peninsular (Tavares, "Acesso ao direito, duração razoável do processo e tutela jurisdicional efetiva nas constituições brasileira e portuguesa: um estudo comparativo" pp. 265-279).
} 
o formam e que são adquiridos ao longo de sua tramitação, terminando com os atos de decisão e imposição do comando. É aquele direito de conhecer e ter acesso ao processo, outorgado às partes e a terceiros, limitados estes por regras de tutela de direitos individuais e de interesses públicos proporcionalmente maiores.

A publicidade (CF, art. 5, LX; art. 93, IX e art. 37, caput) é claro instrumento de reação a regimes totalitários, que traz a devida transparência inerente ao sistema atual. É garantia individual e eficaz elemento de fiscalização popular sobre a atividade dos órgãos de instrução e julgadores, encontrando exceção tão somente para preservação de garantias individuais e interesses públicos.

A motivação das decisões ( $\mathrm{CF}$, art. 93, incs. IX e $\mathrm{X})$ se relaciona com a idéia de publicização e estabelece a estreita correlação entre democracia, liberdade decisória fundamentada, garantias de tratamento isonômico, transparência nos atos de imposição de poder, imparcialidade e rejeição do arbítrio de um órgão julgador, o que resulta em um dever de expor os fundamentos fáticos e jurídicos da decisão. ${ }^{230}$ Respeitadas essas premissas, a fundamentação é instrumento de outorga de legitimidade, validade e justiça de decisões, funcionando ainda como instrumento de redução de litigiosidade em caso de aceitação da fundamentação pela parte sucumbente. ${ }^{231}$

Todos esses dados auxiliam na identificação de uma retroalimentação recíproca que convém à ciência processual: seu nascimento a partir do questionamento de axiomas romanos e sua concepção autônoma originária da obra de Büllow, em 1856, sobre os pressupostos processuais se desenvolvem de tal forma a erigir o processo a garantia constitucional e a instrumento de legitimidade estatal compatível com o regime democrático. A partir daí o as garantias mínimas do processo postas em Constituição tornam-se axiomas para a criação de todo o sistema processual, uma devolutiva inegável que baliza a atividade do legislador e do aplicador do direito na interpretação dos diplomas. Essa retroalimentação fixa os contornos mínimos de um processo administrativo admitido no Estado democrático de direito. A partir dela que se estabelece o sistema

\footnotetext{
230 “Adere a esses valores algo característico do Estado Democrático de direito, o valor democracia, que age de forma instrumental durante todo o processo, refletindo particularmente sobre a necessária motivação das decisões judiciais" (Zanetti Junior, Processo constitucional: o modelo constitucional do processo civil brasileiro, pp. 183).

${ }^{231}$ Cruz e Tucci, A motivação da sentença no processo civil, p. 147; Grotti, "Devido processo legal e o procedimento administrativo", p. 39.
} 
processual administrativo, em especial aquele particular destinado às apurações de conduta anticoncorrencial.

Essa idéia é corroborada pela concepção do processo como ato de imposição de poder (legitimidade) e instrumento de aceitação do poder imposto (legitimação), à luz da ideologia do estado no qual se insere. A relação entre a legitimidade e a legitimação é extraída de elementos subjetivos e objetivos, quais sejam, a relação entre compatibilidade axiológica do sistema e a aceitação, o consentimento da sociedade, desde o sistema político até seu reflexo processual, de modo a garantir a convergência das aspirações do grupo e dos objetivos do poder. ${ }^{232} \mathrm{O}$ transporte desse raciocínio passa por Luhmann, segundo o qual a legitimação se dá na com a "diferenciação e a autonomia que abrem um espaço de manobra para a atuação dos participantes plena de alternativas e de importância básicas, reduzindo a complexidade. Só assim os participantes podem ser motivados a tomarem, eles próprios, os riscos da sua ação, a cooperarem, sob controle, na absorção da incerteza e dessa forma a contraírem gradualmente um compromisso". ${ }^{233}$

Por isso, Dinamarco refere-se ao procedimento como penhor de preservação dos princípios e garantias constitucionais. ${ }^{234}$ Esse respeito axiomático garante "a inserção do sistema processual na ordem constitucional e sua aceitabilidade social". ${ }^{235}$ Nessa mesma linha, Odete Medauar aduz que "o poder, em essência, consiste, dada uma relação entre pessoas, no predomínio da vontade de uma sobre as demais; numa relação entre órgãos, no predomínio de um sobre outros. O exercício do poder, num Estado de direito que reconhece e garante direitos fundamentais, não é absoluto; canaliza-se a um fim, implica deveres, ônus, sujeições, transmuta-se em função, o que leva o ordenamento a determinar o filtro da processualidade em várias atuações revestidas de poder. A processualidade, então, vincula-se à disciplina do exercício do poder estatal. A seiva do tronco comum da processualidade é o poder, que permeia todos os ramos, onde inexiste poder, inexiste utilidade metodológica de uma concepção de processualidade ampla". ${ }^{236}$

\footnotetext{
${ }^{232}$ Dinamarco, A instrumentalidade do processo, pp. 167 e 176.

${ }^{233}$ Luhmann, Legitimidade pelo Procedimento, UnB, Brasília, 1980, p. 64.

${ }^{234}$ Dinamarco, A instrumentalidade do processo, pp. 158.

${ }^{235}$ Dinamarco, A instrumentalidade do processo, p. 158-159. Moreira discorre sobre o déficit de legitimidade de autarquias e o que chamou de processo administrativo como uma "constante forma de relacionamento entre o cidadão e o Estado. Relacionamento esse que tem início desde o momento de formulação das regras até a sua implementação e aplicação" (Cuéllar-Moreira, Estudos de direito econômico, p. 174).

${ }^{236}$ Medauar, A processualidade no direito administrativo, p. 28. A autora afirma ainda que "o processo administrativo oferece possibilidade de atuação administrativa com justiça. Encontra-se mesmo a afirmação
} 


\section{V.3. O papel da teoria geral do processo}

A teoria geral do processo traz a idéia de sistemas de conceitos e princípios elevados ao grau máximo de generalização útil, condensados a partir dos diversos ramos do direito processual. Ela examina as diversas espécies de processos, jurisdicionais ou não, rejeita a desagregação metodológica e propõe uma necessária visão metodológica unitária do direito processual, com idéias comuns tidas como princípios formativos do processo. ${ }^{237} \mathrm{~J}$. E. Carreira Alvim faz coro ao afirmar que "a tendência que se manifesta entre os cultores da ciência do processo é pela unificação doutrinária do direito processual, com estudos dedicados a institutos comuns". 238

Essas linhas gerais do processo trazem um "sistema de institutos, princípios e normas estruturados para o exercício do poder segundo determinados objetivos". ${ }^{239}$ E nessa construção, Dinamarco ampara-se na idéia de Fazzalari para destacar os "princípios comuns aos processos contemplados no nosso ordenamento, desde aqueles que realizam atividades fundamentais do Estado (jurisdição sobretudo, mas não só, sendo o processo empregado também para o cumprimento de outras tarefas: legislação, administração, jurisdição voluntária)". ${ }^{240}$

Esses princípios foram expostos com especial atenção pela doutrina brasileira por Cintra, Grinover e Dinamarco em obra clássica sobre a teoria geral do processo, ${ }^{241}$ que preza pela síntese e didática dos principais tópicos de interesse para o processualista. Com ênfase na premissa processual constitucional, destaca o movimento internacional pela efetividade do processo, pelo oferecimento à população de canais eficientes para o acesso à justiça e pela formação de um diálogo produtivo ao longo da instrução de toda a causa. Examina o processo constitucional conforme exposto acima, a ciência processual como autônoma e pertencente ao ramo de direito público. É pertinente extrair da obra as idéias de que a despeito da função jurisdicional ser reconhecida como

de que 'o núcleo de todas as teorias clássicas do procedimento é a relação com a verdade ou com a verdadeira justiça como objetivo"” (idem, p. 67).

${ }_{237}$ Dinamarco, A instrumentalidade do processo, p. 22.

${ }^{238}$ Carreira Alvim, Teoria geral do processo, p. 49

${ }^{239}$ Dinamarco, A instrumentalidade do processo, p. 69.

240 Dinamarco, A instrumentalidade do processo, p. 70. Para a concepção evolutiva do processo administrativo no Brasil, cfr. Sundfeld, "Introdução ao processo administrativo - processo e procedimento administrativo no Brasil", pp. 20-24.

${ }^{241}$ Cintra-Grinover-Dinamarco, Teoria Geral do Processo, passim. 
pacificadora em sua essência, reconhece a falha do Estado na missão em razão (fruto do conflito segurança-garantias x celeridade) e a importância de novos meios para a solução de conflitos - e será verificado aqui em que medida o processo administrativo se apresenta como solução. Trabalha ainda como o direito processual como complexo de normas e princípios que organizam um método de trabalho, conjugando os princípios processuais constitucionais e outros princípios infraconstitucionais, para a definição de um sistema de imposição de poder destinado à realização dos ditames da ordem social, econômica e jurídica e a dirimir conflitos.

Além dos princípios já examinados no âmbito constitucional (a imparcialidade do juiz, o dever de fundamentar - sistema de persuasão racional, publicidade), é feita referência ao princípio da igualdade (em sua vertente substancial, tratada no âmbito do contraditório e da ampla defesa, com o objetivo de equalizar oportunidades de interação e exposição de razões perante o juiz); o princípio da demanda (pelo qual se atribui à parte a iniciativa de provocar o exercício da função de dizer o direito, também chamado de princípio da inércia; princípios da disponibilidade e indisponibilidade, princípio dispositivo e da livre investigação das provas (de exercício de direitos processuais, que será examinado com especial atenção na disciplina da prova); princípio do impulso oficial (uma vez instaurada e relação processual, cabe ao órgão que a dirige movimentar o procedimento até o esgotamento da função prevista); princípio da oralidade (como instrumento de imediatidade e concentração de atos processuais que favorece a interação, o debate, o consenso e a sujeição das partes à decisão, mas que no Brasil se rende à necessidade de documentação e à inerente desconfiança que assombra o processo); o princípio da lealdade processual (as partes devem pautar suas condutas pela verdade, sem utilizar-se de artifícios, abusos e desvios de conduta com o objetivo de prejudicar outro sujeito processual ou o andamento do próprio processo); princípio da economia e da instrumentalidade das formas (a concepção finalística dos atos processuais e seu necessário equilíbrio com os meios e a atuação do direito com o mínimo emprego de atividades possíveis) e princípio do duplo grau de jurisdição (doble conformidad, outorga de maior segurança às decisões e controle dos atos estatais, à luz da falibilidade humana). ${ }^{242}$

242 Cintra-Grinover-Dinamarco, Teoria Geral do Processo, esp. cap. 4. O direito italiano não distoa, recorrendo aos mesmos preceitos, com denominações específicas: instrumentalidade das formas, da livre valoração das provas, da oralidade, da concentração e da imediatidade (que a despeito de não serem 
Concebido o processo como ramo do direito público e autônomo em relação ao direito material, o exame dos princípios torna-se dado de extrema relevância na definição do ponto de partida de todo e qualquer processo destinado à solução de conflitos, na condensação metodológica do ramo do direito e na percepção da síntese evolutiva histórica e comparativa. Fixam-se as balizas para o questionamento e desenvolvimento de um módulo específico do direito processual - o que se pretende fazer em relação ao processo administrativo de apuração de conduta. Isso porque a partir da concepção constitucional do processo, iluminada ainda por uma sólida teoria geral, o processo administrativo inegavelmente se insere no modelo amplo proposto, como instrumento de exercício do poder da administração: verificam-se claramente os limites ao exercício de poder, o respeito à legalidade, formas institucionalizadas, a participação efetiva dos interessados em bases substancialmente isonômicas e direito de influir e dialogar com o órgão judicante. Por essa razão, "tais e tantos pontos comuns, entre os muitos que marcam a analogia com o processo jurisdicional, impõem que se inclua o direito processual administrativo na teoria geral do processo (modalidade 'processo estatal nãojurisdicional')", 243

No direito administrativo, os princípios processuais são tidos como a legalidade objetiva, oficialidade (iniciativa e movimentação do processo), verdade material (busca por provas sem limitações às considerações dos administrados), pluralidade de instância (com revisão autônoma dos atos ou por provocação), informalismo (dispensa de formas solenes quando a lei determinar), garantia de defesa (audiência do interessado), representação e acessoramento, acessibilidade aos elementos do expediente, ampla instrução probatória, finalidade, motivação, razoabilidade, proporcionalidade, segurança

constitucionais, são corolário de uma justiça rápida e não formalística), da disponibilidade da prova (sem parâmetro constitucional), da economia processual, da conservação dos atos processuais e do duplo grau de jurisdição (Mandrioli, Diritto processuale civile, vol. I, p. 88 e ss.). Conforme Gian Luigi Tosato, no âmbito da Comunidade Européia são reconhecidos princípios de ordem processual, "come il rispetto del contraddittorio, dei dirtti di difesa, della riservatezza della corripondenza tra cliente ed avvocato, il dirtto ad una tutela giurisdizionale effettiva, a non testimoniare contro se stessi (principio di non autoincriminazione), all'inviolabilità del domicilio privato, il diritto di accedere ai documenti delle istituzioni comunitarie. Alcuni di questi principi sono stati considerati dalla Corte alla stregua di veri e propri diritti fondamentali". Trata-se de uma concepção que se assemelha à brasileira (direitos processuais vinculados ao devido processo legal como verdadeiros direitos fundamentais), acrescidos por princípios do sigilo da correspondência entre cliente e advogado, a inviolabilidade do domicílio e a não auto-incriminação. São axiomas pertientes a um histórico particular em relação ao brasileiro, que sobrelevam, de qualquer forma, direitos fundamentais de defesa ("Le fonti", p. 12).

${ }^{243}$ Dinamarco, A instrumentalidade do processo, p. 85. 
jurídica, lealdade e boa-fé, e interesse público, ${ }^{244}$ que em sua essência não distoam dos princípios processuais acima expostos, com as ressalvas que serão feitas ao longo deste trabalho.

Conjuntamente aplicados, os princípios delimitam a construção de um processo administrativo que contribui de maneira efetiva para a consecução de um processo administrativo legítimo e bem estruturado.

\section{V.4. Natureza do processo de apuração de conduta}

O processo administrativo de apuração de conduta tem suas particularidades, em razão especialmente da natureza do direito material ao qual é instrumental, ao procedimento e à estrutura sob a qual é desenvolvido. Tal fato faz com que muitas sejam as dúvidas de sua colocação na disciplina, razão pela qual o assunto merece atenção especial. A questão que se põe parte de perguntas conceituais, que se projetam para aspectos relevantes perante a técnica: trata-se de processo ou procedimento? O processo/procedimento de apuração de conduta anticoncorrencial tem natureza administrativa, civil, penal ou especificamente concorrencial?

É preciso esclarecer inicialmente a questão taxonômica. A distinção entre processo e procedimento há muito é feita e precisa ser reforçada. Muitos são os autores que utilizam a designação procedimento de forma a evitar confusão com o processo judicial, de características próprias, formador de coisa julgada ${ }^{245}$ há inclusive quem entenda que a distinção, de tão imprecisa, é desnecessária no âmbito administrativo. ${ }^{246}$ É fato que o procedimento tem o valor de penhor da legalidade, da preservação de princípios constitucionais e infraconstitucionais no exercício de poder e oferece a seqüência, o encadeamento de acordo com um modelo pré-estabelecido. Porém, melhor seria entender que o processo é definido por aquela relação jurídico processual, pelas garantias e qualificado pelos escopos tutelados, conforme já exposto. Procedimento, é “apenas o meio

\footnotetext{
244 Copilação de princípios indicados por Nery Costa, Processo administrativo e suas espécies, p. 16, Meirelles, Direito Administrativo brasileiro, n. 3.3.3 e Bandeira de Mello, Curso de direito administrativo, pp. 491-495.

${ }^{245}$ Bandeira de Mello, Curso de direito administrativo, cap. XVI; Sundfeld, "A importância do procedimento no direito administrativo", p. 89.

${ }^{246}$ Nery Costa, Processo administrativo e suas espécies, p. 12. O autor certamente se ampara na diversidade de processos administrativos, que classifica em de expediente, de outorga, de restrição pública à propriedade particular, de controle, de gestão, de punição, disciplinar e fiscal, cada qual com características próprias.
} 
extrínseco pelo qual se instaura, desenvolve-se e termina o processo; é a manifestação extrínseca deste, a sua realidade fenomenológica perceptível", ${ }^{247}$ ou então "o processo é, assim, o procedimento animado pela relação processual". ${ }^{248}$

Reduzir o processo ao procedimento é um equívoco corrente em esfera administrativa, ${ }^{249}$ principalmente na tentativa de generalização de todos os atos a ela submetidos - mesmo aqueles em que é efetivamente instaurada uma relação jurídica processual, conforme processos mais complexos, em especial aqueles de natureza sancionatória.

Estabelecida a premissa, como processo desenvolvido perante Secretaria do Ministério da Justiça e julgado por autarquia também vinculada ao Ministério da Justiça e com participação de Secretaria vinculada ao Ministério da Fazenda, seu trâmite se dá inteiramente perante órgãos do Poder Executivo.

O conceito de processo administrativo não é uniforme na doutrina brasileira, havendo quem o defina em sentido estrito como série de documentos que formam uma peça administrativa, um conjunto de atos ordenados para solução de controvérsia administrativa, um conjunto de medidas preparatórias para decisão final da Administração e ainda como um sinônimo de processo disciplinar; o destino seria a concessão de benefícios, direitos, negativa de pedidos ou aplicação de sanções aos administrados. $^{250}$

${ }^{247}$ Cintra-Grinover-Dinamarco, Teoria geral do processo, p. 279.

${ }^{248}$ Dinamarco, A instrumentalidade do processo, p. 153.

249 "Nem é antigo, na doutrina, o emprego do vocábulo processo, fora do âmbito do direito processual stricto sensu. O mais usual é reservá-lo para designar o processo jurisdicional. O processualista tem o hábito de considerá-lo exclusividade sua, deixando à jurisdição voluntária e ao direito administrativo, não sem desdém, o uso do nome procedimento (frequentemente acompanhado do adjetivo mero: 'mero procedimento'), como se o processo não fosse também, antes de tudo e substancialmente, um procedimento. Curiosamente, é do direito administrativo que veio a mais clara das idéias acerca do conceito de processo, hoje alvo de crescente aceitação na doutrina dos processualistas: procedimento com participação dos sujeitos interessados (ou seja, daqueles que receberão a eficácia direta do ato final esperado), eis o conceito de processo na ciência moderna" (Dinamarco, A instrumentalidade do processo, p. 83).

${ }^{250}$ Nery Costa define o processo administrativo como o "conjunto de atos administrativos, produzidos por instituições públicas ou de utilidade pública, com competência expressa, respaldados em interesse público, que são registrados e anotados em documentos que formam peças administrativas, disciplinando a relação jurídica entre a administração e o administrado, os servidores públicos ou outros órgãos públicos" (Processo administrativo e suas espécies, p. 8). Data maxima venia, não se concorda com a definição: desconsidera atos da parte ínsitos ao processo administrativo, inclui a questão da competência criando desnecessária amálgama entre regras definição de atribuições com o conceito de processo; confunde autos com o processo em si ao fazer referência aos registros e documentos. Por essas e outras razões, Meirelles já alertava: "a verdade é que, entre nós, o processo administrativo não tem merecido os estudos teóricos necessários à sua compreensão 
Dada a diversidade de procedimentos administrativos (tipos específicos de externalização do gênero do processo administrativo), qualificados por Nery Costa como processos de expediente, de outorga, de restrição pública à propriedade particular, de controle, de gestão, de punição, disciplinar e fiscal, um corte deve ser feito aqui. Não é objeto avaliar aqui cada um dos tipos para identificar ou não em suas características específicas conotações de ordem processual - apontar relações jurídicas (ônus, deveres, poderes, faculdades e sujeições), em qual medida as garantias e princípios da teoria geral do processo lhes são aplicadas e qual o escopo específico em cada um deles. Pretende-se sim a avaliação do processo administrativo de apuração de conduta anticoncorrencial, em qual tipo de procedimento ele poderia ser encaixado por características próprias e quais as preocupações que devem ser ostentadas em relação a eles, especialmente em função de sua complexidade e de sua relação com o processo judiciário.

Fato que por suas características, o direito antitruste se concretiza por procedimento que na seara administrativa seria qualificado como sancionatório, ou "de punição quanto às infrações contra a ordem pública”, em razão da perquirição feita à violação da lei. Em linhas gerais, um processo (porque, como se verá, são efetivamente processos) dessa natureza é instaurado por auto de infração, representação, denúncia ou peça equivalente, é conduzido por agente o público ou comissão, observa forma e fases, exige necessariamente a garantia da defesa, aplica subsidiariamente disposições processuais penais e resulta em aplicações de advertências, multas, apreensões, embargos ou demolições de obras, suspensão, proibição ou interdição de atividade, cancelamento de alvarás, suspensão de atividades, proibição de negociação com a administração e outros. ${ }^{251}$ Ou seja, para o autor, estaríamos diante de um processo administrativo com aplicação subsidiária penal. Trata-se, portanto, da visão do processo como administrativo.

Para André Marques Gilberto, o processo em análise decorre de manifestação do poder de polícia (condicionadores de liberdades e da propriedade), destinado à aplicação de sanções pelo descumprimento de normas anticoncorrenciais. Seria o instrumento à disposição de órgãos antitruste para identificar, investigar e eventualmente

doutrinária e à sistematização metodológica, que, naturalmente, informaria a legislação e aprimoraria os julgamentos internos da Administração" (Meirelles, Direito administrativo brasileiro, n. 3.3.2).

${ }^{251}$ Nery Costa, Processo administrativo e suas espécies, p. 155-156, 194-200. 
punir, com aplicação subsidiária da lei de processos administrativos (lei n. 9.784/99), do $\mathrm{CPC},{ }^{252}$ da lei da ação civil pública e do Código de Defesa do Consumidor. ${ }^{253}$

José Ignácio Gonzaga Franceschini, por sua vez, defende a natureza processual penal do processo administrativo de apuração de conduta. Ele parte da concepção material do direito da concorrência como ramo do direito penal-econômico que disciplina as relações de mercado entre agentes e consumidores, tutelando a concorrência (direito coletivo) sob sanção. Da relação com um direito material penal decorreria a atuação processual penal, por meio de ação penal destinada ao restabelecimento do equilíbrio da sociedade e proteção do direito subjetivo público do Estado. O CADE seria mandatário da coletividade e advogado da livre concorrência na atuação do jus puniendi. ${ }^{254}$

De fato, há quem sustente que o processo penal possui particularidades a respeito do conceito de lide, por ser dispensável atuação de resistência ou insatisfação por parte de cada um dos 'litigantes' e os reflexos desse raciocínio perante o conceito de pretensão em processo penal; as diferenças entre os sistemas acusatório e inquisitório e os padrões de prova, distribuição de ônus e presunções; a inocorrência de revelia no processo penal; a inexistência de ações cautelares penais. ${ }^{255}{ }^{256}$ No processo penal revela-se a tensão

${ }^{252}$ Sundfeld, por sua vez, sustenta que “o art. 83 desta lei foi derrogado pelos arts. 1o. e 69 da lei 9.784/94 (Lei do Processo Administrativo Federal). Em função destes preceitos, os processos administrativos federais específicos ficaram sujeitos às disposições da lei específica (no caso presente, às disposições próprias da lei 8.884/94) e, subsidiriamente, às normas da Lei Federal de Processo Administrativo. Portanto, esta lei substituiu o CPC quando à incidência como norma processual subsidiária da lei 8.884/94" (Sundfeld, "Lei da concorrência e processo administrativo: o direito de defesa e o dever de colaborar com as investigações" p. 7), com o que, com a devida vênia, não se concorda, conforme será exposto adiante.

${ }^{253}$ Gilberto, O processo antitruste sancionador, pp. 27-32.

${ }^{254}$ Franceschini, "Roteiro do processo penal-econômico na legislação de concorrência", pp. 9-14.

255 Confira-se Florian, Elementos de Derecho Procesal Penal, p. 22; Mazzini, Istituzioni di diritto processuale penale, p. 14; Tucci, Teoria do direito processual penal - jurisdição, ação e processo penal [estudo sistemático], n. 1.1.

${ }^{256}$ Luiso destaca diferenças: "anche il processo amministrativo e quello tributario sono processi 'civili', in quanto hanno come scopo la tutela dei diritti. Sotto questo profilo essi si differenziano radicamente dal processo penale, in cui non ci sono situazioni sostanziali da tutelare, ma illeciti da reprimere, violazione di norme penali cui far conseguire l'applicazione della sanzione penale" (Luiso, Diritto processuale civile, p. 8). Pasquale Gianniti trabalha o confronto entre o processo civil e o penal italianos sob diversos aspectos, dos quais alguns são postos em destaque: (i) em casos de contumácia, afirma a maior atuação do princípio do contraditório pela desingação de um defensor "di fiducia o d'ufficio" e o fato de que o comparecimento espontâneo revoga os efeitos da decisão de contumácia e permite que o réu ofereça declarações espontâneas ou "chiedere di essere sottoposto ad esame"; (ii) a conciliação, permitida na esfera civil, é vedada na penal em razão dos interesses indisponíveis em jogo; (iii) na comparação entre o papel do Ministério Público e do advogado, o último tutela o cliente e o primeiro "resta libero di valutare se un elemento di prova è favorevole rispetto alla richiesta"; (iv) em razão do direito inviolável de defesa efetiva, não se admite a defesa técnica no processo penal pois o direito de defesa "è, in primo luogo, garanzia di contraddittorio e di assistenza tecnicoprofessionale ed è assicurato nella misura in cui si dia all'interessato la possibilità di partecipare ad una effettiva dialettica processuale", (v) no âmbito das nulidades, o princípio da taxatividade é absoluto na esfera penal e relativo na esfera civil, a liberdade das formas tem aplicação reduzida na esfera penal, não haveria 
do binômio liberdade-repressão, a indisponibilidade do jus puniendi, do status libertatis, da ação, da defesa e das mais importantes situações jurídico substanciais. ${ }^{257}$

A qualificação penal do processo de apuração de conduta é rejeitada por Salomão Filho, pela análise do direito material envolvido, especialmente à luz do debate sobre a natureza penal e típica (não meramente exemplificativa) das condutas previstas na lei n. 8.884/94. O autor refuta a idéia de tipicidade, contestando "o próprio caráter penal das normas administrativas. Aliás, no campo do direito concorrencial, a existência de criminalização expressa de certas condutas demonstra que ambas esferas não se confundem". E mais: "pacífica é a doutrina penal ao reconhecer a existência de tipos anormais, caracterizados por conterem elementos normativos e elementos subjetivos. Aqui, interessam-nos os primeiros. São eles palavras, locuções ou orações cujo significado a própria ordem jurídica oferece ou decorre de dados culturais a que a lei penal se reporta. Tais tipos, como refere a doutrina, para sua verificação em concreto, exigem um juízo de valor dentro do próprio plano da tipicidade (...) ou elementos para cujo entendimento não basta o simples emprego da capacidade cognoscitiva, mas cujo sentido tem de ser apreendido". 258

Em outra oportunidade, já sustentei que os argumentos até poderiam ser relevantes para estabelecer alguns padrões técnicos distintos entre o processo civil e o processo penal, ainda que a idéia de lide pudesse ser substituída pelo conceito de demandapretensão, que no processo civil havia um gradativo crescimento dos espectros de atuação do juiz e que a cautelaridade estaria claramente presente no processo penal. Naquela sede,

previsão expressa de nulidade parcial de um ato na esfera penal; (vi) no campo da teoria da ação, a esfera penal teria como peculiaridades a publicidade (visa à satisfação de um interesse público e é proposta por um órgão público, a oficialidade, a obrigatoriedade (que afasta a discricionariedade do Ministério Público), a irretratabilidade como regra geral, a indivisibilidade (a ação deve ser proposta contra todos os participantes), enquanto a ação civil seria privada, proposta após provocação da parte, facultativa, retratável e divisível e eventual; (vii) o princípio da imediatidade (immediatezza) seria relativo no processo civil (e bastante flexibilizado pela jurisprudência), enquanto é tratado com rigor no processo penal, (viii) em relação à matéria probatória, na esfera civil prevaleceria o princípio dispositivo (em processo que tem início por provocação da parte e se movimento por impulso dessa parte), preferindo-se as provas constituídas no processo, enquanto na esfera penal prevaleceria o princípio dell'ufficialità, preferindo-se as provas pré-constituídas. Há ainda a questão do ônus da prova, que na esfera civil se divide entre o autor e o réu e a esfera penal encontra a presunção legal de inocência dispensando o réu de referido ônus, considerando-se ainda o elevado quantum probatório que exige a eliminação de "ogni ragionevole dubbio" e (ix) é inadmissível o julgamento por equidade no processo penal (Gianniti, Processo civile e penale a confronto, passim).

${ }^{257}$ Dinamarco, A instrumentalidade do processo, p. 76. O autor afirma, porém, serem "lamentáveis os posicionamentos ainda existentes no seu trato, como se fora algo empírico e rebelde à teora geral. As garantias constitucionais do processo são explicitamente direcionadas a ele, se não fora por outras razões, só por aí haveria uma ponte de ligação ao sistema processual geral”.

${ }^{258}$ Salomão Filho, Direito concorrencial - as condutas, p. 332. 
debatia-se a adequação de uma teoria geral do processo, que não restou mitigada pelos argumentos contrários, amparada ainda pela idéia de que uma teoria geral não descura das diferenças, mas sobreleva os pontos determinantes em comum, que como visto acima são determinantes em qualquer dos ramos do processo. ${ }^{259}$ Contraditório, ampla defesa, legalidade, isonomia, direito à prova, publicidade de atos, fundamentação e impulso oficial são princípios e garantias que permeiam tanto a produção legislativa quanto a interpretação, quer por respeito ao modelo constitucional brasileiro, quer pelos axiomas de uma teoria geral do processo, que representa a condensação de preceitos aceitos em um regime processual democrático. A identificação de princípios da teoria geral com intensidade maior ou menor em cada uma das esferas não retira a relevância do exame dos axiomas.

Mas então qual seria a natureza desse processo? Opta-se então por desenvolver o raciocínio a partir da conclusão: não é útil estabelecer balizas rígidas taxonômicas a partir das figuras pré-existentes. Tratar o processo como administrativo, penal ou civil certamente acarretará divergências em pontos nevrálgicos do processo antitruste, causando - como já causa - confusões na interpretação da norma.

Do modelo constitucional e da teoria geral o processo administrativo extrai as balizas. Do processo administrativo, respeita a topologia por tratar-se de processo que tramita por autarquia vinculada a órgão da Administração Pública, bem como os preceitos da lei n. 9.784/99, mas não em sua inteireza, visto que ostenta regulamentação específica em lei própria que remete à aplicação meramente subsidiária de normas de cunho processual administrativo naquilo que for compatível com o processo antitruste. É sabido que normas relevantes de processo administrativo, correlatas a princípios da teoria geral do processo, exigem extremos esforços hermenêuticos para serem aplicadas no processo antitruste, como é o caso da cláusula do duplo grau (note-se que à época da edição da norma concorrencial, sequer havia sido editada aquela que regula o processo administrativo, ainda que tal fato não exclua sua aplicação).

Do processo penal, recebe, de fato, alguns influxos relevantes, como a exceção ao princípio da demanda e possibilidade de atuação ex officio dos órgãos do

259 Concluiu-se por um "consenso de que as duas esferas tratam de objetos de demanda distintos e merecedores de tratamentos peculiares, embora vaso-comunicantes, diante de todos os aspectos estruturais que aproximam esses dois ramos científicos" (Burini, Efeitos civis da sentença penal, n. 5). 
SBDC (oficialidade), a existência de procedimentos prévios ao processo, equiparáveis ao inquérito policial, mas não é de todo acertado afirmar que os padrões de provas-presunções são os mesmos daqueles presentes em processos penais; também é o caso do tratamento das preclusões e das formalidades procedimentais, havendo quem "demonize" o princípio da instrumentalidade das formas no processo penal, muito embora sua aceitação seja tranqüila em processos civis e administrativos. Note-se ainda que a relação entre imutabilidade e revisibilidade de decisões não ostenta no processo antitruste aquela "ampla revisibilidade" permissiva do processo penal em prol das liberdades individuais; a própria indisponibilidade penal é questionada no processo antitruste - aliás, mais que questionada, em certa medida a disponibilidade é essencial, especialmente se considerado o incentivo ao acordo de leniência, instrumento de ressabida eficácia no combate aos cartéis.

Já do processo civil extrai seus principais institutos, tais como regras estruturais de competência, limites objetivos e subjetivos da demanda, meios de prova, estabilização, além de valer-se dele por referência expressa da lei n. 8.884/94 (art. 83) ainda que esse seja o argumento menos relevante para uma ponderação desconstrutivazetética. $^{260}$

Também como argumento menos determinante, mas que também auxilia na ilustração, partido do pressuposto da relação entre o direito material e o processual (aquela ligação genética existente, v.g., entre o direito civil e o processo civil, o direito penal e o processo penal) e da idéia de fatos jurídicos de múltipla incidência, temos como resultado que a fixação de preços de venda de bens em acordo com concorrente pode ensejar um ilícito penal, passível de persecução por meio do processo penal (Lei n. 8.137/90, art. $4^{\circ}$, inc. II, $a$ e CP, art. 288), de eventual reparação individual por consumidor ou concorrente lesado, quer por meio de tutelas individuais ou de tutelas de interesses transindividuais, e ainda é um ilícito antitruste, que seria investigado não por um processo que sorve de Mary Shelley aspirações a um moderno prometeu, mas sim por um processo novo que recebe os influxos legítimos de diversas fontes e busca identidade própria. ${ }^{261}$

260 Zetética remete à idéia de dúvida das evidências, perquirição, especulação explícita, infinita e desintegratória sobre o que é uma coisa, enquanto a dogmática parte de dogmas e ensina, doutrina, opina, ressalva opiniões, possibilita a decisão e orienta a ação (Ferraz Jr., Introdução ao estudo do direito - técnica, decisão, dominação, p. 41-43).

${ }^{261}$ Benedetto é consciente ao examinar o argumento, afirmando que, inclusive na Itália o legislador evitou recorrer de forma indiscriminata ao instrumento sancionatório criminal, por sua vez, afirma que "bisogna riconoscere come il legislatore abbia qui opportunamente evitato di ricorrere in maniera indiscriminata allo 
À luz de tantas ponderações, como - e por qual motivo - extrair de tão intrincadas influências e reflexos tão particulares um modelo de orientação em relação à natureza do processo de apuração de conduta? Realmente, não há necessidade. Basta, sim, saber identificar de forma suficiente o direito material e estabelecer uma correta relação com o processo, em operação que leve em consideração adaptabilidade da relação processual, que eleva a plasticidade ao arcabouço de normas procedimentais para atribuir fluência e celeridade ao processo sem prejuízo substancial à segurança jurídica e ao due process of law. ${ }^{262}$

Trata-se de transportar para esta sede a idéia de diálogo das fontes bem trabalhada por Cláudia Lima Marques, de modo "a permitir a aplicação simultânea, coerente e coordenada das plúrimas fontes legislativas convergentes. 'Diálogos' porque há influências recíprocas, 'diálogo' porque há aplicação conjunta das duas normas ao mesmo tempo e ao mesmo caso, seja complementarmente, seja subsidiariamente, seja permitindo a opção voluntária das partes sobre a fonte prevalente, ou mesmo permitindo uma opção por uma das leis em conflito abstrato. Uma solução flexível e aberta, de interpretação, ou mesmo a solução mais favorável ao mais fraco da relação (tratamento diferente dos diferentes)". 263

Se não é possível aproximar em termos absolutos o processo administrativo de apuração de conduta do processo civil ou do penal, não há grande drama nisso. Dadas as particularidades estruturais e do próprio processo de apuração de conduta,

strumento sanzionatorio criminale, con un'opizione che valorizza senz'altro i profili di maggiore effettività collegati all'illecito amministrativo". "La riconduzione della sanzione penale ed amministrativa ad una categoria teleologicamente unitaria - in considerazione della sussistenza di principi sanzionatori amministrativi mutuati direttamente dal diritto penale, del mantenimento della pubblicità dell'intervento sanzionatorio anche in sede amministrativa, dell'indubbio 'disvalore' sociale legato all'illecito amministrativo, del ricorso sempre più frequente alla elaborazione normativa di illeciti amministrativi ab origine - abbia indiscutibilmente consentito di superare la non più recente tesi che lega la sanzione amministrativa alla lesione di un interesse particolare dell'amministrazione a favore di una concezione che ne evidenzi la sostanziale connaturalità alla sanzione penale (...); i limiti dell'utilizzazione della sanzione penale evidenziati anche (...) nella incapacità reale di fungire da deterrente, e dall'altra, nella vanificazione degli effetti sanzionatori per il frequente ricorso ad amnistie; (...) la maggiore flessibilità, nella determinazione sia nell'an che nel quantum, della sanzione amministrativa, più efficace sotto il profilo della punizione dell'autore dell'illecito (...) tutto ciò considerato ci sembra che, nel caso della legge per la tutela della concorrenza e del mercato, la scelta della sanzione amministrativa - e dunque la qualificazione amministrativa dei relativi illeciti - si 'in linea con l'evoluzione della normativa antitrust dei Paesi occidentali, i quali per le relative infrazione prevedono conseguenze civili e sanzioni amministrative pecuniare, mentre tendono a limitare la risposta penale'; e che sia inoltre in grado di imporsi come efficace strumento di regolazione dei comportamenti economici" (Benedetto, L'Autorità garante della concorrenza e del mercato, p. 264).

${ }^{262}$ Dinamarco, A instrumentalidade do processo, p. 356.

${ }^{263}$ Lima Marques-Benjamin-Miragem, Comentários ao Código de Defesa do Consumidor, pp. 24-28. 
parece mais razoável fugir de uma vã tentativa de encapsular o processo segundo o que se faz nesta ou naquela esfera, sendo mais razoável a idéia de permeabilidade e comunicação entre todos os tipos existentes, respeitados os ditames da teoria geral do processo e as necessidades do direito material em discussão.

Ao examinar a concepção do direito econômico, Comparato antevia que o contato com a realidade fenomenal causaria rompimento com o esquema lógico, formal, esquematizado do direito: “fugindo não só ao esplêndido idealismo das doutrinas puras do direito, como ao desprezo sistemático pelas categorias jurídicas formais manifestado pelos práticos, a cultura jurídica tende a encaminhar-se no sentido de uma compreensão global do mundo do direito (...) e o jurista, por ser justamente jurista, tem por missão definir tais categorias, integrá-las num sistema e aprimorar-lhes a expressão formal. (...) Do jurista também se exige a capacidade de escolher e de aprimorar as instituições existentes, ou de criar outras novas em função de objetivos que lhes são propostos pelas necessidades da vida cotidiana". 264

Porém, essa autonomia conceitual do processo administrativo deve ser lida com atenção em termos de legalidade. O direito processual é um ramo de direito público, suas normas são cogentes, seus conceitos basilares estão bem estabelecidos em preceitos constitucionais e infraconstitucionais. Aquela mesma constituição que estabelece princípios mínimos é a mesma que define a competência da União para legislar sobre matéria processual (CF, art. 22, inc. I).

A lei n. 8.884/94, de fato, estabelece algumas regras sobre o tema. Define regras sobre competência, estrutura judicante do CADE, prazos, impedimentos e suspeições de Conselheiros, provocação do órgão, exercício do contraditório e da ampla defesa, provas, forma de julgamento, penalidades possíveis, medidas liminares, recursos, formas de composição de interesses. $O$ tratamento do processo administrativo é complementado por Resoluções do órgão, dentre as quais se destaca o Regimento Interno (Resolução n. 45).

Como visto acima, é o processo que estabelece as balizas da relação jurídico-processual, os ônus, deveres, poderes, faculdades e sujeições lastreados em escopos pré-definidos e o procedimento é apenas sua manifestação extrínseca. Se as

${ }^{264}$ Comparato, “O indispensável direito econômico", p. 25. 
normas processuais são de competência da União, o mesmo não ocorre com as normas procedimentais que, dentro das balizas estabelecidas pela lei, têm liberdade para discorrer sobre o modo de ser do processo. A própria constituição reafirma essa idéia, quando afirma que os tribunais elaboram seus regimentos internos "com observância das normas de processo e das garantias processuais da parte" (CF, art. 96, inc. I). Porém, se há dificuldade em se definir o que é processo e procedimento administrativo, é possível crer que legislador e administrador possam ter descurado da competência normativa constitucional. $^{265}$

Exemplos para reflexão. $\mathrm{O}$ art. 13 da Portaria n. 4 do Ministério da Justiça c/c art. 36 do Regimento Interno do CADE estabelecem a excepcionalidade da participação de terceiro interessados, sujeita a um exame de oportunidade e conveniência, mas a lei não regula a matéria, tampouco estabelece a restrição. A atividade de partes e de terceiros no processo (e sua restrição) tem a ver com a idéia de participação democrática, exercício do contraditório e de ampla defesa, acesso ao órgão na medida dos interesses por ele protegidos, acesso a uma decisão justa como instrumento de pacificação - conceitos que, conforme será visto adiante (v. item n. VI.2.4), condensam escopos jurídicos, políticos e sociais do processo administrativo. A disposição ainda redesenha as relações do terceiro na relação jurídica material com o processo, suas faculdades e poderes. Tais dados conduzem à conclusão de que seria adequado que essa regulamentação deveria ser feita em atenção ao disposto no art. 22, inc. I da Constituição Federal.

O mesmo pode ser dito em relação ao tratamento do sigilo, previsto nos arts. 41 e ss. do Regimento Interno. A relação entre publicidade do processo e sigilo de informações sobre concorrentes toca substancialmente em princípio processual tratado constitucionalmente e infraconstitucionalmente, quando ligados às temáticas do acesso à informação, da transparência (moralidade) na administração pública, também aqui do contraditório e da ampla defesa. Este item não questionará o conteúdo da disciplina (para tal, v. item VI.2.6), mas sim a forma utilizada para sua regulamentação.

\footnotetext{
${ }^{265}$ As críticas são feitas também em relação ao direito material: “o CADE não detém poder normativo, não é uma agência reguladora, porque nenhuma das normas da lei n. 8.884 lhe atribui a competência para formular normas de direito material. Embora as regras contidas nos anexos da Resolução tenham o mérito de tornar mais previsível a condução de um processo na autarquia, elas não são realmente normas de instrução processual, invadindo algumas delas, a esfera do direito substantivo". E mais, "o poder de um órgão administrativo judicante é o de produzir normas jurídicas individuais (como as definiria Kelsen) e não gerais. Seria o equivalente de o Judiciário editar normas de direito material com base em sua jurisprudência. E notese que as resoluções do CADE não se confundem com Súmulas" (Aguillar, Direito econômico - do direito nacional ao direito supranacional, p. 236).
} 
Há ainda a questão das súmulas, previstas nos arts. 56-58 do mesmo diploma. A despeito não terem a natureza vinculante prevista pelo art. 103-A da Constituição Federal, o instituto relaciona segurança, previsibilidade, mensagens aos administrados, além de outros preceitos especialmente relacionados com a regra do livre convencimento motivado e a liberdade do julgador. Também aqui parece razoável compreendê-las como matéria de ordem processual.

Por fim, a título de exemplo, anote-se que a Portaria n. 4 do Ministério da Justiça cria o procedimento administrativo não previsto na lei n. 8.884/94, como uma espécie de procedimento preparatório, investigativo e menos formal que a averiguação preliminar. Note-se que não se trata de definição de regras procedimentais, mas a própria criação de um procedimento que estabelece relações jurídicas processuais mais tênues que aquelas existentes em averiguações preliminares.

Espera-se aqui emitir um breve alerta para alguma fragilidade conceitual do processo administrativo e para necessidade de reforçá-lo em bases mais sólidas. A dinâmica das relações econômicas tem evidentes reflexos perante o processo, mas concebidos o processo e os procedimentos como penhor de legalidade de relações jurídicas, não se pode elevar o grau de mutabilidade normativa em patamares que possam criar insegurança. $\mathrm{O}$ sistema processual brasileiro ainda vive um período de desconfiança plurilateral crônica (entre as partes, entre as partes e o órgão decisório - instrutório), que se reflete em sistemas processuais positivados com alguma rigidez.

Em termos mais concretos, uma proposta de emenda de Regimento Interno do CADE, para ser aprovada, precisa (a) do controle da Procuradoria do CADE, intimada a opinar sobre a matéria, mas cujas palavras sobre regularidade formal e material de normas influenciam sobremaneira as decisões de um órgão - composto não só por juristas e (b) da aprovação pelo Plenário. Trata-se de processo simples que comporta algum debate, mas não oferece a segurança e a legitimação democrática possível que é atribuída às normas.

As relações entre regimentos internos de órgãos judicantes não legislativos e o art. 22, inc. I da Constituição Federal já foi apreciada pelo Supremo Tribunal Federal, que se pronunciou sobre a questão afirmando que "com o advento da Constituição Federal de 1988, delimitou-se, de forma mais criteriosa, o campo de 
regulamentação das leis e o dos regimentos internos dos tribunais, cabendo a estes últimos o respeito à reserva de lei federal para a edição de regras de natureza processual $(\mathrm{CF}$, art. 22, I), bem como às garantias processuais das partes, 'dispondo sobre a competência e o funcionamento dos respectivos órgãos jurisdicionais e administrativos' (CF, art. 96, I, a). São normas de direito processual as relativas às garantias do contraditório, do devido processo legal, dos poderes, direitos e ônus que constituem a relação processual, como também as normas que regulem os atos destinados a realizar a causa finalis da jurisdição". ${ }^{266}$

Não seria condenável então repensar o processo administrativo de apuração de conduta e redesenhá-lo em lei federal, condensando dispositivos esparsos em lei federal, Regimento Interno, Resoluções do CADE, especialmente em um momento em que a reforma da legislação antitruste está em pauta no Congresso Nacional. Seria mais um instrumento da consolidação e do fortalecimento institucional pela via processual que se propõe.

${ }^{266}$ STF, Pleno, ADIN 2970, Rel. Minª. Ellen Gracie, j. 20.4.06. 


\section{OS ESCOPOS DO PROCESSO ADMINISTRATIVO}

Já foi dito que o escopo do direito antitruste em sua vertente material tem por alvo, intenção, objetivo a ser alcançado, a concorrência entre os agentes capaz de produzir bem estar social. O Estado recebe dos indivíduos parcela de liberdade, estabelece regras e lhes outorga imperatividade como medida de preservação da paz social, da manutenção das instituições, sempre na tentativa de proporcionar aos indivíduos sensações de inserção, bem estar, felicidade.

O direito antitruste atua como instrumento de proteção da concorrência como instituição, concebendo que a viabilização de competição entre as empresas pode gerar efeitos concretos positivos para os indivíduos. Nesse aspecto, o antitruste reconhece de maneira bastante clara seu papel: delimita seu campo de atuação sem se descurar de uma perspectiva instrumental própria a partir de retroalimentações e interrelacionamentos entre as expressões de Poder do Estado: a necessidade de proteção da economia por meio da intervenção do Estado em maior ou menor grau, para permitir o fluxo das relações econômicas em um ambiente que preserve segurança e previsibilidade dos movimentos dos players.

A sociedade reconheceu que em um regime democrático é mais adequado proteger a ordem econômica, valorizando a livre iniciativa e a livre concorrência de modo a alcançar um sistema mais justo e equilibrado; esse reconhecimento foi constitucionalizado e recebeu a companhia de outros tantos valores previstos constitucionalmente (o trabalho humano, a existência digna, os ditames da justiça social, a defesa do consumidor, a defesa do meio ambiente, a redução das desigualdades regionais e sociais); essa conjunção de valores compõe um quadro hermenêutico que alimenta normas infraconstitucionais e que retorna à sociedade em forma de norma em quadros deônticos que demandam aplicação escorreita perante um órgão estatal. Os órgãos do SBDC, quando interpretam a norma constitucional e as demais, cuidam da aplicação de todos esses valores de forma a trazer um equilíbrio pró-competitivo que proteja a concorrência nas relações entre os agentes atuantes no mercado, mas cientes de que reflexamente o objetivo final é o bem estar social, da coletividade, dos indivíduos, é assegurar o processo de descoberta do consumidor. 
Para assegurar a proteção da concorrência e o processo de descoberta do consumidor, em matéria repressiva, é necessário um instrumento juridicamente previsto, que imponha poder, mas que ao mesmo tempo apresente elementos que permitam a aceitação do poder imposto.

Desde o marco do direito processual como ciência autônoma que é possível assistir a evolução de um pensamento processual destacado de imanentismos materiais. Recorrendo a lugares comuns como os "movimentos históricos pendulares" e os "repúdios aos extremos", a ciência processual assistiu esse imanentismo transformar-se em autonomia, e a autonomia exacerbada exigir a releitura da ciência processual para que fosse adequada à sua posição na ciência do direito.

Realmente, é possível estudar aspectos do processo de forma autônoma. Mas hoje é lugar comum compreendê-lo em um contexto mais amplo, que coordena o direito material subjacente com os objetivos endógenos esperados de um processo. Foram essas considerações que desembocaram no desenvolvimento da teoria instrumentalista, que claramente serve como guia do presente trabalho.

A intenção é de ir além do que aqueles escopos de resguarda dos administrados e clarividência da atuação administrativa, já estabelecidos para o processo administrativo. $^{267}$

Da obra de Chiovenda ao requintado pensamento de Dinamarco, ${ }^{268} \mathrm{o}$ salto de qualidade do instrumento de efetivação de direitos em 50 anos foi substancial e

\footnotetext{
${ }^{267}$ Bandeira de Mello, Curso de direito administrativo, pp. 487-488. Ampla defesa será apenas um dos tantos tópicos a serem analisados.

${ }^{268}$ Dinamarco, A instrumentalidade do processo, passim. Existem ressalvas à doutrina instrumentalista, calcadas no receio em relação ao "ideal de um processo do tipo que serve à jurisdição voluntária, caracterizado fortemente pela independência do juiz diante da lei, vinculado apenas aos fins sociais e à política do Estado, sempre foi a marca dos regimes de opressão" (Botelho de Mesquita, "As novas tendências do direito processual: uma contribuição para o seu reexame", passim), e à "evidência que o modismo da instrumentalidade camufla, ou conscientemente - perversidade ideológica, a ser combatida -, ou por descuido epistemológico - equívoco a ser corrigido. Ele parece ou finge ignorar o conjunto de fatores que determinaram uma nova postura para o pensar e aplicar o Direito em nossos dias". Mais adiante, o autor conclui: "a pergunta que cumpria fosse feita - quais as causas reais dessa crise (processual - celeridade, efetividade) - jamais foi formulada. Apenas se indagava: o que fazer para nos libertarmos da pletora de feitos e de recursos que nos sufoca? E a resposta foi dada pela palavra mágica 'instrumentalidade', a que se casaram outras palavras mágicas: 'celeridade', 'efetividade', 'deformalização' etc. E assim, de palavra mágica em palavra mágica, ingressamos num processo de produção do Direito que corre o risco de se tornar pura presdigitação. Não nos esqueçamos, entretanto, que todo espetáculo de mágica tem um tempo de duração e desencantamento" (Calmon de Passos, 'Instrumentalidade do processo e devido processo sobre o
} 
merece a atenção no processo administrativo, feitas as devidas adaptações destinadas a uma internalização conceitual coerente, produtiva e eficaz.

A obra analisa os quatro principais conceitos necessários para a compreensão do fenômeno processual - jurisdição, ação, defesa e processo -, elegendo o primeiro deles como principal sustentáculo do conceito; estabelece que a jurisdição tem escopos a perseguir - social, jurídico, político -, elegendo a pacificação com justiça como síntese condensatória de metas; ao final transporta os axiomas para as técnicas processuais.

Os itens anteriores deixaram claro que os ideais de acesso por meio do exercício de ação, de garantia da ampla defesa e do contraditório e de processo como instrumento legitimante de imposição de poder são inerentes a todo e qualquer sistema que se preste à solução de conflitos concretos. Em um Estado democrático, pouco importa se o exercício do poder de decidir é feito em sede jurisdicional, legislativa ou administrativa (em função administrativa judicante ${ }^{269}$ ): os preceitos do modelo constitucional do processo devem ser todos observados e aqueles da teoria geral do processo são observados em maior ou menor intensidade, conforme a natureza do processo, desde que preservadas garantias mínimas de constitucionalidade.

Mas se a proposta é validar o processo administrativo à luz dos avanços da teoria e da técnica do processo jurisdicional, pretende-se estabelecer os pontos de contato entre este e aquele.

O presente capítulo propõe uma coordenação entre os escopos e aspectos técnicos. Após a breve apresentação do sentido do escopo, passa-se à aplicação da idéia a determinados aspectos do processo administrativo que o refletem com maior potencialidade. Faz-se a ressalva, porém, de que os subtítulos referentes a cada escopo não são dele a única decorrência, unívoca e imediata. Cada um dos subtemas poderia ser inserido como parcela representativa de um ou de mais de um escopo, mas por questões de didática ficará atrelado àquele que representa com mais elementos.

tema', in Temas atuais de direito processual civil, pp. 9 e ss.). Mas a instrumentalidade como núcleo de idéias e guia de coordenação de institutos nunca foi convincentemente refutada.

269 A flexibilização na teoria da tripartição de poderes, a admissibilidade de uma função administrativa judicante estruturalmente assemelhada àquela desenvolvida pela jurisdição e a validade do instrumento de imposição de poder por um Tribunal administrativo por meio de um processo. 


\section{VI.1. Escopo Social}

O escopo social da jurisdição atrelado à pacificação é analisado pelo enfoque da justiça da decisão, do processo de aceitação do comando e, em especial, da sua imunização contra o ataque de insatisfeitos. É a eliminação de conflitos por meios idôneos, preservados os mecanismos estatais de proteção de direitos. ${ }^{270}$

Ao Estado cabe eliminar condutas desagregadoras aplicando uma justiça distributiva. O consenso sobre as decisões estatais é difícil de alcançar e tem influência menos relevante que a imunização de uma decisão contra ataques por instrumentos idôneos: "o que importa afinal é tornar inevitáveis e prováveis decepções em decepções difusas (...)" por que "a privação consumada é menos incômoda que o conflito pendente: eliminado este desaparecem as angústias inerentes ao estado de insatisfação e esta, se perdurar, estará desativada de boa parte de sua potencialidade anti-social". ${ }^{271}$

O escopo social é examinado sob o enfoque da imunização, da idoneidade do meio e da finalidade educativa que sobressai das decisões proferidas.

\section{VI.1.1. Imunização, preclusão e coisa julgada}

Perante o poder jurisdicional, a imunização de decisões finais se dá por meio da coisa julgada, ${ }^{272}{ }_{-}^{273}$ instituto de defesa processual da segurança das relações jurídicas de direito material, funcionando como medida de preservação dos negócios, do crédito, da família, da propriedade, da liberdade do indivíduo etc. ${ }^{274}$ Trata-se de um poderoso instrumento processual nas mãos do direito material, funcionando como a medida de

\footnotetext{
${ }^{270}$ Dinamarco, A instrumentalidade do processo, pp. 193-195.

271 "Segurança, ou certeza jurídica, é em si mesma fator de pacificação: a experiência mostra que as pessoas mais sofrem as angústias da insatisfação antes de tomarem qualquer iniciativa processual ou mesmo durante a litispendência, experimentando uma sensação de alívio quando o processo termina, ainda que com solução desfavorável" (Dinamarco, A instrumentalidade do processo, p. 195-196).

${ }^{272}$ Para fins de corte metodológico, aqui não se discutem decisões interlocutórias, mas apenas aquelas decisões finais.

${ }^{273}$ Para Couture, trata-se de uma exigência política para evitar o caos (Couture, Fundamentos del derecho precesal civil, pp. 405-407). Ainda assim, como afirmado nos pressupostos do capítulo, o tema é tratado sob a perspectiva social.

${ }^{274}$ Burini, Efeitos civis da sentença penal, n. 33.1.
} 
equilíbrio entre exigências opostas: o aprimoramento de qualidade de decisão, de outro o ponto final sobre os debates e o oferecimento de solução final. ${ }^{275}$

A coisa julgada é uma qualidade decorrente da imutabilidade de todos os efeitos possíveis de uma sentença: "a coisa julgada nada mais é que essa indiscutibilidade ou imutabilidade da sentença e dos seus efeitos, aquele atributo que qualifica, potencializa a eficácia que a sentença naturalmente produz, segundo a sua própria essência de ato estatal”; "não é o efeito ou um efeito da sentença, mas uma qualidade e um modo de ser e de manifestar-se de seus efeitos, quaisquer que sejam, vários e diversos, conforme as diversas categorias". 276

Essa qualidade é atribuída à coisa julgada material. Dentre as imunizações extra e endoprocessuais existem ainda no processo jurisdicional estudos relevantes sobre a coisa julgada formal como "situação jurídica consolidada a partir da ocorrência da última preclusão possível”, 277 e da preclusão, conceituada como “(...) perda, ou extinção, ou consumação de uma faculdade processual que se sofre pelo fato: a) de não haver observado a ordem assinalada por lei para seu exercício, como os termos peremptórios ou a sucessão legal de atividades e das exceções; b) ou de haver realizado uma atividade incompatível com o exercício da faculdade, como a apresentação de uma exceção incompatível com outra ou a prática de um ato incompatível com a intenção de impugnar uma sentença; c) ou de haver já exercitado validamente uma vez a faculdade (consumação propriamente dita)". $278 \_279$

\footnotetext{
${ }^{275}$ Dinamarco, Instituições de direito processual civil, vol. III, n. 952, pp. 296-297.

${ }^{276}$ Liebman, Eficácia ed autorità della sentenza, p. 6.

277 "Coisa julgada formal é uma situação jurídica consolidada a partir da ocorrência da última preclusão possível em determinado processo e lastreada em todas as demais preclusões anteriormente ocorridas. Diz-se lastreada pois, do ponto de vista lógico, ela tem como pré-requisito a ocorrência de todos os atos da cadeia procedimental. Após ter a preclusão atuado em todas as fases do processo - impulsionando-o em busca de seu resultado e gradativamente impossibilitando aos sujeitos da relação jurídica processual o exercício de faculdades previstas em lei -, tem-se como momento final do processo a prolatação da sentença pelo Estadojuiz" (Giannico, A preclusão no direito processual civil brasileiro, n. 5.5.2). Para Couture, a diferença entre a coisa julgada formal e material está no fato de que a primeira outorga ininpugnabilidad e a segunda, por sua vez, a inmutabilidad (Couture, Fundamentos del derecho procesal civil, pp. 416-417).

${ }^{278}$ Chiovenda, Cosa juzgada y preclusión, in "Ensaios", vol. III, trad. esp. Sentis Melendo, Buenos Aires, 1949, apud Celso Agrícola Barbi, "Da preclusão no processo civil", Revista Forense, vol. 158, p. 59-60.

${ }^{279}$ Em sede administrativa, Bandeira de Melo afirma que "preclusão é a perda de uma oportunidade processual (logo, ocorrida depois de instaurada a relação processual), pelo decurso do tempo previsto para seu exercício, acarretando a superação daquele estágio do processo (judicial ou administrativo)" (Curso de direito administrativo, p. 1.026).
} 
A coisa julgada material, porém, não se verifica em sede administrativa, mesmo em processos que dirimam conflitos por atos administrativos de natureza vinculada. Em razão da cláusula de inafastabilidade do controle jurisdicional, as decisões proferidas por órgãos da Administração pública têm ampla revisibilidade, tanto no corte horizontal (natureza das matérias passíveis de revisão: mérito ou forma) como no corte vertical (profundidade da cognição). O processo administrativo não oferece um instrumento de sedimentação de relações interpessoais ou institucionais capazes de pacificar um conflito de forma definitiva. A doutrina italiana concorda com a posição, ao afirmar que a reforçada estabilidade de provimentos administrativos não pode ser confundida com a coisa julgada material, que deriva, sobretudo, da particular posição e função do órgão jurisdicional. ${ }^{280}$

Essa conclusão não exclui da atividade administrativa alguma imutabilidade, ainda que em grau inferior de efetividade, amparada em preceitos maiores de moralidade administrativa e segurança jurídica.

Perante a administração pública, usualmente, os provimentos podem ser anulados ou revogados pela própria administração ${ }^{281} \mathrm{ou}$ em sede jurisdicional. Porém, há alguma imutabilidade desses provimentos, especialmente em processos administrativos voltados à aplicação da lei a situações concretas, decorrentes de atuação vinculada da administração por meio de Tribunais Administrativos judicantes. Fala-se da existência uma preclusão administrativa, ou efeito preclusivo. Formalmente, essa preclusão é da mesma natureza da coisa julgada formal, de cunho endoprocessual, presente em processos jurisdicionais.

Em razão da moralidade administrativa, "permitir que ela (a administração) pleiteie sua revisão judicial seria atentar contra o princípio da moralidade administrativa, pois implicaria autodestruição do poder que ela exercitou validamente", ${ }^{282}$ conceito reforçado pela atividade não discricionária (vinculada) exercida em determinados

\footnotetext{
${ }^{280}$ Negri, Giurisdizione e amministrazione nella tutela della concorrenza, p. 16 e 17, nota 46. A rejeição sumária de uma denuncia "non implica in alcun modo una presa di posizione della Commissione sulla legalità dei comportamenti denunciati: ciò potrebbe portare lo stesso o un altro denunciante a sottoporre in tempi diversi alla Commissione le stesse fattispecie, creando cosò una situazione di incerteza giuridica" (Leonardo Bellodi, "Le denunce", p. 118).

${ }^{281}$ Nos termos do art. 53, da lei n. 9.784/99.

${ }^{282}$ Harada, "Processo Administrativo Tributário", p. 374.
} 
processos. Para Elody Nassar, trata-se de uma expressão da autovinculação da Administração "como consequência da obrigatoriedade do ato". ${ }^{283}$

A imutabilidade está inserida ainda no princípio da segurança jurídica como pacificação dos vínculos para preservação da ordem (cf. art. $2^{\circ}$ da lei n. 9.784/99), idéia conexa com a boa-fé, pois "se o administrado teve reconhecido determinado direito com base em interpretação adotada em caráter uniforme para toda a Administração, é evidente que a sua boa-fé deve ser respeitada" e com o princípio da proteção da confiança ou a idéia de confiança legítima. ${ }^{284}$

Especificamente em relação ao processo administrativo de apuração de conduta perante o CADE, a lei n. 8.884/94 não estabelece uma regulamentação ampla de institutos imunizantes de decisões finais ou interlocutórias. Limita-se a dispor em seu art. 50, que "as decisões do CADE não comportam revisão no âmbito do Poder Executivo". Porém, em termos endoprocessuais e perante a administração pública, há imutabilidade da decisão em razão da preclusão administrativa.

Meirelles aduz que "nas decisões administrativas finais é, apenas, preclusão administrativa, ou a irretratabilidade do ato perante a própria Administração. É sua imodificabilidade na via administrativa, para estabilidade das relações entre as partes. Por isso, não atinge nem afeta situações ou direitos de terceiros, mas permanece imodificável perante a Administração e o administrado destinatário da decisão interna do Poder Público". 285

Transpondo o conceito para o processo de apuração de conduta, imaginese a prolação de decisão que reconhece a existência de um cartel e determina a condenação dos representados ao pagamento de multa. A decisão proferida pelo Plenário do CADE é a última em sede administrativa e representa a consolidação de uma situação jurídica após a última preclusão possível em sede de processo administrativo, bem como a perda da derradeira possibilidade de a parte de influir sobre o convencimento dos Conselheiros.

A partir de sua prolação e encerrados os prazos para embargos de declaração e pedido de reapreciação (o trânsito em julgado da decisão administrativa), em

\footnotetext{
${ }^{283}$ Nassar, Prescrição na administração pública, pp. 51-52 e 57.

${ }^{284}$ Di Pietro, Direito Administrativo, pp. 84/85.

${ }^{285}$ Meirelles, Direito administrativo brasileiro, p. 653.
} 
sede administrativa, a decisão é imutável. ${ }^{286}$ Caso seja instaurado novo processo perante a SDE, independentemente da parte representante, o dispositivo da decisão condenatória não poderá ser modificado se presentes as mesmas partes, a mesma causa de pedir e o mesmo pedido.

Mais interessante, porém, os casos de arquivamento do processo administrativo. Quer em razão de um manifesto propósito de simplificação do processo, de uma rejeição à jurisdicionalização do processo administrativo ou ainda de uma etapa inferior na evolução conceitual do processo administrativo antitruste, não há uma distinção profícua entre decisões de mérito ou terminativas. ${ }^{287}$ O reflexo dessa disposição é um esforço hermenêutico toda a vez que se pretende interpretar decisão de arquivamento e qual o seu reflexo perante a imutabilidade endógena administrativa.

Imagine-se uma decisão de arquivamento do processo por algum vício formal que não possa ser sanado quando do julgamento. $\mathrm{O}$ arquivamento se equipara à decisão jurisdicional de extinção do processo sem julgamento de mérito, que não é recoberta pela qualidade de coisa julgada material e que, portanto, administrativamente, pode ser objeto de reapreciação caso instaurado processo contra as mesmas partes e valendo-se do mesmo fundamento. ${ }^{288}$

Para as demais decisões de "arquivamento", não há espaço para rediscussão em sede administrativa. Imagine-se o exemplo da rejeição dos termos da nota técnica de instauração do processo (a improcedência da demanda) por ausência de provas. Trata-se de evidente descumprimento, pela SDE, do ônus de provar suas afirmações. Dadas as peculiaridades do processo perante o SBDC, seria possível inclusive a realização de diligências complementares pelo Conselheiro Relator do CADE (conforme o art. 43 da Lei n. 8.8884/93, “o Conselheiro-Relator poderá determinar a realização de diligências

\footnotetext{
${ }^{286}$ Os temas do recurso adminstrativo impróprio ou ainda do recurso hierárquico serão analisados adiante.

287 Os pressupostos de julgamento do mérito, em sede jurisdicional, são dividios em "a) presupposti processuali che attengono all'organo giudicante: la giurisdizione, la competenza, la regolare costituzione del giudice, b) pressuposti processuali che attengono all'oggetto della controversia: la cosa giudicata, la litispendenza e fenomeni assimilabili (continenza), nonché gli altri eventuali impedimenti alla decisioni di merito (ad es., patto compromissorio in arbitrato, giurisdizione condizionata); c) pressuposti processuali che attengono alle parti: la capacità, la legittimazione, interesse ad agire, la rappresentanza tecnica, la instaurazione del contradittório, la integrità del contradditorio" (Luiso, Diritto processuale civile, Milano, p. 48).

${ }^{288}$ Para Fauceglia, nada impede que uma denúncia arquivada possa ser recuperada pela superveniência de "di elementi e di fatti nuovi" (Fauceglia, "L'istruttoria dell'autorità in tema di intese restrittive della libertà di concorrenza e di abuso di posizione dominante", p. 260).
} 
complementares ou requerer novas informações, na forma do art. 35, bem como facultar à parte a produção de novas provas, quando entender insuficientes para a formação de sua convicção os elementos existentes nos autos"). Os sujeitos processuais tiveram a oportunidade de se manifestar e os órgãos do SBDC buscaram o esclarecimento dos fatos ocorridos da forma possível e admissível pelo direito. Porém, a representada foi habilidosa em incutir a dúvida, a SDE não obteve êxito na identificação de elementos suficientes para a condenação ou, de fato, a ausência de provas indicava a inexistência da infração. Nesse caso houve cognição profunda, dado relevante para a estabilização. A administração não poderá aprovar nota técnica de instauração de processo administrativo amparada nos mesmos fatos, em que deduzido o mesmo pedido, envolvendo as mesmas partes antes identificadas (tres eadem).

A idéia está na consistente premissa de que somente nos casos em que há cognição profunda exauriente, ou ao menos quando essa cognição é facultada aos sujeitos processuais ainda que não seja exercida a contento, será possível cogitar da imutabilidade decorrente da preclusão administrativa.

E se descobertos novos fatos relacionados com a mesma infração? Vale aqui uma breve digressão sobre a teoria da eficácia preclusiva e sua aplicação à hipótese.

Conforme definido pela teoria referente aos objetivos da coisa julgada, somente a parte dispositiva da sentença extraída do objeto da demanda fica coberta pela imutabilidade. Transpondo a idéia para o processo administrativo, somente o dispositivo da decisão do Plenário do CADE, que condena ou julga improcedente a demanda, seria administrativamente imutável.

Traçando um paralelo com a esfera jurisdicional, o objeto do processo é revelado à luz da pretensão deduzida pelo autor, que abrange não só o pedido como também a causa de pedir. A coisa julgada material tem reflexos perante o dispositivo e o fato constitutivo do pedido, tornando estes últimos igualmente imutáveis diante da solução dada ao julgamento, presente no dispositivo. ${ }^{289}$ É o que se extrai do art. 468, do Código de Processo Civil, ao afirmar: "a sentença, que julgar total ou parcialmente a lide, tem força de lei nos limites da lide e das questões decididas". Daí a importância da motivação não só

${ }^{289}$ Sobre o tema, confira-se o texto de Grinover, "Considerações sobre os limites objetivos e a eficácia preclusiva da coisa julgada", p. 77. V. também Barbosa Moreira, "Eficácia preclusiva da coisa julgada material no sistema do processo civil brasileiro", pp. 97-109. 
na delimitação do objeto do processo como também para os limites objetivos da coisa julgada. Se à fundamentação não se atribui imutabilidade, ao menos se lhe dá a relevância de esclarecer, determinar e compreender o alcance do dispositivo.

Do ponto de vista de Ada Pellegrini Grinover, se o pedido é compreendido à luz da causa de pedir, o dispositivo não deve ser interpretado dissociado da motivação. Essa correção determina a extensão objetiva dos efeitos da sentença e da autoridade da coisa julgada. ${ }^{290}{ }_{-}^{291}$ Nessa mesma linha, segundo Mandrioli, "il giudicato copre l'azione quale è stata concretamente esercitata sul fondamento dei fatti costitutivi allegati e di tutti quei fatti che, sia perché semplici o secundari e sia perché convergenti nel costituire un unico diritto o nel produrre il medesimo effetto giuridico, debbono intendersi implicitamente inclusi nella medesima causa petendi" ${ }^{292}$

Barbosa Moreira afirma, no mesmo sentido, que "para que a quaestio facti fique coberta pela eficácia preclusiva não é necessário, pois, que o fato seja conhecido pela parte", mas "é necessário, contudo, que já tivesse acontecido. A eficácia preclusiva não apanha os fatos supervenientes". ${ }^{293}$

Também no processo administrativo a idéia de eficácia preclusiva se apresenta clara. Os fatos pré-existentes à condenação ou à rejeição da demanda, quando efetivamente apreciado o mérito, capazes de influir sobre o convencimento do Conselheiro e que poderiam ter sido analisados no processo, consideram-se deduzidos de modo a impedir que chicanas possam atrapalhar o regular desenvolvimento do processo.

Ainda no âmbito da preclusão administrativa, há tema de absoluta relevância que merece comento. A relação entre um agente e o mercado não é algo que, por pressuposto, seja capaz de se exaurir em apenas um movimento, em uma jogada, em um fato isolado. A atuação no mercado por um agente estabelece automaticamente uma relação dinâmica e interativa com os demais sujeitos que ali atuam e que sofrem influência decorrente da participação de um novo agente (os consumidores, o Estado, os concorrentes e demais empresas que de alguma forma sofram efeitos dos atos de um determinado agente

\footnotetext{
${ }^{290}$ Grinover, "Considerações sobre os limites objetivos e a eficácia preclusiva da coisa julgada” p. 77.

${ }^{291}$ Burini, Efeitos civis da sentença penal, n. 33.1.

${ }^{292}$ Mandrioli, Diritto processuale civile, vol. I, p. 89, 99.

${ }^{293}$ Barbosa Moreira, “A eficácia preclusiva da coisa julgada no sistema processual civil brasileiro", p. 107.
} 
econômico). Quanto o Estado se propõe a fiscalizar a instituição da concorrência, ele deve compreender essa relação dinâmica no momento de aplicar o direito. ${ }^{294}$

Essa dinamicidade tem efeito direto sobre a temática da preclusão administrativa. Tornando ao importante paralelo jurisdicional, a coisa julgada tem em sua disciplina algo que lhe é inerente: a cláusula rebus sic stantibus, presente especialmente em sentenças determinativas. ${ }^{295}$ Mesmo em ramos mais "estáticos" do direito, é possível encontrar uma relação jurídica continuativa, que em matéria decisional "não se esgota com o pronunciamento da sentença, mas prossegue, apesar desta, variando, todavia, quanto aos seus pressupostos de qualidade ou quantidade (...). [A decisão] atende aos pressupostos do tempo em que foi proferida, sem, entretanto, extinguir a relação jurídica, que continua, sujeita a variações dos seus elementos constitutivos. (...) são em doutrina conhecidas por sentenças determinativas, denominação que preferimos à de sentenças dispositivas, que outros lhes dão". ${ }^{296}$ Nessa mesma linha Pontes de Miranda esclarece que essas relações têm uma eficácia que se protrai no tempo (tal como na obrigação locatícia, a obrigação de pagar alimentos, a relação tributária, por exemplo). ${ }^{297}{ }_{2} 298$

Em relações continuativas que produzam sentenças determinativas, a dinamicidade permite que fatos novos, supervenientes aos elementos que constituíram a sentença, não inseridos na causa de pedir de demanda anterior e que alterem a

\footnotetext{
294 "An antitrust regime that ignores dynamic efficiencies and innovation and focuses solely on static product market competition is unlikely to improve consumer or total welfare. A regime paralyzed by the fear of deterring innovation such that it fails to intervene in product markets where consumers are threatened by anticompetitive conduct would not fare any better. Accounting for dynamic efficiencies in antitrust analysis is consistent with current antitrust law and policy objectives and would be a desirable goal if such an accounting could be carried out in a manner that the benefits outweigh the sum of administrative and error costs". A dinâmica e a importância da inovação em determinados mercados leva inclusive ao encorajamento de um "approach that would focus on future product market competition by examining current research and development efforts as a proxy for the future competition itself" (Wright, "Antitrust, Multi-Dimensional Competition, and Innovation: Do We Have an Antitrust-Relevant Theory of Competition Now?" pp. 4 e 14).

${ }^{295}$ Marques, Comentários ao Código de Processo Civil, vol. IV, pp. 483/484, Amaral Santos, Comentários ao Código de Processo Civil, vol. III, p. 588/590. A cláusula não se confunde com a eficácia preclusiva da coisa julgada prevista no art. 474 do mesmo diploma (Dinamarco, Fundamentos do Processo Civil Moderno, vol. II, p. 1044-48). Para Grinover "o que a coisa julgada torna imutável é o efeito da sentença (ou seja, a declaração ou a modificação), e não a relação jurídica sobre a qual o efeito incide; relação, esta, sobre a qual as partes podem conservar sua liberdade de disposição e que o juiz pode diversamente declarar, desde que a mesma relação tenha sofrido modificações sucessivas à precedente sentença (rebus sic stantibus)" (Eficácia e autoridade da sentença penal, São Paulo, RT, 1978. pp. 3-4).

${ }^{296}$ Amaral Santos, Comentários ao Código de Processo Civil, vol. IV, p. 483.

${ }^{297}$ Comentários ao Código de Processo Civil, t. V, Rio de Janeiro, Forense, 1974, p. 193.

298 Aqui o paralelo é feito com o processo civil, ciente de uma maior aproximação da preclusão administrativa com a coisa julgada civil que com a coisa julgada penal. A menor intensidade da última e a ampla revisibilidade de decisões contrárias ao indivíduo (v. esp. CPP, art. 621, inc. I) não se coadunam com preceitos de segurança jurídica estabelecidos para as relações concorrenciais.
} 
conformação anterior do pedido, modifiquem a situação concreta que impôs a condenação e permitam a revisão de uma sentença sem que se fira a coisa julgada, nos termos do art. 471, do CPC.

No direito antitruste, relações jurídicas continuativas e decisões determinativas se comunicam com maior facilidade, especialmente se compreendida a dinâmica do mercado em determinados setores. Alterações relevantes do desenho concorrencial se dão em velocidade considerável em alguns mercados, v.g., que envolvem tecnologia, e não podem ser descartados fatos novos que alterem uma determinada relação concorrencial em espaço curto de tempo. Para essas situações, dada a relação continuativa existente entre agente-mercado-consumidor, é sustentável afirmar que no antitruste a cláusula rebus sic stantibus inerente ao instrumento de imutabilidade se faz presente com maior intensidade.

A utilidade dessa constatação? Certamente sua intensidade é menor que aquela sentida jurisdicionalmente. Em caso de condenação de determinado agente por conduta anticoncorrencial, não existem no sistema processual administrativo instrumentos de revisão de decisões transitadas em julgado - não há um procedimento revisional endógeno. $\mathrm{O}$ argumento poderá apenas reforçar considerações em eventual demanda jurisdicional. Já nos casos em que o processo é arquivado, o argumento se volta a favor do SBDC, que poderá superar as limitações da preclusão administrativa para instaurar novo processo administrativo amparado em fatos novos, sem que se esbarre no óbice da preclusão administrativa.

Prosseguindo, como foi dito acima, a concepção dos tres eadem também tem sua aplicabilidade no processo administrativo, mas algumas ponderações merecem destaque. Dadas as suas particularidades, o pólo ativo é de menor relevância, na medida em que, conforme será visto adiante, a legitimidade ativa será sempre da SDE como protetora da instituição da concorrência e o representante é sempre um terceiro no processo, cuja atuação poderá ser qualificada como de assistente (antecipando a discussão do item VI.2.4).

A premissa jurisdicional em relação ao assistente é a de que se ele tem o interesse e efetivamente participa do processo de apuração de conduta, deve "se submeter" às decisões ali prolatadas. Essa submissão envolve não só os efeitos, como também a 
possibilidade de questionamentos futuros. ${ }^{299} \mathrm{O}$ art. 55 do CPC estabelece que o assistente que interveio no processo não pode questionar a "justiça da decisão" transitada em julgado. Considerando que em esfera jurisdicional o assistente não é afetado pelo dispositivo, sua vinculação está adstrita à fundamentação da decisão - o que por óbvio afastaria a natureza de "coisa julgada" a essa imutabilidade. Poderia ser dito que essa imutabilidade decorreria de uma eficácia preclusiva heterodoxa, porque a indiscutibilidade dos fundamentos não funcionaria como um alicerce do dispositivo. ${ }^{300}$

Porém, é preciso deixar claro que existe uma diferença substancial entre o papel do representante no processo administrativo, do assistente civil e do assistente da acusação penal. $\mathrm{O}$ assistente civil tem amplo acesso às informações do processo e, a despeito de receber o processo na fase em que se encontra, exerce "os mesmos poderes e sujeitar-se-á aos mesmos ônus processuais que o assistido" (CPC, art. 52). O assistente da acusação também ostenta amplos poderes (CPP, art. 271).

No processo administrativo de apuração de conduta o representante sofre, de plano, restrições à sua participação no processo decorrente da própria natureza do direito material. Ele não terá acesso a todas as informações dos autos, porque muitas delas são tratadas pela confidencialidade. Não fosse isso, os dispositivos de natureza processual antitruste não garantem sua efetiva participação, mas permitem sua atuação no processo, sujeita ao controle dos órgãos do SBDC (Regimento interno do CADE, art. 36: "a prática de atos processuais por terceiro interessado será excepcional e limitar-se-á às hipóteses em que o CADE julgar oportuna e/ou conveniente para a instrução processual e defesa dos interesses da coletividade"). Logo, se o terceiro participa ma non troppo do processo, não seria razoável impor-lhe a imutabilidade da decisão quando lhe for obstada a participação no processo. ${ }^{301}$

\footnotetext{
${ }^{299}$ Chiovenda, Instituições de direito processual civil, v. II, p. 286.

${ }^{300}$ Dinamarco afirma que "em sua projeção sobre quem não é parte principal no processo, ou seja, sobre quem intervém ad coadjuvandum, essa preclusão causada pela própria coisa julgada é o que se chama de Interventionswirkung (eficácia da intervenção). Tal é o impedimento de rediscutir a justiça da decisão, imposto pelo art. 55, do Código de Processo Civil brasileiro ao assistente. Trata-se, como se vê, de situação que tangencia a coisa julgada e seus limites subjetivos mas que com ela não se confunde" (Intervenção de terceiros, p. 36). Para José Roberto dos Santos Bedaque, o assistente está sujeito aos efeitos da coisa julgada (com relação à parte dispositiva) e à eficácia preclusiva da coisa julgada com relação aos fundamentos do julgado (Bedaque, Código de Processo Civil interpretado, p. 163).

${ }^{301}$ Luiso afirma que "il principio del contraddittorio è quindi la prima e fondamentale regola che governa il problema dei limiti soggettivi di efficacia della sentenza. In via tendenziale ogni estensione soggettiva dell'efficacia della sentenza urta contro il principio del contraddittorio. Infatti, vincolare al contenuto di un
} 
Caso uma representação seja arquivada $a b$ initio ou dê ensejo a uma averiguação preliminar também arquivada, o representante não fica impedido de reapresentá-la, muito embora seja sempre recomendável, em homenagem à boa-fé, o saneamento dos fatos que ensejaram referido arquivamento. Quando a representação dá ensejo a um processo administrativo, será preciso averiguar inicialmente se todas as faculdades processuais que o representante pretendeu exercer lhe foram concretamente outorgadas e se ele teve acesso a todas as informações que serviram como fundamento da decisão. Em caso positivo, é possível dizer que ele está administrativamente vinculado à justiça da decisão. Caso contrário, não. Mas é preciso fazer apenas uma ressalva: essa vinculação será útil somente na hipótese de uma tentativa de representação que apresente os mesmos fatos e fundamentos já afastados pelo CADE, sem impedir, contudo, a investigação do fato perante o Poder Judiciário.

\section{VI.1.2. Idoneidade do meio pacificador: perspectiva estrutural}

Pela perspectiva instrumentalista, a imutabilidade de uma decisão está profundamente relacionada com a idoneidade do meio e sua capacidade de pacificação social, pois “existe a predisposição a aceitar decisões desfavoráveis na medida em que cada um, tendo oportunidade de participar na preparação da decisão e influir no seu teor mediante observância do procedimento adequado (princípio do contraditório, legitimação pelo procedimento), confia na idoneidade do sistema em si mesmo". 302 _ 303

Para o exame da idoneidade do sistema é preciso retornar à temática da função administrativa judicante. Já foi descrito que essa função está presente em todas as expressões de Poder do Estado e que tal função não representa qualquer novidade sistêmica. O ponto que se põe é indagar se o sistema, tal qual se apresenta no Brasil, oferece segurança de realização de justiça: coloca-se em perspectiva a estrutura do SBDC, sua conformação em razão de sua "vinculação" com o Poder Eexecutivo, passível de

provvedimento giurisdizionale un soggetto che non ha avuto modo di difendersi, costituisce la massima violazione del principio del contraddittorio" (Luiso, Diritto processuale civile, p. 156).

302 Dinamarco, A instrumentalidade do processo, p. 196.

303 Garofoli, em concepção estritamente processual, explica em termos processuais adminstrativos exatamente a idéia de legitimação pelo procedimento quando se utiliza de aspectos processuais para justificar a imparcialidade, neutralidade e equidistância da autoridade: a natureza contenciosa do processo de apuração de conduta, a previsão expresa da observância do contraditório, a determinação de pleno conhecimento às partes dos atos instrutórios ("Procedimento, accesso e autorità indipendenti", p. 3347 e ss). 
causar suposta contaminação por valores não-jurídicos capazes de macular a legitimidade decisória do CADE, criando um risco sistêmico para a satisfação do indivíduo.

De um lado, há quem afirme que as agências reguladoras independentes fortalecem o Estado de direito excluindo da política a regulação de atividades sociais e econômicas relevantes, produzindo segurança jurídica e proteção do empreendedorismo. ${ }^{304}$ De outro, pressupõe-se que o mister de interpretar a norma e revelar juízos axiológicos compete aos juízes, mas também à doutrina, aos órgãos administrativos e à lei. Porém, "uma das principais características da função jurisdicional é a independência com que o juiz a exerce". ${ }^{305}$ Indaga-se se é possível compatibilizar a proposta de segurança jurídica por meio de um exame crítico do órgão.

A suspeição sistêmica e estrutural sugerida permite a análise da idoneidade do meio por algumas facetas: independência, autonomia, liberdade, imparcialidade são premissas que, se observadas, reforçam a legitimidade constitucional da função administrativa judicante e a segurança jurídica que ela proporciona. Caso contrário, é relevante identificar pontos de questionamento.

De qualquer forma, a discussão sobre a independência da autoridade, como visto, já foi travada acima, concluindo-se pela legitimidade constitucional de sua instituição - o que, de per si, não assegura a legitimidade relacionada com o escopo social, aqui debatida, o que justifica o prosseguimento da discussão.

Essa suspeição sistêmica não é assunto novo. Celso Campilongo exConselheiro do CADE, já examinou o tema com apuro e afirmou que dizer o direito, judicial ou administrativamente, é ato de direção política (indirizzo politico), em esferas autônomas e neutras em relação ao governo. Reconhece no CADE um órgão técnico, independente, inserido em modelo de Estado que o admite, outorgando-lhe paridade substancial em relação aos demais órgãos do Poder Político. O poder parajurisdicional sancionador seria absolutamente incompatível com a idéia de submissão ao Poder Político e ao Governo. Mais adiante, afirma a existência apenas de uma relação horizontal perante os órgãos políticos, imunuzado contra ingerências do Governo. Não há nem relação de tutela e, muito menos, de orientação do Governo ao CADE, tratando-se de órgão com

\footnotetext{
${ }^{304}$ Aragão, “As agências reguladoras independentes e a separação de poderes - uma contribuição da teoria dos ordenamentos setoriais", RT 786/32.

${ }^{305}$ Dinamarco, A instrumentalidade do processo, p. 48-49.
} 
“independência organizativa e funcional". Esse tribunal administrativo reúne mecanismos para proteger seus Conselheiros de interferências externas ("notório saber, ilibada reputação, nomeação pelo Presidente da República, aprovação pelo Senado, regime de incompatibilidades e garantias do mandato). Afirma que "a sujeição do Conselho, evidentemente, só se dá em relação à Lei, nunca ao poder hierárquico e diretivo da autoridade de governo". 306

De forma semelhante a Taruffo, Campilongo reconhece o contexto social no qual está inserido um operador do direito, com valores políticos, origens sociais, formação e hábitos profissionais que influenciam sua atuação, mas afirma também que as estruturas de direito se não neutralizam as cargas ideológicas de uma decisão, precisam formas, procedimentos e funções. ${ }^{307}$

Se a estrutura é histórica, comparativamente e concretamente independente, conforme visto no item (III.3) resta então prosseguir no exame daquele "membro da sociedade em que vive e participa do seu acervo cultural e dos problemas que a envolvem, advindo daí as escolhas que, através dele, a própria sociedade vem a fazer no processo" 308 - o julgador.

\section{VI.1.3. Imparcialidade}

Em termos gerais e valendo-se da comparação com o Poder Judiciário, para Mandrioli, a atividade jurisdicional se distingue da atividade administrativa porque esta se desenvolve a partir de normas abstratas em relação a casos específicos, porém é desenvolvida pelo Estado em posição não imparcial, "perchè, dal punto di vista funzionale,

\footnotetext{
${ }^{306}$ Voto vista no Ato de Concentração n. ${ }^{\circ}$ 08012.006762/2000-09. Nesse sentido, o Guia Prático do CADE aduz que "o CADE é formado por um plenário composto por um presidente e seis conselheiros, indicados pelo Presidente da República, sabatinados e aprovados pelo Senado Federal, para um mandato de dois anos (havendo a possibilidade de uma única recondução, por igual período) e, portanto, só podem ser destituídos em condições muito especiais. Esta regra confere autonomia aos membros do Plenário do CADE, o que é fundamental para assegurar a tutela dos direitos difusos da concorrência de forma técnica a imparcial" (Conselho Administrativo de Defesa Econômica - CADE, Guia prático do CADE: a defesa da concorrência no Brasil, p. 17).

${ }^{307}$ Campilongo, Política, sistema jurídico e decisão judicial, pp. 182 e ss. O mesmo autor afirma o risco de se corromper códigos que, no caso, resultariam na irrestrita invasão do Poder Judiciário sobre o âmbito da política.

${ }^{308}$ Dinamarco, A instrumentalidade do processo, p. 42.
} 
è orientata ad attuare gli interesse dello Stato stesso (o dei suddetti altri enti), ossia dalla buona amministrazione". ${ }^{309}$ Bellodi, com base em precedentes da Comissão Européia, afirma no mesmo sentido que o tratamento diligente e imparcial de denúncias é expressão do direito a uma boa-administração (referindo-se à Carta de Direitos Fundamentais, que propõe que todo indivíduo tem direito a que questões que lhe digam respeito sejam resolvidas de modo imparcial, equo e em prazo razoável pelas instituições e órgãos da União Européia) e da obrigação de vigilância prevista pelo tratado. ${ }^{310}$

Um primeiro ponto precisa ser reafirmado: a discussão entre o que é político e o que é jurídico já foi travada no item IV supra, com a conclusão de que, em linhas gerais, ambas as formas de exercício de poder se comunicam sem que isso reflita em prejuízos de atuação. ${ }^{311}$ Aqui, pretende-se aprofundar um pouco mais no estudo do tema, sob aspectos mais subjetivos. É que o julgamento dos processos de apuração de conduta é a expressão máxima dos interesses almejados na atuação do CADE. O ponto é identificar se existe interferência externa ao posicionamento subjetivo do julgador, que afete a sua imparcialidade e conflite com os princípios processuais estabelecidos constitucional e infraconstitucionalmente.

O tribunal administrativo, por seus Conselheiros, está sujeito a princípios constitucionais que balizam sua atividade ( $\mathrm{CF}$, art. 37$)$ no oferecimento da tutela no direito antitruste. $^{312} \mathrm{O}$ princípio da legalidade $\left(\mathrm{CF}\right.$, art. $5^{\circ}$, inc. II), corolário do princípio da igualdade $\left(\mathrm{CF}\right.$, art. $5^{\circ}$, caput) demonstra que "a procura pela realização efectiva do direito administrativo deve ser feita em conjunto dado que tanto a função administrativa como a jurisdicional são actividades subordinadas à lei”. ${ }^{313}$

\footnotetext{
${ }^{309}$ Mandrioli, Diritto processuale civile, vol. I, p. 35.

${ }^{310}$ Bellodi, "Le denunce", p. 87 e ss.

311 "Imparcialidade não significa indiferença axiológica; 'isenção do magistrado não significa insensibilidade' (...) ele (o juiz) é um instrumento, sim, mas não a serviço exclusivamente do direito substancial; sua missão mais elevada é a que tem perante a sociedade, para a pacificação segundo critérios vigentes de justiça e para a estabilidade das instituições" (Dinamarco, A instrumentalidade do processo, p. 42).

${ }^{312}$ Conforme Canotilho, os princípios “têm uma 'função normogenética' e uma 'função sistêmica', são os fundamentos de regras jurídicas e têm uma idoneidade irradiante que lhes permite ligar ou cimentar objetivamente todo o sistema constitucional" (Direito constitucional, p. 169). E "mais até que o legislador, o administrador público e o juiz - por não serem senhores, mas servidores da lei - estão intensamente subordinados à Constituição, inclusive a seus magnos princípios" (Carraza, Princípios constitucionais tributários e competência tributária, p. 96).

${ }^{313}$ Fonseca, Introdução ao estudo sistemático da tutela cautelar no processo administrativo, p. 308.
} 
Também o princípio da impessoalidade impõe uma valoração objetiva alheia ao interesse político, o que por definição, afasta (ou procura afastar) influências ilegítimas sobre os julgamentos dos Conselheiros do CADE. O mesmo se extrai do princípio da moralidade, que seria abalado quando um julgamento contrariasse "o senso comum de honestidade, retidão, equilíbrio, justiça, respeito à dignidade do ser humano, à boa-fé, ao trabalho, à ética das instituições". ${ }^{314}$ Atrela-se ainda o princípio da eficiência, que impõe "a persecução do bem comum, por meio do exercício de suas competências de forma imparcial, neutra, transparente, participativa, eficaz, sem burocracia e sempre em busca da qualidade, primando pela adoção de critérios legais e morais necessários para a melhor utilização possível dos recursos públicos, de maneira a evitar-se desperdícios e garantir-se maior rentabilidade social". ${ }^{315}$ A idéia de imparcialidade é ainda reforçada pelos rigores da lei de improbidade administrativa. ${ }^{316}$

Os membros do SBDC também estão sujeitos ao Decreto n. 1.171/94, que institui o Código de Ética do Servidor Público Civil do Poder Executivo Federal. Além disso, o CADE, pela Resolução n. 16/98, estabelece o Código de Ética dos Servidores do CADE. ${ }^{317-318}$ Mas a questão requer aprofundamentos.

\footnotetext{
${ }^{314}$ Di Pietro, Discricionariedade administrativa na Constituição de 1988, p. 111.

${ }^{315}$ Moraes, Direito constitucional, p. 294.

${ }^{316}$ Que estabelece severo regime de controle de atos administrativos que impliquem enriquecimento ilícito, vantagem patrimonial indevida, lesão ao erário por ação ou omissão, dolosa ou culposa, que enseje perda patrimonial, desvio, apropriação, malbaratamento ou dilapidação dos bens públicos e agressão aos princípios da administração pública por ação ou omissão que viole os deveres de honestidade, imparcialidade, legalidade, e lealdade às instituições.

317 Os italianos também criaram um Código de Ética contendo diretivas para o desenvolvimento da tutela da concorrência, considerando a especial natureza da AGCM e a relação entre o público e o privado e a necessidade de preservação da autonomia, diligência, lealdade, confiança e imparcialidade da Autoridade e de seus prepostos. Esse Código aplica-se a todos aqueles vinculados à agência (por indicação, contrato de trabalho, por serem consultores etc.), determinando que o agente "opera con imparzialità, evita trattamenti di favore, respinge pressioni indebite ed assume le proprie decisioni nella massima trasparenza, evitando di creare o di fruire di situazioni di privilegio". Nesse mister, os agentes (a) não devem utilizar informações obtidas para fins privados, (b) não devem passar informações a terceiros, (c) não emanam opiniões pessoais sobre questões submetidas à Autoridade, (d) não participam de encontros informais com sujeitos interessados em questões em exame, exceto por autorização expressa e com a ciência aos interessados, (e) devem comparecer em encontros formais sempre acompanhados de outro agente, (f) não devem freqüentar organismos dos quais possa decorrer obrigação ou vínculo que possa interferir em sua função, (g) não devem atuar em situações de conflito de interesse, inclusive aparente, por si, por cônjuge ou por parentes em até quarto grau - fala-se ainda em situações de desconfiança ou de graves razões de conveniência -, informando o fato ao responsável, (h) não divulgam informações protegidas por sigilo, (i) não dão ou solicitam declarações públicas que possam incidir sobre a imagem da autoridade e se desejam publicar algo, devem solicitar autorização ao Secretário Geral, (j) não aceitam presentes, devendo devolvê-los em procedimento formal - exceto aqueles de valor módico, (k) não aceitam dinheiro em espécie para participação de convenções e seminários e a eventual participação nesses deve ser institucionalmente qualificada, restrita aos aspectos técnicos ou cietíficos de interesse da atividade antitruste, (l) não desenvolvem atividades que contrastam com aquela da Autoridade, (m) não podem realizar operações financeiras com empresas parte em
} 
Alguns pontos são separados para o exame mais aprofundado da imparcialidade: (i) preservação do princípio da demanda, (ii) na preservação do princípio dispositivo, (iii) na idoneidade do recrutamento dos juízes e (iii) nas garantias que cercam a atividade. ${ }^{319}$

\section{VI.1.4. Imparcialidade e o princípio da demanda}

O princípio da demanda, também chamado de inércia judicial, assenta que a jurisdição não pode ser exercida sem a provocação de alguém distinto do juiz, como medida, para além da preservação da imparcialidade, de um repúdio histórico ao juizprocurador. Refuta-se o enviesamento lógico de que quem propõe a hipótese, tende naturalmente a vê-la confirmada (ou buscar sua confirmação) após a instrução probatória. No processo jurisdicional, essa regra é mitigada em raríssimas situações pela atuação $e x$ officio de magistrados em casos de sobrelevação da ordem pública: são algumas concessões de habeas corpus, as medidas cautelares (e às vezes até mesmo as antecipatórias), convolações em falência e instaurações de inventário.

Mandrioli dá destaque ao princípio da disponibilidade da tutela jurisdicional, porém fazendo referência ao fato de que essa disponibilidade está atrelada àquela do direito substancial e ao princípio da demanda. ${ }^{320}{ }_{-}^{321}$

procedimento, (n) na vida social, não se vale da sua posição da agência para obter benefícios, não dá declarações ou deixa transparecer opiniões sem que haja uma necessidade objetiva para tanto, não mantém relações que possam comprometer sua independência.

${ }^{318}$ Para efeitos comparativos, o Code of Conduct for United State Judges estabelece 7 Cânones: 1 - "A judge should uphold integrity and independence of the Jduciary"; 2 - "A Judge should avoid impropierty and the appearance of improprierty in all activities"; 3 - "A Judge should perform the duties of the office impartially and diligently"; 4 - "A judge may engage in extra-judicial activities to improve the law, the legal system and the administration of Justice"; 5 - "A Judge should regulate extra-judicial activities to minimize the risk of conflict with judicial duties"; 6 - "A Judge should regularly file reports of compensation received for lawrelatade and extra-judicial activities"; 7 - "A judge should refrain from political activity".

${ }^{319}$ Dinamarco, A instrumentalidade do processo, p. 200.

${ }^{320}$ Mandrioli, Diritto processuale civile, vol. I, p. 91.

321 Díficil negar essa premissa. Apenas por homenagem ao debate, Negri se refere à Grasso, que traz hipóteses de atuação de ofício na jurisdição italiana para afirmar que tais exceções são "suficientes para negar que o princípio da demanda seja ligado umbilicalmente ao processo e ao ato decisório, sendo certo somente que o princípio prevaleceu até agora na historicidade dos ordenamentos jurídicos”. Tais exceções encontramse na lei falimentar italiana (especialmente a iniciativa cautelar do art. 146 da Lei de Falências) e foram admitidas sob o argumento da existência de um contraditório diferido (Negri, Giurisdizione $e$ amministrazione nella tutela della concorrenza, pp. 6-8). 
No processo administrativo, porém, prevalece o princípio da oficialidade, nos termos da lei n. 9.784/99, art. $2^{\circ}$, par. ún., inc. XII, que autoriza a administração a não só decidir e impulsionar o processo, como também dar início, provocar o próprio funcionamento, instaurá-lo de ofício ${ }^{322}{ }_{-}^{323}$ em razão dos interesses públicos envolvidos, afastando-se a provocação de particulares.

Essa dualidade provoca reflexões. Não é novidade que o processo judicial encontra paralelo relevante nas tutelas de interesses transindividuais, pertencentes à segunda onda renovatória mencionada na obra de Cappeletti-Garth, na perspectiva de massificação de tutelas e superação da concepção individualista e atômica do processo ocorrida em meados de sessenta. ${ }^{324}$

No Brasil, o principal veículo seria a ação civil pública, cuja legitimidade é atribuída a sujeitos determinados pelo art. $5^{\circ}$, da Lei n. 7.347/85. Discute-se sobre a natureza dessa legitimidade. ${ }^{325}$ Quem afirma ser ela ordinária, alega que "o membro do Ministério Público atua por força de lei e de suas funções, mas, além disso a legitimação lhe é própria, eis que a lide não diz respeito à somatória dos direitos individuais, mas aos direitos difusos, coletivos propriamente ditos e individuais homogêneos, pelo que se denomina essa legitimação de autônoma". ${ }^{326}$ Quem contraria essa posição, afirmando uma legitimidade extraordinária (substituição processual), sustenta que "o interesse poderá pertencer a pessoas determinadas ou indetermináveis, mas sempre pertencerá a terceiros que não fazem parte da relação processual". ${ }^{327}$ No processo penal, a legitimidade ativa é

\footnotetext{
322 “O princípio da oficialidade autoriza a Administração Pública a requerer diligências, investigar fatos de que toma conhecimento no curso do processo, solicitar pareceres, laudos, informações, rever os próprios atos e praticar tudo o que for necessário à consecução do interesse público" (Direito Administrativo, pp. 400-402). ${ }^{323}$ Existem, de fato, hipóteses em que a própria SDE pode, de ofício, propor demanda de investigação de conduta e instauração de processo, tal como no caso do chamado cartel das britas (proc. n. 08012.002127/2002-14) - demanda foi originada a partir de denúncia anônima de cartelização por parte de 17 empresas de São Paulo; do caso do Porto de Santos THC2 (proc. n. 08012.007443/1999-17); do caso Microsoft TBA (proc. n. 08012.008024/1998-49) - demanda originada de uma notícia do Jornal O Globo.

${ }^{324}$ Capelletti-Garth, Acesso à justiça, pp. 49-50.

${ }^{325}$ Legitimidade ativa é tratada perante a esfera jurisdicional como condição da ação, como a hipotética possibilidade de acolhimento sob aspecto subjetivo, investigando-se (pela negação) "se il diritto afermato nella domanda stessa non è affermatto come diritto di colui che propone la domanda e contro colui nei cui confronti si propone la domanda", em um conceito individualista que decorre fundamentalmente de escolha de política legislativa em atribui-se aos indivíduos a disponibilidade esclusiva de seus direitos, do requerimento de tutela jurisdicional e dos instrumentos técnicos para o seu exercício. Porém, também por opção de política legislativa, é possível fazer valer em nome próprio direito de terceiros, exatamente nos casos de legitimação extraordinária e substituição processual (Mandrioli, Diritto processuale civile, vol. I, p. 55).

${ }^{326}$ Thereza Alvim, $O$ direito processual de estar em juízo, p. 84.

${ }^{327}$ Pedro Dinamarco, Ação civil Pública, p. 204.
} 
outorgada "ao Estado-Administração, único titular do jus puniendi; só ele tem legitimatio ad causam". 328

A teoria da legitimidade extraordinária parece ter maior aceitação em concepção técnica e histórica, oriunda de um posicionamento coerente não só com as origens individualistas do processo civil, mas também com o enfoque dado ao direito material tutelado. Porém, é inegável que a partir de um direito concorrencial que se correlaciona, mas se destaca dos direitos individuais reflexamente tutelados, é adequado reconhecer a legitimidade ordinária de tutela de direitos de segunda geração, econômicos - e mais do que isso - concorrenciais, nos quais o Estado intervém para proteção não do indivíduo, mas para recuperar e proteger um interesse institucional de forma a fortalecer o papel político do órgão que prolata o comando.

O próximo passo seria identificar quem exerce essa atividade. Como já visto, o SBDC tem uma estrutura bastante particular, composta por uma autarquia autônoma vinculada ao Ministério da Justiça (CADE), uma Secretaria desse mesmo Ministério (SDE) e uma Secretaria pertencente ao Ministério da Fazenda (SEAE). O processo administrativo é instruído perante a SDE e remetido ao CADE para julgamento. Sobre a provocação, é fato que qualquer do povo, pessoa física ou jurídica, de direito privado ou público, pode oferecer representação perante os órgãos do SBDC, encaminhada à instrução ao SDE. E também os próprios órgãos do SBDC também podem, em homenagem ao princípio da oficialidade, requerer a instauração desses processos.

As representações feitas pela SDE e pela SEAE são consideradas de ofício porque como órgãos pertencentes ao SBDC são vinculados às pastas do Poder Executivo e, portanto, à Administração pública. Em atenção à oficialidade, ambas tem o dever de proteção do interesse público, instaurando processo administrativo quando diante de infração concorrencial. A SEAE tem papel menos intenso no processo administrativo em questão, de cunho opinativo; porém a SDE é responsável pela verificação de

\footnotetext{
${ }^{328}$ Essa legitimação é tratada como ordinária. A exceção ocorre justamente quando "a lei eventualmente outorga o direito de exercer a ação ao ofendido na ação privada, ao determinar que a ação penal é publica 'salvo quando a lei expressamente a declara privativa do ofendido'. Ocorre na hipótese o que se denomina legitimação extraordinária, ou substituição processual, em que a lei autoriza a alguém a propor a ação em nome próprio na defesa de interesse alheio, no caso o Estado" (Julio Fabbrini Mirabete, Processo penal, p. 106).
} 
pressupostos de admissibilidade do processo, instrução, ${ }^{329}$ fixação de medidas liminares, e elaboração de parecer final não vinculante, que será apreciado pelo CADE. Sua atuação é determinante não só como órgão instrutor como também, em graus acessórios, um garantidor primário da concorrência quando diante de um processo administrativo de apuração de conduta anticoncorrencial. ${ }^{330}$

O primeiro problema está no fato de que, estruturalmente, a mesma administração que instaura o processo é a administração que julga, maculando o princípio da demanda e a própria legitimação - em sentido processual - do processo administrativo de conduta como instrumento de pacificação social em razão de vício no que diz respeito à imparcialidade. ${ }^{331}$

Essa é uma construção teórica, que empiricamente comporta temperamentos. Não se pode negar que a estrutura do SBDC separa a SDE-instrutora do CADE-julgador. O CADE é uma autarquia autônoma, e não uma secretaria do Ministério da Justiça, o que lhe garantiria alguma imunidade à possível contaminação de interesses expressos pela SDE; entre a presidência do CADE, seus respectivos Conselheiros e o Secretário de Direito Econômico do Ministério da Justiça e suas diretorias (em especial a do Departamento de Proteção e Defesa Econômica), não existe liame condicionante ou vinculativo de ordem processual; tampouco há convivência física, considerando que atualmente o CADE situa-se em prédio autônomo, afastado do Ministério da Justiça.

Se em termos físicos a distância os separa (pouco menos de três quilômetros) e se considerarmos os órgãos como pertencentes ao Poder Executivo, é preciso reconhecer que, ao menos, há algo como uma chinese wall que os divide: é aquela barreira não física, mas ético-jurídica, criada para evitar o vazamento de informações estratégicas de insiders que possam influenciar condutas. Juridicamente não há

\footnotetext{
329 Anote-se, com especial atenção, o art. 16, da Portaria MJ n. 4/06, que estabelece que "os legitimados poderão requerer qualquer providência ou diligência, que será realizada, ou não, a juízo da Secretaria de Direito Econômico".

${ }^{330}$ Essas mesmas considerações são válidas para a ANATEL.

331 Sobre o tema, Sundfeld sustenta apenas que "alguns tipos específicos de processos (procedimentos) administrativos vêm sendo bem desenvolvidos pela legislação, permitindo a subseqüente elaboração teórica quanto às condições para sua instauração; como exemplo, mencionem-se os processos de competência do Conselho Administrativo de Defesa Econômica" (Sundfeld, "Processo e procedimento administrativo no Brasil”, p. 32). Com a devida vênia, a explicação não esgota a problemática desenvolvida neste capítulo.
} 
condicionamentos entre a atividade da SDE e do CADE, sendo o último livre para refutar as conclusões exaradas pela primeira quando do encerramento da instrução. ${ }^{332-333}$

Mas ainda assim teríamos outros dois problemas de resolução mais complexa. Um deles está no fato de que a mesma SDE que instaura o procedimento administrativo dita suas fases e as providências que devem ser tomadas até que seja completada a instrução: ela analisa a admissibilidade das representações, conduz a instrução probatória (indeferindo provas - v. esp. art. 53, par. $1^{\circ}$, da Portaria n. 4 do Ministério da Justiça, realizando as oitivas, determinando as perguntas), define tempestividade ou intempestividade de manifestações, bem como a confidencialidade no tratamento das informações prestadas pelas partes. Sua ingerência é determinante se não para o resultado do processo, ao menos para a existência e qualidade do material probatório acostado aos autos. ${ }^{334}$

Representante e representada dispõem de instrumento endo e extraprocessuais para influir qualitativamente sobre o material colhido em instrução. Dispõem, por exemplo, de recurso voluntário em medida preventiva (v. arts. 118-123, do Regimento Interno do CADE) ou até mesmo do mandado de segurança impetrado perante órgãos jurisdicionais. Mas o representante não é uma parte ordinária tal qual o autor no processo jurisdicional, que mantém eqüidistância do órgão julgador ainda que em hipóteses

\footnotetext{
${ }^{332}$ Na Itália, a AGCM é una, composta pelo órgão decisório, um secretário geral e diversos "uffici" (instrução e investigação, protocolo, circulação de documentos econômicos, jurídicos e normativo, biblioteca, administração e formação de pessoal, jurídico consultivo). O secretário geral é o superintendente das atividades instrutórias, da gestão de despesas, representação externa da autoridade, execução das deliberações da autoridade. É nomeado por ministro do executivo após proposta do Presidente da AGCM (sistema que se assemelha àquele da FTC). Há a "separazione tra funzioni prosecutorial e quasi-judicial (...) Solo nel 1995 si è provveduto distinguere e coordinare, in seno all'Autorità, le figure del responsabile del procedimento, colocatto all'interno delle Direzione Istruttorie, e del relatore interno al collegio (artt. 23-25, regolamento sull'organizzazione ed il funzionamento dell'Autorità del 1995). O Cons. Stato já afirmou que não influi sobre a validade do provimento a participação dos funcionários da Autoridade Concorrencial no processo. Mas a experiência francesa induz o contrário, existindo decisão recente no sentido de que os funcionários encarregados da fase instrutória não devem participar do colégio encarregado do julgamento (Benedetto, L'Autorità garante della concorrenza e del mercato, p. 224).

${ }^{333}$ A mesma mão que dá, também tira. Para Mandrioli, "l'istruzione e la decisione sono attività talmente coordinate l'una all'altra, e talmente interdipendenti, che non è possibile concepire un processo veramente e modernamente concentrato ed immediato nem quale codeste attività non siano svolte dal medesimo organo; mentre viceversa l'attribuizione di tali attività a due organi totalmente distinti non soltanto rallenta il processo e gli attribuisce la pesantezza che fatalmente consegue alla trasposizione sulla carta delle esperienze dell'instruzione, ma compromete la stessa bontà intrinseca del giudizio" (Diritto processuale civile, vol. II, p. 67). Franceschini defende, em artigo publicado em 1998, que a dicotomia CADE-SDE seria inconstitucional em razão de violação dos princípios do juiz natural, do devido processo legal e da ampla defesa. Afirma que não se poderia retirar do julgador os poderes de controle do processo e a capacidade da busca da verdade real, sob pena de suprimiri a unidade teleológica do processo. O julgador que não participa da colheita da prova ("Roteiro do processo penal-econômico na legislação de concorrência", pp. 17).

${ }^{334}$ Negri, Giurisdizione e amministrazione nella tutela della concorrenza, pp. 26 e 27, nota 81.
} 
de legitimação extraordinária. Tampouco a SDE afigura-se como simples parte no processo: ela tem o condão de influir mediante determinação de condutas e seleção de material probatório que será acostado ao processo. Tal fato macula, em termos jurídicoempíricos, o resultado do material probatório, e influi enviezadamente sobre o resultado do processo.

A forma de minimizar os efeitos, de lege lata, está na já mencionada separação e independência do órgão julgador em relação à SDE, da produção por essa de resultado meramente opinativo e não vinculativo perante o $\mathrm{CADE}$, reforçado ainda pela possibilidade do Conselho realizar diligências suplementares caso, por provocação ou valendo-se de positiva atuação inquisitiva. Porém, em termos instrumentais, a tensão deriva da proximidade (em processo administrativo, identidade) da SDE com um dos pólos da demanda e sua ingerência sobre o resultado probatório acquisto ao processo faz com que se questione a efetividade do contraditório, do direito à prova e a própria parcialidade do julgamento. A solução do problema estaria em afastar a SDE do controle da aquisição do material probatório nos autos e da direção da fase instrutória do processo, entregando-a ao julgador. O CADE, diante disso, participaria efetivamente da instrução, e não somente pela atuação probatória diferida que a lei lhe autoriza.

Outra solução seria retirar da SDE a missão de instaurar-conduzir-opinar, o que seria inviável. Não só pela ausência de estrutura, pela atual incompatibilidade normativa, mas também pela dificuldade de substituí-la. Como bem se sabe, o papel do representante é bastante delicado. Ele não é parte, porque "tal posicionamento é um imperativo à preservação dos princípios norteadores da concorrência, que se baseia na assimetria de informações entre os agentes econômicos e, em especial, os concorrentes. Pudesse o Representante ser parte no processo, teria acesso a todas as informações ainda que confidenciais, de seus concorrentes ou empresas de seu interesse porventura constantes dos autos". 335 Ele não tem condições, na qualidade de assistente que é, de exercer a plenitude daqueles poderes, ônus, deveres, faculdades e sujeições necessárias à formação da relação processual e movimentação adequada do processo. Outra possibilidade seria entregar o papel de autor a órgão capaz de proteger de forma isenta o interesse público institucional tutelado pela concorrência. Hoje, vislumbra-se tão somente o Ministério Público como ontologicamente apto para a função. De fato, ele tem atuação custus legis

\footnotetext{
${ }^{335}$ Franceschini, "Roteiro do processo penal-econômico na legislação de concorrência", p. 18.
} 
perante o CADE, mas sugestão comportaria alteração substancial no funcionamento do SBDC, não admissível hoje pela legislação em vigor. A questão deverá ser tratada como opção de lege ferenda.

Restaria então o derradeiro problema, o mais grave, mas também o de mais fácil solução. O princípio da oficialidade permite que inclusive o CADE determine a instauração de processo administrativo de ofício perante a SDE. Nesse caso, a imparcialidade, nos moldes em que idealizada pela concepção instrumentalista do processo, restaria efetivamente comprometida. Mas a solução é simples. Basta ter em mente que existem outros três órgãos capazes de tomar a iniciativa diante de condutas anticoncorrenciais e nenhuma necessidade de se outorgar a mais um - justamente o órgão judicante - a legitimidade para provocar a atuação administrativa sancionatória. Em termos práticos, (a) quando o CADE se depara com possível conduta anticoncorrencial extraída de processo, registra o fato na decisão; nesses casos não há necessidade de determinar a instauração de processo administrativo, bastando que esteja presente um membro da SDE em sessões de julgamento (que são públicas), ou que o órgão desenvolva sistema de monitoramento de decisões do CADE para identificação de possíveis novas condutas a investigar; (b) quando o CADE toma ciência de conduta anticoncorrencial como integrante do SBDC, basta encaminhá-la à SDE após ciência, não como uma determinação de instauração de processo, mas como um encaminhamento de informações ao órgão competente para a atividade. Trata-se de medida singela que não impede a investigação de condutas e reforça a legitimidade institucional do SBDC.

\section{VI.1.5. Imparcialidade e o princípio dispositivo}

O segundo elemento por meio do qual se pode mensurar a imparcialidade é pelo exame da aplicabilidade do princípio dispositivo, paralelamente ao processo jurisdicional. O princípio tem fundamento no brocardo ne procedar iudex ex officcio. Se as partes dispõem da propositura e de seu objeto, também elas devem dispor dos meios para defesa de seus interesses privados. E assim, em tese, deveria ser perante o processo administrativo.

Mas contrariar essa premissa não parece ser um intransponível e atual problema. 
De acordo com o modelo dispositivo, de inspiração em países da common law, prevalecem os poderes da parte na instrução e o juiz exerce um papel inativo e não intervencionista, o que exaltaria sua independência e imparcialidade. Já o modelo inquisitório, o juiz tem iniciativa na direção do procedimento mas também na identificação de fatos relevantes que indiquem a verdade possível, investigando de ofício questões para a solução do processo (um poder dever de investigar), informando as partes sobre seus questionamentos e estimulando a produção de provas por elas próprias. ${ }^{336}$ Esse modelo pode inclusive, em um extremo, levar ao julgamento ultra petita, caso as provas indiquem a necessidade de uma nova tutela, o que a princípio não é admitido no Brasil. As nuances do sistema brasileiro levam a crer em um sistema misto, com um abrandamento da inquisitoriedade - um modelo no qual Comoglio veria uma "gamma di sfumature intermedie e di soluzioni fungibili". ${ }^{337}$ A linha divisória entre uma inquisitoriedade aceitável e a inconstitucionalidade do ativismo do juiz residiria na preservação do contraditório, do direito de defesa e da imparcialidade pelo favorecimento de uma das partes que se afaste da equalização de desiguladades substanciais. ${ }^{338}$

Na Itália, de regra, o juiz está adstrito às alegações e às provas oferecidas pelas partes (CPC italiano, art. 115), em razão do princípio da disponibilità delle prove - o princípio dispositivo. Mas também ali se faz a crítica à passividade. A partir do momento que a tutela é requerida, é do interesse do Estado fornecê-la da melhor forma possível lembrando sempre, porém, que a iniciativa probatória do juiz pode "incrinare, specialmente nei suou pressuposti psicologici, la posizioni di imparzialità del giudice". O sistema italiano civil se qualifica como dispositivo atenuado, com um grau bem mais elevado de

${ }^{336}$ Zanetti Junior identifica o modelo clássico-simétrio-persuasivo que vê a prova como argumento persuasivo de convencimento do julgador, que contempla maior passividade do juiz, a idéia do "juiz Pilatus", presente no adversary sistem americano; o modelo moderno-assimétrico-científico, que entende a prova como instrumento demonstrativo voltado ao conhecimento científico da verdade, que contempla modelos lógicos silogísticos e indutivos de verdades apriorísticas por um "juiz Jupiter" que assume a figura do burocrata controlador e centralizador do sistema; e o modelo de racionalidade prática procedimental pela cooperação entre partes e julgador, que dá extrema importância ao debate, da teoria do discurso prático do caso especial, que demanda a participação conjunta dos sujeitos do processo, sistema contrário ao reducionismo silogístico moderno (Zanetti Junior, Processo constitucional: o modelo constitucional do processo civil brasileiro, p. 91-111).

${ }_{337}$ Comoglio, "Garanzie Costituzionali e 'giusto processo' (modeli a confronto)”, pp. 121-123.

${ }^{338}$ Para Taruffo, "i poteri istruttori del giudice sono comunque accessori e integrativi rispetto a quelli delle parti, ma se un fatto risulta provato per effetto delle iniziative probatorie svolte dal giudice, ciò implica che non sará soccombente la parte che aveva l'onere di provarlo e che pure non ha soddisfatto questo onere". Faz ainda referência ao princípio "di acquisizione processuale", consoante o qual a prova é considerada adquirida e passível de utilização em sede decisória enquanto seja admissível, relevante e útil para o esclarecimento dos fatos (Taruffo, "Onere della prova", p. 72.). Sobre o tema, cfr. Yarshell, Antecipação da prova sem o requisito da urgência e direito autônomo à prova, pp. 129-136, esp. p. 134; De Santo, La prueba judicial, p. 65-68. 
inquisitoriedade no processo trabalhista. ${ }^{339}{ }_{-}^{340} \mathrm{Na}$ Inglaterra, o juiz pode adaptar o procedimento a determinada controvérsia, mas mantém sua distância e imparcialidade em relação às provas. Na Alemanha, o juiz pode ao máximo solicitar à parte que requeira a oitiva de uma testemunha, sem coagi-la a tal. ${ }^{341}$

No Brasil, o processo civil, baluarte dos interesses privados, há tempos vem flexibilizando sua dispositividade, acrescentando elevados graus de inquisitoriedade em seu modo de ser, fundamentado nos poderes de direção formal, ordinatórios e instrutórios, destinados a garantir o contraditório e investigar a integralidade dos fatos. A premissa desse raciocínio está na idéia do direito processual como ramo de direito público, qualificado como instrumento do direito material para a entrega de uma tutela jurisdicional justa.

É essa a posição de Grinover, que destaca justamente o processo publicista, sua função social, a necessidade de pró-atividade judicante no estímulo do contraditório efetivo, a busca da verdade possível, do suprimento de deficiências e desigualdades motivadas por fatores institucionais, econômicos ou culturais em repúdio ao adversarial system: "diante da omissão da parte, o juiz em regra se vale dos demais elementos dos autos para formar seu convencimento. Mas se os entender insuficientes, deverá determinar a produção de outras provas, como, por exemplo, ouvindo testemunhas não arroladas no momento adequado. Até as regras processuais sobre a preclusão, que se destinam apenas ao regular desenvolvimento do processo, não podem obstar ao poder -

\footnotetext{
${ }^{339}$ Mandrioli, Diritto processuale civile, vol. I, p. 108-109. O autor esclarece que "la terminologia che meno di ogni altra sembra prestare il fianco ad equivoci è quella che contrappone al 'principio della disponibilità dell'oggetto del processo' (che si identifica con quello della corrispondenza tra il chiesto e il pronunciato nella necessaria derivazione della disponibilità della tutela giurisdizionale e dalla disponibilità dei diritti), il "principio della disponibilità delle prove" (idem, p. 108). Em casos de direitos indisponíveis, nada teria impedido o legislador de alterar a técnica e impor um processo baseado no impulso de ofício, porém preferiu inserir a figura do Ministério Público, "soggetto appositamente creato per operar nel processo come parte, cioè fruendo di tutte le iniziative che la tecnica del processo affida alle parti, ma con la specifica funzione de perseguire, con quella tecnica, la tutela di quegli interessi pubblici che, in misura più o meno intensa, stanno in correlazione con la più o meno accentuata indisponibilità dei diritti" (idem, p. 115).

${ }^{340}$ Para Gianniti, "I poteri di iniziativa istruttoria d'ufficio del giudice sono: a) eccezionali, in via di principio e di fatto, nel processo civile, nel quale, accanto all'interesse privato delle parti, non sussiste quasi mai un interesse pubblico sottratto alla disposizione delle parti stesse; b) eccezionali in via di principio, ma ordinari in via di fatto, nel processo penale, in considerazione del carattere indisponibile dell'oggetto di quest'ultimo". Na esfera civil o caráter è integrativo, enquanto na esfera penal o caráter seria substitutivo (Gianniti, Processo civile e penale a confronto, pp. 94-95).

${ }^{341}$ Monteleone, "Limiti alla prova di ufficio nel processo civile (cenni di diritto comparato e sul diritto comparato)", pp. 871 e ss.
} 
dever do juiz de esclarecer os fatos, aproximando - se do maior grau possível de certeza, pois sua missão é pacificar com justiça". ${ }^{342}$

Existem precedentes nesse sentido, que afirmam ser “(...) lícito ao juiz determinar, de ofício ou a requerimento das partes, a produção de quaisquer provas que entender necessárias para o correto deslinde da lide. No processo civil, impera o princípio da verdade material sobre a verdade meramente formal. Neste sentido, Ac. da 1 Cam. do TJRS, rel. Athos Gusmão Carneiro, in RJTJRS 124/231: 'É amplo o poder do juiz no sentido de complementar as provas em busca da verdade real',. 343

O posicionamento não é unânime. Há quem entenda, de forma mais reservada, que o juiz não deve substituir o posicionamento das partes e potencializar indevidamente os poderes previstos no art. 130 do CPC. Sua atuação seria apenas complementar, para hipóteses de direitos indisponíveis e matérias de ordem pública. Poderes instrutórios demasiadamente amplos, ainda que inerentes à jurisdição, distorceriam o fenômeno de aplicação. ${ }^{344} 345$

Posições equilibradas, à luz da relação jurídica de direito material e atenta para às partes envolvidas, de forma a criar um processo justo e equo e atingir premissas de igualdade substancial - essa parece ser a orientação mais adequada. O juiz não deve assumir postura desinteressada, porém a potencialização da ânsia pela busca de uma verdade pode exacerbar os limites do tolerável: é o pesquisador, que exauridos todos

\footnotetext{
${ }^{342}$ Grinover, "A iniciativa instrutória do juiz no processo penal acusatório", pp. 78 e ss.

${ }^{343}$ TJ-PR, 3a . Cam., AI n. 175270500, Juiz Eugênio Achille Grandinetti j. 21.8.01.

${ }^{344}$ Barbosa Moreira, "A função social do processo civil moderno e o papel do juiz e das partes na direção e na instrução do processo", pp. 141, 145 e 147) e o precedente STJ, 1a. T., RESP 243311, Rel. Min. Garcia Vieira, j. 21.3.00.

${ }^{345}$ Monteleone afirma que em sistemas que tutelam direitos subjetivos, pertencentes exclusivamente ao individuo, as tutelas a eles referentes dependem de provocação da parte interessada. Na persecução dessse direito, o processo civil é regido pelo sistema do ônus da prova, inerente ao sistema de disponibilidade do direito: "se l'esercizio in concreto della giurisdizione è subordinato alla domanda di chi abbia legittimazione ed interesse ad agire, ache la prova deve esserlo poiche da essa dipende l'accoglimento di quella stessa domanda". A atuação de ofício do juiz esvazia o princípio do ônus da prova e acaba por transferir ao juiz a postura de defesa de um direito subjetivo próprio inexistente. Alega-se ainda que a atividade de ofício do juiz não garante o alcance da verdade porque essa busca poderia ser atingida satisfatoriamente com um sistema de ônus da prova e porque não existem dados que comprovem que a atuação de ofício oferece resultados melhores. A atividade de ofício reflete portanto um sistema jurisdicional (processual civil) paternalístico ou autoritário (ainda que o sistema político possa ser liberal e democrático). Tal concepção publicística pode alongar o processo com atividades instrutórias não requisitadas pelas partes ou cobertas pelas rígidas preclusões na matéria, contrariando a imposição constitucional de que o processo tenha duração razoável. O juiz é livre para valorar provas inseridas no processo, e não para inseri-las livremente sob pena de tornar-se parte e perder sua imparcialidade (Monteleone, "Limiti alla prova di ufficio nel processo civile (cenni di diritto comparato e sul diritto comparato)", p. 863 e ss.
} 
os caminhos plausíveis, testa procedimentos de pouca ou nenhuma objetividade e racionalidade para tentar provar a sua hipótese de investigação. Os limites entre a insistência em instrução na busca da verdade possível e a busca obcecada por uma resposta imaginada é tênue aos olhos jurisdicionados. O juiz deve estar atento para a alocação eficiente do seu tempo: por mais nobre e desejada que seja a atividade, as regras de distribuição de ônus da prova servem justamente como um alerta dado pelo legislador ao juiz para o fato de que é preciso seguir adiante e oferecer ao jurisdicionado uma solução na maior brevidade possível.

Tranportar essas lições ao processo administrativo é missão interessante.

Inicialmente, a divergência exposta revela que alterar o balanço entre o princípio dispositivo e inquisitório não desvincula o instrumento de um modelo processual constitucional e de garantias e princípios inerentes à teoria geral do processo. O processo jurisdicional há tempos debate o tema, ainda hoje tem em seu bojo posicionamento divergentes, de modo que eventual reforço da inquisitoriedade administrativa não é algo novo que mereça, a priori, repúdio.

Na Itália, no âmbito administrativo, os autores divergem sobre a concepção inquisitória ou não do processo e sobre a extensão dos poderes da autoridade. De um lado, Negri afirma que o procedimento administrativo perante a Autorità é informando pelo princípio inquistório, com poderes investigativos penetrantes superiores àqueles da limitada regra do discovery do processo civil. Haveria um amplo poder de inspeção, com auxílio da Guarda di Finanza, que ultrapassa os limites da inspeção judicial do CPC italiano, além do poder de requerer informações e documentos da empresa ré e de terceiros sob pena de sanções pecuniárias pela falta de colaboração (art. 14 da lei 287/1990 e 8 e ss. Do d.p.r. 217/1998). ${ }^{346}$

Ainda ali destacam-se os poderes "di indagine" e "investigativi", 347 normalmente acionados de ofício, em casos de análise de condições de mercado e em casos

\footnotetext{
${ }^{346}$ Negri, Giurisdizione e amministrazione nella tutela della concorrenza, Torino, G. Giapichelli, 2006, pp. 154-156.

${ }^{347}$ Benedetto faz uma distinção dos poderes di indagine e os poderes instruttori. Mas na atividade processual, eles se assemelham. Poderes instrutórios significativos. O primeiro dele, genérico, "di procedere ad indagine conoscitive di natura generale in settori economici in cui sia dato presumere che la concorrenza sia 'impedita, ristretta o falsata"”. Por sua natureza genérica, "i relativi poteri possono essere utilizzati al di fuori dell'istruttoria formale, ma solo nel caso di indagini conoscitive di carattere generale e solo se adeguatamente ridimensionati"' (Benedetto, L'Autorità garante della concorrenza e del mercato, p. 252).
} 
de violações à norma antitruste. É sistema de poderes análogo àqueles da tradição americana "come un sistema inquisitorio in cui l'Autorità deve attivarsi per raccogliere le prove di integrazione dell'illecito concorrenziale e ricostruirne le caratteristiche". Nessa fase, 'l'attività dell'Autorità risponde ai classici canoni del sistema inquisitorio, ovvero spetta alla stessa raccogliere elementi di prova ed individuare le caratteristiche dell'intesa, in ciò utilizzando anche le osservazioni e gli elementi dedotti dai soggetti che partecipano al procedimento". ${ }^{348}$ Especificamente, existem "a) potere di richiedere informazioni, b) potere di richiedere l'esibizione di documenti, c) potere ispettivi, d) potere di disporre perizie, analisi economiche o statistiche, e) potere di servirsi dell'ausilio di esperti in ordine a qualsiasi elemento rilevanti ai fini della istruttoria". ${ }^{349}$

Porém, há ali "una scarsa compatibilità tra la natura sostanzialmente inquisitoria dell'Autorità ed il corpo di disposizioni fortemente garantiste in materia di procedimenti istruttori e di poteri di indagine, che rendono meno fluido ed efficace il procedimento innanzi all'Autorità". Ao final, aduz que "con tali strumenti, difficilmente potrebbe configurarsi una funzione proactive dell'Autorità, con una inevitabile perdita di vigore per l'iniziativa d'ufficio, e il conseguente pericolo di ridurre la funzione antitrust a regolazione occasionale, contingente e fortuita di settori economici". 350

No processo administrativo brasileiro, a estrutura não é essencialmente diversa: a persecução e a investigação são conduzidas por órgão interno do SBDC (primordialmente a SDE), com amplos poderes para condução do processo, de modo a investigar condutas ilícitas, proteger o interesse institucional-concorrencial e os demais escopos da atividade. No equilíbrio entre os pólos do processo, é preciso estabelecer a medida de poderes, deveres, ônus, faculdades e sujeições a cada um deles, fixando a necessidade de intervenção inquisitória ou a passividade dispositiva adequada para a apuração da verdade possível em situação substancialmente isonômica.

\footnotetext{
${ }^{348}$ Benedetto, L'Autorità garante della concorrenza e del mercato, p. 245. Também Fauceglia afirma que "l'attività dell'Autorità risponde ai classici canoni del sistema inquisitorio, ovvero spetta alla stessa raccogliere elementi di prova ed individuare le caratteristiche dell'intesa in ciò utilizzando anche le osservazioni e gli elementi dedotti dai soggetti che partecipano al procedimento. Naturalmente, a chiusura della fase istruttoria e prima della decisione, qualora l'Autorità lo ritenesse opportuno, potranno essere presentate memorie riassuntive e conclusive" (Fauceglia, "L'istruttoria dell'autorità in tema di intese restrittive della libertà di concorrenza e di abuso di posizione dominante", p. 266).

${ }^{349}$ Fauceglia, "L'istruttoria dell'autorità in tema di intese restrittive della libertà di concorrenza e di abuso di posizione dominante", p. 266.

${ }^{350}$ Benedetto, L'Autorità garante della concorrenza e del mercato, p. 258.
} 
De um lado, a SDE se vale de um arcabouço normativo e instrumentos instrutórios coercitivos bastante relevantes, com especial destaque para a busca-eapreensão realizada com autorização do Poder Judiciário por interface feita pela Procuradoria do CADE, e para a inspeção, que sequer necessita de autorização judicial. Esse arcabouço se une à posição estrutural da SDE como membro do SBDC responsável pela condução do processo e gestão das provas produzidas. A união de elementos legais e estruturais fazem com que a balança penda para o lado da administração pública.

O deslocamento de forças em prol da administração é ordinariamente justificado em razão da dificuldade na apuração de condutas anticoncorrenciais e dos padrões de prova admitidos (provas diretas ou indiretas). A SDE em uma de suas cartilhas de combate a cartéis esclarece que "os participantes de cartéis sabem que estão cometendo um ilícito e, por isso, se valem de manobras que criam obstáculos à sua detecção. A comunicação entre os membros do cartel ocorre, via de regra, de maneira sigilosa e com poucos rastros, o que resulta na dificuldade de acesso à prova documental". ${ }^{351}$ A identificação de condutas tanto colusivas quanto unilaterais ficaria facilitada por instrumentos incisivos, tais como foi possível observar no recente caso de indústria de bebidas em relação ao seu programa de fidelidade, dada a importância da inspeção in loco realizada para a coleta de provas e caracterização do abuso do poder de mercado. ${ }^{352}$ No conhecido caso do Cartel dos Vigilantes, uma combinação entre providências extraídas do programa de leniência e documentos obtidos em busca-e-apreensão foram fundamentais para a condenação. ${ }^{353}$

\footnotetext{
${ }^{351}$ SDE, "Combate a Cartéis em Licitações", p. 11.

${ }^{352}$ CADE, proc. n. 08012.003805/2004-10.

${ }^{353}$ CADE, proc. n. 08012.001826/2003-10. Em questão submetida ao STJ após o deferimento de busca-eapreensão amparada em informações obtidas de acordo de leniência, o TRF determinou que "I. A busca e apreensão é medida extraordinária, não podendo ser requerida em caráter amplo e irrestrito.

II. O art. 839 do C.P.C. prescreve os pressupostos processuais objetivos intrínsecos à relação cautelar de busca e apreensão e, na espécie a inicial não traz os motivos justificadores do pedido, não descreve a conduta praticada pelos requeridos que se constitua indício, nem aponta quais "coisas" deveriam ser apreendidas. III. O denominado Acordo de Leniência, ou delação, além de ser unilateral é duvidoso como forma de prova, mormente se não vier acompanhado de um inicio de prova material. IV. A fragilidade da documentação apresentada e dos argumentos trazidas não convencem em respaldar medida tão drástica". O STJ suspendeu os efeitos dessa decisão sob o argumento de que o acórdão recorrido fundamentou-se nos requisitos genéricos das medidas cautelares dispostos no CPC, deixando de aplicar a legislação específica, qual seja, a Lei 8.884/94. Deixou, outrossim, de valorar corretamente como prova o acordo de leniência previsto no art. 35-B da Lei 9.884/94, que tem como substrato a confissão de um dos participantes do cartel" (STJ, 2 ${ }^{\mathrm{a}}$. T., MC 12748, Rela . Min ${ }^{a}$. Eliana Calmon, j. 17.05.07). Preservada assim a utilidade, a inovação e a pertinência do sistema amparado por dois relevantes instrumentos de instrução processual antitruste.
} 
Alguns operadores sujeitos à lei relutam e atestam a severidade da norma. Apenas de forma exemplificativa, tenha-se presente que no Projeto de Lei que altera a formatação do Sistema Brasileiro de Defesa da Concorrência, um instituto que congrega operadores atuantes no SBDC sugeriu a alteração do dispositivo que permite a inspeção, condicionando-a à autorização judicial. ${ }^{354}$ Aquilo que traz efetividade no combate às condutas anticoncorrenciais é também um instrumento que preocupa operadores a administrados, porque outorgam poderes excessivos ao já forte e inquisitório órgão da administração.

Mas os instrumentos são legítimos em sua conformação atual. Os instrumentos processuais não são considerados os vilões do SBDC por órgãos internacionais, os avanços na perquirição e condenação de condutas anticoncorrenciais por eles trazidos são inegáveis e a dificuldade de prova é inerente a um sistema de sujeitos que não raras vazes conhecem o ilícito e também medidas de não detecção. A balança pende efetivamente, mas o remédio adequado não é simplesmente bani-la, e sim prestar atenção aos requisitos prévios à concessão de medidas e aos sistemas de controle. Ou seja, antes de determinar inspeção ou requerer uma busca-e-apreensão, a SDE deve pautar-se em elementos que reforcem seu convencimento da eficácia da medida, ponderar o ato à luz de juízos de proporcionalidade (mal maior, mal menor e mal mais provável em relação à medida pretendida) e, especialmente, fundamentar exaustivamente a determinação - e aqui residiria o maior e mais eficaz remédio de controle de legalidade do ato - de modo a permitir ao administrado, se for o caso, apresentar sua irresignação no próprio processo administrativo ou mesmo em remédio dirigido ao Poder Judiciário.

\section{VI.1.6. Imparcialidade: indicação, mandato e desligamento}

No vértice do SBDC estão os Conselheiros do CADE. De acordo com o art. $4^{\circ}$, da Lei n. 8.884/94, eles são cidadãos com mais de trinta anos de idade, notório saber jurídico ou econômico, reputação ilibada, com um mandato de dois anos, com possibilidade de recondução por mais dois anos. Devem ser nomeados pelo Presidente da República e sabatinados pelo Senado Federal.

${ }^{354}$ Referência ao disposito no art. 13, VI, c, do Projeto de Lei da Câmara n. 6/09, em sua tramitação pelo Senado Federal. 
Benedetto aduz que "la sussistenza di qualificati criteri normativi per la designazione degli organi di vertice di una istituzione rappresenta una prima forma di garanzia a tutela dell'esercizio di funzioni cui debbano necessariamente afferire profili di indipendenza". Destaca que (a) no sistema de indicação pelo presidente e aprovação pelo senado, não existe culpa in eligendo, (b) a despeito da existência de requisitos, a decisão de indicação italiana não tem sido motivada, o que de um lado se justificaria pela alta posição de quem nomeia, mas dá margem à existência de sinais de politização na escolha, o que se liga à amplitude dos requisitos e a vagueza dos critéiros - "massimo livello di vaghezza normativa si raggiunge nella indicazione dei requisiti per la nomina del Presidente dell'AGCM, laddove si richiedono la 'notoria indipendenza' e l'aver 'ricoperto incarichi istituzionali di grande responsabilità e rilievo'; per quanto riguarda i commissari sembrerebbe meglio definito l'ambito di scelta per la individuazione delle categorie di soggetti tradizionalmente considerati per ruolo professionale, rispettivamente, indipendenti ed esperti, ovvero alti magistrati e professori universitari: ma il campo di indagine è nuovamente ampliato dal terzo, alternativo, requisito per cui potrebbero essere nominati componenti dell'AGCM 'personalità provenienti da settori economici dotate di alta e riconosciuta professionalità'. Ci pare, dunque, che si prospettino ampie possibilità di affermazione per un rilevante indirizzo presidenziale-parlamentare nella interpretazione ed attuazione". A praxe diz que são indicados professores universitários. E mais: a indicação pelo Presidente do Senado não representa o pensamento da maioria da casa, existindo exemplos de eleição parlamentar "con voto limitato" (indicação de apenas uma preferência). ${ }^{355}$

Se voltarmos as atenções aos órgãos judicante por excelência, encontraremos no Judiciário brasileiro a seleção de magistrados ordinariamente feita por meio de Concursos Públicos (CF, art. 93, inc. I). Esses concursos são orientados hoje pela Resolução n. 75, de 12.5.09, do Conselho Nacional de Justiça, que prevê uma prova objetiva, duas provas escritas, uma sindicância investigativa, exames de sanidade física e mental, psicotécnicos, uma prova oral e uma fase de avaliação de títulos. A comissão julgadora é composta pelos pares (magistrados), por membros designados da Ordem dos Advogados do Brasil. ${ }^{356}$

\footnotetext{
${ }^{355}$ Benedetto, L'Autorità garante della concorrenza e del mercato, pp. 79-86.

${ }^{356} \mathrm{O}$ particular sistema jurisdicional americano (atento a um federalismo mais fortalecido) é dividido em Justiças Federal e Estadual. Existe ampla liberdade para todas as esferas e todos os Estados na definição
} 
Em tribunais de segunda instância respeita-se a regra do quinto constitucional, pela qual "um quinto dos lugares dos Tribunais Regionais Federais, dos Tribunais dos Estados, e do Distrito Federal e Territórios será composto de membros, do Ministério Público, com mais de dez anos de carreira, e de advogados de notório saber jurídico e de reputação ilibada, com mais de dez anos de efetiva atividade profissional, indicados em lista sêxtupla pelos órgãos de representação das respectivas classes. Parágrafo único. Recebidas as indicações, o tribunal formará lista tríplice, enviando-a ao Poder Executivo, que, nos vinte dias subseqüentes, escolherá um de seus integrantes para nomeação" (CF, art. 94). A composição do Superior Tribunal de Justiça segue a mesma lógica, com a diferença de que dois terços dos Ministros são provenientes de Tribunais de segundo grau e um terço escolhido entre membros do MP e da advocacia (CF, art. 104).

\section{Já o Supremo Tribunal Federal e composto por onze Ministros,} escolhidos dentre cidadãos com mais de trinta e cinco e menos de sessenta e cinco anos de idade, de notável saber jurídico ${ }^{357}$ e reputação ilibada, nomeados pelo Presidente da República, depois de aprovada a escolha pela maioria absoluta do Senado Federal, ou mesmo de respeito do quinto Constitucional. Esse também é o sistema de escolha dos nove

estrutural de funcionamento da Justiça. Na Justiça Federal, todos os magistrados são indicados pelo Senado e aprovados pelo Presidente, sem a fixação de qualificações legais específicas (muito embora costumeiramente exija-se formação e experiências jurídicas e a idade média seja de 45 anos). E em razão da diversidade federalista, os Estados adotam diversos sistemas para seleção de juízes: eleições partidárias e não partidárias, indicação do Governador, indicação pelo Poder Legislativo e referendo. Para os Estados que adotam a seleção por eleição, existe a preocupação decorrente de conflitos de interesse e de uma modesta participação popular em eleições não obrigatórias. Porém, não se pode dizer que o sistema americano seja propriamente um exemplo a ser seguido. São diversas as críticas. Penny Whyte, professora da University of Tenessee College of Law e ex-Juíza da Corte do Tenessee, afirma que ocorrem eleições em 34 Estados americanos ( 21 partidárias). Os gastos com eleições são significativos, a arrecadação é em boa medida financiada por escritórios de advocacia e empresários, o que é motivo de preocupação para $89 \%$ de entrevistados em pesquisas ali realizadas e que para $76 \%$ pode gerar favorecimento. Contudo, faz referência a decisão recente da Suprema Corte (Caperton v. Massey Coal Co.) que determina a declaração de suspeição de juízes em casos de doadores expressivos (http://www.conjur.com.br/2009-jun-29/eleicoes-judiciario-eua-geram-criselegitimidade). O mesmo caso foi debatido por Alan Woodlief, professor associado da Elon University School of Law. Ele aduz que "the U.S. Supreme Court's recent decision in has focused attention on a long-standing debate -- whether state judges should be elected or selected through alternative methods such as merit and appointive retention systems. Caperton highlighted one of the most oft-cited concerns with judicial elections, the potential influence of campaign contributions on judicial independence". Faz referências às lutas para eliminar os pitfalls do sistema, tal como eleições não partidárias, limitações de contribuições, financiamento público para campanhas transparentes, educação dos cidadãos para o voto consciente (http://www.newsrecord.com/content/2009/10/23/article/pro_con_debate_over_reforming_judge_election_system_continues).

357 Conforme lembra Lenza, "o art. 56, Constituição de 1981, falava tão somente em notável saber, sem qualificá-lo. A constituição de 1934 (art. 74) passou a qualificar o notável saber de jurídico. Em razão da permissão da Constituição de 1891, o STF já chegou a ter Ministro que não era jurista, vale lembrar o médico Barata Ribeiro, nomeado pelo Presidente Floriano Peixoto. Atualmente, contudo, e desde o parecer de João Barbalho de 1984, passou-se a entender que todo o Ministro do STF terá que ser, necessariamente, jurista, tendo cursado a faculdade de direito" (Direito Constitucional esquematizado, p. 307), muito embora a questão seja controvertida (cfr. Moraes, Direito Constitucional, p. 462). 
membros da Suprema Corte Americana, nos termos do art. II, Seção 2 da Constituição Americana.

Feita essa breve exposição sobre sistemas de escolhas de sujeitos judicantes, passemos ao exame dos critérios de seleção de Conselheiros do CADE.

O limite de idade tem fundamento em presunção de experiência que não representa uma novidade no texto constitucional: é visto como requisito mínimo para Governador de Estado, Desembargadores de Tribunais, numa gradação que eleva o patamar para trinta e cinco anos nos casos de Presidente, Ministro do TCU, Membros do Conselho da República, Ministro do STF e de Tribunais Superiores, Procurador Geral da República, Advogado Geral da União. O fundamento é constitucional, ao menos objetivo, mas aqui colocado de forma conformista, na medida em que não se tem ciência de estudos científicos que atestem a maturidade acadêmico-profissional de um sujeito aos trinta anos, como se existisse o L'homme de trente ans fundamentado em estudos psicológicos de escritor francês do século XIX.

A questão começa a ganhar contornos mais complexos à luz dos critérios de notório saber jurídico e econômico e reputação ilibada. São aqueles conceitos indeterminados que permitem interpretações diversas, muitas vezes subjetivas e perigosas em processos de seleção, porque dão margens a influências outras que não estritamente técnicas, jurídicas e econômicas. Mas essa também não é uma crítica feita ao processo de seleção de Conselheiros do CADE, porque também presente na escolha de Ministros do TCU, Desembargadores provenientes do quinto constitucional, membros do STM.

O processo de sabatina pelo Senado Federal e a nomeação pelo Presidente da República efetivamente outorga legitimidade democrática à indicação de um Conselheiro. Se o chefe do executivo e os senadores são escolhidos pelo povo, ainda que existam críticas à democracia representativa brasileira, a formatação tende a expressar de forma reflexa a vontade do mesmo povo na escolha de Conselheiros que tenham o condão de cumprir fielmente o munus de proteção da ordem econômica, da concorrência e do bem estar social - pressupondo, por óbvio, a identidade entre o representante e representado. ${ }^{358}$

358 “O problema nessa relação principal-agente ocorre na medida em que, dada a assimetria de informações entre o 'principal' e o 'agente', o 'agente' não necessariamente fará as escolhas que maximizariam os interesses do eleitor, apesar de formalmente apresentar suas escolhas ao público como sendo do 'interesse público’. Por que? Porque dentro do princípio do individualismo metodológico de que os homens são 
O que falta no Brasil é o dever de fundamentação da escolha, a exposição dos motivos, os argumentos que reforçam o notório saber jurídico ou econômico e a reputação ilibada, de forma a poder extrair dessa decisão a transparência necessária para, democraticamente, conhecer os critérios dos representantes e fiscalizá-los, ${ }^{359}$ de modo a minimizar desconfianças decorrentes da própria crise de representação do Congresso Nacional.

Essa formatação aplica-se a Ministros de Tribunais Superiores, membros do CNJ, Ministros do STF, Procurador Geral da República, do Conselho Nacional do Ministério Público, cujos nomes também são submetidos à aprovação do Senado por determinação constitucional.

É certo que a aprovação política de nomes em órgãos políticos é, além de democrática, menos objetiva, sujeita a influxo de forças heterogêneas. A sistemática de concursos públicos criada pela $\mathrm{CNJ}$ é um esforço considerável no sentido de tornar os critérios mais objetivos e unívocos possíveis, evitando impugnações diversas, servindo como blindagem para a imparcialidade e implementação de concorrência pelo cargo. A proposta de legitimação de atividade e eliminação de desconfianças poderia ocorrer, de lege ferenda, pela conjunção de dois sistemas que se somados, agregam valor e eliminam críticas recíprocas: a prova objetiva seguida do exame de critérios mais e menos subjetivos, culminando com a aprovação por órgãos de maior representatividade popular. ${ }^{360}$

Outro ponto digno de comento é a questão do mandato. No Brasil, o Conselheiro é designado para um mandato curto, de doi anos, com possibilidade de recondução por mais dois anos. Algumas são as críticas ao sistema.

egoístas por natureza e buscam maximizar seus interesses pessoais, os políticos em geral não são benevolentes e em geral tendem a maximizar seus interesses pessoais. E os seus interesses pessoais não necessariamente confluem para o 'interesse público' ou o interesse da maioria dos eleitores ("principais").

Mattos, O novo estado regulador no Brasil: direito e democracia, p. 38.

359 "L'esigenze di dare trasparenza alle procedure della nomina, rendendone pubblica - oggetto cioè di pubblicazione - la motivazione e facendovi emergere chiaramente la qualificazione del nominato" (Benedetto, L'Autorità garante della concorrenza e del mercato, p. 358).

${ }^{360}$ Ciente de que seria necessária profunda reforma legislativa para a sua implementação. A idéia é posta em tom conciliador, em crítica construtiva que louva a magistratura e aqueles membros, provenientes de cidades distantes, longe de qualquer suporte, que dedicaram-se integralmente à absorção de conhecimento necessário a superar as dificílimas provas objetivas e ingressam na carreira valendo-se tão somente do orgulho pela superação das cinco etapas previstas pela Resolução n. 75 da CNJ. A proposta louva ainda aqueles que são escolhidos pelo Senado Federal e aprovados pelo Presidente, ciente de que perante os legítimos representates do povo suas mais altas qualidades foram reconhecidas, de modo que o seu notório saber jurídico e econômico poderá ser aplicado em favor da construção de um país mais justo. A junção dos dois sistemas traria ao CADE Conselheiros de profundo conhecimento teórico, respeitabilidade e legitimação popular. Não há razão para não desejar isso. É preciso reconhecer, porém, que não foi identificado em direito estrangeiro sistema semelhante. 
O prazo primário (dois anos) é curto demais para implementação de um trabalho eficiente - não se espera a implementação da vitaliciedade tal qual ocorre com o Poder Judiciário, mas o tempo de mandato estabelecido corresponde tão somente ao período de experiência de magistrados no início de carreira; eliminada a adaptação inicial e alguma desaceleração final, o tempo de efetiva judicância torna-se ainda mais curto. $\mathrm{O}$ Brasil oferece um mandato relativamente curto se comparado com outras estruturas: na AGCM italiana, o mandato é de 7 anos, tal como na Federal Trade Comission americana; na Autoridade portuguesa, o mandato pode chegar a 10 anos. O Projeto de Lei do SBDC pretende ampliar o mandato para 4 anos, proposição louvável mas ainda aquém de sistemas comparados.

Além da ponderação sobre a entrada e permanência de um Conselheiro, valem também as considerações sobre a sua saída. Essa sugestão é ainda um remédio contra a possível captura do órgão.

A captura de Autoridades não é assunto novo. Fonseca traz a idéia de captura como elemento nocivo à imparcialidade. Refere-se a órgãos que perseguem políticas púbicas e exercem papel político decorrente de seu "relacionamento com outras fontes de poder". Suas decisões não seriam políticas - na linha do que já foi exposto acima -, mas haveria uma contaminação por "influências externas", 361 tais como tarefas extramandato, atos de colaboração e outras conexões institucionais, ainda que não se saiba qual é o divisor de águas entre motivação técnica ou política da decisão. ${ }^{362}$

Capelletti e Garth também analisaram a captura ao correlacionar o acesso à justiça e a tutela de interesses difusos. Examinado a criação de agências públicas especializadas, afirmam que "a história recente demonstra que, por uma série de razões, elas têm deficiências aparentemente inevitáveis. Os departamentos oficiais inclinam-se a atender mais facilmente a interesses organizados, com ênfase nos resultados das suas decisões, e esses interesses tendem a ser predominantemente os mesmos interesses das entidades que o órgão deveria controlar. Por outro lado, os interesses difusos, tais como os dos consumidores e preservacionistas, tendem, por motivos já mencionados, a não ser

\footnotetext{
${ }^{361}$ Fonseca, "Papel dos tribunais administrativos e sistema judicial", pp. 32 e ss. Cfr. ainda Posner, "Teorias da regulação econômica", p. 56-58.

${ }^{362}$ Fonseca, "Papel dos tribunais administrativos e sistema judicial", p. 31.
} 
organizados em grupos de pressão capazes de influenciar essas agências". ${ }^{363}$ Uma das explicações para a captura estaria na idéia de que as autoridades nascem, passam por um período de desenvolvimento, ratificam sua posição de proteção do interesse público, acabam por se distanciar dos grupos regulados, perdem apoio político, tendem ao isolamento, afastam-se do controle e da fiscalização, passam a integrar o sistema econômico e tomam decisões de forma a manter o setor econômico regulado e prevenir mudanças que o contrariem.

Mas há alguma diferença de escopo entre a atividade do CADE e a atividade das Agências Regulatórias/Autoridades independentes. Algumas agências reguladoras exercem atividade normativa, que inclusive é o principal mote para as preocupações acima expostas em relação à captura. Exercem ainda atividade judicante, apreciando ilícitos e impondo condenações dentro de seus mercados regulados. O CADE, por sua vez, exerce primordialmente função administrativa judicante (tanto na esfera repressiva quando preventiva), com atividade educativa de importância, porém menos relevante para o debate ora travado; seus atos decisórios estão adstritos à lei e têm natureza vinculada. Por esses motivos, a teoria da captura não exerce aquela pressão sobre o CADE que exerceria sobre Agências tipicamente reguladoras. Na judicância, pretende-se com mais razão manter-se a imparcialidade de julgamentos.

Ainda assim, o CADE é uma autoridade administrativa autônoma, cujos Conselheiros, nomeados para mandatos de dois anos prorrogáveis por mais dois anos, apreciam matéria de natureza concorrencial, cujo grau de especificidade não é tal qual se observa em Agências Reguladoras setoriais, mas é suficientemente técnico para sugerir um relevante mercado, para poucos. ${ }^{364}$

A doutrina italiana vê como remédio à captura um reforço da "previsione di un sistema di incompatibilità successive per i commissari, volto ad ostacolare una loro riconvertibilità professionale nell'ambito di imprese operanti in settori produttivi nel campo di interesse dell'Autorità: in tal modo si contribuirebbe a diminuire il rischio di

\footnotetext{
${ }^{363}$ Capelletti-Garth, Acesso à justiça, pp. 52-53.

364 A afirmação não é fruto de achismo. Em seu escopo educativo, o CADE luta ainda para a sua consolidação institucional. Isso ocorre porque, conforme visto nos capítulos introdutórios, o direito concorrência em sua formatação atual é ainda um adolescente que busca espaço. O direito econômico ainda sofre com algum preconceito entre advogados e economistas; não é regra que as faculdades brasileiras ofereçam cadeira ao direito antitruste; o brasileiro não conhece ainda a extensão de aplicabilidade do direito antitruste e ainda o usa pouco e de forma equívoca. Conforme se verá adiante, isso gera ainda uma demanda acanhada em termos antitruste, em que atuam, via de regra, um grupo pequeno e seleto de operadores.
} 
'cattura' dell'istituzione, e si affermerebbe con forza l'indipendenza dell'Autorità dai gruppi economici". 365

Nesse ponto, $\mathrm{o}$ art. $6^{\circ}$ da lei n. 8.884/94 brasileira não estabelece nenhum tipo de quarentena. O Anexo I do decreto n. 1.171/94 nada dispõe sobre o assunto. Já o Código de Ética do CADE estabelece em seu art. $8^{\circ}$ uma recomendação: "recomenda-se que, no prazo de seis meses após deixar o cargo, o ex-presidente, ex-conselheiro, exprocurador-geral e ex-servidores, voluntariamente, abstenham-se de prestar serviços ou representar qualquer pessoa física ou jurídica, em atividades direta ou indiretamente relacionadas àquelas desenvolvidas pelo CADE". Não se trata de uma norma deôntica, o que fragiliza a disposição. Sendo assim, é preciso não cair no mesmo erro que enseja críticas ao Código de Ética da AGCM italiana, no sentido de que a despeito da inovação, "sembra presentare alcuni limiti strutturali, probabilmente alcune ingenuità di fondo, invitabili considerata l'assenza di un 'sistema etico' auto evidente ed il diffuso relativismo morale che caratterizzano la cultura del nostro tempo. Il livello di 'vaghezza', cioè astrattezza delle norme del Codice pare confermare tali limiti”. 366

O projeto de Lei que altera o Sistema Brasileiro de Defesa da Concorrência, finalmente, vai além e propõe um equilíbrio entre a quarentena e o acesso ao mercado de trabalho, ao estabelecer em seu art. $8^{\circ}$ : " $§ 1^{\circ}$ É vedado ao Presidente e aos Conselheiros, por um período de 120 (cento e vinte) dias, contado da data em que deixar o cargo, representar qualquer pessoa, física ou jurídica, ou interesse perante o SBDC, ressalvada a defesa de direito próprio. $\S 2^{\circ}$ Durante o período mencionado no $\S 1^{\circ}$ deste artigo, o Presidente e os Conselheiros receberão a mesma remuneração do cargo que ocupavam. $\S 3^{\circ}$ Incorre na prática de advocacia administrativa, sujeitando-se à pena prevista no art. 321 do Decreto-Lei n ${ }^{\circ}$ 2.848, de 7 de dezembro de 1940 - Código Penal, o ex presidente ou ex-conselheiro que violar o impedimento previsto no $\S 1^{\circ}$ deste artigo. $\S$ $4^{\circ}$ É vedado, a qualquer tempo, ao Presidente e aos Conselheiros utilizar informações privilegiadas obtidas em decorrência do cargo exercido".

\footnotetext{
${ }^{365}$ Benedetto, L'Autorità garante della concorrenza e del mercato, p. 358. A independência pessoal deve existir em relação aos grupos de pressão e grupos econômicos, com destaque para a exclusividade e o problema dos serviços de consultoria após o término do mandato - "nulla potrebbe obiettarsi circa la legittimità di tale scelta, se non fosse che questa prospettiva personale potrebbe astrattamente condizionare il comportamento del singolo comissario nella direzione di una captatio benevolentiae delle imprese, rendendo possibile la paventata cattura dell'Autorità da parte dei gruppi economici” (idem, p. 97)

${ }^{366}$ Benedetto, L'Autorità garante della concorrenza e del mercato, p. 136-137.
} 
A quarentena já é uma praxe no Poder Judiciário. A Emenda Constitucional n. 45 trouxe a redação do art. 95, par. ún. Inc. V, que veda ao magistrado "exercer a advocacia no juízo ou tribunal do qual se afastou, antes de decorridos três anos do afastamento do cargo por aposentadoria ou exoneração". A determinação é adequada porque coerente com a concessão da aposentadoria e (garantia de remuneração) e restringe a atuação somente sobre a zona de influência do magistrado aposentado ou exonerado, considerando ainda que são diversos os foros e instâncias que permitem a atuação de um advogado.

Três anos perante um determinado foro ou Tribunal do Poder Judiciário não representam grande cerceamento da atividade profissional. Porém, perante o CADE, único tribunal administrativo da Federação em matéria concorrencial, os três anos representariam um excesso. Ainda assim, a regra se impõe como medida de moralização da atividade, mas não deve ser importada ao modelo concorrencial sem ressalvas. Se essa moralização exige algum afastamento de seus pares, teríamos alguns marcos relevantes de afastamento: o prazo de quatro anos (mandato máximo de Conselheiros, período em que presente contemporâneos de Plenário), demasiadamente excessivo, sem par em relação ao Poder Judiciário e excessivamente restritivo de um direito constitucional ao trabalho; o prazo de 3 anos, fixados em emenda constitucional, que poderia ser interpretado analogamente aos tribunais administrativos, mas que pelas particularidades no SBDC acima expostas não pode ser aceito como adequado; o prazo de dois anos (mandato mínimo de Conselheiros), pressupondo alguma renovação, mas que pode ser considerado alto para aquele que sai (o Conselheiro) e para quem paga (o Estado); o prazo de seis meses do Código de Ética do CADE ou o prazo de quatro meses do Projeto de Lei, ambos mais modestos, sem referência a qualquer critério objetivo que pudesse ratificar a sua adequação.

Seguindo a linha do que foi dito acima, seria necessário um estudo sobre a zona de influência dos Conselheiros para apurar a rotatividade de gestores em gabinetes e em organismos vinculados à presidência, de forma a encontrar algum prazo razoável entre os limites máximo e mínimo acima expostos, que fica como sugestão. Esse mecanismo certamente funcionaria como um reforço de legitimidade institucional da imparcialidade dos julgamentos feitos pelo órgão. 


\section{VI.1.7. Extensão da imparcialidade: o SBDC}

É natural que a preocupação com a imparcialidade seja destinada usualmente ao CADE e seus Conselheiros, julgadores por essência. Mas exigências de imparcialidade, isenção, equilíbrio, ética, moralidade, respeito à legalidade, por óbvio, se estendem a todos os participantes do SBDC, funcionários públicos de carreira, em cargo de comissão, contratados, Conselheiros, gestores, todos aqueles que de alguma forma participam da atividade meio e atividade fim.

Destacam-se apenas alguns casos especiais e particulares ao SBDC. O Secretário de Direito Econômico do Ministério da Justiça, hoje, nos termos do art. 13 da Lei n. 8.884/94 é indicado pelo Ministro da Justiça, nomeado pelo Presidente da República e deve ostentar notório saber jurídico ou econômico e ilibada reputação. Repetindo argumentos anteriormente expendidos, a SDE exerce relevante papel no sistema, atuando de tempos em tempos como órgão efetivamente judicante, na medida em que, por exemplo, decide "em primeiro grau" pelo arquivamento de averiguações preliminares, determina a realização de inspeções judiciais, decide sobre pedidos de confidencialidade e realização de provas. Nesse mister, as considerações tecidas no item acima sobre o reforço institucional do sistema por meio da revisão dos critérios de seleção para o cargo, à luz das particularidades do SBDC, são repetidas em relação ao Secretário.

Reconheço um desconforto maior em relação a essa hipótese, por se tratar de um órgão político, responsável ainda por outros departamentos distintos do DPDE e que não adentram no estudo específico a que se destina o presente trabalho. Por isso, vem bem a calhar a proposta do Projeto de Lei que altera o SBDC, pelo qual a SDE é incorporada ao CADE, transforma-se em superintendência da autarquia. $\mathrm{O}$ art. 12, par. $1^{\circ}$, do Projeto de Lei acaba aproximando os requisitos para a indicação do Superintendente aos requisitos atuais dos Conselheiros do CADE ("O Superintendente-Geral será escolhido dentre cidadãos com mais de 30 (trinta) anos de idade, notório saber jurídico ou econômico e reputação ilibada, nomeado pelo Presidente da República, depois de aprovado pelo Senado Federal") - o que é uma evolução, mas ainda não satisfaz de forma completa a orientação destinada à consecução do escopo social. 
O mesmo pode ser dito em relação ao Procurador-chefe do CADE, hoje indicado pelo Ministro da Justiça, aprovado pelo Senado e nomeado pelo Presidente dentre brasileiros de notório conhecimento jurídico.

\section{VI.1.8. Escopo educativo do processo}

O processo instrumentalista tem também o escopo de educar, de conscientizar os membros da sociedade para direitos e obrigações, combater a desinformação e a descrença do brasileiro. Nas teorias pedagógicas, são vários os modelos expostos: a dogmática tradicional; o construtivismo de Piaget (e o questionamento das respostas); o auxílio adequado e oportuno para quem consegue aprender naturalmente de Montessori; o estímulo da capacidade de criação e expressão mediada, afastada de dogmas de Freinet; os statements etários de Waldorf; o estímulo de talentos de Gardner. Algo dessas lições pode ser transposto para este estudo.

Mas o antecedente deve ser a informação da existência do direito antitruste. A população ainda tem um conhecimento limitado sobre a atividade do CADE. O órgão nunca foi uma ferramenta de busca de sítios e internet, tampouco uma sociedade civil de natureza privada que realiza a arrecadação e distribuição de direitos autorais decorrentes de execução pública de músicas. Para combater a desinformação, o SBDC se vale de assessorias de imprensa, com propósitos capilarizadores, bem como um sítio de internet cujo propósito é facilitar o acesso às notícias, aos processos e a legislação sobre a matéria. ${ }^{367}$ Os conselheiros e demais membros com freqüência viajam o Brasil para expor em palestras o que significa concorrência, como as condutas anticoncorrenciais podem prejudicar o desenvolvimento econômico e o consumidor e o que cada um pode fazer para auxiliar em seu combate. A SDE e o CADE disponibilizam cartilhas de fácil acesso e leitura para expor o funcionamento do SBDC, os casos mais importantes e as condutas anticoncorrenciais escolhidas como prioridades de combate. Até mesmo história em quadrinhos elaborada por renomado desenhista brasileiro já expuseram o que é uma conduta anticoncorrencial.

\footnotetext{
${ }^{367}$ Há notícia inclusive de gestores do CADE que se valem de blogs para exposição de conceitos decididos em julgamentos do CADE.
} 
Há uma preocupação relevante sobre medidas de advocacia da concorrência, no interrelacionamento do SBDC com outros órgãos pertencentes ao próprio governo $^{368}$, na interface entre regulação e concorrência. ${ }^{369}$ Porém, em algumas situações, a preocupação excessiva com a educação não guarda o equilíbrio devido com o escopo jurídico (a atuação da vontade concreta da lei), amparado por resquício discricionário que possa conduzir a equívocos na interpretação da vertente educativa do processo. Existem casos em que houve a substituição do prosseguimento de averiguação preliminar pela adoção de medidas de advocacia da concorrência, numa referência clara ao custo benefício da instauração do processo administrativo. ${ }^{370}$ Suprimiu-se a atividade persecutória com base em cognição não exauriente porque o sistema deveria preocupar-se com violações mais prováveis. São dois os equívocos de premissa: a atividade do CADE é vinculada e os indícios insuficientes em averiguação preliminar podem e devem ser investigados com maior profundidade em sede de Processo Administrativo - na dúvida entre investigar e não investigar é preciso insistir; as medidas de advocacia da concorrência são complementares, mas não substitutivas ao alvitre do julgador. ${ }^{371}$

$\mathrm{O}$ ocorrido indica tão somente que a leitura dos escopos do processo jamais pode ser feita de forma compartimentalizada. A atividade administrativa judicante que consiste em reprimir condutas anticoncorrenciais está situada no âmbito da administração pública judicante como um poder-dever-função do Estado. É o reforço do

368 “(i) Auxiliando o ministro de Estado da Fazenda em conselhos governamentais de setores regulados44; (ii) participando de fóruns nacionais e internacionais envolvendo barreiras comerciais; e (iii) opinando sobre propostas de regras regulatórias que possuem impacto na concorrência". Para estudo bastante interessante sobre o tema, confira-se o texto de Carlos Emmanuel J. Ragazzo, "Análise Econômica da Regulação: O Papel da Advocacia da Concorrência", in http://escholarship.org/uc/item/6k0688wp\#.

369 Sobre a questão, cfr. José Antonio Batista Ziebarth, Tendências da advocacia da concorrência contemporânea: um debate sobre a atuação do cade nos espaços e limites entre concorrência e regulação, 2006, no prelo.

${ }^{370}$ CADE, AP n. 08012.005994/2004-65.

${ }^{371}$ Defende-se algo distinto do que ocorre na Itália. Na península, o arquivamento de um procedimento pode ser feito pela AGCM por meio de simples considerações de eficiência da ação administrativa, coisa que o juiz está impedido de fazer em razão das garantias constitucionais da ação. Tal conduta da AGCM não seria comparada, portanto, à extinção do processo sem julgamento do mérito tal qual ocorre perante a jurisdição. $\mathrm{Na}$ relação entre o acesso à justiça e o princípio de economia processual, afirma-se que o juiz não tem discricionariedade para julgar ou deixar de julgar um pedido de quem pede justiça, mas faz referência à obra de Schonk com descreve o conceito de interesse de agir e a idéia de que ao juiz é consentido rejeitar a tutela requerida quando a modéstia dos interesses em jogo não justificam o dispêndio da atividade jurisdicional (Negri, Giurisdizione e amministrazione nella tutela della concorrenza, p. 42-43, nota 131). Algo semelhante ocorre perante a FTC: o Bureau of Competition, com o concurso do Bureau of Economics, é competente para um case selection de casos relevantes. Afirma-se que a FTC tem discricionariedade para não instaurar processo administrativo (Benedetto, L'Autorità garante della concorrenza e del mercato, p. 216 e 228). Neste trabalho, entende-se que o Brasil ainda vive estágio de maturação que demanda mais cautela na suspensão da perquirição por motivos não estritamente jurídicos, permeados pela fluidez que a "modéstia" e a "relevância" sugerem. 
mecanismo, sua utilização freqüente, que provocará a atenção dos operadores e do Estado para a necessidade de um incremento estrutural para a o exercício desse poder-dever, ao contrário do repudiado conformismo da utilização do mecanismo de acordo com as possibilidades. A premência e a necessidade funcionam como relevante catalisador de vontades e busca de soluções eficientes. A acomodação, ao contrário, dificilmente levará ao crescimento estrutural e o desenvolvimento da atividade antitruste no Brasil. Este ponto deve ser inclusive lido também com os olhos do item V.2.2. infra, quando se trata de participação e do acesso ao SBDC.

Seguindo, também os operadores do direito dominam pouco do antitruste. A matéria não faz parte da grade tradicional das universidades de direito e não são raros os casos de cursos de direito que sequer disponibilizam o direito econômico como opcional em sua grade. Nesse sentido, é exaustivo o esforço do CADE na realização de projetos como o CADE - Universidades e a realização de convênios para palestras, criação de grupos de pesquisa, para a divulgação no meio acadêmico de sua atividade. ${ }^{372}$

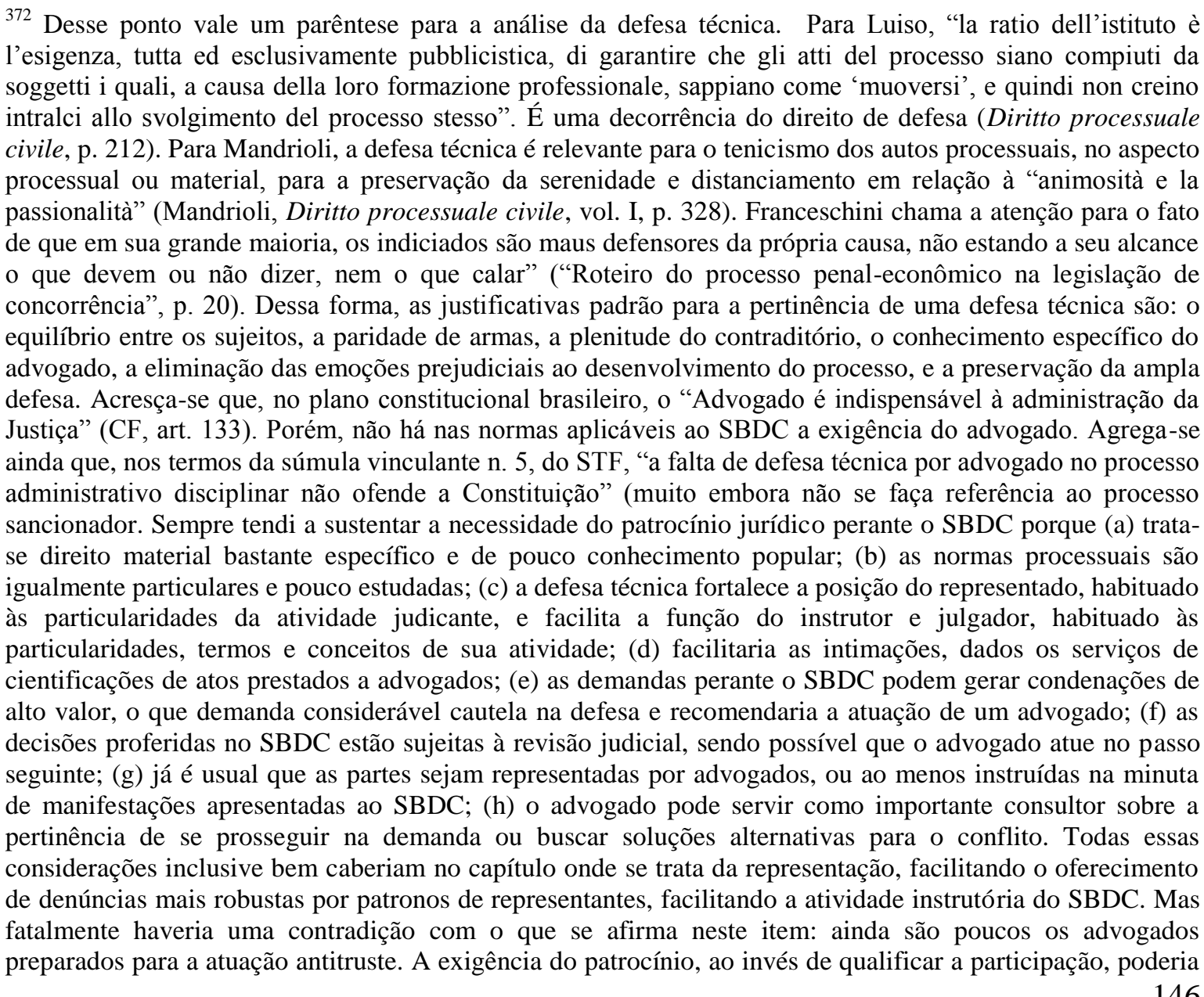


Superado o conhecimento como antecedente, é preciso pensar em como desenvolver formas de se utilizar do processo como forma de educação. ${ }^{373}$

\section{VI.1.9. A educação pela pena e as decisões condenatórias}

Bruno Cavallone, em suas aulas na Universidade de Milão, utiliza freqüentemente como recurso didático a comparação de aspectos processuais com fábulas e contos. Em seu artigo sobre Pinocchio e a função educativa do processo, cita episódio em que o protagonista denuncia dois malandros por um furto e acaba preso após julgamento na cidade de Acchiappacitrulli, em um sistema jurídico paradoxal. Pinocchio teria sido induzido a plantar moedas para que assim crescesse uma árvore plena de outras moedas e ficou fascinado pela idéia do ganho fácil. O juiz determina a prisão do boneco, exatamente por se sensibilizar com sua história e com sua necessidade de aprendizado. Diante dessas considerações, o autor traça um paralelo com o sistema judiciário soviético e seu declarado escopo de educar os cidadãos no espírito de devoção à pátria mãe, ao comunismo, no respeito à lei, à propriedade social, à disciplina do trabalho, à honestidade. O processo teria então a conotação de orientação mental e psicológica. ${ }^{374}$

A idéia de poder pode é complementada com a de sanção como recompensa, invalidade, ineficácia de ato, reparação pecuniária, agravamento de obrigações e até a punição física. Já a coercibilidade é a capacidade física da execução. ${ }^{375}$ 376

A psicologia da pena é fundamentada na retribuição ou reação opressiva ao alarme social (a revanche pela projeção do prejuízo causado). Outras teorias são mais

\footnotetext{
se tornar um impedimento, razão pela qual, no atual estado da arte, sustenta-se aqui a manutenção da dispensa do patrocínio obrigatório em demandas perante o SBDC.

373 Uma ressalva: parcela pedagógica correspondente à idéia de ensinar os administrados sobre as possibilidades de utilização do SBDC (a correlação entre o acesso à Justiça e o acesso ao SBDC) guarda também correlação mais incisiva em relação ao escopo político do processo, razão pela qual ali será analisada.

${ }^{374}$ Cavallone, "Pinocchio e la funzione educativa del processo", pp. 133 e ss.

${ }^{375}$ Dinamarco, A instrumentalidade do processo, pp. 126 e 129.

376 Perante a jurisdição, "se il soggetto obbligato no si attiva nel senso voluto dall'ordinamento, deve intervenire una diversa forma di tutela giurisdizionale che, sul presupposto della omissione di un comportamento positivo, garantisca la soddisfazione della situazione sostanziale, per la realizzazione della quale è previsto l'obbligo di tenere quel comportamento. La tutela in questione è impartita attraverso l'attività giurisdizionale esecutiva che si articola in due forme: la esecuzione forzata in senso proprio e l'esecuzione indiretta" (Luiso, Diritto processuale civile, pp. 16-17).
} 
adaptadas àquela função educativa do processo que informa e ensina: a função éticopedagógica da pena, amparada na idéia farmacológica do caminho em direção do bem (o per crucem ad lucem), que associada à função intimidatória (estímulo efetivo à dissuasão de condutas ilícitas), reforça o sistema deôntico por meio de mensagens positivas de assertividade. $^{377}$

No direito antitruste, identificada uma infração da ordem econômica, a lei n. 8.884/94 (v. arts. 23-26) estabelece que a empresa e seus dirigentes e administradores podem se sujeitar a (i) multas fixas ou diárias calculadas com base no faturamento bruto da empresa no último exercício ou em patamares pré-estabelecidos, (ii) a publicação da decisão que reconhece a infração em jornais, (iii) a proibição de contratação com instituições financeiras oficiais e participação de licitação tendo por objeto aquisições, alienações, realização de obras e serviços, concessão de serviços públicos, junto à Administração Pública Federal, Estadual, Municipal e do Distrito Federal, bem como entidades da administração indireta, por prazo não inferior a cinco anos; (iv) a inscrição no Cadastro Nacional de Defesa do Consumidor, (v) a recomendação a órgãos públicos de concessão de licenças compulsórias de patentes, a não concessão de parcelamento de tributos, o cancelamento de incentivos fiscais. Todas essas formas de penalização estão em consonância com a função educativa. Não se pretende aqui apontar qual das teorias jurisfilosóficas da pena é a mais correta para justificar os sistemas deônticos da lei n. $8.884 / 94 .^{378}$

Proferida a decisão e fixada a pena, até pouco tempo, o acompanhamento do cumprimento era realizado pela Comissão de Acompanhamento de Decisões - CADCADE. Por determinação do Plenário, a CAD-CADE foi extinta pela Resolução CADE n. 53/2009 (com respectiva alteração do Regimento Interno) e as atribuições foram transferidas à ProCADE (ao chamado SCD - Setor de Cumprimento de Decisões), como

377 Costa Júnior, Comentários ao Código Penal, pp. 139-143; Carnelutti, Cuestiones sobre el proceso penal, p. 394.

${ }_{378}$ Apenas como parênteses, retomo brevemente a discussão sobre a natureza do processo administrativo de apuração de conduta. Falar sobre pena pode conduzir o leitor a uma falsa impressão de que o processo seria penal. Em outra oportunidade, sustentei que em razão de middlegrounds between civil e criminal law, os critérios de diferenciação baseados na gravidade do ilícito, gravidade da punição, natureza da punição seriam insuficientes para esclarecer a diferença entre as duas ciências. São inúmeras as situações civis (e administrativas) em que são aplicadas penas, sem que por isso o processo seja penal. O critério mais adequado seria então definir como penal a conduta típica, o que não é o caso (Cfr. Burini, Efeitos civis da sentença penal, nn. 5 e 6 . Confira-se ainda Mann, "Punitive civil sanctions: the middleground between criminal and civil law", 1992, passim). 
medida destinada a atribuir maior celeridade "no emprego dos diversos instrumentos administrativos e judiciais de execução forçada das decisões do CADE, mediante o aumento do conhecimento técnico de cobrança e a eliminação de etapas redundantes e burocráticas, racionalizando os escassos recursos humanos e materiais da autarquia". É essa Procuradoria o órgão responsável por atestar ou não cumprimento das decisões, tomando de plano as medidas destinadas ao seu enforcement.

Com o cumprimento voluntário das obrigações pecuniárias e a efetivação das medidas mandamentais e executivas lato sensu, o CADE esgota sua atividade administrativa. Os valores recolhidos são revertidos ao Conselho Federal Gestor do Fundo de Defesa de Direitos Difusos - CFDD, da Secretaria de Direito Econômico do Ministério da Justiça, que em reuniões periódicas definirá a destinação dos valores arrecadados. ${ }^{379}$

Se as obrigações não são cumpridas espontaneamente, os autos são remetidos à Procuradoria do $\mathrm{CADE}{ }^{380}$ Caso contrário, devem ser utilizados mecanismos (usualmente de coerção, pressão psicológica e subrogação) destinados ao adimplemento da obrigação descumprida.

Os grandes expoentes de penalização constante das condenações estão nas multas e nas obrigações de fazer e não fazer. Nesses casos, “a decisão do Plenário do CADE, cominando multa ou impondo obrigação de fazer ou não fazer, constitui título executivo extrajudicial". Títulos, como se sabe, são "os fatos aos quais o ordenamento jurídico confere aptidão a tornar adequada cada espécie de processo e de provimento jurisdicional. Já o título executivo é "o ato ou fato jurídico legalmente dotado da eficácia de tornar adequada a tutela executiva para a possível satisfação de determinada pretensão". 381

\footnotetext{
${ }^{379}$ Fundo de Defesa de Direitos Difusos (FDD) é um fundo de natureza contábil, vinculado à Secretaria de Direito Econômico do Ministério da Justiça. Criado pela Lei $n^{\circ}$ 7.347, em 24 de julho de 1985, tem como objetivo a reparação dos danos causados ao meio ambiente, ao consumidor, a bens e direitos de valor artístico, estético, histórico, turístico, paisagístico, bem como aqueles ocasionados por infração à ordem econômica e a outros interesses difusos e coletivos. "O Conselho Federal Gestor do Fundo de Defesa de Direitos Difusos (CFDD), responsável pela administração dos recursos, é composto por representantes dos ministérios da Justiça, Meio Ambiente, Cultura, Saúde, Fazenda, Ministério Público Federal, Conselho Administrativo de Defesa Econômica (Cade) e três entidades civis" (Brasil. Conselho Federal Gestor do Fundo de Defesa de Direitos Difusos. Balanço social FDD - Fundo de Defesa de Direitos Difusos 2007/2008. - Brasília: Ministério da Justiça/ CFDD, 2009, p. 17).

${ }^{380}$ Existe a possibilidade de o Ministério Público promover a execução, mas isso não é utilizado. Questionase constitucionalidade, pela vedação ao Ministério Público de representação judicial de entidades públicas (CF, art. 129, inc. IX).

${ }^{381}$ Dinamarco, Execução civil, pp. 430 e 474. Ou ainda, nas palavras de Enrico Tullio Liebman, o título executivo "é fonte imediata, direta e autônoma da regra sancionadora e dos efeitos jurídicos dela
} 
Esse ato ou fato jurídico demonstra que tão alto é o grau de probabilidade da efetiva existência do direito do exequiente, que o ordenamento jurídico se satisfaz com a prevalência do direito de uma parte sobre a outra para autorizar medidas coercitivas ou de subrogação sobre a esfera de direito do executado, de modo a atuar a vontade concreta da lei a sedimentar a pacificação da situação de stress social decorrente de uma injustiça.

Os títulos executivos judiciais ordinariamente decorrem de decisões que debelam uma crise de certeza e agregam a determinação do cumprimento da obrigação sob pena de execução. Atualmente, o cumprimento da obrigação é feita dentro de uma mesma relação processual, sem a necessidade de iniciar-se um novo processo executivo - são os frutos das reformas processuais que deram redação aos arts. 461 e 461-A (para as obrigações de fazer, não fazer e entrega de coisa) e aos art. 475-J (para as obrigações de pagamento de quantia certa). Assim, se a execução era feita ex intervallo, hoje se fala de um processo sincrético.

Porém, é importante dizer que nem todos os títulos judiciais têm amparo em decisões proferidas em um mesmo processo. São casos, por exemplo, da sentença penal condenatória e da sentença arbitral, proferidas em processos de natureza jurisdicional, ${ }^{382}$ trazidas para a esfera civil para serem executadas por "um processo autônomo, de cunho cognitivo, declaratório (diante de uma condenação genérica) e necessário para a tomada de qualquer medida executiva (o cumprimento de sentença)". 383

Por sua vez, há o título executivo extrajudicial fundado em ato estranho a processos jurisdicionais, que a lei toma como "fato jurídico ao agregar-lhe, ela própria, uma eficácia executiva não negociada pelas partes, não incluída no negócio e que, ainda quando

decorrentes. A eficácia abstrata reconhecida ao título é que explica seu comportamento na execução; aí está o segredo que torna o instrumento ágil e expedito capaz de permitir a realização da execução sem depender de qualquer nova demonstração da existência do crédito" (Processo de execução, pp. 38-39).

${ }^{382}$ Não é objeto deste trabalho a discussão da natureza do processo arbitral. Para a discussão, v. Carlos Alberto Carmona, Arbitragem e processo: um comentário à lei n. 9.307/96, $2^{\mathrm{a}}$ ed., São Paulo, Atlas, 2004, caps 1 e 2 .

${ }^{383}$ Conforme afirmei em outra sede (Efeitos civis da sentença penal, n. 16.1). Confira-se também a lição de Yarshell, para quem "quando a lei exige a citação do réu, só se pode e se deve entender que assim o faz porque não houve, com efeito, uma procedente atividade cognitiva em um mesmo processo, a ensejar, dessa forma, uma mera 'fase executiva'. Atividade cognitiva há, mas em outro processo. Dai porque é necessário 'citar' e instaurar um novo processo que, contudo, nem por isso precisa deixar de se submeter às regras de cumprimento da sentença. Não se pode, em outras palavras, extrair da exigência de citação - que mais decorre da natureza das coisas do que de qualquer outra razão - a adoção de um regime que, a rigor, deixou de existir, somente vigorando - aí sim por disposição expressa - para a Fazenda Pública (...)" (“Cumprimento da sentença arbitral: análise à luz das disposições da lei 11.232/2005”, pp. 193-194). 
ali houvesse alguma disposição nesse sentido, teria sempre apoio na lei e não na vontade das partes (a tipicidade legal dos títulos executivos)". ${ }^{384}$

A despeito da reafirmada natureza quase jurisdicional das decisões proferidas pelo CADE e dos argumentos que aproximam essa atividade judicante da função jurisdicional, a lei n. 8.884/94 determina que a cominação de multa ou obrigação de fazer ou não fazer imposta pelo colegiado do CADE é título executivo extrajudicial. Assim, "as cobranças pecuniárias (multas) processam-se como as execuções fiscais (art. 18). No tocante às obrigações de conduta, há naquela lei especial uma disposição equivalente à do art. 461 do Código de Processo Civil (lei cit., art. 62), mas é óbvio que não se pode realizar uma execução imediata com fundamento em decisões desse órgão administrativo, pela simples razão de que elas não são proferidas em um processo judicial e, conseqüentemente, não há um processo judicial a ser continuado; é necessário portanto instaurar um processo executivo autônomo por obrigação de fazer ou de não-fazer, na forma do disposto nos arts. 632 do Código de Processo Civil”. ${ }^{385}{ }^{386}$

É que "na execução administrativa, legitimada pelo princípio da autoexecutoriedade dos provimentos da Administração, bem como nos atos administrativos de natureza constitutiva, reside o mesmo grau de imperatividade que em seus congêneres jurisdicionais e o que os difere destes é a ausência do final enforcing power: trata-se de atos estatais lá e cá, e a censurabilidade dos primeiros em via jurisdicional, como garantia inerente ao Estado-de-direito (princípio da inafastabilidade do controle jurisdicional), é somente um elemento de equilíbrio entre os 'Poderes' do Estado, para a salvaguarda da integralidade da pessoa humana e seus predicados constitucionalmente resguardados". 387

\footnotetext{
${ }^{384}$ Dinamarco, Instituições de direito processual civil, vol. IV, n. 1.480.

${ }^{385}$ Dinamarco, Instituições de direito processual civil, vol. IV, n. 1.518.

386 Da experiência italiana, vale a nota de que a AGCM tem poderes para medidas de cunho executivo, podendo valer-se da atividade da Guarda di Finanzia "che agisce con i poteri ad essa attribuiti per l'accertamento dell'imposta sul valore aggiunto e dell'imposta sui redditi”. A Guardia di Finanzia conta com um Centro tutela concorrenza e mercato, com poderes de imposte dirette e de imposta sul valore aggiunto. Há um protocollo d'intesa entre a AGCM e a Guardia, segundo o qual esta última exerce funções de: colaboração na atividade investigativa, elaboração de relatórios sobre setores econômicos e outros dados probatórios e organização de cursos de formação. A nota interessante nesse aspecto é que, conforme afirma Benedetto, "rispetto alle corrispondenti attività motivate da ragioni fiscali, lo svolgimento di attività ispettive nel settore della tutela della concorrenza e del mercato è normalmente meno invasivo e meglio tolerato", o que é atribuído ao princípio "di non utilizzabilità dei dati (...) anche nei riguardi delle pubbliche amministrazioni”. Sem prejuízo, a execução das multas é feita na forma de execução fiscal. Complementar (Benedetto, L'Autorità garante della concorrenza e del mercato, pp. 259-260).

${ }^{387}$ Dinamarco, A instrumentalidade do processo, p. 116.
} 
Se compararmos a decisão do plenário do CADE com, por exemplo, o contrato assinado pelas partes e duas testemunhas, encontraremos a semelhança no fato de que são títulos executivos extrajudiciais, típicos conforme a lei e que viabilizam a propositura de execução judicial tal qual previsto em diplomas processuais - lembrando-se, porém, que em relação ao CADE, para as multas, o trâmite é o estabelecido pela lei $\mathrm{n}$. 6.830/80, que rege a execução fiscal; já a execução do cumprimento de obrigação de fazer ou não fazer segue o trâmite estabelecido nos arts. 632 e ss. e 461 do Código de Processo Civil. A entrega da tutela jurisdicional estabelecida na lei está em consonância com os predicados da tutela específica, não convertida em perdas e danos (arts. 60-68). ${ }^{388}$

A sutileza está em crer em certa especificidade desse título executivo diante do seu processo de formação. Trata-se de um ato oriundo de processo administrativo, agregado a um dado específico: parte-se nesse trabalho da submissão das decisões do CADE à lei, restringindo-se o âmbito de "discricionariedade" tal que pudesse impedir a revisão judiciária. Mas se a premissa não for acolhida, o mérito das decisões proferidas pelo CADE poderia ser tido por inquestionável perante o Poder Judiciário (conforme brevemente debatido acima). O efeito prático dessa constatação está no fato de que as decisões do CADE seriam capazes de oferecer tutela se agregadas a um processo autônomo executivo cujo mérito da condenação não poderia ser discutido em toda sua abrangência em sede de embargos - limitando-se a interpretação do art. 745, inc. V, do CPC e do art. 16 , §2 $2^{\circ}$, da lei n. $6.830 / 80 .^{389}$

Assim, é legitima a discussão de que a decisão de cunho condenatório proferida pelo plenário do CADE, no exercício de função administrativa judicante, de per si, não tem o condão de oferecer uma tutela plena na direta defesa institucional e reflexa defesa dos consumidores - da mesma forma que outros processos igualmente jurisdicionais. Porém, se agregada à atividade jurisdicional, produz sensações positivas que, ao menos reflexamente, serão sentidas por indivíduos, dentro de uma perspectiva dogmática retributiva de penalização.

\footnotetext{
${ }^{388}$ Confira-se ainda sobre o tema a Resolução n. 40 do CADE.

${ }^{389}$ Contrariando a idéia de que "Quer nas execuções por quantia ou por obrigação de fazer ou de não-fazer, os embargos do executado terão a amplitude permitida pelo art. 745 do Código de Processo Civil, porque se trata de títulos extrajudiciais; na medida em que os atos administrativos comportam controle jurisdicional, o mérito da decisão do Cade pode ser questionado nesses embargos" (Dinamarco, Instituições de direito processual civil, vol. IV, n. 1.518).
} 
Diante, v.g., da cartelização, a atuação do CADE é destinada a impedir a continuação dessa conduta - obrigação de não fazer - sob pena de sanção e de medidas que serão atuadas por meio do binômio função administrativa judicante/atuação jurisdicional. Assim, negar os benefícios trazidos aos consumidores é limitar o entendimento a uma tutela de direitos sem reflexos diretos perante sujeitos de direito, o que não parece completo e limita a compreensão do sentido da tutela.

Mas note-se: de fato, no exercício da função administrativa judicante, o CADE exerce apenas o poder coercitivo, mas não o subrogatório para o cumprimento de decisões, precisando valer-se do Poder Judiciário para efetivar seus comandos. Dessa forma, é inegável que em determinadas situações, a tutela oferecida pelo CADE não é plena e a função educativa das suas decisões não se exaure em si própria. ${ }^{390}$

Tais considerações levam a crer que, de fato, o CADE em sua função administrativa judicante não possui instrumentos para, em todas as hipóteses, fazer cumprir seus comandos de forma autônoma e independentemente do auxílio do Poder Judiciário. Falta-lhe a coercibilidade, a capacidade física da execução. ${ }^{391}{ }^{392}$ A certeza da punição que atribui aquela intimidação como elemento importante na penalização, que se agrega às funções ético-pedagógicas e retributiva para compor o cenário penalizador das decisões do CADE.

\section{VI.1.10. A educação construtivista e as formas de composição de interesses}

Educação está também relacionada com o um processo de construção mútua, de um aprendizado constante das partes em prol da instituição da concorrência. Se é

\footnotetext{
${ }^{390}$ Em relação ao passado, os danos aos consumidores decorrentes de tal conduta não serão objeto de tutela perante o CADE - ou seja, o CADE não indeniza sujeitos lesados por condutas anticoncorrenciais. Nessas situações, há a necessidade do indivíduo valer-se da atuação jurisdicional individual ou dos instrumentos disponíveis à tutela de interesses transindividuais, por meio de entes de representatividade adequada: "no campo processual, através das formas tradicionais de tutela individual, há a já mencionada ação coletiva para a proteção de interesses individuais homogêneos. Assim, toda vez que for possível demonstrar que do ato anticoncorrencial decorreu prejuízo a um grupo identificável de consumidores será possível a qualquer associação de defesa dos consumidores promover a demanda (art. 82, inc. IV, c/c o art. 91, do CDC)”, (Salomão Filho, Direito concorrencial - as condutas, p. 85).

${ }^{391}$ Dinamarco, A instrumentalidade do processo, pp. 126 e 129.

392 Perante a jurisdição, "se il soggetto obbligato no si attiva nel senso voluto dall'ordinamento, deve intervenire una diversa forma di tutela giurisdizionale che, sul presupposto della omissione di un comportamento positivo, garantisca la soddisfazione della situazione sostanziale, per la realizzazione della quale è previsto l'obbligo di tenere quel comportamento. La tutela in questione è impartita attraverso l'attività giurisdizionale esecutiva che si articola in due forme: la esecuzione forzata in senso proprio e l'esecuzione indiretta" (Luiso, Diritto processuale civile, pp. 16-17).
} 
possível estabelecer algo entre Piaget e Freinet, reconheça-se que um processo construtivo mediado, estimulado pela Administração, tem profunda influência sobre os patamares de educação para a concorrência que se pretende atingir.

O SBDC tem procurado formas alternativas para implementar seus comandos de modo que a decisão e a informação seja melhor captada pelos receptores, que o mal seja reparado, que as partes compreendam seu equívoco e que evitem a sua reprodução.

Uma primeira forma de educação por meio de processo interativo resulta da própria estrutura do SBDC, aliada à natureza da matéria e ao volume de processos apreciados. Se comparado com o processo jurisdicional, o número de casos examinados pelos Conselheiros é bastante inferior, o que permite uma análise mais cuidadosa do Gabinete, votos mais bem fundamentados (em casos de maior complexidade, são raros os votos de relator inferiores a 10, 20 laudas) mas, principalmente, um contato entre administrador e administrado superior ao havido entre juiz e jurisdicionado. Há uma substancial distinção qualitativa entre a comunicação havida entre os sujeitos em reuniões agendadas com gestores, Diretores, Secretários e Conselheiros do SBDC e os comuns despachos de advogados com juízes. No primeiro caso, o aproveitamento da interação recíproca é efetivo, no segundo, há menor intensidade. ${ }^{393}$ Quanto maior a interação, a decisão construída torna-se de mais palatável aceitação. ${ }^{394}$

Outra forma construtivista está, por exemplo, nas discussões para a elaboração de um termo de compromisso de cessação.

\footnotetext{
${ }^{393}$ Reconhece-se o perigo da afirmação. Não há estudo duplo cego, multicêntrico e randômico que comprove a assertiva. A afirmação é feita com base em alguma experiência empírica, sujeita a questionamento.

${ }^{394}$ Está também é uma afirmação passível de questionamento. Ela chega a ser romântica, quase idealista, diante do fato de que os advogados são extremamente criativos, os clientes ordinariamente não são conformados em casos de derrotas, o sistema, como visto, admite ampla revisibilidade e os advogados raramente são punidos por insistir em teses "menos ortodoxas". O homem de Hobbes, o fragmentado homo economicus, todos eles se servem um pouco da autodestruição de Freud: "A questão fatídica para a espécie humana parece-me ser saber se, e até que ponto, seu desenvolvimento cultural conseguirá dominar a perturbação de sua vida comunal causada pelo instinto humano de agressão e autodestruição. Talvez, precisamente com relação a isso, a época atual mereça um interesse especial. Os homens adquiriram sobre as forças da natureza um tal controle, que, com sua ajuda, não teriam dificuldades em se exterminarem uns aos outros, até o último homem. Sabem disso, e é daí que provém grande parte de sua atual inquietação, de sua infelicidade e de sua ansiedade. Agora só nos resta esperar que o outro dos dois 'Poderes Celestes' ver, o eterno Eros, desdobre suas forças para se afirmar na luta com seu não menos imortal adversário. Mas quem pode prever com que sucesso e com que resultado?” (Freud, “O mal estar na civilização”, p. 174).
} 
As soluções negociadas têm sido incentivadas no âmbito processual, como forma eficaz de solução de conflitos. É importante que legislador e Administração criem os denominados palcos de conciliaçãoo ${ }^{395}$, em que as partes possam estabelecer frutífero diálogo e a eliminação autocompositiva do processo. ${ }^{396}$

Esses palcos se coadunam com a perspectiva da terceira onda renovatória de Garth e Capelletti, com a busca de soluções alternativas à jurisdição para a solução de conflitos. Eles fazem referência ao "Modelo de Stuttgart", que estabelece que um diálogo oral e ativo entre os envolvidos acelera o procedimento e promove decisões que as partes compreendem e aceitam sem recorrer. Em última instância, a conciliação é a gênese do raciocínio, como alternativa de solução rápida, mediada, cuja solução promove relacionamento complexo e prolongado, como se observou, ainda que em analogia imperfeita, na tradição das Cortes de conciliação japonesas, nos centros de justiça de vizinhança nos Estados Unidos, nos conciliadores franceses, nos tribunais populares chineses, do Nyaya Panchat indiano e em cortes socialistas especialistas, destinadas a moldar relações interpessoais adequadas. ${ }^{397}$

No plano mais amplo, "para Habermas (...) o consenso social é o primeiro elo na cadeia da formação da vontade coletiva e base da legitimação. Ele pode ser considerado como o resultado de uma procura de legitimação, elo terminal na cadeia de produção de lealdade das massas de que o sistema político se provê para livrar-se das restrições que lhe impõe o mundo da vida (...) toda comunicação tende ao entendimento, compartilhando expectativas, pois o que se busca, em última instância, é o acordo". Na concepção mais restrita, a aplicação coercitiva é substituída pelo intuito de satisfação do desejo capaz de produzir uma melhor qualidade de vida aos envolvidos em um conflito. ${ }^{398}$

$\mathrm{Na}$ jurisdição, o consenso ganha progressivamente sua força. É o exemplo dos Juizados de pequenas causas, com especial destaque para as audiências prévias de conciliação previstas tanto cível quanto penalmente, conduzidas por conciliadores (parajurídicos, Rechtspfleger, Mackenzie men) ${ }^{399}$, as conciliações prévias realizadas em primeiro e segundo grau, organizadas pelo Tribunal de Justiça de São

\footnotetext{
${ }^{395}$ Dinamarco, A reforma do Código de Processo, p. 116.

396 Trata-se de disposição que reforça o afastamento do processo administrativo uma identidade processual penal.

${ }^{397}$ Capelletti-Garth, Acesso à justiça, pp. 78-86 e 114-120.

${ }^{398}$ Alberton, "Repensando a jurisdição conflitual", pp. 326-342.

399 Capelletti-Garth, Acesso à justiça, pp. 145-146.
} 
Paulo, ${ }^{400}$ na previsão de tentativa de conciliação no processo cível ordinário - muito embora o valor da conciliação tenha sido relegado ao segundo plano pelo legislador pátrio em prol da celeridade, conforme se depreende da reforma que alterou o art. 331, do CPC, em 2002. ${ }^{401}$

O consenso obtido pelo compromisso de cessação é o veículo oferecido pelo SBDC para a composição do litígio. Em razão das particularidades do SBDC, não se pode afirmar que, em termos técnicos, trata-se de conciliação, mediação e muito menos arbitragem. Na elaboração do compromisso de cessação, não é um terceiro que intervêm mais ou menos para incentivar a composição, sugerindo ou não soluções, tampouco há um acordo prévio para designação de um sistema diverso do jurisdicional para a heterocomposição coercitiva. Trata-se de uma negociação entabulada diretamente entre o administrado-representado e o administrador-judicante CADE (ou com o administradorinstrutor SDE), de modo a buscar uma solução abreviada, consensual e que ao mesmo tempo atinja o escopo de proteção da concorrência, geração de bem estar social e, ainda que de forma velada, "punição" do "possível" infrator. O representado pondera os possíveis prejuízos que poderá ter com eventual condenação e, na ponta do lápis, dentro de uma lógica econômica, avalia se é benéfica a busca de uma alternativa de consenso. $\mathrm{O}$ administrador avalia os custos de manutenção do processo, realiza algum exercício de predição do resultado do processo e, abrindo mão (legalmente autorizado) de seu munus de

\footnotetext{
400 "O Setor de Conciliação tem como objetivo a tentativa de acordo amigável entre as partes, antes do ajuizamento da ação ou durante um processo judicial, para as questões cíveis que versarem sobre direitos patrimoniais disponíveis, questões de família e da infância e juventude. É um meio de resolução de conflitos em que as partes confiam a uma terceira pessoa (neutra), o conciliador, a função de aproximá-las e orientá-las na construção de um acordo" (http://www.tj.sp.gov.br/conciliacao/conciliacao.aspx).

${ }^{401}$ Após idas e vindas sobre a obrigatoriedade da audiência de conciliação em 1973 e 1994, a questão novamente vem a tona: "Em sua primeira reunião, a comissão de juristas que irá elaborar o anteprojeto de CPC aprovou ontem, 30/11, a proposta de obrigatoriedade de realização de audiência de conciliação. A ideia é a de que haja um grande esforço para que as partes entrem em um acordo a fim de que as audiências de conciliação possam efetivamente resultar no fim do processo, como explicou a relatora da comissão, a professora e advogada Teresa de Arruda Alvim Wambier. Segundo o presidente da comissão, ministro Luiz Fux, do STJ, o novo CPC deve ter como princípio informativo a duração razoável dos processos. Para isso, a comissão estuda também a supressão de recursos e outros fatores de atraso do processo. Segundo lembrou a relatora, a audiência de conciliação já está prevista na lei, mas passaria a ser obrigatória. A professora observou que, num primeiro momento, pode haver certa oposição por parte de alguns juízes à ideia, já que a exigência de mais uma audiência significaria uma pauta mais carregada para o juiz. Teresa Wambier disse, no entanto, que essa sugestão, se incorporada ao texto do novo Código, permitirá a redução substancial do número de processos. A relatora registrou que, na reunião da comissão, juízes relataram suas experiências, afirmando que, se houver efetivo empenho do juiz em favor da conciliação, haverá resultado. Sobre esse ponto, o presidente da comissão disse que a proposta "é uma estratégia que acompanha formas alternativas de solução de litígio". Luiz Fux ressaltou que a comissão não se opõe a possibilidades como arbitragem, mediação, competência absoluta dos Juizados Especiais e outras destinadas a desafogar a Justiça (http://www.migalhas.com.br/mostra noticia.aspx?cod=98337, 1.12.09)
} 
instruir e julgar e opta por uma solução diversa dos possíveis rigores dos arts. 23-27 da lei n. $8.884 / 94$.

O tema está previsto na lei n. 8.884/94 (art. 53) e é regulamentado pelo Regimento Interno do CADE (arts. 129-130) e pela Portaria MJ n. 4/06. Trata-se de compromisso pelo qual o representado cessa a prática investigada e mantém a autoridade informada sobre sua atuação no mercado. Como benefício, o representado, sem confessar o ilícito e sem reconhecer a conduta ilícita, tem o processo administrativo suspenso e pode vê-lo arquivado (extinto com o julgamento de mérito) se as obrigações forem cumpridas.

Se firmado perante a SDE, ele é submetido à consulta pública, sujeito ao recebimento de contribuições - ordinariamente proveniente de outros agentes. Perante o CADE, nos termos da lei, ele é proposto pelo Conselheiro Relator. Por trás dessa regra existe um longo trabalho realizado por Comissão de Negociação composta por no mínimo 3 servidores lotados no CADE, (Resolução CADE n. 51/09, que traz emenda ao Regimento Interno). ${ }^{402}$

O ponto delicado está na atribuição de um critério de oportunidade e conveniência, utilizado pelo Plenário, para a aceitação ou não da proposta de termo de compromisso de cessação, nos termos do art. 53, caput, c/c art. $7^{\circ}$, inc. VI, da Lei $n$. 8.884/94. A complexidade dos conceitos de uma Autarquia com função administrativa judicante dentro de um sistema complexo como o do SBDC prega peças e exige algum esforço hermenêutico: a mesma administração acusa, instrui e julga, o que cria desafios para a imparcialidade. Nesse sistema, contudo, já foi dito que não há discricionariedade, as decisões são vinculadas e sujeitas àquela imposição da vontade concreta da lei.

Porém, dentro dessa estrutura complexa, os órgãos se deslocam fluidamente da função de julgador, que realiza o exercício da subsunção do fato à norma, para a função declarada de um protetor de interesse - quase um detentor de interesse subjetivo merecedor de tutela - agindo como negociador capaz de dispor de parcela não de um direito, mas do dever de acusar e de julgar, em prol de uma solução rápida, consensual,

\footnotetext{
${ }^{402}$ Existe ainda a previsão de Grupos Técnicos, cuja hipótese está prevista pela Resolução CADE n. 50. O primeiro Grupo Técnico Criado, o GT-1, tem a missão específica de atuação em Negociações. Seus escopos são: elaboração de estudos sobre o tema, a pedido do Plenário; criação de um plano de trabalho; discussão sobre técnicas de negociação; estudo de práticas internacionais; análise de casos passados e contemporâneos; capacitação dos membros; formação de uma memória de negociações, com base em uma estrutura permanente; e aprendizagem contínua.
} 
pacificadora, destinada a maior aceitabilidade e dotada de um reforço de imutabilidade, eis que o Poder Judiciário, se instado a revisar o Compromisso de Cessação, não avaliará um ato de imposição de poder dos órgãos do SBDC, mas sim um ato de manifestação de vontade da parte, sujeito à anulabilidade por motivos restritos. Nesse momento, o órgão não atua como julgador, mas sim como parte que rejeita ou não a proposta de um acordo, e não como o julgador que julga "discricionariamente".

Tecnicamente, essa fluidez dos órgãos pode criar espécie. Mas o objetivo é legítimo, está em conformidade com o escopo social pacificador, com modernas tendências destinadas à solução de conflitos pelo Estado; existe até mesmo um legítimo firewall: o Ministério Público é cientificado do resultado do processo de negociação de um Compromisso de Cessação e é instado a se manifestar sobre ele; tem assento em sessões de julgamento do CADE, momento em que os Termos de Compromisso de Cessação são homologados ou não pelo Plenário do CADE; tem, portanto, possibilidade e legitimidade para questioná-lo caso verifique a presença de interesse alheio à proteção legítima da concorrência na elaboração do documento.

\section{VI.2. Escopo Político}

Segundo Bobbio, o Estado é visto pela concepção positiva e negativa. Pela positiva, o Estado seria a força organizada de convivência civil destinado à realização de sua própria essência, conduzindo o homem a participar racionalmente da vida em sociedade. Na concepção negativa, destaca-se o Estado como mal necessário. ${ }^{403}$

No exercício desse mal necessário, o Estado exerce poderes, políticas. O antitruste foi definido como instrumento de implementação de políticas públicas voltadas à proteção da instituição da concorrência e o processo administrativo como um instrumento dessa implementação - ciente de que a política pública deriva aí de uma intensa aproximação entre as escolhas administrativas e a positivação jurídica (v. cap. IV supra). As políticas públicas do Estado federal, republicano e presidencialista brasileiro respeitam o regime (forma de aquisição de poder) democrático, que pressupõe o governo do povo, para o povo, pelo povo: "infere-se também que a participação ocupa, aí, um lugar decisivo

\footnotetext{
${ }^{403}$ Bobbio, Estado, Governo e Sociedade: para uma teoria geral da política, pp. 126-133.
} 
na formulação do conceito de Democracia, em que avulta, por conseguinte, o povo - povo participante, povo elemento ativo e passivo de todo o processo político, povo, enfim, no poder". 404

Nessa perspectiva, o processo funciona como o instrumento de imposição de poder, do poder-dever-função de julgar em sede administrativa, do poder definir mediante processo legislativo os sistemas deônticos e de aplicar a norma ao caso concreto, dentro da idéia de atuação da vontade concreta da lei. Ele ainda tem o dever de oferecer um microcosmo democrático/participativo no palco onde ele for realizado.

Para a compreensão do escopo político do processo administrativo, voltase inicialmente a atenção à atividade jurisdicional. $O$ escopo político do processo jurisdicional reside em afirmar a capacidade estatal de decidir imperativamente, cultuar a liberdade, limitar e delinear os contornos do poder e de seu exercício, garantir a dignidade dos indivíduos, e, "finalmente, assegurar a participação dos cidadãos, por si mesmos ou através de suas associações, nos desígnios da sociedade política" - participação como valor democrático inalienável e determinante para a legitimação do processo político. Poder (autoridade), liberdade e participação outorgam estabilidade à instituição do Estado. ${ }^{405}$

No âmbito da função administrativa judicante dos órgãos do SBDC, o escopo político do processo administrativo não difere substancialmente daquele referente ao processo judicial.

\section{VI.2.1. A relação entre o exercício do poder e a liberdade/dignidade do indivíduo}

O processo é um instrumento que delineia e confirma a capacidade de o estado decidir e impor os comandos. Estado é um conceito polissêmico, mas retratado como organização política realizada sobre princípios e lógica própria de funcionamento, criando uma figura simbólica, depositária da identidade social e "suporte permanente do poder". É a essência neutra e independente que almeja o bem comum e o interesse geral coordenado com os interesses particulares. Mais ainda: “o Estado é também o fundamento de toda autoridade. Por detrás da pessoa física dos governantes surge o perfil de uma

\footnotetext{
${ }^{404}$ Paulo Bonavides, "A democracia participativa e os bloqueios da classe dominante" in Direito e poder nas instituições e nos valores do público e do privado contemporâneos, São Paulo, Manole, 2005, p. 427. ${ }^{405}$ Dinamarco, A instrumentalidade do processo, pp. 205-208.
} 
pessoa jurídica, o Estado, ao qual todos os atos de poder devem ser reportados e imputados". 406

O poder é a capacidade de intervir na organização da vida das pessoas e da sociedade, que juridicamente é condicionado, para o que importa neste trabalho, por disposições normativas criadas a partir da conformação coletiva de desejos (behaviorismo), da imposição da vontade (voluntarismo), pela inserção sistêmica de uma vontade no plano da legitimidade (definição sistêmica) ou quando, pela ótica, alguém se submete ou aquiesce a determinado ato de vontade por receio de represália. O poder vive uma relação de conflito-equilíbrio-simbiose com a idéia de liberdade, definida como o direito de fazer o que não prejudica outrem, não ser privado da faculdade de ir, vir, agir, se não por determinação normativa. ${ }^{407}$

O ponto de equilíbrio é a norma, que se insere no sistema jurídico após sua produção conforme e tem como vértice o texto constitucional. Por essa razão que o escopo político do processo, em sede jurisdicional, aponta como uma vertente a preservação das liberdades públicas também pela "incrementação do sistema jurídicosubstancial das liberdades públicas, valendo o sistema processual como instrumento dessa gradual e espontânea evolução "informal do conteúdo substancial da constituição"”. 408

Retomam-se os conceitos tratados no cap. V a respeito, inicialmente, do princípio da legalidade como constitucionalização axiomática da relação entre poder e liberdade. Correlato está o princípio do devido processo legal, criado pelo direito norte americano exatamente como instrumento de combate à arbitrariedade. Essa cláusula de fechamento do sistema veda as limitações indevidas aos direitos fundamentais por meio de normas processuais e institucionaliza o instrumento de proteção de direitos inalienáveis pela preservação da razoabilidade, isonomia e dialética (a paridade de armas) para o alcance de uma justiça procedimental. Dinamarco referiu-se à cláusula como repositório sintético de todas as garantias do processo dentro de parâmetros político-liberais. ${ }^{409}$

\footnotetext{
${ }^{406}$ Arnaud et al., Dicionário enciclopédico de teoria e de sociologia do direito, p. 313. Foge do escopo da tese aprofundar sobre o conceito. Para a análise do Estado como elemento de integração social, instrumento de dominação, sociedade política, nação, território, é irrelevante. Aqui, é relvante destacar sim, sua existência como um "poder de coerção, isto é, a existência de órgãos especializados, investidos do poder de comando e dotados do privilégio do poder de recorrer à força" (idem, pp. 314-315).

${ }^{407}$ Arnaud et al., Dicionário enciclopédico de teoria e de sociologia do direito, p. 591-592.

${ }^{408}$ Dinamarco, A instrumentalidade do processo, pp. 209-210.

${ }^{409}$ Dinamarco, Instituições de direito processual civil, n. 72.
} 
O processo cria o ambiente adequado para atos de imposição de poder que tenham como escopo a garantia de ambiente concorrencial, que respeite as garantias individuais e os fundamentos igualmente constitucionais de liberdade econômica (livre iniciativa e livre concorrência), de modo a finalmente criar um ambiente de bem-estar social. A criação desse ambiente é definida por linhas de interpretação (escolas) que estipulam uma maior ou menor intervenção do Estado sobre o mercado e cujo pensamento pode influenciar o legislador e o intérprete. No Brasil, ensina-se que as normas de direito econômico criam um sistema "instrumental ao funcionamento do sistema econômico e social. Só assim é possível, de uma parte, afugentar o impasse político ideológico e permitir sua aplicação prática e, de outra, garantir seu caráter cognitivo. Garantindo a correção e o equilíbrio das interações econômicas, o próprio indivíduo ou grupos sociais descobrirão suas utilidades e preferências econômicas. Daí por que essas regras têm de assumir nítido caráter procedimental, de verdadeiro due process clause em matéria econômica". 410

Além do sentido material do processo criador de normas, independentemente do grau de intervenção do Estado, a cláusula do devido processo legal pressupõe um processo (atos concatenados destinados ao alcance de um escopo, permeado pela relação jurídico processual) mais ou menos complexo para que se lhe possa outorgar legitimidade. Essa legitimidade está intimamente relacionada com a participação, objeto do tópico seguinte.

\section{VI.2.2. A participação}

A participação é inerente à ideologia democrática. Sua coordenação com o sistema capitalista exige sim uma maior atenção. "Consensus-building, open dialog, and the promotion of an active civil society are the key-ingredients to a long-term sustainable development. Development is a participatory process. (...) Success in a knowledge-based economy requires a highly-educated citizenry, involved in the process of shaping and adapting ideas and policies. Participation and democracy in turn call for greater

\footnotetext{
${ }^{410}$ Salomão Filho, Direito concorrencial - as condutas, pp. 46-47.
} 
transparency and accountability in both corporate and government sectors". ${ }^{411}$ Partindo dessa premissa, Stiglitz afirma que o desenvolvimento é um processo de transformação da sociedade. A perspectiva de alocação de recursos e o aumento do nível de investimentos não são os únicos elementos evolutivos; a mudança de mentalidade vem de dentro e não de influxos externos (ainda que bem intencionados), sendo necessário instituir um governo permeado pelo debate.

A participação vai além da capacidade de votar ou de interação em processos decisórios públicos ou privados. Implica transparência, abertura em todos os processos de participação (nacional, local ou atomizado), criando um senso de comunidade por meio de, v.g., uma imprensa forte, vigorosa e em ambiente competitivo, de modo a impedir o distanciamento entre as ações de um sujeito e os interesses que ele representa. ${ }^{412}$

A questão pode também ser tratada como a procura por minimizar os efeitos das influências dos (mais) ricos sobre a política e a subseqüente concentração de poder econômico ou como implementar políticas que ampliem o processo de participação. Partindo da separação entre Estado e Sociedade e dos decorrentes problemas estruturais em Estados democráticos, Mestmäcker, referindo-se a Lorenz Von Stein, afirma que "a tarefa do Estado é evitar a transformação do interesse econômico e social em privilégio", 413 devendo estar acima das classes sociais. A dificuldade residiria no fato de que o parlamento é composto por representantes de classes sociais: não haveria Estado sem grupos de interesse, tampouco um legislador ou administrador neutro. Em relação ao direito, o autor alerta para a retirada de conflitos de seus contextos jurídicos primários e elevá-los para o contexto político, alterando suas condições decisórias e retirando o crédito de um sistema juridicamente ordenado. Logo, para a solução do problema, o autor propõe o consenso fundado na comunicação livre da dominação, condicionante da validade de toda norma politicamente importante. $\mathrm{O}$ interesse por meio do conhecimento reflete a idéia de que "a liberdade só se realiza onde não subsiste a pressão da natureza em forma de escassez". Os conflitos que pressupõem o direito não teriam sentido se os indivíduos percebem os interesses dos outros ou se a natureza preenchesse nossos desejos e

\footnotetext{
${ }^{411}$ Stiglitz, "Participation and Development: Perspectives from the Comparative Development Paradigm”, pp.163182.

${ }^{412}$ Stiglitz, "Participation and Development: Perspectives from the Comparative Development Paradigm", p. 165. $\mathrm{O}$ autor trabalha ainda, ao longo do texto, a distinção entre os indicativos sociais e econômicos, a importância do desenvolvimento social como promotor de desenvolvimento econômico.

${ }^{413}$ Mestmäcker, "Poder, Direito, Constituição econômica", p. 183
} 
necessidades de forma abundante. ${ }^{414}$ Retomando Stiglitz, o autor sugere como forma de minimização dos efeitos de influências nocivas, dentre várias condutas, "societies should extend citizens' rights to legal recourse, to sue". ${ }^{415}$

A atividade administrativa judicante por meio do processo é um reflexo da ideologia expressa na Constituição - o já repetido à exaustão microcosmo democrático alimentado por um direito processual constitucional.

O processo afigura-se, por sua vez, como fator legitimante de condutas. Para Luhmann, a legitimação pelo procedimento se dá na "diferenciação e a autonomia que abrem um espaço de manobra para a autuação dos participantes pleno de alternativas e de importância básicas, reduzindo a complexidade. Só assim os participantes podem ser motivados a tomarem, eles próprios, os riscos da sua ação, a cooperarem, sob controle, na absorção da incerteza e dessa forma a contraírem gradualmente um compromisso". ${ }^{416}$ Por isso, Dinamarco, comentando o autor, menciona o procedimento como penhor de preservação de princípios constitucionais, dentre eles o acesso e o contraditório. ${ }^{417}$

Para Cuéllar-Moreira, processo, participação e interesse público promoveriam uma "profunda imbricação entre processo e democracia", porque "o cidadão tem o direito democrático de participar ativamente da formação das decisões administrativas do Estado, especialmente aquelas que incidirão sobre seus interesses". ${ }^{418}$

Sob a perspectiva da teoria da escolha pública, decisões políticas e econômicas ficam sujeitas ao conjunto de poderes, que interferem na implementação dessas decisões. Seu cunho processual envolve as preferências dos agentes (racionais e egoístas) e as regras processuais que transformam essas preferências em uma escolha coletiva. Assim, estudando a relação entre o público e o privado, Farber e Frickey tratam do processo legislativo, dos interesses particulares que permeiam a criação da norma,

\footnotetext{
${ }^{414}$ Mestmäcker, "Poder, Direito, Constituição econômica” pp. 183 e ss.

$415 \mathrm{O}$ autor menciona (a) maior transparência administrativa por parte do Estado com a diminuição da corrupção, (b) ampliação do conhecimento econômico de modo a organizar a produção (no âmbito da empresa ou da sociedade), exigindo o aumento do conhecimento individual e redes de informação descentralizadas, (c) o controle antitruste, a taxação redistributiva e o controle mais enfático sobre o excesso ou abuso de poder e influência (por meio do fortalecimento da sociedade, de seus representantes políticos, de associações de consumidores, da criação de ONGs), (d) implementação de políticas de defesa do pleno emprego (Mestmäcker, "Poder, Direito, Constituição econômica", p. 183 e ss.).

${ }^{416}$ Luhmann, Legitimidade pelo Procedimento, p. 64.

${ }^{417}$ Dinamarco, A instrumentalidade do processo, pp. 158.

${ }^{418}$ Cuéllar-Moreira, Estudos de direito econômico, p. 184.
} 
capitaneados por grupos de pressão específicos. O interesse público seria muito fragmentado para gerar uma política pública coerente: "sometimes, the legislature is portrayed as the playgroud of special interest, sometimes as a passive mirror of selfinterested voters, sometimes as a solt machine whose outcomes are entirely unpredictable. These images are hardly calculate to evoke respect for democracy" Dessa forma, a teoria da public choice analisa o comportamento de legisladores, modelos matemáticos de processos de decisões coletivas e estudos empíricos de votações, em uma aplicação da economia para a ciência política. Reflete ainda a relação entre o modelo econômico e o modelo ideológico nas escolhas dos legisladores e no processo político. ${ }^{419}$

Afirma-se que "public choice's emphasis on structure and procedure is congenial to expansion of another judicial function - enforcing structural and procedural constraint on those aspects of the democratic process that public choice suggest are most vulnerable to malfunction". Comenta o devido processo legislativo e as benesses de se reforçar a estrutura de processos de decisão, na medida em que existe uma opção pela ampliação do debate ao invés da ação propriamente dita. ${ }^{420}$

A partir dessas premissas, a participação e o processo confluem de maneira ostensiva. Participação é concebida como o poder de atuar no processo decisório; assim, nenhum elemento do processo pode, como regra, obstar a participação, que não é do titular do poder decisório, mas sim daqueles submetidos a esse poder - essa é a idéia de legitimação democrática do processo, embalada pelo trinômio acesso-procedimentocontraditório. $^{421}$

O acesso, como já visto, vincula-se ao modelo processual constitucional brasileiro (que em relação ao poder judiciário está expresso no art. $5^{\circ}$, inc. XXXV), que dá o direito ao exercício (poder de exigir o exercício) da atividade judicante

\footnotetext{
${ }^{419}$ Farber-Frickey, Law and public choice - a critical introduction, pp. 10 e ss.

${ }^{420}$ Farber-Frickey, Law and public choice - a critical introduction, London, The University of Chicago Press, 1991, p. 10

421 “O modelo habermasiano dá ao Direito uma dupla função. De um lado, o Direito serve para definir e garantir institucionalmente, no plano do sistema, mecanismos de participação pública e deliberação. De outro lado, o Direito serve como ponto - por meio de procedimentos - entre a esfera pública e o sistema político para que demandas de grupos que se formam na sociedade civil sejam levadas, discutidas e internalizadas no interior do sistema. Nesse ponto (...) a própria garantia de mecanismos de participação pública institucionalizados são fundamentais. Mas (...) é igualmente fundamental o grau de atividade de atores relevantes - que não apenas aqueles representantes de empresas reguladas - que possam fazer uso dessas garantias e procedimentos para influenciar a opinião pública e processos de formação do conteúdo da regulação" (Mattos, O novo estado regulador no Brasil: direito e democracia, p. 132).
} 
independentemente de se ter ou não razão e ainda o direito-poder de exigir a resposta à pretensão desde que superados os óbices legítimos. Qualquer que seja a leitura da cláusula, não se pode afastar da participação plúrima e democrática, do diálogo. Na luta contra limitações econômicas, psicossociais e jurídicas, o acesso à justiça e a garantia de participação devem oferecer aquelas "situações e bens da vida que por outro caminho não se poderiam obter" ${ }^{\prime 422}$ (ou ainda, por todos os caminhos legítimos que o sujeito pode se valer para obtê-las). E nesse ponto a tutela oferecida pelo CADE não pode e não deve ser um canal pouco público, pouco institucionalizado, restrito a atores determinados, com déficits de legitimidade.

Participação (em contraditório) revela-se como expressão da democracia. Em conjunto, as premissas estabelecem "formas de influência sobre os centros do poder (...), no sentido de que representam algum peso para a tomada de decisões; conferir ou conquistar a capacidade de influir é praticar a democracia". ${ }^{423}$ O que daí se extrai é uma preocupação científica apurada da ciência processual com a idéia de participação (ampla defesa e contraditório), atrelada a uma concepção democrática imposta à função administrativa judicante. Trata-se de um caminho correto trilhado dentro das estruturas do direito processual.

São diversas as formas de garantir a participação cidadã em processos e estruturas. Do Judiciário, se extra a moderna e inexorável tendência de universalização da jurisdição. Uma das formas de universalizá-la é por meio do tratamento da garantia constitucional da inafastabilidade da tutela jurisdicional, com a eliminação de barreiras internas e externas indevidas do sistema (burocracia, pequena abrangência dos julgamentos, impossibilidade de custear litígios, a falta de informação, a descrença nos serviços judiciários etc.). ${ }^{424}$ Busca-se ali um processo civil de resultados, ou seja, aquele que deixa de ser eminentemente formal e passa a ser um instrumento a serviço da realização concreta dos direitos das partes. O processo não é mais definido como mera técnica, mas, sobretudo, como meio de acesso à justiça. ${ }^{425}$

\footnotetext{
${ }^{422}$ Dinamarco, A instrumentalidade do processo, p. 343-347.

${ }^{423}$ Dinamarco, A instrumentalidade do processo, pp. 163, 207-208.

${ }^{424}$ Dinamarco, Instituições de direito processual civil, n. 42.

${ }^{425}$ Extrai-se linha de pensamento de Karl Marx, para quem é por meio da atividade prática, a revolução (equiparação das forças produtivas com relação ao corpo social), que o corpo social transforma também a sua subjetividade. Haveria assim uma relação dialética entre a produção da vida prática e material para com as idéias. O método dialético de Marx parte da unidade e luta dos contrários (choque e renovação em eterno
} 
Cappelletti e Garth, na já mencionada obra a respeito das três ondas renovatórias do direito processual, referiam-se à assistência jurídica aos necessitados, a possibilidade de inserção de conflitos transindividuais naqueles apreciados pelo Poder Judiciário e o aperfeiçoamento técnico de mecanismos internos do processo. ${ }^{426}$ Essas idéias caminham com os ideais instrumentalistas e contêm o ideal de ampliação de acesso e de alcance da tutela jurisdicional. Nos instrumentos transindividuais, a ampliação da participação pelo processo se revela na criação de instrumentos de proteção de tutela de interesses difusos, com “conotação política muito profunda. Trazendo ao judiciário pretensões de defesa institucional, destinadas ao interesse coletivos, aumenta o papel político do Judiciário, enquanto garantidor dessas instituições". 427

Essas premissas podem e devem ser transportadas ao SBDC. A primeira delas está no tema do acesso.

\section{VI.2.3. Acesso ao SBDC}

Acesso à Justiça pode ser inicialmente interpretado como acesso ao Poder Judiciário, tal como expresso na cláusula constitucional. Perante a administração se fala em direito de petição, "conferido para que se possa reclamar, junto aos poderes públicos, em defesa de direitos contra ilegalidade ou abuso de poder. (...) A característica que diferencia o direito de petição do direito de ação é a necessidade, neste último, de se vir a juízo pleitear a tutela jurisdicional, porque se trata de direito pessoal. Em outras palavras, é preciso preencher a condição da ação interesse processual". ${ }^{428}$ Trata-se da idéia de acesso à ordem jurídica justa. Ampliam-se as pretensões sujeitas à decisão do Estado e as pessoas aptas a receber a devida prestação.

processo de transformação) - (Lyra Filho, "Para uma visão dialética do direito", p. 57-64). Por essa idéia, o processo é evidente instrumento a serviço da dialética. Para Marx, o direito é político, ideológico; é um fenômeno dialético que contém elementos organizacionais conforme o ideal da classe dominante, contendo ainda elementos ocasionais discrepantes, porquanto representativos do pensamento e dos interesses das classes não dominantes (Lyra Filho, "Marx e o Direito, Educação e Sociedade”, p. 97-115). Daí se afirmar da evolução do microcosmo processual quando cria instrumento que permite a participação e exposição de idéias de sujeitos que não necessariamente pertencem à classe dominante.

${ }^{426}$ Cappelletti-Garth, Acesso à justiça, passim.

${ }^{427}$ Dinamarco, A instrumentalidade do processo, p. 32.

${ }^{428}$ Nery Junior, Princípios do Processo Civil na Constituição Federal, p. 97. Nesse mesmo sentido, com rigor diferenciado nas denominações, Dinamarco afirma: “o direito constitucional de petição liga-se à defesa de direitos individuais ou coletivos perante a autoridade pública, como precedente da representação popular e confinando com o direito de representação; tem, inclusive, formação histórica diferente da que a ação teve" (Fundamentos do processo civil moderno, p. 117/118). 
Para tanto, propõe-se a eliminação de óbices ilegítimos ao acesso à tutela jurisdicional, tais como imperfeições da lei processual, da realidade política, sócioeconômica ou cultural. Não se concebe uma justiça seletiva em razão de óbices estruturais, sistemáticos, econômicos ou ético-sociais. ${ }^{429}$

Nesse ponto, a tutela oferecida pelo CADE ainda é incipiente. Se dentro dos escopos do processo está aquele social, que em sua vertente educacional representa a "conscientização dos membros da sociedade para seus direitos e obrigações", o CADE ainda está aquém do seu esperado papel. É inevitável a sensação de demanda por proteção antitruste reprimida, especialmente se analisarmos as limitações estruturais dos órgãos de proteção da concorrência e o pequeno número de processos de apuração de conduta julgados pelo órgão nos últimos anos. Os números do CADE refletem isso:

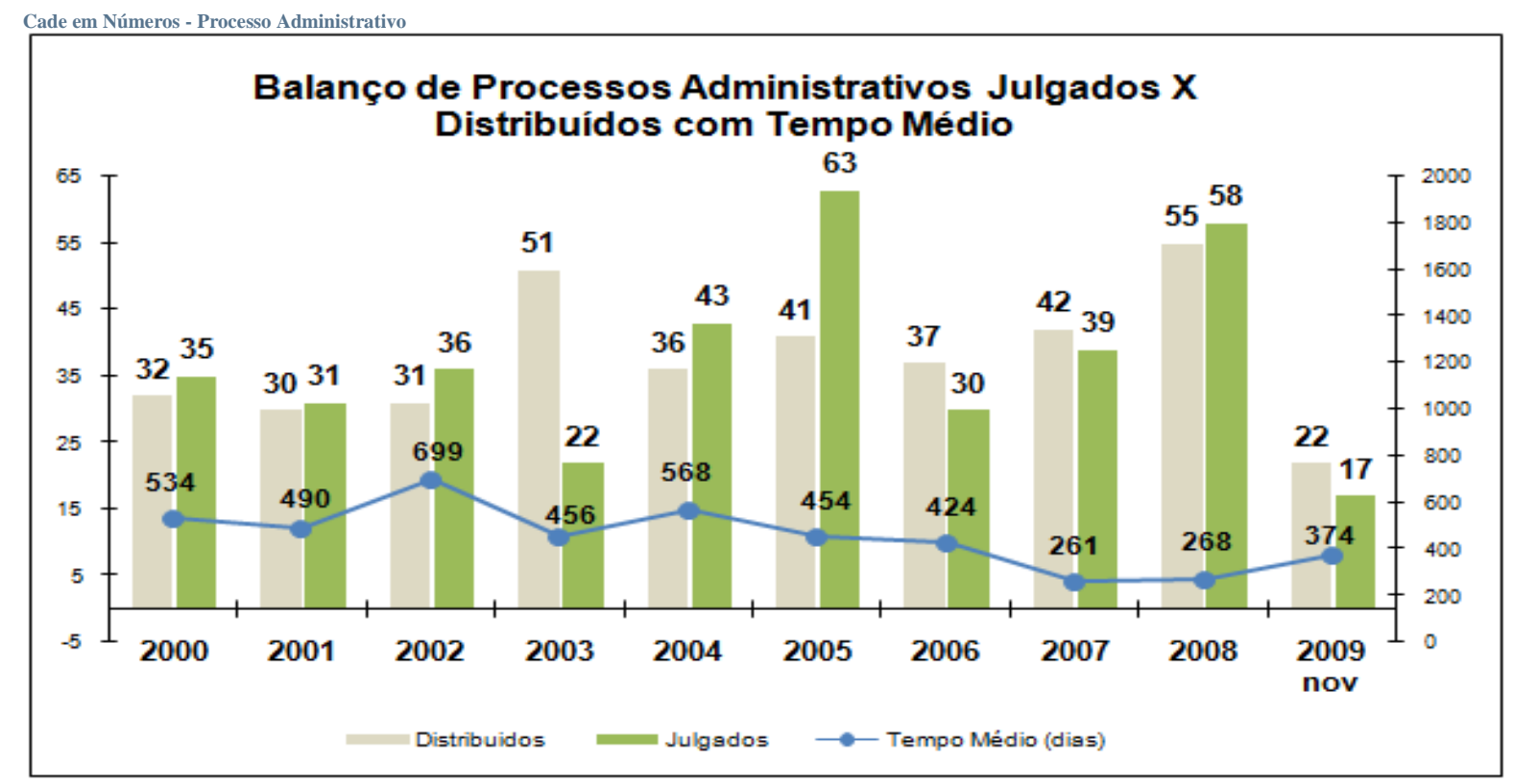

${ }^{429}$ Cfr. Dinamarco "Universalizar a tutela jurisdicional" in Fundamentos de direito processual civil, cap. XXXVIII, passim. 


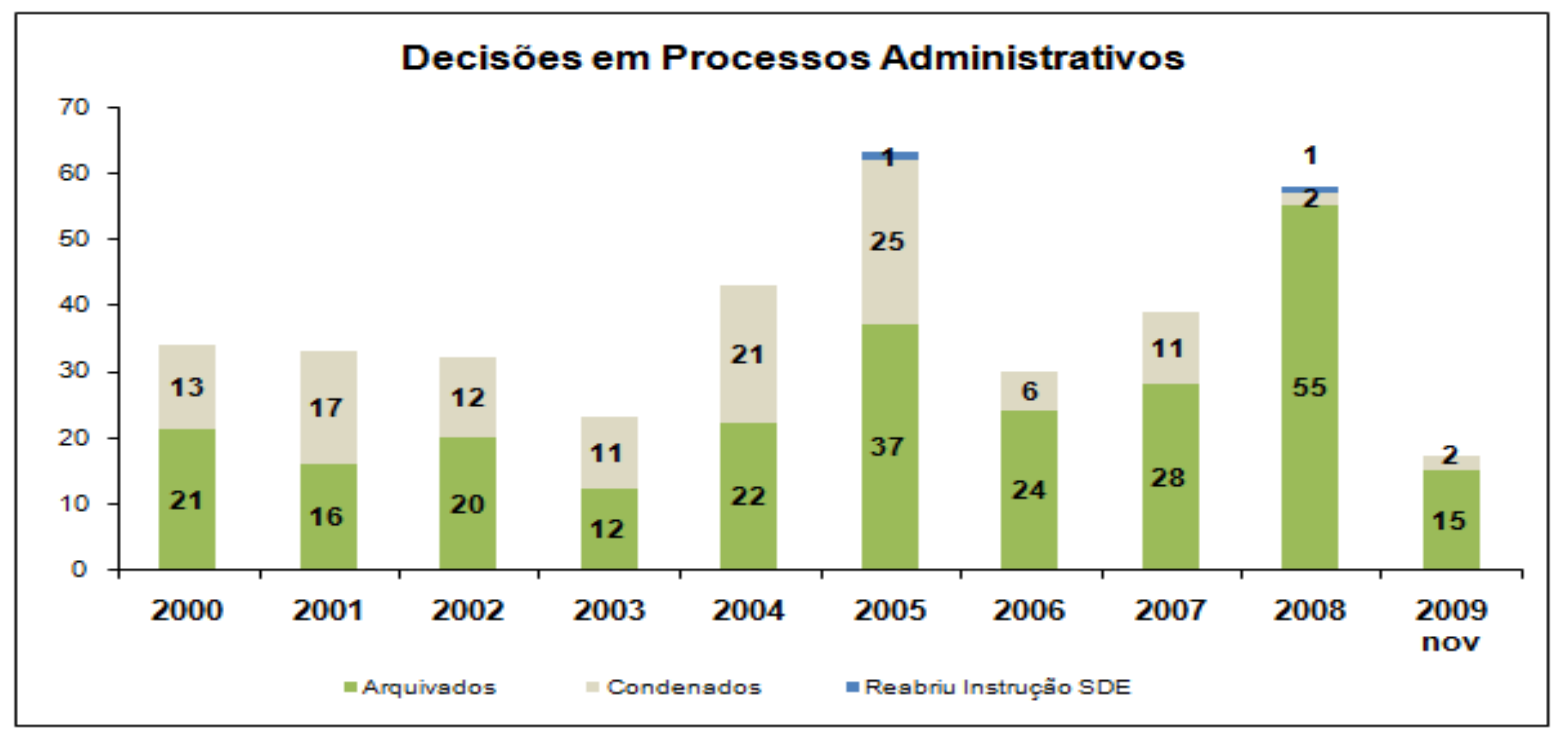

Em um país de proporções continentais, de um mercado bastante amplo, não é crível que a demanda por apurações de condutas seja limitada a aproximadamente quarenta demandas anuais. Não há espaço também para uma possível explicação otimista, no sentido de que o Brasil está mais cônscio da atividade antitruste, e por isso e número de processos vêm reduzindo. Não obstante os inegáveis esforços educativos, é mais crível a existência de uma demanda reprimida do que um desenvolvimento excepcional da cultura da concorrência que causa a redução de processos distribuídos no CADE.

Feitas essas considerações, os órgãos de proteção da concorrência podem ser acionados de diversas formas. A primeira delas já foi tratada acima, quando se discorreu sobre a atuação ex officio. Outra forma de se provocar o SBDC é por meio de representação. Qualquer do povo pode denunciar a existência de condutas anticompetitivas, prevista no art. 30, da lei n. 8.884/94 e regulamentadas pelo par. $3^{\circ}$ do art. 47 da Portaria MJ 4/06 e pelo art. $6^{\circ}$ da Lei n. 9.784/99. O art. 14, inc. III e 30, caput, da lei n. 8.884/94, exigem apenas indícios suficientes para instauração de averiguações preliminares, quando não for o caso de instauração imediata de processo administrativo. ${ }^{430}$

Na FTC, nos casos de uma reclamação de interessado (application for a complaint), é preciso expor um short and simple statement of the facts para a apuração da

\footnotetext{
${ }^{430}$ Em Portugal, a Lei n. 18 estabelece necessariamente a instauração de um inquérito após o oferecimento de uma denúncia (nossa averiguação preliminar), momento em que sao colhidas provas (declarações de empresas envolvidas, de outras empresas que tenham relevancia para a questão, busca-e-apreensao de documentos e selagem de locais, sempre após decisão de autoridade judiciária que determine tais ações autoridade judiciaria compreende o juiz e o Ministério Público, que em Portugal é órgão vinculado a magistratura. Em processo, a parte tem a possibilidade de requerer diligencias complementares. Some-se que toda denúncia tem que, obrigatoriamente, dar ensejo à abertura de inquérito.
} 
existência de uma reason to believe e de um interesse público. Existe fase pré-instrutória na qual a autoridade valora os elementos em seu poder e examina a possível existência de uma violação da norma antitruste, se a comunicação contenha dados gravemente inexatos, incompletos ou inverídicos, especialmente em relação à definição, v.g., de mercado relevante, participação, poder de mercado. ${ }^{431}$

Perante a Comunidade Européia, os processos de apuração de conduta também podem ser instaurados de ofício ou mediante denúncia, que correspondem, em média, a um terço e dois terços, respectivamente. A denúncia tem importância na medida em que são prestadas informações relevantes sobre quem tem conhecimento do mercado objeto do processo e sem a qual a investigação do ilícito não seria possível. Porém, considerando a proposta de descentralização, a Comissão tende a julgar somente casos em que estejam envolvidos ao menos 3 Estados membros (empresas ou efeitos), a decisão seja relevante decisão de âmbito europeu, o caso guarde relação com outras normas comunitárias e tenha provocado o interesse de autoridades de Estados membros na investigação, requisitos que indicam gravidade e extensão da infração. São linhas gerais, porém, que não excluíram nos anos 90 a atenção particular da comissão em setores especiais como energia e telecomunicações. ${ }^{432}$

De qualquer forma, de acordo com as especificidades do direito comunitário e europeu, se um sujeito puder escolher entre um julgamento pela Comissão Européia ou pela Autoridade Judiciária nacional, deve escolher a segunda na medida em que ela (i) está autorizada conceder de forma rápida a indenização por violação às normas antitruste comunitárias, pronunciando-se sobre o mérito, (ii) pode declarar a nulidade de contrato à luz das normas antitruste comunitárias, (iii) encontra-se em melhor condição para oferecer tutelas cautelares, (iv) admite a fundamentação de pretensões em normas de direito comunitário e nacional, (v) condena a parte sucumbente ao ressarcimento de despesas, o que não ocorre diante da Comissão. ${ }^{433}$ Confira-se ainda o site da Comunidade Européia, que recomenda em seu guia de conduta àqueles que se deparam com um ilícito anticoncorrencial: "se a situação detectada for específica e limitada ao país ou à região em que reside, ou se não envolver mais de três Estados-Membros, pode optar por contactar em primeiro lugar a autoridade da concorrência nacional. As autoridades da concorrência de

\footnotetext{
${ }^{431}$ Benedetto, L'Autorità garante della concorrenza e del mercato, p. 216 e 228.

${ }^{432}$ Bellodi, "Le denunce", p. 77 e ss.

${ }^{433}$ Bellodi, "Le denunce", p. 80.
} 
todos os Estados Membros da União Europeia aplicam actualmente as mesmas regras de concorrência que a Comissão Europeia e estão frequentemente bem colocadas para tratar destes problemas. Se suspeita de um maior número de Estados-Membros afectados, pode optar por contactar de preferência a Comissão Europeia. Mesmo se tiver dúvidas quanto à extensão do problema, não hesite em contactar a Comissão Europeia ou uma autoridade da concorrência nacional. As autoridades cooperam e podem decidir entre elas a atribuição do caso em função das informações que lhes foram fornecidas". 434

Ainda no âmbito da Comunidade Européia, o Regulamento CE 1/2003, referente à execução das regras de concorrência estabelecidas pelos arts. 81 e 82 do Tratado impõem que a denúncia deva ser apresentada por quem tenha "legítimo interesse" (prejuízo da posição jurídica da pessoa interessada, lesão direta). ${ }^{435}$ A questão é controversa, mas a doutrina admite a possibilidade de persecução ainda que o denunciante não ostente essa qualidade, desde que presentes os demais requisitos. Dos precedentes constam denúncias de empresas, associações de empresas, associações de consumidores, porém excluem-se intervenientes que atuem pro bono publico, a quem fica reservado o direito de informar a Comissão sem a aquisição da qualidade de denunciante. ${ }^{436}{ }_{-}^{437}$

\footnotetext{
${ }^{434}$ http://ec.europa.eu/competition/consumers/contacts_pt.html\#1.

${ }^{435}$ Art. $7^{\circ}$. do Regulamento 1/2003: Verificação e cessação da infracção 1. Se, na sequência de uma denúncia ou oficiosamente, a Comissão verificar uma infracção ao disposto nos artigos 81.o ou 82.o do Tratado, pode, mediante decisão, obrigar as empresas e associações de empresas em causa a porem termo a essa infracção. Para o efeito, a Comissão pode impor-lhes soluções de conduta ou de carácter estrutural proporcionadas à infracção cometida e necessárias para pôr efectivamente termo à infracção. As soluções de carácter estrutural só podem ser impostas quando não houver qualquer solução de conduta igualmente eficaz ou quando qualquer solução de conduta igualmente eficaz for mais onerosa para a empresa do que a solução de carácter estrutural. Quando exista um interesse legítimo, a Comissão pode também declarar verificada a existência de uma infracção que já tenha cessado. 2. Estão habilitados a apresentar uma denúncia na acepção do n.o 1 as pessoas singulares ou colectivas que invoquem um interesse legítimo, bem como os Estados-Membros.

${ }^{436}$ Bellodi, "Le denunce", p. 77 e ss. De fato, o regolamento n. 773/2004 da Comissão estabelece que "deve também ser prevista a possibilidade de ouvir pessoas que não tenham apresentado uma denúncia nos termos do artigo 7.o do Regulamento (CE) n.o 1/2003 e que não sejam interessados directos a quem tenha sido dirigida uma comunicação de objecções, mas que, não obstante, podem invocar um interesse suficiente. As associações de consumidores que solicitem ser ouvidas devem, em geral, ser consideradas como tendo um interesse legítimo sempre que o processo se refira a produtos ou serviços utilizados pelos consumidores finais ou produtos ou serviços que constituam um elemento directo para o fabrico de tais produtos ou para a prestação de tais serviços. Sempre que o considerar útil para o processo, a Comissão deve também poder convidar outras pessoas a apresentarem os seus pontos de vista por escrito e a participarem na audição oral dos interessados directos a quem for enviada uma comunicação de objecções. Quando adequado, deve também poder convidar essas pessoas a apresentarem os seus pontos de vista na audição oral".

${ }^{437}$ Diante de uma lesão, o sujeito é instruído a: (i) Comunicar as preocupações à Comissão Europeia: Pode contactar por correio electrónico a Comissão Europeia para comunicar as suas preocupações, escrevendo para comp-market-information@ec.europa.eu. Ou pode, em vez disso, enviar uma carta dirigida a Comissão Europeia (...). Solicita-se que indique o nome e endereço, identifique as empresas e os produtos em questão e descreva de forma clara a prática observada. Isto ajudará a Comissão Europeia a detectar os eventuais problemas no mercado e pode ser o ponto de partida para uma investigação; (ii) Apresentar formalmente uma
} 
Deve ainda haver o interesse comunitário, ou seja, (i) deve ser demonstrado que o sujeito não tem a possibilidade de fazer valer seu direito perante um juiz nacional, (ii) a gravidade da infração e a persistência de seus efeitos, (iii) a relevância da infração para o funcionamento do mercado e a probabilidade de auferir o dano, (iv) eventualmente, não perquirir se a prática tiver cessado e se seus efeitos tiverem cessado, (v) que uma empresa se recuse a modificar a conduta voluntariamente. Além disso, a denúncia deve conter informações sobre a parte interessada, a descrição da suposta infração e as respectivas provas (fato, relações comerciais relacionadas com o produto, posição de mercado das empresas interessadas na denúncia), âmbito geográfico, explicação sobre como o comércio entre os Estados membros pode ser prejudicado, qual é a decisão que a comissão deve tomar e qual postura deve assumir. ${ }^{438}$

André Gilberto afirma que, no Brasil, as representações devem ser escritas e fundamentadas para evitar "denúncias manifestamente improcedentes, desconectadas da realidade ou sem o mínimo de indícios suficientes". ${ }^{439}$ Mas a referência precisa ser relida à luz do paralelo com a teoria das condições da ação ${ }^{440}$ e dos pressupostos processuais, óbices legítimos à atividade judicante do Estado.

Em razão da natureza institucional do interesse protegido, dispensa-se o exame da legitimidade de parte, conferindo-se a qualquer cidadão, ainda que (ou mesmo porque) seu interesse seja tutelado no processo de forma reflexa, a legitimidade para a apresentação de uma denúncia. Faz sentido, até porque a legitimação ordinária pertence à SDE, que atua inclusive de ofício, ${ }^{441}$ dispensando-se assim os rigores do art. 267 , do CPC e

denúncia à Comissão Europeia: se for afectado directamente pela prática que suspeita restringir a concorrência e puder fornecer informações precisas à Comissão Europeia, é possível apresentar formalmente uma denúncia. Neste caso deve preencher determinados requisitos jurídicos explicados de forma circunstanciada na comunicação da Comissão sobre o tratamento das denúncias (para mais informações, ver http://europa.eu.int/dgcomp/). Pode ainda enviar uma mensagem electrónica para comp-marketinformation@ec.europa.eu, a fim de obter mais informações sobre a forma de apresentar formalmente uma denúncia; (iii) Informar uma associação de consumidores: Enquanto consumidor pode recorrer a uma associação de consumidores para comunicar o que observou. Esta associação pode então decidir reunir as informações recebidas de diferentes consumidores e apresentar formalmente uma denúncia à Comissão Europeia.

${ }^{438}$ Bellodi, "Le denunce", pp. 92-93.

${ }^{439}$ Gilberto, O processo antitruste sancionador, p. 81.

${ }^{440}$ Essas condições estão relacionadas ao direito de "ação", tipicamente jurisdicional e não aplicável, no rigor conceitual, ao processo administrativo. Tampouco seria adequado fazer referência às condições da petição, porque a atividade administrativa se inicia mesmo de ofício. Condições de admissibilidade do julgamento de mérito parece menos problemático, pressupondo a idéia de mérito como resposta à pretensão condenatória deduzida em sede de despacho do Secretário da SDE.

441 "O problema da legitimação consiste em individualizar a pessoa a quem pertence o interesse de agir (e, pois, a ação) e a pessoa com referência à qual [nei cui confronti] ele existe; em outras palavras, é um 
do art. $9^{\circ}$, da lei n. 9.784/99. Porém, a doutrina faz referência à impossibilidade de denúncias anônimas, ${ }^{442}$ o que não parece ser o melhor caminho. ${ }^{443}$

Um primeiro fundamento é o literal, sempre menos interessante: a lei requer a identificação do representante ${ }^{444}$, mas não veda o anonimato. Seguindo adiante, que ao menos se faça um exame ponderado da questão. ${ }^{445}$ Temos um sistema em que se protege a concorrência e não os concorrentes e o legitimado e maior interessado na constituição de um ambiente de concorrência fluido e seguro é o Estado, que atua por meio da SDE, ou seja, a representação seria dispensável caso a SDE tivesse atuação capilarizada, escritórios em todos os Estados ou mesmo até em cidades e pessoal suficiente para pesquisas de campo acuradas, ou ainda alguma ferramenta de onisciência. Mas isso não ocorre: o SBDC depende do recebimento de informações dos agentes do mercado e de qualquer do povo para uma atuação efetiva; mais ainda, o SBDC deve envidar seus melhores esforços para que todo e qualquer do povo participe da proteção da concorrência, aqui no âmbito da provocação.

Somos cientes de que o mercado não é um mar calmo e tranqüilo, um local de pessoas boas e desprendidas, que pautam suas condutas pelo bem da coletividade. Pense-se ainda que no âmbito dos processos administrativos, existem condutas como o cartel que são objeto de política pública de combate específica e incisiva, causa prejuízo não só à concorrência como também manifesto prejuízo ao consumidor, com sobrepreços que variam de 10 a 20\%, e que, por final, é crime, podendo levar administradores à prisão. Diante desse cenário, uma denúncia de cartel pode não ser vista com bons olhos ao cartelizador. Às vezes, o sujeito, acuado, pode se valer de mecanismos de represália repudiáveis, mas que existem.

problema que decorre da distinção entre a existência objetiva do interesse de agir e a sua pertinência subjetiva" (Liebman, Manual de direito processual civil, p. 208).

${ }_{442}^{4}$ Fonseca, Lei de proteção da concorrência, p. 228.

${ }^{443}$ O CADE já se posicionou a favor de decisões anônimas. V. CADE, PA n. 08012.005160/2004-50.

${ }^{444}$ Cfr. art. 48 da Portaria MJ n. 4/06.

445 “A ponderação não é somente um método jurídico mundialmente praticado, mas um método de reflexão de forma geral. Qualquer um que tiver que tomar uma decisão podera argumentos e contra-argumentos, vantagens e desvantagens: o médico leva em consideração os riscos e chances de cura de um tratamento, o educador o faz com as chances de êxito de um método de educar, até mesmo o delinquente compara as vantagens que poderá obter através do delito com a probabilidade de ser descoberto e da provável penal" (Hubman, Die Methode der Abwägung, apud Brasil Júnior, Justiça, direito e processo - a argumentação e o direito processual de resultados justos, p. 103. 
A ponderação que se propõe é bastante semelhante àquele juízo de mal maior e mal mais provável que ordinariamente se faz em concessão de medidas liminares, valendo-se de dois extremos: de um lado, há o prejuízo ao representado, obrigado a se defender no processo, sujeito a prejuízos sofridos pela simples existência de processo administrativo movido contra si e que, ao final, não terá quem responsabilizar por esses prejuízos; ${ }^{446}$ de outro lado o sujeito, às vezes pequeno empresário, ou pessoa física indignada em relação a uma conduta ilícita da qual têm ciência, mas nada pode fazer por receio de represália, permitindo o dano intenso à coletividade oprimida pela colusão horizontal.

Sem dados estatísticos possíveis sobre índices de litigância predatória (ainda incipientes no Brasil) e sobre litigiosidade concorrencial contida, é preciso interpretar a norma de acordo com premissas maiores. Em razão do acesso, da necessidade de participação motivada por onda renovatória e da racionalidade que presume o ordinário e exige a prova do extraordinário, é de se admitir a plenitude da denúncia anônima, desde que presentes os demais elementos que identifiquem a existência de uma infração à ordem econômica. Recomenda-se, no entanto, uma maior cautela da SDE na apreciação desse tipo de denúncia, considerado o risco de desperdício de energia com demandas infundadas. $\mathrm{O}$ risco é calculado: no futuro, se o índice de denúncias anônimas infundadas ou maliciosas de má-fé - for elevado, que se recrimine a interpretação aqui dada. Até lá, espera-se que o SBDC já esteja julgando mais de 60 processos administrativos ao ano.

No âmbito do interesse, a atuação do SBDC e a não exclusão das vias judiciais ordinárias para a satisfação de interesses particulares faz com que a necessidade da tutela administrativa seja premente, não havendo maiores debates no âmbito de cognição sumária. Porém, em relação à adequação, há que se ter maior atenção. "O provimento, evidentemente, deve ser apto a corrigir o mal de que o autor se queixa, sob pena de não ter razão de ser"447 - é aqui que reside o motivo determinante para o arquivamento (leia-se extinção da representação sem a apreciação do mérito). O pequeno conhecimento do ainda adolescente SBDC faz com que muitos indivíduos, por desconhecimento do escopo de atuação do órgão, façam denúncias voltadas à proteção de

\footnotetext{
${ }^{446}$ Referência aqui a questão da sham litigation, abordada mais adiante no item VI.2.5.

${ }^{447}$ Cintra-Grinover-Dinamarco, Teoria geral do processo, p. 260.
} 
interesses individuais e não coletivos. Nessas hipóteses, a denúncia também merecerá arquivamento.

Já a possibilidade jurídica do pedido é condição da ação revista até mesmo por quem a concebeu. Quando Buzaid concebeu o Código de Processo Civil de 1973, era evidente a influência de Enrico Tullio Liebman sobre sua obra. Tanto que o mestre acolheu na carta processual toda a teoria desenvolvida das condições da ação. Porém, as reflexões constantes do mestre italiano desenvolveram e atualizaram sua obra com o passar dos anos. Um dos frutos desse desenvolvimento foi a conclusão, de parte do próprio Liebman, de que as condições da ação eram apenas duas: legitimidade de parte e interesse de agir. Excluiu a impossibilidade jurídica desse rol, considerada então como aspecto do mérito, a ser apreciado mediante cognição exauriente quando do julgamento da demanda em sua inteireza, ou ainda como aspecto atrelado ao interesse de agir. ${ }^{448}$

Isso não quer dizer que, pelo mérito, uma representação possa ser arquivada - aliás, é isso que a letra da lei propõe. Lembremo-nos do CPC, que instituiu o julgamento sumário do mérito pelo seu art. 285-A, como instrumento de prestígio da jurisprudência diante de teses repetitivas, economia processual, racionalização da atividade jurisdicional, combate ao assoberbamento do Poder Judiciário. O dispositivo afirma que "quando a matéria controvertida for unicamente de direito e no juízo já houver sido proferida sentença de total improcedência em outros casos idênticos, poderá ser dispensada

\footnotetext{
${ }^{448}$ Sobre o tema confira-se a ilustrativa nota explicativa de Dinamarco à obra de Liebman "A partir de quando, na famosa aula inaugural referida na nota 126, Liebman deu por construída a sua teoria da ação, extraordinário prestígio essa colocação passou a desfrutar na doutrina brasileira. Entre os mais fiéis adeptos do Mestre, conta-se Alfredo Buzaid (Do agravo de petição, esp. n. 39, pp. 87 ss.), o qual, na condição de autor do Anteprojeto que veio a dar no Código vigente, incluiu as conhecidas três condições hauridas da doutrina liebmaniana (possibilidade jurídica, legitimidade ad causam, interesse de agir): CPC, arts. 267, inc. VI, e 295, incs. I-III e par., inc. III. Sucede que, tendo entrado em vigor na Itália, no ano de 1970, a lei que instituiu o divórcio (lei n. 898, de 1.12.70), na terceira edição de seu Manuale o autor sentiu-se desencorajado de continuar a incluir a possibilidade jurídica entre as condições da ação (afinal, esse era o principal exemplo de impossibilidade jurídica da demanda). E nisso tudo vê-se até certa ironia das coisas, pois no mesmo ano de 1973, em que vinha a lume o novo Código de Processo Civil brasileiro, consagrando legislativamente a teoria de Liebman com as suas três condições, surgia também o novo posicionamento do próprio pai da idéia, renunciando a uma delas (cfr. Dinamarco, Direito processual civil, n. 7, letra C, p. 20). Por sugestão do próprio Mestre, contudo, inclui-se nesta nota a parte da segunda edição em que essa condição da ação vem exposta, visando-se com isso a oferecer ao leitor brasileiro a expressão do pensamento de Liebman que está à base do nosso próprio direito positivo. Anota-se que, na terceira e na quarta edições, os casos de provimento jurisdicional não admitido pela lei (v.g., prisão por débitos) passam a ser encarados como de ausência de interesse de agir, quando era justamente ali que residia, para Liebman, a impossibilidade jurídica. Apesar de controvertido o conceito dessa condição da ação suprimida da obra do nosso Autor e apesar de polêmica a própria existência dessa condição, perante o direito positivo permanece o interesse no assunto, em face da adesão dada pelo Código à teoria aqui referida (...)" (Liebman, Manual de direito processual civil, vol. I, pp. 204-205).
} 
a citação e proferida sentença, reproduzindo-se o teor da anteriormente prolatada". O que se destaca aqui é a cautela do legislador no julgamento sumário (rectius, rejeição sumária) de uma demanda pelo mérito, atribuindo essa possibilidade apenas em casos de matéria de direito já apreciada anteriormente pelos órgãos do SBDC. Não se desconsidera que em processo judicial o autor é alegadamente parte interessada e que ostenta, de regra, um direito subjetivo próprio, razão pela qual é preciso cautela em imunizar decisões sem a cognição exauriente (dispensa-se o contraditório justamente porque o réu se beneficia com a imutabilidade da decisão pela improcedência). Perante o SBDC, o representante não atua como parte processual e não tutela um interesse próprio e, por essa razão, não haveria excessiva preocupação no arquivamento de uma representação. Tampouco há, no CADE, a vedação expressa à repropositura. O que existe é uma rejeição pelo mérito travestida de extinção do processo sem julgamento do mérito, numa potencialização da teoria assertista.

Sobre os pressupostos processuais, ${ }^{449}$ em seus aspectos subjetivos, a competência da SDE (ou da ANATEL) para provocação e instrução e do CADE para julgamento limitam o espaço para dúvida sobre o paralelo com a demanda e a investidura ${ }^{450}$ a imparcialidade já foi objeto de estudo nos itens VI.1.3 a VI.1.7; no que diz respeito à capacidade para ser parte, o direito antitruste admite a responsabilização de “pessoas físicas ou jurídicas de direito público ou privado, bem como a quaisquer associações de entidades ou pessoas, constituídas de fato ou de direito, ainda que temporariamente, com ou sem personalidade jurídica, mesmo que exerçam atividade sob regime de monopólio legal" (lei n. 8.884/94, art. $15^{451}$ ); sobre capacidade postulatória, cfr. item VI.1.8 e a dispensa da interveniência de advogado.

\footnotetext{
${ }^{449}$ Por todos, v. Bedaque, Pressupostos Processuais e Condições da Ação. passim.

${ }^{450}$ A Agência Nacional de Telecomunicações - ANATEL, por determinação do art. 19, inc. XIX, da lei n. 9.472/97 (a Lei Geral de Telecomunicações - LGT), exerce competências legais em matéria de controle, prevenção e repressão às infrações à ordem econômica, sendo responsável pela instrução de processos administrativos dentro de sua competência, fazendo as vezes da SDE.

${ }^{451}$ Perante a Comissão Européia, o conceito de empresa é substancialmente vago, (em contraposição a uma rigidez formal), polimorfo, adaptável aos diversos ramos de aplicação. A empresa pode ser identificada sempre que possível isolar um ato econômico que incida sobre o mercado comum, integrando-se ao conceito jurídico de sujeito de direito aquele econômica, que autoriza a identificação de uma empresa com base em elementos de fato mesmo na ausência de elementos formais. Falcione se refere a Höfner para qualificar empresa como "qualsiasi entità che esercita un'attività economica, a prescindere da sua stato giuridico e dalle sua modalità di finanziamento", pressupondo-se apenas a existência de um mercado. Incluem-se, portanto, associações - ainda que temporâneas -, cooperativas, fundações, fundos de pensão, entes de natureza pública, empresas que tenham encerrado atividades, pesoas físicas. São aindas sujeitos em matéria de direito da concorrência a pluralidade de sujeitos jurídicos, ligados por uma relação de controle, considerados como um "unico centro di imputazione effettivo dell'attività del gruppo", desde que com o exame da situação de fato estejam presentes os requisitos de ação autômona, respeito de diretivas, posições de controle, influência
} 
No âmbito dos pressupostos objetivos, também a SDE está sujeita à aptidão do despacho de instauração do processo administrativo, integrado pela respectiva nota técnica, razão pela qual deve se ater ao disposto no art. 295, par. ún. do CPC e descrever adequadamente o pedido e a causa de pedir, estabelecer a correlação lógica entre os fatos narrados e o pedido de condenação por ilícito anticoncorrencial, bem como a coerência entre os próprios pedidos; deve cuidar ainda para que não exista litispendência e preclusão administrativa sobre o tema; ${ }^{452}$ a perempção é típica do processo civil e o arquivamento injustificado de representações dá ensejo a responsabilidade administrativa do agente público; e pela escopo específico do SBDC, sua atuação é inafastável por convenções de arbitragem, porque também inafastável o munus público de proteção da concorrência por ato de disposição prévio particular (excetuadas as hipóteses compositivas típicas do SBDC).

O resultado dessa comparação entre o Judiciário e o SBDC está no fato de que ao SBDC - em especial à SDE -, é dado rejeitar de plano uma denúncia. Mas tal só pode ocorrer quando a SDE tiver convicção de sua conduta, pautada em um exame cauteloso dos fatos narrados, ${ }^{453}$ de uma cautela com a análise de precedentes no mesmo sentido e, mais importante, que exponha seus motivos em decisão fundamentada. Trata-se de "ato decisório que resulta de um processo lógico de indução e dedução, não podendo,

dominante, detenção de cotas de participação, gestão direta ou indireta (causando a responsabilização da empresa mãe em razão de determinação atuação determinante para a violação ou simples conhecimento da infração). $\mathrm{O}$ abuso de posição dominante pode ainda ser sancionado se duas empresas jurídica e economicamente distintas atuem conjuntamente ostentando posição dominante - a posizione dominante collettiva (Laura Falcioni, "Ambito di applicazione”, n. 2.1).

452 Aqui o SBDC ainda deve evoluir. O sistema de registro de demandas não é acertivo suficiente para garantir um filtro adequado aos funcionários e impedir, de início, a formação de uma relação processual já existente ou já examinada, comunicando-se do fato aos diretores competentes, ao Secretário da SDE ou aos Conselheiros do CADE.

${ }^{453}$ O próprio CADE, em guia elaborado em conjunto com o CIEE, orienta: "o que se deve fazer em casos de suspeita de atos prejudiciais à concorrência? Encaminhar denúncia à SDE ou ao CADE. De preferência, mas não necessariamente, tal denúncia deve ser feita de forma detalhada, sendo acompanhada de documentos que possam orientar a sua avaliação. Caso se conclua pela existência de indícios suficientes da conduta anticoncorrencial, o Secretário da SDE instaura processo (averiguação preliminar ou processo administrativo), para que sejam iniciadas as investigações. As denúncias pode ser feitas em caráter informal, por telefone, fax e até por e-mail, inclusive contendo fitas cassete, fitas de video, folhetos de publicidade, recortes de jornais e revistas, enfim, tudo o que puder servir como prova, desde que legalmente obtida. Devese observar que as denúncias relativas a condutas comercialmente desleais entre particulares, que não afetam a dinâmica concorrencial mais geral, ou que seu efeito se limite apenas às relações de compra e venda, sem impactos para a concorrência, não são de competência do CADE, devendo ser encaminhadas aos órgãos de defesa do consumidor, ao órgão que tenha competência específica relativa ao caso concoreto ou ainda, ao próprio poder judiciário" (Conselho Administrativo de Defesa Econômica - CADE, Guia prático do CADE: a defesa da concorrência no Brasil, p. 30). 
assim, e nem devendo, ser guardado interiormente pelo Secretário, pois a sua subjetividade não impede, pelo contrário, autoriza, sua objetivação (...)". ${ }^{454}$

Ainda mais poderia ser pensado. O Regulamento 773/2004, referente ao processo administrativo concorrencial na Comunidade Européia, dispõe em seu art. $7^{\circ}$ que "1. sempre que a Comissão considere, com base nas informações de que dispõe, que não existem fundamentos bastantes para lhe dar seguimento, deve informar o autor da denúncia das respectivas razões e estabelecer um prazo para que este apresente, por escrito, as suas observações. A Comissão não é obrigada a tomar em consideração quaisquer outras observações escritas recebidas após o termo do referido prazo. 2. Se o autor da denúncia apresentar as suas observações dentro do prazo estabelecido pela Comissão e as observações escritas por ele apresentadas não conduzirem a uma alteração da apreciação da denúncia, a Comissão rejeitará a denúncia mediante decisão. 3. Se o autor da denúncia não apresentar as suas observações dentro do prazo fixado pela Comissão, a denúncia é considerada retirada". É o paralelo com o aditamento da petição inicial (CPC, art. 294) feitas todas as ressalvas, em especial a distinção entre a representação e a instauração do processo administrativo -, pelo qual o SBDC poderia se valer com mais frequiência desse esclarecimento voltado ao aproveitamento de denúncias factíveis, porém apresentadas de forma não satisfatória.

Essas medidas, dentro do escopo político participativo que equaliza poder e liberdade por meio do devido processo legal, refletem bem aquele equilíbrio entre participação-acesso (o direito à representação) e o dever, da SDE e do CADE, de oferecer uma resposta.

Por fim, é preciso ainda enaltecer aspectos positivos do acesso ao SBDC. Todos os órgãos integrantes do Sistema são localizados em Brasília e não existem escritórios regionais. Em épocas de desenvolvimento de comunicação via rede de computadores, fez bem o CADE em oferecer a possibilidade de denúncia mediante o preenchimento de formulário eletrônico, por meio de banner visível e de fácil operação, denominado clique denúncia localizado nos sítios da SDE (www.mj.gov.br/sde), da SEAE (http://www.seae.fazenda.gov.br/servicos_main/denunciar) e do CADE (www.cade.gov.br), independentemente do recolhimento de custas.

\footnotetext{
${ }^{454}$ Franceschini, "Roteiro do processo penal-econômico na legislação de concorrência", p. 42.
} 
Ausentes os óbices legítimos à atuação do SBDC, o Secretário da SDE "ao concluir pela existência de ato com aptidão de produzir efeitos anticoncorrenciais no mercado, praticado por agente econômico em condições de atuar com independência em relação às forças de mercado, - seja pela conclusão das averiguações preliminares, seja pelos indícios já aparentes na descrição do ato ou fato, - há que instaurar o competente Processo Administrativo". 455

\section{VI.2.4. Participação e os papéis do representante e do terceiro}

O representante não é parte e, portanto, não lhe são outorgados os mesmos poderes, deveres, faculdades, ônus e sujeições que são outorgados, v.g., ao autor de uma demanda civil. Aliás, sequer seria necessária, no âmbito técnico procedimento, sua figura no desenho institucional atual do processo administrativo, que pode ser instaurado de ofício e tem sua movimentação provocada pela própria administração.

Essas restrições decorrem do direito material em questão, pois o exercício pleno na relação jurídica de direito material depende do escopo do processo e da ciência plena dos elementos fáticos debatidos na demanda, o que se afasta em razão de um interesse não individual tutelado e dos segredos protegidos pela lei inseridos nos autos pelo, via de regra, concorrente-representado para sustentar suas razões.

O representante pode ser qualquer do povo. Nada impede que um cidadão de Mucajaí apresente denúncias sobre a existência de um cartel de padarias em São Paulo, desde que seja ele capaz de preencher os requisitos de admissibilidade de apreciação do mérito de sua representação. Porém, a praxe demonstra que usualmente o representante é ou alguém do mercado, um concorrente, um agente ou ente vinculado ao Estado e estranho ao SBDC, um indivíduo, grupo de indivíduos ou entidade que têm ciência ou sofre os possíveis efeitos nocivos de uma alegada conduta anticoncorrencial.

De qualquer forma, não há limitador normativo. Não é exigida a demonstração da legitimatio ad causam das ações individuais (cf. visto acima, no item VI.1.1), da legitimação da ação civil pública (lei n. $7.347 / 85$, art. $5^{\circ}$ ) e da ação popular (lei

\footnotetext{
${ }^{455}$ Klajmic, "A apuração das práticas restritivas da concorrência - averiguações preliminares e processos Administrativos", p. 25.
} 
n. $7.417 / 65$, art. $1^{\circ}$ ). Tampouco se aplica aqui o conceito de representatividade adequada da class action americana, existente em razão das especificidades daquele sistema de tutela de interesses transindividuais e do receio da extensão ultra partes de efeitos de decisões tomadas em processos movidos por altruístas bem intencionados, porém incompetentes, ímprobos, inexperientes ou desprovidos de suficiente capacidade financeira, ou por sujeitos egoístas, que as promovem apenas porque o resultado serve seu interesse próprio. Fala-se ainda do risco de colusão, conflito de interesses, risco de contrariedade aos interesses da classe, submissão a acordos espúrios e chantagens. ${ }^{456}$

Até este ponto - o acesso, o "ingresso", a dedução de denúncias -, não há qualquer crítica que se possa fazer ao sistema no âmbito da participação. Como visto, em termos legais o acesso é ainda mais flexível que em outros sistemas, cumprindo de forma adequada a premissa político-democrática de participação em consonância com o atual estágio de desenvolvimento da atuação antitruste no Brasil.

Mas se o acesso à denúncia é facilitado, as regalias do representante terminam aí. Nos termos da Portaria MJ n. 4/06, o representante é considerado "interessado" no processo, pode ser intimado a prestar esclarecimentos sobre sua denúncia em audiência, pode sustentar oralmente em sessão de julgamento perante o CADE. Mas, a partir desse ponto, a prática de atos por ele é "excepcional e limitar-se-á às hipóteses em que a Secretaria de Direito Econômico julgar conveniente para a instrução processual e defesa dos interesses da coletividade" (art. 15). O Regimento interno do CADE, em seu art. 36, determina que "a prática de atos processuais por terceiro interessado será excepcional e limitar-se-á às hipóteses em que o CADE julgar oportuna e/ou conveniente para a instrução processual e defesa dos interesses da coletividade".

O representante, após o oferecimento da denúncia, não tem acesso amplo às informações, não exerce amplos poderes no processo, não se sujeita aos mesmos ônus

\footnotetext{
${ }^{456}$ Jay Tidmarsh “ Rethinking adequacy of representation”, p. 1 e 20. Para registro, revisitando o requisito, o professor Tidmarsh propõe a releitura do conceito, de modo que "representation by class representatives and counsel is adequate if, and only if, the representation makes class members no worse off than they would have been if they had engaged in individual litigation". Sobre o tema, cfr. Pedro Dinamarco, Ação Civil Pública, n. 10.6. O conceito de legitimidade adequada também está presente no Código Modelo de Processos Coletivos para a Ibero-América, quando determina que é requisito da demanda coletiva a adequada representatividade do legitimado, que deve considerar a credibilidade, capacidade, prestígio e experiência do legitimado; seu histórico na proteção judicial e extrajudicial dos interesses ou direitos dos membros do grupo, categoria ou classe; sua conduta em outros processos coletivos; a coincidência entre os interesses dos membros do grupo, categoria ou classe e o objeto da demanda; e o tempo de instituição da associação e a representatividade desta ou da pesoa física perante o grupo, categoria ou classe (v. art. $2^{\circ}$ ).
} 
processuais da SDE (se comparado ao processo civil, conforme o CPC, art. 52); nem mesmo tem poderes ainda que tópicos (se comparado ao processo penal, conforme o CPP, art. 271). Ele não é parte, mas é um terceiro interessado no âmbito processual ${ }^{457}$ e pode ostentar inclusive um interesse jurídico-econômico e material reflexo no processo caso faça parte do mercado afetado pela possível conduta anticoncorrencial. Se concorrente, pode ser mediatamente prejudicado pelo ilícito concorrencial e, para tanto, pode valer-se de demanda autônoma perante a Jurisdição para fazer valer seus direitos subjetivos. Considerando que os consumidores também podem ser lesados (nos casos, v.g., de sobrepreço causado por cartéis), a tutela de interesses transindividuais também lhes serve. O art. 29 da Lei n. 8.884/94, estabelece que "os prejudicados, por si ou pelos legitimados do art. 82 da Lei n $^{\circ}$ 8.078, de 11 de setembro de 1990, poderão ingressar em juízo para, em defesa de seus interesses individuais ou individuais homogêneos, obter a cessação de práticas que constituam infração da ordem econômica, bem como o recebimento de indenização por perdas e danos sofridos, independentemente do processo administrativo, que não será suspenso em virtude do ajuizamento de ação”.

Com seu ingresso no processo, ele deixa de ser terceiro para ostentar a figura de assistente, porém não um assistente comparável ao assistente da acusação, ou à figura da assistência simples no processo civil. Trata-se de uma assistência ainda mais atenuada, privada de muitos dos poderes, deveres, ônus, faculdades e sujeições outorgados à parte e aos intervenientes em processo jurisdicional. ${ }^{458}$

\footnotetext{
${ }^{457}$ Segundo Franceschini, eventual representante não figuraria nem mesmo como terceiro interessado por não poder pleitear seu ingresso como assistente da acusação, amparando-se na idéia de que o conflito concorrencial tem natureza de direito público. Afirma que o representante é um "prejudicado sem interesse jurídico" (Franceschini, "Roteiro do processo penal-econômico na legislação de concorrência”, pp. 17, 21). Não se defende a mesma posição neste trabalho. O representante ostenta as mesmas (e parcas) faculdades e sujeições de um terceiro interessado (conforme se verá adiante), qualificado em algumas momentos. Mas não há razão para se lhe alocar uma qualificação jurídico-processual autônoma e ainda menos favorável.

458 Perante a jurisdição italiana, a intervenção voluntária é regulada pelo art. 105 do c.p.c. ("ciascuno può intervenire in un processo tra altre persone per far valere, in confronto di tutte le parti o di alcune di esse, un diritto relativo all'oggetto o dipendente dal titolo dedotto nel processo medesimo. Può altresì intervenire per sostenere le ragioni di alcuna delle parti, quando vi ha un proprio interesse"). Fala (a) do intervento principale ad excludendum quando o direito alegado volta-se contra todos, o que se assimila à oposição e não merece exame mais profundo nesta sede; (b) do intervento litisconsortile ou adesivo autonomo "quando l'interventore fa valere nei confronti di alcune delle parti originarie un diritto relativo all'oggetto o dipendente dal titolo dedotto in processo medesimo", com os mesmos pressupostos do litisconsórcio facultativo e a diferença de ser realizado ulteriormente à propositura da ação - não parece cabível nessa modalidade por falta de legitimidade ativa e do escopo do processo administrativo; ou (c) do intervento adesivo dipendente "quando l'interventore partecipa in via adesiva al processo, senza proporre una propria domanda, al fine di ottenere una sentenza favorevole ad una delle parti" (Luiso, Diritto processuale civile, $\mathrm{p}$. 293; no mesmo sentido, Mandrioli, Diritto processuale civile, vol. II, p. 378-379). No intervento adesivo dependente "il terzo interviene a sostengo delle ragioni di una delle parti, perché vi ha un proprio interesse. In
} 
Vejamos então o terceiro interessado ${ }^{459}$ que não foi responsável pela representação e que, por isso, deve ainda solicitar seu ingresso no processo.

$\mathrm{Na}$ assistência da acusação penal, o interveniente é o ofendido (ou representante legal, sucessores) "titular do bem jurídico lesado ou posto em perigo pela conduta criminosa". ${ }^{460}$ No processo civil, a assistência (intervenção ad coadjuvandum) não altera o objeto do processo e reflete situação em que o assistente é titular de uma "situação jurídica conexa ou dependente da res in judicium deducta", sua qualificação depende da sua relação jurídica com o adversário e os efeitos da intervenção são disciplinados pelas lições de eficácia preclusiva da coisa julgada. ${ }^{461}$ Ainda assim, a assistência se justifica porque o interveniente tem a finalidade de "colaborar com vistas a melhorar o resultado a ser dado nesse litígio, tendo em vista a parte a que passa a assistir, seja porque tenha interesse próprio (art. 50), ou seja, porque seu próprio direito possa ser afetado". ${ }^{462}$ Já a lei no processo administrativo (lei n. 9.784/99, art. 9) determina que "São legitimados como interessados no processo administrativo: I - pessoas físicas ou jurídicas que o iniciem como titulares de direitos ou interesses individuais ou no exercício do direito de representação; II - aqueles que, sem terem iniciado o processo, têm direitos ou interesses que possam ser afetados pela decisão a ser adotada; III - as organizações e associações representativas, no tocante a direitos e interesses coletivos; IV - as pessoas ou as associações legalmente constituídas quanto a direitos ou interesses difusos.

No processo administrativo perante o CADE, o terceiro não é titular do bem jurídico lesado (como ocorre no direito penal), não ostenta posição jurídica próxima a

questo caso il terzo non interviene per far valere un suo diritto, ma per sostenere le ragioni di una delle parti, senza chiedere la tutela di una propria situazione sostanziale (...) la situazione sostaziale dedotta in giudizio rimane sempre una sola, quella originaria. Il terzo, senza dedurre in giudizio una propria situazione sostanziale, si limita a sostenere le ragioni di una delle parti, perché ha interesse che essa vinca. Se la parte non vincesse, egli ne subirebbe un pregiudizio. Il terzo, dunque, deve essere titolare di una situazione giuridicamente protetta, riconosciuta dall'ordinamento, tale da essere condizionata dal riconoscimento che la parte adiuvata ottenga di una propria situazione sostanziale (...)" (Luiso, Diritto processuale civile, p. 298.). Para Mandrioli, busca-se uma tutela dos efetiso reflexos que a sentença inter alios pode impor em relação ao interveniente, decrrendo seu interesse de uma genérica expectativa de vantagem com o acolhimento da demanda (uma esperança potenciada pelo fundamento jurídico), correlata à vantagem proporcionada à parte principal (Mandrioli, Diritto processuale civile, vol. II, p. 379). A situação do assistente no processo administrativo se aproxima, ainda que discretamente, com a figura do intervento adesivo dependente.

${ }^{459}$ A norma faz referência a figura de terceiro interessado mesmo após seu ingresso no processo, o que é um equívoco. Terceiro não é parte na relação processual. Quem ingressa no processo e dele participa, ainda que em grau de interveniência bastante baixo, merece qualificação diversa de simples terceiro. Os requisitos para o ingresso merecem comento.

${ }^{460}$ Mirabete, Processo penal, p. 348.

${ }^{461}$ Dinamarco, Intervenção de terceiros, p. 34-36.

${ }^{462}$ Arruda Alvim, Manual de direito processual civil, vol. II, p. 116. 
do assistido porque perante o processo, não possui vínculo com a SDE (logo não há indicativo de assistência simples) e tampouco é direta e imediatamente vinculado ao resultado da demanda (considerando que toda demanda pode ser revisada perante o Poder Judiciário, sem ser vinculante em qualquer medida, e que a eficácia da decisão não se estende ao interveniente em razão do déficit de participação já tratado neste trabalho).

Porém, ainda assim, admite-se a sua participação no processo. Por que?

Já foi dito que o direito antitruste brasileiro vive período de amadurecimento institucional. Dentre os diversos reflexos dessa constatação, está na pequena estrutura de que dispõe o SBDC para as atividades de persecução, instrução e julgamento. Numa realidade como essa - que não é dado ao direito processual desconhecer - o enforcement antitruste não só quer como precisa, depende da colaboração popular. É a fiscalização popular realizada nos rincões de um país de proporções continentais que têm a capacidade de identificar condutas anticoncorrenciais em mercados relevantes de menor extensão geográfica, mais distantes dos grandes centros e nem por isso menos relevantes para o enforcement antitruste - afinal, o que se pretende é capilarizar a atuação da concorrência de modo a desenvolver a cultura concorrencial, em atenção ao escopo socialeducativo já exposto. São os concorrentes que conhecem o mercado que tem informações técnicas e relevantes, que inúmeras vezes são determinantes no SBDC para definição de conceitos relevantes em mercados específicos, como, v.g., na definição geográfica e de produto do mercado, com o cálculo das elasticidades, de atividades menos ortodoxas que podem ser praticadas - estamos no campo de ilícitos que podem ter inclusive repercussão penal.

Consumidores e concorrentes são, em conjunto com o Estado, os grandes beneficiários finais da proteção da concorrência. O consumidor tem acesso a mais produtos, a produtos mais baratos, podendo dispor melhor de sua riqueza; o concorrente se sentirá prestigiado e estimulado a buscar na inovação e na eficiência a razão de sua atividade e do aumento legítimo de seus lucros. O Estado estará satisfeito com a sedimentação de um ambiente seguro e previsível onde o mercado possa se desenvolver com fluidez. Com a condenação ou não do representado, os beneficiários terão participado 
do processo de formação da decisão, intervindo ativa e produtivamente sobre o convencimento do órgão julgador. ${ }^{463}$

Nada do que foi dito destoa da idéia de participação democrática defendida neste capítulo.

Em perspectiva ontológica, não se pode concordar com a discricionariedade sobre a admissão ou rejeição da intervenção de terceiros. Beira a inconstitucionalidade dizer que um órgão pode escolher quem pode ou não pode participar do processo, mesmo em ambiente no qual são proferidas decisões vinculadas, o processo é pautado pela legalidade, é acessível a todos, está adstrito ao modelo constitucionais, à cláusula do devido processo legal, à idéia de acesso à ordem jurídica justa (porque também o tribunal administrativo deve ser preocupar em proferir decisões justas) e preocupa-se constantemente em afastar qualquer suspeição estrutural-institucional que possa ser atribuída ao órgão julgador. ${ }^{464}$

Se participar é a regra e restringir é a exceção, sempre de lege ferenda, o tratamento do tema da intervenção merece uma gradação. Inicialmente, seria de se permitir a participação de todo e qualquer do povo no processo. A inserção de material probatório e de argumentos só teria a acrescentar. Seriam dados novos, opiniões, pontos de vistas que contribuiriam para que fosse robustecida a tese e a antítese, legitimando institucionalmente ainda mais a síntese oferecida pelo CADE. Porém - e sempre existe um porém - num modelo ideal, onde o antitruste é difundido e a massa popular tem acesso às informações processuais do órgão, a condução do processo tornar-se-ia impraticável. Teríamos intervenções multitudinárias que ao invés de auxiliar no fornecimento de

\footnotetext{
${ }^{463} \mathrm{Na}$ Itália, iniciada uma instrutória, notificam-se empresas e interessadas, e também sujeitos com um interesse direto, imediato e atual, que tenham apresentado denuncia ou informações utéis à instauração do procedimento, situação que amplia a participação procedimento de sujeitos de fato, estranhos à contorvérsia (Garofoli, "Procedimento, accesso e autorità indipendenti", p. 3352-3353). No âmbito da FTC admite-se a construção partecipativa do ato conclusivo e a atitude geral de se favorecer a intervenção de terceiros no curso da do processo (Benedetto, L'Autorità garante della concorrenza e del mercato, p. 211).

${ }^{464}$ Por essa razão, discorda-se respeitosamente do posicionamento corrente da Procuradoria do CADE, que se vale correntemente de parecer proferido no Proc. n. 08012.007443/99-17 - parecer n. 326/2004: "deve a autoridade julgadora verificar, em cada caso que lhe é submetido, a idoneidade e/ou adequação do comparecimento de terceiros ao feito, haja vista que é sua competência sopesar os interesses envolvidos, sendo que os efeitos de sua decisão poderão atingir toda a coletividade envolvida, inclusive a que não compareceu indiretamente ao processo. Referido entendimento reforça a importância do Conselheiro Relator na aplicação da lei 8.884/94, eis que o exercício de seu poder discricionário é que estabelecerá os limites para que a intervenção da coletividade, na forma acima exposta, seja tida como digna de tutela ou não por essa entidade, separando, portanto, os que se enquadram nas hipóteses que mereçam tutela administrativa, de outras que assim não se apresentem, culminando por gerar tumulto ao processo".
} 
informações, provocariam a juntada aos autos de "informações demais", sem que fosse possível na atual estrutura do SBDC dar atenção a toda massa crítica de dados acostados.

Seria necessário um corte. A idéia de relação jurídica com a pretensão deduzida é mediata e de nada serve para qualificar a assistência, conforme já visto; já em relação à rejeição jurisdicional da inserção do interesse econômico do processo, ${ }^{465}$ algo de interessante pode ser extraído. Se no judiciário é repudiada a existência de um interesse econômico para justificar a intervenção do assistente, no direito econômico-concorrencial esse interesse poderia bem ser utilizado como requisito de intervenção. Mas um cuidado, o interesse econômico a ser tratado não é o simples interesse pecuniário, ${ }^{466}$ mas sim um legítimo interesse antitruste, ainda que reflexo, trazido por um consumidor do produto objeto da conduta, ou mesmo de um concorrente possivelmente prejudicado.

Ainda no plano das hipóteses, poderíamos nos deparar com inúmeros concorrentes ou consumidores aptos à demonstração de um interesse econômico para participação no processo. A solução poderia ser recorrer aos critérios existentes para a tutela de interesses transindividuais e para a tutela constitucional do processo, um pouco na esteira do que determina o art. $9^{\circ}$ da lei n. 9.784/99. Se a atomização é capaz de gerar assistências multitudinárias, o mesmo não ocorreria se a intervenção pudesse ser atribuída

\footnotetext{
465 “Concluiu o Min. Relator, a recorrente não ostenta posição jurídica que a habilite a figurar como assistente litisconsorcial ou mesmo como assistente simples. Ela não mantém qualquer vínculo jurídico com a impetrante e a relação jurídica que ela ostenta em face da impetrada é autônoma e independente da que está posta em questão no mandado de segurança. Seu interesse é simplesmente econômico. STJ, $1^{\text {a }}$ T., REsp 1.065.574-RJ, Rel. Min. Teori Albino Zavascki, j. 2.10.08).

${ }^{466}$ Intervenções anômalas em razão de interesses econômicos não são novidade no direito brasileiro, havendo espaço para a criatividade legislativa. $\mathrm{O}$ art. $5^{\circ}$, par. ún. da lei n. 9.469/97 prevê a regulamentação da intervenção da União em processos pendentes nos quais se fizerem presentes interesses econômicos, dispondo que "as pessoas jurídicas de direito público poderão, nas causas cuja decisão possa ter reflexos, ainda que indiretos, de natureza econômica, intervir, independentemente da demonstração de interesse jurídico, para esclarecer questões de fato e de direito, podendo juntar documentos e memoriais reputados úteis ao exame da matéria e, se for o caso, recorrer, hipótese em que, para fins de deslocamento de competência, serão consideradas partes". A conceituação do que é econômico se dá da mesma forma que a aqui proposta: reflexos sobre o funcionamento de um mercado, sobre o desenvolvimento das atividades econômicas, no qual a atividade da União (e sua influência sobre elemento da infra-estrutura brasileira) está umbilicalmente inserida. Carneiro cometeu o mesmo erro de reduzir o conceito de interesse econômico em interesse pecuniário nos casos dessa referida intervenção anômala ("Da intervenção da União Federal, como amicus curiae. Ilegitimidade para, nesta qualidade, requerer a suspensão dos efeitos da decisão jurisdicional. Leis n. 8.437/92, art. $4^{\circ}$ e n. 9.469/97, art. $5^{\circ}$ ", RF 363/181). Wald, com mais acerto, afirma que "a introdução do parágrafo único do artigo $5^{\circ}$ teve como finalidade permitir que as pessoas jurídicas de direito público resguardassem não só os seus interesses jurídicos, mas também os seus interesses econômicos, e tomassem as providências para garantir o bom funcionamento das instituições. Enquanto, no caso do artigo 50 do Código de Processo Civil, o tribunal aprecia o risco de prejuízo juridicamente relevante, ao contrário, na 'assistência especial' do art. $5^{\circ}$, parágrafo único, basta que a Administração esteja defendendo posição por ela assumida no exercício de suas funções para que se justifique sua presença no processo", (Pareceres: direito das concessões, p. 287).
} 
somente aos constitucionalmente legitimados ou então àqueles entes determinados pela Lei da ação civil pública. Ainda assim, poderia ser criada alguma resistência pelo fato de que muitas associações poderiam desejar intervir no processo, assoberbando os órgãos do SBDC. A satisfação e regojizo de podermos chegar a esse ponto exigiria também uma solução para esse problema bom: seria então o caso de recorrer aos critérios de representatividade adequada do direito americano e bem esclarecidos no Código Modelo de processos coletivos da Ibero-américa. Somente aqueles entes que objetivamente tivessem credibilidade, capacidade, prestígio, experiência, histórico na proteção judicial e extrajudicial dos interesses ou direitos dos membros do grupo, categoria ou classe, conduta ilibada em outros processos coletivos, algum tempo desde sua fundação e, por fim, a coincidência entre os interesses dos membros do grupo, categoria ou classe e o objeto do processo.

Essa solução pressupõe a superação de todas as circunstâncias fáticas das demais. As limitações impostas seriam necessárias à preservação do próprio processo e do seu resultado útil. A única solução inviável seria a restrição na forma atualmente existente.

\section{VI.2.5. Acesso e abuso}

Partindo da idéia de acesso como garantia política, é preciso ter em mente que o direito de ação exige o seu uso responsável. A repressão de interesses espúrios expostos em processos já é uma preocupação freqüente, examinada endoprocessualmente à luz do instituto da litigância de má-fé.

O princípio geral da boa-fé se associa ao princípio da confiança, pelo qual "uma pessoa adere, em termos de actividade ou de crença, a certas representações passadas, presentes ou futuras, que tenha por efectivas". É uma ponte entre a boa-fé subjetiva sobre a qual o legislador prevê condutas esperadas específicas, tipificadas ou não: “a consagração dos dispositivos gerais, implícitos no dever de actuar de boa-fé e no exercício inadmissível de posições jurídicas, capazes de, nalgumas das suas facetas mais significativas, proteger a confiança, demonstram, nesta, um vector genérico. Mas dão também o tom da generalização possível: a confiança, fora das normas particulares a tanto dirigidas, é protegida quando, da sua preterição, resulte atentado ao dever de actuar de boa- 
fé ou se concretize um abuso de direito". Em termos de pressupostos e conseqüências, a boa-fé e a confiança decorreriam de uma boa-fé subjetiva e ética de alguém que, sem violar direitos, ignora a lesão à posição alheia, os elementos objetivos capazes de provocar uma crença plausível, ou um "assentar efectivo de actividades jurídicas sobre a crença consubstanciada, em termos que desaconselhem o seu preterir". ${ }^{467}$

A objetivação-positivação da boa-fé no processo se deu por meio do disposto no art. 14, do CPC: "Art. 14. São deveres das partes e de todos aqueles que de qualquer forma participam do processo: I - expor os fatos em juízo conforme a verdade; II - proceder com lealdade e boa-fé; III - não formular pretensões, nem alegar defesa, cientes de que são destituídas de fundamento". As partes devem ter suas condutas processuais pautadas pela boa-fé nas relações recíprocas e nas relações perante o órgão jurisdicional. Em contraposição, a má-fé é consubstanciada em ato doloso, gravemente culposo, ${ }^{468}$ malicioso e desleal. ${ }^{469}$ A litigância de má-fé seria então um "abuso de direito, fere o princípio do equilíbrio, da busca da harmonia social, ferindo parâmetros éticos que devem nortear a lide judicial. Não se pode transformar o processo, de instrumento eficaz em busca da afirmação do direito em veículo de chicanas, que vão se concretizando por ardis e astúcias". 470

O STF afirma correntemente que "o ordenamento jurídico brasileiro repele práticas incompatíveis com o postulado ético-jurídico da lealdade processual. $\mathrm{O}$ processo não pode ser manipulado para viabilizar o abuso de direito, pois essa é uma idéia que se revela frontalmente contrária ao dever de probidade que se impõe à observância das partes. O litigante de má-fé - trate-se de parte pública ou de parte privada - deve ter a sua conduta sumariamente repelida pela atuação jurisdicional dos juízes e dos tribunais, que não podem tolerar o abuso processual como prática descaracterizadora da essência ética do processo". 471

De fato, o art. 17 do CPC traz o instituto da litigância de má-fé como instrumento da proteção da confiança e da boa-fé na relação processual. Dispõe, no seu inc. III, que "reputa-se litigante de má-fé aquele que (...) usar do processo para objetivo

${ }_{467}$ Menezes Cordeiro, Da boa-fé no direito civil, \$49.

${ }^{468}$ Carreira Alvim, "Litigância de má-fé e lealdade processual", p. 11-12.

${ }^{469}$ Theodoro Jr., Código de processo civil anotado, p. 22.

${ }^{470}$ Felker, Litigância de má-fé e conduta processual inconveniente, p. 24.

${ }^{471}$ STF, Pleno, Min. Rel. Celso de Mello, AI 567171, DO. 6.2.09. No mesmo sentido: STF, RE 167787, AI 177313, RE 179502, RE 190841, RE 202097, AI 260266, RTJ 186/715. 
ilegal", respondendo por perdas e danos, conforme previsto nos arts. 16 e 18 do mesmo Diploma. A conduta ilícita deveria estar conexa, nesses casos, a uma ausência de fundamento legal e lógico decorrente de ação consciente na utilização da ação para causar prejuízo à parte contrária. ${ }^{472}$

Abdo interpreta com clareza o dispositivo: "o objetivo ilegal a que se refere à lei há que ser outro, não diretamente ligado ao petitum: expor a parte contrária à desonra pública, abalar-lhe o crédito, exercer sobre ela pressão psicológica ou econômica para obter favores ou vantagens indevidas etc. Como se vê, consagra-se ainda uma vez o critério do desvio de finalidade como principal elemento do abuso do processo, ao lado da aparência de legalidade e do uso livre (não vinculado) de uma ou mais situações subjetivas processuais". ${ }^{473}$ Esse desvio de finalidade pode representar a utilização do processo para além da causa petendi, uma destinação anormal, imprópria, a utilização da máquina judiciária para fins estranhos ao processo, exercício disfuncional ou distorção no emprego do processo. ${ }^{474}$

As redações dos arts. 16-18 do CPC são suficientemente genéricas para comportar uma série de interpretações. Dentre elas, conforme exposto acima, não há razão para limitar o ilícito ao seu aspecto processual, e sim permitir uma sanção processualmente prevista sobre uma conduta materialmente condenável. Isso seria possível e aceito com maior tranqüilidade se considerada a litigância de má-fé como instituto bifronte, ao qual Dinamarco se refere para explicar aquele que "recebendo do direito processual parte de sua disciplina (na sua técnica), mas também dizendo respeito a situações dos sujeitos fora do processo (às vezes, até antes dele), compõe um setor a que a doutrina já denominou direito processual material (Chiovenda). Eles são (...) integrados por um intenso coeficiente de elementos definidos pelo direito material e - o que é mais importante - de algum modo dizem respeito à própria vida dos sujeitos e suas relações entre si e com os bens da vida. Constituem pontes de passagem entre o direito e o processo, ou seja, entre o plano substancial e o processual do ordenamento jurídico". 475

\footnotetext{
${ }^{472}$ Reginald Felker, Litigância de má-fé e conduta processual inconveniente, p. 69.

473 Abdo, Abuso do processo, p. 159.

${ }^{474}$ Abdo, Abuso do processo, p. 89.

${ }^{475}$ Dinamarco, Instituições de direito processual civil, n. 6. "Competition law illustrates how procedural law and substantive law interact and how blurred the distinction between procedural law and substantive law can be. The rules on proof are perceived to be procedural but no one shall contest that the existence of sufficient
} 
Ocorre que, sabidamente, o instituto da litigância de má-fé é utilizado com cautela (excessiva ou não) pelos órgãos do Poder Judiciário. O reconhecimento da má-fé em processos, ainda que se admita a natureza processual-material do instituto da litigância de má-fé, é sempre excepcional, mesmo em um cenário em que doutrinadores cheguem a sustentar sua tipificação penal. ${ }^{476}$ Tal fato é agregado por uma atuação ainda pequena dos órgãos de classe e do próprio Poder Judiciário na responsabilização de causídicos que promovam demandas infundadas ou com objetivos não-lícitos. ${ }^{477}$

Da mesma forma no SBDC. É previsto o instituto da enganosidade, no art. 26, caput da Lei n. 8.884/94, mas de parca utilização inicialmente por um vício na própria redação do dispositivo. A enganosidade (sabe-se lá por qual motivo não foi denominada de má-fé de modo a simplificar o entendimento) está atrelada a condutas ilícitas sujeitas a preceitos cominatórios. Mas não raras vezes o ato do litigante de má-fé se exaure em apenas um movimento que, se constatado, enseja punição a ser fixada pelo julgador de plano, independentemente de algum lapso temporal. A inserção da enganosidade em meio a sugestões coercitivas cominatórias faz com que o aplicador tenha o cuidado de arbitrar com parcimônia as multas.

Por tais motivos, os instrumentos de reação então se multiplicam. São diversas as hipóteses de fatos jurídicos de múltipla incidência. Determinado fato - a falta de boa-fé na propositura de demandas - pode abrir espaço não só para aquela atuação "endoprocessual" de instituto bifronte, mas para persecuções que passam pela caracterização genérica do ilícito civil amparada pelos arts. 186 e 927 do CC, amparadas na idéia de que "todos os homens, pelo simples fato de serem sujeitos de direitos, têm o poder abstrato de recorrer aos tribunais para obterem a tutela jurisdicional; mas se num caso concreto exercerem esse poder, apesar de saberem perfeitamente que o põem ao

proof or not of a cartel, touches on the merits of the case" (Parret, "Sense and Nonsense of Rules on Proof in Cartel Cases", p. 3).

${ }^{476}$ Tamanha a indignação de alguns, que sustentam posições mais enérgicas: “urge, pois que o legislador vá além das penalidades civis, porque estas não têm sido o redutor dessa ignomínia e os pressupostos processuais da litigância de má-fé, em sua maioria, ultrapassam os limites da ilicitude civil. Para barrar de vez essa constrangedora e dolorosa situação, a reforma deverá atingir o cerne da questão, criminalizando de vez essa conduta, quando o dolo estiver plenamente configurado, exteriorizado na atuação distorcida das partes" (Szklarowsky, "Litigância de má-fé", p. 279).

477 Sobre a maior severidade no controle da atuação do advogado em sistemas de common law, confira-se Abdo, Abuso do processo, n. 28. 
serviço da pretensão ilegal, praticam um ato ilícito, que se traduz no abuso do direito de acionar ou de contestar". ${ }^{478}$ Trata-se de um abuso macroscópico. ${ }^{479}$

O direito de ação ou o direito de petição deixam de ser tratados como absolutos. Partindo da aproximação de ambos nesta sede, José Olimpio de Castro Filho ensina que "o comumente chamado direito de ação não é absoluto. Isso mesmo mostrou Niceto Alcalá Zamora Y Castillo, salientando que as diversas teorias que procuram explicar a natureza jurídica da ação se viram obrigadas a qualificar o 'direito de ação' com algo mais: 'direito abstrato de agir' (Degenkolb); 'direito potestativo autônomo' (Chiovenda); 'direito subjetivo processual' (Carnelutti)... E o mesmo Zamora Y Castillo concluiu, num belíssimo raciocínio, que, a rigor, não se devia nem falar em direito de ação, mas em faculdade, poder, ou possibilidade de ação. A isso acresce que, se há um direito ou faculdade incontestável de demandar e contestar, coexiste também uma obrigação, frente à parte contrária, de não molestar outrem com o processo. Justifica-se, por isso mesmo, a repressão do abuso no exercício de um direito, que é nocivo à parte contrária, e, pois, à ordem jurídica" ${ }^{480}$ - se há restrição em relação ao direito de ação, que se dirá em relação ao direito de petição.

A coibição do uso abusivo de um direito constitucional e democrático em nenhuma hipótese resulta em restrição ao acesso à justiça, ${ }^{481}$ como bem destaca Pontes de Miranda: "há limites aos direitos e há abusos sem traspassar limites. Não se confundam limitação aos direitos e reação ao abuso do exercício do direito, ou melhor, o exercício lesivo. Quando o legislador percebe que o contorno de um direito é demasiado, ou que a força, ou intensidade, com que se exerce, é nociva, ou perigosa a extensão em que se alcança, concebe as regras jurídicas que o limitem, que lhe ponham menos avançados os marcos, que lhe tirem um pouco da violência ou do espaço que conquista". 482

\footnotetext{
${ }^{478}$ Alberto dos Reis, Código de Processo Civil Anotado, p. 259. Americano afirma: "na ausência do direito que justifica a acção, levante-se contra o autor o direito que tem o réo de não ser levado a juiz sem motivo; desaparece o interesse do autor, que é a causa proxima actionis, verifica-se o damno, si não moral, pelo menos patrimonial do reo" ( $O$ abuso do direito no exercício da demanda, pp. 65/66).

${ }^{479}$ Valendo-me de expressão utilizada por Abdo, Abuso do processo, n. 30.1.

${ }^{480}$ Castro Filho, Abuso do Direito no Processo Civil, p. 40.

481 "Em outros termos, a teoria do abuso do direito processual não nega o permanente direito que a todos assiste de demandar ou defender-se, 'senão apenas visa evitar que o exercício de tal direito seja abusivo" (Theodoro Júnior, Abuso de direito processual no ordenamento jurídico brasileiro, p.110).

${ }^{482}$ Pontes Miranda, Comentários ao Código de Processo Civil, t. 1, pp. 351-352.
} 
A situação de abuso é exposta também na lição clássica de Jorge Americano, para quem "os incommodos, a diminuição patrimonial causada pelo contracto de honorarios, a producção de provas difficies e custosas, o abandono de negocios urgentes, que perecem para attender ás necessidades da demanda, emfim, a repercussão material mais ou menos intensas, além do damno moral, que só em parte serão reparados na sentença". 483

Em recente tentativa de sistematização, a doutrina determina que para a caracterização do abuso de demandar, é preciso que haja o direito do qual o agente é titular, que esse direito tenha sido exercido, que os limites impostos pelo fim social e econômico, boa-fé e bons costumes tenham sido extrapolados de forma manifesta. ${ }^{484}$

O abuso do direito de demandar pela perspectiva civilista depende da substância da relação jurídica invocada (existência do direito em contraposição à improcedência manifesta e ao erro grosseiro), da condição do agente (interesse, qualidade e capacidade) e modalidade do seu exercício (forma acintosa, coativa, emulativa ou dolosa). ${ }^{485}$

E "age em fraude à lei, quando exercendo uma seqüência de atos lícitos obtém resultado contrário ao preceito jurídico". ${ }^{486}$

O exercício de um direito é condicionado a sua finalidade, qual seja, proteger um direito subjetivo de quem o exerce, conforme se observa da leitura de precedente do Supremo Tribunal Federal nesse particular: “o direito de petição e o acesso ao Poder Judiciário para reparar lesão ou ameaça a direito são garantias previstas na Constituição Federal. Contudo, o exercício abusivo desses direitos acaba por atrapalhar o bom andamento de ações que deveriam ser ininterruptas e mais céleres possíveis, Justamente para garantir ao jurisdicionado a efetiva prestação da tutela pretendida". ${ }^{487}$

A múltipla incidência da má-fé do direito de demandar pode gerar conseqüências também na esfera antitruste. A doutrina reconhece o exercício da litigância predatória com objetivos anticoncorrenciais em ações ou petições em que nenhum litigante

\footnotetext{
${ }^{483}$ Americano, $O$ abuso do direito no exercício da demanda, p. 50.

${ }^{484}$ Abdo, Abuso do processo, p. 46; Comoglio, Abuso del processo e garanzie costituzionale, p. $327 / 328$.

485 Americano, $O$ abuso do direito no exercício da demanda, p. 64.

${ }^{486}$ STJ, $1^{\text {a }}$ T., Min. Rel. Humberto Gomes de Barros, Resp. 207.484, dj. 14.03.2000 - RSTJ 135-136.

${ }^{487}$ STF, $1^{\text {a }}$ T., HC 94170 / SP, Min. Rel. Menezes Direito, dj. 10.06.08
} 
razoável espera, de forma realista, sair vencedor e que tal conduta camufle um objetivo contrário à livre concorrência. Nesses casos, o custo da demanda é sempre proporcionalmente maior e mais danoso para quem detém menor capacidade financeira. $\mathrm{O}$ direito de ação é usado como ferramenta para impedir atividade comercial ou macular a imagem da empresa perante o mercado, para excluir competidores, impedir que novas empresas ingressem no mercado ou para a maximização do poder de mercado. ${ }^{488}$

Essa conduta configura-se pela utilização de procedimentos administrativos ou processos judiciais para criar barreiras artificiais à entrada de novos competidores no mercado, bem como para prejudicar a atividade dos competidores. ${ }^{489}$

Os americanos são pioneiros no tratamento da matéria no direito antitruste. A fim de atribuir maior segurança jurídica para o reconhecimento desses institutos, criaram-se critérios para se caracterizar esse sham litigation: (a) a demanda deve ser objetivamente infundada no sentido de que nenhum litigante razoável iria de forma realista esperar seu sucesso - eliminando-se a idéia de exercício regular de direito $^{490}$; (b) a conduta é anticoncorrencial se a ação é objetivamente destituída de fundamento e visa a interferir diretamente na atividade comercial de um concorrente através de procedimento ou processo perante o aparato governamental. ${ }^{491}{ }_{-} 492$

Klein explica que o sham litigation deve ser visto como uma litigância predatória ou fraudulenta com efeitos anticompetitivos que se dá pelo uso impróprio dos tribunais e outros procedimentos administrativos contra rivais para alcançar danos à competitividade. ${ }^{493}$ Areeda e Hovenkamp explicam que a prática de sham litigation refere-

488 “Any lawsuit that aims primarily to exclude a competitor from the market in order to enhance the market
power of the incumbency is a sham. Thus, even if the plaintiff has a valid claim, if the real motive of the
lawsuit is anticompetitive exclusion, the plaintiff may lose Noerr immunity" (Hylton, Antitrust and the state,
p. 370).
489 City of Columbia v. Omni Outdoor Advertising, INC. 499 U.S. 365 (1991).
490 Professional Real Estate Investors, Inc. v. Columbia Pictures Industries, Inc., 113 S.Ct. 1920, 1928, 123
L.Ed.2d 611, 26 USPQ2d 1641, 1646 (1993) ("sham" litigation must be 'objectively baseless' and intended
to use the litigation process to interfere directly with a competitor's business); Carroll Touch, Inc. v. Electro
Mechanical Systems, Inc., 15 F.3d 1573, 1581-83 (Fed.Cir.1993) (rejecting claim that filing a lawsuit was
part of a scheme to restrain and monopolize trade, invoking the Noerr-Pennington immunity rule).
491 V. 113 S.Ct. at 1928,26 USPQ2d at 1646.
492 A Suprema Corte Americana destaca ainda que um sucesso preliminar no mérito não significa que a ação
é seria "objetivamente fundada" (Boulware v. State of Nevada, 960 F.2d at 788-89 - 9th Cir. 1992).
493 "Historically, sham litigation has generally been defined legally as anticompetitive litigation that is
"baseless or otherwise without any legitimate foundation. (...) A definition of sham litigation that more in
keeping with economic reasoning would identify sham litigation as predatory or fraudulent litigation with
anticompetitive effect, that is, the improper use of the courts and other government adjudicative processes
against rivals to achieve anti competitive ends" (Christopher C. Klein, The Economics of Sham Litigation - 
se à pretensão inadequada e não busca obter a satisfação do pedido, mas somente a exclusão de um rival, o aumento de seus custos, o prejuízo à sua produção ou a criação de um dano similar à concorrência. ${ }^{494}$ Como explicam Gavil, Kovacic e Baker, ao contrário do que ocorre no processo legislativo e administrativo, as Cortes seriam menos capazes de se protegerem contra a utilização das partes para propósitos anticoncorrenciais. ${ }^{495}$

De forma muito similar, a União Européia também reconhece e aplica esses institutos. Em caso envolvendo grupo de medicamentos AstraZeneca, a Comissão Européia condenou essa empresa pelo uso abusivo do direito de ação devido às reiteradas petições sem fundamento protocoladas perante os escritórios de registro de patentes com vistas a prejudicar as empresas concorrentes. ${ }^{496}$

Nem mesmo nos casos em que envolvidas medidas governamentais, o direito, aqui de ação e de petição, estaria livre de análise à luz dos pressupostos da litigância predatória, à luz das relações entre a Noerr-Pennigton Doctrine, a State Action Doctrine e a sham exception. Entre as décadas de 60 e 70 , prevalecia a imunidade antitruste quando autorizadas por medidas governamentais: "antitrust challenges to anticompetitive government action often include claims directed at private parties who have succeeded in soliciting government action that reduces competition. Although the government entity may be immune from antitrust liability by virtue of the state action doctrine or some other exemption, such claims pose a distinct question: should that immunity extend to the private parties that have actively sought the anticompetitive state action? The actions of such parties frequently are challenged as monopolization or attempts to monopolize under Section 2 of the Sherman Act". 497

Três decisões deram corpo à teoria. No primeiro caso, a Suprema Corte americana questionou a aplicação do Sherman Act para corrigir as consequências

Theory, Cases and Policy, Bureau of Economic Staff Report to the Federal Trade Commission, Estados Unidos, 1989, disponível em <http://www.ftc.gov/be/econrpt/232158.pdf>, acesso em 27.8.09).

494 "Strictly speaking, the term sham, refers to a petition to the government that is improper in that it is not intended to obtain the request relief from the government entity, but only to exclude a rival, raise its costs, constrain its output, or cause similar competitive harm" (Areeda-Hovenkamp, Antitrust Law. An Analysis of Antitrust Principles and Their Application, p. 205).

${ }^{495}$ Nesse sentido: "In contrast to legislative, executive and administrative processes, the courts are less able to protect themselves from being used for anticompetitive purposes" (Gavil-Kovacic-Baker. Antitrust Law In Perspective: cases, concepts, and problems in competition policy, pp. 993/994).

${ }^{496}$ Integra da decisão disponível em http://ec.europa.eu/competition/antitrust/cases/decisions/37507/en.pdf.

${ }^{497}$ Gavil-Kovacic-Baker, Antitrust Law In Perspective: cases, concepts, and problems in competition policy, p. 993 . 
anticoncorrenciais geradas à indústria de transporte rodoviário devido à atividade legislativa e executiva que beneficiou empresas de transporte ferroviário: "the Court immunized joint efforts by 24 railroads and an association of railroad presidents to obtain legislative and executive action unfavorable to competing trucking firms. The Court emphasized that condemning the railroad's lobbying campaign 'would impute to the Sherman Act a purpose to regulate, not business activity, but political activity, a purpose which would have no basis whatever in the legislative history of that Act". 498 Dessa decisão, surgiu a chamada Noerr-Pennington Doctrine. Essa teoria, aplicável somente a entes públicos, imuniza a regulação do Estado e dos entes governamentais da legislação antitruste, mesmo que essa regulamentação viole a livre concorrência.

Posteriormente, a teoria Noerr imunity foi estendida para imunizar as medidas anticompetitivas das agências administrativas em outros dois importantes casos (United Mine Workers v. Pennington, 381 U.S. 657 (1965) e California Motor Transport Co. v. Trucking Unlimited, 404 U.S. 508 (1972)).

Nada obstante, a aplicação da Noerr Doctrine foi afastada para os casos em que empresas privadas exploradoras de atividade econômica se utilizam de forma abusiva do direito de ação para influenciar ações governamentais no sentido de prejudicar concorrentes por meio de interferências diretas em sua atividade. ${ }^{499}$ Nesse sentido: "predation by abuse of governmental procedures, including administrative and judicial processes, presents an increasingly dangerous threat to competition. Antitrust law is beginning to catch up with it, but the criteria that are to govern this field are not yet fully formulated. (...) As a technique for predation, sham litigation is theoretically one of the most promising. Litigation, whether before an agency or a court, can often be framed so that the expenses to each party will be about the same. Indeed, if, as is usual, the party seeking to enter the market bears the burden of going forward with evidence, litigation expenses may be much heavier for him. (...) This mode of predation is particularly insidious because of its relatively low antitrust visibility". 500

\footnotetext{
${ }^{498}$ Gavil-Kovacic-Baker, Antitrust Law In Perspective: cases, concepts, and problems in competition policy, p. 993; .No mesmo sentido: Eastern R.R. Presidents Conference v. Noerr Motor Freight, Inc., 365 U.S. 127 (1961).

${ }^{499}$ Nesse sentido, Eastern R. Conference v. Noerr Motors, 365 U. S. 127 (1961): "ostensibly directed toward influencing governmental action, is a mere sham to cover".

${ }^{500}$ Bork, The Antitrust Paradox - a policy at war with itself, pp. 347/348.
} 
A não aplicação dessa teoria a determinados casos decorria da chamada sham exception.

Dos diversos posicionamentos expostos pela doutrina americana, tem-se que os critérios estipulados para a caracterização da sham litigation não são estritamente objetivos, unívocos ou de alto grau de determinabilidade a ponto de permitir uma identificação simples do que seria a litigância predatória. Falou-se sobre diversos conceitos em branco que exigem acurada análise do caso concreto para a qualificação de uma demanda como incursa nos pressupostos da sham litigation, tais quais: (a) pressuposto de detenção de poder de mercado, (b) expectativa razoável de vitória - ação objetivamente infundada; (c) ocultação de interesse contrário à concorrência, (d) custo da demanda proporcionalmente maior e mais danoso para quem detém menor capacidade financeira, (e) ação como ferramenta para macular a imagem da empresa perante o mercado, (f) intenção de criar barreiras artificiais à entrada ou excluir competidores no mercado, (g) prejuízo da atividade de competidores pelo aumento de custo, prejuízo à produção ou dano similar, (h) influência de ações governamentais no sentido de prejudicar concorrentes.

Tais requisitos definiriam a qualificação da sham litigation ainda que determinada ação fosse amparada por medida administrativa ou legislativa fruto de intervenção de concorrente.

No Brasil, recorre-se à aplicação de um juízo de proporcionalidade entre princípios constitucionais, na medida em que "o direito de acesso à justiça somente pode ser limitado, sem maiores prejuízos, em razão de outro direito ou outra liberdade constitucionalmente protegidos", 501 ou ainda da relação entre direitos que ocupam o mesmo espaço, apontada por José de Aguiar Dias. ${ }^{502}$

Falando especificamente da relação entre o abuso e a livre concorrência, Jeferson Antonio Erpen faz uma coletânea de referências civilísticas para apontar que "mesmo que alguém, agindo no que seria a atuação dentro da órbita de seu direito, prejudica a outrem, exsurge o dever de indenizar, se o exercício do direito mostra-se abusivo, levando-se em conta, também, que inexiste prejuízo sem causa. Se o dano sofrido

\footnotetext{
${ }^{501}$ Cunha, "Do abuso do direito de demandar", pp. 13/14.

502 José de Aguiar Dias, Da responsabilidade civil, v. II, Rio de Janeiro, Forense, 1995, p. 457.
} 
possui uma causa, e esta causa deriva de um ato abusivo, o agente desta causa tem o dever de reparar os danos que a causa provocou". Copilando critérios, fala também nesta sede de da ação claramente improcedente, da promoção de temor de sucumbência com redução de demanda e de investimentos na produção, do espírito de emulação, do manifesto propósito de prejudicar alguém ou abalar seu crédito, da intenção de prejudicar, do exercício anormal, imprudente e pouco diligente de um direito. E faz referência ao art. 187 do CC, consoante o qual "também comete ato ilícito o titular de um direito que, ao exercê-lo, excede manifestamente os limites impostos pelo seu fim econômico ou social, pela boa-fé ou pelos bons costumes". 503

Quando o direito de ação estiver em conflito com outros direitos, o aplicador do direito deve sopesá-los a fïm de maximizar a aplicação de ambos. ${ }^{504}$ É preciso compatibilizar o direito de petição e o da livre concorrência (CF, art. 170, inc. IV). Quando uma empresa se vê obrigada, de forma infundada, a investir seus recursos para se defender judicialmente ou administrativamente, quem sai perdendo são os consumidores e, ao final, a sociedade como um todo, que se vê privada de melhores produtos e preços pela ausência de competição no mercado.

Por esses motivos, a teoria do abuso (sham litigation) afigura-se como válvula de escape legítima para a ampliação de acesso que se sinaliza nos itens anteriores.

\section{VI.2.6. Acesso à informação: publicidade e sigilo}

A publicidade do processo também se insere em princípio democrático do direito. No plano constitucional, decorre do direito de acesso à informação como função social expressa no direito da coletividade à informação em contraponto à liberdade individual de expressão ${ }^{505}\left(\mathrm{CF}\right.$, art. $5^{\circ}$, incs. $\left.\mathrm{XIV}^{506} \mathrm{XXXIII}^{507}\right)$. A administração o

\footnotetext{
${ }^{503}$ Erpen, "O abuso do direito no exercício da ação e a livre concorrência”, pp. 122/124.

${ }^{504}$ Nesse sentido: STF, $2^{\text {a }}$ T., Min. Rel. Eros Grau, dj. 28.3.06, v.u. Ainda, sobre o assunto: "Na contemporaneidade, não se reconhece a presença de direitos absolutos, mesmo de estatura de direitos fundamentais previstos no art. $5^{\circ}$, da Constituição Federal, e em textos de Tratados e Convenções Internacionais em matéria de direitos humanos" (STF, $2^{\mathrm{a}}$ T., Min. Rel. Ellen Gracie, HC 93250 / MS, dj. 10.06.2008, v.u.); "não existem direitos absolutos, de sorte que os mesmo os direitos fundamentais podem sofrer mitigação" (Nery Junior-Andrade Nery, Constituição Federal comentada e legislação constitucional, p. 173).

${ }_{505}$ Afonso da Silva, Curso de direito constitucional positivo, p. 258-259.

506 "É assegurado a todos o acesso à informação e resguardado o sigilo da fonte, quando necessário ao exercício profissional".
} 
fundamenta no dever de transparência e de não ocultação de atos aos administrados, tratado no art. 37 da CF. Na teoria geral do processo, afigura-se como garantia individual ao exercício do poder judicante, instrumento de fiscalização popular sobre operadores do direito no que diz respeito à independência, imparcialidade e responsabilidade do julgador. ${ }^{508}$ Também se ampara na constituição e para além dela, como é o caso italiano no qual não se prevê o requisito da publicidade, mas a Corte Constitucional o considera "coessencial aos princípios a que deve conformar-se a administração da justiça numa ordem democrática fundada na soberania popular, que é o fundamento do poder de administrar a justiça (Const., art. 101, 2ª parte)". ${ }^{509}$

Não obstante sua justificativa, o princípio da publicidade comporta temperamentos. A própria Constituição não exaspera a publicidade, restringindo-a quando houver ameaça à segurança da sociedade e ao Estado. No que diz respeito a processos perante o Poder Judiciário, o CPC estabelece exceções à publicidade em casos de proteção de interesse público. O CPP estabelece o sigilo do inquérito quando necessário à elucidação do fato e proteção de interesses da sociedade e a restrição de publicidade em caso de possibilidade de escândalo, inconveniente ou perigo de perturbação da ordem. Na administração pública, a lei de processos administrativos reitera o conceito constitucional.

No processo administrativo de apuração de conduta, o papel do SBDC não poderia ser diverso, mas o tema aqui reflete um delicado equilíbrio que merece atenção dos operadores.

De um lado, o aplicador (o SBDC) tem o poder-dever-função de julgar ilícitos anticoncorrenciais. Para isso, é indispensável que tenha acesso a subsídios e informações que possam nortear seu caminho e permitir um julgamento o mais justo possível. Nesse cenário, ele precisa valer-se de instrumentos capazes de compelir os agentes a fornecer as informações necessárias ou tão somente oferecer-lhes segurança de que as informações não serão apresentadas aos concorrentes ou publicizadas. ${ }^{510}$ Ampara

\footnotetext{
507 "Todos têm direito a receber dos órgãos públicos informações de seu interesse particular, ou de interesse coletivo ou geral, que serão prestadas no prazo da lei, sob pena de responsabilidade, ressalvadas aquelas cujo sigilo seja imprescindível à segurança da sociedade e do Estado". A questão é regulada também pela lei n. $11.111 / 05$.

${ }^{508}$ Cintra-Grinover-Dinamarco, Teoria geral do processo, p. 69-70.

${ }^{509}$ Liebman, Manual de direito processual civil, vol. I, n. 3.

${ }^{510}$ Se o órgão de defesa da concorrência quiser gozar da confiança e cooperação dos setores comerciais, ele deve proteger a confidencialidade de toda a informação que não for pública que ele obtém ao longo da
} 
esse direito à colheita de informações no princípio inquisitório (já tratado no item n. VI.1.5 supra) e no dever de boa-fé e veracidade dos administrados no momento da apresentação de informações nos autos.

A exigência de boa-fé e contribuição para a atuação digna do CADE é fundamento razoável para compelir o agente a entregar (voluntária ou coercitivamente) a documentação solicitada. O princípio da não autoincriminação, reafirmado recentemente em caso clamoroso em trâmite perante o Col. STF, ${ }^{511}$ compreende o direito ao silêncio, direito de não declarar contra si, não confessar, declarar o inverídico, não produzir provas contra si, de larga aplicação no processo penal, sofre alguns temperamentos em matéria antitruste. Como visto anteriormente, os ilícitos antitruste perquiridos em sede administrativa não são considerados penais porque, em sua maioria, não são tipificados como tal. O legislador não outorgou ao juiz penal a competência para a apreciação da matéria e não atribuiu ao julgador administrativo as mesmas regras de julgamento do processo penal. Por tais motivos, ao administrado é assegurado não o direito ao silêncio, de não declarar ou produzir provas contra si, de não confessar; mas no exercício do ônus de afirmar e do ônus de provar, a administração pode e deve tomar as medidas coercitivas para a obtenção de informações que, se sigilosas, serão tratadas como tal. Por sua vez, o administrado não tem o direito de declarar o inverídico - ao contrário, ele tem o dever de dizer a verdade, sob pena de imputação de enganosidade.

De outro, um agente cria seu modelo de negócio calculando os possíveis diferenciais capazes de superar a concorrência. São, v.g., informações ordinariamente não divulgadas e de divulgação não obrigatória, segredos empresariais frutos de conquistas licitamente alcançadas por meio de evolução tecnológica, estratégias de negócio bem sucedidas e até mesmo informações protegidas pelo direito, dados contábeis, fiscais, comerciais e bancários, listas de clientes e fornecedores etc. ${ }^{512}$ Alguma assimetria de

investigação ou processo" (OECD, Diretrizes para elaboração e implementação de política de defesa da concorrência, p. 314).

511 STF, HC 95.037, Despacho do Min. Celso de Mello, em 26.6.08, no caso em que se acusa médico de pedofilia.

512 Benedetto fala de limitações ao princípio da publicidade em razão da natureza do procedimento: "una certa compromibilità del diritto in relazione alla riservatezza di informazioni a 'carattere personale, commerciale, industriale e finanziario; la sottrazione all'accesso di documenti che contengano segreti commerciali e dei verbali del collegio; l'adozione di accorgimenti che tutelino, in caso di accesso, l'interesse alla riservatezza delle imprese; la possibilità di disporre il differimento dell'accesso". Examinando o caso americano, a autora afirma que em procedimentos perante a FTC fala-se de abuso de poderes investigativos pela publicação de informações confidenciais, causando prejuízo a testemunhas. Nesses casos, o Federal Trade Commission Act e o Freedom of Information Act e a jurisprudência prevêem tutela especifica para a 
informações é considerada por alguns até mesmo fundamental à concorrência. ${ }^{513}$ Para o disclosure dessas informações, o agente precisa encontrar um ambiente seguro para que se sinta instado a contribuir para o esclarecimento da verdade sem que free-riders se valham dessas informações facilmente conquistadas para alavancar seus negócios sem o mérito do esforço concorrencial.

Da correlação entre a aquisição de informações no processo, a regulação dos ônus de afirmar e provar, o princípio da publicidade e seu antagonista, a garantia de sigilo de informações, o direito antitruste traz a regulação sobre a confidencialidade-sigilo dos autos.

A lei n. 8.884/94 regula a matéria em diversos dispositivos que garantem aos órgãos do SBDC o poder de requisitar informações e o dever de guardar sigilo quando for o caso, bem como o poder de realização de diligências em sigilo prévio. O Regimento Interno do CADE contém subseção específica destinada à regulamentação do pedido de confidencialidade e a Portaria MJ n. 4/06 discorre longamente sobre o tema, inovando inclusive ao estabelecer a diferença entre matérias confidenciais (sujeitas somente ao exame do julgador) e sigilosas (sujeitas ao exame do julgador e outros agentes do SBDC).

Algumas questões merecem breves apontamentos, à luz do acesso ao processo como garantia democrática e de preservação do escopo político do processo.

No âmbito da Comunidade Européia, a Comissão faz a distinção entre documentos não comunicáveis (que contêm segredos ou informações reservadas) e documentos que, não subsumíveis à categoria, devem ser disponibilizados às partes. De qualquer forma, a Comissão concilia o interesse à tutela das informações sensíveis, o interesse público em impedir o prosseguimento da violação à concorrência e o direito de defesa. Usa como parâmetro a pertinência das informações em relação à infração, a sua

preservação de informações confidenciais que "prevedono, pertanto, una specifica tutela per assicurare la riservatezza delle informazioni confidenziali e del segreto industriale, che sono peraltro protetti anche attraverso escamotage elaborati dalla giurisprudenza" (Benedetto, L'Autorità garante della concorrenza e del mercato, p. 248).

${ }^{513}$ Franceschini, "Roteiro do processo penal-econômico na legislação de concorrência", pp. 28-32. Perante a Comissão, as denunciantes e empresas rés não possuem o mesmo direito e garantias. Os denunciantes tem o direito de serem ouvidos e não de receber informações reservadas (Bellodi, "Le denunce", p. 119). 
força probatória, sua indispensabilidade, seu nível de sensibilidade (o quão prejudicial será a divulgação aos interesses da empresa) e a gravidade da infração. ${ }^{514} 515$

${ }^{514} \mathrm{O}$ regulamento 773/2004, por sua vez, estabelece que "facultando o acesso ao processo, a Comissão deve assegurar a protecção dos segredos comerciais e de outras informações confidenciais. A categoria de 'outras informações confidenciais' inclui informações que não sejam segredos comerciais, que possam ser consideradas confidenciais, na medida em que a sua divulgação possa prejudicar de forma significativa uma empresa ou uma pessoa. A Comissão deve poder exigir às empresas ou associações de empresas que apresentem ou tenham apresentado documentos ou declarações que procedam à identificação das informações confidenciais. Sempre que for necessário recorrer a segredos comerciais ou outras informações confidenciais para provar uma infraç̧ão, a Comissão deve determinar, relativamente a cada documento, se a necessidade de divulgação é superior ao prejuízo susceptível de resultar da divulgação". E mais: "artigo 15. Acesso ao processo e utilização dos documentos 1 . Se solicitado, a Comissão facultará o acesso ao processo aos interessados directos a quem tiver sido enviada uma comunicação de objecções. $O$ acesso será facultado após a notificação da comunicação de objecções. 2 . O direito de acesso ao processo não abrange segredos comerciais e outras informaçães confidenciais ou documentos internos da Comissão ou das autoridades responsáveis em matéria de concorrência dos Estados-Membros. O direito de acesso ao processo também não abrange a correspondência entre a Comissão e as autoridades responsáveis em matéria de concorrência dos Estados-Membros ou entre estas últimas, sempre que do processo da Comissão conste correspondência deste tipo. 3. Nada no presente regulamento impede a Comissão de divulgar e utilizar as informações necessárias para fazer prova de uma infracção aos artigos 81 ou 82 do Tratado. 4. Os documentos obtidos através do acesso ao processo nos termos do presente artigo só podem ser utilizados para efeitos de processos judiciais ou administrativos de aplicação dos artigos 81 e 82 do Tratado. Artigo 16. Identificação e protecção de informações confidenciais 1. As informações, incluindo documentos, não serão comunicadas, nem a Comissão facultará o acesso a tais informações se contiverem segredos comerciais ou informações confidenciais de qualquer pessoa. 2. Qualquer pessoa que apresente observações nos termos do $\mathrm{n}$. 1 do artigo 6, n. 1 do artigo 7, n. 2 do artigo 10 e nos. 1 e 3 do artigo 13.o ou que transmita posteriormente outras informações à Comissão no âmbito do mesmo processo deve identificar claramente os dados que considere confidenciais, apresentando a respectiva fundamentação, e fornecer uma versão não confidencial em separado, até ao final do prazo estabelecido pela Comissão para a apresentação de observações. 3. Sem prejuízo do disposto no n. 2 do presente artigo, a Comissão pode solicitar às empresas e associações de empresas que apresentem documentos ou declarações nos termos do Regulamento (CE) n. 1/2003 que identifiquem os documentos ou as partes dos documentos que entendam conter segredos comerciais ou outras informações confidenciais que lhes pertençam, bem como que identifiquem as empresas relativamente às quais esses documentos devem ser considerados confidenciais. A Comissão pode, do mesmo modo, solicitar às empresas ou associações de empresas que identifiquem as eventuais partes de uma comunicação de objecções, de um resumo conciso do processo elaborado nos termos do n.o 4 do artigo 27. do Regulamento (CE) n. 1/2003 ou de uma decisão tomada pela Comissão que, no seu entender, contenham segredos comerciais. A Comissão pode estabelecer um prazo para que as empresas e associações de empresas: a) Justifiquem o seu pedido de confidencialidade relativamente a cada um dos documentos ou partes dos documentos, declarações ou partes de declarações; b) Forneçam à Comissão uma versão não confidencial dos documentos ou declarações com as passagens confidenciais suprimidas; c) Forneçam uma descrição concisa de cada parte das informações suprimidas. 4. Se as empresas ou associações de empresas não respeitarem o disposto nos nos 2 e 3, a Comissão pode considerar que os documentos ou declarações em causa não contêm informações confidenciais".

${ }^{515}$ Garofoli, "Procedimento, accesso e autorità indipendenti", pp. 3360 e ss. O sistema italiano conjuga "l'esigenza di segretezza, avvertita in relazione ai dati, alle notizie e alle informazioni acquisiti nel corso dell'istruttoria, il canone della tendenziale trasparenza e pubblicità degli stessi". Logo o sigilo é preservado, mas o acesso é permitido sempre que a requisição seja proveniente de quem "abbia interesse per la tutela di situazioni giuridicamente rilevanti, evidentemente rimettendo all'Autorità il compito di contemperare gli interessi in conflitto". Devem ser considerados, para a negativa de acesso, as exigências de segurança, defesa nacional, relações internacionais, política monetária, ordem pública, prevenção e repressão de crimes, à intimidade de terceiros, pessoas, grupos e empresas (nesses últimos casos "garantendo peraltro ai interessati la visione degli atti relativi ai procedimenti amministratitivi, la cui conoscenza sia necessaria per curare o difendere i loro interessi”), segredos industriais ou comerciais, em decisão sempre motivada (Garofoli, "Procedimento, accesso e autorità indipendenti", p. 3356 e ss). 
Tal procedimento, amparado em critérios mais abertos, porém mais adstritos à finalidade do tratamento sigiloso de documentos, é mais interessante que aquele adotado pelo sistema descritivo e apriorístico do art. 44 do Regimento Interno do CADE e do art. 26 da Portaria MJ n. 4/06. ${ }^{516}$

Deferida a confidencialidade, as informações sigilosas serão autuadas em apartado e serão acessíveis somente à parte que as ofereceu e seus procuradores. As demais informações de posse do CADE são acessíveis ao público em geral, sem restrição. No mais, não parece razoável a distinção entre informações sigilosas e confidenciais, na medida em que todo funcionário público responde administrativa, civil e penalmente pelo manejo de informações dessa natureza. Restrições excedentes podem dificultar a operação de toda a burocracia.

Com relação às medidas instrutórias deferidas em sigilo, assim o são em homenagem à preservação prévia da utilidade. São diligências tais como a busca-eapreensão (lei n. 8.884/94, art. 35-A), providenciadas cautelarmente sem a prévia comunicação da parte, que não devem causar espécie porque (a) o sigilo prévio é destinado à garantia de utilidade da medida e a esfera de competência da SDE para disposição sobre o sigilo está limitada ao processo administrativo; (b) a medida é requerida em demanda judicial deduzida perante órgãos jurisdicionais, que poderão auferir tanto a legalidade do requerimento de confidencialidade jurisdicional, quanto a própria legitimidade da medida; (c) o sigilo cessa com a concessão da medida, permitindo ao representado o exercício do direito de contraditório e ampla defesa de forma diferida. O princípio da publicidade aqui busca equilíbrio com outras normas materialmente constitucionais, como as que dispõem sobre o devido processo legal e a proteção da livre iniciativa e livre concorrência.

Outro ponto é a definição do que é sigiloso ou não. As normas estabelecem casos excepcionais em que informações serão tratadas aprioristicamente como sigilosas (v.g., o acordo de leniência e algumas informações fixadas pela Portaria MJ n. 4/06). Para todos os demais casos, a identificação do que é e do que não é sigiloso depende

\footnotetext{
${ }^{516}$ Aqui uma crítica que já poderia ter sido feita antes nesse trabalho, mas aqui fica evidente. A sobreposição de normas processuais e procedimentos no âmbito do SBDC é um convite a antinomias e problemas hermenêuticos, havendo casos, como o do tratamento da confidencialidade e do sigilo, em que uma resolução do CADE e uma portaria do Ministério da Justiça discorrem sobre a mesma matéria, em termos bastante semelhantes, contando inclusive com a repetição de textos. É verdade que não é exclusividade das normas do SBDC a repetição de comandos normativos. Aqui, apenas se reiterou uma prática de um ente que, por excesso de zelo, descuido ou descrença na melhor técnica legislativa, repete erros já cometidos em outras sedes.
} 
da manifestação expressa da parte e do controle do requerimento pelos órgãos do SBDC essencialmente, em matéria de processo administrativo, pelo CADE e pela SDE. A lógica da determinação é evidente: é o agente que tem o controle de seus segredos e é ele a pessoa mais indicada para apontá-los. Para o SBDC, a regra é a publicidade e o sigilo é a exceção, razão pela qual se não houver qualquer motivo ope legis ou requisição explícita, pressupõe-se a publicidade de todo e qualquer documento. Eventual controle prévio de confidencialidade pelos órgãos do SBDC é supletivo (v. Regimento interno do CADE, art. 44, caput); já o controle pós-requerimento é mandatório, para se verificar a legitimidade do pedido de sigilo à luz dos critérios legais estabelecidos pelo Regimento Interno do CADE e pela Portaria MJ, n. 4/06.

Klajmic sustenta que a garantia do sigilo "só se aplica como exceção, pois confronta-se com as garantias contidas nos princípios fundamentais do processo administrativo, quais sejam, os princípios da publicidade e da oficialidade, pelos quais a autoridade administrativa submete-se ao controle da coletividade". O sigilo somente seria deferido em relação a dados específicos e fundamentados, após o exame da real motivação, cabendo à autoridade o exame da conveniência e oportunidade do pedido. ${ }^{517}$ Mas, de fato, “a previsão de confidencialidade de documentos e informações que envolvam estratégias e conhecimentos de mercado existe para que se preservem os interesses das empresas envolvidas e se impeça que terceiros de má-fé requeiram processos apenas com o intuito de se obter informações acerca do concorrente". 518

Outro ponto está no art. 172 do Regimento Interno do CADE. O dispositivo prevê que "Os autos dos procedimentos confidenciais arquivados estarão disponíveis para consulta pública após 05 (cinco) anos da decisão final do CADE”, podendo essa confidencialidade ser estendida por mais cinco anos a requerimento da parte interessada. Órgãos que congregam interesses de advogados constestaram essa disposição, a procuradoria do CADE opinou pela ofensa a princípios legais e constitucionais. Considerando que o dispositivo entrou em vigor em 2007, o CADE optou por respeitar a regra da irretroatividade da norma, postergando decisão sobre o mérito para 2012, esgotado o qüinqüênio para processos sob a sua égide.

\footnotetext{
${ }^{517}$ Klajmic, "A apuração das práticas restritivas da concorrência - averiguações preliminares e processos Administrativos", p. 30.

${ }^{518}$ Conselho Administrativo de Defesa Econômica - CADE, Guia prático do CADE: a defesa da concorrência no Brasil, p. 30.
} 
Bons argumentos favorecem a manutenção do sigilo: a natureza confidencial da informação não se desnatura com o tempo (v.g., um extrato de movimentação bancária não deixa de sê-lo pelo decurso de cinco anos); os dados se não são úteis no momento, pertencem exclusivamente à memória da empresa e, como documentação privada, caberia à própria empresa decidir pela sua divulgação ou não; se uma empresa crê na inviabilidade de divulgação de informação em cinco anos, será desestimulada a cooperar com a Administração Pública pelo fornecimento de documentos solicitados; o ato que estabelece a flexibilização da norma sobre publicidade/sigilo processual consta de resolução e não de lei; ordinariamente advogados representam seus clientes e passados cinco anos, prazo em que se é possível a perda de contato, não teriam como avisá-los da possível abertura de documentos. A favor a publicidade estaria na contribuição desses documentos para criação de uma memória institucional de decisões do CADE; o fato de que a dinâmica de mercado usualmente torna supérfluas informações de mais de cinco anos. A maior razoabilidade dos argumentos pró-sigilo não exclui uma possível solução salomônica: o CADE deve intimar os agentes e/ou seus procuradores da intenção de publicizar as informações - não pelo seu site, mas de forma inequívoca; os agentes devem expor fundamentadamente as razões pelas quais não pretendem ver divulgadas as informações. Seria de bom alvitre ainda que o agente informasse por mais quanto tempo gostaria de ver as informações mantidas em sigilo.

\section{VI.3. Escopo Jurídico}

Pela teoria instrumentalista, o escopo jurídico do processo não é a produção de decisões, a composição das lides, o estabelecimento de regra para o caso concreto, a criação de título executivo ou a imunização pela coisa julgada. Trata-se sim da atuação prática da vontade jurídica preexistente, a atuação da vontade concreta da lei ou ainda a atuação da vontade concreta do direito, mediante a aplicação de técnicas que revelam o direito, em um ambiente de segurança jurídica, como "efeito do exercício imperativo do poder estatal", 519

\footnotetext{
519 Dinamarco, A instrumentalidade do processo, pp. 217, 235, 245 e 255. Sobre a atuação da vontade concreta da lei como característica da jurisdição, v. também Mandrioli, aduzindo sobre a capacidade do ordenamento de alcançar a certeza objetiva na imposição da regra em situações concretas, mediante a atividade do juiz. Na atividade cognitiva judicial o juiz elimina subjetivamente incertezas internas (Diritto processuale civile, vol. I, p. 83).
} 
O processo de atuação da vontade concreta da lei não pretende alcançar a utópica verdade, especialmente quando se vale de ônus processuais (ônus de afirmar, da prova, de recorrer, de comparecer, de adiantar despesas), em razão dos quais "pode a parte endereçar o processo por rumos tais que afinal ele venha a produzir um resultado que não é precisamente aquele correspondente à vontade do direito no caso concreto (...) são distorções inevitáveis a que está sujeito o sistema (...). A dialética do contraditório é mesmo composta assim das incertezas em que se refletem perspectivas, possibilidades, chances, expectativas e ônus (...) se o resultado do processo se afastou dos desígnios do direito substancial nada de mau ou muito significativo reside nisso, desde que o escopo social de pacificação haja sido atingido". 520

Isso leva a crer que o escopo jurídico deve necessariamente interligar-se com os demais, sob pena de atingir uma indesejada indiferença político-social e uma tendência ao individualismo: exige-se uma "interpretação dinâmica". A vontade concreta do direito "não é necessariamente a vontade da lei para a solução de conflito envolvendo estritamente dois antagonistas perfeitamente personalizados e individualizados, numa situação jurídica reduzida à singularidade. $\mathrm{O}$ verdadeiro sentido atual da fórmula precisa ser descoberto através dessa observação do social agindo sobre o jurídico, gerando a inexorabilidade da agilização e universalização da Justiça". ${ }^{521}$

Dessas breves considerações instrumentalistas surge uma interessantíssima gama de questões de técnica ${ }^{522}$ examinadas sob a ótica do processo administrativo: a possibilidade de o processo administrativo atuar a vontade concreta do direito, a temática jurisfilosófica da relação entre a verdade e a necessidade de resolução (tempestiva) de conflitos, a moldura procedimental estabelecida pela técnica, adequada à atuação da vontade concreta da lei, o instrumento probatório como forma de busca da verdade possível, os recursos como instrumento de alcance da verdade possível, os reflexos

\footnotetext{
${ }^{520}$ Dinamarco, A instrumentalidade do processo, pp. 249-250.

${ }^{521}$ Dinamarco, A instrumentalidade do processo, pp. 260-266.

522 "Tem-se por técnica a predisposição ordenada de meios destinados a obter certos resultados. Toda técnica, por isso, é eminentemente instrumental, no sentido de que só se justifica em razão da existência de alguma finalidade a cumprir e de que deve ser instituída e praticada com vistas à plena consecução da finalidade. Daí a idéia de que todo objetivo traçado sem o aporte de uma técnica destinada a proporcionar sua consecução é estéril" (...) "o direito enquanto sistema de atribuição de bens e organização social, não é uma técnica. Ele é a positivação do poder, ou seja, conjunto de normas em que transparecem as decisões do Estado (centro de poder) e destinadas a orientar a conduta das pessoas e as suas relações em sociedade". "Técnica processual é, nessa ótica, a predisposição ordenada de meios destinados à realização dos escopos processuais" (Dinamarco, A instrumentalidade do processo, p. 274-275).
} 
da uniformização de decisões sobre a determinação do resultado final do processo, sempre com os olhos no direito material em jogo - o direito antitruste.

\section{VI.3.1. Atuação da vontade concreta do direito antitruste}

O escopo jurídico do processo está na atuação da vontade do direito. Essa vontade concreta do direito reconhece a distinção entre o material do processual.

Essas breves considerações nos leva à diferenciação entre a teoria unitarista e dualista do ordenamento jurídico, que remontam a polêmica entre Windscheid e Muther, a obra de Büllow, e o reconhecimento de dois planos diversos do direito: o substancial e o processual.

Os unitaristas defendem que os dois planos estão fundidos em um, porque o direito subjetivo nasce do exercício da atividade pelo processo dentro de uma função criadora do órgão judicante. ${ }^{523}$ Seriam casos, v.g., de julgamento por eqüidade, sentenças constitutivas ou injustas. Os dualistas, por sua vez, distinguem os dois planos, reconhecendo um direito material criado pelo legislador em termos abstratos por meio da valoração de fatos, apto à incidência no mundo desses fatos antes da própria existência do processo e da atividade do operador do direito. A judicância é atividade de mera aplicação, como instrumento de reconhecimento da vontade concreta da norma abstrata e prédeterminada. O direito pré-existe ao processo ${ }^{524}$

O tema ganha proporções interessantes na atividade antitruste, na medida em que muitas das condutas anticoncorrenciais dependem de projeções para o futuro (as predições econômicas, realizadas em cálculos econométricos ${ }^{525}$ ). É o caso de possíveis condutas anticoncorrenciais em certos mercados que comportam alto grau de desenvolvimento e inovação. Conforme já dito acima "an antitrust regime that ignores dynamic efficiencies and innovation and focuses solely on static product market competition is unlikely to improve consumer or total welfare". ${ }^{526}$ Não só para casos de

\footnotetext{
${ }^{523}$ Carnelutti, Lezioni di diritto processuale civile, vol. I, pp. 75-79.

${ }^{524}$ Liebman, Manual de direito processual civil, vol. I, n. 1; Chiovenda, Instituições de direito processual civil, pp. 3-29.

${ }_{525}^{525}$ Tratados mais adiante no tema sobre provas (v. item VI.3.4).

${ }^{526}$ Wright, “Antitrust, Multi-Dimensional Competition, and Innovation: Do We Have an Antitrust-Relevant Theory of Competition Now?”, p. 4.
} 
análise de estruturas como também em casos de condutas, a administração deve estar atenta para o fato de que a dinâmica tem influência sobre o resultado do processo. Pressupondo casos complexos que envolvam muitas partes ou que exijam investigações mais profundas, eventuais processos podem durar anos (embora sejam uma minoria). Evoluções tecnológicas em mercados que sofrem inovações profundas e velozes podem transformar o que ab initio poderia ser qualificado como uma conduta em algo que, ao final do processo, não o foi. Por isso que os exercícios de predição, típicos do direito concorrencial, devem ser feitos com bastante atenção de modo a não estabelecer barreiras indevidas ao desenvolvimento de determinados setores do mercado.

A influência dessa concepção para o escopo jurídico guarda coerência com o que já foi dito acima sobre o escopo social e a preclusão administrativa. A mutação da realidade não retira a validade da teoria dualista. Permanecem existentes dois planos de atuação do direito.

O prolongamento do tempo do processo e as sucessivas inovações apresentadas no mercado nesse ínterim não fazem com que o processo administrativo crie um direito em favor do representado ou retire progressivamente do Estado a possibilidade de condená-lo pela conduta anticoncorrencial: há apenas o aclaramento dos fatos ou ainda o reconhecimento (ainda que não manifesto) de que o exercício de predição estava sendo feito de forma equivocada e que eventual interpretação da eficiência não era a mais correta. Tudo isso, no entanto, está no plano conjectural, pois o julgador não antecipa o resultado do julgamento ao longo do processo. Importante tão somente que, ao final, a decisão proferida seja tomada com base em elementos trazidos aos autos, que demonstrem a profunda mutabilidade do mercado à luz de inovações constantes e permitam um adequado exercício de predição, capaz de projetar os efeitos positivos sobre a proteção da concorrência e sobre o bem estar social, estabelecidos como escopo da atividade antitruste como um todo e, assim, a atuação da vontade concreta de um direito prévio e estabelecido pela norma.

Por sua vez, há outro tópico a considerar. Há quem diga que a jurisdição atua a vontade concreta da lei e a administração, a despeito da adstrição à lei, teria por objetivo a proteção de um interesse público. Essa distinção faz a diferenciação finalística das duas atividades inserindo um oceano de distância entre as duas expressões de poder do Estado (a Administrativa e a Jurisdicional). É certo que existem diferenças substanciais 
entre as duas atividades; a dúvida estaria no acerto de se distanciar dessa forma especificamente a atividade administrativa judicante da atividade jurisdicional.

Odete Medauar afirma que, de fato, "administração e jurisdição seriam funções similares porque executam a lei”. Porém, a administração visaria ao fim do próprio Estado, em um interesse primário (interesse público) e secundário do indivíduo, enquanto a jurisdição estaria voltada aos interessados (interesse primário do indivíduo). ${ }^{527}$ CintraGrinover-Dinamarco também partem da premissa inegável de que em sua atividade administrativa, o Estado cumpre a lei, mas afirmam que a atividade do administrador não teria o escopo de atuação da lei, não teria caráter substitutivo e suas decisões não teriam caráter definitivo: "acima de tudo, só na jurisdição reside o escopo social magno de pacificar em concreto os conflitos entre pessoas, fazendo justiça na sociedade". ${ }^{28}$ A doutrina estabelece um confronto apriorístico entre o interesse público e o interesse privado, como se a satisfação do indivíduo fosse contrária à satisfação social.

As definições, irretocáveis em termos seus genéricos termos, merecem temperamentos quando se está diante de uma função administrativa judicante.

O conceito genérico de ato administrativo é de "declarações do Estado (...) no exercício de prerrogativas públicas, manifestadas mediante providências jurídicas complementares da lei a título de lhe dar cumprimento, e sujeitas a controle de legitimidade por órgão jurisdicional". 529

Mas o fruto do processo administrativo de apuração de conduta não se revela no exercício de competência discricionária da Administração, emanada por Portaria, Resolução, Instrução, Regulamento ou mesmo da celebração de um Contrato Administrativo. Trata-se de decisão vinculada, proferida em operação de subsunção de fatos à norma antitruste pré-estabelecida, que reconhece ou não a existência de um fato ou ato contrário ao direito e, se for o caso, imputa sanção. Em seu desenho, não se distingue de um ato jurisdicional. ${ }^{530}$ Não há espaço na norma para proteger mais um menos o

\footnotetext{
${ }^{527}$ Medauar, A processualidade no direito administrativo, p. 47.

${ }^{528}$ Cintra-Grinover-Dinamarco, Teoria geral do processo, p. 135.

${ }^{529}$ Bandeira de Mello, Curso de direito administrativo, p. 378.

${ }^{530}$ Negri chama a autoridade antitruste de organismo parajurisdicional ou neutro - neutralidade de terzietà -, não inserido nos paradigmas da administração, de natureza contenciosa voltada para a solução de controvérsias mediante a aplicação da lei no caso concreto (Negri, Giurisdizione e amministrazione nella tutela della concorrenza, pp. 6-8).
} 
interesse público: se for caracterizada a infração, será aplicada a sanção, porque condizente com a vontade concreta do direito antitruste e com o pressuposto de proteção do interesse público; se não for caracterizada, o arquivamento do processo é igualmente medida de atuação da vontade concreta da norma e de proteção do interesse público, porque se não há ilícito, o Estado deseja passar a mensagem de que não condena inutilmente, mantendo o já referido equilíbrio entre poder e liberdade.

Não se pode entender que a proteção do interesse público estaria sempre na condenação de um sujeito com base na norma antitruste, por infração que não ocorreu: dedicou-se muito deste trabalho na tentativa reforçar a imunização da atividade do SBDC por meio de garantias de imparcialidade (v. Cap. VI.1). Não seria condizente afirmar aqui que o interesse público da Administração-SBDC certamente penderia sempre contra $o$ administrado, o representado.

Repete-se também aqui o que já foi dito no capítulo IV sobre a relação entre a implementação de políticas públicas de natureza antitruste, a função administrativa judicante, o binômio discricionariedade-vinculação e a interpretação da lei. Remete-se ainda ao que foi dito sobre o âmbito de aplicação de políticas públicas na atividade do SBDC e também do Poder Judiciário, para se chegar à conclusão de que há atuação da vontade concreta da lei, de forma afirmadamente autônoma e imparcial no exercício da função administrativa judicante pelo CADE.

A lei ordinária deve ser elaborada em termos genéricos de modo a permitir o exercício de subsunção diante do caso concreto e "em regra edita normas gerais e abstratas, motivo por que, na lição usual, é conceituada em função da generalidade e da abstração".531 Atuar a vontade concreta da lei nada mais é que uma atividade de interpretação dos fatos à luz das normas (exercício de subsunção, dentro da concepção da fattispecie). Parte-se do comando normativo e, por meio da captação da situação concreta, valendo-se das diversas técnicas de interpretação dentro da hermenêutica (interpretação literal, lógica, sistêmica, histórica), aplica-se o direito, exara-se o comando lastreado em tal ou qual norma, com conteúdo impositivo que vincula as partes a ele sujeitas e impõe a sanção.

${ }^{531}$ Ferreira Filho, Curso de direito constitucional, pp. 162-163. 
No exercício da função judicante, a administração não se desvincula das balizas da norma e transita nos limites do que permite a estrutura da norma e de seus conceitos abertos. Logo, é perfeitamente possível afirmar que o CADE atua a vontade concreta do direito antitruste.

\section{VI.3.2. Verdade e paz}

O escopo jurídico do processo está intimamente relacionado à idéia de busca da verdade. A teoria instrumentalista aduz que, por meio do exercício de subsunção, atua-se a vontade concreta e preexistente do direito por meio de técnicas que, sempre que necessário, incidem sobre fatos.

Em determinadas hipóteses, surgem questões de direito, porque não haveriam questões de fato (mas direito é fato, valor e norma). Os debates estariam centrados apenas em questões jurídicas (mas também o jurídico não exclui o fato, especialmente pelo exercício hermenêutico sobre fatos). Preciosismos à parte, excluídos os casos em que o processo não examina questões de fato porque irrelevantes ou porque estes são incontroversos nos autos, o processo esclarece a verdade com base na versão das partes e que foi declarado nos autos.

Zanetti Junior estabelece uma gradação positiva entre verdade real, ${ }^{532}$ provável, verossímil e possível, para criticar as posições correntes e abandonar perspectivas matemáticas. Abraça a idéia de contraditório preventivo sobre questões de fato e de direito que resultem em conseqüências perante a decisão final para alcançar a verdade obtida com alto grau de debate, que elimina outra solução racional por meio de uma prudente apreciação das partes e do juiz acerca da prova. ${ }^{533}$

Essa verdade é aquela que "si coglie (quella verità che gli uomini possono raggiungere con l'imperfezione dei mezzi a loro disposizioni) quanto più il

\footnotetext{
${ }^{532}$ Longe de ser raro identificar precedentes jurisprudenciais no sentido de que "no processo civil, impera o princípio da verdade material sobre a verdade meramente formal" (TJ-PR, 3 ${ }^{\text {a }}$. Cam., AI n. 175270500, Juiz Eugênio Achille Grandinetti j. 21.8.01).

${ }^{533}$ Zanetti Junior, Processo constitucional: o modelo constitucional do processo civil brasileiro, pp. 79-84.
} 
dialogo è aperto e quanto più ampie sono le possibilità di dire e contraddire". ${ }^{534} \mathrm{O}$ fato e a verdade são um inter se convertuntur onde o primeiro resta preso no tempo e envolto pela sombra do passado, razão pela qual as tentativas de conhecê-lo decorrem de uma valoração crítica decorrente de processo mental e psicológico que desemboca em uma declaração subjetiva de certeza (afirmada por determinada prova ou decorrente do convencimento motivado do juiz). ${ }^{535}$

Resíduos de incerteza psicológica não têm qualquer relevância jurídica. A certeza é a manifestação subjetiva da verdade e se "a convicção não pode corresponder à certeza, é inevitável correr riscos, sob pena de inviabilizar os juízos. Basta que o juiz tenha atingido grau suficiente de convicção, a ponto de preferir afirmar o fato e ter por irrelevantes os motivos divergentes". ${ }^{536}$ Biavati estabelece a relação entre o contraditório e a imparcialidade, porque o processo deve se esforçar para atingir o maior nível possível de verdade. A verdade processual não necessariamente coincide com a verdade histórica, mas com aquela obtida por meio da dialética. O contraditório seria então "una modalità sostanziale dell'approcio giudiziário della verità", na medida em que as partes trazem aos autos um ou outro aspecto dos fatos conforme seus interesses. Sem contraditório, não existe verdade judiciária, mas tão somente a precompreensão unilateral de um sujeito, vista através de um filtro de interesses. Fala-se de um procedimento "molto processualizzato", mas sempre um procedimento como importante reflexo de civilidade jurídica, mas que não se realiza "em contraditório" - é sempre uma verificação unilateral. ${ }^{537}$

O assunto é antigo, transita do filosófico ao semântico, mas tem profunda utilidade na disciplina do processo. O julgador deve esforçar-se ao máximo para proferir

\footnotetext{
${ }^{534}$ Luiso, Processo civile p. 29. Calmon de Passos afirmou: "por mais requintados que sejam os instrumentos de verificação disponíveis, jamais haverá segurança absoluta de que, mediante sua utilização, se alcance, com segurança, no operar jurídico, a verdade real, o que realmente aconteceu no mundo da vida. Nem pode o operador do direito vincular-se necessariamente ao que efetivamente ocorreu. Trabalha o jurista com a certeza processualmente verificada e certificada e somente com ela pode operar, corresponda ou não àquela verdade real já mencionada" (Esboço de uma teoria das nulidades aplicada às nulidades processuais, p. 26). Para Aguiar Silva, "não è mais uma verdade absoluta que se procura. A presença da prova legal adaptada a um modo de integração da verdade dos fatos foi um dos grandes objetivos do Código de Processo Civil, este ensejando a pesquisa da verossimilhança, plausibilidade ou probabilidade, na rebusca material ou formal da possibilidade credível" (Aguiar Silva, As provas no cível, pp. 46-47). Taruffo também examina o tema com profundidade, estabelece uma relação entre verdade relativa, verdade absoluta como ponto de motivação, verossimilhança e probabilidade. E afirmar de forma objetiva, que qualquer que seja o conceito de verdade, a prova é o meio de obtê-la (Taruffo, Trattato di diritto civile e commerciale - la prova dei fatti giuridici, pp. 64, 143 e ss.).

${ }^{535}$ Monteleone, "Limiti alla prova di ufficio nel processo civile (cenni di diritto comparato e sul diritto comparato)", p. 865.

536 Dinamarco, A instrumentalidade do processo, p. 286.

${ }^{537}$ Biavati, "Il diritto processuale e la tutela dei diritti in materia di concorrenza", p. 108.
} 
decisões justas, o que não seria possível de alcançar caso as premissas fáticas sejam equivocadas, pautadas em mentiras, meias verdades, informações errôneas. ${ }^{538}$ Exige-se ao menos um esforço de fidelidade de provimentos à verdade possível, passível de ser atingido tão somente pela conjunção de instrumentos processuais de acesso, participação, contraditório e defesa. Sem qualquer utopia, ela é destinada à "verificación de las afirmaciones de las partes respecto de los hechos, del modo en que la organización judicial lo permite y las fuerzas del hombre alcancen a lograrlo, poniendo un límite a esa investigación". 539

A verdade processual, qualificadora do escopo jurídico do processo, deve ser coordenada com a missão de pacificação pela solução definitiva e célere de controvérsias, qualificadora do escopo social. Como visto acima (item VI.1.5), a busca incessante pela verdade, além de criar distorções sobre a imparcialidade (especialmente no SBDC), pode prolongar indefinidamente o processo. Essa situação determinaria um conflito entre o escopo jurídico de realização do direito pela descoberta da verdade e aplicação da vontade concreta do direito ao fato por meio de exercício de subsunção e o escopo social pacificador retratado na estabilização da controvérsida por meio da decisão definitiva sobre determinado conflito. ${ }^{540}$ Partindo do dualismo do ordenamento e da premissa de que um órgão judicante reconhece a violação no momento em que ela é comunicada aos órgãos do SBDC, o tempo de tramitação do processo não poderá causar danos potencializados a quem tem razão: "il tempo del processo non deve dar luogo ad effetti estintivi, mentre, d'altra parte, quando il dirirro viene riconosciuto, ciò deve avvenire come se avvenisse al momento della proposizione della domanda". ${ }^{541}$

Celeridade e subsequente imunização são duas variáveis que exercem profunda pressão sobre a busca da verdade processual. Porque esta toma tempo e, no processo, o tempo é inimigo. ${ }^{542}$

\footnotetext{
538 Equívocos esses que jamais poderão ser auferidos com absoluta certeza. Quisera o Estado que cada julgador possuisse um DeLorean, para atribuir certeza inequívoca, absoluta, ou qualquer que seja o nome que se dá à identidade entre o que se narra e o que aconteceu.

${ }^{539}$ De Santo, La proba judicial, p. 61.

540 "O verdadeiro sentido atual da fórmula (atuação da vontade concreta da lei) precisa ser descoberto através dessa observação do social agindo sobre o jurídico, gerando a inexorabilidade da agilização e universalização da Justiça" (Dinamarco, A instrumentalidade do processo, pp. 260-266).

${ }^{541}$ Mandrioli, Diritto processuale civile, vol. II, p. 28.

542 "O passar do tempo, além de sujeitar a riscos de deterioração o próprio resultado jurídico do processo, prolonga as angústias do conflito e o estado de insatisfação que o serviço jurisdicional visa a eliminar. Com razão, foi dito que o tempo é inimigo do processo e que contra ele, para evitar os males que pode causar, o
} 
No item V.I. supra já foi feita referência à importância da imunização das decisões, de modo a "tornar inevitáveis e prováveis decepções em decepções difusas" porque "a privação consumada é menos incômoda que o conflito pendente". 543

O processualista moderno vive o desafio de coordenar a complexidade material das relações jurídicas, as deficiências estruturais na prestação de serviços judicantes e a necessidade de cada vez mais reduzir o tempo na prolação de decisões. O modelo de processo justo e equo de Comoglio ${ }^{544}$ só é acançado se a tutela efetiva e adequada for também tempestiva ${ }^{545}$ e se o processo se encerrar em prazo razoável, conforme estabelecido pelo Pacto de São José da Costa Rica. Rui Barbosa já afirmava que a a justiça atrasada não é justiça, senão injustiça qualificada e manifesta.

O direito elevou a preocupação com a celeridade ao patamar constitucional quando afirmou que "a todos, no âmbito judicial e administrativo, são assegurados a razoável duração do processo e os meios que garantam a celeridade de sua tramitação" (art. $5^{\circ}$, inc. LXXVIII). Trata-se de uma tendência mundial e antiga respaldada por outros ordenamentos que protegem "la garanzia della ragionevole durata del processo. Anche in questo caso il legislatore costituzionale ha recepito e costituzionalmente garantito un principio fondamentale del processo: quello dell'economia processuale", 546 coforme dispõe os arts. 24 e 111, II, da Constituição italiana.

No caso específico do processo administrativo antitruste, haveria alguma tendência em se afirmar que a dinâmica das relações de mercado e a necessidade de se atribuir segurança e a previsibilidade ao ambiente para preservação da concorrência e do bem estar social potencializaria a preocupação com o tempo de duração do processo sancionatório. Uma leitura menos atenta poderia subsidiar esses fundamentos com a pressa

juiz deve estar em estado permanente de guerra entrincheirada. Por isso é que em certas situações o angustiante desafio da 'tensão entre conhecimento e ignorância' há de ser contornado e o sistema exige que o juiz se conforme e pacifique sem haver chegado ao ponto ideal de assimilação da verdade. A boa técnica processual incumbe o estabelecimento do desejado racional e justo equilíbrio entre as duas exigências opostas, para que não se comprometa a qualidade do resultado da jurisdição por falta de conhecimento suficiente, nem se neutralize a eficácia social dos resultados bem concebidos, por inoportunidade decorrente da demora" (Dinamarco, A instrumentalidade do processo, p. 283).

543 "Segurança, ou certeza jurídica, é em si mesma fator de pacificação: a experiência mostra que as pessoas mais sofrem as angústias da insatisfação antes de tomarem qualquer iniciativa processual ou mesmo durante a litispendência, experimentando uma sensação de alívio quando o processo termina, ainda que com solução desfavorável" (Dinamarco, A instrumentalidade do processo, pp. 195-196).

${ }^{544}$ Comoglio, "Il 'giusto processo' civile in Italia e in Europa", passim.

${ }^{545}$ Watanabe, "Tutela antecipatória e tutela específica das obrigações de fazer e não fazer: arts. 273 e 461 do CPC", p. 48.

${ }^{546}$ Luiso, Diritto processuale civile, p. 37. 
estabelecida pela legislação atual para a análise de atos de concentração. Essa posição não parece correta.

Não se nega a preocupação com a tramitação do processo antitruste. ${ }^{547}$ Mas ele não pode ser considerado aprioristicamente como merecedor de uma tutela premente, mais urgente que a presente em outros ramos do direito e que demande um regime processual especialíssimo. Há necessidade de dinamismo aqui tanto quanto em, v.g, ações penais em que se põe em jogo a liberdade do indivíduo, em tutelas de interesses transividuais em que existem severos danos ambientais que demandem tutelas cominatórias urgentes, ações de natureza civil em que imprescindível tutela de natureza alimentar.

É necessário então, a partir de juízos de probabilidade in abstrato e in concreto, encontrar o equilíbrio entre as exigências de busca da verdade e celeridade, com base na avaliação de intensidade de riscos, gravidade de males, expectativas de vantagens. Além da relação entre dispositividade e inquisitoriedade, o sistema processual se vale usualmente de técnicas de aceleração do processo pautadas em regimes de ônus, preclusões e presunções.

Ônus é um imperativo do próprio interesse. Trata-se do encargo que compele a parte à realização voluntária e conveniente de um ato, ciente de que essa realização possa trazer benefícios ou impedir que a sua situação jurídica seja prejudicada. ${ }^{548}$ Carnelutti estabelecia, nos reflexos, a distinção entre ônus e obrigações: “enquanto que a obrigação é subordinação de um interesse do obrigado ao interesse de outrem, o ônus é subordinação de um interesse do onerado a um (outro) interesse próprio". ${ }^{549}$ Ônus também se distingue da faculdade porque o descumprimento do primeiro gera efeito danoso ao sujeito que a segunda não produz. Também distinto do dever, porque aqui o sujeito é compelido psicologicamente ao adimplemento e seu descumprimento não se reverte em um ato ilícito.

\footnotetext{
547 Fauceglia afirma que "al fine di evitare un lungo periodo di incertezza che potrebbe risultare pregiudizievole all'attività delle imprese, la legge si preoccupa, in modo tutt'altro che razionale, di scandire il profilo temporale", embora afirme que não há prazo peremptório de duração de istruttoria" ("L'istruttoria dell'autorità in tema di intese restrittive della libertà di concorrenza e di abuso di posizione dominante", p. 271-272).

${ }^{548}$ Goldschmidt, Derecho procesal civil, p. 8. É definido ainda como "o encargo, atribuído pela lei a cada uma das partes, de demonstrar a ocorrência dos fatos de seu próprio interesse para as decisões a serem proferidas no processo. (...)" (Dinamarco, Instituições de direito processual civil, nn. 792 e ss.)

${ }_{549}$ Carnelutti, Teoria geral do direito, p. 274.
} 
Os ônus, em uma teoria geral do processo, são vários. Dentre eles, relevantes os de afirmar, impugnar, provar e recorrer.

Todo autor tem o ônus de afirmar. No âmbito do processo em estudo, representante apresenta informações necessárias para a instauração de averiguação preliminar ou de processo administrativo em sua representação (v. item VI.2.3). A despeito da falta de regras objetivas para a aceitação ou não da representação - porque o processo pode ser instaurado de ofício -, as indicações mínimas do formulário eletrônico da SDE, dos arts. 30 e 14, inc. II, da Lei n. 8.884/94, par. $3^{\circ}$ do art. 47 da Portaria MJ 4/06 e do art. $6^{\circ}$ da Lei n. 9.784/99 precisam ser respeitadas sob pena de arquivamento da representação. ${ }^{550}$

O ônus de afirmar da SDE é qualificado. O despacho de instauração de processo administrativo é usualmente amparado por nota técnica elaborada internamente, que deve expor os pressupostos de admissibilidade de julgamento do mérito do processo administrativo. É preciso identificar o(s) réu(s), expor os fatos (causa petendi próxima) e fundamentos jurídicos (causa petendi remota) utilizados, anexar os documentos que consubstanciam a suficiência de indícios para a instauração do processo e deduzir o pedido (a condenação pelo ilícito anticoncorrencial). ${ }^{551}{ }^{552}$ Aqui são estabelecidos os limites

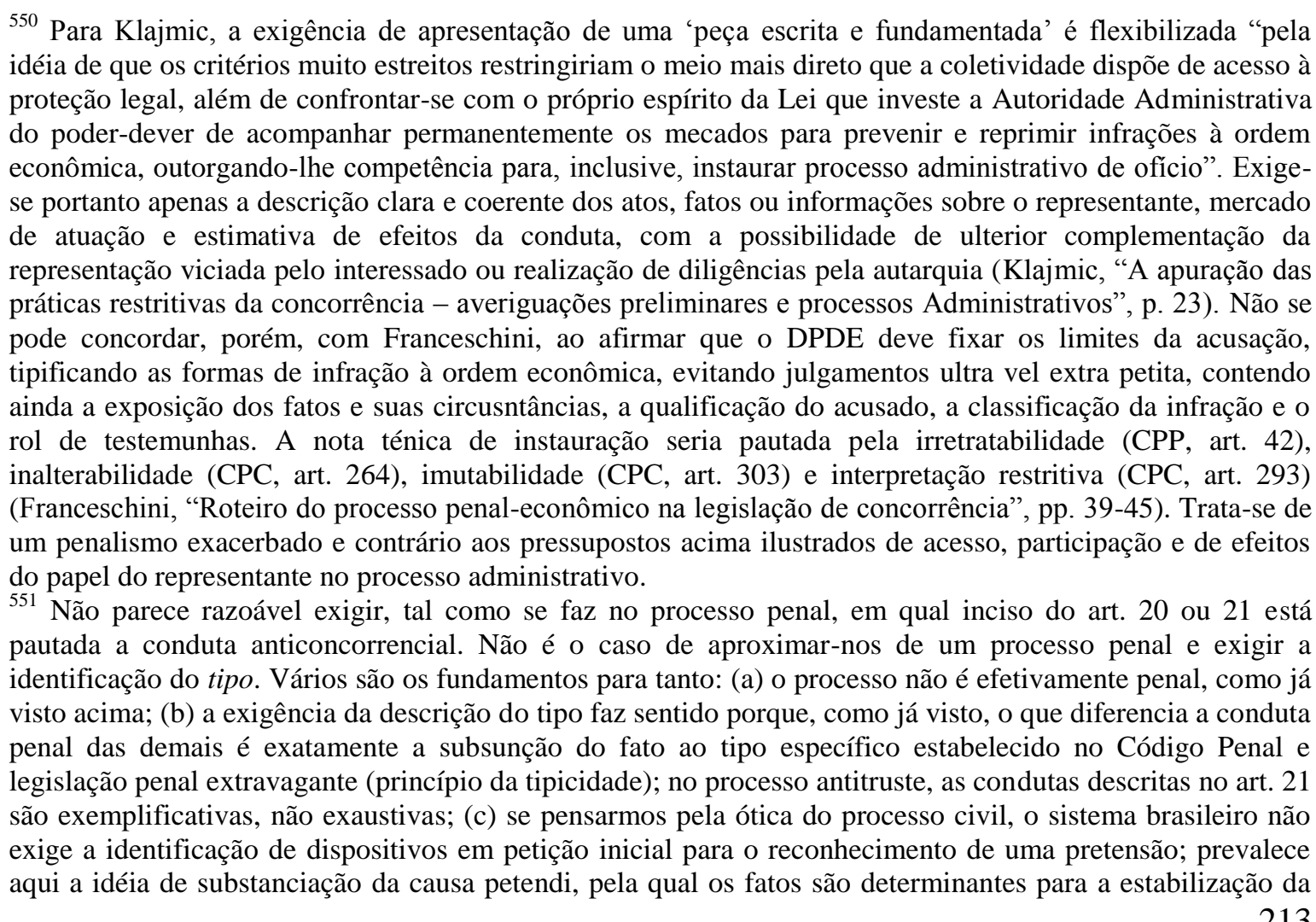


objetivos da demanda, ou do objeto do processo, qual seja, a definição do bem da vida feita à luz do pedido mediato, "che peraltro non può essere considerato in modo del tutto avulso sia da petitum immediato e sia dalla causa petendi". ${ }^{553}$ O pedido imediato é aquele deduzido perante o órgão julgador e se refere ao provimento (condenação, declaração, a medida acautelatória etc.). Já o mediato volta-se à parte contrária; é o bem da vida (uma coisa, uma prestação, um não fazer). É o que se diz da natureza bifronte do pedido. A causa de pedir é qualificada como razão da demanda, razão jurídica, título jurídico, a razão objetiva que fundamenta a demanda, ou mesmo o direito substancial afirmado. ${ }^{554}$

A partir desse ponto, os ônus se aproximam das técnicas de aceleração do processo. O ônus de responder (face do ônus de afirmar, aqui contradizendo), no processo administrativo, reflexo do devido processo legal, da garantia do contraditório e da ampla defesa, tem seu primeiro expoente na defesa, prevista no art. 33 da lei n. 8.884/94, e corroborada pelo art. 52, inc. V da Portaria MJ n. 4/06. Fala-se do oferecimento de defesa no prazo de 15 dias, e só.

No processo jurisdicional, muito se discorre sobre a contestação como peça na qual as partes devem deduzir todos os fundamentos de defesa, sob pena de

demanda e delimitam a atuação do magistrado - essa teoria se opõe a da individuação da causa petendi, pela qual o dispositivo citado teria função vinculante no processo.

552 Note-se que apesar de o direito italiano ser historicamente reconhecido como exemplo de individuação (vinculação pela qualificação jurídica atribuída pela parte), Mandrioli adimite a substanciação como regra, ao afirmar que "il giudice è libero di applicare le norme di diritto che meglio ritiene adattabili al caso concreto, ossia di mutare la qualificazione giuridica, o nomen juris", com expressa referência ao brocardo iura novit curia, ressalvando apenas que a iniciativa deve ser submetida ao contraditório - tal posição é referendada pela Corte de Cassação, que não entende nulo julgamento com amparo em normas não invocadas pela parte. Porém, faz referência expressa à divisão da doutrina italiana a esse respeito, referindo-se que as duas teorias são, em verdade, duas faces da mesma realidade ou diversos ângulos que não são mutuamente exclusivos. Por fim, refere-se a Canova, que ressalta que "la funzione individuatrice spetta ai fatti costitutivi di un diritto e quindi ai fatti come idonei a dare luogo a un effetto giuridico; e questo implica la prospetazione di un raporto giuridico, in base ad una qualificazione giuridica che, in quanto non vincola il giudice, è piuttosto un'ipotese di qualificazione giuridica". Deve-se estar sempre atento ao fato constitutivo do direito alegado, o episódio historicamente individuado, o chamado fato principal correlacionado com o fato lesivo do direito alegado, que determina o objeto do processo, deixando à margem os fatos secundários, marginais e que não incidem sobre o núcleo relevante dos fatos. No exame do objeto do processo, o direito italiano ainda reconhece a distinção entre demandas autodeterminantes (demandas que exaurem a individuação do seu conteúdo no tipo de tutela invocado, nos sujeitos e no seu efeito jurídico), relacionadas com direitos reais (exceto os de garantia) e direitos a uma prestação específica; e heterodeterminantes (demandas cuja individuação é completada pelo acontencimento histórico gerador da situação), relacionadas com direitos reais de garantia e a uma prestação genérica (Mandrioli, Diritto processuale civile, vol. I, pp. 94-95, 159164).

${ }^{553}$ Mandrioli, Diritto processuale civile, vol. I, p. 17. Note-se que "l’indicazione degli element di diritto non ha altra funzione che quella di prospettare la suddetta riconducibilità dei fatti ad una o più norme e perciò può essere estremamente generica, o addirittura implicita, oltre ad essere non vincolante e soggetta a modificazione secondo la regola iura novit curia" (idem, p. 18).

${ }^{554}$ Mandrioli, Diritto processuale civile, vol. I, p. 156. 
preclusão (já definida no item VI.1.1 supra) e de serem presumidos ${ }^{555}{ }^{556}$ verdadeiros os fatos alegados na petição inicial e não contestados. ${ }^{557}$ Mais que uma regra formalista, o sistema compele as partes a uma postura de lealdade, exigindo que todas as cartas sejam colocadas na mesa o quanto antes e que o contraditório seja exercido a contento. Impedese assim que as defesas sejam apresentadas a conta-gotas, como uma estratégia canhestra

de protelação da atividade instrutória e judicante. É ainda uma exigência voltada à identificação prematura do cenário litigioso, de modo que todas as questões (no sentido carneluttiano) no processo sejam expostas o quanto antes para que a instrução seja concentrada em esclarecer eventuais divergências fáticas sobre pontos controvertidos.

$\mathrm{Na}$ administração, há quem sustente visão diversa. Amparando-se na busca da verdade real, o representado estaria legitimado a deduzir sempre novos argumentos em sua defesa, ${ }^{558}$ fato corroborado pelo art. 27 da lei n. 9.784/99, que nega a confissão sobre fatos quando de uma intimação não atendida.

A crítica desse posicionamento tem amparo em conceitos já trabalhados anteriormente: (a) a verdade real é filosófica, utópica ou obtida mediante recursos de ficção científica; (b) o processo deve coordenar a busca pela verdade processual, possível, com a pacificação extraída de uma decisão final e definitiva; (d) permitir que não haja um ônus de oferecer a defesa na primeira oportunidade abre espaço para chicanas processuais, autorizando defesas a destempo, após a realização de atos de instrução, e legalizando

\footnotetext{
555 A presunção é estabelecida por meio de um "processo racional do intelecto, pelo qual do conhecimento de um fato infere-se com razoável probabilidade a existência de outro ou o estado de uma pessoa ou coisa" (Dinamarco, Instituições de direito processual civil, vol. III, p. 113). Essa presunção também revela uma técnica de aceleração do processo quando, pela revelia ou inadimplemento de um ônus processual, ao julgador é autorizado pressupor que o sujeito admita como tolerável a conduta desfavorável que lhe será imposta.

${ }^{556} \mathrm{O}$ processo administrativo não contempla em geral presunções legais, ainda que em certas hipóteses sejam adotadas presunções relativas por alguns autores. Veja-se o exemplo da prova na recusa de contratar: "em caso de rompimento não justificado por razões negociais evidentes de relações contratuais já existentes há indício de objetivo anticoncorrencial. Esse indício, como visto, tem efeito direto sobre o ônus de apresentar justificativa" (Salomão Filho, Direito concorrencial - as condutas, p. 246).

557 "La non contestazione non elimina l'inceteza sul fatto allegato, né fa venir meno l'onere della parte che lo ha allegato di darne la prova, né tanto meno preclude al giudice la possibilità di porsi il problema del sua accertamento. La non contestazione delle allegazioni avversarie non è in realtà priva di rilievo, mas si colloca - quando si tratti di comportamento chiaro ed univoco - sul piano probatorio invece che su quello della ripartizione degli oneri di prova. Essa può infatti costituire un comportamento, valutabile dal giudice ai sensi e nei limiti dell'art. $116,2^{\circ}$ com., c.p.c. ("Il giudice può desumere argomenti di prova dalle risposte che le parti gli danno a norma dell'articolo seguente, dal loro rifiuto ingiustificato a consentire le ispezioni che egli ha ordinate e, in generale, dal contegno delle parti stesse nel processo") ossia come fonte di argomenti di prova" (Taruffo, "Onere della prova", p. 71).

${ }_{558}$ Cfr. Gilberto, O processo antitruste sancionador, p. 134.
} 
reviravoltas processuais que retardam a decisão final e prejudicam a consecução do escopo social do processo; (e) inovações processuais podem ser questionadas até mesmo pela idéia de eficiência, preceito tão celebrado no âmbito do direito material concorrencial; (f) o argumento tem amparo em uma flexibilização procedimental que deve ser lida com muita cautela no âmbito do processo administrativo de apuração de conduta, conforme será tratado no item seguinte. ${ }^{559}$

Há um outro ponto relevante. A idéia de ônus de oferecer toda a defesa na primeira oportunidade está relacionada com o ônus da administração de afirmar. Por respeito ao princípio da moralidade administrativa, à ampla defesa, ao direito à prova e à eficiência, a SDE deve se valer de boa técnica processual para que o despacho instaurador do processo administrativo delimite o objeto do processo (como já dito acima, ele é revelado à luz da pretensão deduzida pelo autor, que abrange não só o pedido como também a causa de pedir) e autorize o administrado a conhecer adequadamente todos os fundamentos da denúncia que lhe é dirigida. Caberia então ao administrado responder exaustivamente as acusações que lhe foram feitas. Considerar o contrário seria romper com essa paridade e isonomia que a técnica atribui aos sujeitos processuais e iniciar um jogo que tende ao infinito: a SDE denuncia um роисо, o representado responde um pouco, a SDE agrega um fato diferente, o representado responde um pouco desse fato novo; a SDE traz argumentos diferentes; o representado responde esses argumentos e lembra de inserir outros argumentos de defesa referente aos primeiros fatos alegados. Tumulto, comprometimento da celeridade, decorrente de posturas que pouco podem contribuir para uma busca eficiente da verdade possível e se afastam do escopo jurídico do processo. ${ }^{560}$

\footnotetext{
559 Imagine-se então incorporar as lições do Direito Europeu no sentido de que "premesso che la Commissione ha l'obbligo (doppo aver ricevuto le osservazioni dell'interessato) di adottare una decisione definitiva entro un termine ragionevole, ritine doversi presumere che in mancanza di un espresso provvedimento di archiviazione, la Commissione abbia confermato implicitamente le valutazioni esposte nella precedente comunicazione e che pertanto la denincia debba considerarsi come implicitamente respinta sulla base dei motivi già formulati" (Bellodi, "Le denunce", p. 118). Ou então ainda o sistema prescricional português, que pela sua aproximação com o direito penal (as contra-ordenações) assume que a prescrição não se interrompe pela existência do processo administrativo. A busca da verdade real transformar-se-ia na procura de um motivo para reconhecer a prescrição.

${ }^{560}$ Em linha de princípio, essa conduta atentaria contra o princípio da concentração da prova. Não ostante, “as consequüências mais funestas dessa prática têm sido não só o desvio do contraditório, o que por si só é grave, como também o desvio da proposição da prova pela parte induzida a suposições ilusórias. Ao mesmo tempo, com a vinda posterior do documento inicialmente sonegado, já poderá ter o juiz deferido a realização de diligências probatórias tornadas inúteis ante a presença desse meio de prova. Atrasa-se o andamento do feito, inclusive pela necessidade de proferimento de despacho concedendo à parte contrária prazo (de cinco dias) para dizer sobre esse documento, impondose ao juiz um inoportuno reexame de prova" (Aguiar Silva, As provas no cível, p. 30, 218-219).
} 
A solução do problema não está em uma postura injustificadamente restritiva ou demasiadamente tolerante. Importar soluções adequadas e equilibradas da prática jurisdicional para promover maior aceitação das premissas do processo administrativo antitruste parece ser o caminho mais adequado. Pondere-se o pensamento de Grinover, para que "até as regras processuais sobre a preclusão, que se destinam apenas ao regular desenvolvimento do processo, não podem obstar ao poder - dever do juiz de esclarecer os fatos, aproximando - se do maior grau possível de certeza, pois sua missão é pacificar com justiça". ${ }^{561}$

A proposta envolve a coordenação da estabilização da demanda, do princípio do iura novit curia, da idéia de fato novo e de alguma flexibilização procedimental.

A estabilização da demanda jurisdicional se dá com o saneamento do processo e início das providências instrutórias. A partir daí, não é mais possível o aditamento do processo, em especial em relação aos pedidos. No processo administrativo, o pedido é primariamente sancionatório e tem por objetivo a aplicação das penas fixadas nos arts 23 e 24 da Lei n. 8.884/94, com pouca margem para inovação. Com relação aos argumentos não fáticos - hermenêuticos, prevalece o princípio do iura novit curia, cabendo ao aplicador o conhecimento de argumentos dessa natureza, razão pela qual a inserção de novos não implica inovação de matéria fática. Já em relação aos fatos, a questão ganha contornos de complexidade, na medida em que pela teoria da substanciação eles são vinculantes e que perante o Poder Judiciário somente serão considerados no processo fatos distintos daqueles apresentados em momento postulatório caso eles sejam novos, ou seja, ocorridos após o momento processual em que ordinariamente deveriam ter sido apresentados. ${ }^{562}$

\footnotetext{
${ }^{561}$ Grinover, “A iniciativa instrutória do juiz no processo penal acusatório”, pp. 78 e ss. Repita-se, porém: é preciso estar sempre atento para as particularidades do SBDC e para a recomendação vista no item VI.1.5 de que a inquistoriedade no processo administrativo de apuração de conduta deve sofrer temperamentos. Essa razão corrobora a observância de um sistema de ônus e preclusões.

562 "Os fatos novos de que trata o art. 462 só podem ser entendidos como os que ocorrem depois da propositura da ação. Não se trata, aqui, dos fatos que, ocorridos anteriormente, não foram oportunamente agitados pelo autor ou pelo réu por qualquer motivo. O dispotivo, dessa forma, não excepciona e não desconsidera eventuais preclusões já consumadas em desfavor do autor ou do réu em virtude da não-alegação (e correspondente prova) de fato pretérito, preexistente. Para os fins do art. 462, mister que o fato tenha nascido depois da propositura da ação" Scarpinela Bueno, Codigo de Processo civil interpretado (coord. Antonio Carlos Marcato), p. 1.421.
} 
As propostas seriam, então, as seguintes: fatos novo e quaisquer alegações "de direito", dentro de um mesmo objeto processual, podem sempre ser conhecidas e analisadas quando do proferimento de sentença. A única exigência que se faz é a garantia de contraditório sobre essas questões, o que não implica substancial atraso ao desenvolvimento do processo - manifestações sobre fatos novos pode ser apresentadas em prazos relativamente exíguos sem prejuízo às partes. Não há qualquer inovação nisso.

Sobre alterações do objeto do processo e adição de fatos velhos, uma consideração de lege ferenda que tenta contemporizar a demanda por flexibilização concorrencial e a certeza de que questões dessa natureza serão reexaminadas pelo Poder Judiciário, em sede civil: que se permita a alteração, balizada por juízos de ponderação, proporcionalidade e boa-fé e bom senso, dentro de uma perspectiva instrumentalista conciliadora de escopos atenta ao direito material e as especificidades do processo em estudo. ${ }^{563}$

As alterações mencionadas só seriam admitidas se, e somente se, a inserção de novos elementos no processo ordinariamente vedados: (a) não seja utilizada para dedução de pretensões prescritas; (b) não prejudique substancialmente o trâmite do processo, atrasando-o; (c) a eficiência na prestação da tutela e os benefícios para a demanda orginal em razão do aproveitamento de atos processuais sejam consideravelmente maiores se comparados com a necessidade de denúncia autônoma e trâmite separado das pretensões; (d) dos argumentos apresentados pelo sujeito processual não for possível inferir má-fé (estratégia processual destinada à postergação da tutela administrativa); (e) for rigorosamente observado o contraditório e a parte contrária, intimada, não apresentar argumentos convincentes destinados a demonstrar a necessidade premente de obtenção de uma solução para o processo e de rejeição do debate.

Esses critérios são uma tentativa de atribuir coerência e objetividade a um sistema que, na sua conformação atual, não equilibra adequadamente os escopos do processo administrativo de apuração de conduta.

\footnotetext{
${ }^{563}$ A recomendação de De Santo reforçam a necessidade de apresentação célere, mas tangenciam a posição ora adotada: "razones de economía procesal, mejor justicia y plenitud de la cosa juzgada aconsejan la introducción y estimación de hechos nuevos si se dan las condiciones subjetivas, objetivas y de oportunidad que exige esta norma, con las cuales no se afectan nu el derecho de defensa ni el buen orden del debate judicial". Esses requisitos seriam a produção da prova posterior à contestação, de natureza integrativa à pretensão, que possa intervir sobre a decisão, requerida de forma clara, concreta e individualizada, e acompanhada de todas as provas necessárias a sua demonstração (La prueba judicial, p. 167-169).
} 
Outro ônus digno de nota seria o ônus da prova, ${ }^{564}$ regra que define como se deve julgar uma demanda quando uma das partes, ou ambas, não conseguem demonstrar as circunstâncias de fato que alegaram (objeto de explícita controvérsia entre as partes ${ }^{565}$ ), porque não ofereceram provas, porque a prova proposta não foi admitida ou porque o resultado da produção da prova não confirmou a hipótese afirmada, vedado o non liquet.

Trata-se de instrumento voltado à decisão final, que surge quando a inexistência de um fato processual e juridicamente relevante torna impossível aplicar a norma que pressupõe a sua existência. A disciplina cria então um instrumento auxiliar (regole operative) que atua quando não é aplicável a norma de direito substancial pressuposta por falta de provas. ${ }^{566}$

Sobre a distribuição do ônus no sistema processual administrativo, afirma-se que ele recai sobre a autoridade e não sobre o administrado. ${ }^{567}$ Trata-se apenas de incorporação da regra geral pela qual, em situações ordinárias, ao autor (a SDE) cabe o ônus de provar os fatos constitutivos de seu direito alegados em petição inicial (despacho de instauração/nota técnica) e ao réu (representado) cabe o ônus da prova dos fatos modificativos, impeditivos ou extintivos. ${ }^{568}$ Se à SDE incumbe a prova da afirmação

${ }^{564}$ Sobre a evolução de critérios de distribuição de ônus da prova, confira-se De Santo, La prueba judicial, pp. $139-158$.

${ }_{565}$ Taruffo, "Onere della prova", p. 71.

${ }^{566}$ Taruffo, "Onere della prova", p. 66. Yarshell critica o aspecto corrente negativo, aduzindo que "a qualificação 'negativa' da prova como ônus é, com efeito, insuficiente para explicar sua dimensão positiva no contexto das garantias constitucionais enfeixadas pela garantia síntese que é o devido processo legal. Mais que isso, aquela qualificação também é inadequada, só por si, para justificar um direito ou poder (...)" (Yarshell, Antecipação da prova sem o requisito da urgência e direito autônomo à prova, p. 47)

${ }^{567}$ Como expresso pela Advocacia Geral da União - AGU, no Processo no ${ }^{\circ}$ 03000-005894/95-10, Parecer GQ nº. 136, de 19 de janeiro de 1998, aprovado pelo Presidente da República em 26/01/98:“(...) II - No Processo Administrativo Disciplinar o ônus da prova incumbe à Administração" - ainda que não se trate de um processo disciplinar, trata-se de referência de pensamento. No direito comunitário, nos termos do art. $2^{\circ}$ do Regulamento n. 1/2003, "em todos os processos nacionais e comunitários de aplicação dos artigos 81.o e 82.o do Tratado, o ónus da prova de uma violação do n.o 1 do artigo 81 .o ou do artigo 82.o do Tratado incumbe à parte ou à autoridade que alega tal violação. Incumbe à empresa ou associação de empresas que invoca o benefício do disposto no n.o 3 do artigo 81.o do Tratado o ónus da prova do preenchimento das condições nele previstas".

${ }^{568} \mathrm{Na}$ Inglaterra é aplicado o critério geral assemelhado ao brasileiro; nos Estados Unidos, trata-se de divisão feita caso a caso segundo critérios discricionais, diversos, variáveis e conforme a matéria em questão; na Alemanha, existem diversas normas que regulam a alocação do ônus em hipóteses específicas. Na Itália, existe a regra geral do art. 2.697 do Código Civil, que afirma: "chi vuol far valere un diritto in giudizio (Cod. Proc. Civ. 163) deve provare i fatti che ne costituiscono il fondamento (Cod. Proc. Civ. 115). Chi eccepisce l'inefficacia di tali fatti ovvero eccepisce che il diritto si è modificato o estinto deve provare i fatti su cui l'eccezione si fonda" (Taruffo, "Onere della prova", pp. 66-69). Fato costitutivo é o "fatto che rappresenta la premessa giuridicamente necessaria delle conseguenze che tali norme prevedono. Questo fatto 'costituisce' il diritto appinto perché ne rappresenta la condizione necessaria e sufficiente". Por sua vez, explica "i fatti impeditivi, così chiamati perché idonei a precludere la manifestazione degli effetti del diritto, i fatti modificativi, che ne mutano l'oggeto o il contenuto, e i fatti estintivi, che lo fanno venir meno". Mandrioli 
(constituição do direito) e não cumpre esse ônus, em julgamento sua pretensão poderá ser rejeitada; se a SDE cumpre com seu mister e o representado não prova os fatos modificativos, impeditivos, ou extintivos, a regra de julgamento autoriza o acolhimento da pretensão-denúncia.

A distribuição do ônus da prova comporta temperamentos e considerações. No caso de fato notório - fato relativo à cultura média do tempo e lugar da decisão, ainda que restrita a um lugar ou a um específico âmbito social ou profissional e de conhecimento do juiz, por meios acessíveis a qualquer $u^{569}$ - não se atribui o ônus da prova a qualquer das partes. Se, v.g., o fato notório é simplesmente afirmado pelo autor, o ônus da prova de modificação, extinção ou impedimento volta-se automaticamente ao representado (notoria non egent probatione). O mesmo acontece quando o julgador determina a realização de provas de ofício, que alteram a disposição da regra sobre o ônus da prova, ${ }^{570}$ hipótese na qual a aquisição da prova é neutra e não influi sobre a distribuição do ônus entre as partes. O tema enseja debates também sobre fatos negativos. Mas nesse nesses casos de afirmação positiva e resposta que dependa de prova de fato negativo, não há alteração na distribuição do ônus da prova por ser possível sua prova por meio da afirmação de fatos positivos incompatíveis com a verdade do fato do qual se pretende demonstrar a inexistência, assumindo ainda a possibilidade de prova direta de fato negativo. $^{571}$

Existem ainda outras disposições relevantes sobre a inversão do ônus da prova. Afastadas as inversões convencionais (pattizie) em razão da natureza pública indisponível do processo e do direito material envolvido, ${ }^{572}$ é sutil a disciplina de inversões

alerta sobre a dificuldade de se estabelecer a linha divisória entre os fatos constitutivos e impeditivos: "quella linea che separa quei fatti che, essendo sicuramente causali rispetto al diritto, vanno senz'altro considerati come fatti costitutivi, da quei fatti che essendo presenti nella fattispecie costitutiva, soltanto in via occasionale, debbono invece essere considerati (al negativo) come fatti impeditivi" (Diritto processuale civile, vol. II, p. 186-187).

569 Taruffo, "Onere della prova", p. 66.

${ }^{570}$ Mandrioli, Diritto processuale civile, vol. II, p. 193.

571 Taruffo, "Onere della prova", p. 71 e também em seu Trattato di diritto civile e commerciale - la prova dei fatti giuridici, pp. 229-230 e 433, explorando o conceito de fatos incompatíveis. Para De Santo, a prova de fato negativo é admissível "en todos aquellos casos en que una norma erige a un hecho negativo en presupuesto de um efecto determinado, pues cuando ello sucede no meida razón válida alguna para dispensar la carga de la prueba e la parte que invoque un hecho de ese tipo como fundamento de una pretensión o de una oposición” De Santo, La prueba judicial, pp. 162.

${ }^{572}$ Admitidas exceções em TCC's e acordos de leniência. 
legais e de inversões judiciais. ${ }^{573}$ A rejeição das inversões a priori tem fundamento na delicada relação de equilíbrio entre a situação jurídica dos sujeitos processuais estabelecida no processo administrativo antitruste, reconhecida a posição privilegiada das autoridades em relação às empresas no que toca à satisfação do ônus da prova e "l'inferiore capacità delle parti private di attingere a fonti di prova e materiali di rilievo ai fini dell'accertamento dei fatti". ${ }^{574}$ Ainda assim presunções podem ser examinadas, conforme será demonstrado de forma exemplificativa no item VI.3.4 infra.

Dois outros pontos interessantes sobre os temperamentos da regra do ônus da prova e a idéia de facilidade na produção da prova. Em caso de fato constitutivo e impeditivo contemporâneos, "si deve sciegliere quella soluzione, in virtù della quale diventa onerato della prova il soggeto per cui la prova è più facile, cioè il soggetto più vicino alle fonti di prova (criterio della vicinanza)". 575

Em outro caso, em situações versando direitos indisponíveis, diminui o peso representado pelo ônus da prova, que se torna "imperfeito", relativo, e se distancia dos chamados ônus absolutos. Nesses casos, relativiza-se a regra, reduz-se o seu peso quando o juiz, em sua consciência, "tiver por bem mais provável a existência do que a inexistência e sem chegar aos extremos de exigência que só se compreenderiam e legitimariam se fosse possível o encontro da verdade pura e indiscutível mediante a instrução e se a certeza absoluta fosse algo tangível na cognição processual". ${ }^{576}$ Em situações como a do processo administrativo, os ônus se mantém, mas não de forma absoluta, ainda que a relativização deva ser promovida com a cautela proposta.

Pela aplicação de todas essas técnicas de aceleração do processo, o resultado pode ser até injusto, porque os desvios e equívocos das partes podem não desembocar na aplicação da vontade concreta da lei. Mas se compreendida a separação

\footnotetext{
${ }^{573}$ Que se fundam na normalidade e racionalidade do fato alegado. Porém, é feita uma analogia à prova prima facie ("la giurisprudenza ritiene sufficiente che una parte dimostri l'apparenza di un fatto, solitamente fornendo indizi tali da poter essere ricondotti entro una 'costellazione' che si ritiene tipica di specifiche situazioni"), que é criticada porque a inversão deve estar afeita à lei e sua admissão pode gerar sensação de incerteza, aleatoriedade em relação à disciplina do ônus da prova, admitindo uma violação da garantia do contraditório por meios discricionários e subreptícios (Taruffo, "Onere della prova", p. 78).

574 Querzola, "La tutela cautelare antitrust fra processo e amministrazione, riflessioni minime", p. 285. A afirmação, como visto acima, comporta temperamentos em razão da dificuldade ordinariamente encontrada por autoridades para a identificação de ilícitos anticoncorrenciais.

${ }_{575}$ Luiso, Diritto processuale civile, p. 241.

${ }^{576}$ Dinamarco, A instrumentalidade do processo, p. 304-310; cfr. tb. Yarshell, Antecipação da prova sem o requisito da urgência e direito autônomo à prova, pp. 118-125.
} 
dualista entre o plano processual e o plano do direito material e a coordenação instrumentalista entre ambos, ainda assim o julgamento será elemento pacificador - uma distorção tolerada e aceita pelo sistema que, ao final, prestigiará o elemento social em razão das aberturas fornecidas pelo jurídico: "são distorções inevitáveis a que está sujeito o sistema (...). A dialética do contraditório é mesmo composta assim das incertezas em que se refletem perspectivas, possibilidades, chances, expectativas e ônus (...) se o resultado do processo se afastou dos desígnios do direito substancial nada de mau ou muito significativo reside nisso, desde que o escopo social de pacificação haja sido atingido". 577

Esses instrumentos de técnica processual rendem efetiva a coordenação entre o escopo social e o jurídico do processo, de modo a alcançar o escopo magno da pacificação com justiça, mas que inegavelmente reconhece a prevalência do primeiro sobre o segundo.

\section{VI.3.3. Processo e procedimento antitruste}

Como visto na parte introdutória deste capítulo, a consecução do escopo jurídico do processo depende da aplicação de técnicas que revelem o direito em ambiente de segurança jurídica, de modo a dar vazão ao exercício imperativo do poder estatal. Aqui, examinam-se o processo e o procedimento como instrumentos de segurança.

Os atos jurídicos em geral são compostos de forma (manifestação extrínseca do ato, objetivamente individuado e apreciado) e conteúdo (a matéria, o elemento intrínseco). Os atos processuais têm, como características específicas, uma disciplina formal estabelecida de forma minuciosa e rigorosa, sem preocupar-se com a formação e manifestação da vontade, de seus elementos incidentais e da causa. Como regra, "la validità e l'efficacia degli atti processuali, mentre dipende dall'osservanza delle forme, non dipende da alcun controllo sulla formazione o la manifestazione della volontà degli effetti etc.". ${ }^{578}$ A disciplina desses atos exige que sua validade possa ser apurada com base em dados objetivos e de fácil controle (especialmente no que diz respeito à facilidade de correlação entre forma e conteúdo), para todos os sujeitos do processo. Eliminam-se os

\footnotetext{
${ }^{577}$ Dinamarco, A instrumentalidade do processo, pp. 249-250.

${ }^{578}$ Mandrioli, Diritto processuale civile, vol. I, p. 417.
} 
elementos acidentais do ato processual, afastando-se elementos subjetivos sem descurar-se do escopo do ato. ${ }^{579}$

No que é relevante para este trabalho, o processo é o instrumento de outorgas de tutelas pelo Estado refletido em um procedimento cujas formas são estabelecidas por lei, constituído ainda por uma relação processual em ambiente de garantias constitucionais e infraconstitucionais. Trata-se da atuação concreta do direito conforme seus escopos específicos.

A relação entre processo e procedimento administrativo não foge à disciplina geral. Como visto, também perante o CADE o processo é informado pela relação jurídica, pelo contraditório e por uma manifestação extrínseca (procedimento) formal.

A lei n. 9.784/99, que disciplina o processo administrativo, estabelece "a adoção de formas simples, suficientes para propiciar adequado grau de certeza, segurança e respeito aos direitos dos administrados” (art. $2^{\circ}$, par. ún., inc. IX). A interpretação dessas disposições poderia levar à idéia de que o processo administrativo é mais flexível, célere, efetivo e desapegado das formas.

Essas premissas levaram Fonseca a afirmar que "a justiça administrativa tende a se orientar pelos princípios da economia (eficiência dos meios), velocidade nas decisões, capacidade de adaptação à variação de condições, flexibilidade nas tecnicalidades formais, pouca aderência ou vinculação aos seus precedentes e formação eclética dos membros do colegiado. Ademais, a justiça administrativa combina prática com teoria, busca uma abordagem multidisciplinar e se submete a uma revisão interna e externa", sem a necessidade de se "judicializar" uma agência. ${ }^{580}$ Klajmic corrobora o pensamento e afirma serem aplicáveis os princípios da legalidade objetiva, da oficialidade, da verdade, da garantia da defesa e, especialmente, do informalismo, que "dispensa formas rígidas, sendo suficientes aquelas necessárias à obtenção da certeza jurídica e à segurança procedimental". 581

As lições precisam, efetivamente, ser lidas com cautela no direito brasileiro. Por tudo que já escrito até o momento, o SBDC deve ter um olho em seu

\footnotetext{
${ }^{579}$ Mandrioli, Diritto processuale civile, vol. I, p. 419.

${ }^{580}$ Fonseca, "Papel dos tribunais administrativos e sistema judicial", p. 37.

${ }^{581}$ Klajmic, "A apuração das práticas restritivas da concorrência - averiguações preliminares e processos Administrativos", p. 27.
} 
procedimento e outro na manutenção de suas decisões. Não deve temer a revisão judicial, mas deve estar aberto aos influxos e evoluções do processo judicial para exatamente ver mantidos seus comandos. Logo, todo o processo busca a eficiência de meios e decisões velozes, mas mantém um equilíbrio necessário com a busca da verdade possível; a aderência ou vinculação aos precedentes é um bom reflexo de segurança jurídica, preceito tão importante para as relações de mercado; a formação eclética de seu colegiado jamais deve se descurar das tecnicidades de um ramo do direito que atua sobre uma realidade extremamente dinâmica e exige a capacitação de seus operadores.

Na Itália, o procedimento é regulado pela legge n. 287 e pelo DPR 217. ${ }^{582}$ A normativa foi reestruturada de modo a garantir o pleno e correto desenvolvimento "della partecipazione procedimentale e del diritto alla difesa e potenziando - attraverso una formalizzazione - il ruolo propositivo degli uffici”. ${ }^{583} \mathrm{O}$ procedimento é considerado informal sem particulares regras. Afirma-se que se de um lado o encontro dialético e construtivo entre empresas fora do sistema procedimental ordinário possa representar um perigo, a flexibilidade evidencia um papel não meramente punitivo de uma autoridade que pode "svolgere più agevolemente ina attività di prevenzione, riducendo al tempo stesso i costi economici del contenzioso e affermando una interpretazione di ruolo che difficilmente potrebbe essere confusa con l'attività giurisdizionale". ${ }^{584}$ Negri, porém, afirma que esse posicionamento pode ser atribuído às constantes reclamações sobre o complicado processo civil italiano, o que impede que se socorra do Código de Processo Civil peninsular para suprir lacunas do direito processual antitruste. $^{585}$

Fauceglia, por sua vez, entende que o exame de casos relatados em imprensa revela que a ausência de normas procedimentais perante a AGCM pode ser "tanto più pericolosa quanto più incidente sulla completezza e ragionevolezza

\footnotetext{
${ }_{582}^{583}$ matéria de publicidade enganosa, o procedimento é previsto no DPR 627.

${ }^{583}$ Negri concorda com a idéia de "contraditório ponteciado em relação ao modelo geral". A ausência de controle dos atos da Autoridade pelo Poder Executivo (o chamado circuito democrático entre governo e parlamento) e o vazio de legitimação criado leva a doutrina a acentuar as garantias ditas procedimentais, assegurando um mínimo de participação e transparência (Negri, Giurisdizione e amministrazione nella tutela della concorrenza, p. 25).

${ }^{584}$ Benedetto, L'Autorità garante della concorrenza e del mercato, p. 222-223. A autora afirma ainda que "l'Autorità amministrativa, diversamente da quella giudiziale, rimane titolare, sebbene di un interesse speciale (quello pubblico), pur sempre di un interesse 'proprio' (...) Ad essa in sostanza è consentito ricercare nuove forme procedurali e perfino 'contrattarle' con i diretti interessati, rinvenendo di volta in volta le modalità per assicurare adeguata 'garanzia' per le varie posizioni soggettive procedimentale" (p. 73-74).

${ }^{585}$ Negri, Giurisdizione e amministrazione nella tutela della concorrenza, p. 25.
} 
dell'istruttoria, il cui simulacro è dato riconoscere in brevi incisi posti ad apertura delle singole decisioni ('sentite le parti', 'lette le controdeduzioni’ e così continuando)". ${ }^{586}$

É conhecida a reserva dos operadores do direito econômico em relação ao formalismo processual como dado supostamente contrário ao dinamismo das relações econômicas e de sua regulação. A questão, como visto, não passa despercebida pela processualística moderna.

É desnecessário aqui tecer maiores considerações sobre a evolução do pensamento processual desde Büllow até hoje. Basta entender que, atualmente, os estudos processuais "transcendem a dimensão da técnica, sem desconhecê-la, para se alçarem à esfera das preocupações constitucionais e da compreensão dos objetivos sociais e políticos da função jurisdicional". 587

Bedaque aborda a questão, impondo ser, de fato, o formalismo exagerado como uma das mazelas da justiça e afirma que "a forma e a técnica devem ser compreendidas em conformidade com as exigências do devido processo constitucional e com os objetivos do instrumento" e que o "formalismo é necessário, mas deve limitar-se a assegurar os objetivos do processo". ${ }^{588}$ Liebman conscientemente afirmava que "uma indulgência exagerada para com a violação das formas deixaria sem eficácia as disposições da lei e ameaçaria a segurança da ordem processual e, conseqüentemente, a regularidade e eficiência no desempenho da função jurisdicional". E fechava a idéia com a conhecida afirmação de que "as formas são necessárias, mas o formalismo é uma deformação". 589

A forma não é puramente um mal a ser combatido. Na ausência de formas procedimentais, a confusão, a incerteza e a desordem seriam imperativos de um Estado que não legitima suas decisões, proferidas por juízes que definem procedimentos aleatoriamente, sem um padrão mínimo de segurança e instituem a surpresa como forma organizativa.

O processo e o procedimento devem estabelecer "um clima de segurança para as partes" e a "regulamentação legal representa a garantia destas em suas relações

\footnotetext{
${ }^{586}$ Fauceglia 'L'istruttoria dell'autorità in tema di intese restrittive della libertà di concorrenza e di abuso di posizione dominante", p. 267.

${ }^{587}$ Palavras introdutórias da obra A marcha do processo, São Paulo, Forense Universitária, 2000.

${ }^{588}$ Bedaque, Efetividade do processo e técnica processual, cap. I e síntese conclusiva.

${ }^{589}$ Liebman, Manual de processo civil, p. 327-328.
} 
recíprocas com o juiz; por isso, as formas procedimentais devem ser certas e determinadas". 590

Teóricos da public choice encampam a idéia de que "uniform enforcement of procedural rules will tend to produce better results on the average" - o respeito a essas regras constitui limite ao comportamento estratégico de parcela dos legisladores, modera as influências dos grupos de interesse e reduz a chance de resultados arbitrários. $^{591}$

Os procedimentos modernos não são inspirados em ritualística ou simbologismos primitivos. As formas são destinadas ao cumprimento de objetivos predeterminados constitucionalmente ou infraconstitucionalmente pelo Estado sob pena de serem paulatinamente desprezadas e desaparecem por soluções endógenas que, v.g., estabelecem uma estreita correlação entre nulidades e o princípio da instrumentalidade das formas.

A preocupação concreta do combate ao formalismo se revela, no Poder Judiciário, em normas como a dos Juizados Especiais em que se atribui liberdade formal não arbitrária. Ali, o juiz cria maneiras de "tratar a prova, de colher a instrução ou de sentir as pretensões das partes: interroga-las-á livremente, dialogará com elas e permitirá o diálogo entre elas ou delas com as testemunhas; visitará o local dos fatos, ou examinará as coisas trazidas com sinas ou vestígios de interesse para a instrução; permitirá que argumentem a qualquer tempo e lhes dirigirá perguntas ainda quando declarada finda a instrução". Nenhuma dessas possibilidades altera o respeito da idéia de postulaçãodiscussão-decisão, tampouco desconsidera garantias constitucionais do processo. Essa é a razão pela qual cada ato colocado em lei deve "cumprir certas funções do processo e porque existem as funções a cumprir. Daí a grande elasticidade a ser conferida ao princípio da instrumentalidade das formas, que no tradicional processo legalista assume o papel de válvula do sistema, destinada a atenuar e racionalizar os rigores das exigências formais". ${ }^{592}$

Mandrioli comenta a evolução do processo italiano e revela que o legislador de 1940 já estava preocupado com a "rapidità del giudizio attraverso un dialogo

\footnotetext{
${ }^{590}$ Cintra-Grinover-Dinamarco, Teoria geral do processo, pp. 324-325.

${ }^{591}$ Daniel Farber e Phillip Frickey, Law and public choice - a critical introduction, pp. 117-127.

592 Dinamarco, A instrumentalidade do processo, pp. 156-157.
} 
pratico e senza inutili formalismi, tra le parti e il giudice", com foco nos princípios da oralidade, imediatidade e concentração. ${ }^{593}$

No processo administrativo, a necessidade de formas e o repúdio ao formalismo já foram reconhecidos por Medauar há mais de quinze anos, quando afirmou que "a idéia, veiculada durante muito tempo, da atividade administrativa como atividade quase totalmente livre, revela-se incompatível com atuações parametradas processualmente". A aproximação havida entre o Estado e os administrados nas últimas décadas exigiu a abertura dos modos de atuação administrativa, da participação do cidadão $^{594}$ por meio de uma processualidade ampla, pela qual se reconhece o processo como instrumento de todas as expressões de poder do Estado; um ambiente para o debate de idéias opostas que permitem o alcance de uma verdade. ${ }^{595}$

Em uma autoridade administrativa, não se desconhece a importância do procedimento como garantia de eliminação de custos adicionais, de tratamento isonômico, independentemente da experiência de operadores e, finalmente, de oferecimento de segurança aos agentes e representantes. ${ }^{596}$ Inegável ainda que no âmbito da análise econômica do direito, o "incremento do grau de segurança e previsibilidade proporcionado pelo sistema jurídico leva ao azeitamento do fluxo de relações econômicas", de modo a criar um ambiente institucional estável, no qual os agentes podem calcular/prever os resultados de seu comportamento e daqueles com quem se relacionam. ${ }^{597}$

$\mathrm{Na}$ outra ponta, estão aqueles que assumem um discurso mais preocupado. Se acima o discurso partia da informalidade ao equilíbrio, os mais receosos partem do rigor formal para desembocar naquele mesmo equilíbrio. É ilustrativa a opinião de Franceschini, (que defende natureza do processo administrativo não adotada neste trabalho), que parte de uma concepção penal-processual penal (cuja origem é de claro repúdio às premissas instrumentais, flexibilizadoras e voltadas aos escopos processuais) para afirmar que diante da "natureza repressiva da legislação antitruste (independentemente da taxonomia da lei), atingindo o 'status libertatis' dos agentes econômicos e balizando a legitimidade do princípio constitucional da liberdade de

\footnotetext{
${ }^{593}$ Mandrioli, Diritto processuale civile, vol. II, p. 65.

${ }^{594}$ Medauar, A processualidade no direito administrativo, p. 14-16.

${ }_{595}$ Medauar, A processualidade no direito administrativo, p. 17, fazendo referência a Couture.

${ }^{596}$ Fonseca, "Papel dos tribunais administrativos e sistema judicial", p. 25-26.

${ }^{597}$ Forgioni, “Análise econômica do direito: paranóia ou mistificação?", passim.
} 
iniciativa, por sua importância e gravidade, não poderia ela satisfazer-se com regras processuais de aplicação informal. A forma, sem resvalar para o formalismo da velha praxe, é, no caso, a garantia da liberdade econômica". 598

Essas breves linhas têm a intenção apenas de esclarecer que o problema do formalismo não é sistêmico, ou melhor dizendo, o combate ao formalismo e o equilíbrio entre a celeridade/efetividade/eficácia versus segurança jurídica é a tônica do pensamento processual moderno, cabendo exclusivamente aos operadores do direito a compreensão e aplicação dessa releitura de diretrizes. Essas considerações não têm o condão de impedir que as premissas sobre, v.g., postulação, contraditório, direito à prova, limites da decisão, motivação dessas decisões e preclusão sejam aplicados ao processo administrativo em um paralelo (de cunho instrumental) em relação ao processo jurisdicional.

Trata-se de um processo de adequação, de combate à chicana e de proteção de formas adequadas, princípios corretos: "al di lá di impostazioni eccessivamente formalistiche, va rilevato dall'impianto normativo, oltre che dalla recente prassi dell'Autorità, la tendenza a facilitare una costante dialettica tra controllato e controllore, nella ricerca di uno sforzo di adeguamento dei comportamenti delle impresse $(\ldots), 599$

A batalha pela compreensão da real finalidade da forma, de fato, indica que os operadores do processo ainda se ressentem de ranços históricos e formalistas, oriundos daquele pensamento autonomista exacerbado, do processo pelo processo. Mas as maçãs podres estão em todos os cestos. Na aplicação do processo ao CADE, os operadores devem se limitar ao que realmente traduz a processualística moderna.

Por fim, um último ponto merece consideração. A FTC americana exercita sua atividade por meio da adjudication, processo que envolve a identificação dos fatos, a formulação dos princípios legais aplicáveis a situações de determinado gênero e a aplicação dos princípios aos fatos. Aplica-se o Administrative Procedure Act de 1946 para os processos de adjudication em geral perante as agências, que estabelece uma uniformidade procedimental pautada pela publicidade e transparência, veda contatos

\footnotetext{
${ }^{598}$ Franceschini, “A cláusula ‘devido processo legal’ e a lei antitruste nacional”, p. 216.

${ }^{599}$ Fauceglia, "L'istruttoria dell'autorità in tema di intese restrittive della libertà di concorrenza e di abuso di posizione dominante", p. 264.
} 
informais com empresas representadas, limita arbitrariedades, mas admite flexibilidade suficiente para fixar procedimentos case-by-case. ${ }^{600}$

Talvez esse seja um caminho para a proposta de simplificação procedimental que o processo administrativo almeja, com os temperamentos de um sistema de civil law: a norma processual estabelece as garantias, os princípios e os procedimentos que devem ser observados; contudo, em determinadas situações estabelece aberturas, espaços onde o instrutor-julgador pode determinar o procedimento sem que isso acarrete violações aos axiomas, nulidades ou prejuízos aos sujeitos do processo.

Trata-se da concretização do princípio da adaptabilidade do órgão às exigências do processo. Conforme esse princípio, o arcabouço de normas procedimentais varia para permitir uma fluência processual eficaz e célere, sem prejuízo substancial ao due process of law. ${ }^{601}$ Auletta refere-se ao case managment system, cabendo ao juiz a fixação de procedimento conforme as peculiaridades da controvérsia que, consciente da reserva legal sobre normas processuais, acaba por se revelar na fixação de procedimentos especiais fixados pelo legislador, nem sempre capaz de avaliar a adequação do procedimento à controvérsia. ${ }^{602}$

Capelletti e Garth fazem referência à adaptabilidade e à "necessidade de correlacionar e adaptar o processo civil ao tipo de litígio. Existem muitas características que podem distinguir um litígio de outro. Conforme o caso, diferentes barreiras ao acesso podem ser mais evidentes, e diferentes soluções, eficientes". 603

Porém, é preciso deixar claro que essa regulação procedimental não existe na atual conformação das normas processuais e regras procedimentais previstas para o processo administrativo antitruste. O silêncio não é interpretado como uma área de atuação do Juiz, mas como uma lacuna a ser preenchida por diplomas de aplicação subsidiária. No caso antitruste, a aplicação da lei n. 9.784/99 e a referência expressa ao Código de Processo Civil conduzem a um fechamento do sistema e de pouca adaptabilidade no âmbito da matéria em estudo.

\footnotetext{
${ }^{600}$ Benedetto, L'Autorità garante della concorrenza e del mercato, pp. 214-215.

${ }^{601}$ Dinamarco, A instrumentalidade do processo, p. 356.

${ }^{602}$ Auletta, "Una lezione di analisi aconomica del diritto processuale", p. 633 e ss.

${ }^{603}$ Capelletti-Garth, Acesso à justiça, p. 71.
} 


\section{VI.3.4. A disciplina da prova (os meios de prova)}

Prova é um termo polissêmico usualmente utilizado para designação da disciplina, do meio, da fonte. Na concepção do processo por seus escopos, é por meio da disciplina da prova que o julgador busca alcançar a verdade possível sobre fatos, essencial à promessa estabelecida pelo escopo jurídico, determinante para uma maior pacificação social. $^{604}$

$\mathrm{O}$ acesso à prova é mais que uma possibilidade ou mera faculdade no processo. $\mathrm{O}$ direito à prova ${ }^{605}$ decorre dos princípios constitucionais do acesso à justiça, do contraditório, do devido processo legal ${ }^{606}$ e do próprio direito ao processo. Trata-se do direito a exercer as oportunidades oferecidas pela norma constitucional ou legal para influir sobre o convencimento do juiz mediante a demonstração de fatos relacionados com a demanda. É o contradizer provando, em ambiente participativo, ${ }^{607}$ impedindo decisões baseadas em elementos externos a esse ambiente. Ele é exercido mediante o emprego de fontes de prova legitimamente obtidas e a regular aplicação das técnicas representadas pelos meios de prova.

\footnotetext{
${ }^{604}$ Para Aguiar Silva, prova é "todo meio em condições de obter o resultado, assim como o próprio resultado, na pesquisa da verdade processual" (Aguiar Silva, As provas no cível, p. 8.

${ }^{605}$ Dinamarco não concorda com a expressão direito à prova: "inexistem 'direitos' de natureza processual, tanto quanto o Estado não tem 'obrigações' perante as partes. Cada uma das partes tem liberdade para produzir provas admissíveis e isso são 'faculdades'; e tem poderes relacionados com a prova, em face dos quais lhe é lícito exigir a realização de atividades probatórias do juiz" (A instrumentalidade do processo, $\mathrm{p}$. 349). Mandrioli também vê com ressalvas a expressão afirmando que o fundamento constitucional do direito à prova só pode ser aceito como "accentuazione dell'esigenza di adeguamento della disciplina in tema di ammissibilità e rilevanza delle prove al principio costituzionale del diritto alla tutela giurisdizionale". Referese ainda à inutilidade sistemática da expressão, sendo que a admissibilidade dos meios de prova é controlada de forma satisfatória à luz da razoabilidade, do contraditório e do dever de fundamentação (Mandrioli, Diritto processuale civile, vol. II, p. 173). Yarshell, por sua vez, distinguindo o direito à prova do direito de provar, reconhece no primeiro um "direito cujo conteúdo se limita à garantia de acesso, descoberta e documentação de certos fatos mediante a intervenção estatal" e no segundo uma decorrência do feixe de direitos compreendidos entre o exercício de ação e de defesa (Yarshell, Antecipação da prova sem o requisito da urgência e direito autônomo à prova, pp 232-234).

${ }^{606}$ Grinover, Os princípios constitucionais e o Código de Processo civil, p. 19; Aguiar Silva, As provas no civel, pp. 12-13.

${ }^{607}$ A evolução do pensamento científico processual do CADE deve se impor para que fatos como esse não sejam mais narrados como o anti-exemplo: "em processo perante o CADE, órgão que, embora integre a Administração, exerce função judicante, deparamo-nos com diligências realizadas - em autêntico processo, e não mero procedimento - de forma secreta pela autoridade presidente. Em uma delas o voto-condutor da condenação imposta às partes procurou justificar a providência na circunstância de que a prova se dirige ao julgador e que o papel daquela é formar a convicção deste (autos n. 08012.004086/2000-21). Portanto, o risco indicado no texto (distorções que afetam a produção da prova) existe, e merece reflexão (Yarshell, Antecipação da prova sem o requisito da urgência e direito autônomo à prova, p. 240).
} 
O direito à prova é subjetivo, público e cívico, destinado à introdução de material probatório no processo. Serve como elemento de preservação da imparcialidade, legitimidade e correção da prestação jurisdicional, prestando-se à manifestação essencial da garantia constitucional da ação e da defesa. É ainda um instituto bifronte pertencente ao direito processual mas também uma ponte de passagem com o direito: "tão grande é a influência do substancial, que vozes muito autorizadas chegam a iludir-se com as aparências a crer na pertinência a esse plano. Esses estrangulamentos significam, porém, somente que em alguns momentos a natureza instrumental fica mais sensível e vem à tona de modo mais agudo, a ponto de as normas e critérios do direito material, assim como as características da relação jurídica perante este, influenciarem com mais intensidade as soluções que o direito processual dispõe". ${ }^{608}$

A disciplina da prova é inicialmente examinada por suas fontes e meios. Fontes são pessoas e coisas - elementos e meios instrumentais externos - das quais são extraídas informações relevantes para o processo e para o deslinde das questões postas. Meios são as técnicas utilizadas na obtenção dessas informações. ${ }^{609}$

No processo administrativo, as fontes de prova não se distinguem substancialmente das fontes presentes em outros processos. São pessoas que prestam seus depoimentos perante agentes públicos da SDE ou do CADE, são coisas e documentos de natureza variada juntados ao processo (relatórios internos da empresa, documentos contábeis, documentos apresentados por associações, declarações escritas de sujeitos em respostas a ofícios, documentos prestados por outros entes da Administração, emails, degravações), documentos ou coisas inspecionadas e reduzidas a termo etc.

Os meios de prova ostentam alguma particularidade. São eles os instrumentos processuais por meio dos quais o juiz forma seu convencimento sobre a verdade ou inverdade dos fatos afirmados pelas partes. ${ }^{610}$ No iter lógico jurídico da

\footnotetext{
${ }^{608}$ Dinamarco, A instrumentalidade do processo, p. 222- 227. Ilustra a natureza bifronte do instituto o fato de que na Itália as normas sobre prova estão localizadas no Código de Processo civil (assunção, ingresso e apreciação por parte do juiz) e no Código Civil (admissibilidade dos meios de prova). Sobre o tema, cfr. ainda Mandrioli, Diritto processuale civile, vol. II, p. 176-177.

${ }^{609}$ Dinamarco, Instituições de direito processual civil, n. 804

${ }^{610}$ Mandrioli, Diritto processuale civile, vol. II, p. 168. Yarshell define os meios como "instrumentos ou atividades pelos quais os elementos de prova (ou 'dados probatórios') são introduzidos e fixados no processo, ou ainda, como os 'canais de informação' de que se serve o juiz" (Yarshell, Antecipação da prova sem o requisito da urgência e direito autônomo à prova, p. 33).
} 
disciplina da prova, avalia-se a admissibilidade e relevância do meio, a assunção da prova e a valoração do resultado probatório. ${ }^{611}$

Judicialmente, os sujeitos do processo se valem ordinariamente do depoimento pessoal das partes, da oitiva de testemunhas, da juntada de documentos, da perícia e da inspeção judicial. ${ }^{612}$ Os meios estabelecidos para o processo administrativo não se distinguem ontologicamente daqueles, nos termos da Portaria MJ n. 4/06, mas comportam particularidades que merecem comento.

A oitiva de testemunhas ${ }^{613}$ e o depoimento pessoal não são tratados de forma minuciosa pela norma antitruste. Na dinâmica do processo administrativo, a coleta dessas manifestações orais é conduzida por servidor da $\operatorname{SDE}^{614}{ }_{-}^{615}$ (e excepcionalmente por

${ }^{611}$ Os meios estabelecidos pelas normas processuais antitruste estão em conformidade com o conceito de tipicidade da prova, que representa a idéia de que "non esistono altre vie per far entrare nel processo gli strumenti di convincimento del giudice, all'infuori di quelle che la legge espressamente disciplina (...). Né, d'altra parte, esistono regole di ammissibilità o di attribuzione di efficacia probatoria diverse da quelle contenute nel codice". A despeito da regra, nem todas as situações de inserção de material probatório no processo estão codificadas, razão pela qual se faz referência à prova atípica (prova não prevista em lei), tais como declarações escritas por terceiros, provas produzidas em outros processos extintos, em outras esferas, apresentadas diante juiz incompetente (que são considerados indícios e pressupõem a realização de contraditório no processo de origem), as afirmações de fato em uma sentença (Mandrioli, Diritto processuale civile, vol. II, p. 178-80).

${ }^{612}$ Prova pré-constituída se forma fora e normalmente antes do processo, tem efeito demonstrativo ou de convencimento sobre determinado acontecimento sem a necessidade de atividade particular que não o seu oferecimento no processo. São exemplos as provas documentais. Provas constituendas, são meios que se formam somente no processo, não produzem o efeito de convencimento do juiz sem que sejam respeitados o desenvolvimento de uma atividade procedimental particular com o "scopo di rendere attuale quell'efficacia dimostrativa che nel momento in cui la prova viene offerta (...) è soltanto pontenziale o ipotetica". Toda a fase instrutória é dedicada às provas constituendas. O juiz deve sempre valorar se, de acordo com o objeto do processo, é necessário ou não uma atividade aquisitiva decorrente da produção de uma prova constituenda. A distinção tem relevância para a temática da admissibilidade, utilidade e relevância dos meios de prova, de modo que as circunstâncias possam ser provadas e que isso possa ser um contributo efetivo ao julgamento do mérito (Mandrioli, Diritto processuale civile, vol. II, p. 108).

${ }^{613}$ Prova testemunhal envolve a narração de fatos por aquele que tem conhecimento, não é partes, não tem interesses sobre o processo, é imparciais, mas sujeito às falhas da memória e a algumas deformações. Por isso, o julgador deve ter ampla liberdade para valorá-la. É preciso ter em conta também ter em conta a inadmissão do testemunho em caso de incapacidade e vedação, em casos em que questiona-se a legitimidade e a parcialidade do depoimento (Mandrioli, Diritto processuale civile, vol. II, pp. 264-278).

${ }^{614}$ Discute-se sobre a competência para a condução da oitiva das testemunhas. Para além das divergências de interpretação das normas aplicáveis (arts. 34, e 37, par. ún. da Lei n. 8.884/94 e art. 53, par. $2^{\circ}$ da Portaria MJ n. 4/06; cfr. ainda pelo conceito, o parecer da SDE no proc. n. 08012.009088/99-48), restaria examinar se compete ao Secretário da SDE ou a qualquer agente a condução da oitiva. A eventual falta de experiência do responsável, que justificaria a condução pelo Secretário, poderia causar danos que culminassem com a inutilização de prova por nulidade e sua necessidade de repetição. Mas (a) esse não é um problema insanável - até porque nada impede que a testemunha seja novamente argüida em diligência complementar no CADE (conceito que se aproxima daquele expresso no art. 515, par. $4^{\circ}$ do CPC), (b) a razão da atribuição específica da oitiva estaria no princípio da imediatidade, mitigado pelo sistema do SBDC, afirma-se haver uma impossibilidade prática de que o Secretário de Direito Econômico conduza todos os atos instrutórios de feitos em trâmite perante a SDE. Os argumentos convencem. Realmente, prevalece a idéia exposta na Portaria MJ n. $4 / 06$. 
gestor do CADE em caso de instrução complementar), pode ser acompanhada por advogado e é reduzida a termo para juntada no processo.

No âmbito do depoimento pessoal, repetem-se as considerações feitas no item VI.2.6. sobre o princípio da não autoincriminação e o direito ao silêncio. Em relação à prova testemunhal, destaca-se apenas a particularidade do processo administrativo concorrencial e as oitivas de representante e terceiros interessados no processo, especialmente em função de alguma celeuma suscitada a respeito de uma suspeição natural de concorrentes, que deve ser afastada. ${ }^{616}$ A aplicabilidade subsidiária do CPC remete ao fato de que a testemunha presta compromisso - ou seja, se compromete com a verdade, sob pena de responsabilidade (CPC, art. 415) - e pode ser contraditada (e ainda assim ser ouvida como informante - CPC, arts. 405 , par. $4^{\circ}$ e 414 , par. $1^{\circ}$ ). No mais, prevalece o princípio do livre convencimento motivado do juiz. ${ }^{617}$

Uma diferença digna de nota entre a norma antitruste e a disciplina judicial da intimação para a oitiva de sujeitos. No processo civil, o não comparecimento de uma testemunha enseja a condução policial e a responsabilidade pelas despesas de adiamento. Sobressai a medida de coerção (pela força) fundada no dever de colaboração (CPC, arts. 339, 341 e 412). ${ }^{618}$ No processo penal, a testemunha que não comparece pode ser conduzida coercitivamente, sujeita ao pagamento de multa e ainda pode responder por crime de desobediência (CPP, arts. 218, 219 e 458, CP, art. 330). Já o não comparecimento de uma das partes para depoimento pessoal no cível enseja a atuação de regras sobre a distribuição do ônus da prova, presumindo-se confessados os fatos contra ela alegados em

\footnotetext{
${ }^{615}$ Nos termos do Regulamento 773/2004, art. $3^{\circ}$ da Comunidade Européia, a audição de um sujeito é precedida do fundamento legal do ato, do registro que será feito, da sua finalidade e do reforço de sua voluntariedade. Pode ser feita eletronicamente ou por telefone. Ao final, é disponibilizada cópia da transcrição ao sujeito depoente, que poderá sugerir correções. Se o sujeito não tiver sido autorizado a falar em nome de determinada empresa, esta poderá retificar, alterar o aditar as explicações, registrando-se ulteriormente.

${ }^{616}$ Cfr. CADE, proc. n. 08012.005669/2002-31 e 08012.004086/2000-21.

${ }^{617}$ Essa afirmação não exclui que "conquanto sabido que o sistema brasileiro, como regra, não tarifa os meios de prova, por outro lado, não lhe é estranha a idéia de que aquela primeira encontra limites. Não se trata de abolir a prova testemunhal em certos casos, mas simplesmente de induzir a parte à pré-constituição da prova documental". Trata-se da adoção da idéia de prova melhor, ou best evidence principle, que reflete a busca pela melhor prova possível (Yarshell, Antecipação da prova sem o requisito da urgência e direito autônomo à prova, pp. 84-85).

618 Trata-se, porém, de medida extrema aplicada como ultima ratio (Tabosa, Código de processo civil interpretado, p. 1270).
} 
caso de ausência (CPC, art. 343). ${ }^{619}$ Dentre os vários sistemas existentes, o SBDC escolhe do pagamento de multa em valor fixo, prevista no art. 26, par. $5^{\circ}$ da lei n. 8.884/94. A escolha é intuitiva, dado que o crime de desobediência demandaria tipificação que não se coaduna com a efetividade que se espera da disposição, especialmente porque a desobediência é crime de menor potencial ofensivo cuja solução dificilmente será a restrição da liberdade. Além disso, medidas de condução, dependeriam de coordenação entre a polícia (judiciária) e a administração, o que iria requerer rearranjos institucionais. A multa sobressai como opção viável. A regra do rearranjo dos ônus da prova poderia ser instituída, acrescentando mais uma variável à difícil equalização entre os poderes da SDE, do CADE, o princípio dispositivo mitigado, a isonomia e o contraditório perante o SBDC.

Sobre a juntada de documentos, ${ }^{620}{ }^{621}$ vale o que dito no item anterior sobre documentos novos ou velhos. Dada a inexistência de disposições específicas nas

\footnotetext{
${ }^{619}$ Trata-se, porém, de técnica de aceleração do processo, pautada em presunção relativa (que admite prova em contrário) e que será valorada em conjunto com as demais provas produzidas nos autos - ciente de que há muito afastada a idéia de confissão como a rainha das provas.

${ }^{620}$ São considerados documentos "tutti quegli oggetti materiali che sono in qualsiasi manera idonei a rappresentare o a dare conoscenza di un fato" ou, de forma mais restrita, "segni grafici apposti, in funzione rappresentativa di un fatto, su un supporto caraceo o equipollente", mas sem uma restrição tal a excluir potencial sobreposição entre as duas categorias (Cavallone, "Esibizione delle prove nel diritto processuale civile", p. 667). Tem sua função representativa através da atividade do sujeito "percipiente", ligada à atividade do sujeito autor da documentação. Pode ser por escrito, que representa a externalização de um pensamento, sendo de relevância a definição do sujeito e do conteúdo, a colocação do documento no tempo e no espaço de modo a atribuir-lhe segurança. Pode ser privado (cuja proveniência decorre da subscrição ou outros elementos de segurança menor, mas que pode ser potenciada pelo reconhecimento da autenticidade da firma) ou público (quando redigidos por sujeito com fé pública, com eficácia "indiscutível" sobre a proveniência, momento, lugar - os elementos extrínsecos, tratados como prova legal). Em certos casos, a lei atribui a necessidade de forma escrita para externalização do ato justamente em razão da sua função probatória ("maggior facilità con la quale è possibile offrire la prova di un atto redatto per iscritto rispetto ad un atto verbale") e da maior confiança que dele se desume. Porém, quando a forma escrita é fixada sob pena de nulidade, ou seja, ad substantiam, a questão transcende a mera função probatória e alcança a validade do ato (Mandrioli, Diritto processuale civile, vol. II, p. 207-211). Para De Santo é um documento "todo objeto, producto de un acto humano, que represente a otro hecho o a un objeto, una persona o una escena natural $\mathrm{o}$ humana" (La prueba judicial, p. 195).

${ }^{621}$ Sobre documentos informáticos subscritos com firma eletrônica, a forma escrita é satisfeita e sua valoração é livre, considerada a sua característica objetiva e segurança. Se a firma é digital, garantindo a "conessione univoca al firmatario e la sua univoca identificazione creeata com mezzi sui quali il firmatario può conservare un controllo esclusivo"). Já o documento eletrônico sem firma, v.g., página de internet impressa, teria valor probatório se colhida com garantias de correspondência ao original e de referibilidade, sendo os demais casos (tais como um email), privado de eficácia probatória (Mandrioli, Diritto processuale civile, vol. II, p. 223-224). Concorda-se com as afirmações, exceto no que diz respeito aos emails desprovidos de assinatura, que se contextualizados e não contestados podem ser valorados pelo julgador. Outro ponto interessante é que documentos privados (declarações, cartas, registros domésticos, escrituras contábeis) fazem prova contra o seu autor e não a seu favor, "per l'ovvia ragione che non si dicono né tanto meno si scrivono cose contro i propri interessi se non sono vere" (Mandrioli, Diritto processuale civile, vol. II, p. 227).
} 
normas antitruste, a aplicabilidade subsidiária do CPC é de praxe e a relevância que se atribui ao tema é comparada aos padrões juridicionais. ${ }^{622}$

A busca-e-apreensão é meio importante no enforcement antitruste. Ela é disciplinada pelo art. 35-A da lei n. 8.884/94 e requerida pela SDE à Advocacia geral da União, que promove demanda judicial com fulcro nos arts. 839 e ss. do CPC. ${ }^{623}$ Ela disciplina a coleta subrogatória de provas documentais amparada na importância da surpresa no combate à renitência na apresentação de provas, aos subterfúgios usados por aqueles que cometem ilícito antitruste para impedir a atuação investigativa da SDE e, especialmente, como uma contra-medida de reequilíbrio do poder instrutório em relação ao princípio da não auto-incriminação. ${ }^{624}$ De um lado, o representado tem o direito de não

${ }^{622}$ Em parecer no proc. n. 08012.009866/2008-14, em nota técnica a SDE reconhece as lições de que, na esteira do pensamento de Yarshell (Antecipação da prova sem o requisito da urgência e direito autônomo à prova, pp. 84-85), "o respeito e a fiabilidade que se dá a esse meio de prova advêm de sua própria essência, de prova pré-constituída, cuja função é de eternizar os atos e fatos jurídicos. A propósito, lembram Neves e Castro e Pontes de Miranda que 'os jurisconsultos e legisladores de todos os países cultos são unânimes em reconhecer, como um princípio de ordem pública, que é indispensável admitir um gênero de prova, que em todo o tempo as partes possam invocar quando precisarem defender os seus direitos e tornar patente uma certa ordem dos fatos. $O$ testemunho individual não podia satisfazer a esse fim, não só porque é de muito curta duração a vida humana, mas também porque este gênero de prova está sujeito a acidentes numerosos e indefinidos, não podendo por isso, mesmo em épocas muito próximas, dar uma idéia, mesmo remota, dos fatos que pretendêssemos provar. Pelo contrário, a prova documental é aquela que, em razão de sua estabilidade, pode, para assim dizer, perpetuar a história dos fatos e as cláusulas dos contratos celebrados pelas partes, e é por isso que, conquanto não se possa conferir a este gênero de prova força d'uma certeza filosófica, as legislações de todos os países são uniformes em dar-lhe inteiro crédito, enquanto pelos meios legais não for demonstrada a falsidade dos documentos autênticos." (Marinoni-Arenhart, Processo de Conhecimento, Vol. 2., p. 338).

${ }^{623} \mathrm{Na}$ Itália existe a possibilidade de sequestro judiciário de "libri, registri, documenti, modelli, campioni e di ogni altra cosa da cui si pretende desumere elementi di prova", mas por uma análise sistemática é impossível a execução forçada do provimento quando ele tiver forma de ordinanza, existindo ainda outras dificuldades que remetem a uma aplicação rara do instituto (Benedetto, L'Autorità garante della concorrenza e del mercato, p. 252). Fauceglia segue a mesma linha e afirma, mais specificamente, que "l'autorità potrà richiedere le informazioni oppure l'esibizione di documenti in uno dei modi indicati dall'art. 4, che vanno dalla lettera raccomandata al telefax con prova di ricevimento. Le richieste possono essere formulate anche oralmente nel corso di ispezioni ed audizioni. In ogni caso, però, dovrà essere assegnato un congruo termine per adempiere alle richieste, le quali dovranno sinteticamente indicare i fatti e le circostanze in ordine ai quali si chiedono i chiarimenti, lo scopo degli stessi, le modalità attraverso cui dovranno essere fornite le informazioni oppure esibiti i documenti e le eventuali sanzioni applicabili in caso di rifiuto, omissione o rittardo" (Fauceglia, "L'istruttoria dell'autorità in tema di intese restrittive della libertà di concorrenza e di abuso di posizione dominante", p. 266).

${ }^{624}$ No processo contra-ordenacional português ele é sentido com especial ênfase: "O direito à não autoincriminacão ou princípio nemo tenetur se ipsum accusare é, tradicionalmente, um dos direitos de defesa dos acusados. Referenciado na Magna Charta, consagrado no direito inglês a partir de 1679, foi positivado na Constituição dos EUA pelo famoso Fifth Amendment, complementado pela não menos famosa decisão do Supreme Court de 1966 Miranda vs. State of Arizona. Direito consistentemente consagrado nas constituições dos modernos Estados de direito, ou reconhecido ao abrigo das suas disposições, encontra acolhimento também em importantes instrumentos internacioonais, entre os quais a Convenção Européia dos Direitos do Homem, incluído no direito a um processo equitativo previsto no respectivo art .6 - cfr. Acs Funke de 25/02/93, Saunders de 17/12/96, John Murray de 08/02/96, Heaney and McGuiness de 21/12/00 e Shannon de 04/10/05, entre outros. Tecnicamente, como direito de defesa e, na economia dos direitos, liberdades e garantias constitucionalmente consagrados em uma garantia, destinando-se a assegurar outros bens, no caso, 
produzir provas contra si próprio e, em algumas oportunidades, se vale dessa disciplina como proteção para manter a ilicitude de sua conduta e esconder provas que lhe prejudiquem; de outro, a administração tem o dever de investigar, instruir e combater condutas anticoncorrenciais, sendo a ela outorgado o agressivo instrumento da busca-eapreensão, concedido se, e somente se presentes todos os requisitos exigidos pelo Código de Processo Civil (em especial a ampla fundamentação a respeito da necessidade da medida para o processo administrativo).

Para o que é importante neste trabalho, são três as considerações. Da forma como implementada a busca-e-apreensão no sistema processual antitruste, verificam-se aspectos positivos relacionados com os escopos processuais, na medida em que o instrumento utilizado é examinado por órgão do Poder Judiciário, o que elimina dúvidas em relação ao escopo social da medida e eleva o patamar de segurança sobre a necessidade da medida. Outro aspecto importante está na importância de buscas-eapreensões para a identificação de condutas anticoncorrenciais. Não se trata apenas do famoso caso do cartel das britas (CADE, proc. n. 08012.002127/2002-14). Conforme já informado acima, só em 2008 a SDE realizou 84 operações de busca-e-apreensão. ${ }^{625}$

Por fim, a busca-e-apreensão é importante ainda para quem sustente a discussão sobre o padrão de prova ${ }^{626}$ exigido para a condenação de cartéis. O debate é antiga e envolve o cotejo de regras de distribuição do ônus da prova e provas préconstituídas diretas ou indiretas da existência de condutas anticoncorrenciais.

Para Calixto, exige-se prova da convergência expressa de vontades que demandas às vezes uma caricatural busca por encontros furtivos e documentos secretos. "A tendência é e tem sido ampliar enormemente aquilo que pode ser considerado prova de

o direito a liberdade e seguranca previsto no art. 27 da CRP - neste sentido Jorge Miranda in Direitos Fundamentais - introducao geral, pgs. 56-57. Várias são as manifestações deste principio na lei ordinária, sendo certamente as mais importantes acolhidas na legislação processual penal, destacando-se os arts. 61, n. 1 al. c, do CPP, sobre o qual nos deteremos mais adiante e o art. 132, n .2 (A testemunha não é obrigada a responder a perguntas quando alegar que das respostas resulta a sua responsabilização penal), mas com outras concretizacoes como a prevista no art. 89, n. 2, al. c) do CPA" (Tribunal do Comércio de Lisboa, proc. n. 205/06.0TYLSB).

${ }^{625}$ Outra possibilidade é a busca-e-apreensão de natureza criminal, não integrante do processo administrativo antitruste, mas que pode ser ferramenta útil em caso de atividades coordenadas entre o SBDC e o Ministério Público. Considerando que cartel é crime tipificado, o produto da atuação jurisdicional pode ser ulteriormente transportado ao processo administrativo por meio da simples juntada de documentos publicizados ou da importação de provas emprestadas.

${ }^{626} \mathrm{O}$ padrão de prova seria o "level of certainty that proof must achieve and that has to be attained for a jurisdiction to establish whether or not the law has been infringed and/or measures have to be taken" (Parret, "Sense and Nonsense of Rules on Proof in Cartel Cases", p. 6). 
acordo. Sequer são necessários indícios. Bastam, com freqüência, suposições. Com isso, de um lado, direitos individuais diversos passam a ser desrespeitados e, de outro, as investigações são, com freqüência, infrutíferas". Porém, segundo o professor, habitualidade, movimentos idênticos e condições estruturais para dominação de mercado (acrescido de mudanças de preços sempre para mais, ausência de aumento significativo de custo, um sistema de informações recíprocas entre concorrentes e a rapidez da mudança de preços) autorizam a presunção de cartel. São comportamentos sociais típicos que dispensam a certeza da conduta ${ }^{627}$ e enquadram-se no conceito de prova indireta. ${ }^{628}$

Há quem sustente que a prova do fato constitutivo deve ser realmente ostensiva, em homenagem à distribuição do ônus da prova, da imperatividade de que a administração faça a prova do fato constitutivo do direito de acusar (existência do cartel) e da impossibilidade de se impor ao representado o ônus da prova de fato negativo. Porém, como já dito acima no item VI.3.2, é possível sua prova pelo menos por meio da afirmação de fatos positivos incompatíveis com a verdade do fato do qual se pretende demonstrar a inexistência.

Perante a Comunidade Européia, utilizam-se padrões de prova definidos nos seguintes termos: "accurate, reliable and consistent", "information which must be taken into account in order to assess a complex situation and whether evidence can substantiate the conclusions drawn from it", informações "sufficiently precise and consistent evidence to support the firm conviction that the alleged infringement took place", ou que tenham um "number of coincidences and indicia which, taken together, may, in the absence of another plausible explanation, constitute evidence of an

\footnotetext{
${ }^{627}$ Salomão Filho, Direito concorrencial - as condutas, p. 265-278.

628 "La prueba indirect se da cuando el juez no percibe el hecho a probar, sino un hecho diverso de éste. Por tanto, la percepción del juez no basta aquí por sí sola para la búsqueda del hecho a probar, sino que ha de integrarse con la deducción del hecho a probar respecto del hecho percibido" (Carnelutti, La prueba civil, p. 62). Em Portugal, decidiu-se já pela utilização de prova indireta, como no cartel de cereais. Ali, 12 Empresas enviaram aos clientes circulares comunicando aumento extrtaordinário do preço das farinhas com efeito a partir do mesmo dia, circulares enviadas com distancia de uma semana. O cartel perdurou por 3 anos: "não sendo os aumentos heterogêneos compagináveis com as diferenças de dimensão, estrutura de custos e de produção, possibilidades de acesso ao mercado de cereais e capacidade de armazenamento de cada uma das argüidas e com o facto de o aumento ser comum a todos os tipos de fariha (milho, trigo e centeio), consubstanciando um acordo ou pratica concertada de fixacao de precos" (Tribunal do Comércio de Lisboa, proc. n. 205/06.0TYLSB).
} 
infringement of the competition rules". Ainda em termos de padrão de prova, não se exigiria a inequívoca certeza, mas apenas um juízo de balance of probabilities. ${ }^{629}$

$\mathrm{Na}$ verdade, esses standards não inovam sobre a regra do livre convencimento motivado (v. item VI supra) ${ }^{630}$ e da existência de julgadores humanos (um fator $\mathrm{X}$ ) que participam do mundo e que interpretam o direito (e os conceitos abertos acima expostos no item IV supra) à luz de elementos interiores balizados pela lei e controlados pela análise da motivação (duty to state reasons). ${ }^{631}$ Os fluidos dados econométricos e os conceitos abertos utilizados para definição de um standard revelam que nem o direito, nem a economia buscam uma tarifação de prova necessária para a caracterização do cartel. $\mathrm{O}$ conjunto, revelado case-by-case e à luz do convencimento motivado do julgador que estabelecem um patamar adequado para a demonstração. Tudo isso não exclui as tentativas legítimas em se atribuir maior capacidade de enforcement ao antitruste, porque a aproximação do julgador da verdade processual possível reflete a vontade real de aplicação do direito aos fatos.

As inspeções também são relevantes na disciplina da prova. Não se trata aqui da inspeção judicial prevista nos arts. 440-443, do CPC, em que há o deslocamento do juiz e partes em direção do bem inspecionado, favorecendo a percepção sensorial (quod oculus videt, nemo fideliter negat ${ }^{632}$. De qualquer forma, o modelo judicial de inspeção potencializa a imediatidade e é admissível em razão da aplicação subsidiária do CPC ao processo administrativo (embora não se tenha notícia de utilização por Conselheiros, mas sim por agentes públicos da SDE no âmbito da investigação).

Nos termos do art. 35, par. $2^{\circ}$, da lei n. 8.884/94, para esta modalidade de meio de prova, é possível a realização de inspeção em sede social, estabelecimento, escritório, filial ou sucursal de representada, bastando a determinação fundamentada do

\footnotetext{
629 "Furthermore, there is also something one might call the "proof paradox" in cartel cases. The paradox is that in fact, certainly nowadays at the EC level and in jurisdictions with a mature system of enforcement, the most serious cartels that the authorities want to discover and end, are those that are usually the most difficult to find and to prove. If the goal is to have effective competition law enforcement, this paradox should lead to a cautious approach towards rules on proof that can make it even more difficult for authorities but there shall be a clear tension with the protection of the rights of parties which has to be resolved. The difficulty to discover the most serious infringements of competition law is also one of the reasons why leniency has become such an essential part of current antitrust practice" (Parret, "Sense and Nonsense of Rules on Proof in Cartel Cases", p. 10).

${ }^{630}$ Presente no art. 253 do Tratado da Comunidade Européia e no art. 41 da Carta de Direitos Fundamentais.

${ }^{631}$ Parret, "Sense and Nonsense of Rules on Proof in Cartel Cases", pp. 20-21.

${ }^{632}$ Cfr. Aguiar Silva, As provas no cível, p. 345.
} 
Secretário da SDE, o respeito à exigência de notificação prévia do ato (vinte e quatro horas) e ao horário de realização. ${ }^{633}$ Como coerção ao cumprimento da ordem de inspeção, o art. 26-A da lei n. 8.884/94 autoriza a fixação de multa no valor de R \$21.200,00 a R\$ 425.700,00 caso, de alguma forma, a diligência seja obstruída. ${ }^{634}$

Não se trata aqui de um instrumento de fishing expedition. ${ }^{635} \mathrm{Ou}$ ao menos existem meios relevantes para evitá-la. No âmbito do processo administrativo de apuração de conduta, o objeto do processo já foi definido em nota técnica/despacho da SDE. A despeito da coincidência entre o órgão que requer e que realiza a inspeção, a determinação da providência deve ser fundamentada e seus motivos devem guardar pertinência não só com a pretensão, como também com as questões controvertidas estabelecidas no processo. ${ }^{636} \mathrm{O}$ despacho deve conter específica indicação do documento

${ }^{633}$ No processo civil italiano, a compara-se a providência com a exibição, criada pelo legislador de 1940 como "il potere conferito al giudice di ordinare d'ufficio ${ }^{633}$ ispezioni sulla persona delle parti o di un terzo, ovvero sulle cose in loro possesso; ed altresì il potere di ordinare, a istanza di parte, la esibizione in giudizio di cose in possesso delle parti o del terzo, corrispondono, in conformità dei voti della dottrina e della pratica, a quelle stesse considerazioni di solidarietà sociale e di cooperazione dei cittadini al miglore funzionamento (Cavallone, "Esibizione delle prove nel diritto processuale civile", pp. 665-666).

${ }^{634}$ Especificamente sobre a inefetividade da ordem em razão da inexistência de sanção específica para o descumprimento, Cavallone examina o tema sob o enfoque dos instrumentos que poderiam ser aplicados em tais situações: (i) execução forçada: inaplicável porque naquele sistema, a decisão tem natureza de ordinanza istruttoria, que não é "coattivamente eseguibile" por não ser título executivo; (ii) sanções penais: cogitam-se alguns tipos penais, mas que seriam aplicáveis somente mediante uma "concezione esasperatamente pubblicistica del processo civile", com a qual não concorda, ou ainda pela falta de adequada tipificação; (iii) aplicação de medidas coercitivas indiretas: as astreintes francesas e o sistema de sanções da discovery, inaplicáveis por falta de previsão legal e pela rejeição de uma interpretação jurisprudência evolutiva; (iv) a responsabilidade do terceiro por danos: o que é impensável porque depende do dano decorrente de uma prova não apresentada e não valorada; ou, por fim, (v) consequiências negativas sob o plano probatório: é polêmica a possibilidade de "desumere argomenti di prova" em razão da negativa de apresentação, embora o autor reconheça que "il rifiuto di esibire è di per sé un 'contegno processuale' significativo, embora de eficácia indireta e marginal. Prefere-se esta última, afirmando-se que a "ficta confessio merita di essere incoragiata" (Cavallone, "Esibizione delle prove nel diritto processuale civile", n. 13). Mesmo sustentando que em geral, haja perante a AGCM um contraditório potenciado, Negri afirma que a falta de coercibilidade da medida residiria nas "diverse e minori garanzie di contraddittorio afferte alle parti del procedimento amministrativo, che non assicura affatto la paritaria partecipazione del soggetto indagato nella formazione della prova" (Negri, Giurisdizione e amministrazione nella tutela della concorrenza, p. 152).

${ }_{635}$ Devem ser esclarecidos "i fatti intorno ai quali si chiedono chiarimenti, lo scopo della richiesta, la modalità per rendere le informazioni o esibire i documenti, il 'congruo' termine entro cui adempiere, e le sanzioni in caso di mancata o non esatta ottemperanza all'obbligo" (Benedetto, L'Autorità garante della concorrenza e del mercato, p. 252). Fauceglia segue a mesma linha e afirma, mais specificamente, que "l'autorità potrà richiedere le informazioni oppure l'esibizione di documenti in uno dei modi indicati dall'art. 4, che vanno dalla lettera raccomandata al telefax con prova di ricevimento. Le richieste possono essere formulate anche oralmente nel corso di ispezioni ed audizioni. In ogni caso, però, dovrà essere assegnato un congruo termine per adempiere alle richieste, le quali dovranno sinteticamente indicare i fatti e le circostanze in ordine ai quali si chiedono i chiarimenti, lo scopo degli stessi, le modalità attraverso cui dovranno essere fornite le informazioni oppure esibiti i documenti e le eventuali sanzioni applicabili in caso di rifiuto, omissione o rittardo" (Fauceglia, "L'istruttoria dell'autorità in tema di intese restrittive della libertà di concorrenza e di abuso di posizione dominante", p. 266).

${ }^{636}$ Sobre a amplitude e invasividade da discovery americana, cfr. Negri, Giurisdizione e amministrazione nella tutela della concorrenza, p. 155. 
ou da coisa, a indicação dos fatos que pretendem ser exibidos, indicação do conteúdo do documento, de forma a evitar confusão, sendo vedada exibição explorativa. E o requisito da especificidade deve valer também para exibições de ofício no limite de sua admissibilidade. ${ }^{637}$

Vale a nota sobre o projeto de lei que reestrutura o SBDC. Pela redação original do projeto, a inspeção estaria mantida com amparo no art. 13, inc. IV, c. Porém, por sugestão de órgão que congrega operadores na área antitruste (em sua maioria, advogados), solicitou-se a abolição desse meio de prova em seu desenho atual, determinando-se que a inspeção seja deferida apenas por decisão judicial.

Da leitura do dispositivo não se extrai inconstitucionalidades. O meio de prova não é uma novidade no sistema, respeita o contraditório (antecedente de forma breve, mas certamente diferido), não importa grande impacto nas atividades da empresa (que não será privada de qualquer bem ou documento, dos quais serão apenas tiradas cópias ou registros em atas de inspeção), comporta inclusive uma comunicação prévia de modo que a empresa possa se preparar para receber a diligência da SDE e, como dito, encontra paralelo ainda mais severo na legislação comunitária (onde sequer se notifica previamente o interessado). Mas as mesmas ponderações estruturais sobre a autorização judicial na realização de buscas-e-apreensões e reforço democrático institucional também cabem aqui. ${ }^{638}$ Aguarda-se o posicionamento do Congresso Nacional.

Por fim, o meio foi utilizado em processo julgado recentemente pelo CADE (proc. n. 08012.003805/2004). Ali, o representado afirmou que a inspeção só pode ser deferida quando imprescindível, necessária, e quando da não existência de meios menos gravosos. A relatoria do caso entendeu de forma diversa, afirmando que a inspeção foi justificada, necessária e se encontra dentre as providências instrutórias regulares passíveis de serem autorizadas pelas normas antitruste.

Mais que isso, a inspeção, como visto acima, não ostenta o mesmo grau de incisividade, gravosidade e ingerência sobre bens particulares que a busca-e-apreensão, razão pela qual falece a idéia de maior ou menor gravosidade para o deferimento da

\footnotetext{
${ }^{637}$ Cavallone, "Esibizione delle prove nel diritto processuale civile", pp. 670-671. Anote-se ainda que o ônus financeiro da exibição é sempre da parte que deduziu o pedido (idem, p. 676).

${ }^{638}$ Confira-se, em especial, os pareceres juntados ao PLC 06/09. Afirma-se que "A chancela judicial atribui força diferenciada à prova colhida e reduz a margem de questionamentos ulteriores de decisões pautadas por documentos obtidos em inspeção devidamente autorizada".
} 
medida. Apenas como ilustração, esse conceito é utilizado freqüentemente para sustentar nulidades ou substituições de penhora, posição que por muito tempo impediu a satisfação de créditos reconhecidos em títulos executivos e figurou como um dos motivos que desembocou em profunda reforma do CPC; ele faz parte ainda da composição de critérios para concessão de medidas liminares, ${ }^{639}$ sendo que a inspeção não é realizada apenas em situações de urgência. A diligência da SDE em fundamentar o requerimento, em atenção aos limites estabelecidos pela lei é, ao mesmo tempo, essencial para o deferimento da medida como também um forte instrumento de legitimação do meio de prova. ${ }^{640}$

As requisições também compõem o cenário de meios de provas disponíveis no SBDC. Elas podem ser dirigidas a sujeitos de direito privado, pessoas físicas ou jurídicas, que devem prestar as informações solicitadas com amparo no dever de colaboração (CPC, arts. 339 e 341), cabendo-lhe apenas as escusas legais, sob pena de imposição também de multa com base no art. 26, da lei n. 8.884/94. ${ }^{641}$ Trata-se de fundamento autônomo para infração administrativa, independentemente de o sujeito ser parte na relação jurídico-processual originária. Nenhuma inovação há quanto a essa determinação, com paralelo satisfatório no ato atentatório à dignidade da justiça, imputável a terceiro, nos termos do art. 14, do CPC.

\footnotetext{
${ }^{639}$ Aquele juízo de mal maior, mal menor e mal mais provável que deve fazer o julgador antes da sua concessão (cfr. Dinamarco, Nova era do processo civil, n. 27).

${ }^{640}$ Apenas como paralelo para comparação, a Corte de Cassação entende que exibições de documentos italianas só são deferidas quando indispensáveis - quando a prova não pode ser obtida por outros meios com o que não se concorda pelos motivos expostos. De qualquer forma, essa valoração "è rimessa all'aprezzamento discrezionale del giudice di merito, e non è censurabile in sede di legittimità, neppure "soto il proflio del difetto di motivazione" (Cavallone, "Esibizione delle prove nel diritto processuale civile", pp. 672-673). No âmbito do enforcement, a falta de observância da ordem de exibição é um comportamento processual do qual o juiz "può trarre argomenti di prova", existindo ainda quem admita por verdadeiros os fatos que seriam provados pelo documento objeto da exibição (Mandrioli, Diritto processuale civile, vol. II, p. 242). A sobrevivência do princípio "nemo tenetur edere contra se" também se afigura como um problema pautado na idéia de que o detentor de documento privado não precisa expor seu conteúdo se ele não for comum ou que não nasça "con una potenziale destinazione alla conoscenza da parte di una pluralità intedeterminata di terzi" (Cavallone, "Esibizione delle prove nel diritto processuale civile", pp. 665-666). Benedetto também fala da vedação à self incrimination (direito de não se auto-incriminar, sem sanção). Reconhece que o ônus da prova é da autoridade, porém, essa construção limitaria os seus poderes instrutórios, principalmente com a retirada do texto originário da lei 287 , que previa "la possibilità di desumere argomenti di prova dal rifiuto o dalla inottemperanza all'obbligo di fornire informazioni o di esibire i documenti richiesti per lo svolgimento dell'istruttoria". Por isso, sustenta que não são oponíveis alegações de "vincoli di riservatezza, esigenze di autotutela o segreto industriale" (Benedetto, L'Autorità garante della concorrenza e del mercato, pp. 253-254).

641 "A requisição é uma ordem, de cumprimento obrigatório, cujo desrespeito é punido. O atendimento a esse tipo de requisição é um dever cívico, a que estão sujeitas todas e quaisquer pessoas dentro da sociedade, que são obrigadas a colaborar com os Poderes Públicos na elucidação de fatos de relevância social" (Sundfeld, "Lei da concorrência e processo administrativo: o direito de defesa e o dever de colaborar com as investigações" p. 2).
} 
Quando as requisições forem dirigidas a órgãos públicos, o dever de colaboração é potenciado, mas a sanção é mitigada. Essas considerações ficaram bem claras nos debates sobre o projeto de lei que altera a estrutura do SBDC. O texto original da norma de reforma afirmava que "as autoridades federais, os diretores de autarquia, fundação, empresa pública e sociedades de economia mista federais e agências reguladoras são obrigados a prestar, sob pena de responsabilidade, toda a assistência e colaboração que lhes for solicitada pelo CADE, inclusive elaborando pareceres técnicos sobre as matérias de sua competência" (art. $9^{\circ}$, par. $3^{\circ}$ ). Foi proposta a eliminação dessa redação não para se instituir a recusa institucional à colaboração, mas sim para a eliminação de um desconforto no dever ser-sanção da estrutura da norma. ${ }^{642}$

Seguindo, a perícia ganha em interesse perante o SBDC justamente em razão da sua rara utilização. Prevista no Código de Processo civil (arts. 420-439), ela oferece à atividade judicante um auxílio técnico sobre um conhecimento que o juiz não possui $^{643}$ ou, se possui, não exerce em homenagem à imparcialidade e em prestígio da atividade técnica específica pericial. Pressupõe-se que o juiz deve ser profundo conhecedor do seu mister, relegando-se a terceiros atividades que exijam conhecimentos específicos suplementares. Trata-se ainda de uma padronização da atividade judicante, medida de isonomia para evitar julgamentos díspares entre, v.g., casos de responsabilidade médica julgados rapidamente por juiz também formado em medicina que dispensa perícia e um juiz formado exclusivamente em direito que demanda a intervenção de um auxiliar eventual da justiça.

No processo administrativo de apuração de conduta, a premissa de existência das autoridades descentralizadas autônomas de conhecimento técnico especializado, associada à competência específica do SBDC para a investigação de ilícitos anticoncorrenciais e à composição dos membros do CADE (usualmente juristas e economistas, tanto Conselheiros como gestores) e da SDE reforça a pouca utilização do instituto da perícia.

\footnotetext{
${ }^{642}$ Agrega-se ainda que no âmbito da requisição de servidores, a redação original previa que "as requisições de servidores para os órgãos referidos no caput deste artigo serão irrecusáveis e deverão ser prontamente atendidas, até o limite e prazo fixados na forma do art. 123 desta lei, ressalvados os casos expressamente previstos em lei” (art. 122). Também foi proposta a eliminação dessa redação.

643 "L'attività del consulente tecnico serve, in definitiva, per integrare l'attività del giudice come organo decidente sia in quanto può offrire elementi per valutare le risultanze di determinate prove (...) e sia anche in quanto può offrire elementi diretti di giudizio" (Mandrioli, Diritto processuale civile, vol. II, p. 197).
} 
O fenômeno típico narrado - a dispensa de perícia em razão de conhecimentos técnicos próprios e especializados de um órgão - provoca um fenômeno interesse e particular: o raciocínio ordinariamente desenvolvido em perícias, decorrentes, v.g., de cálculos econométricos, ${ }^{644}$ desloca-se da fundamentação de um parecer a ser valorado para a fundamentação de uma decisão do CADE. É o que se verifica, por exemplo, nos casos em que decisões do CADE se esmeram em aplicar padrões de prova, testes, métodos e modelos aos casos concretos. ${ }^{645}$

Freqüentemente o CADE se vale de cálculos econométricos, que podem envolver predições, mas que variam em graus de simplicidade conforme as correntes de pensamento (as escolas do antitruste - cf. cap. II supra). Esses modelos, métodos e testes variam conforme a proposta de pensamento, a escola adotada. Para uns, eles refletem algo que se aproxima de presunções, que usualmente têm o efeito de "invertire l'assetto degli oneri probatori fra le parti che esisterebbe se la presunzione non fosse prevista, e si dovesse quindi applicare la regola generale (...). La presunzione opera mediante una relevatio $a b$

${ }^{644}$ Calixto traz construção interessante sobre a importância desses cálculos no exame do art. 20 da Lei n. 8.884/94: "a lei brasileira não impõe a produção concreta dos efeitos para caracterizar a ilicitude. Basta a potencialidade de sua ocorrência. Além disso, os efeitos (ou sua potencialidade) não são um critério único, mas apenas uma alternativa à existência da intenção (objetivo) de eliminar os concorrentes do mercado (...) A lei só pode ser interpretada no sentido de que, no ambiente econômico, a existência de uma intenção racional ou plausível de atingir determinada posição de mercado já implica o risco de produção de efeitos, e viceversa. É verdade que a intenção é, em teoria, mais ampla. Pode ser demonstrada sua existência através de documentos internos da empresa acusada de comportamento ilícito, mesmo nos casos em que os dados econômicos indicam que não é possível produzir os resultados esperados (...)" mas "na grande maioria dos casos inexiste documentação interna comprobatória das intenções do agente econômico. Conseqüentemente, é preciso lançar mão de dados econômicos que permitam presumir essa intenção" (...) "documentos internos da empresa só podem representar verdadeira intenção na medida em que essa tenha uma mínima capacidade de atingir os objetivos desejados". Pela teoria da incipiência (incipiency), "a limitação à concorrência deve ser temida já no seu início. Exatamente porque a limitação à concorrência faz parte da racionalidade monopolista, tão mais difundidas e repetidas serão as condutas anticoncorrenciais quanto maior for o poder no mercado. Conseqüentemente, tão mais fácil será sancioná-lo quanto mais na origem, no início ou na incipiência for ele descoberto e as práticas ilícitas sancionadas. A conclusão, portanto, é que dominação do mercado haverá toda vez que existir risco de limitar a concorrência em seu sentido institucional, isto é, reduzir a escolha do consumidor. Isso ocorrerá tanto quando houver risco de exclusão de concorrente ou de colusão entre concorrentes que possa ter impacto sobre o mercado, limitando a escolha do consumidor. (...) Exatamente porque não é mais necessário fazer previsões sobre os efeitos econômicos para os consumidores e concorrentes, desaparecem as complexas e incertas previsões sobre os efeitos quantitativos de condutas nas estruturas do mercado. Desaparecem ou diminuem muitíssimo de importância as intermináveis discussões sobre a realização, ou não, de eficiência por determinadas condutas (...) em matéria de controle das condutas, o comportamento em si substitui as complexas avaliações de participação e estrutura do mercado tópicas do controle estrutural do poder econômico nos mercados" (Salomão Filho, Direito concorrencial - as condutas, pp. 93-95, 121-123).

${ }^{645}$ São diversos os exemplos. Para análise do grau de concentração do mercados relevantes, de acordo com a disponibilidade de dados sobre o mercado, utilizam-se os índices "Ci”" ou Herfindahl Hirchsman "HHI" (cfr. item 2.3.1 da Resolução n. 20 do CADE). Existem testes para determinar a extensão de mercados relevantes, tais como o da elasticidade cruzada da demanda, o teste de correlação de preços ao longo do tempo (price correlation over time), o teste do monopolista hipotético, o teste Areeda-Turner para investigação de preço predatório. 
onere probandi in favore della parte che invoca il fatto presunto". Na presunção absoluta, existe uma regulamentação da fattispecie substancial, razão pela qual não ocorre uma verdadeira inversão de ônus processuais. Já a presunção relativa - a que admite prova contrária do fato alegado e tem fundamento no "normale o più probabile andamento delle cose" - tem fundamento na vontade de favorecer situações processuais de uma parte em relação à outra para tornar mais ágil o exercício de um direito ou quando a prova detalhada de um fato se mostra muito difícil ou impossível. ${ }^{646}$

Porém, aqui, mais que o aspecto negativo da presunção (a inversão dos ônus), os testes apontam aspectos positivos do instituto, numa perspectiva do quod prelumque accidit utilizada em fundamentação e na presunção hominis ou facti, prevista no art. 335 do CPC (“em falta de normas jurídicas particulares, o juiz aplicará as regras de experiência comum subministradas pela observação do que ordinariamente acontece e ainda as regras da experiência técnica, ressalvado, quanto a esta, o exame pericial" ${ }^{647}$ ). As presunções de modelos para realização de cálculos econométricos por julgadores não são propriamente presunções relativas, porque, como no caso da definição de mercado relevante, ${ }^{648}$ não favorecem esta ou aquela parte, mas permitem a definição de uma premissa na avaliação de condutas. Tampouco são presunções absolutas, porque não existe um grau de indiscutibilidade tal de seus preceitos que permita verdadeira regulação de fattispecie substancial (aqueles "expedientes com os quais o legislador constrói certas ficções e nelas se apóia para impor as conseqüências jurídicas que entende conveniente" $\left.{ }^{949}\right) .{ }^{650}$ Conforme ensina Forgioni, "não há uma fórmula matemática para a

\footnotetext{
${ }^{646}$ Taruffo, “Onere della prova”, p. 77; cfr. também Mandrioli, Diritto processuale civile, vol. II, p. 191. ${ }^{647}$ Cfr. Aguiar Silva, As provas no cível, p. 26, 75-76.

${ }^{648}$ Cfr. Bruna, para quem "o conceito de mercado relevante denota algo como mercado relativo, ou mercado pertinente, no qual os produtos dele integrantes são, em conjunto, objeto da concentração de ofertas e procuras que caracterizam a própria noção econômica de mercado (Bruna, $O$ poder econômico e a conceituração do abuso em seu exercício, p. 80).

${ }^{649}$ Dinamarco, Instituições de direito processual civil, vol. III, p. 116.

${ }^{650}$ Confira-se, v.g., apenas a título de ilustração, discussões a respeito do teste do monopolista hipótetico: Finally, pattern analysis, generally associated with shipments patterns and price relationships, serves to create presumptions of markets for further review. As these methodologies suffer from well-known pitfalls, care must be taken to look beyond the raw numbers and build some understanding on how the competitive process plays out. Rejecting these battle-tested techniques simply because theoreticians can present scenarios in which the methods generate flawed results is not appropriate (Coate-Fischer, "A Practical Guide to the Hypothetical Monopolist Test for Market Definition", p. 33). Para críticas a esse teste em two-sided markets, cfr. Filistrucchi, Lapo, "A SSNIP Test for Two-Sided Markets: The Case of Media”, passim.
} 
determinação do mercado relevante, mas apenas métodos que acabam por nos fornecer indicativos que, utilizados de forma conjugada, auxiliam nessa ingrata tarefa". ${ }^{651}{ }^{652}$

Podem, contudo, aproximar-se daquela primeira categoria, em razão do escopo de facilitar a demonstração de um pressuposto fático calcado em raciocínio testado economicamente e que, de acordo com o estágio atual de desenvolvimento da ciência econômica, demonstraria grau de probabilidade de acerto, mas que admite questionamento à luz de variáveis apresentadas no processo.

Há, porém, quem sustente que os testes, modelos ou métodos econométricos refletem apenas argumentos de retórica. Dierdre conceitua o que é retórica, a forma literária de se ver a economia, a linguística como um modelo adequado para vê-la. Identifica, por fim, severos problemas em dados estatísticos, o embate entre a filosofia e a matemática e até mesmo a impossibilidade de predições econômicas. ${ }^{653}$ Mais otimista, Surcan dos Santos afirma que "a teoria econômica não é capaz de prover com segurança soluções para todos os problemas observados no mundo real. Há um distanciamento entre os modelos de concorrência perfeita e de monopólio com as situações observadas de fato. Porém, a teoria econômica tem avançado no sentido de reduzir a distância entre a teoria e a realidade". ${ }^{654}$ Os cálculos econométricos seriam então raciocínios interpretativos pautados em bases concretas passíveis de amplo questionamento - o que reflete a incidência da livre apreciação das provas condicionada à ulterior fundamentação do julgador.

Essa perspectiva não causa espécie maior que aquela decorrente das particularidades do SBDC, já apontadas no capítulo VI.1. Perante o escopo jurídico do

${ }^{651}$ Forgioni, Os fundamentos do antitruste, p. 232.

652 Nos casos de Preços predatórios, examina-se preço abaixo do custo variável médio, intenção de eliminação de concorrência, recuperação com prática de preços extraordinários, barreiras à entrada e limitação temporal de eventual promoção. Mas “a prova da prática de preço predatório é muito complexa. Os dados empresariais sobre custo de produtos e formas de contabilização de investimentos em pesquisa e desenvolvimento são meras estimativas, não oferecendo elementos seguros para elaboração de presunções econômicas" (Salomão Filho, Direito concorrencial - as condutas, pp. 160-178).

653 McCloskey, The rhetoric of economics, passim. Em interessante passagem, a autora afirma: "predictionism cannot be rescued by arguing that the big bank economist makes merely conditional predictions ("If the government deficit continues to grow, the interest rate will rise"). Conditional predictions are cheap: if the sea were to disappear, a rock would accelerate in falling from sea level to the sea floor at about 32.17 feet per second per second. But a serious prediction has serious boundary conditions. If it does, then it must answer the American Question: If you're so smart, why ain't you rich? As an economist would put it, in his gnomic way, at the margin (because that is where economics works) and on average (because some people are lucky) the industry of making economic predictions, which includes universities, earns merely normal returns" (idem, p. 151).

${ }^{654}$ Surcan dos Santos, Condutas colusivas horizontais: uma análise crítica da aplicação de conceitos econômicos na interpretação da legislação de defesa da concorrência no Brasil, pp. 138-139. 
processo e na utilização de meios para a busca da verdade possível, a realização de investigações técnicas pelo próprio órgão é inclusive um instrumento de celeridade compatível com os escopos de atuação do órgão.

Não significa dizer, por óbvio, que se incorpora também a dinâmica pericial de indicação de perito, formulação de quesitos, debates sobre laudos ou apresentação de laudos complementares. O que ocorre é tão somente a dispensa da opinião técnica de um terceiro porque justamente se entende que o órgão é tecnicamente capacitado para solucionar a controvérsia com base em conceitos jurídicos e econômicos próprios, embasados em informações obtidas em atividade instrutória ordinária da SDE ou complementar do CADE.

Também não significa dizer que a perícia é excluída. Determinadas situações, por sua especificidade, podem exigir conhecimentos que desbordam aqueles “econômicos e jurídicos" e demandem a atuação de perito para a definição de mercados relevantes, participação de mercado, barreiras à entrada, justificativas econômicas específicas relacionadas com eficiências, e recomendem a realização de uma perícia. Mas aí outro problema (na verdade, um falso problema) de ordem prática demandaria solução, novamente em relação à dinâmica própria do SBDC. O ônus financeiro de uma perícia cabe a quem a requer e a regra deve ser aplicada indistintamente à SDE (cabendo-lhe adequar seu orçamento aos elevados custos das perícias econômicas) e à representada. ${ }^{655}$ Quanto ao CADE, caberia a analogia ao mesmo art. 33 do CPC, pelo qual o ônus financeiro de provas requeridas jurisdicionalmente de ofício é atribuído inicialmente ao autor, ou seja, também à SDE.

Deferida a perícia, devem ser observadas as normas do CPC naquilo que aplicáveis, ratificando-se critérios de garantia, objetividade, transparência e contraditório na realização da perícia. ${ }^{656}$

\footnotetext{
${ }^{655}$ Que não raro prefere ao invés disso valer-se de pareceres técnicos contratados.

${ }^{656}$ Fauceglia, "L'istruttoria dell'autorità in tema di intese restrittive della libertà di concorrenza e di abuso di posizione dominante", p. 267. Benedetto esclarece que "è stato sollevato il problema della estensibilità delle norme del codice di rito previste per i consulenti tecnici d'ufficio agli esperti consultati in occasione di un procedimento innanzi all'Autorità garante. Questa ipotesi deve però ritenersi scarsamente percorribile, dal momento che la natura dell'attività svolta dagli esperti non è giurisdizionale, ma amministrativa, e che a questa vanno applicati esclusivamente 'i criteri di garanzia ed obiettività rispondenti alla trasparenza dell'agire amministrativo" (Benedetto, L'Autorità garante della concorrenza e del mercato, p. 255).
} 
Outro instrumento reside na juntada de informações orais e escritas pela via do Programa de Leniência. A vasta literatura sobre o tema remonta o sucesso do programa americano a partir de 1993, seu ingresso no sistema brasileiro a partir de 2000, por meio da lei n. $10.149 / 00$, que alterou a lei n. $8.884 / 94 .{ }^{657}$ Tem sua razão em diversos fatores: o efeito inibidor e desestabilizador que gera a partir do temor de que alguém de dentro denuncie a prática colusiva, ${ }^{658}$ o benefício da identificação de condutas anticoncorrenciais praticadas por diversos sujeitos em troca de se abdicar da persecução em relação a um deles, a dificuldade ordinariamente enfrentada na identificação de cartéis por outros meios de prova (o problemático enfrentamento do ônus da prova e de possíveis debates sobre padrões de provas, dados econométricos etc.).

Perante o escopo jurídico do processo, o programa de leniência é um recurso extremamente válido na identificação da verdade possível e da subsunção adequada de fatos à norma, de forma a atuar-se a vontade concreta da lei. Para tanto, não se insere no objeto deste trabalho os requisitos do programa de leniência, mas sim a preocupação de que ele seja efetivamente utilizado. Para tanto, é importante que o estímulo seja suficiente.

Em relação aos benefícios estabelecidos pela lei, a extinção da ação punitiva ou a redução de um a dois terços da penalidade aplicável sempre pareceu um critério atrativo; a idéia de leniência plus também é bastante interessante. Conforme informações do Ministério da Justiça, foram mais de 10 acordos concluídos desde 2003, que tiveram reflexos sobre buscas-e-apreensões objetivas e reflexos positivos na eliminação de condutas anticompetitivas, e outras tantas tratativas em andamento. ${ }^{659}$

O problema reside em uma crise criada pela falta de coordenação (ou coordenação excessiva) no combate dos ilícitos anticoncorrenciais. Como já exposto, o ilícito é um fato jurídico de múltipla incidência, com repercussões perante diversas competências jurisdicionais (penal e civil) e expressões do Poder estatal (jurisdição, administração). Para estimular um whistleblower a denunciar o cartel por meio de

${ }^{657}$ Sobre o tema, confira-se Hammond, "Cracking cartels with leniency programs", passim; Aubert-ReyKovaci, "The impact of leniency and whistleblowing programs on cartels", passim. No Brasil, confira-se Oliveira-Rodas, Direito e economia da concorrência, pp. 253-257.

${ }^{658}$ Esse motivo justificaria o debate sobre o programa de leniência no item VI.1, reportando-se ao positivo impacto pedagógico que o programa de leniência enfrenta. Mas o impacto sobre a verdade justificou o seu posicionamento nesta parte do trabalho.

${ }^{659}$ Cfr. em www.mj.gov.br (condutas anticompetitivas/Programa de leniência). 
programas de leniência, é relevante que ele seja beneficiado de sua conduta (ou ao menos que os benefícios superem os malefícios do ato). Para tanto, é preciso que a premissa de extinção da ação punitiva ou redução da penalidade seja observada em todas as competências-expressões de poder - em todas as formas nas quais o Estado seja capaz de punir o sujeito por aquele ilícito de múltipla incidência.

O problema se revela pelo fato de que as atividades de repressão a ilícitos concorrenciais tem sido foco de esforços políticos intensos. Como visto acima, verifica-se um incremento na cooperação entre órgãos do Estado, em especial Ministério Público, Polícia Federal, Secretarias de Estado, Conselho Nacional dos Procuradores-Gerais de Justiça, do Grupo Nacional de Combate às Organizações Criminosas. Nesse intenso repúdio, procura-se impor aos condenados por cartéis todas as penas possíveis, em todas as esferas de imposição de poder pelo Estado, para que a pena produza seus efeitos seja lá qual for a concepção que se tenha sobre a sua função (retributiva, ético-pedagógicafarmacológica ou intimidatória).

Porém, nem todas as atividades de imposição da pena têm sido “encerradas" com a celebração de um acordo de leniência, o que pode servir como desestímulo ao instituto e um retorno aos sistemas usuais de investigação de condutas (e um retorno aos exercícios hermenêuticos que eles exigem). Por exemplo, a lei oferece a extinção total ou parcial da penalidade administrativa e também seja extinta a punibilidade em relação ao crime de cartel previstos na Lei n. 8.137/90. Porém, os beneficiários dos acordos de leniência vêm sendo processados por crime de quadrilha ou bando, previstos no art. 288, do CP.

É importante que essa anistia seja estendida também ao referido tipo penal, conforme sugerido pelo projeto. ${ }^{660}$ Caso contrário, um possível candidato se sentirá fortemente compelido a não aderir ao programa de leniência se ciente de que, fornecendo informações à administração, estará também alimentando a ação penal pública exercida pelo Ministério Público.

A estratégia coordenada que compeliu ao amplo combate precisa agora rever o momento de abaixar as armas em prol de benefícios consideráveis. No limite da

\footnotetext{
${ }^{660}$ Sobre o tema, cfr. Zane, "The price fixer's dilemma: applying game theory to the decision of whether to plead guilty to antitrust crimes", pp. 30-32.
} 
retórica, é preciso escolher as batalhas ou perder as armas. De lege ferenda, é necessária rápida intervenção legislativa sobre o art. $35-\mathrm{C}$ da lei n. $8.884 / 94$, de modo a manter o Programa de Leniência nessa trajetória de ascendência e eficácia.

As interceptações são assunto teoricamente tormentoso e de prática solução. Tendo em mente que o espírito desatento tem menor propensão à mentira, que esta é um dos raciocínios humanos mais complexos e que sujeitos conscientes têm maior propensão a esconder verdades em atos volitivos, as interceptações são instrumentos do cotidiano forense para a descoberta de fatos que possam conduzir o juiz a formar seu convencimento.

A doutrina discorre longamente sobre o tema. ${ }^{661}$ A Constituição estabelece as garantias dos art. $5^{\circ}$, incs. X e XII. A lei n. 9.296/96 regulou a questão. Para o escopo do item e do trabalho, basta o pressuposto de adequação do CADE à premissa já estabelecida jurisprudencialmente, porque o CADE tem sim por escopo a busca da verdade possível para a consecução do escopo jurídico, desde que ela seja adquirida no processo de forma legal e constitucional e que possa ser utilizada na formação do convencimento dos conselheiros e na fundamentação dos acórdãos.

Nessa esteira, o STF consigna que "a regra é a inviolabilidade das comunicações telefônicas, tendo como exceção as hipóteses de crimes apenados com reclusão e desde que a interceptação sirva como prova em investigação criminal e em instrução processual penal. Nesse sentido, a lição de José Afonso da Silva: ‘(...) Abriu-se excepcional possibilidade de interceptar comunicações telefônicas, por ordem judicial, nas hipóteses e na forma que a lei estabelecer para fins de investigação criminal ou instrução processual. Vê-se que, mesmo na exceção, a Constituição preordenou regras estritas de garantias, para que não se a use para abusos. O 'objeto de tutela é dúplice: de um lado, a liberdade de manifestação de pensamento; de outro lado, o segredo, como expressão do direito à intimidade' (...)". ${ }^{662}$ O STJ segue a mesma linha ao afirmar que "embora existam na doutrina diversas críticas acerca do critério de seleção do legislador acerca das hipóteses nas quais seria admissível a interceptação telefônica, o certo é que, não sendo a infração penal punida, no máximo, com pena de detenção, encontra-se preenchido um dos

\footnotetext{
${ }^{661}$ Cfr. Grinover-Scarance Fernandes-Gomes Filho, As nulidades no processo penal, p. 219; Aguiar Silva, As provas no cível, p. 19.

${ }^{662}$ STF, Ext. 1021, Rel. Min. Celso de Mello, DO de 28.9.07.
} 
requisitos para a autorização de tal medida. Todavia, o citado diploma legal condiciona a flexibilidade do sigilo à observância de mais dois requisitos, quais sejam, a existência de indícios razoáveis da autoria ou participação na infração penal investigada; e a demonstração de que não existam outros meios idôneos para a colheita da prova pretendida. Tratam-se de requisitos cumulativos, sendo ilegal o deferimento da medida quando não observado qualquer um destes". ${ }^{663}$

No âmbito do SBDC, o TRF-1 já decidiu especificamente que "não se reveste de ilegalidade a utilização de prova extraída de inquérito policial (interceptação telefônica), obtida por ordem judicial, para instrução de processo administrativo, no âmbito da Secretaria de Direito Econômico - SDE, que visa apurar suposta violação à concorrência no mercado de transporte de veículos, ainda mais quando o objeto da investigação policial corresponde à denúncia que está sendo apurada pela SDE”. ${ }^{664}$

A orientação é bastante razoável. A restrição constitucional de utilização do meio em investigações criminais usualmente se ampara na gravidade do ilícito penal, a justificar a relativização de garantia constitucional democrática da inviolabilidade. A suposição de um processo penal mais garantístico, capaz de assegurar a cautela no deferimento de medidas dessa natureza, reforça o entendimento. Superadas essas premissas, ${ }^{665}$ uma vez regularmente produzida a prova e tornada pública nos autos de processo penal, não há qualquer óbice para sua transposição para os autos de um processo administrativo, viável inclusive sua utilização nas razões de decidir. A verdade encontrada não é egoísta, utilizada somente em processos penais, fazendo vistas grossas em relação aos demais. É preciso lembrar que o Poder do Estado se divide funcionalmente, o Poder Jurisdicional se separa por regras de competência, mas em sua função judicante, o Estado deve sempre pautar-se pela busca de uma verdade possível. Uma vez encontrada, por meio do processo mais garantidor possível, não só é possível como recomendável que seus resultados sejam transportados para outras esferas e que lá possam produzir seus regulares efeitos.

\footnotetext{
${ }^{663}$ STJ, HC 128.087, Rel. Min. Jorge Mussi, j. 14.12.09. Há notícia de que a matéria já foi submetida por três vezes ao conhecimento do STJ, em casos relacionados especificamente com o SBDC (MC 15.047, RESP 1.094.933 e HC 113.477), hipóteses em que, para infelicidade acadêmica, o mérito não foi apreciado. ${ }^{664}$ TRF1, proc. n. 2007.01.000131528.

665 As assertivas são questionáveis. Existem ilícitos praticados em outras searas capazes de rivalizar a garantia constitucional da inviolabilidade e outros processos capazes de garantir o pleno exercício do contraditório e da ampla defesa.
} 
Essa temática remete à utilização da prova emprestada. Trata-se de instituto com sucinta previsão legal em normas processuais administrativas (v. art. 42 do Regimento Interno do CADE e 24 da Portaria MJ n. 4/06), mas que permite a utilização de prova em processo em andamento, constituída num processo anterior, ${ }^{666}$ preservando-se o quadrinômio igualdade, economia, segurança e respeitabilidade. O instituto tem amparo na prevalência da economia processual e da celeridade no trâmite do processo sobre o princípio da imediatidade e da oralidade. Para que a prova emprestada seja eficaz, deve ser respeitado o contraditório, de modo que as partes tenham participado ativamente da constituição da prova em processo anterior. ${ }^{667}$ Tem aplicação mais freqüente em interceptações, perícias e oitivas.

O ponto delicado que merece comento está na certeza da nãocoincidência entre o pólo ativo das demandas, o que parece menos relevante. Na ação penal, o Ministério Público atua em substituição processual do interesse da coletividade no exercício do jus puniendi; no processo administrativo, a SDE atua em modelo de legitimação ordinária, mas que corresponde ao interesse institucional que não é idêntico, mas se assemelha a interesses difusos. Porém, é sempre o representado que atua no pólo passivo e que deve exercer a plenitude do contraditório no processo de origem. Dessa forma, satisfeita a identidade passiva e a garantia de participação do prejudicado, admissível a utilização da prova emprestada. ${ }^{668}$

\section{VI.3.5. Os recursos no processo antitruste}

A revisibilidade das decisões é tema que sempre mereceu especial atenção perante o Poder Judiciário. A questão é amplamente debatida à luz da idéia de

\footnotetext{
${ }^{666}$ Sobre o tema, cfr. Dinamarco, Instituições de direito processual civil, vol. II, n. 811. "A prova emprestada somente poderá surtir efeito se originalmente colhida em processo entre as mesmas partes ou no qual figure como parte quem por ela será atingido. Em hipótese alguma, por violar o princípio constitucional do contraditório, gerará efeitos contra quem não tenha figurado como uma das partes no processo originário" (Camargo Aranha, Da prova no processo penal, p. 189-90).

${ }^{667}$ Para Grinover, são ainda requisitos de admissão (a) proveniência de um processo onde figuraram as mesmas partes; (b) instituição do contraditório perante o mesmo juiz da segunda causa, como instrumento de preservação do juiz natural; (c) identidade de regras e princípios que regem a prova, tendo em vista a natureza jurídica original, nos dois processos, o de origem e o segundo ("Prova emprestada", Revista Brasileira de Ciências Criminais - 4, pp. 63-67). Com a devida vênia, a visão proposta é bem mais permissiva que a da professora, pelos motivos expostos.

${ }^{668}$ Nesse sentido, cfr. CADE, proc. 08012.005669/2002-31. A ProCADE concorda com esse posicionamento (v. parecer 80/2009, nos autos da medida cautelar CADE, proc. 08700.001507/2007-80).
} 
devido processo legal, de existência ou não de um princípio ou garantia constitucional à revisão de decisões (o duplo grau de jurisdição), a relevância dos recursos para a legitimação das decisões de órgãos do Estado e os reflexos do tema perante a celeridade e efetividade da prestação de tutela jurisdicional. Põe-se aqui a questão do duplo grau em processos administrativos, considerando as especificidades do SBDC, suas preocupações com a celeridade, com as relações jurídicas de direito material estabelecidas, com a atividade administrativa judicante exercida e com a certeza, justiça, acertividade, legitimação democrática, jurídica, política e social da decisão.

Um dos tópicos relacionados com a efetividade da cláusula do due process of law é a revisão dos atos decisórios. Tendo por pressuposto as normas constitucionais, a idéia de direito processual constitucional e de teoria geral do processo, a idéia de revisão não distingue formas de atuação de poder e divisões de competência. O fundamento axiológico da revisão e do recurso, qualquer que seja a esfera de atuação de poder, não se altera.

No âmbito internacional, após um século (XX) de intenso interrelacionamento entre Estados e de cooperação internacional, merecem destaque as convenções, pactos e tratados (ratificados pelo Brasil com o objetivo de sua inserção na Comunidade internacional). Deles, e para o que interessa ao estudo, destaca-se o Pacto Internacional sobre Direitos Civis e Políticos, explícito ao afirmar em seu art. 14, §5º que “toute personne déclarée coupable d'une infraction a le droit de faire examiner par une jurisdiction supérieure la déclaration de culpabilité et la condamnation, conformément à la loi"; a Convenção Européia dos Direitos do Homem, que afirma no art. $2^{\circ}$ que "toute personne déclarée coupable d'une infraction pénale par un tribunal a le droit de faire examiner pau un jurisdiction supérieure la déclaration de culpabilité ou la condamnation". ${ }^{669}$ Gabriele Verrina afirma que tais diplomas atribuem um modelo de garantias processuais e que o direito fundamental do indivíduo a um processo equo e justo está ligado ao princípio do duplo grau de jurisdição. ${ }^{670}$

\footnotetext{
${ }^{669}$ No mesmo sentido, o art. $2^{\circ}, \S 1^{\circ}$, do Protocolo n. 7 da Convenção para a Proteção dos Direitos dos Homens e das Liberdades Fundamentais.

${ }^{670}$ Verrina, "Doppio grado di giurisdizione, convenzioni interlazionali e Costituzione", p. 144.
} 
No Brasil, o duplo grau tem fundamento, ainda que reflexo (como princípio $^{671}$ ou garantia ${ }^{672}$ ) na constituição de $1824,{ }^{673}$ no Código de Processo Criminal de 1932, no Regulamento 737 de ordem processual civil, na Consolidação Ribas e em subseqüentes regulamentações infraconstitucionais não principiológicas.

A questão da (não) previsão constitucional do duplo grau já foi bastante debatida. Comoglio já teceu crítica ao modelo constitucional brasileiro afirmando que "manca invece - in piena coerenza con il modello internacionale e con le tradizioni comuni ad altre Costituzioni degli ordinamenti di civil law - una proclamazione espressa del doppio grado di giurisdizione di merito, pur profondamente radicato nel sistema processuale e, sotto certi aspetti, integrativo delle garanzie racchiuse nel devido processo legal". 674

A despeito da constitucionalização do processo (v. CF, arts. $5^{\circ}$, inc. LVI, LV, XII, 93, inc. IX) e do silêncio constitucional, a garantia do duplo grau no Brasil poderia ser extraída de elementos que prevêem a pluralidade de graus e a diversidade de recursos em tribunais, em consonância com garantias das instituições políticas do regime democrático, numa inerência ao direito à ampla defesa. Ou ainda é garantia expressa no Pacto de São José da Costa Rica, recebido conforme a teoria monista no ordenamento jurídico com força de norma constitucional (por interpretação da $\mathrm{CF}$, art. $5^{\circ}$, par. $2^{\circ}$, art. 84, inc. VIII e art. 49, inc. I) pela relevância temática e relação com ampliação de direitos fundamentais. ${ }^{675}$

Por sua vez, há quem diga que o silêncio eloqüente da $\mathrm{CF}$, a prevalência do direito nacional sobre toda e qualquer ingerência externa (corrente dualista ${ }^{676}$ ) e o

671 Confira-se o posicionamento jurisprudencial entendendo-o como princípio em STJ, $3^{\mathrm{a}}$ T., REsp n. 361.814, rel. Min ${ }^{\mathrm{a}}$. Nanct Andrighi, j. 21.2.02; STJ, 6 ${ }^{\mathrm{a}}$ T., HC n. 5640, rel. Min. Anselmo Santiago, j. 10.6.97,; STF, $1^{\text {a }}$ T., HC n. 71124, rel. Min. Sepúlveda Pertence, j. 28.6.94; STF, $2^{\text {a }}$ T., RHC n. 80.919, rel. Min. Nelson Jobim, j. 12.6.01.

${ }^{672}$ Confira-se o posicionamento jurisprudencial entendendo-o como garantia em STJ, ${ }^{\mathrm{a}}$ T., REsp n. 258.174, rel. Min. Sálvio de Figueiredo Teixeira, j. 15.8.00; STJ, $3^{\mathrm{a}}$ T., REsp n. 114.533, rel. Min. Carlos Alberto Menezes Direito, j. 20.3.01; STJ, 6 ${ }^{\mathrm{a}}$ T., RHC n. 8.833, rel. Min. Vicente Leal, j. 18.11.99. V. ainda TJ-SP, $8^{\mathrm{a}}$ Cam., Ap. n. 1.139.801/2, rel. Des. Ericson Marinho, j. 8.4.99.

${ }^{673} \mathrm{CF} / 1824$, art. 158, "para julgar as causas em segunda, e última instância haverá nas Províncias do Império as Relações, que forem necessárias para a commodidade dos povos".

${ }^{674}$ Comoglio, “Garanzie Costituzionali e 'giusto processo' (modeli a confronto)”, p. 143.

${ }^{675}$ Piovesan, "Direitos humanos globais, justiça internacional e o Brasil”, p. 239

676 A jurisprudência vacilou, tendo acolhido a sistemática dualista, conforme se infere do julgamento do RExt. 80.004-SE, apesar da posição defendida pelo Exmo. Ministro Xavier de Albuquerque, adotando o primado do direito internacional sobre o interno (que poderia ser considerado para efeitos do presente estudo um tertium gens nas teorias sobre o recebimento de tratados internacionais no ordenamento jurídico 
recebimento de tratados internacionais como normas infraconstitucionais ${ }^{677}$ retiraria do duplo grau a natureza de garantia constitucional. Sendo assim, é possível cogitar de um "processo obediente ao princípio do devido processo legal sem que haja, necessariamente, previsão do duplo grau de jurisdição. Permite-se, portanto, o estabelecimento de um sistema de reexame restrito sem qualquer ofensa às garantias constitucionais processuais (...). Tanto isso é certo que, entre os elementos essenciais ao devido processo legal, não se pode incluir o duplo grau de jurisdição, que é mero elemento acidental", ${ }^{678}$

Ainda que a questão hermenêutica e hierárquica seja debatida, o duplo grau contém em seu núcleo conceitos que demandam equilíbrio: verdade, certeza jurídica, justiça, efetividade, tempestividade, celeridade, à luz do binômio garantia-direitos.

De um lado, o duplo grau aproxima a decisão da verdade processual e da correta distribuição de justiça, na medida em que a chance de erro é minimizada quando uma mesma questão é examinada mais de uma vez. É ainda um instrumento garantístico, inerente ao direito de defesa, ligado à tutela da liberdade como expoente dos direitos humanos; também um instrumento de controle técnico quando uma decisão tem o condão de ser reexaminada por órgão hierarquicamente superior, composto por sujeitos de maior experiência. Há ainda o fundamento político, ${ }^{679}$ eis que "nenhum ato estatal pode escapar de controle", dentro da idéia de que todo ato de autoridade e obrigatório estatal é passível de revisão. ${ }^{680}$

Adalberto Aranha sintetiza o pensamento acima exposto e afirma que a amplitude revisional deveria preponderar sobre a irrecorribilidade com base em quatro fatores determinantes: o jurídico filosófico, “em razão do melhor atendimento pelo Estado na tarefa da distribuição da justiça, diminuindo a possibilidade de decisões erradas ou dolosas"; o psicológico, pois "atende ao instinto de inconformação e luta do homem"; o histórico, pois a revisão de decisões "sempre esteve presente nas sociedades civilizadas"; e

nacional). O fundamento residiria na potencialização da importância dada ao aspecto mundial e unificado da vontade dos povos, legitimado por atitude voluntária de seu chefe de Estado.

677 “As normas previstas nos atos, tratados, convenções ou pactos internacionais, devidamente aprovadas pelo Poder Legislativo e promulgadas pelo Presidente da República, inclusive quando prevêem normas sobre direitos fundamentais, ingressam no ordenamento jurídico como atos normativos infraconstitucionais" (Moraes, Direito Constitucional, pp. 569-571).

${ }^{678}$ Laspro, Duplo grau de jurisdição no direito processual civil, pp. 95-97.

${ }^{679}$ De fato, não se trata daquele controle político de outrora. Pode-se dizer porém que o duplo grau de jurisdição está plenamente imune a princípios políticos, na medida em que nenhum ato estatal pode ficar imune a controles (Grinover-Cintra-Dinamarco, Teoria geral do processo, pp. 74-75).

${ }^{680}$ Gomes Filho-Fernandes-Grinover, Recursos no processo penal, p. 22. 
o político, como "meio de resguardar as liberdades individuais contra o arbítrio, o despotismo e as fraquezas", 681

Há ainda quem proponha, à luz do direito material tutelado no processo penal, a indispensabilidade da dupla análise no mesmo sentido (la doble conformidad $^{682}$ ) para aplicação de penas como forma de proteção da liberdade individual.

Para contrapor (ou ao menos provocar uma reflexão sobre) todas as afirmadas benesses trazidas pelo duplo grau, há uma perspectiva pragmática e realística. A certeza jurídica caminha pari passu com a idéia de tempestividade de qualquer que seja a tutela. A celeridade foi elevada a garantia constitucional, prevista no art. $5^{\circ}$, inc. LXXVIII: "a todos, no âmbito judicial e administrativo, são assegurados a razoável duração do processo e os meios que garantam a celeridade de sua tramitação". De fato, a celeridade é princípio do processo moderno destinado a "evitare che (...) il tempo necessario per lo svolgimento del processo torni a danno da chi ha ragione. Ciò, in sostanza significa, innanzi tutto, che il tempo del processo non deve dar luogo ad effetti estintivi, mentre, d'altra parte, quando il diritto viene riconosciuto, ciò deve avvenire come se avvenisse al momento della proposizione della domanda". ${ }^{683}$

Tal preocupação se dá, como na promessa constitucional, também em processos administrativos "al fine di evitare un lungo periodo di incertezza che potrebbe risultare pregiudizievole all'attività delle imprese, la legge si preoccupa, in modo tutt'altro che razionale, di scandire il profilo temporale". ${ }^{64}$ Apenas um parêntese: não se pode defender uma necessidade de maior celeridade dos processos administrativos em comparação com os demais "processos" do Estado. O direito material tutelado é relevante, porém tão relevante quanto tantos outros.

A questão pode ser observada ainda sob a perspectiva das garantias constitucionais. O duplo grau deve estar em equilíbrio com a garantia constitucionalprocessual de celeridade de decisões. Mais uma vez recorro às idéias de Dinamarco, aplicadas em prestigioso posicionamento sobre a relativização da coisa julgada e que encontra perfeita aplicação ao tema. Amparado na interpretação sistemática e evolutiva de

\footnotetext{
${ }^{681}$ Aranha, Dos recursos no processo penal, p. 11.

${ }^{682}$ Cruz, Garantias processuais nos recursos criminais: igualdade, ampla defesa e contraditório, p. 47.

${ }^{683}$ Mandrioli, Diritto processuale civile, p. 28

${ }^{684}$ Fauceglia, 'L'istruttoria dell'autorità in tema di intese restrittive della libertà di concorrenza e di abuso di posizione dominante", p. 271-272.
} 
princípios e garantias constitucionais do processo, o autor afirma que "nenhum princípio constitui um objetivo em si mesmo e todos eles, em seu conjunto, devem valer como meios de melhor proporcionar um sistema processual justo, capaz de efetivar a promessa constitucional de acesso à justiça (entendida esta como obtenção de soluções justas acesso à ordem jurídica justa). Como garantia-síntese do sistema, essa promessa é um indispensável ponto de partida para a correta compreensão global do conjunto de garantias constitucionais do processo civil", com a consciência de que "os princípios existem para servir à justiça e ao homem, não para serem servidos como fetiches da ordem processual", 685

O autor ainda traz a idéia do tempo como "inimigo do processo", que deteriora o resultado jurídico, prolongando as angústias do conflito e o estado de insatisfação. Nessa verdadeira guerra travada pelo aplicador, o que se busca é o desejado racional e o justo equilíbrio entre as exigências opostas, sem comprometer a qualidade ou neutralizar a eficácia social dos resultados, ainda que se pacifique sem o alcance do ponto ideal de assimilação da verdade. Ao final o que importa é a "minimização dos riscos, mediante apuro das técnicas processuais para a participação efetiva das partes (contraditório) e do juiz (temperamentos inquisitórios ao sistema dispositivo) e, de um modo geral, mediante a imposição efetiva do respeito às garantias constitucionais do processo". 686

O desafio está em encontrar a medida exata desse equilíbrio em relação ao tema deste trabalho.

Seja como garantia ou mero princípio norteador, a revisibilidade de decisões do Estado se faz bastante presente no cotidiano dos operadores, mas contêm variações relevantes.

Perante a esfera civil, a recorribilidade é ampla. Partindo de uma definição sedimentada de atos jurídicos decisórios, decorrente da análise dos arts. 162 e 496 e ss. do CPC, verifica-se uma ampla recorribilidade no processo civil. No processo penal, a recorribilidade tem gradação inferior, decorrente de um sistema de definição de atos jurídicos passíveis de recurso e uma correlação mais restrita com os tipos recursais

\footnotetext{
${ }^{685}$ Dinamarco, Instituições de direito processual civil, p. 249.
}

${ }^{686}$ Dinamarco, A instrumentalidade do processo, pp. 283-297. 
previstos. No processo trabalhista, por exemplo, dois princípios relevantes exercem razoável pressão para redução dos recursos interpostos: a irrecorribilidade das interlocutórias e a oralidade; conseqüência disso é a restrição da tipicidade e do cabimento de recursos. ${ }^{687}$

$\mathrm{Na}$ esfera administrativa, a idéia de recursos tem sua exegese no direito de petição, na garantia do contraditório e da ampla defesa perante a esfera administrativa e, mais especificamente, na Lei do Processo Administrativo (lei n. 9.784/99), em seu art. $2^{\circ}$, par. ún., inc. $\mathrm{X}^{688}$ e art. 56 caput e par. $1^{\circ}$. O diploma discorre sobre a disciplina recursal, estabelecendo regras sobre cabimento, processamento, requisitos formais e materiais, limitação de revisibilidade ("no máximo por três instâncias administrativas"), legitimidade ativa na interposição, efeitos do recebimento, procedimento para julgamento e extensão da revisibilidade. Oliveira-Rodas inclusive afirmam que "admitir-se a revisão de decisões por parte do órgão administrativo que prolatou a decisão constitui-se em direito líquido, certo e incondicional, sendo suficiente a não aceitação e a provocação de quem de direito". ${ }^{6} 9$

Porém, a despeito da regra geral de aplicação subsidiária do Código de Processo Civil e da Lei do Procedimento Administrativo nos processos perante o SBDC, o subsistema concorrencial não ostenta uma estrutura bem definida de decisões judiciais e, principalmente, não contém um sistema amplo de revisão de decisões.

No âmbito das revisões endógenas, do Regimento Interno do CADE constam tão somente o pedido de reconsideração, o pedido de reapreciação (previsto no art. 151, que por essência não tem natureza recursal e concretamente tem restrito âmbito de devolutividade) os embargos declaratórios (arts. 147 e ss., cuja natureza recursal é questionável), o recurso voluntário em medida preventiva (art. 118, aqui sim, com vestes típicas recursais), e a "impugnação" e "recurso" em caso de lavratura de auto de infração,

\footnotetext{
${ }^{687}$ Apenas um alerta já conhecido em relação à tendência de restrição do cabimento de recursos: o cabimento do mandado de segurança para "proteger direito líquido e certo, não amparado por 'habeas-corpus' ou 'habeas-data', quando o responsável pela ilegalidade ou abuso de poder for autoridade pública ou agente de pessoa jurídica no exercício de atribuições do Poder Público" (CF, art. $5^{\circ}$ inc. LXIX). Ausente o recurso, vem sempre à tona a discussão sobre a utilização do mandado de segurança como sucedâneo de recursos típicos, ponto que, p.ex., recentemente voltou a ser debatido na esfera cível com a eliminação de agravos regimentais contra decisões concessivas de liminares em agravos de instrumento. No processo penal, também se faz presente a utilização do habeas corpus como sucedâneo de recursos não previstos.

${ }^{688}$ Nos termos da lei de processos administrativos, serão observados, entre outros, os critérios de: (...) X garantia dos direitos à comunicação, à apresentação de alegações finais, à produção de provas e à interposição de recursos, nos processos de que possam resultar sanções e nas situações de litígio;

${ }^{689}$ Oliveira-Rodas, Direito e economia da concorrência, p. 288.
} 
para o Diretor do DPDE e ao Secretário da SDE, respectivamente (o segundo teria mais elementos de recursos que o primeiro).

Bem se vê que não é uma grande gama de recursos, ainda que existam paralelos restritivos em outros subsistemas processuais. A questão então está na análise de adequação e suficiência desse sistema à luz do preceito constitucional do devido processo legal.

Buscando aspectos comparativos, os atos decisórios no processo jurisdicional seriam as decisões interlocutórias simples, que resolvem questões relativas à regularidade do processo penal, com conteúdo decisório que não penetra no mérito da demanda penal (recebimento da denúncia, indeferimento do pedido de assistência e da fiança), usualmente não recorríveis e, portanto, sujeitas a remédios constitucionais e correições parciais; as interlocutórias mistas, terminativas ou não terminativas (pronúncia, rejeição da denúncia e a declaração sumária da ilegitimidade de parte); e as sentenças em sentido próprio (condenatórias, absolutórias ou terminativas de mérito, que declaram extinta a punibilidade, sem condenar ou absolver o acusado) ${ }^{690}$ teriam o condão de encerrar a atividade cognitiva de primeiro grau mediante declaração emitida pelo juiz.

Em outra sede, amparado pelas lições de Ada Pellegrini Grinover, Antonio Magalhães Gomes Filho e Antonio Scarance Fernandes já tive a oportunidade de sustentar que tal conceituação gera complexidades desnecessárias, cujo reflexo é a manutenção até hoje, de forma expressa, do princípio da fungibilidade recursal perante o processo penal. ${ }^{691}$ Para tanto, as decisões nessa esfera devem ser classificadas em (a) as que encerram o processo com ou sem julgamento de mérito, (b) as que não encerram o processo (equiparadas às decisões interlocutórias) e (c) os despachos de mero expediente (idênticos nas duas esferas). ${ }^{62}$ Tal qualificação era equiparada à até então bem sucedida experiência processual civil.

De fato, até 2005, os atos do juiz no processo civil tinham como referência o critério topológico e eram divididos em três tipos, conforme o art. 162, do CPC: as sentenças (ato pelo qual o juiz põe termo ao processo, decidindo ou não o mérito),

\footnotetext{
${ }^{690}$ Sobre o sistema de classificação das sentenças penais, cfr. Tourinho Filho, Processo penal, pp. 195 e Mirabete, Processo penal, pp. 445 e ss.

${ }^{691}$ Burini, Efeitos civis da sentença penal, n. 15.

${ }^{692}$ Gomes Filho-Grinover-Fernandes, Recursos no processo penal, pp. 59-60.
} 
as decisões interlocutórias (que resolvem questão incidente no curso do processo) e os despachos, considerados todos os demais atos.

Por alguma pressão de setores doutrinários, que consideravam tautológico o conceito de sentença, o par. $1^{\circ}$ do art. 162 do CPC foi alterado, definindo-se sentença como os atos do juiz que impliquem a extinção do processo com ou sem julgamento de mérito, nos termos dos arts. 267 e 269, do CPC. Tal alteração "refina" o conceito, porém retoma uma série de discussões superadas especialmente em relação à disciplina de recursos, tal como a existência de sentenças "interlocutórias" que em tese ensejariam a interposição de apelação, não formada por instrumento e que, em tese, provocariam a paralisação do processo e remessa dos autos para a solução dessa questão incidental (v.g., a exclusão de litigante por ilegitimidade).

No processo trabalhista, a despeito de utilizar subsidiariamente as normas do processo civil e não definir conteúdos, vale a nota sobre o princípio da irrecorribilidade das interlocutórias, a teor do art. 893 , par. $1^{\circ}$, da CLT (o protesto contra uma decisão desfavorável a uma das partes fica consignado nos autos e a questão é apreciada quando do recurso interposto contra a decisão final), relativizado pela súmula n. 214 do TST, que admite recurso contra decisão interlocutória de TRT contrária à Súmula ou Orientação Jurisprudencial do TST, decisão suscetível de impugnação mediante recurso para o mesmo Tribunal ou decisão que acolhe exceção de incompetência.

No processo administrativo lato sensu, não há um rigor classificatório. Algo pode ser extraído do art. 50 da Lei do Processo Administrativo, ao indicar que devem ser fundamentados os atos que neguem, limitem ou afetem direitos ou interesses, imponham ou agravem deveres, encargos ou sanções, decidam recursos administrativos, decorram de reexame de ofício, deixem de aplicar jurisprudência firmada sobre a questão ou discrepem de pareceres, laudos, propostas e relatórios oficiais, importem anulação, revogação, suspensão ou convalidação de ato administrativo. Ou ainda do art. 56 do mesmo diploma, consoante o qual "das decisões administrativas cabe recurso, em face de razões de legalidade e de mérito". Note-se que não há uma sistematização. Os atos do administrador são chamados exclusivamente de decisões, sem distinção do tipo.

Especificamente em relação ao processo antitruste, o tratamento das decisões é inexistente, como já foi sinalizado no item VI.I.I supra. Os reflexos na 
disciplina dos recursos são automáticos: (i) a preocupação com a celeridade e tempestividade das tutelas oferecidas pelo CADE traz uma rejeição institucional à disciplina dos recursos, e subseqüentemente a desnecessidade de regulamentação de atos decisórios, (ii) são pouquíssimos os recursos típicos, o que reforça a desnecessidade de regulamentação específica; (iii) a própria estrutura do SBDC não contempla internamente um órgão superior e outro inferior, na medida em que a SDE é um órgão "acusador" e “decisório", sem que seja estruturalmente subordinada ao CADE - há momentos em que a relação CADE-SDE se estabelece em competências diversas; em outros, há uma relação de hierarquia entre os órgãos.

Se utilizado como parâmetro o CPC pré-reforma de 2005, a decisão final em processo administrativo concorrencial pode ter natureza terminativa - aquelas que determinam o arquivamento da representação - e de mérito - aquela que afasta as imputações feitas em nota de instauração ou que condena o representado conforme o art. 23 da lei n. 8.884/94. A identificação das decisões interlocutórias - aquelas que resolvem questões ${ }^{693}$ incidentes, têm conteúdo decisório e podem afetar os resultados processuais e materiais daquele processo - exige um pouco mais de esforço. Conforme dito acima, são dois os órgãos capazes de produzir "decisões" em processos administrativos: a SDE e o CADE. É interessante partir exemplificatviamente de alguma delas como exemplo e estabelecer uma relação entre seu conteúdo, interesse na sua revisão/modificação e instrumento disponível:

- a exclusão de um dos representados do processo, como decisão interlocutória. Nesse caso há uma convergência de interesses entre o representante e o representado. Mas não se exclui que um terceiro, que figure como assistente, demonstre que a exclusão prejudica a apuração da violação à concorrência e é equivocada. Não há recurso típico para reexame da questão;

- a determinação da SDE que rejeita indevidamente o ingresso de assistente (terceiro interessado), prejudicial à concorrência e à própria participação como instrumento democrático. Não há recurso típico previsto;

- a decisão que afasta suspeição e impedimento de Conselheiro, também interlocutória. O representado que alega a questão e a vê refutada, tem interesse na revisão

\footnotetext{
${ }^{693}$ A referência às "questões" aqui tem aquele sentido carneluttiano de pontos controvertidos.
} 
da decisão, mas os diplomas processuais não lhe oferecem um instrumento, muito embora a Lei do Processo Administrativo preveja recurso, em seu art. 21;

- as decisões controversas sobre revelia e seus efeitos, em especial o direito à repetição de atos, também de natureza interlocutória. O representado teria manifesto interesse e o reconhecimento indevido de revelia pode afetar o direito ao contraditório e à prova, legitimando sua solução prévia à conclusão da instrução e da própria decisão. Mas não há recurso previsto.

- as decisões no âmbito da instrução probatória, interlocutórias por essência. Aqui, destaque para as decisões da SDE ou do Conselheiro Relator (monocraticamente) pela tomada de medidas preventivas do art. 52 da lei n. 8.884 contra atos do representado que possam "causar ao mercado lesão irreparável ou de difícil reparação, ou torne ineficaz o resultado final do processo". ${ }^{694}$ Contra tal decisão cabe o chamado recurso voluntário. Porém outras decisões nessa seara podem gerar prejuízos e não contemplam recursos típicos, como, p.ex., o desentranhamento de documentos, a determinação de realização de inspeção, a admissibilidade da prova emprestada etc.;

- as decisões de lavratura de auto de infração por enganosidade ou desídia da parte ou terceiros ao longo da instrução (lei n. 8.884/94, arts. 26, caput, par. $5^{\circ}$ e 26-A), incidente processual resolvido por decisão interlocutória destinado ao início de um processo incidente. Nesse caso a portaria MJ n. 4 prevê a interposição de "impugnação" nos seus arts. 56 e ss. Mas é um recurso que é dirigido ao Diretor do DPDE, que pode ele próprio ter solicitado a providência. E contra essa decisão cabe um novo "recurso", agora ao Secretário de Direito Econômico. Mas nada é dito caso a decisão seja proferida pelo Conselheiro Relator;

- a decisão interlocutória que rejeita o pedido de trâmite do processo em sigilo, ou de reconhecimento da confidencialidade. Em sede de PA's, inúmeros dados comerciais e mercadológicos podem ser necessários para a investigação (não compõem o ato ilícito mas são significativos a compreensão, p.ex., do mercado relevante). A Portaria MJ n. 4 prevê tão somente, no seu art. 30, que "a decisão a respeito do pedido de confidencialidade constará dos autos e poderá ser revista a qualquer tempo, de ofício ou a requerimento de parte interessada". Nada consta também no Regimento Interno do CADE.

\footnotetext{
${ }^{694}$ Fonseca, "Papel dos tribunais administrativos e sistema judicial", p. 249.
} 
- apenas a título ilustrativo, na Autoridade italiana fala-se da possibilidade de um particular prejudicado recorrer da decisão que determina o arquivamento do processo. Inicialmente, negava-se esse direito, firme na idéia de diferença entre a legitimação processual e legitimação no procedimento administrativo. Fala-se que o denunciante tem direito ao menos a uma decisão de rejeição da denúncia, motivada, que se não proferida abre a possibilidade para a interposição de um recurso. O denunciante possuidor de um interesse qualificado pode recorrer da decisão de arquivamento como medida “dell'interesse all'efficienza dell'agire amministrativo con quello alla repressione delle distorsioni della concorrenza”. Existem sinais na jurisprudência italiana de abertura também às associações de consumidores da possibilidade de recorrer contra decisões de arquivamento. ${ }^{695}$

Os despachos, por exclusão, não teriam conteúdo decisório são emitidos para simples movimentação da máquina, da prática de atos para dar andamento aos atos processuais. Se a qualificação de decisões interlocutórias e sua relação com os recursos não é homogênea, a identificação dos despachos seria ainda mais difícil - a definição por exclusão ganharia em complexidade. De qualquer forma, nenhum recurso é previsto e tampouco seria admissível.

E em qualquer ato decisório proferido pelos órgãos do SBDC é sujeito aos embargos de declaração, com previsão nos arts. 535 do CPC, de aplicação subsidiária em PA's conforme o art. 83 da lei n. 8.884/94. Trata-se de instrumento cuja qualificação como recurso é bastante controvertida, tendo em vista os limites de devolutividade (cabível somente em casos de omissão, obscuridade, contrariedade e de erro material) efeitos (exceto por infringência, não provoca a reforma a decisão) e, especialmente, pelo fato de ser oposto e julgado pelo mesmo órgão que emite a decisão atacada.

O exame feito acima leva a crer que não há uma disciplina geral e ampla de qualificação de decisões e atribuição de revisões genéricas. O que existe são alguns poucos instrumentos de revisão típicos destinados à contraposição de decisões específicas. $^{696}$

\footnotetext{
695 Negri, Giurisdizione e amministrazione nella tutela della concorrenza, p. 45-48.

${ }^{696}$ Nem mesmo o projeto de lei n. 5.877/05, que reestrutura a defesa da concorrência no Brasil mediante o redesenho institucional do Sistema Brasileiro de Defesa da Concorrência e a alteração da Lei no 8.884, de
} 
Um último tópico que merece análise é o chamado recurso hierárquico impróprio, dirigido ao Ministro da Justiça (lembrando sempre que o CADE é autarquia "vinculada" ao Ministério da Justiça, órgão do Poder Executivo). A questão que se põe é basicamente se tal recurso é ou não cabível dentro da estrutura do SBDC.

Em parecer da AGU sobre o caso, ${ }^{697}$ afirmou-se que "não há suficiente autonomia (das Agências ...) que lhes possa permitir ladear, mesmo dentro da lei, as políticas e orientações da administração superior, visto que a autonomia de que dispõem serve justamente para a precípua atenção aos objetivos públicos. Não é outra, portanto, a conclusão com respeito à supervisão ministerial que se há de exercer sempre pela autoridade ministerial competente, reduzindo-se, no entanto, à medida que, nos limites da lei, se atendam às políticas públicas legitimamente formuladas pelos Ministérios setoriais. Por isso, se afirma que a autonomia existe apenas para o perfeito cumprimento de suas finalidades legais". Utilizam-se como fundamento dispositivos específicos ao caso concreto (sobre a ANTAQ), além do Decreto-lei n. 200/67, ${ }^{698}$ da vedação à delegação de decisão de recurso pelo art. 13 da Lei do Processo Administrativo.

Porém, o parecer, à luz do art. 50 da Lei n. 8.884/94, faz uma importante ressalva em relação ao CADE: "a despeito de o CADE se constituir administrativamente como uma autarquia, suas decisões em processos atinentes à defesa da ordem econômica não estão sujeitas ao controle hierárquico de mérito. Em outras palavras, as decisões do CADE em seus processos de sua área fim, a defesa da ordem econômica, somente podem ser revistas administrativamente por ele próprio, mas não pelo Ministro da Justiça ou mesmo pelo Presidente da República...". ${ }^{699}$ A jurisprudência historicamente vacila, ${ }^{700}$ mas atualmente se rende à tendência acima referida. ${ }^{701}$

1994 (Lei de Defesa da Concorrência) traz inovações sobre a matéria, mantendo a mesma disciplina recursal atual.

${ }^{697}$ Cf. Parecer da AGU no proc. n. 50000.029371/2004-83, DO 19.06.06, interessado TECON Salvador S.A.

${ }^{698}$ Art . 19. Todo e qualquer órgão da Administração Federal, direta ou indireta, está sujeito à supervisão do Ministro de Estado competente, excetuados unicamente os órgãos mencionados no art. 32, que estão submetidos à supervisão direta do Presidente da República.

${ }^{699}$ É feita referência ainda ao Parecer CGR L- 084/1975, da lavra do então Consultor-Geral da República, Luiz Rafael Mayer, aprovado pelo Presidente da República, e publicado no Diário Oficial da União em 02.12.75: Parecer CGR L-084/1975: "o CADE, como órgão autônomo, integrante da estrutura do Ministério da Justiça, está sujeito à supervisão ministerial prevista nos arts. 19 e 25 do Decreto-Lei no 200-67. Entretanto, o processo específico de apuração e repressão de abuso ao poder econômico, no molde de sistema misto, administrativo-judicial, está exaustiva e completamente regulado, em todos os seus trâmites, na Lei ${ }^{\circ}$ 4.137/62 (arts. 26-71), não comportando incidentes, procedimentos ou recursos que não os previstos explicitamente. As decisões do CADE, nessa matéria específica, estão apenas sujeitas ao controle judicial 
Mais que a mera literalidade, o art. 50 da lei n. 8.884/94 reflete o ideal de autonomia decisória que se espera do órgão administrativo judicante como forma de reforço institucional e consecução de um escopo político-econômico (conceito em perspectiva instrumental).

O preço a pagar por esse posicionamento, porém, é evidente. Se de um lado é afastado o controle ministerial sobre as "políticas e orientações da administração superior", que ostentaria aquele objetivo histórico do duplo grau, a ausência de controle fulmina o recurso analisado pela nova concepção do duplo grau, ou seja, como instrumento de revisão destinada à correta distribuição de justiça e minimização de erros, de resposta ao instinto inconformista do homem e de controle político de resguardo das liberdades individuais contra abusos. Não há, portanto, qualquer instrumento de revisão endógena das decisões finais, terminativas ou de mérito, proferidas pelo CADE e a utilização dos embargos de declaração para tal finalidade (efeitos infringentes) é apenas um inadequado paliativo.

O CADE, enquanto autarquia vinculada ao Ministério da Justiça, trava e sempre travará uma luta institucional para legitimar sua função administrativa judicante, em uma comparação sempre ingrata com a atividade desenvolvida pelo Poder Judiciário, conforme visto ao longo deste trabalho. Dentro desse contexto, ainda que se entenda que o duplo grau não seja uma garantia imanente ao devido processo legal, descartá-lo em no ambiente de um sistema que trava uma luta constante para refutar posicionamentos

necessariamente subseqüente, não sendo suscetíveis de revisão por via de recurso hierárquico." Alguns entendimentos flexibilizam a idéia em relação ao CADE, porém em hipóteses na qual o órgão excede sua competência, não para revisar o mérito de sua decisão (Cfr. Parecer CGR SR-97/1989, com amparo nos entendimentos de Hely Lopes Meirelles e Celso Antonio Bandeira de Mello), ou ainda na hipótese excepcionalíssima do art. 17 do Decreto-Lei no 200/67, e que, em qualquer caso, "o Presidente da República, por motivo relevante de interesse público, poderá avocar e decidir qualquer assunto na esfera da Administração Federal".

${ }^{700}$ STJ, 1a . Sec., MS 1814/DF, Rel. Min. Francisco Peçanha Martins. j. 27.10.92: "Mandado de Segurança. Decisão do CADE. Recorribilidade. Efeitos do recurso, arts. 5, LIV e LV da Constituição Federal; 21, da Lei n. 8158/91; 23, do Decreto 36/91, e 1., "B", da Lei 4348/64. 1. O Conselho Administrativo de Defesa Econômica - CADE, exerce atividades judicantes na esfera da Administração. 2. Das suas decisões cabe recurso para o Ministro da Justiça. 3. Incumbe a este declarar os efeitos em que o recebe. 4. Inteligência dos dispositivos constitucionais e legais acima indicados. 5. Segurança concedida para determinar o recebimento, no efeito suspensivo, do recurso administrativo interposto pelo impetrante". Note porém que o posicionamento decorre de dispositivos específicos de leis já revogadas que positivavam tal recurso".

${ }^{701}$ STJ, MS n. 10.138, Rel. Min. Eliana Calmon: "Independentemente do acerto ou desacerto da decisão do CADE em relação à negativa de tutela preventiva pleiteada para anular a licitação para a contratação dos serviços de coleta de lixo em São Paulo, entendo que está sub judice a apreciação do ato do Senhor Ministro da Justiça que, ao receber o recurso hierárquico do Ministério Público Federal, ordenou o seu arquivamento, à mingua de interesse da entidade para recorrer. $\mathrm{O}$ ato impugnado pautou-se no disposto no art. 50 da Lei 8.88494, que dispõe expressamente quanto a irrecorribilidade das decisões do Cade (...)”. 
contrários à própria instituição seria questionável. O exercício do duplo grau é amplamente verificado em todas as esferas de atuação do Estado. No regime processual - sempre de direito público - a disponibilização de instrumentos de revisão é corrente.

Essa tendência reflete a necessidade de se equilibrar a necessidade de busca da verdade formal e outorga de decisões justas, quer pelo enfoque jurisfilosófico, quer pela perspectiva de hermenêutica constitucional e infraconstitucional. Não se pode, sob a justificativa de celeridade, simplesmente abolir uma sistemática adequada de revisão de atos decisórios; tampouco seria adequado criar um sistema de tal forma complexo e intrincado que minasse a celeridade dos processos administrativos.

Concretamente, partindo do binômio ato decisório-recurso, no processo concorrencial podem ser proferidas diversas decisões "interlocutórias", porém poucos são os recursos cabíveis. Também não há nenhum recurso que proporcione a revisão da decisão final, ao menos em sede administrativa. Se considerado o duplo grau como uma garantia constitucional, acena-se aqui para um problema de legitimidade.

É preciso atentar para um elevado grau de atenção no momento de definir a orientação na edição de normas de cunho processual em processos antitruste. A idéia de atenção está distante de significar a inserção de um formalismo exarcebado, justificado em situações em que um Estado mereça nada além de desconfiança. Atenção significa tão somente a busca do equilíbrio. Significa sopesar se um sistema que prevê poucos ou nenhum recurso, mas preza pela celeridade, atinge os seus escopos com maior legitimidade que um processo que contenha mais recursos (maior revisibilidade), mas que tal previsão sirva como instrumento de compensação, ou seja, uma das possíveis respostas àqueles que atacam a legitimidade democrática de órgãos administrativos judicantes, ainda que se perca em termos de celeridade.

A segunda proposição parece acertada. De lege ferenda, algumas reflexões podem ser feitas, consideradas as particularidades estruturais do SBDC: a implementação de julgamentos monocráticos finais ou ainda julgamento em turmas julgadoras pelo CADE, estabelecendo-se o acesso ao colegiado ou pleno como possibilidade recursal (em um paralelo com o agravo regimental e os embargos infringentes); e/ou a ampliação do rol de decisões que possam efetivamente causar um gravame à parte durante a instrução, permitindo a sua revisão pelo CADE. Seriam 
paliativos, adotando uma irrecorribilidade mitigada tal qual se observa no processo penal e do trabalho. Afinal, como diz Mandrioli, "in realtà, se si ha riguardo alla fallibilità di ogni giudizio umano, neppure una lunga serie di giudizî di riesame potrebbe assicurare il giudizio perfetto, tale cioè da esprimere una certezza assoluta. Perciò il numero delle possibilità di riesame $(. .$.$) deve essere convenzionalmente limitato", 702$

É evidente que tal postura deve ser acompanhada por um necessário incremento estrutural, que passa pela ampliação física, de pessoal, pela capacitação de operadores, pela implementação de ferramentas tecnológicas e toda e qualquer medida que permita uma compensação pelo tempo "perdido" com recursos e que mantenha a celeridade dos julgamentos do órgão.

\section{VI.3.6. A uniformização das decisões e a segurança}

Nos itens VI.3.2 e VI.3.4 debateu-se a relação entre celeridade e verdade, com especial enfoque sobre as questões fáticas passíveis de investigação e sujeitas a serem solucionadas por meio dos instrumentos oferecidos pelo processo - os meios de prova.

Aqui, neste tópico, não é bem a verdade que se aborda, como aquela demonstração fática de um retrato (ou, pela sua dinâmica, um filme) sobre o passado, mas aquela certeza que se pode oferecer sobre a interpretação de determinados fatos idênticos ou que se assemelhem.

Não se trata, porém, de um discurso sobre técnica hermenêutica, melhor tratada no campo da filosofia do direito. Certo que a partir do momento em que um determinado fato é apresentado para um julgador e dele exija o exercício de subsunção, pode este se valer de interpretações literais, históricas, sistêmicas. O controle do acerto de uma decisão isolada perante o processo é feito pela análise da preservação das garantias processuais tratadas ao longo deste trabalho, dentro de um sistema estruturalmente isento, funcional e legítimo. Na concepção atomizada, naquele caso, aplicou-se a vontade concreta do direito antitruste, por meio de um processo participativo que legitimou a imposição de poder pelo estado, por meio decisão administrativamente imunizada que produziu a sua pacificação (limitada à preclusão adminstrativa).

\footnotetext{
${ }^{702}$ Mandrioli, Diritto processuale civile, vol. I, p. 21, 93.
} 
Essa certeza atomizada, quando potenciada, pode revelar não uma verdadeira interpretação, mas sim uma sinalização de que, diante de fatos customizados, o órgão judicante será capaz de oferecer uma decisão igualmente customizada. Segurança/previsibilidade são valores cultuados por todos os sistemas de direito, incluído o processual e o material estudados.

Segurança vem do latim securus, que remete ao sossego, à ausência de inquietude e de perigo. Segurança jurídica é um princípio geral do direito. Com amparo nessa idéia, da parte da ciência processual, já foi referido acima que o processo bem estruturado é penhor de segurança dos litigantes (virtude procedimental); que o devido processo legal comporta a interação entre lei, moralidade, bem estar do povo e segurança; que o escopo social exerce constante luta para contemporizar valores como segurança de decisões, garantias processuais versus celeridade; que o duplo grau atribui segurança às decisões; que a segurança jurídica é princípio do processo administrativo; ou que a imunização de decisões é importante instrumento de segurança nas relações jurídicas; que a atuação da vontade concreta da norma depende da aplicação de técnicas que revelem o direito em ambiente de segurança jurídica. No direito administrativo, a segurança jurídica além de ser princípio processual, faz-se presente na atuação do Estado por meio de autoridades independentes que excluem da política regulação de atividades sociais e relevantes e protegem o empreendedorismo. Do ponto de vista econômico, a criação da ordem jurídica do mercado estabelece comportamentos calculáveis destinados a oferecer segurança e previsibilidade e possibilitar o fluxo das relações econômicas por meio de uniformidade e de regularidade de condutas.

Em linhas gerais, a mais bem intencionada objetividade da lei e as idéias, v.g., de homem médio, senso comum e vontade nacional refletem uma tentativa de customização que sempre sucumbiu às divergências decorrentes de interpretações que consideram a concepção humana e sociológica do julgador, inserido em um contexto de valores axiológicos, culturais e históricos, meta-jurídicos instáveis, em uma sociedade heterogênea e no contexto de uma cultura complexa, dinâmica. No cotidiano forense não é raro observar que fatos juridicamente semelhantes, da mesma natureza, em um mesmo momento histórico, que comportam inclusive análise abstrata, podem dar ensejo a decisões distintas ou antagônicas. 
A divergência crônica pode ser interpretada como reflexo positivo de discussão dinâmica e desenvolvimento da ciência jurídica, inerente à atividade hermenêutica e à liberdade funcional dos julgadores. Mas pode também ser fator de insegurança jurídica porque não estabelece elementos seguros e velozes para refutar pedidos improcedentes fundados em teses repetitivas, não permite o cálculo do movimento dos agentes de mercado (e demais consumidores de justiça) para antecipação de sucesso ou fracasso de uma tese ou pretensão, contraria a tendência de racionalização dos provimentos jurisdicionais e preceitos de tempestividade, celeridade e efetividade da tutela jurisdicional.

Se o precedente individualizado é importante, ainda mais a jurisprudência é o "conjunto das soluções dadas pelos tribunais às questões de Direito", 703 Pode ser entendida como "ponto de referência pertinente às interpretações acerca da aplicação daquelas fontes de direito sobre o caso concreto", ${ }^{704}$ ou como fonte do direito. ${ }^{705}$

A pretensão uniformizadora da jurisprudência é eficaz instrumento de celeridade e segurança, sempre presente na atividade processual, ${ }^{706}$ com especial atenção para a atividade jurisdicional no âmbito da ação avocatória perante o STF (art. 119, inc. I, $o$, da CF - EC 01/69), nos recursos fundados em dissídio jurisprudencial, no controle difuso ou concentrado da constitucionalidade de atos do Poder Público, nas tutelas de interesses transindividuais e no incidente de uniformização de jurisprudência.

Ainda no âmbito da jurisdição, destaque para as súmulas, conceituadas como preceitos, enunciados que traduzem o posicionamento dominante de um tribunal, criadas para dar vazão de forma célere e objetiva às teses repetitivas apresentadas perante tribunais. Sua utilização é corrente nas instâncias extraordinárias (STJ e STF), vértices da estrutura judiciária brasileira, responsáveis pela uniformização do pensamento jurídico

\footnotetext{
${ }^{703}$ Maximiliano, Hermenêutica e aplicação do direito, p. 144 .

${ }^{704}$ Ráo, Ato jurídico, p. 25.

705 Nesse último aspecto, analisado o modelo constitucional brasileiro e valendo-se da teoria circular dos planos, Zanetti Junior, afirma que "a jurisprudência em um direito de princípios e cláusulas gerais, ao densificá-los na aplicação, cria direito, e não prescinde de um caráter vinculativo para fazer valer uma certa estabilidade desse direito criado. A jurisprudência é, portanto, fonte primária de direito, ao lado da lei" (Zanetti Junior, Processo constitucional: o modelo constitucional do processo civil brasileiro, pp. 205 e ss.).

${ }^{706}$ Buzaid afirmava que: "uma interpretação uniforme e simultânea não deve impedir uma interpretação variável e sucessiva. Este conceito já emitido por Calamandrei resume a substância do pensamento acerca da uniformização de jurisprudência. A súmula é estabelecida não para impor cega obediência ao primado da exegese, estancando, desvanecendo ou estiolando o espírito criador dos juristas em busca de fórmulas novas que atendam aos objetivos da justiça. A sua finalidade é por um clima de segurança na ordem jurídica, sem a qual fenecem as esperanças na administração da justiça" (Buzaid, "Uniformização da jurisprudência", pp. 189 e ss.).
} 
nacional em matéria constitucional e infraconstitucional. São elas divididas em súmulas persuasivas, sem conteúdo vinculativo, mas de relevante incidência concreta sobre o pensamento dos tribunais, na certeza da proveniência de órgão hierarquicamente competente para a última palavra sobre a matéria; ${ }^{707}$ e súmulas vinculantes, criadas pela Reforma do Judiciário (criação do art. 103-A da CF por meio da EC 45/04), e regulamentadas pela lei n. 11.417/06, diferenciadas justamente pela vinculação de seus preceitos, pelos sistemas de controle do seu cumprimento e pela extensão de seus efeitos também à administração pública. ${ }^{708}$

O CADE, como vértice administrativo de processos de natureza concorrencial também se propõe à edição de súmulas, nos termos dos arts. $9^{\circ}$ e $56-58$ do Regimento Interno do CADE. ${ }^{709}$ Uma primeira consideração a ser feita reside na própria necessidade no âmbito do processo administrativo antitruste.

Como visto, a finalidade da súmula é atribuir segurança jurídica, especialmente no caso do Poder Judiciário que comporta vários níveis (dois graus de jurisdição e duas instâncias extraordinárias), recursos, e um número elevado de magistrados. A súmula ali é poderoso instrumento de orientação e controle hierárquico dos órgãos superiores em relação aos inferiores e à administração pública (no caso das súmulas vinculantes), usualmente em teses repetitivas com abrangência territorial e um número elevado de jurisdicionados submetidos aos seus preceitos (como, por exemplo, nos casos previdenciários e tributários, ainda que não exclusivamente).

O CADE não se inclui em nenhuma dessas hipóteses. Trata-se de única instância administrativa responsável pelo julgamento de demandas voltadas à análise de pretensões de natureza antitruste, seu sistema recursal é escasso e o volume de processos que aprecia não é substancial se comparado ao examinado pelo Poder Judiciário. ${ }^{710}$ Anote-

\footnotetext{
${ }^{707} \mathrm{O}$ disposto nos arts. 285-A, 475, $3^{\circ}, 518, \S 1^{\circ}, 544, \S 3^{\circ}, 557$ e $\S 1^{\circ}$-A do CPC ratificam a importância sistêmica das súmulas persuasivas. São mais de 730 editadas pelo STF, desde 1963 e mais de 330 pelo STJ, desde 1990.

${ }^{708}$ Sobre o tema, cfr. Vigliar, "A Reforma do Judiciário e as súmulas de efeitos vinculantes", passim; Mendes, "Passado e futuro da súmula vinculante: considerações à luz da emenda constitucional n. 45/2004", passim. São atualmente 24 enunciados que projetam seus efeitos para o Poder Judiciário e para a administração pública direta e indireta, nas esferas federal, estadual e municipal.

${ }^{709}$ Foram 7 súmulas editadas até a presente data.

${ }^{710} \mathrm{O}$ número de processos administrativos e averiguações preliminares é ainda pequeno se comparado com o número de atos de concentração. Porém, anote-se que, ainda que não seja objeto deste estudo, um número substancial de atos de concentração é submetido ao procedimento sumário e aprovado sem restrições. Esse
} 
se ainda que, pelas particularidades materiais e estruturais do SBDC, há um dinamismo significativo da matéria examinada e alta rotatividade dos Conselheiros - em razão do curto mandato, já objeto de comento (v. item VI.1.6). ${ }^{711}$

Tais fatos conduzem à conclusão de que a súmula é um mecanismo sofisticado, importado ao processo administrativo de apuração de conduta de forma precoce. Isso está muito longe de significar que a uniformização de julgados não se faz presente, ou seria objeto de repúdio, perante o SBDC. Ao contrário. A crítica é feita tão somente à queima de etapas levada a efeito.

Em termos concretos - pragmáticos, mas com reflexos conceituais significativos - o CADE preocupa-se constantemente com a sua informatização. A notícia positiva é que todas as decisões proferidas atualmente ${ }^{712}$ são digitalizadas e disponibilizadas. O órgão disponibiliza ainda ferramenta de pesquisa jurisprudencial realizada sobre as ementas de julgados constantes dos acórdãos. Porém, o sistema ainda não permite a identificação minuciosa em razão de informações não exaustivas inseridas em ementas e a não incidência da ferramenta de busca sobre os textos dos votos (a digitalização não permite o reconhecimento de caracteres). Essa constatação de cunho bastante prático tem reflexo teórico relevante: as pesquisas eletrônicas não identificam a gama de julgados sobre um mesmo tema.

Em outras palavras, o operador do direito, munido de ferramentas adequadas, hoje, é capaz de construir estatisticamente uma idéia bastante factível do entendimento de um órgão a partir dos seus precedentes. Essa construção toma algum tempo, mas permite que o próprio operador conheça o posicionamento uniforme do órgão e as eventuais divergências pontuais (decisões minoritárias). Munido desse cenário, ele é capaz de calcular o sucesso ou o fracasso de sua pretensão, decidindo inclusive sobre sua

fato indica que apenas uma pequena parte dos casos é submetido ao exame em cognição exauriente suficiente para justificar uma tomada de posição do órgão - ou seja, o espaço amostral de decisões é ainda menor.

${ }^{711}$ De fato a súmula não impede processo criativo em razão de mecanismos de revisão estabelecidos pelo Regimento Interno. Aliás, se de um lado a análise econômica do direito processual demandaria previsibilidade de julgamentos e apoiaria o fortalecimento da vinculação aos precedentes, jurisprudência, súmula, Taruffo afirma que deve existir um grau de elasticidade dos vínculos, como válvula para casos de obsolescência do precedente, mutações de condições históricas, econômicas, sociais, peculiaridades acentuadas do caso concreto que justifiquem a sua não aplicação. Afinal "il problema non dipende dalla circostanza che una corte supreta muti orientamento e non segua passivamente i propri precedenti: il problema sorge quando queste variazioni sono troppo frequenti, arbitrarie, casuali e prive di seria giustificazione" (Taruffo, "Precedente e giurisprudenza", p. 720).

${ }_{712}$ Não só elas como a integralidade dos autos públicos provenientes dos órgãos instrutores. 
estratégia processual - maiores esforços instrutórios, colação de pareceres técnicos, identificação da divergência e exposição das razões pelas quais a jurisprudência dominante deva ser alterada, ou, simplesmente, v.g., o reconhecimento da pretensão, a celebração de TCC's ou acordos de leniência. Ao invés disso, o operador tem fácil acesso à súmula, mas não um fácil acesso à totalidade de precedentes, numa inversão de etapas. ${ }^{713}$

De qualquer forma, o esforço do CADE tem sido positivo no sentido de fornecer ao administrado a segurança de que diante um determinado fato, sua interpretação será coerente com precedentes. Trata-se de expediente que legitima o instrumento e auxilia substancialmente na atuação da vontade concreta do direito por meio de uma interpretação uniforme e simultânea para casos de maior ou menor relevância subjetiva e objetiva

Essa uniformidade, quer por meio de súmulas, quer por meio da adequada publicização de precedentes, ostenta também a qualidade de emitir mensagens aos administrados. Marc Galanter aduz que a competência de um órgão para solução de causas não significa que somente aquele organismo é capaz de resolvê-las, existindo outros efeitos daí decorrentes: incitar as partes a cumprir suas obrigações, censurar e legitimar comportamentos, encorajar ou tornar impossível o exercício de uma ação, tornar fácil ou difícil a apreciação de comportamentos ou resoluções sobre tal comportamento. Logo, “os efeitos assim produzidos não são apenas 'efeitos especiais' (special effects) (...); resultarão também 'efeitos gerais' das informações prestadas pela jurisdição ou a elas relativas e da reacção que essas informações podem suscitar em terceiros que não sejam as partes". 714

São mensagens emitidas por um órgão com função judicante e uma regulação de comportamentos, dentro de um sistema complexo. Assim, em interessante visão sobre o acesso à justiça, em um mundo que repudia o centralismo jurídico, ${ }^{715}$ Galanter refere-se a uma vertente relevante do acesso à justiça em razão da influência do precedente comunicado, em um acesso às mensagens dadas pelo órgão julgador. ${ }^{716}$

Se a alta densidade jurídica de um precedente atomizado não for suficiente para atuar o direito, a ampliação subjetiva por meio de preceitos uniformizantes é capaz de gerar o volume necessário a uma repercussão suficiente. O resultado de ações

\footnotetext{
${ }^{713} \mathrm{O}$ que permitiria, inclusive, o controle da legitimidade da própria súmula.

${ }^{714}$ Galanter, “A justiça não se encontra apenas nas decisões dos Tribunais”, 1993.

${ }^{715}$ Galanter, "A justiça não se encontra apenas nas decisões dos Tribunais”, p. 85.

${ }^{716}$ Galanter, "A justiça não se encontra apenas nas decisões dos Tribunais", p. 97.
} 
versando sobre tutelas institucionais em que há uma efetiva ou potencial extensão subjetiva e objetiva do comando, pode inclusive ser instrumento de influência jurídica sobre políticas econômicas.

Para Dinamarco, “o poder costuma ser considerado, também, em termos de influência (...) o poder dispõe de menor extensão e maior compreensão que a influência, estando para esta como a espécie para o gênero. A influência só se faz poder quando atinge graus suficientes de intensidade, adquirindo imperatividade". ${ }^{717}$ Mandrioli aduz que a ausência de vinculação formal do precedente não afasta a "persuasività" do argumento e a aplicação da regra da "ugualianza" prevista constitucionalmente. Existe maior grau de influência de precedentes de órgãos de revisão da decisão a ser proferida e, em último grau, da própria Corte de Cassação, responsável pela uniformização da jurisprudência. ${ }^{718}$

A aplicação da teoria econômica ao processo também se associa à maior previsibilidade de êxito, à redução dos custos processuais, à redução do tempo na solução e ao maior nível de especificidade dos imperativos jurídicos. ${ }^{719}$

Calixto segue a mesma linha, examinando os comportamentos paralelos e o específico papel do Estado diante do SBDC. Afirma que "havendo uma sanção comportamental uma vez verificados os indícios retrodescritos, os agentes econômicos compreenderiam que existe um outro 'jogador' no mercado, que é exatamente a autoridade antitruste, que reage a seus comportamentos. Assim, uma atuação tendente a evitar o comportamento paralelo, depois de iniciada a conduta, pode ser extremamente eficaz, pois não apenas evitará o comportamento oligopolista naquela situação específica como, também, desincentivará o comportamento paralelo futuro. Também em futuros jogos os oligopolistas resistirão muito mais à idéia de seguir qualquer atitude de seu concorrente. Para usar a terminologia da teoria dos jogos, o jogo transformar-se-á de duração infinita ou indeterminada em jogo de duração finita (e o fim é exatamente a intervenção da autoridade antitruste). Haverá, portanto, incentivo ao comportamento independente (estratégico individual) dos oligopolistas no futuro". ${ }^{720}$

\footnotetext{
${ }^{717}$ Mas influência nem sempre é poder, podendo, em sentido mais amplo, ser a "relação entre dois agentes, em que um agente induz outros agentes a agirem por uma forma que de outra maneira não agiriam" (Dinamarco, A instrumentalidade do processo, pp. 130-131).

${ }_{718}^{71}$ Mandrioli, Diritto processuale civile, vol. I, p. 97.

${ }^{719}$ Auletta, "Una lezione di analisi aconomica del diritto processuale", p. 633 e ss.

${ }^{720}$ Salomão Filho, Direito concorrencial - as condutas, p. 283.
} 
São as mensagens a partir do exercício da influência sobre a postura de agentes econômicos, amparada na segurança oferecida pela jurisprudência, que fortalece ainda mais o sistema e disciplina os jogadores. 


\section{CONCLUSÕES}

A presente tese propôs-se a examinar a possibilidade de se transportar a teoria instrumentalista ao processo administrativo de apuração de condutas perante o SBDC. A instrumentalidade do processo, que tem seu expoente no Brasil em Cândido Rangel Dinamarco e é exposta em obra homônima, mostrou-se sempre uma profícua concepção processual e, mais que isso, um interesse pressuposto metodológico para exame de processos da mas variada natureza.

Partindo então de uma comparação metodológica, pretendeu-se aqui o cotejo de premissas estruturais e de técnicas processuais, de modo a examinar se o processo administrativo de apuração de condutas anticoncorrenciais, dentro de uma perspectiva instrumentalista, seria hábil para a consecução do escopo magno de pacificação com justiça, valendo-se de técnicas processuais adequadas para o alcance daqueles escopos sociais, políticos e jurídicos estabelecidos como premissa de raciocínio.

A conclusão alcançada é a de que o processo administrativo examinado caminha de forma frutífera, mas enfrenta problemas consideráveis para sua plena legitimação. Alguns pressupostos sensíveis da interpretação instrumentalista não são satisfeitos a contento, razão pela qual foram submetidos a discussões mais aprofundadas, com sugestões de lege ferenda ao longo do texto, amparadas na experiência internacional e nas particularidades do sistema brasileiro. Essas ponderações estão distantes de retirar do processo administrativo de apuração de conduta a sua utilidade e importância no cenário antitruste brasileiro, mas alertam para a necessidade de um constante desenvolvimento do pensamento técnico processual aplicado. Equilíbrio e concessões recíprocas entre o direito processual e o direito material antitruste devem ser feitas para alçar o processo antitruste a um novo patamar de desenvolvimento.

Para o alcance dessas conclusões gerais, de forma específica, foram trabalhadas as seguintes idéias:

1. A evolução histórica do pensamento antitruste ajuda a explicar as razões da intervenção do Estado na economia, desde a obra de Adam Smith, passando pela 
edição do Sherman Act, pela criação da Federal Trade Comission, pela quebra da Bolsa de Nova York até, mais recentemente, o duelo das chamadas escolas de pensamento a respeito do antitruste (v.g., Harvard, Chicago, pós-chicago, institucionalista e suas diversas variações). Contrapõem-se e equilibram-se preceitos como a eficiência, a pulverização da concorrência, a proteção institucional, a integração nacional, a influência do direito e de preceitos constitucionais sobre a economia, sempre de modo a estabelecer uma maior ou menor intervenção estatal.

2. No Brasil, a despeito de discussões iniciais sobre o direito concorrencial na década de 30 e a Criação do CADE como Conselho na década de 60, foi apenas a partir dos anos 90 que o direito concorrencial ganha expressão, com o fim do regime ditatorial, as "privatizações", a abertura da economia nacional, o fenômeno da globalização, a estabilização da moeda e o estímulo da economia de mercado. O SBDC, em sua conformação atual, nasce em 1994.

3. Sem desconsiderar os influxos de todas as escolas de pensamento, o direito antitruste brasileiro tem por escopo a garantia efetiva da concorrência como instituição, elevando-a a instrumento de promoção de bem estar social.

4. O Estado é uno, expresso em funções e objetivos específicos. A jurisdição é a função essencialmente repressiva, contando com juízes com poder de dizer o direito e impor coercitivamente os comandos, oferecendo tutela aos jurisdicionados. Não obstante, por meio de expressão administrativa do poder do Estado, é possível o oferecimento de tutela por meio de órgão judicante distinto dos órgãos do Poder Jurisdicional. Trata-se da função administrativa judicante, concebida a partir da ausência de rigidez da concepção tripartite das funções-poderes-atividades do Estado. O SBDC contempla estrutura de julgamentos em que o CADE seria um Tribunal administrativo de natureza quase jurisdicional.

5. O CADE é uma autoridade. Esse conceito é concebido a partir do modelo da common law para regulação de setores sensíveis e para decisões em matérias específicas e ostentando escopos pré-determinados. A disciplina econômica-antritruste, pela sua especificidade, merece em sistemas estrangeiros a atenção de uma autoridade. $\mathrm{O}$ Estado deixa de ser um ator privilegiado e assume a função de árbitro, intermediário em relação aos interesses em jogo, de modo a melhorar a relação entre os cidadãos e a 
administração pela correção de desvios do mercado e controle da iniciativa econômica. Cria-se então órgão de alta especialização técnica, independente e autônomo - um palco de contato entre os três poderes, mas que não escapa de discussões sobre um apontado déficit democrático.

6. É grande a aproximação atribuída aos órgãos do SBDC à política, quer pela vinculação do CADE ao Ministério da Justiça, quer pela participação de secretarias pertencentes a pastas dos Poder Executivo. Porém, no exercício da função administrativa judicante, as "escolhas" (com base em, v.g., prioridades, metas e opções axiológicas e discricionárias) de um conselheiro do CADE refletem, na verdade, ato de subsunção do fato à norma tanto quanto ocorre perante o Poder Judiciário. No momento de construção da decisão, tanto o Conselheiro quanto o juiz se valem de "linguagem técnica e linguagem comum, esquemas e modelos de argumentação, formas dedutivas, juízos de valor, instrumentos de persuasão retórica, conhecimentos de variada natureza, regras éticas e de comportamento, interpretações, escolhas de diversos gêneros" (Taruffo) e são influenciados por "seu modo de entender as coisas, seja por sua origem, por seu envolvimento pessoal, pela educação cultural recebida, por suas experiências próprias e profissionais, e muitos outros fatores" (Larenz). Ambos realizam processos interpretativos a partir de normas (específicas ou lastreadas em conceitos vagos), subjetivamente abertos à política mas nunca condicionados por ela.

7. Importante discutir se, nesse cenário, as Autoridades são dotadas de meios processuais capazes de preservar o sistema concorrencial, fazendo cessar as violações através de instrumentos punitivos que permitam desestimular novo descumprimento à norma.

8. O processo é um "microcosmo democrático do Estado-de-direito, com as conotações da liberdade, igualdade e participação (contraditório), em clima de legalidade e responsabilidade" (Dinamarco); ele estabelece uma relação jurídica entre os sujeitos, atribuindo-lhes poderes, deveres, ônus, faculdades e sujeições. Essa relação é permeada por garantias constitucionais e infraconstitucionais, segue forma estabelecida por regras procedimentais e tem a finalidade de alcançar a prolação do comando, a decisão, a emanação do preceito declarando o direito da parte, atuando-o ainda de forma concreta, em conformidade com os seus escopos sociais, políticos e jurídicos e atento ao direito material correlato. 
9. A Constituição oferece a justificativa de métodos e a base de aplicação do processo, projetando garantias e princípios mínimos. No modelo processual constitucional brasileiro, na busca do giusto processo (Comoglio), destacam-se as seguintes garantias e princípios: devido processo legal, acesso à justiça, o direito de ação e petição, contraditório e a ampla defesa (e direito à prova), legalidade, independência e imparcialidade do juiz, duração razoável do processo, publicidade e motivação das decisões. A teoria geral do processo, por sua vez, condensa os princípios e garantias de nível constitucional e infraconstitucional para estabelecer uma visão unitária do direito processual que ofereça canais eficientes de acesso, diálogo produtivo, decisão justa, implementação legítima de comandos e equilíbrio na relação segurança-celeridade. Esses preceitos são aplicados a processos jurisdicionais e também a processos administrativos de apuração de conduta anticoncorrencial.

10. O processo administrativo em questão é bastante peculiar. Amolda-se ao conceito de processo (e não de procedimento). É administrativo pela posição topológica, mas recebe influxos penais e civis. Taxá-lo de penal ou civil é contraproducente. Seu tratamento específico não demanda uma classificação sui generis, mas a consciência de sua inserção em um modelo constitucional e do respeito à disposições da teoria geral, que estabelece uma moldura adaptável ao processo e ao procedimento à luz do direito material, alimentando-se de fontes que dialogam entre si. Afinal, exige-se do jurista a "capacidade de escolher e de aprimorar as instituições existentes, ou de criar outras novas em função de objetivos que lhes são propostos pelas necessidades da vida cotidiana" (Comparato). Porém, é preciso estar sempre atento para a competência constitucionalmente estabelecida para legislação a respeito de matéria processual, considerando-se inclusive a oportunidade para uma regular condensação das normas processuais do SBDC.

11. Propôs-se então a análise do processo por meio de seus escopos e pelas técnicas de atuação dos respectivos escopos, a partir da estrutura fornecida pelo pensamento instrumentalista do processo de Dinamarco.

12. O escopo social representa a pacificação por decisão justa, proferida por meios idôneos, imune e educativa. 
- sobre a imunização, após um paralelo entre a coisa julgada e a preclusão administrativa, assentou-se que (a) ela é justificada pelos princípios da moralidade, segurança jurídica, boa-fé e proteção da confiança; (b) dá-se exclusivamente perante a esfera administrativa quando examinado o mérito do processo instaurado (cognição não superficial) e é passível de revisão judicial (ou seja, não se trata de uma imunização exauriente a respeito da pretensão); (c) aplicável aqui a idéia de eficácia preclusiva da coisa julgada (rectius, eficácia preclusiva da preclusão administrativa), na medida em que fatos pré-existentes à condenação ou à rejeição da demanda, capazes de influir sobre o convencimento do Conselheiro e que poderiam ter sido analisados no processo, consideram-se deduzidos; (d) a dinâmica de mercado (relações continuativas/sentenças determinativas) não altera o regime da preclusão administrativa em razão da cláusula rebus sic stantibus que lhe é inerente; e (e) pelas especificidades do SBDC, o representante atua como assistente, perante o qual não se opera a imunização em razão de seu reduzido papel na relação processual.

- Sobre a idoneidade do meio, o CADE está inserido na perspectiva da função administrativa judicante, independente e legitimada constitucionalmente em sua estrutura. Trata-se de órgão técnico, independente (organizativa e funcionalmente), inserido em modelo de Estado que o admite, outorgando-lhe paridade substancial em relação aos demais órgãos do Poder Político. O poder parajurisdicional é incompatível com a idéia de submissão ao Poder Político e ao Governo.

- O princípio da demanda é pressuposto de imparcialidade, mas o sistema processual administrativo prevê a oficialidade: perante o SBDC, a mesma administração instaura (eventualmente, de ofício), instrui e julga, (a despeito de uma espécie de chinese wall entre a SDE e o CADE e da independência e autonomia da autarquia). A SDE não é simples parte no processo, podendo influir mediante a determinação de condutas e seleção do material probatório que será acostado ao processo, o que influi sobre o resultado do processo (a despeito da independência do $\mathrm{CADE}$ em relação à SDE). 
- O princípio dispositivo aduz que se as partes dispõem da propositura e de seu objeto, também devem dispor dos meios para defesa de seus interesses privados. Mas o processo administrativo assume postura inquisitória, na medida em que a administração propõe e instrui de forma ativa na busca da verdade processual para a proteção de um interesse institucional. Anote-se que, se no processo civil, exemplo de dispositividade, a regra não intervencionista sofre temperamentos, a inquisitoriedade administrativa não pode causar espécie, desde que exercida de forma equilibrada, à luz da relação jurídica de direito material e do caso concreto.

- Para blindagem da imparcialidade, a sistemática atual de seleção de julgadores pode ser associada à regra usualmente atribuída aos magistrados pela CNJ, o mandato pode ser estendido para a implementação de um trabalho eficiente e é preciso observar o critério da quarentena no momento do desligamento de um julgador. Essas considerações podem ser estendidas a todos aqueles que exercem atividade fim do órgão.

- O escopo sócio-educativo do processo administrativo de apuração de conduta concorrencial é expresso não só nos atos de divulgação de sua existência perante o CADE, mas também pela sua vertente de educação pela pena (função retributiva ou reação opressiva ao alarme social) e de educação construtivista, expressa nos profícuos contatos entre operadores do direito antitruste e nas formas de composição de interesses (v.g., elaboração de TCC).

14. O processo, em seu escopo político, é instrumento de imposição do poder de decidir imperativamente e impor concretamente os efeitos comando. É a afirmação da capacidade estatal de decidir imperativamente, cultuar a liberdade, limitar e delinear os contornos do poder e de seu exercício, garantir a dignidade dos indivíduos e assegurar a participação dos cidadãos nos desígnios da socidade.

- O equilíbrio entre a imposição do poder e a liberdade do indivíduo está no respeito à norma. O princípio da legalidade, como constitucionalização axiomática da relação entre poder e liberdade, associa-se ao devido processo legal como instrumento de combate à arbitrariedade para compor um cenário de imposição de poder sem desrespeito à liberdade individual. 
- A participação é inerente à ideologia democrática. Implica transparência, acesso e abertura em todos os processos (nacional, local ou atomizado) e a criação de um senso de comunidade; ela minimiza efeitos das influências dos mais ricos e legitima condutas pelo procedimento participativo. No processo, participação é o poder de atuar no processo decisório; assim, nenhum elemento do processo pode, como regra, obstar a participação, que não é do titular do poder decisório, mas sim daqueles submetidos a esse poder.

- Participar do processo significa ter acesso a ele e à ordem jurídica justa. No processo administrativo, o acesso se dá por meio do exercício do direito de petição sem óbices ilegítimos (quantitativamente ainda incipiente no Brasil).

- Concretamente, o acesso se dá pela representação, aberta a qualquer cidadão sem questionamento sobre legitimidade (admissíveis inclusive denúncias anônimas). Também podem participar terceiros interessados, que ingressam no processo como assistentes. Essa figura deve ser amplamente aceita no processo e paulatinamente restrita em caso de assistentes multitudinários, de modo a garantir a participação de sujeitos mediatamente prejudicados-protegidos pelo direito concorrencial. O acesso é ainda balizado pelos pressupostos de admissibilidade do julgamento de mérito e pelo abuso do direito de petição (aplicação de teoria do sham litigation).

- O acesso também se expressa na publicidade dos autos, limitada tão somente por questões atinentes ao sigilo.

O escopo jurídico do processo é a atuação prática da vontade jurídica preexistente mediante técnicas que revelem o direito em ambiente de segurança jurídica. De fato:

- Respeitada a distinção entre os planos processual e material, as predições econômicas, os cálculos econométricos e a dinâmica do mercado não criam um direito, mas reconhecem a adequação da predição referida.

- Ao contrário do que se usa afirmar, na atividade judicante exercida no SBDC, o CADE não protege um interesse público, mas atua a vontade concreta da lei. 
- O escopo está relacionado com a busca da verdade possível sobre os fatos, num esforço para se atingir o maior nível possível de verdade (Biavatti). Essa busca deve ser contrabalanceada pelo ideal de pacificação por meio de solução definitiva e célere de controvérsias. Utilizam-se juízos de probabilidade baseados na avaliação de intensidade de riscos, gravidade de males e expectativas de vantagens. Além da relação entre dispositividade e inquisitoriedade, o sistema processual se vale usualmente de técnicas de aceleração do processo pautadas em regimes de ônus, preclusões e presunções.

- A segurança jurídica pode ser alcançada por meio de formas procedimentais estabelecidas por lei. É preciso atribuir com cuidado a medida entre a proposta de informalismo administrativo-antitruste e o exacerbado tecnicismo contecioso. A medida está em lições instrumentais, preocupadas com a finalidade do ato, atenta à moderna concepção do processo e a uma possível adaptabilidade do órgão às exigências do processo e do direito material. Vale a referência a Liebman: "as formas são necessárias, mas o formalismo é uma deformação".

- O direito à prova também é observado no processo administrativo. Aos administrados são garantidos todos os meios legítimos e não vedados em direito para a defesa de seus interesses. Os instrumentos em destaque são a oitiva de testemunha, o depoimento pessoal (destaque para técnicas de coerção à oitiva/depoimento), a busca-e-apreensão de documentos (controlada pelo Poder Judiciário, de utilização produtiva na identificação de condutas anticoncorrenciais à luz da discussão sobre padrões de prova); as inspeções (sem controle judicial, delimitada pelas questões controvertidas no processo), as requisições (e o dever de colaboração de terceiros e órgãos públicos), a perícia (com atenção para sua escassez, a freqüente utilização de argumentos técnicos em decisões e a relevância desse fato na estrutura da fundamentação dos atos decisórios), a juntada de documentos pela via do programa de leniência (e o tema das condições para um programa efetivo), as interceptações (e sua relação com os preceitos de inviolabilidade) e a prova emprestada.

- O duplo grau, a despeito de discussões sobre sua natureza constitucional ou não e sobre a recomendação de sua estrita observância, não é observado de 
forma suficiente no processo administrativo. São poucas as hipóteses e tipos recursais, o que não contribui para a legitimação das decisões proferidas no âmbito do SBDC.

- A uniformização de decisões é instrumento de segurança e previsibilidade na interpretação sobre fatos semelhantes. No CADE, a pretensão uniformizadora se reflete a partir da edição de súmulas; ainda que elas não se justifiquem no atual estado da arte, trata-se de esforço adequado ao alcance do escopo jurídico do processo. 


\section{Bibliografia}

Abdo, Helena Najjar, Abuso do processo, São Paulo, RT, 2007.

Afonso da Silva, José, Curso de direito constitucional positivo, $20^{\mathrm{a}}$ ed., São Paulo, Malheiros, 2002.

Aguiar Dias, José de, Da responsabilidade civil, v. II, Rio de Janeiro, Forense, 1995.

Aguiar Silva, João Carlos Pestana de, As provas no cível, Rio de Janeiro, Forense, 2003.

Aguillar, Fernando Herren, Direito econômico - do direito nacional ao direito supranacional, São Paulo, Atlas, 2006.

Alberto dos Reis, José, Código de Processo Civil Anotado, $3^{\mathrm{a}}$ ed., Coimbra, Almedina, 2005.

Alberton, Ganacéia da Silva, "Repensando a jurisdição conflitual", in Bases científicas para um renovado direito processual, vol. 1, Brasília, IBDP, 2008.

Albino de Souza, Washington Peluso, Primeiras linhas de direito econômico, $3^{\mathrm{a}}$ ed., São Paulo, Ltr, 1994.

Alvim, Thereza, O direito processual de estar em juízo, São Paulo, RT, 1996.

Amaral Santos, Moacyr, Comentários ao Código De Processo Civil, vol. IV, Rio de Janeiro, Forense, 1976.

Amendoeira Jr., Sidnei, Poderes do Juiz e tutela jurisdicional: a utilização racional dos poderes do Juiz como forma de obtenção de tutela jurisdicional efetiva, justa e tempestiva, São Paulo, Atlas, 2006.

Americano, Jorge, $O$ abuso do direito no exercício da demanda, $2^{\mathrm{a}}$ ed., São Paulo, Saraiva, 1932.

Andolina, Italo e Vignera, Giuseppe, I fondamenti costituzionali della giustizia civile - il modelo costituzionale del processo civile italiano, Torino, G. Giappichelli Editore, 1997.

Andrade, José Carlos Vieira de, A justiça administrativa, Coimbra, Almedina, 1999. 
Aragão, Alexandre Santos, "As agências reguladoras independentes e a separação de poderes - uma contribuição da teoria dos ordenamentos setoriais”, RT 786/32.

Aranha, Adalberto José Q. T. de Camargo, Dos recursos no processo penal, São Paulo, Saraiva, 1988.

Araújo Cintra, Antonio Carlos de, Comentários ao código de processo civil, vol. IV (arts. 332 a 475), Rio de Janeiro, Forense, 2000.

Areeda, Phillip E., Hovenkamp, Herbert, Antitrust Law. An analysis of antitrust principles and their Application, Estados Unidos, Wolters Kluwer, Law \& Business, 2008.

Arnaud, André-Jean (et al.), Dicionário enciclopédico de teoria e de sociologia do direito, Rio de Janeiro, Renovar, 1999.

Arrow, Kenneth J., Social Choice and Individual Values, London, Yale University Press, 1951.

Arruda Alvim, J. M. de, Manual de direito processual civil, vol. II, $6^{\text {a }}$ ed., São Paulo, RT, 1997.

Assis, Araken de, Eficácia civil da sentença penal, São Paulo, RT, 1993.

Aubert, Cécile, Rey, Patrick, Kovaci, William E., "The impact of leniency and whistleblowing programs on cartels", in International journal of industrial organization, 2005 (disponível em (www.idei.fr/doc/by/rey/leniency.pdf).

Auletta, Ferruccio, "Una lezione di analisi aconomica del diritto processuale", in Rivista trimestrale di diritto e procedura civile, ano LXI, 2007.

Bandeira de Mello, Celso Antonio, Curso de direito administrativo, 25 a ed., São Paulo, Malheiros, 2008.

Discricionariedade e Controle Jurisdicional, $2^{a}$ ed., São Paulo, Malheiros, 1996.

Barbosa Moreira, José Carlos, "Eficácia preclusiva da coisa julgada material no sistema do processo civil brasileiro", in Temas de direito processual - primeira série, $2^{\mathrm{a}}$ e.d, São Paulo, Saraiva, 1988.

. "A função social do processo civil moderno e o papel do juiz e das partes na direção e na instrução do processo" - Revista de Processo 37. 
Bedaque, José Roberto dos Santos, Tutela cautelar e tutela antecipada: tutelas sumárias e de urgência (tentativa de sistematização), $2^{\text {a }}$ ed., São Paulo, Malheiros, 2001. . "Pressupostos Processuais e Condições da Ação", in Justitia, São Paulo, v. 156, 1991.

. Efetividade do processo e técnica processual, São Paulo, Malheiros, 2006.

Bellodi, Leonardo, "Le denunce", in Il nuovo diritto europeo della concorrenza: aspetti procedurali, Milano, Giuffrè, 2004.

Benedetto, Maria del, L'Autorità garante della concorrenza e del mercato, Il Mulino, Bologna, 2000.

Bernardes de Mello, Marcos, Teoria do fato jurídico - plano da existência, $7^{\mathrm{a}}$ ed., São Paulo, Saraiva, 1995.

Bernini, Giorgio, "In tema di norme a tutela della libertà di concorrenza: il caso Italia", in Riv. int. sc. soc., 1998.

Biavati, Paolo, "Il diritto processuale e la tutela dei diritti in materia di concorrenza", in Rivista trimestrale di diritto e procedura civile, ano LXI, 2007.

Black, Julia, "Procedimentalizando a regulação" in Regulação econômica e democracia o debate europeu, São Paulo, Singular, 2006.

Bobbio, Norberto, "Democracia representativa e democracia direta", in $O$ futuro da democracia (trad. Marco Aurélio Nogueira), São Paulo, Paz e terra, 2002.

Estado, Governo e Sociedade: para uma teoria geral da política. São Paulo, Paz e terra, $7^{a}$ ed., 1999.

Bonavides, Paulo, "A democracia participativa e os bloqueios da classe dominante" in Direito e poder - nas instituições e nos valores do público e do privado contemporâneos, São Paulo, Manole, 2005.

Bork, Robert H. The Antitrust Paradox, 2a ed., New York, Free Press, 1993.

Botelho de Mesquita, José Inácio, “As novas tendências do direito processual: uma contribuição para o seu reexame”, Revista Forense, 361/47. 
Brasil. Conselho Federal Gestor do Fundo de Defesa de Direitos Difusos. Balanço social FDD - Fundo de Defesa de Direitos Difusos 2007/2008, Brasília, Ministério da Justiça/CFDD, 2009.

Brasil Júnior, Samuel Meira, Justiça, direito e processo - a argumentação e o direito processual de resultados justos, São Paulo, Atlas, 2007.

Bruna, Sérgio Varella, O poder econômico e a conceituação do abuso em seu exercício, São Paulo, RT, 1997.

Burini, Bruno Corrêa, Os efeitos civis da sentença penal, São Paulo, Atlas, 2007.

Buzaid, Alfredo, "Uniformização da jurisprudência", in Ajuris n. 34/189, Porto Alegre, 1985.

Calamandrei, Piero, Instituciones de derecho procesal civil - segun el nuevo código, vol. I, Buenos Aires, Ediciones Jurídicas Europa-America, 1973.

Calmon de Passos, J. J., "Instrumentalidade do processo e devido processo sobre o tema", in Temas atuais de direito processual civil - coord. de César Augusto de Castro Fiuza, Maria de Fátima Freire de Sá e Ronaldo Brêtas C. Dias, Belo Horizonte, Del Rey, 2001.

Esboço de uma teoria das nulidades aplicada às nulidades processuais, Rio de Janeiro, Forense, 2002.

Camargo Aranha, Adalberto José de, Da prova no processo penal, $2^{\mathrm{a}}$ ed., São Paulo, Saraiva, 1987.

Campilongo, Celso, Política, sistema jurídico e decisão judicial, São Paulo, Max Limonad, 2002.

Canotilho, José Gomes, Direito constitucional, Coimbra, Almedina, 1995.

Capelletti, Mauro e Garth, Bryant, Acesso à justiça, Porto Alegre, Sergio Antonio Fabris, 2002.

Carmona, Carlos Alberto, Arbitragem e processo: um comentário à lei n. 9.307/96, $2^{\mathrm{a}}$ ed., São Paulo, Atlas, 2004.

Carneiro, Athos Gusmão, "Da intervenção da União Federal, como amicus curiae. Ilegitimidade para, nesta qualidade, requerer a suspensão dos efeitos da decisão jurisdicional. Leis n. 8.437/92, art. $4^{\circ}$ e n. 9.469/97, art. 5\%", in RF 363/181. 
Carnelutti, Francesco, Teoria geral do direito (trad. Antonio Carlos Ferreira), São Paulo, Lejus, 1999.

. Cuestiones sobre el proceso penal, trad. Santiago Sentís Melendo, Buenos Aires, Ediciones Jurídicas Europa-América, 1961. . Lezioni di diritto processuale civile, vol. I, Padova, Cedam, 1920. . La prueba civil, Buenos Aires, Arayú, 1955.

Carraza, Roque, Princípios constitucionais tributários e competência tributária, São Paulo, RT, 1986.

Carreira Alvim, J. E., Teoria geral do processo, 8ª ed., Rio de Janeiro, Forense, 2002. . "Litigância de má-fé e lealdade processual”, in Jurisprudência brasileira, 199, p. $11 / 12$

Castro Filho, José Olimpio de, Abuso do Direito no Processo Civil, Rio de Janeiro, Forense. $2^{\mathrm{a}}$ ed., 1960.

Cavallone, Bruno, "Pinocchio e la funzione educativa del processo", in Rivista di diritto processuale, anno LXIII, n. 1, 2008.

Chiovenda, Giuseppe, Instituições de direito processual civil, vol. II, $3^{\mathrm{a}}$ ed., Campinas, Bookseller, 2002.

Cintra, Antonio Carlos Araújo, Grinover, Ada Pellegrini e Dinamarco, Cândido Rangel, Teoria Geral do Processo, 12a ed., São Paulo, Malheiros, 1996.

Coate, Malcolm B., Fischer, Jeffrey H., "A Practical Guide to the Hypothetical Monopolist Test for Market Definition”, in Potomac Papers in Law and Economics 06-01, 2007 (disponível em SSRN: http://ssrn.com/abstract=940667).

Comoglio, Luigi Paolo, "Il 'giusto processo' civile in Italia e in Europa”, in Revista de Processo, n. 116, 2004.

. “Garanzie Costituzionali e 'giusto processo' (modeli a confronto)” in Revista de Processo n. 90, 1998.

Abuso del processo e garanzie costituzionale, in Rivista di dirtto processuale, $\mathrm{n}$. 2, 2008. 
Comparato, Fabio Konder, "O indispensável direito econômico”, in Ensaios e pareceres de direito empresarial, Rio de Janeiro, Forense, 1978.

Conselho Administrativo de Defesa Econômica-CADE, Guia prático do CADE: a defesa da concorrência no Brasil, $3^{\mathrm{a}}$ Ed., CIEE, 2007.

Costa Júnior, Paulo José da, Comentários ao Código Penal, 7ª ed., São Paulo, 2002.

Couture, Eduardo J., Fundamentos del derecho procesal civil, Buenos Aires, Depalma, 1969.

Crane, Daniel A., "Obama's antitrust ambitions", in Michigan Law, Setembro 2009 (disponível em http://ssrn.com/abstract=1474957).

Cruz, Rogerio Schietti Machado, Garantias processuais nos recursos criminais: igualdade, ampla defesa e contraditório. Tese de doutorado, USP, 2001.

Cruz e Tucci, José Rogério, A motivação da sentença no processo civil, São Paulo, Saraiva, 1987.

Cuéllar, Leila e Moreira, Egon Bockmann, Estudos de direito econômico, Belo Horizonte, Fórum, 2004.

Cunha, Rosanne Gay, "Do abuso do direito de demandar", in Informativo Jurídico In Consulex, n. 29, 2002.

Cunha Ferraz, Ana Cândida da, Conflito de poderes, o poder congressual de sustar atos normativos do Poder Executivo, São Paulo, RT, 1994.

De Santo, Víctor, La prueba judicial, Editorial Universidad, Buenos Aires, 2005.

Dinamarco, Cândido Rangel, A instrumentalidade do processo, $8^{\mathrm{a}}$ ed., São Paulo, Malheiros, 2000.

. Instituições de direito processual civil, São Paulo, Malheiros, 2001.

. Fundamentos do processo civil moderno, $4^{\mathrm{a}}$ ed., São Paulo, Malheiros, 2001. . Intervenção de terceiros, São Paulo, Malheiros, 1997.

. Execução civil, 8a ed., São Paulo, Malheiros, 2002.

. A reforma do Código de Processo Civil, 4ª ed., São Paulo, Malheiros, 1997.

. Nova era do processo civil, $3^{\mathrm{a}}$ ed., São Paulo, Malheiros, 2009. 
Dinamarco, Pedro da Silva, Ação civil Pública, São Paulo, Saraiva, 2001.

Di Pietro, Maria Sylvia Zanella, Direito Administrativo, 15ª ed., São Paulo, Atlas, 2003. Discricionariedade administrativa na Constituição de 1988, São Paulo, Atlas, 1991.

Dos Santos, Antonio Carlos, Goncalves, Maria Eduarda e Marques, Maria Manuel Leitão, Direito economico, $4^{\mathrm{a}}$ ed., Coimbra, Almedia, 2001.

Erpen, Jeferson Antonio, "O abuso do direito no exercício da ação e a livre concorrência" in Revista Síntese de Direito Processual civil, n. 22, 2003.

Falcioni, Laura, "Ambito di applicazione", in Il nuovo diritto europeo della concorrenza: aspetti procedurali, Milano, Giuffrè, 2004.

Farber, Daniel e Frickey, Phillip, Law and public choice - a critical introduction, London, The University of Chicago Press, 1991.

Farina, Elizabeth, "Do processo administrativo e da natureza do ato", Revista do IBRAC, v. 3, n. 6 .

Fauceglia, Giuseppe, “L'istruttoria dell'autorità in tema di intese restrittive della libertà di concorrenza e di abuso di posizione dominante", in Rivista di diritto Commerciale e del Diritto Generale delle Obbligazioni, 1993.

Felker, Reginald, Litigância de má-fé e conduta processual inconveniente, São Paulo, LTr, 2007.

Ferraz Jr., Tércio Sampaio, Introdução ao estudo do direito - técnica, decisão, dominação, $2^{a}$ ed., São Paulo, Atlas, 1996.

. "Discricionariedade nas decisões do CADE sobre atos de concentração econômica", Revista do IBRAC, v. 4, n. 4.

Ferreira Filho, Manoel Gonçalves, Curso de direito constitucional, 23 ${ }^{\mathrm{a}}$ ed., São Paulo, Saraiva, 1996.

Filistrucchi, Lapo, "A SSNIP Test for Two-Sided Markets: The Case of Media", in NET Institute Working Paper No. 08-34, 2008 (disponível em SSRN: http://ssrn.com/abstract=1287442). 
Fiss Owen M., "The Social and Political Foundations of Adjudication" in Law and Human Behavior, Vol. 6, No. 2, 1982 (disponível em http://www.jstor.org/stable/1393806).

Florian, Eugenio, Elementos de Derecho Procesal Penal, (trad. Pietro Castro), Barcelona, Bosch, 1931.

Fonseca, Antonio, "Papel dos tribunais administrativos e sistema judicial", Revista do IBRAC vol. 6, n. 3.

Fonseca, João Bosco Leopoldino da, Lei de proteção da concorrência, Rio de Janeiro, Forense, 2007.

Forgioni, Paula A., Os fundamentos do antitruste, 2a . ed., São Paulo, RT, 2005. . “Análise econômica do direito: paranóia ou mistificação?”, in Diálogos constitucionais, Coutinho-Lima, (Org.), Rio de Janeiro, Renovar, 2006.

Franceschini, José Inácio Gonzaga, "Roteiro do processo penal-econômico na legislação de concorrência”, Revista do IBRAC, v. 5, n. 10, 1998.

- “A cláusula 'devido processo legal' e a lei antitruste nacional”, in Revista de informação legilsativa, n. 104, 1989.

Freud, Sigmund, "O mal estar na civilização", In O futuro de uma ilusão, o mal-estar na civilização e outros trabalhos (edição standard brasileira das Obras Psicológicas Completas de Sigmund Freud), Vol. XXI, Rio de Janeiro, Imago, 1976.

Furtado, Celso, Formação econômica do Brasil, São Paulo, Companhia das Letras, 2007.

Gaban, Eduardo Molan e Domingues, Juliana Oliveira, Direito antitruste: o combate aos cartéis, São Paulo, Saraiva, 2009.

Galanter, Marc, “A justiça não se encontra apenas nas decisões dos Tribunais” in Justiça e litigiosidade: história e prospectiva (coord. António Hespanha), Porto, Fundação Calouste Gulbenkian, 1993.

Garofoli, Roberto, "Procedimento, accesso e autorità indipendenti", in Il Foro Amministrativo, vol. LXXIV, 1998.

Gavil, Andrew I., Kovacic, William E., Baker, Jonathan B., Antitrust Law In Perspective: cases, concepts, and problems in competition policy. Estados Unidos, Thomson West, 2002. 
Giannico, Maurício, A preclusão no direito processual civil brasileiro, São Paulo, Saraiva, 2004.

Gianniti, Pasquale, Processo civile e penale a confronto, Padova, Cedam, 2003.

Gilberto, André Marques, O processo antitruste sancionador, Dissertação de Mestrado, USP, 2008.

Goldschmidt, James, Derecho procesal civil, Barcelona, Labor, 1936.

Gomes Filho, Antonio Magalhães, Scarance Fernandes, Antonio, Grinover, Ada Pellegrini, Recursos no processo penal, $2^{\mathrm{a}}$ ed., São Paulo, RT, 1999.

Grau, Eros Roberto, A ordem econômica na Constituição de 1988, 4ª ed., São Paulo, Malheiros, 1998.

Grinover, Ada Pellegrini, As garantias constitucionais do direito de ação, São Paulo, RT, 1973.

. O processo em evolução, Rio de Janeiro, Forense Universitária, 1996.

. "O conteúdo da garantia do contraditório", in Novas tendências do direito processual, Rio de Janeiro, Forense Universitária, 1990.

- "Considerações sobre os limites objetivos e a eficácia preclusiva da coisa julgada”, in Revista do Advogado, n. 65, 2001.

Eficácia e autoridade da sentença penal, São Paulo, RT, 1978.

. "A iniciativa instrutória do juiz no processo penal acusatório", in A marcha do processo, Rio de Janeiro, Forense universitária, 2000.

. "Prova emprestada", Revista Brasileira de Ciências Criminais, São Paulo, vol. 4, 1993.

Grinover, Ada Pellegrini, Scarance Fernandes, Antonio e Gomes Filho, Antonio Magalhães, As nulidades no processo penal, 10ª ed., São Paulo, RT, 2007.

Grotti, Dinorá Adelaide Musetti, "Devido processo legal e o procedimento administrativo", in Revista Trimestral de direito Público, n. 18, 1997.

Hammond, Scott D., "Cracking cartels with leniency programs", OECD Competition Committee, Working Party n. 3, Prosecutors program, Paris, França, 2005 (disponível em http://www.justice.gov/atr/public/speeches/212269.pdf). 
Harada, Kiyoshi, "Processo Administrativo Tributário", in Processo Administrativo Tributário (Pesquisas Tributárias, Nova Série, n 5), Ives Gandra da Silva Martins (coord.), São Paulo, RT, 1999.

Hovenkamp, Herbert J., “Antitrust Policy After Chicago”, Iowa Legal Studies Research Paper No. 09-21, Michigan Law Review, Vol. 84, 1985 (disponível em SSRN: http://ssrn.com/abstract=1396788).

. "The Harvard and Chicago Schools and the Dominant Firm", Iowa Legal Studies Research Paper No. 07-19, 2007, (disponível em SSRN: http://ssrn.com/abstract=1014153.

Hylton, Keith N., Antitrust and the state, Cambridge, Cambridge University Press, 2003.

Justen Filho, Marçal, "Agências reguladoras: existe um déficit democrático na regulação independente?” RDPE, n. 2, 2003.

Klajmic, Magali, “A apuração das práticas restritivas da concorrência - averiguações preliminares e processos Administrativos”, in Revista do IBRAC, vol. 5, n. 9, 1998.

Klein, Christopher C. "The Economics of Sham Litigation - Theory, Cases and Policy", Bureau of Economic Staff Report to the Federal Trade Commission, Estados Unidos, 1989 (disponível em http://www.ftc.gov/be/econrpt/232158.pdf).

Komatsu, Roque, Da invalidade no processo civil, São Paulo, RT, 1991.

Krugman, Paul R. e Obstfeld, Maurice, International economics: theory and policy, $7^{\mathrm{a}}$ ed., Boston, Addison-Wesley, 2005, pp. 226 e ss.

Larenz, Karl, Derecho justo, Madrid, Civitas, 1985.

Laspro, Oreste Nestor de Souza, Duplo grau de jurisdição no direito processual civil, São Paulo, RT, 1995.

Leitão Marques, Maria Manuel, Um curso de direito da concorrência, Coimbra, Coimbra Editora, 2002.

Lenza, Pedro, Direito Constitucional esquematizado, 6ª ed., São Paulo, Método, 2003.

Liebman, Enrico Tullio, Manual de processo civil, $3^{\mathrm{a}}$ ed., São Paulo, Malheiros, 2005. Eficácia ed autorità della sentenza - ed altri scritti sulla cosa giudicata, Milano, Giuffrè, 1962. 
Processo de execução, Araraquara, Bestbook, 2003.

Lima Marques, Cláudia, Benjamin, Antonio H. V. e Miragem, Bruno, Comentários ao Código de Defesa do Consumidor, São Paulo, RT, 2003.

Linares, Juan Francisco, Razonabilidad de las leyes - el 'debido proceso como garantía innominada em la Constitución Argentina, Buenos Aires, Astrea de Rodolfo Depalma y Hnos., 1970.

Luhmann, Niklas, Legitimidade pelo Procedimento, UnB, Brasília, 1980.

Luiso, Franceso P., Diritto processuale civile, Milano, Giuffrè, 2000

Lyra Filho, Roberto "Para uma visão dialética do direito", in Sociologia e Direito: textos básicos para a disciplina de sociologia jurídica (Coord. Cláudio Souto e Joaquim Falcão, 2a ed., São Paulo, Thomson, 1999.

Mandrioli, Crisanto, Diritto processuale civile, vol. I, 17 ed., G. Giapichelli, Torino, 2000.

Mankiw, N. Gregory, Introdução à economia (trad. Allan Vidigal Hastings), São Paulo, Cengage Learning, 2009, p. 11 e 154.

Mann, Kenneth "Punitive civil sanctions: the middleground between criminal and civil law”, The Yale law journal, vol. 101:1795, 1992.

Marcato, Antonio Carlos (coord). Código de Processo Civil interpretado, São Paulo, Atlas, 2004.

Marinoni, Luiz Guilherme, Arenhart, Sérgio Cruz, Processo de Conhecimento, vol. 2., $7^{\mathrm{a}}$ ed. São Paulo, RT, 2008.

Marques, José Frederico, Comentários ao Código de Processo Civil, vol. IV, arts. 332 a 475, Forense, Rio-São Paulo, 1976.

Mattos, Paulo Todescan Lessa, O novo estado regulador no Brasil: direito e democracia, tese de doutorado, USP, 2004.

Maximiliano, Carlos, Hermenêutica e aplicação do direito, $19^{\mathrm{a}}$ ed., Rio de Janeiro, Forense, 2004.

Mazzini, Vicenzo, Istituzioni di diritto processuale penale, Padova, Cedam, 1967.

McCloskey, Deirdre N., The rhetoric of economics, University of Wisconsin Press, 1998.

Medauar, Odete, A processualidade no direito administrativo, São Paulo, RT, 1993. 
Meirelles, Hely Lopes, Direito administrativo brasileiro, $28^{\mathrm{a}}$ ed., São Paulo, Malheiros, 2003.

- "Repressão ao abuso do poder econômico", Estudos e Pareceres de Direito Público, vol. IV, São Paulo, Revista dos Tribunais, 1981.

Mendes, Gilmar, "Passado e futuro da súmula vinculante: considerações à luz da emenda constitucional n. 45/2004”, in Reforma do Judiciário [coord. Renault-Bottini], São Paulo, Saraiva, 2005.

Menezes Cordeiro, Antonio Manuel da Rocha e, Da boa-fé no direito civil, Coimbra, Almedina, 2001.

Mestmäcker, Ernst Joachim, "Poder, Direito, Constituição econômica”, Revista do IBRAC vol. 12 , n. 4, 2005.

Mirabete, Julio Fabbrini, Processo penal, 8ª ed., São Paulo, Atlas, 1998.

Monteleone, Girolamo, "Limiti alla prova di ufficio nel processo civile (cenni di diritto comparato e sul diritto comparato)", Rivista di diritto processuale, anno LXII, n. 4, 2007.

Morado de Andrade, Samira Hamud, "O princípio do devido processo legal e o processo administrativo", in Revista de direito constitucional e internacional, n. 37, 2001.

Moraes, Alexandre de, Direito constitucional, São Paulo, Atlas, 1999.

Nassar, Elody, Prescrição na administração pública, São Paulo, Saraiva, 2004.

Negri, Marcela, Giurisdizione e amministrazione nella tutela della concorrenza, Torino, G. Giapichelli, 2006.

Nery Costa, Nelson, Processo administrativo e suas espécies, Rio de Janeiro, Forense, 2005.

Nery Junior, Nelson, Princípios do Processo Civil na Constituição Federal, $6^{\mathbf{a}}$ ed., São Paulo, RT, 2000.

Nery Junior, Nelson e Andrade Nery, Rosa Maria de, Constituição Federal comentada e legislação constitucional, $2^{a}$ ed., São Paulo, RT, 2009.

Nusdeo, Fábio, Curso de economia, $4^{\mathrm{a}}$ ed., São Paulo, RT, 2005. 
OECD, "Competition law and policy in Brazil", in Policy Brief, 2005 (disponível em http://www.oecd.org/dataoecd/62/35/35415135.pdf).

- Diretrizes para elaboração e implementação de política de defesa da concorrência, São Paulo, Singular, 2003.

Oliveira, Gesner e Rodas, João Grandino, Direito e economia da concorrência, Rio de Janeiro, Renovar, 2004.

Parret, Laura, "Sense and Nonsense of Rules on Proof in Cartel Cases", in TILEC Discussion Paper No. 2008-004, 2008 (disponível em SSRN: http://ssrn.com/abstract=1088959).

Pazzaglini Filho, Marino, Princípios constitucionais reguladores da administração pública, São Paulo, Atlas, 2000.

Piovesan, Flávia, "Direitos humanos globais, justiça internacional e o Brasil", in $O$ cinqüentenário da declaração universal dos direitos do homem, São Paulo, Edusp, 1999.

Pontes de Miranda, Comentários ao Código de Processo Civil, Rio de Janeiro, Forense, 1974.

Posner, Richard, "The legal protection of children", Economic analysis of law, 4a ed., Boston, Little Brown, 1992.

. "Teorias da regulação econômica", in Regulação econômica e democracia, São Paulo, Editora 34, 2004.

Raffaelli, Enrico Adriano, "L'applicazione del diritto antitrust comunitario tra giudici nazionali e comissione", in Rivista di diritto processuale, anno LXIII, n. 3, 2008.

Ragazzo, Carlos Emmanuel J., “Análise Econômica da Regulação: O Papel da Advocacia da Concorrência”, (disponível em http://escholarship.org/uc/item/6k0688wp\#).

Ráo, Vicente, Ato jurídico, $4^{\text {a }}$ ed., São Paulo, RT, 1997.

Salomão Filho, Calixto, Direito concorrencial - as condutas, $1^{\mathrm{a}}$. ed., $2^{\mathrm{a}}$. tir, São Paulo, Malheiros, 2007.

Direito concorrencial - as estruturas, São Paulo, Malheiros, 1998. 
. "Monopólio colonial e subdesenvolvimento", in Direitos humanos, democracia e república - homenagem a Fabio Konder Comparato, São Paulo, Quartier Latin, 2009.

Scarance Fernandes, Antonio, "Princípios e garantias processuais penais em 10 anos de Constituição Federal”, in Os 10 anos da Constituição Federal, São Paulo, Atlas, 1999.

Schroeder, Jeanne L., "Economic Rationality in Law and Economics Scholarship". Oregon Law Review (disponível em SSRN: http://ssrn.com/abstract=245488 or doi:10.2139/ssrn.245488).

Sundfeld, Carlos Ari, "A importância do procedimento no direito administrativo", in Revista de Direito Público, n. 84, 1997.

Surcan dos Santos, Rodrigo, Condutas colusivas horizontais: uma análise crítica da aplicação de conceitos econômicos na interpretação da legislação de defesa da concorrência no Brasil, USP, dissertação de mestrado, 2007.

Stiglitz, Joseph E., "Participation and Development: Perspectives from the Comparative Development Paradigm", Reviewof Development Economics, Blackwell, 2002.

Sundfeld, Carlos Ari, "Lei da concorrência e processo administrativo: o direito de defesa e o dever de colaborar com as investigações" (disponível em http://www.sundfeld.adv.br/_elementos/_pdf/lei_da_concorrencia_e_processo.pdf). . "Processo e procedimento administrativo no Brasil" in As leis de processo administrativo, São Paulo, Malheiros, 2000.

. "Introdução às agências reguladoras", in Direito administrativo econômico, São Paulo, Malheiros, 2002.

Szklarowsky, Leon Fredja, “Litigância de má-fé” in Revista de processo, n. 112.

Taruffo, Michele, "Senso comum, experiência e ciência no raciocínio do juiz" (trad. Cândido Rangel Dinamarco e Luiz Felipe Duarte Martins Costa), transcrição de palestra na Associação dos Advogados de São Paulo, 2001.

. "Onere della prova", in Digesto delle discipline privatistiche - Sezione Civile, Vol. XIII, Utet, Torino, 1991. 
. "Precedente e giurisprudenza", in Rivista trimestrale di diritto e procedura civile, ano LXI, 2007.

- Trattato di diritto civile e commerciale - la prova dei fatti giuridici, Milano, Giuffrè, 1992.

Tavares, “Acesso ao direito, duração razoável do processo e tutela jurisdicional efetiva nas constituições brasileira e portuguesa: um estudo comparativo" in Constituição e processo: a contribuição do processo ao constitucionalismo democrático brasileiro , Belo Horizonte, Del Rey, 2009.

Theodoro Jr., Humberto, Código de processo civil anotado, $1^{\mathrm{a}}$ ed., Rio de Janeiro, Forense, 2007.

. Abuso de direito processual no ordenamento jurídico brasileiro [Coord. José Carlos Barbosa Moreira], Rio de Janeiro, Forense, 2000.

Tidmarsh, Jay, "Rethinking Adequacy of Representation" (November, 18 2008). Texas Law Review, Vol. 87, 2009; Notre Dame Legal Studies Paper No. 08-35, (disponível em http://ssrn.com/abstract=1303497).

Tosato, Gian Luigi, "Le fonti", in Il nuovo diritto europeo della concorrenza: aspetti procedurali, Milano, Giuffrè, 2004.

Tourinho Filho, Fernando da Costa, Processo penal, vol. IV., 5ª ed., Bauru, Jalovi, 1978.

Tucci, Rogério Lauria e Cruz e Tucci, José Rogério, Devido processo legal e tutela jurisdicional, São Paulo, RT, 1993.

Tucci, Rogerio Lauria, Teoria do direito processual penal - jurisdição, ação e processo penal [estudo sistemático], São Paulo, RT, 2002.

Vanberg, Viktor J., “The Frieburg school: Walter Eucken and ordoliberalism”, Freiburg Discussionpapers on Constitutional Economics 04/11 (disponível em http://www.walter-euckeninstitut.de/fileadmin/bilder/Publikationen/Diskussionspapiere/04_11bw.pdf).

. "Consumer Welfare, Total Welfare and Economic Freedom - On the Normative Foundations of Competition Policy", Freiburg Discussionpapers on Constitutional Economics 09/3 (disponível em http://www.walter-euckeninstitut.de/fileadmin/bilder/Publikationen/Diskussionspapiere/09_03bw.pdf. 
Veríssimo, Marcos Paulo, Aproximação sistemática ao controle judicial das agências de regulação econômica no Brasil, dissertação de mestrado, USP, 2002.

Verrina, Grabrielle Lino, "Doppio grado di giurisdizione, convenzioni interlazionali e Costituzione", in Sottani, Sergio. Il controllo dele decisioni giudiziare nella progressione processuale, Torino, UTET, 1998.

Vigliar, José Marcelo, “A Reforma do Judiciário e as súmulas de efeitos vinculantes” in Reforma do Judiciário, analisada e comentada [coord. Tavares, Lenza e Alarcón], São Paulo, Método, 2005.

Wald, Arnoldo, Pareceres: direito das concessões, Rio de Janeiro, América Jurídica, 2004.

Watanabe, Kazuo, "Tutela antecipatória e tutela específica das obrigações de fazer e não fazer: arts. 273 e 461 do CPC", in Reforma do código de processo civil, São Paulo, Saraiva, 1996.

Wright, Joshua D., “Antitrust, multi-dimensional competition, and innovation: do we have an antitrust-relevant theory of competition now?" (August 28, 2009), George Mason Law \& Economics Research Paper No. 09-44 (disponível em SSRN: http://ssrn.com/abstract=1463732).

Yarshell, Flávio Luiz, Tutela jurisdicional, São Paulo, Atlas, 1998.

- "Cumprimento da sentença arbitral: análise à luz das disposições da lei 11.232/2005", in Execução civil e cumprimento de sentença (Coord. Gilberto Gomes Bruschi), São Paulo, Método, 2006.

. Antecipação da prova sem o requisito da urgência e direito autônomo à prova, São Paulo, Malheiros, 2009.

Zane, Phillip C, “The price fixer's dilemma: applying game theory to the decision of whether to plead guilty to antitrust crimes”, in Antitrust Bulletin, v. 48, 2003.

Zanetti Junior, Hermes, Processo constitucional: o modelo constitucional do processo civil brasileiro, Rio de Janeiro, Lumen Iuris, 2007.

Ziebarth, José Antonio Batista, Tendências da advocacia da concorrência contemporânea: um debate sobre a atuação do cade nos espaços e limites entre concorrência e regulação, 2006, no prelo. 